

\title{
III INTERNATIONAL SCIENCE CONFERENCE ON E-LEARNING AND EDUCATION
}

Abstracts of III International Scientific and Practical Conference

\author{
Lisbon, Portugal
}

February 2-5, 2021 


\section{Library of Congress Cataloging-in-Publication Data}

UDC 01.1

The III International Science Conference on E-Learning and Education, February 2 5, 2021, Lisbon, Portugal. 390 p.

ISBN - 978-1-63684-354-4

DOI - 10.46299/ISG.2021.I.III

\section{EDITORIAL BOARD}

\begin{tabular}{ll} 
Pluzhnik Elena & $\begin{array}{l}\text { Professor of the Department of Criminal Law and Criminology } \\
\text { Odessa State University of Internal Affairs Candidate of Law, } \\
\text { Associate Professor }\end{array}$ \\
\hline$\underline{\text { Liubchych Anna }}$ & $\begin{array}{l}\text { Scientific and Research Institute of Providing Legal Framework for } \\
\text { the Innovative Development National Academy of Law Sciences of } \\
\text { Ukraine, Kharkiv, Ukraine, Scientific secretary of Institute }\end{array}$ \\
\hline$\underline{\text { Liudmyla Polyvana }}$ & $\begin{array}{l}\text { Department of Accounting and Auditing Kharkiv } \\
\text { National Technical University of Agriculture named after Petr } \\
\text { Vasilenko, Ukraine }\end{array}$ \\
\hline$\underline{\text { Mushenyk Iryna }}$ & $\begin{array}{l}\text { Candidate of Economic Sciences, Associate Professor of } \\
\text { Mathematical Disciplines, Informatics and Modeling. Podolsk State } \\
\text { Agrarian Technical University }\end{array}$ \\
\hline$\underline{\text { Prudka Liudmyla }}$ & $\begin{array}{l}\text { Dnipropetrovsk State University of Internal Affairs } \\
\text { Dnipro, Ukraine }\end{array}$ \\
\hline$\underline{\text { Slabkyi Hennadii }}$ & $\begin{array}{l}\text { Odessa State University of Internal Affairs, } \\
\text { Associate Professor of Criminology and Psychology Department }\end{array}$ \\
\hline $\begin{array}{l}\text { Doctor of Medical Sciences, Head of the Department of Health } \\
\text { Sciences, Uzhhorod National University. }\end{array}$ \\
$\begin{array}{l}\text { Ph.D. in Machine Friction and Wear (Tribology), Associate } \\
\text { Professor of Department of Tractors and Agricultural Machines, } \\
\text { Maintenance and Servicing, Lecturer, Deputy dean on academic } \\
\text { affairs of Engineering and Energy Faculty of Mykolayiv National } \\
\text { Agrarian University (MNAU), Mykolayiv, Ukraine }\end{array}$ \\
\hline $\begin{array}{l}\text { Candidate of Technical Sciences, specialty 05.22.20 - operation and } \\
\text { repair of vehicles. }\end{array}$
\end{tabular}


TABLE OF CONTENTS

\section{AGRICULTURAL SCIENCES}

\begin{tabular}{c|l|c|}
1. & $\begin{array}{l}\text { БУцик Р.М. } \\
\text { ПРОДУКТИВНІСТЬ СУНИЦІ САДОВОЇ ЗА РІЗНИХ } \\
\text { ТЕХНОЛОГІЙ ВИРОЩУВАННЯ }\end{array}$ & 14 \\
\hline 2. & $\begin{array}{l}\text { СТанКевИч С.В. } \\
\text { СЕРЕДЗЕМНОМОРСЬКА ПЛОДОВА МУХА CЕRATITIS } \\
\text { САРІТАТА (WIEDЕМАNN) В УКРАЇНI }\end{array}$ & 18 \\
\hline \multicolumn{1}{|c|}{ АRT }
\end{tabular}

\begin{tabular}{l|l}
3. & Родіна Д.В., КостенКо І.О. \\
& ТИПОГРАФІКА ЯК ЗАСІБ РІШЕННЯ ФУНКЦІОНАЛЬНИХ ТА \\
ЕСТЕТИЧНИХ АСПЕКТІВ У ДИЗАЙНІ РЕКЛАМНО- \\
ПОЛІГРАФІЧНОЇ ПРОДУКЦІЇ РАННЬОГОМОДЕРНІЗМУ \\
$(1910-1935)$
\end{tabular}

\section{BIOLOGICAL SCIENCES}
4. Федорова Е.Ю., Смоленкова О.В.
ВЛИЯНИЕ СЕЗОНА ГОДА НА УРОВЕНЬ АКТИВНОСТИ MFGM -АТФA3

\section{CHEMICAL SCIENCES}
5. $\quad$ Tkach V., Kushnir M., Minakova T.
OS EXERCÍCIOS INTERDISCIPLINARES COMO MEIO EFICIENTE DE INTEGRAR O ENSINO DE QUÍMICA COM MATEMÁTICA NAS CONDIÇÕES DE ENSINO REMOTO
6. Tkach V., Ivanushko Y.G., Silva A.O.
A DESCRIÇÃO TEÓRICA DA DETECÇÃO ELETROANALÍTICA DO ALCALOIDE PIRROLIZIDÍNICO RETRONECINA, ASSISTIDA PELO COMPÓSITO DE POLINAFTOQUINONAS COM O OXIHIDRÓXIDO DE COBALTO

\section{CULTUROLOGY}

7.

Коцур Л., Коцур В.

ЛІТЕРАТУРНІ УПОДОБАННЯ УКРАЇНСЬКОЇ МОЛОДІ: ВИКЛИКИ ЦИФРОВОЇ ЕПОХИ 
ECONOMIC SCIENCES

\begin{tabular}{|c|c|c|}
\hline 8. & $\begin{array}{l}\text { Бабенко Т.Є., Головко К.Є., Пожидаєва М.В. } \\
\text { МЕТОДИЧНІ АСПЕКТИ ТА ПРАКТИЧНА РЕАЛІЗАЦІЯ } \\
\text { ОБЛІКУ, АУДИТУ ТА АНАЛІЗУ ОСНОВНИХ ЗАСОБІВ } \\
\text { ПІДПРИЄМСТВА }\end{array}$ & 44 \\
\hline 9. & $\begin{array}{l}\text { Бойко В.О., Драгота І.П. } \\
\text { ІННОВАЦІЙНІ ФОРМИ ТУРИСТИЧНОГО ПРОДУКТУ В } \\
\text { ГОТЕЛЬНОМУ БІЗНЕСІ }\end{array}$ & 47 \\
\hline 10. & $\begin{array}{l}\text { Бузан Г.С. } \\
\text { ОЦІНКА ВПЛИВУ НА ДОВКІЛЛЯ ТРАНСПОРТНИХ } \\
\text { СПОРУД: КРИТЕРІЇ ТА ПОКАЗНИКИ }\end{array}$ & 51 \\
\hline 11. & $\begin{array}{l}\text { Парубець О.М. } \\
\text { ОЦНКА ІННОВАЦІЙНО-ІНВЕСТИЦІЙНОГО ПОТЕНЦІАЛУ } \\
\text { МОРСЬКОГО ТРАНСПОРТУ УКРАЇНИ }\end{array}$ & 57 \\
\hline 12. & $\begin{array}{l}\text { Ткачук І.Я., МартинюК А.Ю. } \\
\text { ПРОБЛЕМИ ДЕРЖАВНОГО ФІНАНСУВАННЯ } \\
\text { ГРОМАДСЬКИХ ОРГАНІЗАЦЙ В УКРАЇНІ }\end{array}$ & 60 \\
\hline 13. & $\begin{array}{l}\text { ТрУшкина Н.В., ШкригУн Ю.О. } \\
\text { ПРИОРИТЕТНЫЕ НАПРАВЛЕНИЯ РАЗВИТИЯ } \\
\text { ЭЛЕКТРОННОЙ КОММЕРЦИИ В ПОРТУГАЛИИ }\end{array}$ & 63 \\
\hline 14. & $\begin{array}{l}\text { Цимбалюк Г.С., Сем’янчук П.М., Оліх Г.І. } \\
\text { ФІНАНСОВИЙ МЕХАНІЗМ ДОСЯГНЕННЯ } \\
\text { МАКРОЕКОНОМІЧНОЇ РІВНОВАГИ }\end{array}$ & 70 \\
\hline 15. & $\begin{array}{l}\text { Череп О.Г., Дрозд А.С. } \\
\text { ГЕНДЕРНА ПОЛІТИКА: ДОСВІД РОЗВИНЕНИХ КРАЇН } \\
\text { СВІТУ }\end{array}$ & 76 \\
\hline \multicolumn{3}{|c|}{ GEOGRAPHICAL SCIENCE } \\
\hline 16. & $\begin{array}{l}\text { Картавий А., Федонюк В., Федонюк М. } \\
\text { ОСОБЛИВОСТІ ОРГАНІЗАЦІЇ ДИСТАНЦІЙНОГО ВИВЧЕННЯ } \\
\text { ПРИРОДНИЧО-ГЕОГРАФІЧНИХ ДИСЦИПЛІН }\end{array}$ & 80 \\
\hline
\end{tabular}




\section{HISTORICAL SCIENCES}

17. Загребельна Н., Яретик М.

РОЛЬ МІЖНАРОДНОГО КОНКУРСУ 3 УКРАЇНСЬКОЇ МОВИ ІМЕНІ ПЕТРА ЯЦИКА У ВИХОВАННІ МОЛОДОЇ ГЕНЕРАЦІЇ УКРАЇНЦІВ У ПАРАДИГМІ УКРАЇНОЦЕНТРИЧНОСТІ

LEGAL SCIENCES

18. Vinnyk O. M., Shapovalova O.V.

LEGAL E-EDUCATION USING THE ACHIEVEMENTS OF LEGAL SCIENCE

19. Грущинська Н.I.

ВІДПОВІДАЛЬНІСТЬ РІЕЛТОРА ЗА ДОГОВОРОМ ПРО НАДАННЯ РІЕЛТОРСЬКИХ ПОСЛУГ

20. Жмур Н.В., Лавренчук М.М.

ОСОБЛИВОСТІ СИСТЕМИ КАДАСТРОВОГО ОБЛІКУ ПІД ЧАС ПРОВЕДЕННЯ ЗЕМЕЛЬНОЇ РЕФОРМИ

\section{MANAGEMENT, MARKETING}

21. Mandych O., Mykytas A., Babko N.

COMMUNICATION AS THE BASIS OF BUSINESS AND MARKETING ACTIVITIES

22. Romaniuk I., Kviatko T., Azizov O.

FEATURES OF DEVELOPING A DIGITAL MARKETING STRATEGY FOR A COMPANY

23. Блинова Е.А.

АНАЛИЗ ВЛИЯНИЯ ПАНДЕМИИ COVID-19 НА ЭКОНОМИЧЕСКУЮ СИТУАЦИЮ В РОССИИ

24. Ерошкина Т.В., Борисенко С.С., Кролевецкая И.Э.

СТИЛЬ УПРАВЛЕНИЯ И ФУНКЦИИ МЕНЕДЖЕРА ОРГАНИЗАЦИЙ

\section{MEDICAL SCIENCES}

25. Bohdan T., Slobodianyk O., Bohdan V.

AMINO ACIDS IMBALANCE AS A POSSIBLE PATHOGENETIC LINK OF DISTURBANCE OF GAS TRANSMITTERS SYNTHESIS IN STABLE ANGINA 


\begin{tabular}{|c|c|c|}
\hline 26. & $\begin{array}{l}\text { Zalyubovska O.I., Hladkykh N.O. } \\
\text { THYROID TRANSCRIPTION FACTOR } 1 \text { IN THYROID } \\
\text { NEOPLASMS }\end{array}$ & 115 \\
\hline 27. & $\begin{array}{l}\text { Дерпак Ю.Ю., Кучер О.В., Видиборець С.В. } \\
\text { СЕМІНАРСЬКІ ЗАНЯТТЯ В МЕДИЧНІЙ ПІСЛЯДИПЛОМНІЙ } \\
\text { ОСВІТІ ТА МЕТОДОЛОГІЧНІ ПІДХОДИ ДО ЇХ ПРОВЕДЕННЯ }\end{array}$ & 117 \\
\hline 28. & $\begin{array}{l}\text { Зазуляк Т., Призиглей Г., Швец І. } \\
\text { ГОСТРА ТОКСИЧНІСТЬ НАФАЗОЛІН НІТРАТУ }\end{array}$ & 122 \\
\hline 29. & $\begin{array}{l}\text { Канзюба А.І. } \\
\text { ОСОБЛИВОСТІ ТОТАЛЬНОЇ АРТРОПЛАСТИКИ ПРИ } \\
\text { ПРОГРЕСУЮЧИЙ ДИСПЛАЗЇ КУЛЬШОВОГО СУГЛОБА }\end{array}$ & 126 \\
\hline 30. & $\begin{array}{l}\text { Курташ Н.Я., Кравчук І.В., Ласитчук О.М. } \\
\text { ЕКОНОМІЧНА ДОЦІЛЬНІСТЬ ПРОВЕДЕННЯ БІОХІЧНОГО } \\
\text { ДОСЛІДЖЕННЯ ФУНКЦІЙ ПЕЧІНКИ У ВАГІТНИХ } 3 \\
\text { БЕЗСИМПТОМНИМ НОСІЙСТВОМ НВSАG }\end{array}$ & 131 \\
\hline 31. & $\begin{array}{l}\text { Кучер О.В., Дерпак Ю.Ю., Видиборець С.В. } \\
\text { ДЕЯКІ СКЛАДОВІ НАВЧАЛЬНОГО ПРОЦЕСУ ТА ЇХ } \\
\text { ЗНАЧЕННЯ У ФОРМУВАННІ ОСОБИСТОСТІ ЛІКАРЯ }\end{array}$ & 133 \\
\hline 32. & $\begin{array}{l}\text { ПотіХа Н.Я., КОВаЛИК О.С. } \\
\text { ОСОБЛИВОСТІ РЕАЛІЗАЦЇ ОСВІТНЬОЇ СКЛАДОВОЇ } \\
\text { ОСВІТНЬО-НАУКОВОЇ ПРОГРАМИ ЗДОБУВАЧІВ ТРЕТЬОГО } \\
\text { (ОСВІТНЬО-НАУКОВОГО РІВНЯ) ВИЩОЇ ОСВІТИ З } \\
\text { ВИКОРИСТАННЯМ ТЕХНОЛОГІЙ ЕЛЕКТРОННОГО } \\
\text { НАВЧАННЯ В УМОВАХ ВПРОВАДЖЕННЯ КАРАНТИННИХ } \\
\text { ЗАХОДІВ, СПРИЧИНЕНИХ ПАНДЕМІСЮ КОРОНАВІРУСНОЇ } \\
\text { ІНФЕКЦІЇ СОУІD-19, В ТЕРНОПІЛЬСЬКОМУ } \\
\text { НАЦІОНАЛЬНОМУ МЕДИЧНОМУ УНІВЕРСИТЕТІ ІМЕНІ І.Я. } \\
\text { ГОРБАЧЕВСЬКОГО МІНІСТЕРСТВА ОХОРОНИ ЗДОРОВЯЯ } \\
\text { УКРАЇНИ }\end{array}$ & 138 \\
\hline 33. & $\begin{array}{l}\text { Стусь В.П., Поліон М.Ю., Сніцар Г.М. } \\
\text { НОКТУРІЯ - НЕДООЦІНЕНА ПРОБЛЕМА }\end{array}$ & 141 \\
\hline 34. & $\begin{array}{l}\text { Удод О.А., Яковлева Н.М., Вороніна Г.С. } \\
\text { ОСОБЛИВОСТІ ДИСТАНЦЙ̆НОГО НАВЧАННЯ ГІГІЄНІ } \\
\text { ПОРОЖНИНІ РОТА ДІТЕЙ ШКІЛЬНОГО ВІКУ }\end{array}$ & 143 \\
\hline
\end{tabular}


PEDAGOGICAL SCIENCES

\begin{tabular}{|c|c|c|}
\hline 35. & $\begin{array}{l}\text { Abaturov A., Nikulina A. } \\
\text { ENSURING CONTROL OF STUDENTS' KNOWLEDGE IN } \\
\text { DISTANCE LEARNING }\end{array}$ & 146 \\
\hline 36. & $\begin{array}{l}\text { Arystova L. } \\
\text { ПРИНЦИПИ МУЗИЧНОГО НАВЧАННЯ І ВИХОВАННЯ }\end{array}$ & 152 \\
\hline 37. & $\begin{array}{l}\text { Barannyk S., Barannyk C., Shevtsov V. } \\
\text { ASPECTOS METODOLÓGICOS Y EDUCATIVOS DE LA } \\
\text { FORMACIÓN DEL FUTURO CIRUJANO ESPECIALIZADO } \\
\text { CUALIFICADO }\end{array}$ & 157 \\
\hline 38. & $\begin{array}{l}\text { Dorosh T., Lebedeva V. } \\
\text { СПЕЦИФІКА ПРОВЕДЕННЯ ІНДИВІДУАЛЬНИХ МУЗИЧНИХ } \\
\text { ЗАНЯТЬ У ЗВО В ДИСТАНЦІЙНОМУ РЕЖИМІ }\end{array}$ & 162 \\
\hline 39. & $\begin{array}{l}\text { Gataullina Z., Makhayeva A. } \\
\text { USAGE OF EDUCATIONAL ONLINE PLATFORMS FOR } \\
\text { FORMING PROFESSIONAL LEXICAL SKILLS AT ECONOMIC } \\
\text { UNIVERSITY }\end{array}$ & 166 \\
\hline 40. & $\begin{array}{l}\text { Heronovych M. } \\
\text { CONVERGENCE ONLINE } 15 \text { TECHNIQUES FOR BRINGING } \\
\text { TOGETHER STUDENTS IN ONLINE LEARNING }\end{array}$ & 170 \\
\hline 41. & $\begin{array}{l}\text { Husak L.Y., Vorobiova T.V. } \\
\text { DISTANCE LEARNING VIABILITY IN TEACHING ENGLISH } \\
\text { FOR SPECIFIC PURPOSES }\end{array}$ & 178 \\
\hline 42. & $\begin{array}{l}\text { Kamiyeva G., Moldakhmetova Z. } \\
\text { ИНФОРМАЦИОННЫЕ ТЕХНОЛОГИИ В ОБРАЗОВАНИИ (НА } \\
\text { ПРИМЕРЕ КАЗАХСТАНА И ТУРЦИИ) }\end{array}$ & 181 \\
\hline 43. & $\begin{array}{l}\text { Kashchenko O., Narbutova T., Volokhova G. } \\
\text { THE ROLE OF THE CASE-METHOD IN IMPROVING THE } \\
\text { EFFECTIVENESS OF TRAINING MEDICAL STUDENTS IN } \\
\text { DISTANCE EDUCATION }\end{array}$ & 187 \\
\hline 44. & $\begin{array}{l}\text { Khalina V., Butskyi V. } \\
\text { DEVELOPMENT OF TRANSFORMATION LITERACY }\end{array}$ & 189 \\
\hline
\end{tabular}




\begin{tabular}{|c|c|c|}
\hline 45. & $\begin{array}{l}\text { Kindrat P. } \\
\text { TEACHER-STUDENTS INTERACTION IN DISTANCE } \\
\text { TEACHING OF PROGRAMMING }\end{array}$ & 191 \\
\hline 46. & $\begin{array}{l}\text { Kireyev I., Zhabotynska N. } \\
\text { FEATURES OF DISTANCE EDUCATION STUDENTS OF } \\
\text { SPECIALTY "PHYSICAL THERAPY, ERGOTHERAPY" }\end{array}$ & 194 \\
\hline 47. & $\begin{array}{l}\text { Koroviaka Y., Pashchenko O., Khomenko V. } \\
\text { MODERN PARADIGM OF LEARNING WITH DISTANCE } \\
\text { TECHNOLOGIES }\end{array}$ & 196 \\
\hline 48. & $\begin{array}{l}\text { Mashynets L. } \\
\text { ДИСТАНЦІЙНЕ НАВЧАННЯ З ХОРЕОГРАФІЇ ІЗ УЧНЯМИ } \\
\text { МОЛОДШОГО ШКІЛЬНОГО ВІКУ }\end{array}$ & 200 \\
\hline 49. & $\begin{array}{l}\text { Mytchenok M.P., Mytchenok A.V. } \\
\text { MEDICAL ETHICS AND DEONTOLOGY }\end{array}$ & 203 \\
\hline 50. & $\begin{array}{l}\text { Nykyporets S. } \\
\text { SCAFFOLDING IN THE FOREIGN LANGUAGE LEARNING } \\
\text { PROCESS OF TERTIARY EDUCATION }\end{array}$ & 206 \\
\hline 51. & $\begin{array}{l}\text { Oleynik O. } \\
\text { CONTEMPORARY PEDAGOGY CHALENGE INSUING FROM } \\
\text { THE COVID SITUATION AND FORCED DISTANT EDUCATION }\end{array}$ & 209 \\
\hline 52. & $\begin{array}{l}\text { Shalaieva O. } \\
\text { CLOUD TECHNOLOGIES FOR DISTANCE LEARNING OF } \\
\text { ENGLISH }\end{array}$ & 211 \\
\hline 53. & $\begin{array}{l}\text { Shulska N., Rymar N. } \\
\text { THE PRACTICAL EXPERIENCE OF ORGANIZING CLASSES IN } \\
\text { THE FORMAT OF DYNAMIC TRAINING USING THE } \\
\text { TECHNOLOGY OF THE WORKSHOP }\end{array}$ & 216 \\
\hline 54. & $\begin{array}{l}\text { Turukina О. } \\
\text { ФОРМУВАННЯ ГОТОВНОСТІ МАЙБУТНІХ УЧИТЕЛІВ } \\
\text { МУЗИКИ ДО КОНЦЕРТНИХ ВИСТУПІВ }\end{array}$ & 223 \\
\hline
\end{tabular}




\begin{tabular}{|c|c|c|}
\hline 55. & $\begin{array}{l}\text { Білаш В.П., Лисаченко О.Д., Єрошенко Г.А. } \\
\text { ОСОБЛИВОСТІ ЧИТАННЯ ЛЕКЦІЙ ІНОЗЕМНИМ } \\
\text { СТУДЕНТАМ НА КАФЕДРАХ МОРФОЛОГІЧНОГО } \\
\text { ПРОФІЛЮ МЕДИЧНИХ ВУЗІВ }\end{array}$ & 226 \\
\hline 56. & $\begin{array}{l}\text { Гаращенко Л.В. } \\
\text { ФОРМУВАННЯ МОТИВАЦІЇ У МАЙБУТНІХ ПЕДАГОГІВ } \\
\text { ДОШКІЛЬНОЇ ОСВІТИ ДО ЗДОРОВ’ЯЗБЕРЕЖУВАЛЬНОЇ } \\
\text { ДІЯЛЬНОСТІ }\end{array}$ & 229 \\
\hline 57. & $\begin{array}{l}\text { Годлевська В. } \\
\text { ДИСТАНЦЙНЕ НАВЧАННЯ МОЛОДШИХ ШКОЛЯРІВ: } \\
\text { ОСОБЛИВОСТІ ЗАСТОСУВАННЯ }\end{array}$ & 232 \\
\hline 58. & $\begin{array}{l}\text { Дарпинян Р.С., ЛубЫшев Е.А. } \\
\text { МЕЖДУНАРОДНЫЕ ИНТЕГРАЦИОННЫЕ ПРОЦЕССЫ В } \\
\text { СФЕРЕ ФИЗИЧЕСКОЙ КУЛЬТУРЫ И СПОРТА }\end{array}$ & 235 \\
\hline 59. & $\begin{array}{l}\text { Докаль О.Я., Решетнікова Л.Ю., Зрибнєва І.В. } \\
\text { ЕКОЛОГІЧНЕ ВИХОВАННЯ ТА ЕКОЛОГІЧНА КУЛЬТУРА } \\
\text { ДЛЯ РОЗВИТКУ ТВОРЧОЇ ОСОБИСТОСТІ }\end{array}$ & 241 \\
\hline 60. & $\begin{array}{l}\text { Кодак О.А. } \\
\text { ПИТАННЯ ЯКОСТІ ДИСТАНЦІЙНОГО ТЕСТУВАННЯ У ВНЗ }\end{array}$ & 246 \\
\hline 61. & $\begin{array}{l}\text { Коробко Т.О. } \\
\text { ПСИХОЛОГІЧНІ ПРОБЛЕМИ ІНФОРМАТИЗАЦІЇ } \\
\text { ГУМАНІТАРНОЇ ОСВІТИ }\end{array}$ & 249 \\
\hline 62. & $\begin{array}{l}\text { Кравцова Н.В., Ходаківська О.В., Кравцов Г.О. } \\
\text { РОЛЬ ШТУЧНОГО ІНТЕЛЕКТУ ЯК ІНТЕЛЕКТУАЛЬНОГО } \\
\text { АГЕНТА В ІНТЕРАКТИВНОМУ НАВЧАННІ СТУДЕНТІВ }\end{array}$ & 255 \\
\hline 63. & $\begin{array}{l}\text { КрасиЛЬНИКОВ А.А. } \\
\text { ИГРОВЫЕ И СОРЕВНОВАТЕЛЬНЫЕ МЕТОДЫ В } \\
\text { ФИЗИЧЕСКОМ ВОСПИТАНИИ КАК ФАКТОР } \\
\text { ФОРМИРОВАНИЯ МОТИВАЦИИ ШКОЛЬНИКОВ К } \\
\text { ЗАНЯТИЯМ ДВИГАТЕЛЬНОЙ АКТИВНОСТЬЮ }\end{array}$ & 259 \\
\hline 64. & $\begin{array}{l}\text { Ластовецька І.Ю. } \\
\text { САМООСВІТА-ПІДВИЩЕННЯ КОМПЕТЕНТНОСТІ } \\
\text { ПЕДАГОГІВ }\end{array}$ & 265 \\
\hline
\end{tabular}




\begin{tabular}{|c|c|c|}
\hline 65. & $\begin{array}{l}\text { ЛичУК С.В. } \\
\text { АКТУАЛЬНІ ПИТАННЯ ТА ВИМОГИ ЩОДО ВОЛОДІННЯ } \\
\text { УКРАЇНСЬКОЮ МОВОЮ ЯК ІНОЗЕМНОЮ ДЛЯ ІНОЗЕМНИХ } \\
\text { СТУДЕНТІВ СПЕЦІАЛЬНОСТІ "СТОМАТОЛОГІЯ" }\end{array}$ & 269 \\
\hline 66. & $\begin{array}{l}\text { Літвінова А.М., Пєнов В.В., Тимченко Г.М. } \\
\text { ВИКОРИСТАННЯ ВІДКРИТОГО ОСВІТНЬОГО РЕСУРСУ } \\
\text { НАВЧАННЯ ЗДОРОВ’Ю В УНІВЕРСИТЕТІ }\end{array}$ & 272 \\
\hline 67. & $\begin{array}{l}\text { Мартинюк О.П., Ненюк І.О., Басюк Л.В. } \\
\text { АДАПТАЦІЯ РЕСУРСІВ ДИСТАНЦІЙНОЇ ОСВІТИ ДЛЯ } \\
\text { ФОРМУВАННЯ КРЕАТИВНОСТІ МАЙБУТНІХ ПЕДАГОГІВ } \\
\text { ПРОФЕСІЙНОГО НАВЧАННЯ }\end{array}$ & 276 \\
\hline 68. & 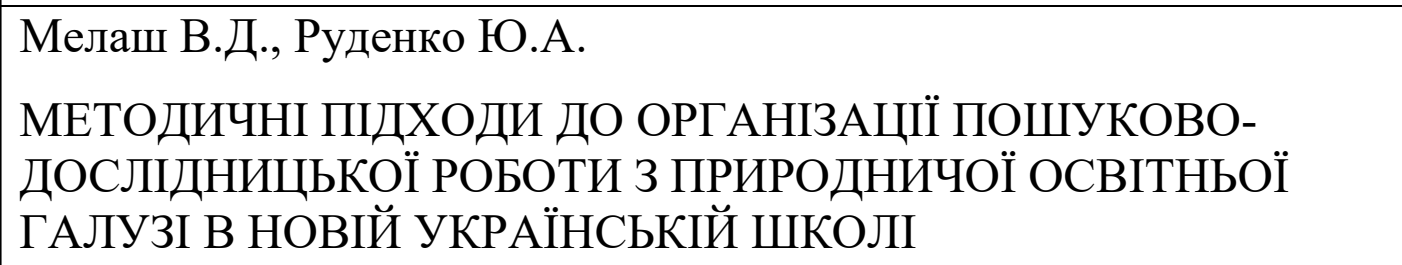 & 279 \\
\hline 69. & $\begin{array}{l}\text { МельнИК Л.М. } \\
\text { УКРАЇНСЬКА ОСВІТА ЯК ПРОВІДНИК ІНТЕГРАЦІЙНИХ } \\
\text { ЗМІН НА ОСНОВІ "ІСТОРІЯ ПОНЯТТЯ }\end{array}$ & 282 \\
\hline 70. & $\begin{array}{l}\text { Носовець Н.М., Пискун О.М., Джевага Г.В. } \\
\text { ЗДАТНІСТЬ ДО САМООСВІТНЬОЇ ДІЯЛЬНОСТІ ЯК } \\
\text { СКЛАДОВА ПРОФЕСІЙНОЇ КОМПЕТЕНТНОСТІ } \\
\text { МАЙБУТНЬОГО ВЧИТЕЛЯ }\end{array}$ & 288 \\
\hline 71. & $\begin{array}{l}\text { Півень О.П., Горбенко М.І. } \\
\text { ТЕОРЕТИЧНІ ОСНОВИ ІНДИВІДУАЛІЗАЦІЇ НА УРОКАХ } \\
\text { ФІЗИЧНОЇ КУЛЬТУРИ }\end{array}$ & 294 \\
\hline 72. & $\begin{array}{l}\text { Решта В.М., Овсяник Л.М., Кисла І.І. } \\
\text { ДИСТАНЦІЙНА ОСВІТА В ШКОЛІ ПІД ЧАС КАРАНТИНУ. } \\
\text { БІЛЬШЕ ПЕРЕВАГ ЧИ НЕДОЛІКІВ? }\end{array}$ & 300 \\
\hline 73. & $\begin{array}{l}\text { ГаЛецьКИй С.М. } \\
\text { СПІВВІДНОШЕННЯ КРИТЕРІЇВ ТА ПОКАЗНИКІВ } \\
\text { КОМУНІКАТИВНОЇ КОМПЕТЕНТНОСТІ МАЙБУТНІХ } \\
\text { ВИКЛАДАЧІВ ІНОЗЕМНИХ МОВ }\end{array}$ & 303 \\
\hline
\end{tabular}




\begin{tabular}{|c|c|c|}
\hline 74. & $\begin{array}{l}\text { Сидоренко Л. } \\
\text { КВЕСТ-ТЕХНОЛОГІЯ ЯК НОВА ОСВІТНЯ ФОРМА У ВИЩИХ } \\
\text { НАВЧАЛЬНИХ ЗАКЛАДАХ }\end{array}$ & 307 \\
\hline 75. & $\begin{array}{l}\text { СУЛіцЬКИЙ В.В. } \\
\text { СОЦІАЛЬНО-ПЕДАГОГІЧНА ПРОФІЛАКТИКА } \\
\text { ПОВТОРНОГО КРИМІНАЛЬНОГО ПРАВОПОРУШЕННЯ } \\
\text { НЕПОВНОЛІТНІМИ }\end{array}$ & 310 \\
\hline 76. & $\begin{array}{l}\text { Трофімчук В.М., Трофімчук Л.О., Дідик В.А. } \\
\text { ОСОБЛИВОСТІ ВИКОРИСТАННЯ ХМАРНОГО } \\
\text { СЕРЕДОВИЩА GОOGLE CLASSROОМ ПРИ ВИКЛАДАННІ } \\
\text { ДИСЦИПЛІНИ «БЕЗПЕКА ЖИТТЄДІЯЛЬНОСТІ» }\end{array}$ & 315 \\
\hline 77. & $\begin{array}{l}\text { Шапран Ю., Шапран О., Шапран О. } \\
\text { ПЕРСПЕКТИВНІСТЬ ВИКОРИСТАННЯ СМАРТ } \\
\text { ТЕХНОЛОГІЙ В СУЧАСНІЙ УНІВЕРСИТЕТСЬКІЙ ОСВІТІ }\end{array}$ & 320 \\
\hline 78. & $\begin{array}{l}\text { ШеВченКо І.Ю. } \\
\text { ЕЛЕКТРОННИЙ КУРС-РЕСУРС ЯК ЗАСТОСУНОК ДЛЯ } \\
\text { ДИСТАНЦЙНОГО НАВЧАННЯ ЗДОБУВАЧІВ ВИЩОЇ } \\
\text { ОСВІТИ }\end{array}$ & 326 \\
\hline 79. & $\begin{array}{l}\text { Шопіна М.О., ЯКУнін Я.Ю. } \\
\text { ОСОБЛИВОСТІ ДИСТАНЦИЙНОГО НАВЧАННЯ МЕДИЧНИХ } \\
\text { СЕСТЕР НАВЧАЛЬНИХ ЗАКЛАДІВ НА КУРСАХ } \\
\text { ПІДВИЩЕННЯ ПЕДАГОГІЧНОЇ КВАЛІФІКАЦІЇ }\end{array}$ & 328 \\
\hline \multicolumn{3}{|c|}{ PHARMACEUTICAL SCIENCES } \\
\hline 80 . & $\begin{array}{l}\text { Огарь С.В., ШУльга Л.І., ГУбченко Т.Д. } \\
\text { СУЧАСНІ ПІДХОДИ ДО РОЗРОБКИ ДИСТАНЦІЙНИХ } \\
\text { КУРСІВ З ФАРМАЦЕВТИЧНОЇ ТЕХНОЛОГІЇ У СИСТЕМІ } \\
\text { ПІСЛЯДИПЛОМНОЇ ОСВІТИ }\end{array}$ & 332 \\
\hline \multicolumn{3}{|c|}{ PHILOLOGICAL SCIENCES } \\
\hline 81. & $\begin{array}{l}\text { Davydenko N.V. } \\
\text { АНГЛОМОВНА МЕДИЧНА ТЕРМІНОЛОГІЯ: АНАЛІЗ, } \\
\text { ІСТОРІЯ СТАНОВЛЕННЯ ТА ОСОБЛИВОСТІ }\end{array}$ & 334 \\
\hline 82. & $\begin{array}{l}\text { Derik I. } \\
\text { JAIL SLANG IN LINGUISTICS }\end{array}$ & 339 \\
\hline
\end{tabular}




\begin{tabular}{|c|c|c|}
\hline 83. & $\begin{array}{l}\text { Kushmar L., Kolot L., Dubinina O. } \\
\text { ONLINE LEARNING: ADVANTAGES AND DISADVANTAGES }\end{array}$ & 341 \\
\hline 84. & $\begin{array}{l}\text { Максименко О.О. } \\
\text { ТЕСТ НА ВЖИВАННЯ МОДАЛЬНИХ ДІЄСЛІВ “SHALL” ТА } \\
\text { "SНOULD” }\end{array}$ & 344 \\
\hline 85. & $\begin{array}{l}\text { Муляр В.І. } \\
\text { ФЕНОМЕН ГАРМОНІЇ У ЇЇ ЗАХІДНОЄВРОПЕЙСЬКИХ } \\
\text { ЗРАЗКАХ }\end{array}$ & 346 \\
\hline 86. & $\begin{array}{l}\text { ЮсУПОВ К.А. } \\
\text { ИЗУЧЕНИЕ В СОВРЕМЕННОЙ КАРАКАЛПАКСКОЙ ЛИРИКЕ }\end{array}$ & 349 \\
\hline \multicolumn{3}{|c|}{ PHILOSOPHICAL SCIENCES } \\
\hline 87. & $\begin{array}{l}\text { Бередіна О.В. } \\
\text { ПСИХОЛОГІЧНІ БАР’'СРИ У КАР’ЄРНОМУ ЗРОСТАННІ } \\
\text { СУЧАСНИХ УКРАЇНСЬКИХ ЖІНОК }\end{array}$ & 354 \\
\hline 88. & $\begin{array}{l}\text { Кавиліна Г.К. } \\
\text { ОСОБЛИВОСТІ КОНСТРУКТИВНОГО ВИРІШЕННЯ } \\
\text { КОНФЛІКТУ МІЖ ВЧИТЕЛЯМИ ТА ПІДЛІТКАМИ }\end{array}$ & 357 \\
\hline 89. & $\begin{array}{l}\text { Артемова О. } \\
\text { ПСИХОЛОГІЧНІ АСПЕКТИ ІНТЕРНЕТ-ЗАЛЕЖНОСТІ } \\
\text { МОЛОДІ }\end{array}$ & 361 \\
\hline 90. & $\begin{array}{l}\text { Шпортун О.М., Пачевська А.П. } \\
\text { РЕЗУЛЬТАТИ ДОСЛІДЖЕННЯ ОСОБЛИВОСТЕЙ } \\
\text { ДЕЦЕНТРАЦІЇ ОСІБ ЮНАЦЬОГО ВІКУ }\end{array}$ & 364 \\
\hline \multicolumn{3}{|c|}{ PHYSICAL AND MATHEMATICAL SCIENCES } \\
\hline 91. & $\begin{array}{l}\text { Hubal } \mathrm{H} . \\
\text { INFORMATION TECHNOLOGIES IN TEACHING STUDENTS IN } \\
\text { MATHEMATICAL DISCIPLINES }\end{array}$ & 370 \\
\hline 92. & $\begin{array}{l}\text { Байсунова А.Н., СарсенгаЛИева Л.М. } \\
\text { МАТЬЕ, БЕССЕЛЬ ТЕНДЕУЛЕРІН ШЕШУДЕ МАРLЕ } \\
\text { ЖҮЙЕСІНІН МҮМКІНДІКТЕРІН ПАЙДАЛАНЫП } \\
\text { ГРАФИКТЕР ТҰРҒЫЗУ }\end{array}$ & 375 \\
\hline
\end{tabular}


III International Science Conference on E-Learning and Education

TECHNICAL SCIENCES

\begin{tabular}{|c|c|c|}
\hline 93. & $\begin{array}{l}\text { Кавин Я.М., Кавин С.Я., Кавин Б.Я. } \\
\text { ВИБІР ПРОГРАМНОГО ЗАБЕЗПЕЧЕННЯ ДЛЯ ЦИФРОВОЇ } \\
\text { ОБРОБКИ ЗОБРАЖЕНЬ }\end{array}$ & 381 \\
\hline 94. & $\begin{array}{l}\text { Матейко О.Д., Соловйова В.В. } \\
\text { ВЕБ-ПОСЛУГИ } 3 \text { ЕЛЕКТРОННОГО НАВЧАННЯ }\end{array}$ & 385 \\
\hline \multicolumn{3}{|c|}{ TOURISM } \\
\hline 95. & $\begin{array}{l}\text { Борисова О.В. } \\
\text { ВТРАЧЕНІ ОБ’ ЄКТИ ІСТОРИКО-КУЛЬТУРНОЇ СПАДЩИНИ } \\
\text { УКРАЇНИ ЯК РЕСУРС ПІЗНАВАЛЬНОГО ТУРИЗМУ }\end{array}$ & 388 \\
\hline
\end{tabular}




\title{
ПРОДУКТИВНІСТЬ СУНИЦІ САДОВОЇ ЗА РІЗНИХ ТЕХНОЛОГІЙ ВИРОЩУВАННЯ
}

\author{
Буцик Роман Миколайович \\ кандидат сільськогосподарських наук \\ доцент кафедри плодівництва і виноградарства \\ Уманський Національний Університет Садівництва
}

На даний час на світовому рівні розробляють кілька напрямів адаптивного землеробства (органічний, біологічний, екологічний), які виникли як результат усвідомлення людством зростаючої екологічної загрози внаслідок інтенсифікації сільського господарства. Запропоновані технології дозволять забезпечити населення України суницею 3 якісними та безпечними для життя людини показниками [1]. Незважаючи на екологічну складову, яка поєднує між собою наведені технології, вони суттєво відрізняються між собою за рівнем удобрення культури, застосування біологічно активних сполук природного походження $\mathrm{i}$ мікробіологічних препаратів, рівнем використання засобів хімізації, продуктивністю [2, 3]. Тому $\epsilon$ необхідність порівняння економічних ефективностей вирощування суниці за традиційною (інтенсивною) та деякими адаптивними технологіями. При цьому, виникає низка питань стосовно ефективності таких агрозаходів на чорноземних грунтах Правобережного Лісостепу України і продуктивності суниці залежно від їх застосування.

Вивчення різних технологій вирощування суниці з отриманням екологічно чистої продукції виконували в умовах дослідного поля Уманського університету садівництва у 2018-2019 роках з використанням двох сортів суниці - Дукат (середньостиглий) і Мальвіна (пізньостиглий). Рослини були висаджені за схемою $90+40$ х 30 см у першій декаді квітня 2018 року розсадою холодильного зберігання - «фріго», класу А+. Грунт - чорнозем опідзолений важкосуглинковий на лесі з вмістом гумусу 3,3 \%. Реакція грунтового розчину слабокисла - pH 6,2-6,6, вміст у грунті азоту (за нітрифікаційною здатністю при 14-денному компостуванні) - 23,1 мг/кг, $\mathrm{P}_{2} \mathrm{O}_{5}-302$ і $\mathrm{K}_{2} \mathrm{O}-264$ мг/кг (за методом Егнера - Ріма - Домінго).

Схема досліду включала найбільш поширені технології вирощування суниці: інтенсивну (передбачала систему традиційних агрозаходів, що включали застосування мінеральних добрив, пестицидів неорганічної природи тощо), біологічну (включала оптимізацію грунтового живлення, росту й розвитку рослин, захист від хвороб і шкідників із використанням препаратів тільки природного походження - Азотофіт, Поліміксобактерін, Фітоцид, Регоплант та ін.), екологічну (включала адаптацію інтенсивної технології до біологічної, що полягало в максимальному впровадженні елементів біологізації). За контроль слугувала інтенсивна технологія, як найбільш поширена в більшості 
промислових насаджень. Варіанти утримання грунту передбачали мульчування грунту в рядах суниці подрібненою соломою, чорною поліетиленовою плівкою товщиною 40 мкм та чорною агротканиною щільністю $60 \mathrm{r} / \mathrm{m}^{2}$. За контроль слугував не замульчований грунт. У міжряддях перед квітуванням суниці на всіх дослідних ділянках, крім контрольних, розстеляли пшеничну солому. У відповідні фази росту суниці визначали площу листкової поверхні, кількість ріжків і квітконосів, урожайність $[4,5]$.

За використання мульчування грунту було одержано найвищі показники ростової продуктивності, у варіантах 3 чорною агротканиною в поєднанні із соломою. Середні за роки показники площі листкової поверхні для сорту Дукат змінювались в межах 22,1-28,4 тис. м²/га, а для сорту Мальвіна - 23,7-29,1 тис. $\mathrm{m}^{2} /$ га. Згідно статистичної обробки даних різниця з ділянками не замульчованого грунту була достовірною і становила відповідно 8,4-10,6 тис. м²/га і 6,8-9,9 тис. $\mathrm{m}^{2} /$ га. За мульчування грунту чорною плівкою в поєднанні із соломою приріст асиміляційної поверхні був дещо менший за попередній варіант, але достовірно перевищував показники контрольного варіанту в середньому на 45-50 \% для обох дослідних сортів суниці.

Серед застосованих технологій вирощування суниці найвищим середнім показником площі листкової поверхні відзначився варіант із екологічною технологією. Пересічно за роки досліджень показник для сорту Дукат становив

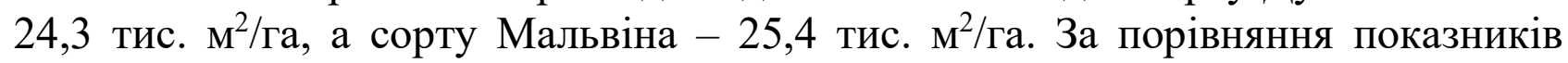
інтенсивної та екологічної технологій вирощування суниці достовірна перевага належала останній з різницею в площі асиміляційної поверхні 2-3 тис. м²/га. На противагу цьому, вирощування суниці за лише біологічною технологією сприяло зменшенню ростової активності рослин, і зокрема, площі листкової поверхні. За такої технології площа асиміляційної поверхні суниці для сортів Дукат i

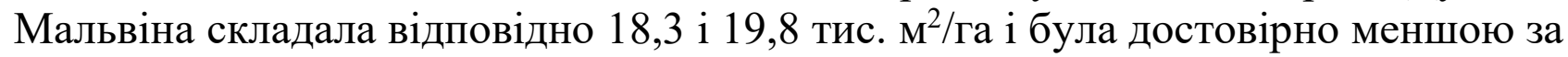
показник 3 інтенсивною технологією на 17 \%. Це вказує про недостатнє забезпечення умов росту суниці за використання лише заходів біологічної природи.

Істотно вищі показники кількості ріжків для сортів Дукат і Мальвіна отримано за мульчування грунту чорною агротканиною в поєднанні із соломою. В середньому за роки досліджень він змінювався в межах 11,1-15,2 шт./кущ для обох сортів та достовірно перевищували показники не замульчованого грунту 7,4-10,7 шт./кущ. Подібні показники отримано і за мульчування грунту чорною плівкою в поєднанні із соломою - 10,3-14,4 шт./кущ у середньому для обох сортів.

Формування ріжків було інтенсивнішим за екологічної технології вирощування суниці. Пересічно за роки досліджень середні показники по сортах суниці Дукат і Мальвіна склали 11,5-13,2 шт./кущ, що достовірно перевищувало показник із традиційної технології на 1,0-1,6 шт./кущ.

За числом квітконосів серед мульчувальних матеріалів перевага склалась на користь сумісного застосування чорної агротканини і соломи (таблиця 1). Пересічно по всьому досліду показники для сортів суниці змінювалися в межах 6,6-7,3 шт./кущ (Дукат) і 5,8-6,7 шт./кущ (Мальвіна). Різниця в порівнянні з не 
замульчованими ділянками склала в середньому для обох сортів 1,4-1,8 шт./кущ i була достовірною за $\mathrm{HIP}_{05}=0,5$. Серед інших варіантів мульчування грунту показники кількості квітконосів були меншими, але також достовірно перевищували контрольний варіант. За мульчування грунту чорною плівкою в поєднанні із соломою число квітконосів було в середньому на 15-20 \% більшим за показник з не замульчованого грунту, а за мульчування лише соломою - 6$11 \%$.

Порівняльне оцінювання технологій вирощування суниці свідчить про найбільшу кількість сформованих квітконосів за екологічної технології.

Таблиия 1.

Генеративна продуктивність сортів суниці залежно від технології вирощування та мульчування грунту в насадженні, (середнс за 20192020pp.)

\begin{tabular}{|c|c|c|c|c|c|}
\hline \multirow{2}{*}{ 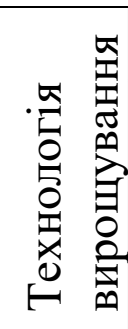 } & \multirow[b]{2}{*}{ Мульчування грунту } & \multicolumn{2}{|c|}{ Дукат } & \multicolumn{2}{|c|}{ Мальвіна } \\
\hline & & $\begin{array}{c}\text { Кількість } \\
\text { квітко- } \\
\text { носів } \\
\text { шт./кущ }\end{array}$ & $\begin{array}{c}\text { Урожай- } \\
\text { ність, } \\
\text { т/га }\end{array}$ & $\begin{array}{c}\text { Кількість } \\
\text { квітконосів } \\
\text { шт./кущ }\end{array}$ & $\begin{array}{c}\text { Урожай- } \\
\text { ність, } \\
\text { т/га }\end{array}$ \\
\hline \multirow{4}{*}{ 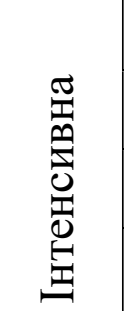 } & Без мульчування (контроль) & 5,2 & 12,7 & 4,4 & 10,2 \\
\hline & Солома & 5,8 & 15,9 & 4,9 & 11,7 \\
\hline & Чорна плівка + солома & 6,4 & 18,4 & 5,6 & 12,8 \\
\hline & Чорна агротканина + солома & 6,9 & 19,7 & 6,2 & 14,7 \\
\hline \multirow{4}{*}{ 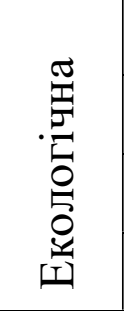 } & Без мульчування (контроль) & 6,1 & 13,9 & 5,2 & 10,9 \\
\hline & Солома & 6,5 & 16,7 & 5,8 & 12,2 \\
\hline & Чорна плівка + солома & 7,0 & 20,2 & 6,4 & 13,8 \\
\hline & Чорна агротканина + солома & 7,3 & 21,5 & 6,7 & 15,5 \\
\hline \multirow{4}{*}{ 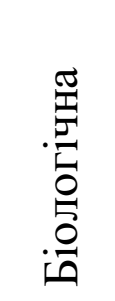 } & Без мульчування (контроль) & 4,9 & 9,8 & 4,2 & 9,7 \\
\hline & Солома & 5,4 & 12,7 & 4,6 & 10,9 \\
\hline & Чорна плівка + солома & 6,1 & 14,4 & 5,1 & 12,1 \\
\hline & Чорна агротканина + солома & 6,6 & 15,9 & 5,8 & 13,3 \\
\hline & $H I P_{05}$ & 0,5 & 1,8 & 0,4 & 1,2 \\
\hline
\end{tabular}

Середня їх кількість для сорту Дукат становила 6,7 шт./кущ, а для сорту Мальвіна - 6,0 шт./кущ, що достовірно перевищувало показники інтенсивної технології на 0,6 і 0,7 шт./кущ відповідно $\left(\mathrm{HIP}_{05}=0,5\right)$. За біологічної технології ці показники були на 0,3-0,4 шт./кущ меншими, хоча така різниця не завжди була достовірною. Отримана закономірність простежувалась по обох дослідних сортах суниці. Зміна показника урожайності відбувалась під впливом всіх 
застосованих у дослідженнях заходів. Найвищою врожайністю відзначились сорти суниці за мульчування грунту в насадженні чорною агротканиною в сукупності із соломою. При цьому, середній дворічний показник досягав пересічно по досліду 21,5 т/га для сорту Дукат та 15,5 для сорту Мальвіна. Істотне перевищення показників із не замульчованого грунту складало відповідно 7,6 т/га і 4,6 т/га ягід. Найвищий рівень урожайності сортів суниці отримано за екологічної технології вирощування. Для сорту Дукат середній показник становив 18,1 т/га, а сорту Мальвіна - 13,1 т/га. Перевищення інтенсивної технології складало 1,5 т/га і 0,7 т/га, що було в межах похибки досліду, або на межі достовірності. Перехід вирощування суниці на біологічну технологію спонукало до зменшення середньої врожайності суниці на 0,9-3,5 т/га. Хоча така різниця не завжди була достовірною, але це вказує на неповне забезпечення оптимальних умов росту й розвитку суниці.

Висновки. За мульчування грунту в насадженні суниці чорними плівкою i агротканиною на 45-50 \% формується більша площа листкової поверхні суниці та на $30 \%$ - багаторічна стеблова частина. Найбільшій генеративній продуктивності суниці сприяє мульчування грунту чорною агротканиною в поєднанні із соломою. При цьому інтенсивніше, на 15 \%, формуються квітконоси, а врожайність зростає на $35 \%$. Найвищі показники ростової і генеративної продуктивності суниці отримано за екологічної технології ії вирощування. Товарна якість ягід зростає до максимального рівня - 93,4 \% за вирощування суниці за екологічною технологією, що передбачає мульчування грунту сумісно чорною агротканиною і соломою.

\section{Список літератури:}

1. Буцик Р. М., Коваленко О. С. Ефективність вирощування органічної суниці в садівничих підприємствах України. Збірник наукових праџь Харківського НАУ. Харків, 2014. Вип. 7. С. 203-213.

2. Burliai A. P., Burliai O. L., Butsyk R. M., Nepochatenko O. A., Nesterchuk Y. A. Featyres of organic production technology. Innovative development of the economy: global trends and national features. - Collective monograph. Lithuania: Publishing House "Baltija Publishing”, 2018. P.18-33 . ISBN 9789934-571-76-3

3. Karpenko V., Burliai O., Burliai A., Mostovyak M. Ukrainian gardening market trends under globalization. Economic Annals-XXI, 2016, no. 9-10, pp. 51-55.

4. Марковський В. С., Завгородній І. В. Методика проведення агрономічних дослідів з ягідними культурами. Київ, ІС УААН, 1993. С. 13-17.

5. Учеты, наблюдения, анализы, обработка данных в опытах с плодовыми и ягодными растениями: Метод. рекомендации / Под ред. Г.К. Карпенчука и А.В. Мельника. Умань: Уман. с.-х. ин-т, 1987. 115 с. 


\title{
СЕРЕДЗЕМНОМОРСЬКА ПЛОДОВА МУХА CERATITIS CAPITATA (WIEDEMANN) В УКРАÏHI
}

\author{
Станкевич Сергій Володимирович \\ кандидат сільськогосподарських наук, доцент \\ Харківський національний аграрний університет ім. В.В. Докучаєва
}

Середземноморська плодова муха (Ceratitis capitata (Wiedemann) = Ceratitis citriperda MacLeay, C. hispanica De Breme, Pardalaspis asparagi Bezzi, Tephritis capitata Wiedemann.) належить до класу Insecta (Комахи), ряду Diptea (Двокрилі), родини Tephritidae (Осетниці).

Це багатоїдний вид. До рослин-господарів належать рослини з різних родин, шкідники розвиваються на плодах таких культур: апельсин, мандарин, авокадо, хурма, інжир, кавове дерево, банан, лимон, суниця, гранат, абрикос, персик, груша, яблуня, слива, черешня, виноград, фінік, томат, баклажан, перець, а також понад 70 інших видів рослин.

Середземноморську плодову муху неодноразово виявляли у Флориді i Каліфорнії. За оцінками, вартість кожного з попередніх проникнень у США (вартість ліквідації осередків і втрати у виробництві) коливалася від 0,3 до 200 млн дол. Спалахи розмноження C. capitata в Каліфорнії протягом останніх 25 років коштували американським платникам податків близько 0,5 млрд дол., у той час як на ліквідацію цієї мухи в одній лише області Тампа Бей у Флориді в 1997 p. було витрачено до 25 млн дол. Країни Східного Середземномор'я також зазнали значних втрат, пов'язаних 3 розповсюдженням плодової мухи, їх оцінено в 192 млн дол. В Австрії цей шкідник з'явився у 1954 р., а вже у 1956 р. в садах на околицях Відня муха пошкодила 90-100\% плодів. У цей же період на півдні Німеччини втрати абрикосів від середземноморської плодової мухи досягли 80 \%, персиків - $100 \%$. Пошкодження плодових культур часто дуже значне i може досягати $100 \%$ (особливо персиків). У Центральній Америці 1989 р. втрати культури кави досягали $15 \%$, ягоди дозрівали раніше і осипалися на землю, їх якість була низькою.

Поблизу Севастополя восени 1964 р. персик ушкоджувався на 100 \%, груші - на 40-70\%.

Як і в країнах, де муха є ендемічною, в умовах появи осередків у вільних регіонах економічні наслідки включають скорочення виробництва, підвищення витрат на контроль і втрату ринків збуту.

Природний ареал середземноморської мухи - Африка на південь від Сахари. На початку XIX ст. була виявлена в південних частинах Свропи, звідки згодом поширилася на інші частини земної кулі і стала космополітом. У Свропі поширена в таких країнах як Австрія, Албанія, Болгарія, Боснія та Герцеговина, Греція, Іспанія, Італія, Мальта, Кіпр, Португалія, Росія, Румунія, Сербія, Словенія, Україна, Франція, Хорватія, Чорногорія, Швейцарія; в Азії - Ізраїль, Ірак, Іран, Ємен, Йорданія, Саудівська Аравія, Сирія, Туреччина; в Африці Алжир Ангола, Бенін, Ботсвана, Буркіна-Фасо, Бурунді, Габон, Гана, Гвінея, ДР 
Конго, Сгипет, Ерітрея, Есватіні, Ефіопія, Замбія, Звмбабве, Кабо-Верде, Камерун, Кенія, Коморські о-ви, Конго, Кот-д’Івуар, Ліберія, Лівія, Мадагаскар, Малаві, Малі, Маврикій, Марокко, Мозамбік, Намібія, Нігер, Нігерія, ПАР, о. Реюньон, о. Св. Олени, Сан-Томе і Принципі, Сейшельські о-ви, Сенегал, Сьєрра-Леоне, Судан, Танзанія, Того, Туніс, Уганда; у Північній Америці США; у Центральній Америці та країнах Карибського басейну - Гватемала, Гондурас, Коста-Рика, Мексика, Нікарагуа, Панама, Пуерто-Рико, Сальвадор; у Південній Америці - Аргентина, Болівія, Бразилія, Венесуела, Еквадор, Колумбія, Парагвай, Перу, Чилі. Також шкідник поширений і у Австралії (рис. 1).

Незважаючи на те, що за офіційними даними в Україні шкідник відсутній, осередки середземноморської плодової мухи було виявлено в Одеській області у 2013 р., а станом на 2019 р. площа осередку в м. Чорноморськ Одеської області становить 9,9 га.

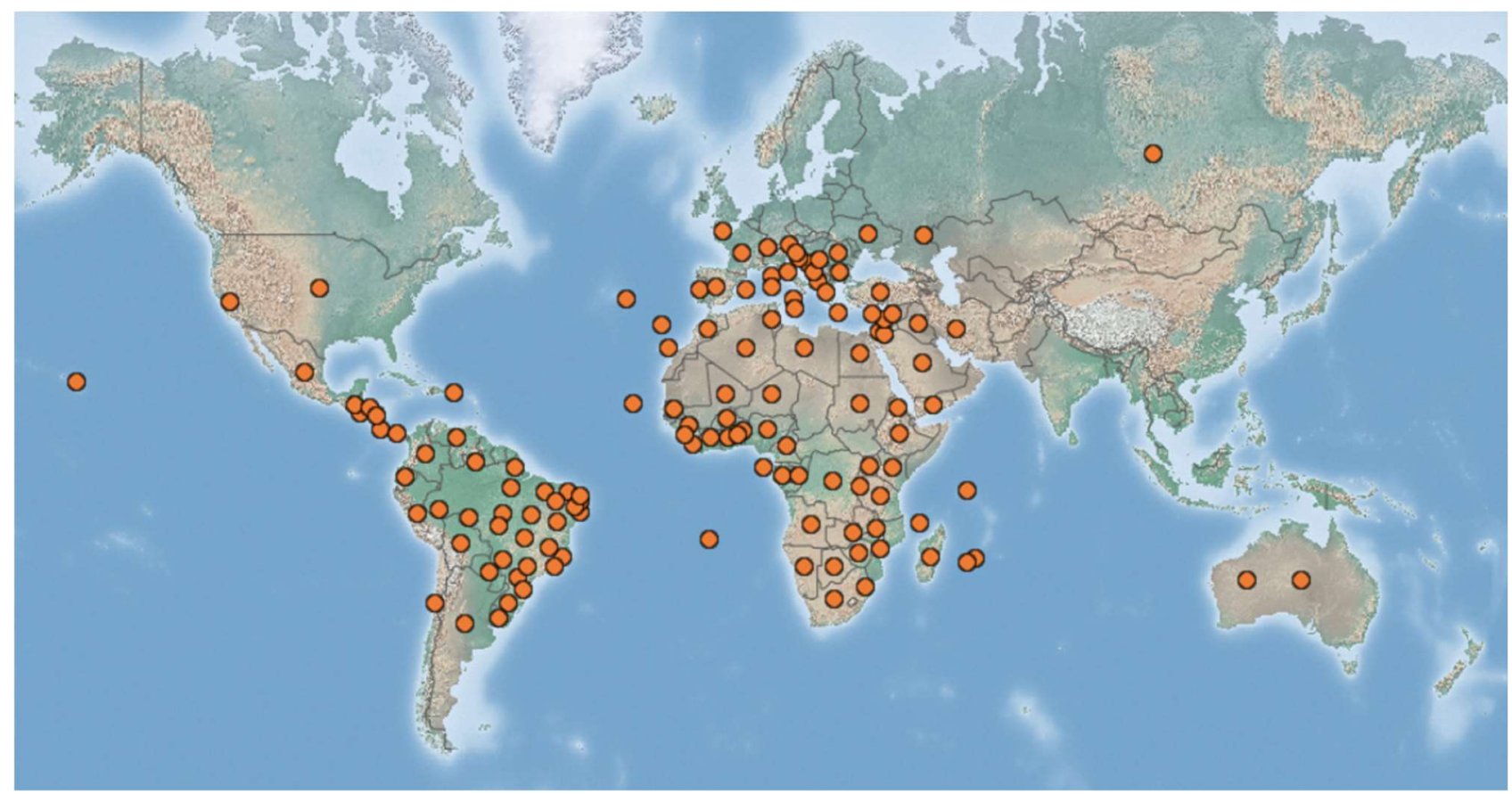

\section{Рис. 1. Світовий ареал Ceratitis capitata Wiedemann}

Самка мухи відкладає яйця у достигаючі плоди. під шкірочку за допомогою гострого яйцеклада. В один плід можуть відкласти яйця кілька самок. Середня плодючість - 300 яєць, максимальна - 1000. Ембріональний розвиток становить 1-2 доби. Личинки живляться всередині плоду протягом 2-3 тижнів. Ушкоджені плоди передчасно достигають та опадають. 3 плодів личинки йдуть на незначну глибину, де заляльковуються. Личинки вміють стрибати, тому пупарії можна знайти в радіусі 2-3 м від плодів, які впали.

Тривалість розвитку залежить від кліматичних умов. За температури $26{ }^{\circ} \mathrm{C} \mathrm{i}$ $70 \%$ вологості повітря розвиток покоління відбувається за 18-20 діб, за температури $21{ }^{\circ} \mathrm{C}-$ за $40-70$ діб, $16^{\circ} \mathrm{C}$ - за 100 діб. 
У Північній Франції для повного розвитку покоління потрібно 40 діб. На Кіпрі та в Бразилії муха дає 8-9 поколінь, в Ізраїлі - 8, в Італії -6-7, в Австрії та Німеччині - 2.

Важливим при діагностуванні є знання морфологічних особливостей мухи, адже в Україні поширені і місцеві види з тої ж самої родини.

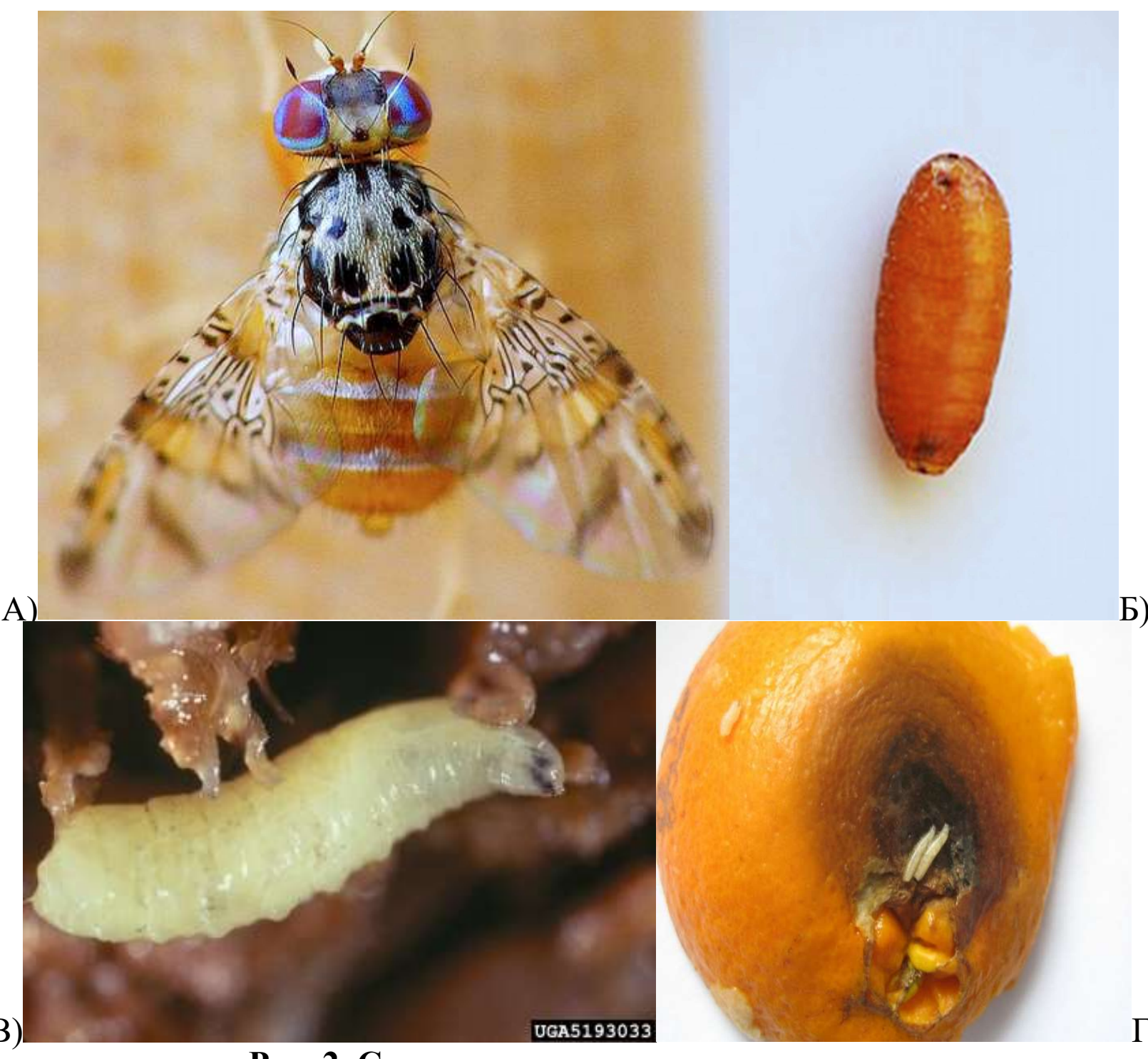

Рис. 2. Середземноморська плодова муха:

А) імаго; Б) пупарій; В) личинка; Г) характер пошкодження

Імаго. Довжина 3,5-5 мм, мухи мають специфічне забарвлення (рис. 2, А). Голова самки біло-сіра, очі у мертвих екземплярів - винно-червоні, у живих - 3 металево-зеленим блиском. Груди блискучо-чорні, з біло-сірими плямами та смугами, які утворюють характерний малюнок, щиток чорний, на верхівці 3 дугоподібною біло-сірою поперечною смугою. Плечі з характерними білими кільцями. Крила з широким поперечними смугами, забарвлені у жовті кольори в основній частині та сірі - по краях. Черевце жовте або світло-жовто-коричневе із сіро-сріблястими поперечними смугами. Яйцеклад самці добре відрізняються від інших видів роду ромбоподібно розширеною передньою орбітальною щетинкою. 
Яйце. Довге, 0,9-1,0 мм, вигнуте, загострене з верхнього та заднього кінця, гладке і блискучо-біле.

Личинка. Тіло видовжене, головний кінець загострений. Довжина личинки 1го віку 1 мм, тіло переважно прозоре; тіло личинки 2-го віку частково прозоре; довжина личинки 3-го віку 6,8-8,2 мм, тіло повністю непрозоре, біле, частково просвічується, або має колір їжі (рис. 2, В). Ротові гачки із зубцями.

Пупарій завдовжки 4-5 мм, від жовтого до темно-коричневого 3 помітною сегментацією та задніми дихальцями (рис. 2, Б).

У період яйцекладки самки середземноморської плодової мухи пошкоджують плоди, проколюючи їхню шкірку яйцекладом. Після відродження личинок, унаслідок їхнього живлення, у м'яких тканинах плодів розвиваються вторинні мікроорганізми (грибки), плоди загнивають i опадають. Зазвичай ушкоджені мухами плоди мають на поверхні темні плями, які при натисканні продавлюються. Однак на початкових стадіях ураження «хворі» плоди можуть зовні не відрізнятися від здорових. Лише розрізавши пошкоджені плоди, всередині можна виявити білувато-кремових личинок мухи. На шкірці персиків, у місцях проколів яйцекладом з'являються краплини камеді. На апельсинах (рис. 2, Г), айві, яблуках ушкоджені місця тверднуть і темнішають; частіше ушкодження виявляють 3 нижнього боку висячих плодів. Влітку найдужче пошкоджуються апельсини, абрикоси, персики та інші плоди, які мають жовтопомаранчеве забарвлення. На заселених плодах зазвичай можна помітити місця проколів яйцекладом (темніші від основного забарвлення плоду та маслянисті плямочки). У плодів, що мають високий вміст цукру, пошкодження супроводжується витіканням солодкого соку, який склеює сусідні плоди. Залежно від властивостей шкірки плодів, їх стійкість до ушкоджень середземноморською плодовою мухою дуже відрізняється. Значення мають щільність, наявність воскового нальоту, товщина, структура поверхні і навіть колір (жовті, помаранчеві та червоні плоди ушкоджуються частіше, ніж зелені). Такі властивості шкірки, як вміст кислот, таніну та ефірних олій також можуть несприятливо впливати на життєздатність яєць і личинок. На інтенсивність зараження впливає і ступінь достигання плодів: зелені і тверді плоди майже не пошкоджуються мухою, стиглі й перестиглі - навпаки, пошкоджуються дуже сильно.

Основним джерелом розповсюдження C. capitata $є$ заселена шкідником рослинна продукція. В основному це заселені плоди кормових рослин. Дорослі комахи за допомогою вітру можуть пасивно переноситися на значні відстані (до 20 км). При міжнародній торгівлі шкідник розповсюджується з плодами (яйця, імаго, личинки) та садивним матеріалом рослин-живителів (пупарії на коренях рослин з грунтом) з регіонів поширення.

Для вилову дорослих мух застосовують жовті клейові пастки та феромонні пастки, личинок виявляють під час огляду тари та пакувальних матеріалів.

Щоб не допустити проникнення середземноморської плодової мухи з країн, де зафіксований цей шкідник, овочі та фрукти ретельно перевіряють у фітосанітарних лабораторіях. Найчастіше фахівці цих лабораторій виявляють середземноморську плодову муху у вантажах (цитрусові) з Туреччини і Сгипту 
в зимовий період. У такому разі заражений вантаж направляють на спеціальну обробку, що призводить до загибелі мухи. У крайніх випадках його може бути знищено або повернено до країни-імпортера. Неприпустимо складування імпортних плодів (особливо цитрусових) і тари 3-під них поряд 3 плодовими насадженнями, виноградниками і ягідниками. Найбільший ризик це несе в літній період, особливо в південних областях нашої країни. 


\title{
ТИПОГРАФІКА ЯК ЗАСІБ РІШЕННЯ ФУНКЦІОНАЛЬНИХ ТА ЕСТЕТИЧНИХ АСПЕКТІВ У ДИЗАЙНІ РЕКЛАМНО-ПОЛІГРАФІЧНОЇ ПРОДУКЦЇ̈ РАННЬОГОМОДЕРНІЗМУ (1910-1935)
}

\author{
Родіна Дар'я Володимирівна \\ Студентка
}

\author{
Костенко Ігор Олегович \\ ( к.т.н., доцент ) \\ Київська державна академія \\ декоративно-прикладного мистецтва і \\ дизайну імені Михайла Бойчука \\ м. Київ, Україна
}

Анотація У статті розглядаються принципи використання типографіки в поліграфічній рекламній продукції, особливості організації шрифтових композицій. На основі стилістичного аналізу зразків рекламної поліграфічної продукції епохи раннього модернізму різних напрямків (футуризм, баухаус, конструктивізм, ардеко) виявлено художньо-стилістичні особливості типографічних композицій. Розкривається зв'язок візуально-образної мови дизайну рекламної поліграфічної продукції з соціальними настроями епохи раннього модернізму. Результати дослідження підтримають ідею, що типографіка епохи раннього модернізму входила в нові відносини зі своєю аудиторією, безкомпромісно створюючи нові форми, нову візуально-образну мову, нові конструктивні рішення. У статті розкривається вплив друкованої реклами на культурне та громадське життя, що відображає стильові особливості епохи - динаміку футуризму, експресію ар-деко, нові рішення конструктивізму та баухаусу. Представлені результати мають важливе значення при створенні лекційних курсів з теорії та історії графічного дизайну, а також при проведенні семінарів та практичних занять, присвячених проблемам типографіки.

Ключові слова: типографіка, модернізм, поліграфічна рекламна продукція.

Образне рішення в дизайні поліграфічної реклами - синтез вербальних, візуальних, художньо-графічних засобів виразності. Психологічно споживач спочатку сприймає текстову інформацію набрану шрифтом.

Типографіка в дизайні поліграфічної рекламної продукції:

- $є$ складовою частиною реклами, елементом комунікативного процесу, де товаровиробник через закодоване звернення намагається донести до споживача 
інформацію з метою створити установку на придбання даного товару, послуги та ін.;

- виступає однієї зі складових візуально образної мови, $€$ одним 3 найважливіших засобів комунікації у графічному дизайні в сучасному світі, відіграє важливу роль у сприйнятті реклами, особливо друкованої, формує інтерес до всього рекламного тексту.

Потреба сучасного суспільства в ефективній, яскравій і переконливій рекламі велика як ніколи, і роль дизайн-проектування в підвищенні ії естетичної якості $\epsilon$ вирішальною. Візуально графічна виразність, втілена в художньому образі типографічних композицій, має велике значення для сприйняття сенсу, вона $€$ носієм естетичної цінності дизайну рекламної поліграфічної продукції. Це визначає актуальність мистецтвознавчого дослідження типографіки в контексті теорії та методології графічного дизайну. Дане дослідження було проведено згідно за планом науково-дослідної роботи кафедри графічного дизайну Харківської державної академії дизайну і мистецтв.

Мета роботи полягає в аналізі особливостей типографіки як інструменту рішення функціональних та естетичних аспектів у дизайні поліграфічної рекламної продукції епохи раннього модернізму.

Виклад основного матеріалу дослідження. Поняття типографіка трактується як мистецтво знаходження шрифту та складових поліграфічного набору на визначеному форматі. Для дизайнера графіка, який займається створенням друкованої продукції, літери являють собою складову художньо-графічної мови. У кожному разі друкована реклама втілюється в життя через типографіку, яку М. Жуков характеризує як систему оформлення набору і верстки друкованого видання в цілому або його елементів [7; 14: 275]. Друкована реклама активно використовує культурну спадщину, що залишена відомими майстрами типографіки. Періодично в центрі сучасної рекламної творчості певні стилі стають більш затребуваними або - модними. В даний час популярними знову стають стилі, що виникли в епоху раннього модернізму.

За своїми принципами ранній модернізм протистоїть всьому антикварному й застарілому. Модерністи відчували безрозмірну любов до геометричних форм $\mathrm{i}$ зневажали орнаменти. Термін модернізм часто вживається, коли $є$ навмисний розрив 3 минулим. Епоха раннього модернізму характеризується мажорним настроєм і експериментальним підходом у дизайні рекламної поліграфічної продукції, що виходить за рамки класичної естетики 3 використанням оригінальних, новаторських засобів вираження.

На формування візуально-образної мови типографіки та основоположних принципів художньої виразності у дизайні рекламної поліграфічної продукції 1910-1935-ті рр. вплинули кардинальні зрушення в суспільній свідомості, що були співзвучні з історичним розвитком визначеного періоду. Типографіка епохи раннього модернізму входила в нові відносини зі своєю аудиторією, створюючи нові форми, нову візуально-образну мову, нові конструктивні рішення: 
- футуристи були першими у графічному дизайні, що використовували образотворчий потенціал слова. Їх роботи повні експерименту, шуму, безладу. Стверджено, що типографіка композиційно відокремлена від ілюстрації або існує в якості декоративного елементу. Шрифт стає таким же абстрактним об'єктом графіки, як геометрична фігура і лінія, він втрачає функціональність сприйняття та набуває візуальної експресії композиції;

- типографіка у рекламних виданнях баухаусу проста за формою, лаконічна та виразна.

Доведено, що рекламні повідомлення збалансовані геометричною схемою, типографічні композиції гармонійно вписані у чітку структуру, що доповнюють візуальні та функціональні аспекти рекламного плакату;

- дизайнери конструктивізму вирішували типографічні композиції як маленький закличний плакат. Принцип конструктивного компонування текстових блоків (паралельного, перпендикулярного або під кутом 45 градусів) по відношенню один до одного уподібнював композиції структурі інженерної конструкції.

Шрифтові елементи наділялися образною виразністю та стилістичної активністю завдяки характерному принципу їх компоновки, що стало візитною карткою дизайну поліграфічної реклами конструктивізму. Серед графічних виразних засобів реклами 1920-х рр. слід виділити: використання елементів гротескового набірного шрифту в якості засобів акцентування тексту, пристрасть до широких плашок і смужок;

- типографіка ар-деко представляє собою химерну суміш шрифтових елементів неокласицизму, конструктивізму, кубізму, модерну, ар-нуво i футуризму. Констатовано, що ар-деко тяжів до геометрії і чистоти — прямі лінії, трапеції і прямокутники, геометричні шрифти. В цей період рекламний плакат у ще більшому ступені став виконувати функції засобу масової комунікації, тиражувати не тільки прагматичну інформацію, а й соціальні стандарти, візуальні та вербальні стереотипи, моделі поведінки.

Стверджено, що рекламні повідомлення раннього модернізму відображали «соціальний нерв» свого часу. Новий час потребував нові форми та нові конструктивні рішення. Стилістика рекламних повідомлень раннього модернізму була новою художньою мовою, що вірно відображала настрої епохи.

\section{Список літератури}

1. Аксенов Г. П. Эволюция художественно-образной выразительности графического дизайна в процессе развития полиграфических средств: дисс. на соиск. учен. степ. канд. искусствоведения: специальность 17.00.06 - Техн. Эстетика и дизайн / Аксенов Геннадий Петрович; Всерос. научноисслед. ин-т техн. эстетики. - Москва, 2008. - 169 с. 
2. Аникст М. А., Черневич Е. В., Бабурина Н. И. Русский графический дизайн 1880-1917 / М. А. Аникст, Е. В. Черневич, Н. И. Бабурина. - М.: Внешсигма, 1997. - $160 \mathrm{c}$.

3. Архипова Н. Эволюция художественно-графического языка иллюстраций журналов мод: дисс. на соиск. учен. степ. канд. искусствоведения: специальность 17.00.06. - Техн. эстетика и дизайн / Н. Архипова;Моск. гос. Текстильный университет им. А. Н. Косыгина. - Москва, 2011. - 410 с.

4. Бабурина Н. И. Русский плакат. Вторая половина XIX - начало XX века / Н. И. Бабурина. — Л.: Художник РСФСР, 1988. — 192 с.

5. Герман М. Модернизм. Искусство первой половины XX века / М. Герман. - СПб.: Азбука-классика, 2003. - 473 с.

6. Глинтерник Э. М. Графиче ский + дизайн как художественнокоммуникативная система и средство рекламы: Монография / Э. М. Глинтерник. - СПб.: Изд-во Петербургского института печати, 2002. - 136 с.

7. Жуков М. Г. Типографика Эмиля Рудера / М. Г. Жуков // Типографика /Э. Рудер. - М.: Книга, 1982. - С. 275-286. 


\title{
ВЛИЯНИЕ СЕЗОНА ГОДА НА УРОВЕНЬ АКТИВНОСТИ МFGМ -АТФАЗ
}

\begin{abstract}
Федорова Е.Ю.,
доктор биологических наук, профессор, зав. лабораторией, руководитель программы магистратуры: Спортивная адаптология. ГАОУ ВО Московский городской педагогический университет
\end{abstract}

\author{
Смоленкова О.В., \\ кандидат биологических наук, Курская государственная \\ сельскохозяйственная академия имени И.И. Иванова
}

Общеизвестно, что ионные насосы занимают особое место в транспорте ионов и, соответственно, транспорте предшественников компонентов молока из крови, что в свою очередь обуславливает состав и свойства секрета и, как следствие, качество выработанных из него продуктов $(3,4)$.

Неодинаковый уровень активности АТФаз молока коров различных пород $(1,2)$ как индикатор метаболизма оказывает влияние на физико-химические свойства молока и зависит от ряда факторов: возраста животных, условий кормления, сезона года.

В целом, минимальная АТФазная активность мембран глобул молочного жира (MFGM) коров черно-пестрой и симментальской пород отмечалась весной, а максимальная - зимой. Было обнаружено, что $\mathrm{Na}+, \mathrm{K}+$-АТФаза была наиболее активной в пробах молока от коров симментальской породы (кроме того, зимой на 31,2\% выше по сравнению с весной), тогда как НСО3- -АТФаза имела самую низкую активность (на 42,1\% ниже весной по сравнению с зимой). Аналогичная картина наблюдалась в случае образцов молока от черно-пестрых коров: активность $\mathrm{Na}+, \mathrm{K}+$-АТФазы была самой высокой (на 32,7\% выше зимой по сравнению с весной), тогда как активность НСО3- - АТФаза (на 41,9\% ниже весной по сравнению с зимой).

Увеличение активности транспортного фермента и, следовательно, интенсивности обмена веществ у обеих пород коров в осенний и зимний периоды связано с высоким накоплением питательных веществ в организме и особенностями периода лактации.

Результаты корреляционно-регрессионного анализа с высокой достоверностью ( $<<0,001)$ показали наибольшее влияние времени года на $\mathrm{Na}+$, $\mathrm{K}+$-АТФазную активность жировых шариков молока обеих пород: коэффициент детерминации в группе черно-пестрых коров было 0,934, в группе симменталов - 0,950. Са2 + -АТФазная активность жировых шариков чернобелого коровьего молока зависела от сезона на 84,92\%, коровьего молока симментальской - на 91,51\%. 
Наименьшая степень влияния сезона на АТФазную активность глобул молочного жира в группе черно-пестрых коров отмечена для $\mathrm{Mg} 2+$-АТФазы (коэффициент детерминации составил 0,81 ), в группе коров симменталов - для НCO3- -АТФазы (коэффициент детерминации составил 0,84).

Двухфакторный дисперсионный анализ, где независимыми факторами были сезон года (фактор А) и порода крупного рогатого скота (фактор В), показал, что активность $\mathrm{Mg} 2$ + -, $\mathrm{Na}$ +, $\mathrm{K}$ + -, $\mathrm{Ca} 2$ + - и $\mathrm{HCO} 3-$ - АТФазы мембран жировых глобул молока крупного рогатого скота с высокой степенью достоверности (Р $<0,001$ ) определяли по сезону (около $41,43 \%$; 60,62\%; $54,27 \%$ и $62,28 \%$ соответственно).

Влияние породы крупного рогатого скота было достоверно $(\mathrm{P}<0,05)$ выраженным в случае активности $\mathrm{Na}+, \mathrm{K}+$-АТФазы (коэффициент детерминации составил 0,156). В случае других АТФаз влияние породы крупного рогатого скота было незначительным (3,3-8,8\%). Совместное влияние этих факторов на активность всех исследованных АТФаз не было выявлено для конкретного сезона.

Также, двухфакторный дисперсионный анализ был выполнен с учетом следующих независимых факторов: сезон (фактор А) и оуабаин (фактор В). Присутствие оуабаина показало наибольшее влияние на общую активность АТФазы с высокой степенью достоверности (Р <0,001). Таким образом, коэффициент детерминации в породе симментальской породы составил 0,95; в группе черно-пестрой породы - 0,92. Влияние сезона было незначительным для обеих пород скота $(0,82 \%$ и $1,32 \%$ соответственно) и с низкой достоверностью $(\mathrm{P}>0,05)$ для обеих групп крупного рогатого скота.

Так называемая «динамическая активность» изучаемых АТФаз (в течение года) была менее выраженной в случае образцов молока от черно-пестрых коров, вероятно, из-за уменьшения поступления предшественников молока через мембрану секреторных клеток. В пробах молока от коров симментальской породы содержалось больше всего сухого вещества, жира и белка.

Выявленные сезонные колебания АТФазной активности молока коров обеих пород служат индикатором обменных процессов в организме животных, обусловленных сезонной линькой, снижением уровня накопленных питательных веществ в организме, периодом отелов, что напрямую отражается на химическом составе и свойствах (физико-химических, биохимических и технологических) молока как сырья для переработки.

\section{Литература}

1. Мосягин В.В., Максимов В.И., Федорова Е.Ю. Возрастная динамика АТФазной активности эритроцитов крупного рогатого скота симментальской и черно-пестрой породы // Вестник Орловского государственного аграрного университета. 2011. № 1 (28). С. 59-60.

2. Максимов В.И., Мосягин В.В., Фурман Ю.В., Федорова Е.Ю. Особенность функционирования АТФазных ферментных систем эритроцитов у птиц свиней и крупного рогатого скота // В сборнике: Современная физиология: 
от клеточно-молекулярной до интегративной - основа здоровья и долголетия. 2011. С. 172-173.

3. Федорова Е.Ю., Максимов В.И., Василевич Ф.И. Физиологобиохимические особенности АТФазной активности крови и молока коров / Монография. Курск. 2016.

4. Федорова Е.Ю., Пушкина В.Н., Гернет И.Н., Сизов А.Е. Типовой портрет физической активности обучающихся общеобразовательных организаций Москвы // Ученые записки университета им. П.Ф. Лесгафта. 2019. № 9 (175). С. 304-309.

5. Федорова Е.Ю., Василевич Ф.И., Максимов В.И. Возрастная динамика АТФазной активности молока коров черно-пестрой и симментальской пород // Ученые записки Казанской государственной академии ветеринарной медицины им. Н.Э. Баумана. 2013. Т. 214. С. 470-473.

6. Федорова Е.Ю. Особенности функционирования АТФаз крови и молока различных видов сельскохозяйственных животных // Вестник Курской государственной сельскохозяйственной академии. 2015. № 8. С. 181-184.

7. Максимов В.И., Мосягин В.В., Фурман Ю.В., Федорова Е.Ю. Особенности функционирования АТФазных ферментных систем эритроцитов у птиц, свиней и крупного рогатого скота // В сборнике Современная физиология: от клеточно-молекулярной до интегративной - основа здоровья и долголетия 2011. С. 172-173.

8. Федорова Е.Ю., Максимов В.И. Породные особенности функционирования АТФазных ферментных систем эритроцитов и молока коров // Вестник Российской академии сельскохозяйственных наук. 2012. № 4. С. 77 78.

9. Красильников А.А., Федорова Е.Ю. Медико-социальные особенности пациентов со стенокардией и сахарным диабетом 2 типа // В сборнике: СУЧАСНI ВИКЛИКИ І АКТУАЛЬНІ ПРОБЛЕМИ НАУКИ, ОСВІТИ ТА ВИРОБНИЦТВА: МІЖГАЛУЗЕВІ ДИСПУТИ. Матеріали IX Міжнародної науково-практичної інтернет-конференції. 2020. С. 255-264.

10. Stradze A.E., Pushkina V.N., Fedorova E.Yu., Sizov A.E., Emelyanov A.V. Using wearable devices to stimulate students motor of physical activity and consequence physiological response // Propositos Y representaciones, 2020.T.8 № 2. C. 8 .

11. Пушкина В.Н., Оляшев Н.В., Гернет И.Н., Федорова Е.Ю. Функциональные способности кардиореспираторной системы у лиц с разным типом кровообращения // В сборнике: Физическая культура, спорт, туризм: инновационные проекты и передовые практики. Материалы Международной научно-практической конференции, посвященной 90-летию основания кафедры физического воспитания. Под редакцией Л.Б. Андрющенко, С.И. Филимоновой. 2019. C. 711-718.

12. Stradze A.E., Pushkina V.N., Fedorova E.Yu., Sizov A.E., Emelyanov A.V. Study of school child motor activity using individual wearable devices - fitnesstrackers // Religacion. Revista De Ciencias Sociales Y Humanidades.- Vol. 4 Núm. 19 (2019): 30 años después de la caída del muro de Berlín: la izquierda latinoamericana. 
13. Zakirov F.Kh., Krasilnikov A.A. Age-related differences in decision-making process in the context of healthy aging // В сборнике: BIO Web of Conferences. 2020. C. 01022 .

14. Мосягин В.В., Федорова Е.Ю. Возрастная динамика АТФазной активности эритроцитов у свиней и крупного рогатого скота // Проблемы биологии продуктивных животных. 2011. № 1. С. 85-88.

15. Суворова В.Н., Федорова Е.Ю., Максимов В.И. Особенности функционирования АТФаз овец // Acta Naturae (русскоязычная версия). 2016. № S1. C. 195-196.

16. Федорова Е.Ю., Василевич Ф.И., Максимов В.И. АТФазная активность молока коров в зависимости от сезона года // В сборнике: Адаптационные механизмы и регуляция физиологических функций. 2017. С. 15-19.

17. Zakirov F. H., Krasilnikov A. A., Pushkina V. N., Gernet I. N., Andruschenko L. B., Yamaletdinova G. A. The role of damages and epigenetic modifications of dna in alzheimer's disease // Indo American Journal of Pharmaceutical Sciences. 2019. - T. 6. - №5 - С. 9700-9703.

18. Василевич Ф.И., Максимов В.И., Федорова Е.Ю. Оценка активности различных АТФ-аз в секретах и тканях коров // В сборнике: Достижения и перспективы супрамолекулярной и биологической химии в биомедицине и сельском хозяйстве. 2017. С. 7.

19. Пушкина В.Н., Гернет И.Н., Федорова Е.Ю., Оляшев Н.В. Трансформация подходов к занятиям физической культурой в современной образовательной среде // В сборнике: Трансформация подходов к физическому воспитанию в образовательных организациях. сборник статей по материалам Межрегиональной научно-практической конференции института естествознания и спортивных технологий. 2019. С. 102-107. 


\title{
OS EXERCÍCIOS INTERDISCIPLINARES COMO MEIO EFICIENTE DE INTEGRAR O ENSINO DE QUÍMICA COM MATEMÁTICA NAS CONDIÇÕES DE ENSINO REMOTO
}

\author{
Tkach Volodymyr \\ Universidade Nacional de Chernivtsi, Ucrânia \\ Kushnir Marta \\ Ginásio \#5 Municipal de Chernivtsi, Ucrânia \\ Minakova Tetyana \\ Ginásio \#5 Municipal de Chernivtsi, Ucrânia
}

A propagação rápida do SARS-CoV-2, que levou a um andaço progressivo da doença CoViD-19 no mundo inteiro, impôs aos estabelecimentos de ensino a incumbência de adaptar à realidade escolar as técnicas de ensino remoto. Destarte, além de providenciar o acesso às plataformas digitais de videoconferências, como Google Meet, Zoom, Microsoft Teams, entre outras, é necessário conduzir o processo letivo dentro da nova realidade.

A depender to tipo de aula, usam-se várias estratégias de aumentar a eficácia do ensino remoto, difíceis ou até pouco possíveis de usar em sala de aula. Dessas estratégias as mais usadas são entrevistas com expertos, visitas guiadas virtuais e, também, as aulas integradas e binárias, em que a aula é conduzida de duas ou mais disciplinas ao mesmo tempo seja apenas por um professor, seja por professores de todas as cadeiras envolvidas na produção de aula.

Haja vista que o aluno sói estar mais distraído numa aula remota que em sala de aula, é preciso aplicar um esforço a mais para atrair a atenção dele. Outrossim, surge o problema de ensinar a matéria ao aluno de forma diferente das tradicionais - tanto nas aulas teóricas como nas práticas. Destarte, a resolução de ambos os problemas é de maior importância para a condução eficiente do ensino à distância, e o uso de aulas integradas, aliado à resolução de exercícios integrados ajudar-nos-ia na resolução de ambos os assuntos em questão.

Neste trabalho, será avaliada a possibilidade de combinar o ensino de Química com o de Matemática no âmbito escolar em tempos da pandemia por meio da resolução de 
questões integradas. $\mathrm{O}$ grupo de autores desta pesquisa, tendo analisado os exercícios de Química, incluídas nas provas de Vestibular nas universidades federais brasileiras nos anos 2000 e 2010, aproveitou esta experiência para a elaboração de exercícios integrados e a sua resolução em sala de aula. Ao contrário dos exercícios pura e simplesmente teorizados, tradicionalmente usados nas escolas da Ucrânia, estes vêm sendo mais adaptados ao uso prático do tema. Isto é previsto na concepção pedagógica de Paulo Freire, que propõe isto como uma alternativa ao sistema tradicional de acumulação de conhecimentos pelo aluno sem percepção clara do próprio conceito.

Sendo uma das ciências exatas, a Química usa o aparato de Matemática para descrever as suas regras e leis sob a forma de relação quantitativa. Por outro lado, Matemática, como disciplina mais universal, precisa de um apoio aplicativo, quando vem ensinada no curso escolar. O lecionamento isolado de duas disciplinas mencionadas fará a estratégia de ensino errada e o conhecimento adquirido pusilânime. Destarte, a integração de ambas as disciplinas é necessária, o que pode ser realizado na resolução de questões integradas, que envolvem o uso de conhecimento de ambas as matérias.

Por exemplo, ambas as disciplinas utilizam o conceito de volume. A conexão entre Matemática e Química, destarte, realizar-se-ia de várias maneiras. O parâmetro geométrico poderia ser calculado a partir dos parâmetros químicos e outro parâmetro geométrico e vice-versa. Outra conexão poderia ser feita na elaboração e resolução de equações matemáticas, baseadas nos coeficientes da equação química balanceada. Estes tipos de interdisciplinaridade pôr-se-iam em prática com facilidade, especialmente nas condições de ensino remoto.

Eis um exemplo de um exercício interdisciplinar, que pode ser oferecido numa aula integrada remota. O exercício vem sendo acompanhado da sua resolução.

1. Em Fevereiro de 2018, houve um acidente na aula de Química na Escola Secundária George Elliot no Condado de Lake, Colúmbia Britânica, Canada. Ao tentar mostrar aos seus alunos a reação de "vulcão de bicromato", o professor não tomou todas as medidas necessárias de precaução, o que resultou num incêndio. $O$ prejuízo causado foi de até 60 mil dólares canadianos.

Segundo o noticiário local, ao realizar a reação, o professor não usou o jaleco, as luvas e os óculos de segurança, necessários para realizar a reação com cuidado. Outro erro do professor foi faltar em ligar a ventilação na sala e despejar os restos dos reagentes na lixeira comum em vez do contentor especial. Assim, a lixeira de plástico ficou inflamada, o que resultou na propagação rápida do fogo pelos elementos de madeira no prédio escolar. 
Como resultado, o conselho provincial de educação afastou o professor das suas funções. Além do prejuízo, o conselho considerou que a demonstração da reação de “vulcão de Boetther" em escolas era proibida em vários países, não só por necessidade de aplicação de medidas de segurança, mas também pela toxicidade do reagente e do produto sólido da reação.

$$
a\left(\mathrm{NH}_{4}\right)_{2} \mathrm{Cr}_{2} \mathrm{O}_{7} \rightarrow b \mathrm{Cr}_{2} \mathrm{O}_{3}+c \mathrm{~N}_{2}+d \mathrm{H}_{2} \mathrm{O}
$$

O bicromato de amónio manifesta ações mutagénica, cancerígena, alergénica e genotóxica. Outrossim, a inalação de vapor ou poeira, que contém o bicromato de amónio, além do produto da sua descomposição - óxido de cromo trivalente, pode provocar asma. Destarte, a proibição da demonstração do "vulcão" em sala de aula tem senso, e a própria demonstração pode ser feita mediante a reprodução de vídeo.

1.1. Balanceie a reação e resolva a equação $x^{2}-a x-(b+c+d)=0 . A$ raiz positiva da equação é correspondente ao número atómico de um dos metais alcalinos. Qual?

$$
\left(\mathrm{NH}_{4}\right)_{2} \mathrm{Cr}_{2} \mathrm{O}_{7} \rightarrow \mathrm{Cr}_{2} \mathrm{O}_{3}+\mathrm{N}_{2}+4 \mathrm{H}_{2} \mathrm{O}
$$

$$
a=1, b=1, c=1, d=4
$$

$$
\begin{gathered}
\mathrm{x}^{2}-\mathrm{x}-6=0 \\
\mathrm{D}=1+24=25 \\
x_{1,2}=\frac{1 \pm 5}{2}=\left\{\begin{array}{c}
x_{1}=3 \\
x_{2}=-2
\end{array}\right.
\end{gathered}
$$

O elemento, cujo número é 3, é, realmente, um dos metais alcalinos e é o lítio: ${ }_{3}^{7} \mathrm{Li}$.

1.2. Indique a única opção errada sobre a reação

a) O grau de oxidação de cromo decresce durante a reação, enquanto que o grau de oxidação de nitrogénio cresce - $C$

b) O grau de oxidação de nitrogénio no íon amónio é igual a -4 - E

c) Quando um mol de bicromato de amónio se descompõe, obtém-se um resíduo sólido $100 \mathrm{~g}$ menos pesado - C

d) A descomposição de uma substância com uma ligação dativa rende três outras substâncias, sendo uma apolar - C 
e) O sal de um ácido de cromo transforma-se num óxido anfotérico - C

A: O grau de oxidação de cromo decresce de +6 até +3 , e o grau de oxidação de nitrogénio cresce de -3 a 0 . Então, a opção A está certa.

B: O grau de oxidação de nitrogénio no íon amónio é igual a -3, e não -4. Então, a opção $B$ está errada.

C: A massa molar do bicromato de amónio é de $252 \mathrm{~g} / \mathrm{mol}$, e do óxido de cromo (III), de $152 \mathrm{~g} / \mathrm{mol}$. Como os seus coeficientes são iguais, a diferença far-se-á, realmente, de $100 \mathrm{~g}$. Então, a opção C está certa

D: O íon amónio possui uma ligação dativa, e a molécula de nitrogénio é apolar. Então, a opção D está certa

E: Bicromato é anião, correspondente a uma das formas ácidas de crómio hexavalente. Já o óxido de crómio trivalente pode agir tanto como básico, quanto como ácido. Então, a opção E está certa.

1.3. Num laboratório, a reprodução do vulcão químico rendeu um gás, que, em condições normais, preenche o vaso de paralelepípedo. A longitude do vaso é de $80 \mathrm{~cm}$, a latitude de $40 \mathrm{~cm}$ e a altitude de $2 \mathrm{~cm}$. Calcule o peso do bicromato, que reagiu.

A resolução desta questão exige o conhecimento básico de geometria. É necessário achar o volume da vasilha de nitrogénio, para obter o peso do bicromato, necessário para obtê-lo.

Para obter o volume da vasilha, multiplicamos a longitude, a latitude e a altidude do vaso:

$$
V=a b h=80 * 40 * 2=6400 \mathrm{~cm}^{3}
$$

A quantidade de nitrogénio em mols, destarte, obter-se-á com a divisão do volume pelo volume molar. Neste caso, obtém-se uma fração normal:

$$
N=\frac{V}{V_{m}}=\frac{6400 \mathrm{~cm}^{3}}{22400 \mathrm{~cm}^{3} / \mathrm{mol}}=\frac{2}{7} \mathrm{~mol}
$$

Haja vista a equação balanceada da reação, podemos concluir que a relação molar entre o bicromato e nitrogénio gasoso é de 1:1. Destarte, a quantidade de nitrogénio e do bicromato é igual. O peso do bicromato pode ser calculado com a multiplicação da 
massa molar do bicromato de amónio pela quantidade dele, encontrada na reação (2). Como o valor aproximado da massa molar do bicromato de amónio é divisível por sete, a fração desaparece (3):

$$
m_{\text {bicr }}=252^{g} / \mathrm{mol}^{*} \frac{2}{7} \mathrm{~mol}=72 \mathrm{~g}
$$

Como se vê, o exercício tem um prefácio, que mostra ligação clara do material em questão à vida real. Este prefácio tem vistas a aumentar o interesse pelos discípulos no conhecimento químico.

Três testes, que fazem parte do exercício, são diferentes entre si e avaliam os diferentes conceitos de conhecimento. O primeiro teste pode ter-se feito mais complicado, se ao aluno for perguntado não só achar os coeficientes da equação balanceada, mas também reproduzir a própria equação.

A parte de escolha múltipla exige análise clara de cada uma das alternativas para que seja dada uma resposta certa. A análise das alternativas exige conhecimento suficiente na área descrita e exclui a possibilidade de "adivinhar" a resposta.

Alfim, a terceira parte contem duas etapas - a matemática e a química. A etapa matemática deixa calcular o volume do gás a partir dos parâmetros geométricos da vasilha. Então, o valor do volume é usado na etapa química e deixa concluir o exercício.

Do supracitado, pode-se concluir que a integração de Química com Matemática é uma ferramenta eficiente para aumentar o interesse dos alunos no estudo. Além de providenciar a ligação clara com a aplicação do conhecimento adquirido, ela providencia uma aprendizagem mais eficaz no ensino à distância. 


\title{
A DESCRIÇÃO TEÓRICA DA DETECÇÃO ELETROANALÍTICA DO ALCALOIDE PIRROLIZIDÍNICO RETRONECINA, ASSISTIDA PELO COMPÓSITO DE POLINAFTOQUINONAS COM O OXIHIDRÓXIDO DE COBALTO
}

\author{
Volodymyr V. Tkach, \\ Universidade Nacional de Chernivtsi, Ucrânia \\ Yana G. Ivanushko, \\ Universidade Estatal de Medicina de Bucovina, Ucrânia \\ Adriano O. da Silva \\ Universidade Federal do Oeste do Pará, Brasil
}

Retronecina (Fig. 1) é um dos representantes dos alcalóides pirrolizidínicos, encontrados em várias plantas alimentares e decorativas. É uma substância com efeitos hepatotóxico, pneumotóxico, carcinogénico e mutagénico. A toxicidade é dependente da dose, podendo, destarte, ser crónica e fatal. Assim, o desenvolvimento de um método de detecção rápida e eficiente das suas concentrações é realmente atual, e os métodos eletroanalíticos poder-se-iam usar com eficácia.

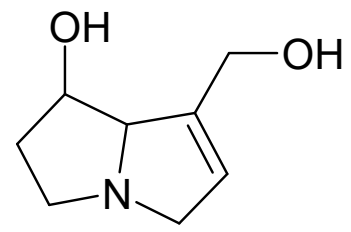

Fig. 1. Retronecina

Como a retronecina contém grupos, fáceis de oxidar, os métodos de oxidação anódica aplicar-se-ão bem ao caso. Entretanto, os elétrodos não modificados são inconvenientes, haja vista a sobretensão e adsorção dificultada do analito. Assim, o elétrodo deverá ser modificado para o uso em sistema eletroanalítico.

Existem vários modificadores de elétrodo, já usados para oxidar os compostos semelhantes. Um deles é o oxihidróxido de cobalto. É um material semicondutor do tipo $\mathrm{p}$, visto por alguns dos pesquisadores como alternativa ao dióxido de titânio, mas, ao contrário deste, com uma maior flexibilidade no comportamento eletroquímico, já 
que possui o cobalto em grau de oxidação mediano. A possibilidade de o oxihidróxido de cobalto oxidar os álcoois e fenóis já tem sido verificada teórica e experimentalmente. Outrossim, a própria basicidade da retronecina aumenta a capacidade do oxihidróxido de cobalto de oxidá-la, já que $\mathrm{CoO}(\mathrm{OH})$ é um oxidante eficaz em meio básico.

Para aumentar a eficácia do oxihidróxido de cobalto, bem como a sua estabilidade em condições da electroanálise, ele se depõe sobre o polímero condutor orgânico na sua forma oxidada. Um dos exemplos pode ser a naftoquinona.

Entretanto, já que todos os sistemas semelhantes soem acompanhar-se por instabilidades eletroquímicas, como a oscilatória e monotónica, que podem prejudicar a eficiência eletroanalítica, é preciso, antes de ser usado na prática, avaliar o novo método eletroanalítico por meio de uma análise teórica. Isto será feito neste trabalho.

O mecanismo do desempenho do oxihidróxido de cobalto com a retronecina pode-se descrever conforme a Fig. 2:

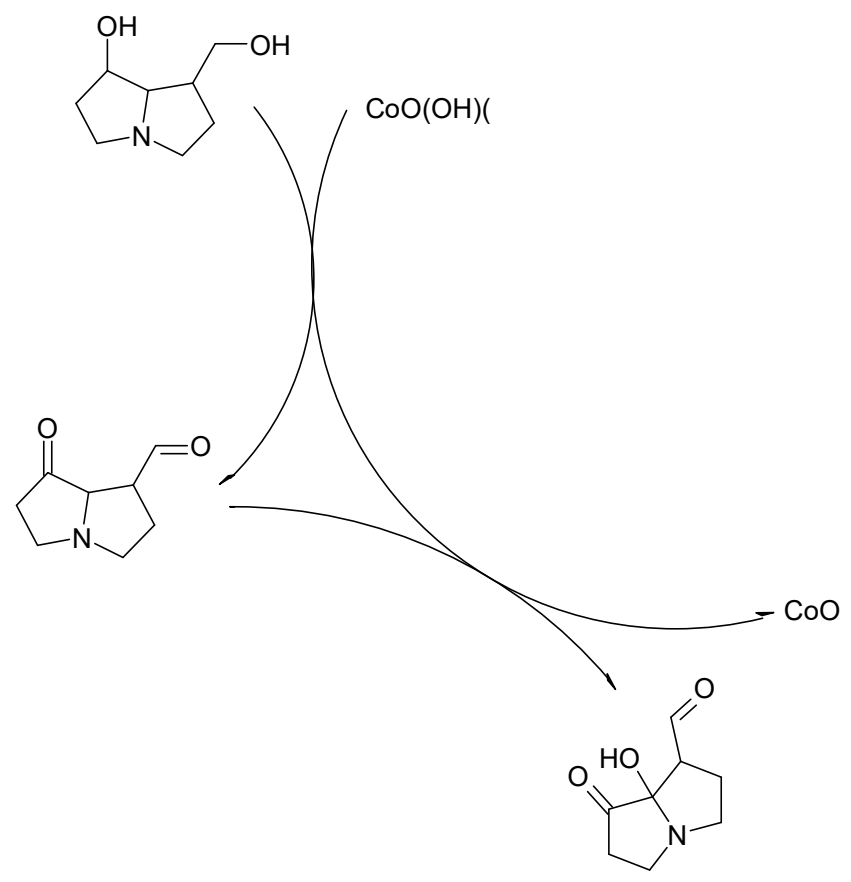

Fig. 2. Mecanismo da eletrooxidação da retronecina sobre o $\mathrm{CoO}(\mathrm{OH})$

Na primeira etapa, forma-se uma aldeidocetona. Por outro lado, a realização da reação na segunda etapa é favorecida pela formação da ligação de hidrogénio entre a nova hidroxila ternária e o grupo cetona. 
III International Science Conference on E-Learning and Education

Assim, havendo vista essa ligação, a probabilidade da instabilidade oscilatória far-se-á mais provável que no caso mais comum. No entretanto, isso não impede que seja o oxihidróxido de cobalto um modificador de elétrodo capaz de detectar eficientemente a retonecina. 


\title{
ЛІТЕРАТУРНІ УПОДОБАННЯ УКРАЇНСЬКОЇ МОЛОДІ: ВИКЛИКИ ЦИФРОВОЇ ЕПОХИ
}

\author{
Коцур Леся, \\ Кандидат історичних наук, доцент кафедри політології \\ Університету Григорія Сковороди в Переяславі \\ Віталій Коцур, \\ Доктор історичних наук, професор \\ кафедри публічного управління і адміністрування \\ Університету Григорія Сковороди в Переяславі
}

Читання і любов до книги є одним із найнеобхідніших навичок в житті будьякої людини. Начитані громадяни роблять неабиякий внесок у створення процвітаючого, працездатного суспільства. Відомо, що у 1990-х - на початку 2000-х рр. в Україні помітно знизився інтерес до книги. Але це було пов'язано не 3 книгою, а з складним фінансовим становищем у державі, і люди думали, як вижити та втриматися на плаву. Вже в умовах сучасного інформаційного суспільства надважливо зберегти любов до книги серед молоді, яка часто відволікається на інші спокуси запропоновані глобальною мережею Інтернет. У цьому контексті актуально проаналізувати, яку роль відіграє книга у житті сучасної української молоді, і які літературні смаки має сучасна українська молодь.

Так, за даними компанії TNS Ukraine, якщо ще в 2003 році молодих українців, які читають налічувалося 57\%, то в 2008-му вже 52\% [10]. Соціологи, бібліотекарі й експерти стверджують, що кожен четвертий українець не любить читати, особливо це помітно серед молоді. Наприклад, у 2009 р. щодня книжку відкривав $31 \%$ людей до 30 років, а у 2011 р. цей показник впав до 26\% [6]. В останні роки молодь усе рідше відвідує бібліотеки, а якщо і бере до рук художню літературу, то лише ту, яка входить в освітню програму. Дехто обмежується фразою: «Я читаю лише глянцеві журнали». Мовляв, читати зараз «не модно», та й навіщо, коли багато літературних творів, навіть класичних, екранізовано [15].

Проте, з такою думкою згідні не всі експерти і заперечують вищевказану тезу, наголошуючи на тому, що «молоді українці читають досить багато, просто вони це роблять інакше, аніж їхні ровесники десять- двадцять років тому». Зокрема, координатор літературного клубу «Маруся» Дмитро Стретович зазначає: «якщо у цій країні хтось і читає, так це молодь, особливо студентство», хоча потребу молоді в читанні український книжковий ринок і не задовольняє, оскільки мало якісної белетристики: детективів, жіночих романів та фантастики Підтримує таку точку зору й керівник рейтингу «Книжка року» Костянтин Родик 
- він зауважує, що якщо молодь не купує паперових книжок, це не означає, що вона їх не читає - просто читають електронні книги [6]. Хоча соціологічні опитування свідчать, що $90 \%$ респондентів надають перевагу книгам не 3 Інтернету, оскільки Інтернет вирізняється своєю безликістю та безособливістю, тоді як справжня книга має власну індивідуальність. І що найголовніше, вона має власника. Інтернетом молодь переважно користується для того, щоб читати наукову літературу чи ті книги, котрі є занадто рідкісними і дорогими, або ж яких взагалі не знайдеш на українському книжковому ринку [11].

Іншим фактором, на думку фахівців, $є$ те, що люди повертаються до бібліотеки, особливо часто ії відвідує молодь, яка шукає літературу, що розвиває. Має популярність література 3 психології, 3 основ економічної грамоти, цікавляться літературою з порадами побудови власного бізнесу, як проводити переговори, як комунікувати з іншими людьми, зав'язувати гарні знайомства тощо. Проте статистичні дані свідчать, що найбільше молодь читає художню літературу (77\%), фахову й детективи (12\%), любовні романи $(9 \%)$, класику (6\%), суспільно-історичну, мотиваційну (3\%) та релігійну (1\%) [16]. Натомість легенькі романи читають люди старшого покоління. Більше того, старше покоління більш активно відвідує бібліотечні заклади [5].

Цікавим $є$ те, що дівчата активніше відвідують бібліотеку, ніж юнаки [17]. Люди 3 вищою освітою читають більше. Більше того, люди, які читають та купують книжки, є значно активнішими - вони частіше за інших читають газети, журнали, слухають музику, ходять в кафе, кіно і на виставки. Парадоксально, що люди, які багато читають, також багато часу «сидять» в інтернеті. Переважно там вони шукають інформацію або читають новини [14].

При цьому, літературні смаки української молоді різняться. Зокрема, українська молодь віддає перевагу читанню книг сучасних українських авторів, а не класичної української літератури. Популярними є книги: Сергія Жадана, Оксани Забужко, Грицька Чубая, Надійки Гербіш, Павла Коробчука, Василя Шкляра, Ліни Костенко, Люко Дашвар, Тараса Прохаська, Юрка Іздрика, «Століття Якова» Володимира Лиса та інших [15]. Популярними серед молоді $\epsilon$ й історичні романи Семена Скляренка - «Святослав» і «Володимир» [8]. У списку «Топ-10 найбільш популярних зарубіжних книг для молоді» на сьогоднішній день входять наступні твори: Михайло Булгаков «Майстер i Маргарита», Стефані Майєр «Сутінки. Сага», Пауло Коельо «Алхімік», Габріель Гарсіа Маркес «Сто років самотності», Януш Вишневський «Самотність в мережі», Джоан Роулінг «Гаррі Поттер», Антуан де Сент-Екзюпері «Маленький принц», Федір Достоєвський «Злочин і кара», Маргарет Мітчелл «Віднесені вітром», «Щоденник Анни Франк» та ін. [18]. Також популярними книгами сьогодні є «Полювання на овець» Харукі Муракамі та «Метро 2033» Дмитра Глухівського [4]. А серед філософів абсолютними лідерами є Маркс, Ніцше і Сартр [11].

Від себе слід додати, що вражаючими книгами є: оповідання американського психотерапевта Ірвіна Ялома «Ліки від кохання та інші оповіді психотерапевта»; «Утопія» Томаса Мора; роман-антиутопія «1984», Джорджа Орвела; 
«Психологія народів і мас» Г. Лебона та ін. Проте саме зазначені книги, читати слід усвідомлено і у більш зрілому віці.

Щодо преси, то світові показники вказують, що 56\% молоді віком 18-34 роки читають друковані медіа або їхні онлайн-еквіваленти. 60\% представників цієї вікової групи довіряють контенту локальних видань чи їхнім вебсайтам. I 55\% таких вірять, що друковані 3МІ дотримуються етичних норм та слугують громадським інтересам [22]. Водночас британська молодь читає паперові версії газет частіше за електронні [1]. В Україні кількість людей, які щоденно читають новини в інтернеті до Євромайдану і війни на сході, становила, за словами медіаексперта Максима Саваневського, 280 тисяч чоловік. Наразі ж вона складає близько 1 мільйона. Якщо раніше новини, які читали українці в соцмережах - це жовта преса, то тепер в лідерах - матеріали про зону АТО. Такі матеріали впливають на людину, розхитуючи нервову систему. Після десятка таких новин зі стрічки в соцмережі у людини часто пропадає бажання брати у руки книжку [13].

Фахівці наголошують, що коли не впроваджувати програм 3 популяризації читання серед молоді, якщо не змінювати ставлення до книги, країна втрачатиме інтелектуальний потенціал нації. Адже книга вчить думати. Навіть розважальна література дозволяє працювати нашій уяві, дає змогу концентруватися i сприймати культурний код мови. Більше того, брати Капранови показали цікаву статистичну тенденцію під час президентських виборів 2004 р.: що менше бібліотек в області на 10 тисяч виборців - то більший відсоток підтримки був у Януковича, а не Ющенка [13].

Тому, для заохочення молоді до читання й популяризації книги бібліотекарі й активісти використовують різні креативні методи й заходи: «Тиждень молодіжної книги», «Великоолександрівська молодь читає», «Молодь читає країна процвітає» [19; 7]. Започаткований Всеукраїнський проект «Книжкова сотня» та Всеукраїнська акція «Українська молодь читає». Зокрема, акція має на меті залучити до читання 1000000 зацікавлених [2]. Всеукраїнська акція «Україна читає», Всеукраїнська ініціатива «Додай читання», продовженням якої стала книжкова виставка «Київська весна 2015». Проекти «Книга в літньому рюкзаку», «Читацькі рекорди», «Диво в книгах» та інші [9]. Спецпроект «Читай. Молодь» - передбачає публікування розмов з цікавими, творчими та начитаними молодими людьми з різних куточків України [12]. У Харкові діє літературний осередок, основним напрямом діяльності якого $є$ популяризація читання як способу життя. Крім літературних зустрічей і конкурсів, мешканці міста започаткували створення якісної бібліотеки, суть якої полягає у тому, що необхідно придбати один цікавий журнал, прочитати його і принести до бібліотеки. Після цього, читач-благодійник отримує право протягом одного місяця читати будь-які інші журнали [21]. У Луцьку культурне об'єднання «100 Вт» започаткувало проект «3 домашньої бібліотеки», метою якого є об'єднання книголюбів, аби вони могли спілкуватись та обмінюватись враженнями від книги [20].

Масштабним дійством 2018 року було проведення з 30 травня по 3 червня 2018 року у Мистецькому Арсеналі VIII-го Міжнародного фестивалю 
«Книжковий Арсенал» на якому представили свої літературні доробки близько 200 українських письменників і 100 гостей з 31 країн світу. Окрім того, інтелектуальна подія країни об'єднала літературу й мистецтво. Понад 150 видавництв і нішевих проектів представили свої найкращі новинки, а дизайнери, ілюстратори, художники - виставкові проекти [3]. Характерно, але молодь була одним із найактивніших учасників цього заходу.

Отже, українська молодь дійсно цінує книгу. I хоча, відсоток читаючої молоді дійсно не високий, але з кожним роком він зростає, оскільки читати нині модно. Позитивним у цьому плані $\epsilon$ те, що кожного року в Україні відбувається десятки й сотні заходів як на загальнодержавному, так і на регіональному та місцевому рівнях, покликаних популяризувати книгу. Не менш важливо, коли участь у таких проектах, програмах і флешмобах беруть статусні й авторитетні люди, з яких молодь бере приклад. Також в Україні активно популяризують книгу педагоги та освітяни. Проте як зазначають фахівці: любов до книги має формуватися, у першу чергу, в родинному середовищі, про що слід пам'ятати.

\section{Література}

1. Британська молодь читає паперові версії газет частіше за електронні / 14 грудня, 2017 / https://ua.ejo-online.eu/3860/mediaekonomika/brytanska-molodchytaye-paperovi-versii-gazet (07.08.2018).

2. Всеукраїнська акція «Українська молодь читає» http://reading.4uth.gov.ua/addmillion (07.08.2018).

3. Книжковий Арсенал 2018 / https://artarsenal.in.ua/uk/knyzhkovyj-arsenal/proproekt/ (09.08.2018).

4. Мода на літературу: що зараз модно читати / MegaSite.In.UA, Статті, поради, інструкції / http://megasite.in.ua/109374-moda-na-literaturu-shho-zarazmodno-chitati.html (07.08.2018).

5. Молодь зараз читає більш глибоку літературу / Pogliad.ua - Вторник, 07 Августа 2018 / https://pogliad.ua/ru/news/interview/molod-zaraz-chitae-bilshgliboku-literaturu-346290 (07.08.2018).

6. Молодь читає, просто інакше - книжковий експерт / Анастасія Москвичова, 05 Жовтеня 2012, «Радіо свобода» https://www.radiosvoboda.org/a/24730139.html (07.08.2018).

7. «Молодь читає - країна процвітає» / 2016 / http://partnerpres.km.ua/articles/molod-chytaye-krayina-protsvitaye-381.html (07.08.2018).

8. Про що зараз читає українська молодь / 2 ноября 2012, Тетяна Навроцька / https://blogs.korrespondent.net/blog/users/3231955-pro-scho-zaraz-chytaieukrainska-molod (07.08.2018).

9. Україна читає. Всеукраїнська молодіжна акція / Черкаси - 2015 / https://www.slideshare.net/Oks123/ss-45935260 (07.08.2018).

10. Українці читають книги найменше у Європі /ТСН, 12 серпня 2011 / https://tsn.ua/ukrayina/ukrayinci-chitayut-knigi-naymenshe-u-yevropi.html (07.08.2018).

11. Чи читає книги українська молодь? / «КиевВласть» - Новости Киева и http://kievvlast.com.ua/text/chi_chita_knigi_ukranska_molod53047 (07.08.2018). 
12. «Читай. Молодь»: Олена Проскуровська / 2016-08-26 / http://chytayua.com/blog.php?id=294 (07.08.2018).

13. Чому молодь не читає? / Інтернет-видання Полтавщина, 21 грудня 2014 / https://blog.poltava.to/povzyk/3683/ (07.08.2018).

14. Що і як читають українці / Ольга Красько, 11 вересня 2014 / https://zaxid.net/shho_i_yak_chitayut_ukrayintsi_n1322081 (07.08.2018).

15. Що читає молодь? / «Вісті Калущини», 15.08.2014 / http://vistikalush.com.ua/articles/category/society/2014/08/15/9692/view (07.08.2018).

16. Що читає молодь? / U-Report / https://ukraine.ureport.in/poll/2227/ (07.08.2018).

17. Що читає сучасна молодь? / Тетяна Василенко, 2009 p. / http://www.romen.org.ua/novosti-goroda/scho-chitae-suchasna-molod.html (07.08.2018).

18. Що читає сучасна молодь? / http://wjournal.com.ua/shho-chitaesuchasna-molod.html (07.08.2018).

19. Що читає сучасна молодь? http://volexrda.gov.ua/index.php?option=com content\&view=article\&id=2289:schochitae-suchasna-molod\&catid=1:novini-rda\&Itemid $=40$ (07.08.2018).

20. Що читає молодь Луцька / 4 грудня 2013 https://www.volynnews.com/news/city/shcho-chytaye-molod-lutska/ (07.08.2018).

21. Що читає молодь Харкова і які книги змінюють їі світогляд / Жанна Титаренко, 13 січня 2011 / https://varta.kharkov.ua/news/art/1083043 (07.08.2018).

22. $56 \%$ молоді читають газети чи їхні онлайн-ресурси - інфографіка / http://ms.detector.media/web/online_media/56_molodi_chitayut_gazeti_chi_ikhni_on laynresursi_infografika/ (07.08.2018). 


\title{
МЕТОДИЧНІ АСПЕКТИ ТА ПРАКТИЧНА РЕАЛІЗАЦІЯ ОБЛІКУ, АУДИТУ ТА АНАЛІЗУ ОСНОВНИХ ЗАСОБІВ ПІДПРИЕМСТВА
}

\author{
Бабенко Тетяна Євгенівна
}

Головко Катерина Євгенівна

\author{
Пожидасва Марина Володимирівна \\ Студенти \\ Харківський Інститут ПРАТ «ВНЗ» МАУП \\ м.Харків, Україна
}

Вступ. Від рівня забезпеченості підприємства основними засобами залежить ефективність організації виробничого процесу, випуск готової продукції та створення належних умов для праці. Сукупна вартість основних засобів визначає виробничу потужність підприємства, рівень віддачі, місткості, озброєності основними засобами й ряд інших техніко-економічних показників діяльності підприємства. Облік засобів праці повинен забезпечити таку інформацію: точну величину надходження, вибуття i переміщення основних засобів; своєчасне і правильне нарахування амортизації; визначення результату від реалізації і ліквідації окремих об'єктів; розрахунок витрат на ремонти; отримання даних про рух основних засобів, їх початкову i залишкову вартість та інші показники використання основних засобів.

Мета дослідження. Проведення аналізу господарської діяльності підприємства з метою виявлення стану господарських процесів на аналізуємому підприємстві, а також резервів їх поліпшення.

Методи дослідження. Використовувалися наступні методи: порівняння для встановлення відмінностей і спільних рис у досліджуваних процесах та явищах; абстрагування - для виділення суттєвих факторів, що мають найбільше значення для дослідження процесу руху основних засобів; аналіз - для деталізації предмету дослідження на складові частини; логічний - при побудові логіки й структури дипломної роботи; синтез - для з'єднання окремих рис предмета дослідження в єдине ціле; методичний апарат економіко-математичного моделювання, а саме: регресія - для виявлення складових, що забезпечують поліпшення рівня віддачі основних засобів підприємства; зведення - 3 метою формулювання рекомендацій, реалізація яких дозволить поліпшити ефективність господарювання.

Висновки. Економічна діяльність підприємств в Україні відбувається в умовах обмеженості інвестиційних ресурсів, що обумовлює необхідність 
раціонального використання наявних у них основних засобів. При дослідженні технічного стану основних засобів було виявлено, що завдяки перевищенню збільшення початкової вартості основних засобів над збільшенням суми їх зношеності відбулося зменшення коефіцієнта зношеності.

Позитивні зміни виявлені при аналізі ефективності використання основних засобів. Рівень використання основних засобів визначили за допомогою таких показників, як віддача i місткість основних засобів. Збільшення віддачі обумовило проведення факторного аналізу віддачі, який дав змогу виявити та оцінити ступінь впливу факторів на неї. Збільшення віддачі було обумовлено значним випередженням зростання обсягу продаж у порівнянні зі зростанням середньорічної вартості основних засобів. Продуктивність праці підвищилась за рахунок збільшення віддачі та озброєності основними засобами.

Незважаючи на складність в сучасних умовах економіки, оновлення основних засобів дозволить підвищити технічний рівень основних засобів, що $\epsilon$ найважливішим резервом зростання віддачі.

Підвищення ефективності використання основних засобів підприємства безпосередньо знизить собівартість виготовлюваних виробів, а в кінцевому підсумку дасть змогу збільшити прибуток підприємства та підвищити рентабельність його діяльності.

\section{Список використаних джерел.}

1. Податковий кодекс України від 02.12.2010 № 2755-VI [Електронний pecypc]. - Режим доступу: http://zakon4.rada.gov.ua/laws/show/2755-17

2. Положення про документальне забезпечення записів у бухгалтерському обліку від 24.05.1995 № 88 [Електронний ресурс]. - Режим доступу: http://zakon2.rada.gov.ua/laws/show/z0168-95

3. Положення (стандарт) бухгалтерського обліку 7 «Основні засоби»: затв. наказом Міністерства фінансів України від 27.04.2000 р. №92. [Електронний ресурс]. - режим доступу: http://zakon5.rada.gov.ua/laws/show/z0288-00.

4. Положення ( стандарту ) бухгалтерського обліку 14 «Оренда », що затверджено наказом Міністерства фінансів України від 28 липня 2000 р. № 181 зі змінами і доповненнями. [ Електронний ресурс ]. - Режим доступу : http://zakon4.rada.gov.ua/laws/show/z0487-00

5. 1С:Бухгалтерія для України [Електронний ресурс] - Режим доступу до pecypcy: http://1c.ua/v8/RegionalSolutions_UA_BUH.php.

6. Азаровська Ю.В. Міжнародна практика та вітчизняний досвід удосконалення обліку необоротних активів / Ю.В. Азаров // Студентський науковий вісник Миколаївського державного аграрного університету. Миколаїв. - 2010. - С. 9-14.

7. Андренко О. А. Конспект лекцій з дисципліни "Організація і методика аудиту" / О. А. Андренко; Харк. нац. акад. міськ. госп-ва. - Х.: ХНАМГ, 2012. $35 \mathrm{c}$.

8. Андросова О. Ф. Методика аудиту основних засобів і нематеріальних активів та їі вплив на якість аудиту / О. Ф. Андросова, К. А. Калугіна // Вісник 
Хмельницького національного університету. - 2011. - №3. - Т. 3. - С. 250-255 Режим 201133 3/250-255.pdf

9. Артюх О. В. Нарахування амортизації основних засобів у податковому та бухгалтерському обліку / О. В. Артюх, Л. В. Кукава // Вдосконалення результативності політики економічного зростання: теорія, організація та методика: збірник тез наукових робіт учасників міжнародної науково-практичної конференції для студентів, аспірантів та молодих учених (м. Київ, 11-12 листопада 2016 р.). У 2-х частинах. - Київ: Аналітичний центр «Нова Економіка», 2016. - Ч. 2. - С. 28-32.

10. Бабіч В. Витрати на ремонт та поліпшення основних засобів: обліковий і податковий аспекти [Текст] / В. Бабіч // Бухгалтерський облік і аудит. 2012. № 8. C. 10-13. 


\section{ІННОВАЦІЙНІ ФОРМИ ТУРИСТИЧНОГО ПРОДУКТУ В ГОТЕЛЬНОМУ БІЗНЕСІ}

\section{Бойко Вікторія Олександрівна,}

к.е.н., доцент

Херсонський державний аграрно-економічний університет

Драгота Ірина Петрівна,

здобувач вищої освіти

Херсонський державний аграрно-економічний університет

Сучасний туризм та готельна індустрія широко розповсюджені динамічні галузі, які суттєво впливають на економічний розвиток кожної країни, в період кризи COVID-19 понесли великі фінансові втрати [1]. Першу половину 2020 р. український готельний ринок проводжав без особливого жалю. Відсутність ділових туристів, зменшення наполовину заповнюваності готелів майже у всіх сегментах, зниження середнього чеку стали основними проблемами для готельєрів. Незважаючи на певний консерватизм у готельному та туристичному бізнесі всім довелося швидко адаптуватися до мінливих обставин та фіксувати провідні тенденції, створювати нові ідеї та переформатовувати бізнес.

Щоб пережити кризу, готельєри повинні були адаптувати продукт до нової реальності. Наприклад, глобальні готельні мережі, такі як Radisson та Accor, практикували поєднання готелів 3 офісними центрами, коворкінгами. Ribas Hotels Group розглядав таку можливість і для українського ринку. Починаючи 3 наметів для глемпінгу та тіпісів, закінчуючи каютами, юртами та будиночками на деревах - для тих, хто шукає поєднання сільської розкоші та незайманої природи, пропонуються десятки видів житла [2-4]. Попит на внутрішні напрямки для проведення відпусток, навіть попри побоювання підхопити вірус, був вельми стабільним фактично впродовж усього літа - із середини червня до початку навчального року у вересні.

Протягом останніх кількох років «глемпінг» став одним із тих популярних брендів туристичної галузі, що набув великої популярності серед мандрівників. Поєднуючи слова «гламур» та «кемпінг», ця тенденція зросла, оскільки підйом масового туризму змусив більше людей сприйняти екологічний дух відповідальних подорожей. Згідно з Оксфордським словником, глемпінг - це «форма кемпінгу, що передбачає розміщення та зручності, розкішніші за традиційні кемпінги». Вперше це слово було використано у Сполученому Королівстві у 2005 р., але до словника було додано лише у 2016 p. 
Зараз у світі налічується близько тисячі працюючих глемпінгів. На сьогоднішній день найбільші ринки - США, Британія і Австралія, а загальний обсяг світового ринку становить \$3 млрд. За даними британського туристичного бюро Campingselection, ринок глемпінгів зростає на $21 \%$ щорічно, і за прогнозами до 2021 р. його обсяг складе вже близько \$ 4 млрд. Глемпінг це набагато більше, ніж гарний намет, і по всьому світі $€$ безліч неймовірних напрямів - від популярних еко-глемпінгів, трейлерного глемпінгу або ж антарктичний лакшері-табір на льодовику [5].

Південна частина нашої країни - одне з таких місць, яке має значний ресурс $\mathrm{i}$ робочий потенціал для розвитку всіх видів туризму. Питання розвитку готельного та туристичного бізнесу в Херсонській області, на наш погляд, надзвичайно важливі, зрештою, вони орієнтовані як на зовнішній, так і на внутрішній соціально-економічний розвиток. Херсонщина - унікальна територія для туризму, відпочинку та рекреації, яка має достатньо переваг для формування та розвитку потужного курортно-туристичного комплексу. Область має широкий вихід до Дніпровської водної магістралі, і це єдина з областей України, яка має вихід одночасно до 2 морів - Чорного і Азовського. Саме на Херсонщині розташовані: єдина в Європі природна пустеля - Олешківські піски, найбільший у світі рукотворний ліс і навіть унікальні горні ландшафти посеред степу «Станіславські кручі» [6,7].

Короновірус цього року вніс суттєві зміни до планів відпочинку багатьох людей не лише для зовнішнього, але й для внутрішнього туризму. Громадяни України, для яких ціни відпочинку на морських і гірських карпатських курортах $\epsilon$ зависокими, здійснюють подорожі по відомим їм мальовничим місцям власними або орендованими автівками, маючи особисті намети для відпочинку та домашне харчування замість готельних номерів, ресторанів і кафе [8-12]. Альтернативою традиційним формам відпочинку та ночівлі можуть стати комфортабельні глемпінги, що не поступатимуться за зручностями готелям. Але на відміну від готелів, глемпінги мають великі переваги, їх можна встановлювати будь-де, переміщувати з місця на місце без оформлення всіляких бюрократичних довідок, лише 3 дозволу органів місцевого самоврядування. Глемпінги можна встановлювати там, де заборонене будь-яке будівництво - що очевидно неможливо з готелями та базами відпочинку.

Міністерством захисту довкілля та природних ресурсів України спільно 3 Асоціацією органів місцевого самоврядування «Сврорегіон Карпати - Україна» та національними природними парками було підготовлено проєкт «Глемпінги створення ексклюзивного туристичного продукту в природоохоронних територіях». Особливість проєкту - розвиток туризму на територіях природнозаповідного фонду, що не буде негативно впливати на природну екосистему. I 
саме глемпінги, зазначили у міністерстві, стануть тим поєднанням традиційних кемпінгів з комфортними умовами готельного типу для туристів.

Згідно з проєктом, комфортабельні кемпінги передбачено створити у Регіональному ландшафтному парку «Краматорський» (Донецька область), Національному природному парку «Синевир» (Закарпатська область), Національному природному парку «Сколівські Бескиди» (Львівська область) та Регіональному ландшафтному парку «Дністровський» (Івано-Франківська область). Цим проєктом планується підвищити ефективність використання туристичного потенціалу природоохоронних територій та створити ексклюзивний продукт для туризму - облаштування глемпінг-локацій» в мальовничих місцях України, що буде поштовхом для суттєвого зростання ii конкурентоспроможності серед передових туристичних держав.

\section{Список літератури:}

1. Oleksii LYULYOV, Yana US, Tetyana PIMONENKO, Aleksy KWILINSKI, Tetyana VASYLIEVA, Nataliya DALEVSKA, Jan POLCYN and Viktoriia BOIKO “ The Link Between Economic Growth and Tourism: Covid-19 Impact" Proceedings of the 36th International Business Information Management Association (IBIMA), ISBN: 978-0-9998551- 5-7, 4-5 November 2020, Granada, Spain.

2. Огляд ринку готелів: як відновлюються готелі України. URL:https://thepage.ua/ua/real-estate/gotelnij-rinok-ukrayini-golovni-trendi-za-1pivrichchya-2020-roku

3. Завідна Л. Д. Готельний бізнес : стратегії розвитку : монографія. К. : Київ. нац. торг.-екон. ун-т, 2017. 600 с.

4. Грановська В. Г., Бойко В. О. Функціонування екоготелів в Україні як чинник активізації підприємницької діяльності. Економіка АПК. 2020. № 3. С. 57 - 65. https://doi.org/10.32317/2221-1055.202003057

5. Намет з кондиціонером та Wi-Fi: що таке глемпінг та чи $\epsilon$ він в Україні. URL:https://shotam.info/namet-z-kondytsionerom-ta-wi-fi-shcho-take-hempinh-tachy-ie-vin-v-ukraini/

6. Бойко, В.О. Розвиток зеленого туризму у південному регіоні. Підприємництво в аграрній сфері: глобальні виклики та ефективний менеджмент: Матеріали I Міжнародної науково-практичної конференції у 2 ч. (с. 65-68). 12-13 лютого 2020, Запоріжжя, Україна: ЗНУ.

7. Boiko, V. O. Green tourism as a perspective direction for rural entrepreneurship development. Scientific approaches to modernizing the economic system: vector of development: collective monograph. Lviv-Toruń : Liha-Pres, 2020. pp. 1-18.

8. Бойко В.О., Драгота І.П. Глемпінг - ексклюзивний туристичний продукт сьогодення. The I International Science Conference on Multidisciplinary Research, January 19 - 21, 2021, Berlin, Germany. pp. 208-210 
9. Romanenko, Y. O., Boiko, V. O., Shevchuk, S. M., Barabanova, V. V., \& Karpinska, N. V. Rural development by stimulating agro-tourism activities. International Journal of Management, 2020. № 11(4), C. 605-613. doi:10.34218/IJM.11.4.2020.058

10. Kyrylov, Y., Hranovska, V., Boiko, V., Kwilinski, A., \& Boiko, L. (2020). International Tourism Development in the Context of Increasing Globalization Risks: On the Example of Ukraine's Integration into the Global Tourism Industry. Journal of Risk and Financial Management, 13(12), 303. https://doi.org/10.3390/jrfm13120303

11. Бойко В. О. Сільський зелений туризм в Україні: проблеми та перспективи. Агросвіт. 2020. № 22. $\quad$ С. $\quad$ 58-65. DOI: 10.32702/23066792.2020 .22 .58

12. Бойко В. О., Ключник А. В., Півньова Л. В. (2020). Зміцнення конкурентоспроможності підприємств екологічного (зеленого) туризму. Вісник Херсонського Національного Технічного Університету. №3. С. 213-222. https://doi.org/10.35546/kntu2078-4481.2020.3.28 


\section{ОЦНКА ВПЛИВУ НА ДОВКІЛЛЯ ТРАНСПОРТНИХ СПОРУД: КРИТЕРІЇ ТА ПОКАЗНИКИ}

\section{Бузан Галина Сергіївна}

Державна екологічна академія післядипломної освіти та управління

Реалізація Закону України «Про Оцінку впливу на довкілля» потребує розробки окремих нормативно-правових актів та документів, що дозволять ефективно здійснювати оцінку впливу на довкілля (ОВД) для окремих суб'єктів господарювання при реалізації проектної чи планової діяльності [1].

Першим суттєвим кроком, здійсненим в цьому напрямку для транспортних споруд (ТC), є прийняття двох нормативних документів, що запроваджують механізм здійснення ОВД: ДСТУ 9060:2020 Оцінка впливу на довкілля. Транспортні споруди. Критерії оцінки та показники впливу на довкілля [2] та ДСТУ 9061:2020 Оцінка впливу на довкілля. Транспортні споруди. Настанова щодо підготування звіту з оцінки впливу на довкілля [3].

Ці стандарти встановлюють критерії оцінки та показники впливів на довкілля автомобільних шляхів та доріг, мостів, гідроспоруд та інших транспортних споруд. Окрім впливів на об'єкти довкілля, включені критерії щодо енергоефективністі, ресурсозбереження (заміна природних матеріалів техногенними), впливів на соціальне і техногенне середовище. Такий підхід відповідає Стратегічним цілям державної екологічної політики до 2030 року та 12 Цілі сталого розвитку «Стале споживання і виробництво» [4]. І головне, - чіткі критерії дозволяють надати неупереджену оцінку, що забезпечує прозорість процедури для всіх учасників процесу будівництва, ремонту та експлуатації ТС: замовників, виконавців, перевіряючих органів, громадськості.

Розробка стандартів здійснювалася на основі принципів та процедур, представлених в міжнародному стандарті ISO 21929-1:2015 [5], що встановлює базові критерії оцінювання життєвого циклу об'єктів будування, а також низки інших міжнародних стандартів 3 екологічного управління, оцінки життєвого циклу, екологічної ефективності тощо.

Стандарти надають особливу увагу питанням збереження природних ресурсів, що застосовуються для будівництва та ремонту ТС. Ця практика широко застосовується в європейських країнах, в якості поняття «врятований матеріал». При визначені відсотку вмісту таких матеріалів по ряду умов застосування оцінюється еколого-економічна доцільність об'єктів.

Критерій та/або показник - це кількісний, якісний або описовий спосіб представлення певного впливу будівництва, реконструкції та/або експлуатації TC на один чи більше аспектів довкілля [6]. Критерії та/або показники відносять до сфери інтересів зацікавлених сторін і загальних цілей оцінювання. Вибір релевантної системи чи набору критеріїв та/або показників повинен відображати вплив ТС на довкілля, що потрапляє до сфери уваги зацікавлених сторін i належне представлення цілей оцінки [7]. 
Крім вимог, викладених у вищезазначених ДСТУ, під час ОВД ТС можуть застосовуватися принципи та процедури, представлені в ISO 21929-1 [5], ДСТУ ISO 14040 [8], ДСТУ ISO 14020 [9], ДСТУ ISO 14021 [10] та ДСТУ ISO 14024 [11]. Також у разі доцільності слід брати до уваги принципи, викладені в ISO $26000[12]$.

Під час розроблення критеріїв та показників оцінки впливу ТС на довкілля необхідно враховувати особливості ТС різних видів транспорту (наземного, водного та повітряного), місцеві особливості всіх компонентів довкілля, які ймовірно зазнають впливу планованої діяльності, взаємозв'язки між цими компонентами та ймовірний кумулятивний вплив на них від інших видів господарської діяльності чи об'єктів. Критерії та показники представляють аспекти ТС, які потенційно можуть впливати на екологічну стійкість. Основні зони захисту стосовно ТС - це екосистема; природні ресурси; здоров'я та процвітання; соціальна рівність; культурна спадщина; економічне процвітання; економічний капітал.

Головні аспекти впливу на довкілля ТС відносять до таких категорій:

- вплив на якість приземного шару атмосферного повітря;

- обсяг споживання невідновлювальних ресурсів;

- вплив на якість водного середовища;

- ефективність поводження з відходами;

- вплив на якість земельних ресурсів;

- вплив на якість геологічного середовища;

- фізичні чинники впливу на довкілля;

- вплив на рослинний і тваринний світ, заповідні об'єкти;

- вплив ТС на соціальне середовище;

- вплив ТС на техногенне середовище.

У таблиці 1 наведено базові критерії та показники їх оцінювання, а також особливості впливу на довкілля ТС різних видів транспорту [2], зокрема:

- базові критерії, що оцінюють впливи ТС на довкілля;

- показники, які характеризують впливи ТС на довкілля;

- основні впливи на довкілля, що є найбільш характерними для ТС певного виду транспорту. 
Таблиця 1

Базові критерії, показники та основні впливи ТС різних видів транспорту на довкілля

\begin{tabular}{|c|c|c|c|c|c|}
\hline \multirow{3}{*}{ Критерій } & \multirow{3}{*}{ Показник } & \multicolumn{4}{|c|}{$\begin{array}{c}\text { Транспортна галузь, до якої } \\
\text { відносять ТС }\end{array}$} \\
\hline & & \multicolumn{2}{|c|}{$\begin{array}{l}\text { TС наземного } \\
\text { транспорту }\end{array}$} & \multirow{2}{*}{ 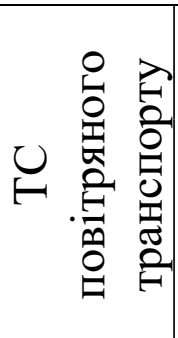 } & \multirow{2}{*}{ 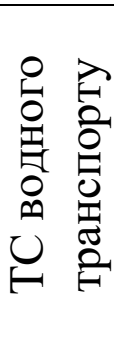 } \\
\hline & & $\begin{array}{l}\text { Рухомий } \\
\text { транспорт }\end{array}$ & $\begin{array}{l}\text { Доро } \\
\text { жні } \\
\text { спор } \\
\text { уди }\end{array}$ & & \\
\hline 1 & 2 & 3 & 4 & 6 & 7 \\
\hline \multirow[t]{4}{*}{$\begin{array}{l}\text { Якість } \\
\text { приземного } \\
\text { шару } \\
\text { атмосферного } \\
\text { повітря }\end{array}$} & $\begin{array}{l}\text { Масова концентрація } \\
\text { забруднювальної речовини у } \\
\text { приземному шарі } \\
\text { атмосферного повітря за } \\
\text { певний проміжок часу у } \\
\text { визначеній зоні впливу ТС }\end{array}$ & $\mathrm{XX}$ & $\mathrm{XX}$ & $\mathrm{XX}$ & $\mathrm{X}$ \\
\hline & $\begin{array}{l}\text { Вміст озоноруйнівних } \\
\text { речовини }\end{array}$ & $\mathrm{X}$ & - & $\mathrm{XX}$ & $\mathrm{X}$ \\
\hline & $\begin{array}{l}\text { Концентрація ПГ у } \\
\text { приземному шарі } \\
\text { атмосферного повітря у } \\
\text { визначеній зоні впливу ТС }\end{array}$ & $\mathrm{XX}$ & $\mathrm{X}$ & $\mathrm{XX}$ & $\mathrm{XX}$ \\
\hline & $\begin{array}{l}\text { Масова концентрація твердих } \\
\text { забруднювальних речовин } \\
\text { (пилу) }\end{array}$ & $\mathrm{XX}$ & $\mathrm{XX}$ & $\mathrm{X}$ & $\mathrm{X}$ \\
\hline \multirow{5}{*}{$\begin{array}{l}\text { Ресурсозбере- } \\
\text { ження. } \\
\text { Енергозбере- } \\
\text { ження }\end{array}$} & $\begin{array}{l}\text { Використання металургійних } \\
\text { шлаків під час будівництва } \\
\text { TC }\end{array}$ & $\mathrm{X}$ & $\mathrm{XX}$ & $\mathrm{XX}$ & $\mathrm{XX}$ \\
\hline & $\begin{array}{l}\text { Використання матеріалів з } \\
\text { переробленого пластику } \\
\text { та/або гумового матеріалу під } \\
\text { час будівництва ТС }\end{array}$ & $\mathrm{X}$ & X X & $\mathrm{X}$ & $\mathrm{X}$ \\
\hline & $\begin{array}{l}\text { Споживання природних } \\
\text { ресурсів }\end{array}$ & $\mathrm{XX}$ & $\mathrm{XX}$ & $\mathrm{XX}$ & $\mathrm{XX}$ \\
\hline & Екологічність транспорту & $\mathrm{XX}$ & $\mathrm{X}$ & $\mathrm{X}$ & $\mathrm{X}$ \\
\hline & $\begin{array}{l}\text { Використання } \\
\text { альтернативних джерел } \\
\text { енергії }\end{array}$ & $\mathrm{XX}$ & $X$ & $\mathrm{X}$ & $\mathrm{X}$ \\
\hline $\begin{array}{l}\text { Якість } \\
\text { водного } \\
\text { середовища }\end{array}$ & $\begin{array}{l}\text { Використання екологічної } \\
\text { продукції (матеріали та } \\
\text { обладнання), які пройшли }\end{array}$ & $\mathrm{XX}$ & $\mathrm{XX}$ & $\mathrm{XX}$ & $\mathrm{XX}$ \\
\hline
\end{tabular}




\begin{tabular}{|c|c|c|c|c|c|}
\hline & $\begin{array}{l}\text { відповідну сертифікацію та } \\
\text { мають } \\
\text { відповідне маркування }\end{array}$ & & & & \\
\hline & $\begin{array}{l}\text { Концентрація } \\
\text { забруднювальних речовини у } \\
\text { водних об'єктах }\end{array}$ & $\mathrm{X}$ & $\mathrm{X}$ & $\mathrm{X}$ & $\mathrm{XX}$ \\
\hline & $\begin{array}{l}\text { Рівень споживання кисню } \\
\text { (біохімічний та хімічний) }\end{array}$ & - & $X$ & - & $\mathrm{XX}$ \\
\hline & $\begin{array}{l}\text { Вплив на екологічний стан } \\
\text { масиву поверхневих вод }\end{array}$ & $\mathrm{X}$ & $X$ & $\mathrm{X}$ & $\mathrm{XX}$ \\
\hline $\begin{array}{l}\text { Поводження } 3 \\
\text { відходами }\end{array}$ & $\begin{array}{l}\text { Кількість (обсяг) утворення } \\
\text { відходів }\end{array}$ & XX & XX & XX & XX \\
\hline & $\begin{array}{l}\text { Застосування безпечних } \\
\text { технологій поводження } 3 \\
\text { відходами }\end{array}$ & $\mathrm{XX}$ & XX & XX & $\mathrm{XX}$ \\
\hline $\begin{array}{l}\text { Якість } \\
\text { земельних } \\
\text { ресурсів }\end{array}$ & $\begin{array}{l}\text { Масова концентрація } \\
\text { забруднювальних речовин у } \\
\text { грунтах }\end{array}$ & $\mathrm{X}$ & $\mathrm{XX}$ & $\mathrm{X}$ & $\mathrm{X}$ \\
\hline & Фрагментація територій & $\mathrm{X}$ & $\mathrm{XX}$ & $\mathrm{X}$ & - \\
\hline & Збереження зелених зон & $\mathrm{X}$ & $\mathrm{XX}$ & $\mathrm{X}$ & $\mathrm{X}$ \\
\hline Якість & Вплив на геологічні процеси & - & $\mathrm{X}$ & - & - \\
\hline $\begin{array}{l}\text { геологічного } \\
\text { середовища }\end{array}$ & $\begin{array}{l}\text { Вплив } \\
\text { процеси }\end{array} \quad$ га $\quad$ гідрологічні & - & $\mathrm{X}$ & - & $\mathrm{XX}$ \\
\hline $\begin{array}{l}\text { Фізичні } \\
\text { чинники }\end{array}$ & $\begin{array}{l}\text { Акустичний вплив на } \\
\text { довкілля }\end{array}$ & XX & $\mathrm{X}$ & XX & $\mathrm{X}$ \\
\hline & Вплив вібрації & $\mathrm{XX}$ & $X$ & XX & $\mathrm{X}$ \\
\hline & $\begin{array}{l}\text { Світлове } \\
\text { довкілля }\end{array}$ & - & $\mathrm{X}$ & XX & $\mathrm{X}$ \\
\hline & Електромагнітний вплив & $\mathrm{XX}$ & $\mathrm{X}$ & $\mathrm{X}$ & $\mathrm{X}$ \\
\hline & $\begin{array}{l}\text { Теплове забруднення } \\
\text { довкілля }\end{array}$ & $\mathrm{X}$ & - & $\mathrm{X}$ & $\mathrm{X}$ \\
\hline & $\begin{array}{l}\text { Радіаційне забруднення } \\
\text { довкілля }\end{array}$ & - & $X$ & $\mathrm{X}$ & $X$ \\
\hline Біорізноманіт & Рослинний світ & $\mathrm{XX}$ & $\mathrm{XX}$ & $\mathrm{XX}$ & $\mathrm{XX}$ \\
\hline & Тваринний світ & $\mathrm{X}$ & $\mathrm{XX}$ & $\mathrm{XX}$ & $\mathrm{XX}$ \\
\hline & Природно-заповідні об’єкти & $\mathrm{X}$ & $\mathrm{X}$ & $\mathrm{X}$ & $\mathrm{X}$ \\
\hline $\begin{array}{l}\text { Соціальне } \\
\text { середовище }\end{array}$ & $\begin{array}{l}\text { Транспортна доступність ТС } \\
\text { до основних об’єктів } \\
\text { життєзабезпечення }\end{array}$ & $\mathrm{XX}$ & $\mathrm{XX}$ & $\mathrm{X}$ & $\mathrm{X}$ \\
\hline & $\begin{array}{lcc}\text { Наближеність } & \text { ТС } & \text { до } \\
\text { громадського транспорту } & \end{array}$ & $\mathrm{XX}$ & $\mathrm{XX}$ & $\mathrm{X}$ & $X$ \\
\hline
\end{tabular}




\begin{tabular}{|c|c|c|c|c|c|}
\hline & $\begin{array}{l}\text { Комфортність території, що } \\
\text { зайнята ТС або навколо неї }\end{array}$ & XX & XX & $X$ & $X$ \\
\hline \multirow{4}{*}{$\begin{array}{l}\text { Техногенне } \\
\text { середовище }\end{array}$} & $\begin{array}{l}\text { Культурно-історична цінність } \\
\text { території, вплив на місцеву } \\
\text { культурно-історичну } \\
\text { спадщину території }\end{array}$ & $\mathrm{X}$ & $\mathrm{XX}$ & $\mathrm{X}$ & $X$ \\
\hline & $\begin{array}{l}\text { Умови проживання населення } \\
\text { в зоні впливу ТС }\end{array}$ & $\mathrm{X}$ & $\mathrm{XX}$ & $\mathrm{X}$ & $X$ \\
\hline & $\begin{array}{l}\text { Вплив небезпек природного } \\
\text { характеру під час } \\
\text { будівництва/експлуатації/рек } \\
\text { онструкції ТС }\end{array}$ & $\mathrm{XX}$ & $\mathrm{XX}$ & $\mathrm{XX}$ & $\mathrm{XX}$ \\
\hline & $\begin{array}{l}\text { Вплив небезпек техногенного } \\
\text { характеру при будівництві / } \\
\text { експлуатації / реконструкції } \\
\text { ТC }\end{array}$ & XX & XX & XX & XX \\
\hline
\end{tabular}

Система критеріїв та показників впливу ТС на довкілля має охоплювати критерії та показники, які є репрезентативними стосовно аспектів ТС, що впливають на один чи більше аспектів довкілля.

Процес вибору, розроблення та застосування критеріїв та показників, якісні, кількісні чи описові методи оцінювання окремих критеріїв та показників повинні прозоро відображатися у звіті з ОВД.

Для кількісного визначення показників ОВД ТС установлюють взаємодію між видами планованої діяльності (або групами чинних факторів) та компонентами довкілля (екологічними характеристиками). Для цього відповідно до ДСТУ 6090 застосовують комбінований підхід за допомогою удосконаленої матриці Леопольда [13] та його подальше дослідження за допомогою функції Харрінгтона.

\section{Перелік використаних джерел}

1 Про оцінку впливу на довкілля (Закон України). № 2059-VIII.(2017).

2 Оцінка впливу на довкілля. Транспортні споруди. Критерії оцінки та показники впливу на довкілля: ДСТУ 9060:2020. (2020). Київ: ДП УкрНДНЦ.

3 Оцінка впливу на довкілля. Транспортні споруди. Настанова щодо підготування звіту з оцінки впливу на довкілля: ДСТУ 9061:2020. (2020). Київ: ДП УкрНДНЦ.

4 Про Основні засади (стратегію) державної екологічної політики України на період до 2030 року (Закон України). № 2697-VIII.(2019). 
5 Sustainability in building construction - Sustainability indicators - Part 1: Framework for the development of indicators and a core set of indicators for buildings: ISO 21929-1:2011. (2011). International Organization for Standardization.

6 Олех, Т. М., Колесникова, Е. В. \& Руденко, С. В. (2013). Экологическая оценка проектов. Праці Одеського політехнічного університету, (2 (41)), 276-282. Вилучено з http://nbuv.gov.ua/UJRN/Popu_2013_2_52

7 Зуб, Л. М., Костюшин, В. А., Хрутьба, В. О., Лєвіна, Г. М., Сумський, Є. Д., Пилипович, О. В., Костюшин, С. В., Матус, С. А., Ямелинець, Т. С. \& Галайко, М. Б. (2019). Підготовка звіту з оцінки впливу на довкілля при будівництві та реконструкції автодоріг: методичний посібник. Київ: б. в. Вилучено 3 $\mathrm{http}: / / \mathrm{www}$.interregdanube.eu/uploads/media/approved_project_output/0001/35/ac3f9cab374ab1227bf6a 3bf35369fefd74fb306.pdf

8 Екологічне управління. Оцінювання життєвого циклу. Принципи та структура: ДСТУ ISO 14040:2013 (ISO 14040:2006, IDT). (2006). Київ: Держспоживстандарт України.

9 Екологічні марковання та декларації. Загальні принципи: ДСТУ ISO 14020:2003 (ISO 14020:2000, IDT). (2004). Київ: Держспоживстандарт України.

10Екологічні марковання та декларації. Екологічні самодекларації (екологічне марковання типу II): ДСТУ ISO 14021:2016 (ISO 14021:2016, IDT). (2016). Київ: ДП УкрНДНЦ.

11Екологічні марковання та декларації. Екологічне марковання типу I. Принципи та процедури: ДСТУ ISO 14024:2018 (ISO 14024:2018, IDT). (2018). Київ: ДП УкрНДНЦ.

12Настанови щодо соціальної відповідальності: ДСТУ ISO 26000:2019 (ISO 26000:2010, IDT). (2018). Київ: ДП УкрНДНЦ.

13Leopold, L. B., Clarke, F. E., Hanshaw, B. B. \& others. (1971). A procedure for evoluting environmental impact. Washington: w. p. Вилучено 3 https://pubs.usgs.gov/circ/1971/0645/report.pdf 


\title{
ОЦІНКА ІННОВАЦІЙНО-ІНВЕСТИЦІЙНОГО ПОТЕНЦІАЛУ МОРСЬКОГО ТРАНСПОРТУ УКРАЇНИ
}

\author{
Парубець Олена Миколаївна, \\ д.е.н., професор, професор кафедри \\ фінансів, банківської справи та страхування \\ Національний університет «Чернігівська політехніка»
}

Морський транспорт України переживає важкі часи, пов'язані 3 невизначеністю перспектив діяльності в умовах пандемії. Пошук виходу із кризової ситуації можливий завдяки оцінці наявного інноваційногоінвестиційного потенціалу морського транспорту і розробки на іiі основі перспективних напрямів його подальшого розвитку.

Питання стосовно дослідження державного регулювання інноваційного розвитку морської галузі, аналізу показників ії діяльності та розробці перспектив розвитку присвячені праці багатьох вітчизняних вчених, зокрема О. М. Аляб’євої, І. А. Голубкової, В. В. Жихарєвої, О. М. Кібик, І. М. Колегаєва, О. М. Котлубая, М. Т. Примачова, А. Ф. Яворської та ін.

В умовах коронакризи збереження статусу України як морської держави потребує внесення суттєвих змін до існуючих стратегій розвитку морського транспорту, особливо у напряму підвищення його інноваційно-інвестиційного потенціалу. Стан останнього залежить від багатьох факторів як внутрішнього, так і зовнішнього середовища, а також тісно взаємопов'язаний з морським, транзитним, торговельним i, особливо, трудовим потенціалом.

У прийнятій Морській доктрині України до 2035 року під морським потенціалом розуміється сукупність природних ресурсів моря, а також надбань людини i активів держави та можливостей їх використання у процесі провадження морської діяльності. При цьому зазначається, що однією із головних складових зазначеного потенціалу є військово-морський потенціал [1].

Транзитний потенціал характеризується пропускною спроможністю транспортної мережі країни, розвитком об'єктів транспортної та виробничої інфраструктури. Сучасний стан розвитку портової інфраструктури на фоні зменшення морського транзитного вантажопотоку потребує значного обсягу інвестицій для впровадження інноваційних змін 3 метою підвищення конкурентоспроможності морської портової галузі. У Стратегії розвитку морських портів України до 2038 року вказано, що саме від ефективності діяльності, техніко-технологічного оснащення та відповідності розвитку інфраструктури морських портів України сучасним міжнародним вимогам залежить конкурентоспроможність усієї транспортної системи на світовому ринку. При цьому портовій галузі виділяється пріоритетна роль у зростанні вітчизняної економіки. Загальна кількість портів України складає вісімнадцять одиниць, п’ять із яких знаходяться на тимчасово окупованій території Автономної Республіки Крим. Серед морських портів України найпотужнішими за обсягом вантажопереробки є Південний, Миколаїв, Одеса та Чорноморськ [2]. 
На сайті Міністерства інфраструктури України зазначено, що основними завданням розвитку морського транспорту $\epsilon$ підвищення конкурентоспроможності портової галузі та приведення діяльності морських портів до міжнародних вимог; створення мережі морських кластерів; активізація участі у міжнародних морських організаціях; розширення меж транскордонних перевезень вантажів морським транспортом тощо [3].

В Законі України «Про морські порти України» [4] вказується на те, що у вітчизняній портовій галузі впроваджується практика модернізації існуючих та розробки нових перевантажувальних потужностей за рахунок розвитку державно-приватного партнерства, що передбачає вкладення як державних, так і приватних інвестицій в зазначені об'єкти. Не дивлячись на розвиток такої позитивної практики існують проблеми, пов'язані 3 недостатньою участю органів місцевого самоврядування в процесах розвитку морських портів України, що знижує можливості застосування у вітчизняній практиці моделі «порт-лендлорд», яка передбачає залучення коштів інвесторів для розбудови об'єктів портової інфраструктури.

На стан покращення інвестиційного клімату в морській галузі України та забезпечення інноваційної спрямованості зовнішніх та внутрішніх інвестицій впливають тенденції розвитку торговельного потенціалу та можливості здійснення вантажоперевезень морським транспортом. Як зазначає автор роботи [5], на міжнародному ринку морських перевезень вітчизняний флот практично не представлений, а кількість судів під українським прапором складає $0,34 \%$ світового флоту. На фоні скорочення транзитного вантажопотоку Україна по причині політичних, економічних, тарифних, митних та соціальних чинників втрачає можливості розвитку вантажопотоків з Китаю до країн Європейського Союзу по Шовковому Шляху.

Зростання інноваційно-інвестиційного потенціалу морського транспорту неможливе без збереження та розвитку трудового потенціалу. Правове становище, склад, кваліфікація, громадянство, репатріація членів екіпажу морського судна та особливості трудових відносин на судні регулюються Кодексом торговельного мореплавства України, Кодексом законів про працю України, Конвенцією про репатріацію моряків, Положенням про звання осіб командного складу морських суден та порядок їх присвоєння тощо. Однак, моральне і фізичне зношення вантажних і пасажирських морських суден, низький рівень заробітної плати обумовлюють високий рівень трудової міграції вітчизняних моряків. Негативні наслідки такої ситуації стають особливо відчутними, враховуючи те, що одне робоче місце у морській галузі забезпечує створення 4-5 робочих місць у суміжних галузях вітчизняної економіки. Натомість переважна більшість морських держав світу у зв'язку з пандемією Covid 2019 визнала моряків як одних з основних працівників, що забезпечують перевезення необхідних для боротьби з коронавірусною інфекцією лікарських засобів та медичних товарів.

Пріоритети інноваційного розвитку морського транспорту знайшли відображення у Національній транспортної стратегії України на період до 2030 року [6] і передбачають реалізацію проектів приєднання нашої держави до 
морського «Блакитного поясу» навколо Свропи; створення умов для розвитку систем інформаційного спостереження за суднами та вантажами; впровадження європейських стандартів забезпечення безпеки судноплавства; розвитку берегової інфраструктури; зростання рівня екологічної безпеки морського транспорту; підвищення ефективності функціонування національної системи 3 пошуку i рятування на морі. Також одним із пунктів Стратегії зазначено сприяння розвитку відповідних портових потужностей 3 метою включення морських портів України до 100 найбільших портів світу.

Реалізація зазначених заходів потребує не тільки фінансової підтримки 3 державного і місцевих бюджетів, але значного обсягу внутрішніх і зовнішніх інвестицій. Станом на кінець 2019 р. обсяг капітальних інвестицій у вантажний морський транспорт складав 238,4 млн грн., що в декілька разів перевищував їх обсяг в попередніх роках. Натомість у пасажирський морський транспорт на протязі багатьох останніх років інвестиційні кошти не вкладалися [7]. Покращення інвестиційного клімату та створення сприятливих умов для інвесторів, готових вкладати кошти в інноваційний розвиток морської транспортної галузі України, потребує внесення відповідних змін до існуючих та прийняття нових нормативно-законодавчих актів. Також необхідно змінити підходи стосовно ставлення до морського судноплавства i визнати на державному і місцевому рівнях його пріоритетною галуззю для підвищення конкурентоспроможності держави i iii морських регіонів на світовому транспортному ринку.

\section{Список літератури}

1. Про затвердження Морської доктрини України на період до 2035 року. Постанова Кабінету Міністрів України від 7 жовтня 2009 р. № 1307. URL: https://zakon.rada.gov.ua/laws/show/1307-2009-\%D0\%BF\#Text

2. Про затвердження Стратегії розвитку морських портів України на період до 2038 року. Розпорядження Кабінету Міністрів України від 11 липня 2013 р. № 548-p. URL: https://zakon.rada.gov.ua/laws/show/548-2013-\%D1\%80\#Text

3. Міністерство інфраструктури України. URL: https://mtu.gov.ua/content/zadachi-ministerstva-v-ramkah-galuzi-morskogotransportu.html

4. Про морські порти України. Закон України від 17 травня 2012 року № 4709VI. URL: https://zakon.rada.gov.ua/laws/show/4709-17\#Text

5. Ниякий И. Судов под украинским флагом практически не осталось: что делать. Ліга. Бізнес. URL: https://biz.liga.net/ekonomika/transport/opinion/sudovpod-ukrainskim-flagom-prakticheski-ne-ostalos-chto-delat

6. Про схвалення Національної транспортної стратегії України на період до 2030 року. Розпорядження Кабінету Міністрів України від 30 травня 2018 р. № 430-p. URL: https://zakon.rada.gov.ua/laws/show/430-2018-\%D1\%80\#Text
7.
Державна
служба
статистики
України.
URL:

http://www.ukrstat.gov.ua/druk/publicat/kat_u/2020/zb/10/zb_trans_19.pdf 


\section{ПРОБЛЕМИ ДЕРЖАВНОГО ФІНАНСУВАННЯ ГРОМАДСЬКИХ ОРГАНІЗАЦІЙ В УКРАЇНІ}

\section{Ткачук Ірина Ярославівна}

к.е.н., доцент

Чернівецький національний університет імені Юрія Федьковича Економічний факультет, кафедра: Фінансів і кредиту

\section{Мартинюк Анна Юріївна}

Чернівецький національний університет імені Юрія Федьковича Економічний факультет, кафедра: Фінансів і кредиту

Актуальність дослідження: На сучасному етапі розвитку, враховуючи ринкові відносини та розвиток технологій, роль і значення діяльності громадських організацій (далі - ГО) стає все вагомішою в суспільнополітичному житті України. Функціонування ГО впливає на формування доходів суб'єктів економіки, рівень благополуччя населення, вони володіють інноваційним потенціалом, здатні залучати значні інвестиції у власну діяльність. Проте, діяльність ГО невід'ємно пов'язана із залученням та використанням фінансових ресурсів, від обсягів яких суттєво залежить ефективність їх діяльності. Держава, яка зацікавлена у якісному наданні послуг ГО (адже вона по суті делегує їм частину власних повноважень), спрямовує на їх підтримку значні обсяги фінансових ресурсів, втім, існуюча модель державного фінансування ГО в Україні характеризується значними недоліками.

Aналіз попередніх досліджень: проблеми державного фінансування ГО в Україні досліджували у своїх роботах такі вчені як: Вінніков О.Ю., Кириленко О.П., Ковальчук В.А., Коніщева Н.Й., Лациба М.В., Матвійчук А.А., Опарін В.М., Петрушенко Ю.М. Проте, не дивлячись на результати досліджень згаданих вище науковців, а також зважаючи на постійні зміни умов функціонування $\Gamma О$, подальшого дослідження вимагають проблеми державного фінансування ГО.

Предметом дослідження виступають проблеми державного фінансування ГО в Україні

Мета дослідження полягає у висвітлені проблем державного фінансування ГО в Україні.

До основних джерел фінансового забезпечення діяльності ГО відносять: державні кошти, членські внески, благодійні внески фізичних і юридичних осіб (ними можуть бути як резиденти, так і нерезиденти), надходження від господарської діяльності (як власної, так і підприємств, установ та організацій заснованих ГО) [1]. 
Через відсутність цілеспрямованої державної політики, ГО не можуть розвиватися швидкими темпами. Прогнозувати позитивні зміни фінансування ГО можна тільки за умови вирішення проблем у функціонуванні державних та місцевих фінансів [2].

Здійснюючи аналіз економічної та політичної ситуації в Україні з часів незалежності, помітною $є$ необхідність розвитку громадянського суспільства та значущість заохочення громадян знаходити однодумців для пошуку рішень проблем, які зараз актуальні і вирішення яких, окремими суб'єктами неможливо, або для побудови ефективної моделі співпраці громадян із державою.

Доречним буде виділення таких проблем державного фінансування ГО в Україні, як:

- дискримінація, спричинена положенням частини 3 статті 8 Закону України «Про об'єднання громадян», що пов'язана з тим, що ГО може розраховувати на фінансову допомогу з Державного бюджету України виключно за наявності всеукраїнського статусу;

- нестача конкурсних програм, за результатами яких можна отримати фінансову підтримку;

- недостатня кількість коштів в бюджетах органів державної влади та місцевих самоврядувань, що мають бути направлені на фінансову допомогу ГО, нестача довгострокового фінансування;

- існування певної невизначеності у законодавчій базі, цілях, які ставлять перед собою органи влади, неточні критерії у конкурсах на отримання державної фінансової підтримки діяльності ГО;

- певна умовність сум бюджетних асигнувань, що означає, що розрахована сума коштів, яка передбачена у бюджеті може зменшуватися, авансові платежі, зазвичай, не використовуються, фінансова підтримка здійснюється у хаотичному порядку;

- вимога власного внеску, який повинен мати грошову форму;

- затримка при перерахуванні фінансової підтримки від Державного казначейства через те, що фінансова допомога ГО не належить до переліку захищених статей бюджетних витрат.

- існування великої кількості необгрунтованих обмежень стосовно напрямів використання коштів;

- суб' єктивність оцінювання під час конкурсу, дискримінація «молодих» ГО через відсутність або малу кількість досвіду у реалізації проєктів;

- відсутність уніфікації документів, необхідних для бюджетного фінансування ГО;

- існування значних розбіжностей у відомчих практиках звітності, контролю, моніторингу та оцінки проектів ГО;

- низький рівень участі ГО в конкурсах на отримання державного фіннасування, що пов'язано із суб'єктивним ставлення активістів ГО до представників чинної влади, особисті контакти представників влади та активістів ГО.

Висновки. Низка вище перелічених проблем, притаманних ГО України, потребує швидких та ефективних дій, які наблизять нашу державу до їх 
вирішення. Без впровадження комплексного, а не вибіркового підходу, проблеми неможливо буде вирішити. Для вирішення проблем державного фінансування ГО України варто вдосконалити механізм податкового стимулювання функціонування ГО, можливим є впровадження стандартів країн Європи, для визначення податкового режиму для діяльності ГО (яскравим прикладом слугує податкова політика Німеччини та Великобританії). Доцільним $є$ розгляд можливості зміни статусу ГО на суспільно корисні організації, що може бути головною умовою для появи кількох нових податкових стимулів [3].

\section{Сиисок літератури}

1. Вінніков О. Ю. Показники розвитку громадянського суспільства в Україні. Укр. незалеж. центр політ. дослідж., Київ, 2012 С.80

2. Діяльність громадських організацій в Україні. Демографічна та соціальна статистики Суспільна діяльність. Державна служба статистики України. URL: http://www.ukrstat.gov.ua.

3. Матвійчук А.А. Основні способи взаємодії громадських організацій із державою: науковий вісник. Київ: 2014p. № 91. С.389-394. 


\section{ПРИОРИТЕТНЫЕ НАПРАВЛЕНИЯ РАЗВИТИЯ ЭЛЕКТРОННОЙ КОММЕРЦИИ В ПОРТУГАЛИИ}

Трушкина Наталья Валерьевна К.Э.Н.

Шкригун Юлия Олеговна аспирантка Институт экономики промышленности НАН Украины (г. Киев)

Португалия - развитая европейская страна с высоким уровнем жизни, имеющая сухопутную границу с Испанией. Экономика Португалии росла быстрее, чем в среднем по ЕС в 1990-х гг. Но позже темпы ее роста замедлились. В мае 2011 г. Португалия стала третьей страной еврозоны, которой удалось выйти из кризиса суверенного долга [1].

Португалия имеет 39-й по величине рынок электронной коммерции. Как и во многих европейских странах, в Португалии наблюдается стремительное развитие электронной коммерции как одной из эффективных форм организации логистической деятельности компаний с применением цифровых технологий и информационных систем [2-8].

Прирост рынка электронной коммерции Португалии составил в 2019 г. $11 \%$ (в мире $-17 \%$ ). Согласно мнения экспертов, глобальный рост продолжится в течение следующих нескольких лет. Будут наблюдаться предпосылки к появлению новых рынков. Существующие рынки имеют потенциал для дальнейшего развития. Этому будет способствовать Восточная и Юго-Восточная Азия с растущим средним классом и отстающей инфраструктурой офлайншоппинга [9].

В 2019 г. выручка рынка электронной коммерции Португалии составила 2,9 млн долл. США [9]. Прогнозируется, что в 2021 г. показатель составит 3,8 млн долл. США. Ожидается, что годовой темп роста выручки (CAGR 20212025 ) составит $5,3 \%$, что приведёт к рассчитываемому объёму рынка в 4,7 млн долл. США к 2025 г. [10].

Среднегодовые расходы на онлайн-корзину в Португалии составляют 1513 евро, что незначительно меньше показателей в Испании. Португалия развивает собственную культуру покупок в Интернете. «День онлайн-покупок», как локальная версия «Чёрной пятницы», был запущен в 2011 г. А в 2019 г. к ежегодной инициативе присоединились 245 онлайн-брендов [11].

Самым крупным игроком на португальском рынке электронной коммерции является Amazon.es. Выручка магазина составила в 2019 г. 77 млн долл. США, затем следуют магазины Zara.com с выручкой в 75 млн долл. США и Apple.com с выручкой в 72 млн долл. США (рис. 1). В целом, на три ведущих магазина приходится $10 \%$ онлайн-доходов в Португалии. 


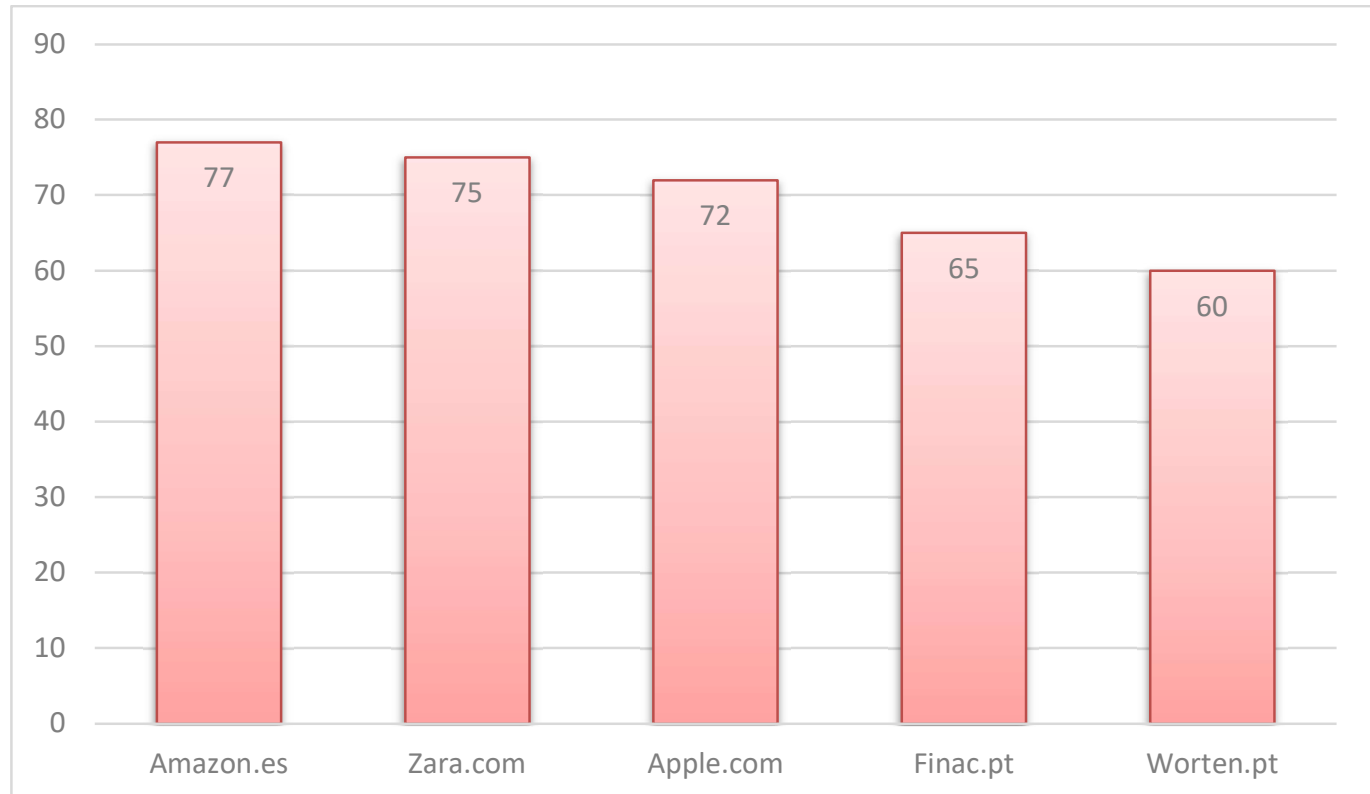

Рис. 1. Крупнейшие магазины электронной коммерции в Португалии по объёму чистой выручки в 2019 г., млн долл. США (построен по даннымм [9])

Локальный магазин Kicks.pt является одним из самых быстрорастущих магазинов на португальском рынке. Объем продаж магазина составил в 2019 г. около 2,5 млн долл. США. Рост выручки составил в 2018 г. $106 \%$.

По оценкам экспертов, рассматриваются пять крупнейших сегментов рынка электронной коммерции. Сектор моды является самым крупным сегментом в Португалии, на него приходится $34 \%$ доходов от электронной коммерции в стране [9] (рис. 2).

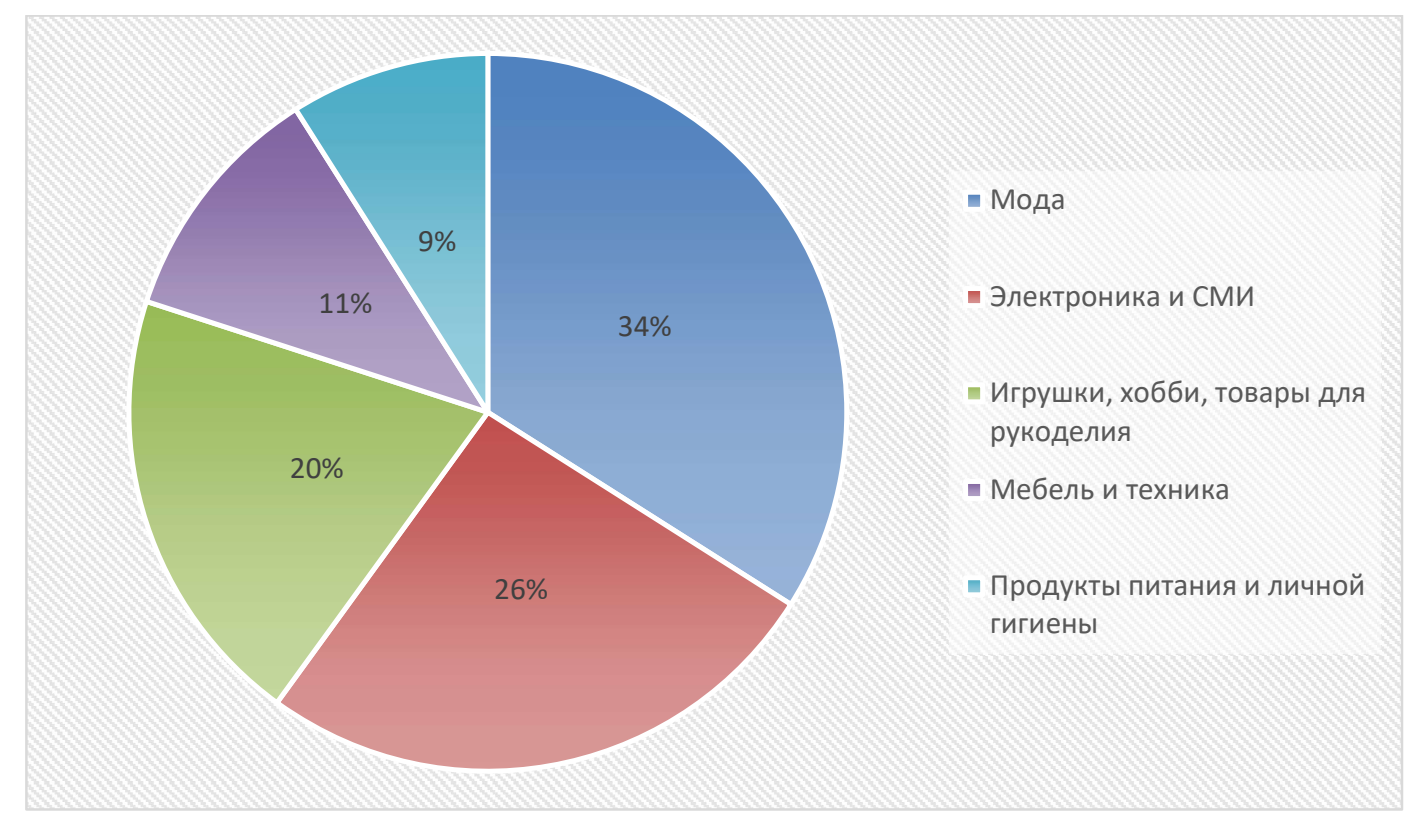

Рис. 2. Сегменты рынка электронной коммерции в 2019 г., \% ( построен по данным [9])

Согласно обзорам рынка Португалии, специалисты отмечают, что потребительское поведение характеризуется тенденцией планирования домашнего бюджета, минимальным количеством импульсивных приобретений, 
ростом интереса к экологичности продуктов. Цены и рекламные акции являются основными мотиваторами покупок. Несмотря на относительно высокий уровень развития электронной коммерции, покупки в оффлайн-магазинах имеют свою клиентскую базу, особенно среди старшего поколения. Типичный португальский потребитель ценит знания и опыт продавца, которые влияют на его привязанность и лояльность. Электронная торговля в Португалии больше распространена среди потребителей моложе 30 лет [12].

Трансграничные покупки составляют $23 \%$ всего рынка электронной коммерции в стране, Китай является самой популярной страной для покупок (рuc. 3). Преимуществом Испании является язык и возможность более быстрой доставки. В то время как сайты Китая и Великой Британии предлагают более широкий выбор товаров, но и более сложный пользовательский интерфейс.

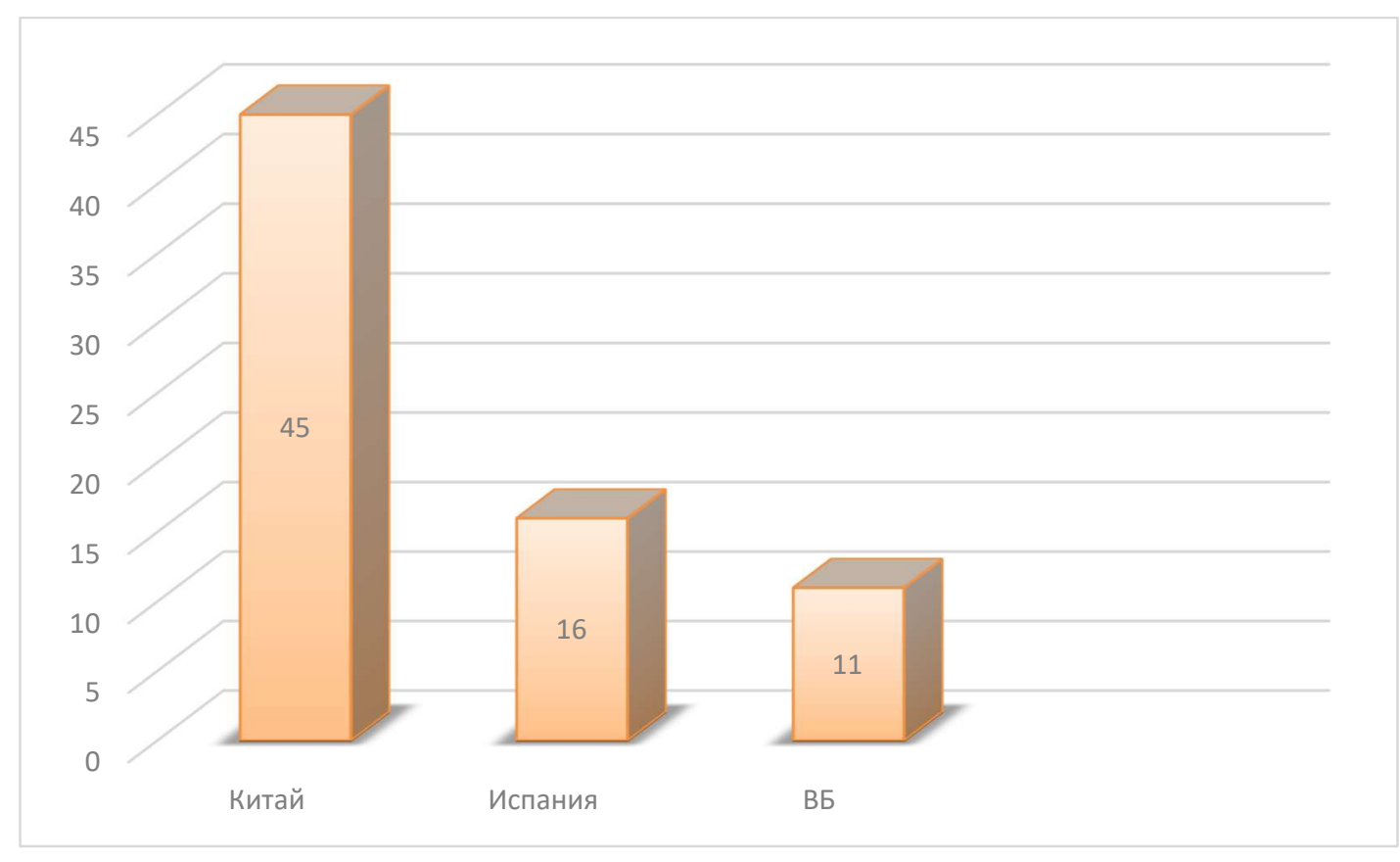

Рис. 3. Удельный вес трансграничных покупок в разрезе крупнейших рынков, $\%$ (построен по данным [11])

Как член Европейского Союза, Португалия руководствуется правилами ЕС в отношении импортных тарифов. Китай прилагает усилия для развития торговых отношений с Португалией, подписав в конце 2018 г. несколько новых соглашений о сотрудничестве [11].

Chronopost является наиболее популярным оператором услуг доставки среди интернет-магазинов (согласно 13\% опрошенных). Компании DHL и UPS входят в тройку ведущих компаний по доставке, предлагаемых интернет-магазинами в Португалии (по 10\%) [9].

Взаимоотношения Португалии и Испании крайне тесные. На данный момент на фоне продления общенациональной изоляции Португалии до середины февраля 2021 г. между Португалией и Испанией разрешено передвижение для перевозки товаров для здоровья [13]. 
Банковские карты являются самым популярным способом онлайн-платежей в Португалии, занимающий 40\% рынка. При этом дебетовые карты являются предпочтительным типом платёжных карт (рuс. 4).

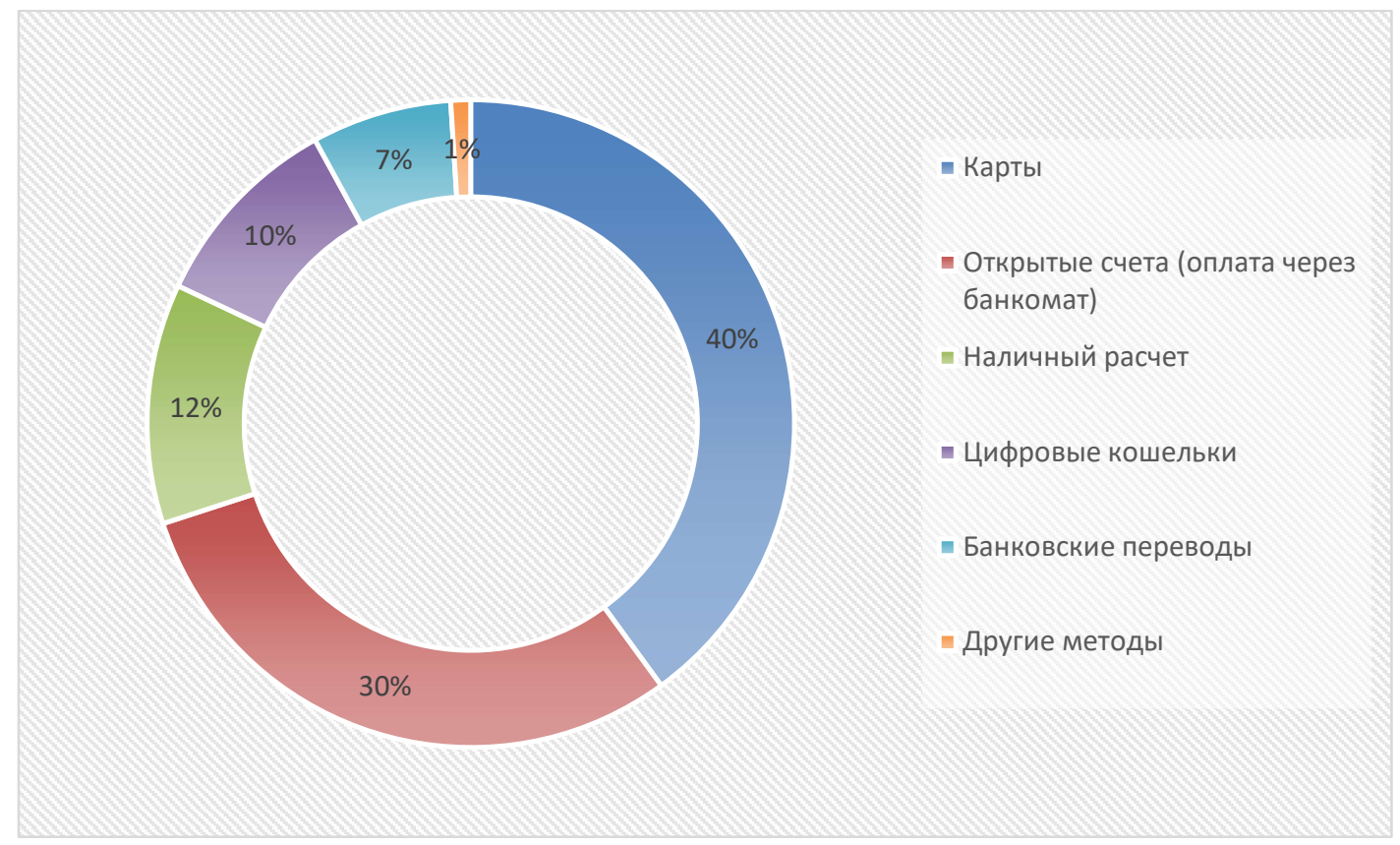

Рис. 4. Методы платежей электронной коммерции, \% (построено по данным [14])

Необходимо отметить, что способ оплаты через банкомат является ключевой частью португальской платёжной культуры. Система Multibanco занимает 30\% рынка платежей. Данная система была запущена в 1985 г. и позволяет пользователям оплачивать счета в банкоматах. Все основные португальские банки участвуют в системе, которая позволяет международным онлайнпродавцам, предлагающим оплату с помощью этого метода, получить доступ к подавляющему большинству португальских покупателей рынка электронной коммерции. Поставщики цифровых кошельков Paysafecard и PayPal имеют опыт сотрудничества с Multibanco, что в будущем может стимулировать использование цифровых кошельков в Португалии [14].

В январе 2020 г. уровень проникновения Интернета в Португалии составил $83 \%$, а социальных сетей - $69 \%$. В стране более 8,5 млн пользователей Интернета. В период с 2019 по 2020 гг. количество пользователей увеличилось на 251 тыс. (прирост 3\%) [15], из которых 7 млн активны в социальных сетях. По сравнению с 2019 г. количество пользователей социальных сетей увеличилось на $6,6 \%$ [12]. В Лиссабоне (83\%) самый высокий уровень проникновения интернета по стране [11]. 97\% активных пользователей социальных сетей предпочитают доступ через мобильный телефон. Самым популярным приложением является YouTube, затем предпочтение отдано платформе Facebook.

В январе 2020 г. в Португалии было 15,8 млн мобильных подключений. С января 2019 г. по январь 2020 г. количество мобильных подключений снизилось на 410 тыс. (2,5\%) и было эквивалентно $155 \%$ общей численности населения [15]. 
Уровень проникновения смартфонов составляет 74\%. Данный показатель аналогичен Испании (72,5\%), но является более низким, чем в странах с крупным рынком электронной торговли, таких как Германия и Франция.

Самым популярным устройством для доступа к электронной коммерции в Португалии являются компьютеры (62 \%), затем следуют смартфоны (35\%) и планшеты $(2 \%)$. Использование приложений остаётся предпочтительным способом (54\% от продаж) [11].

Показатель мошенничества в сфере электронной коммерции в Португалии относительно невысокий. Ежегодно в этой сфере затрагивается $1 \%$ онлайнпокупателей, по сравнению со средним показателем по Европе равным 2\% [14].

Эксперты отмечают, что государство поддерживает электронную торговлю как путь к экономическому росту. Правительство Португалии и Ассоциация электронной коммерции и интерактивной рекламы (АСЕРІ) продвигают электронную коммерцию среди граждан и локальных продавцов. Реализуется Программа цифровой торговли, АСЕРІ предоставляет малым и средним предприятиям инструменты для создания сайтов электронной коммерции [11].

Таким образом, исходя из вышеизложенного, можно сделать такой вывод. Португалия является крупным рынком электронной коммерции по объёмам продаж среди европейских стран. Характеризуется лояльностью к международным торговым площадкам и соответствием глобальным тенденциям электронной коммерции. На фоне приверженности к банковским картам, как способу оплаты, рынок имеет особенность оплаты счетов через банкоматы с помощью локальной системы Multibanko.

Правительство Португалии активно содействует развитию электронной коммерции в стране. Это, в свою очередь, влияет на высокий уровень безопасности электронного рынка. Вместе с тем специалисты обращают внимание на возможное ухудшение ситуации с развитием и увеличением масштаба рынка электронной торговли.

Потребительское поведение характеризуется некоторым консерватизмом среди категории населения старше 30 лет, что выражается к предпочтению оффлайн-шоппинга. Следует отметить, что в условиях пандемии COVID-19 ожидается постепенное смещение фокуса внимания всех категорий потребителей на онлайн-магазины.

Особенностью рынка Португалии является высокий уровень развития. К приоритетным направлениям развития электронной коммерции можно отнести увеличение количества локальных продавцов; интеграцию локального рынка с международными торговыми площадками в контексте ассортимента, акций и программ лояльности. При этом с развитием электронной торговли возникает необходимость совершенствования логистической сети и увеличения количества объектов складской инфраструктуры.

В дальнейших научных исследованиях планируется обобщить европейский опыт развития электронной коммерции и разработать предложения о возможностях его применения в Украине. 


\section{Список литературы:}

1. Ecommece news Europe. Ecommerce in Portugal. URL: https://ecommercenews.eu/ecommerce-in-europe/ecommerce-portugal/.

2. Tryfonova O., Trushkina N. E-commerce as an effective form of organization of logistics activities of enterprises. Modern Technologies in Economy and Management: collective scientific monograph / Edited by O. Nestorenko, T. Pokusa; The Academy of Management and Administration in Opole. Opole: Publishing House WSZiA w Opole, 2019. P. 397-406.

3. Kwilinski A., Trushkina N. Development of digital marketing in conditions of transformational change. Research and Innovations: collection of scientific articles. Yonona Publishing, New York, USA, 2019. P. 170-173.

4. Tryfonova O., Trushkina N. Application of information technologies in logistic activities of enterprises. Conceptual aspects management of competitiveness the economic entities: collective monograph / Edited by M. Bezpartochnyi, I. Britchenko. In 2 Vol. / Higher School of Social and Economic. Przeworsk: WSSG, 2019. Vol. 1. P. 161-172.

5. Kwilinski A., Trushkina N. Features of digital marketing in the context of informational economy. Modern innovative and information technologies in the development of society: monograph / Edited by M. Ekkert, O. Nestorenko, M. Szynk; Katowice School of Technology. Katowice: Wydawnictwo Wyzszej Szkoly Technicznej w Katowicach, 2019. P. 158-165.

6. Місюкевич В. І., Трушкіна Н. В., Шкригун Ю. О. Електронна комерція у глобальному цифровому просторі: нові виклики та напрями. Формування системи внутрішньої торгівлі України: теорія, практика, інновачї: колективна монографія / за ред. В. В. Лісіци, В. І. Місюкевич, О. М. Михайленко. Полтава: ПУЕТ, 2020. С. 150-162.

7. Trushkina N., Bezpartochnyi M., Shkrygun Yu. E-commerce in the conditions of digitalization of business processes. Strategies, models and technologies of economic systems management in the context of international economic integration: scientific monograph / edited by M. Bezpartochnyi, V. Riashchenko, N. Linde. 2nd ed. Riga: Institute of Economics of the Latvian Academy of Sciences, 2020. P. 245256.

8. Trushkina N., Bezpartochna O., Shkrygun Yu. Priority directions for development of digital marketing in the conditions of globalization. Pandemic Economic Crisis: Changes and New Challenges to Society: scientific monograph / edited by M. Bezpartochnyi; VUZF University of Finance, Business and Entrepreneurship. Sofia: VUZF Publishing House "St. Grigorii Bogoslov", 2020. P. 227-238.

9. EcommeceDB. The eCommerce market in Portugal. URL: $\mathrm{https}: / /$ ecommercedb.com/en/markets/pt/all.

10. Statista. eCommerce Portugal. URL: https://www.statista.com/outlook/243/147/ ecommerce/portugal\#market-revenue.

11. J.P. Morgan. Portugal's e-commerce market is steadily expanding, with younger citizens driving growth. 2020. URL: https://www.jpmorgan.com/merchantservices/insights/reports/portugal-2020. 
12. Odziemek K. European Ecommerce Overview: Portugal. URL: https://ecommercegermany.com/blog/european-ecommerce-overview-portugal.

13. France24. Portugal extends lockdown, restricts travel amid record Covid-19 surge. 2021. 29 January. URL: https://www.france24.com/en/europe/20210129-portugalextends-lockdown-restricts-travel-amid-record-covid-19-surge.

14. J.P. Morgan global payment trends. 2019 Global Payments Trends Report Portugal Country Insights. Portugal insights report. URL: https://www.jpmorgan.com/merchant-services/insights/reports/portugal.

15. Kemp S. Digital 2020: Portugal. 2020. 18 February. URL: https://datareportal.com/reports/digital-2020-portugal. 


\section{ФІНАНСОВИЙ МЕХАНІЗМ ДОСЯГНЕННЯ МАКРОЕКОНОМІЧНОЇ РІВНОВАГИ}

Цимбалюк Ганна Сергіївна, кандидат економічних наук Хмельницький інститут МАУП

Сем'янчук Петро Михайлович, кандидат економічних наук Хмельницький інститут МАУП

\section{Оліх Галина Іванівна,}

старший викладач Хмельницький інститут МАУП

Макроекономічна рівновага - це ситуація, якої прагне досягти економічна політика країни і яка має кілька економічних параметрів національного рівня.

Перший індикатор - це рівність сукупного (агрегованого) попиту і сукупної (агрегованої) пропозиції, як показано на рис. 1.

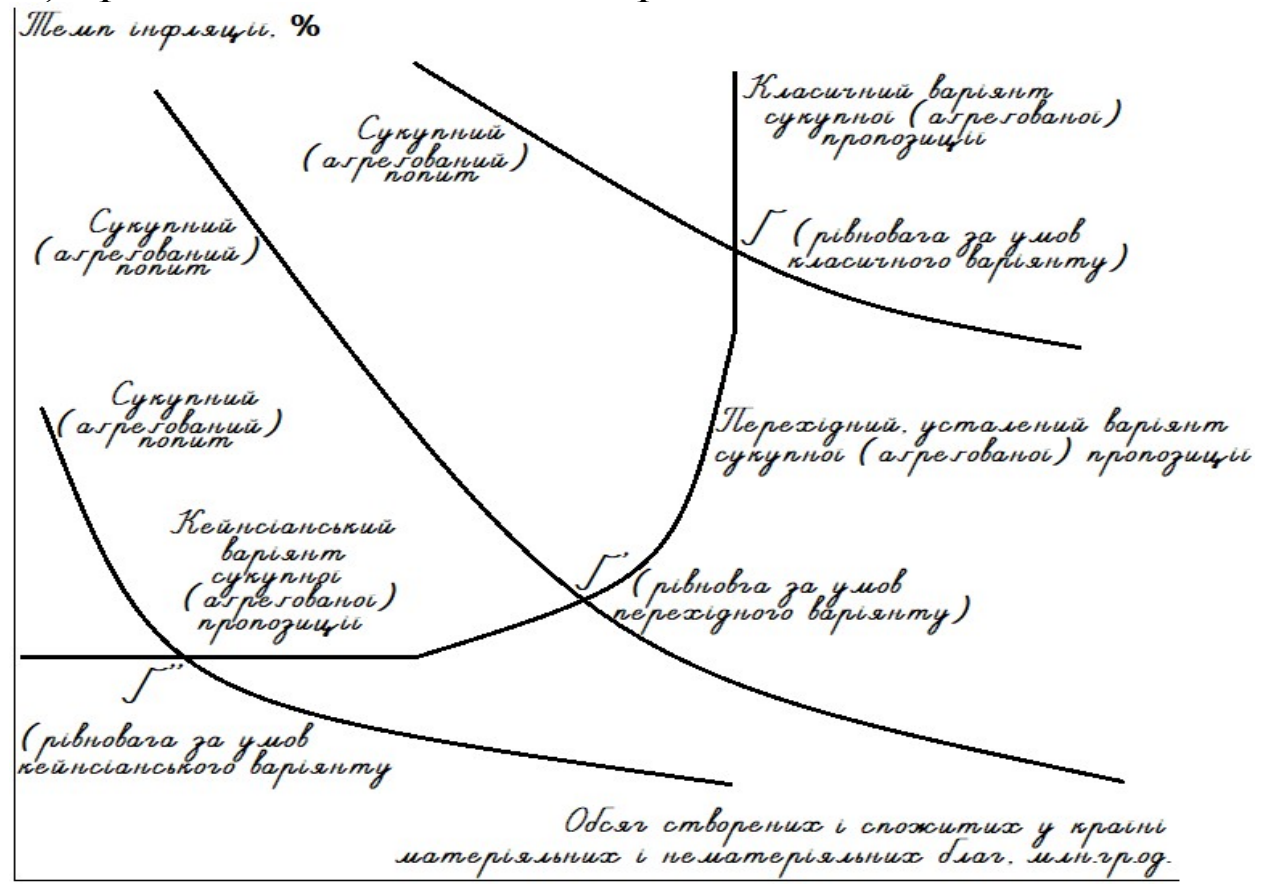

Рис. 1. Рівновага сукупного попиту і пропозиції

Джерело: складено авторами на основі власних теоретичних узагальнень

Тепер детальніше зупинимося на специфіці ілюстрованого матеріялу та особливостях даного параметру макроекономічної рівноваги. Сукупна пропозиція $\epsilon$ агрегованою кривою, позаяк даний параметр прямо залежить від ринкового періоду. Класична, неокласична і нова класична економічна теорія акцентуючи увагу й дослідження на довгому періоді, з'ясували ії незмінний характер, внаслідок виходу економіки на свій потенціал, і представляють через вертикальну лінію. Представники раннього, пізнього та сучасного кейнсіанства, 
услід за своїм родоначальником вважають за доцільне та правильне досліджувати економіку в короткому періоді, де сукупна пропозиція має стандартний характер зміни, внаслідок нарощування своїх потужностей, i подається горизонтальною лінією. Представники инших економічних шкіл та окремі прихильники попередніх вважають, що у перехідному періоді пропозиція нерівномірно змінюється, внаслідок дії різних чинників, і має форму кривої. Відтак, досягнення рівноваги між сукупним попитом і пропозицією має три варіянти: в короткому (точка $\left.\digamma^{\prime \prime}\right)$, перехідному (точка $\digamma^{\prime}$ ) та довгому (точка $\left.\zeta^{\prime}\right)$ періодах.

Другий індикатор - це рівність попиту на гроші та грошової пропозиції, як це зображено на рис. 2.

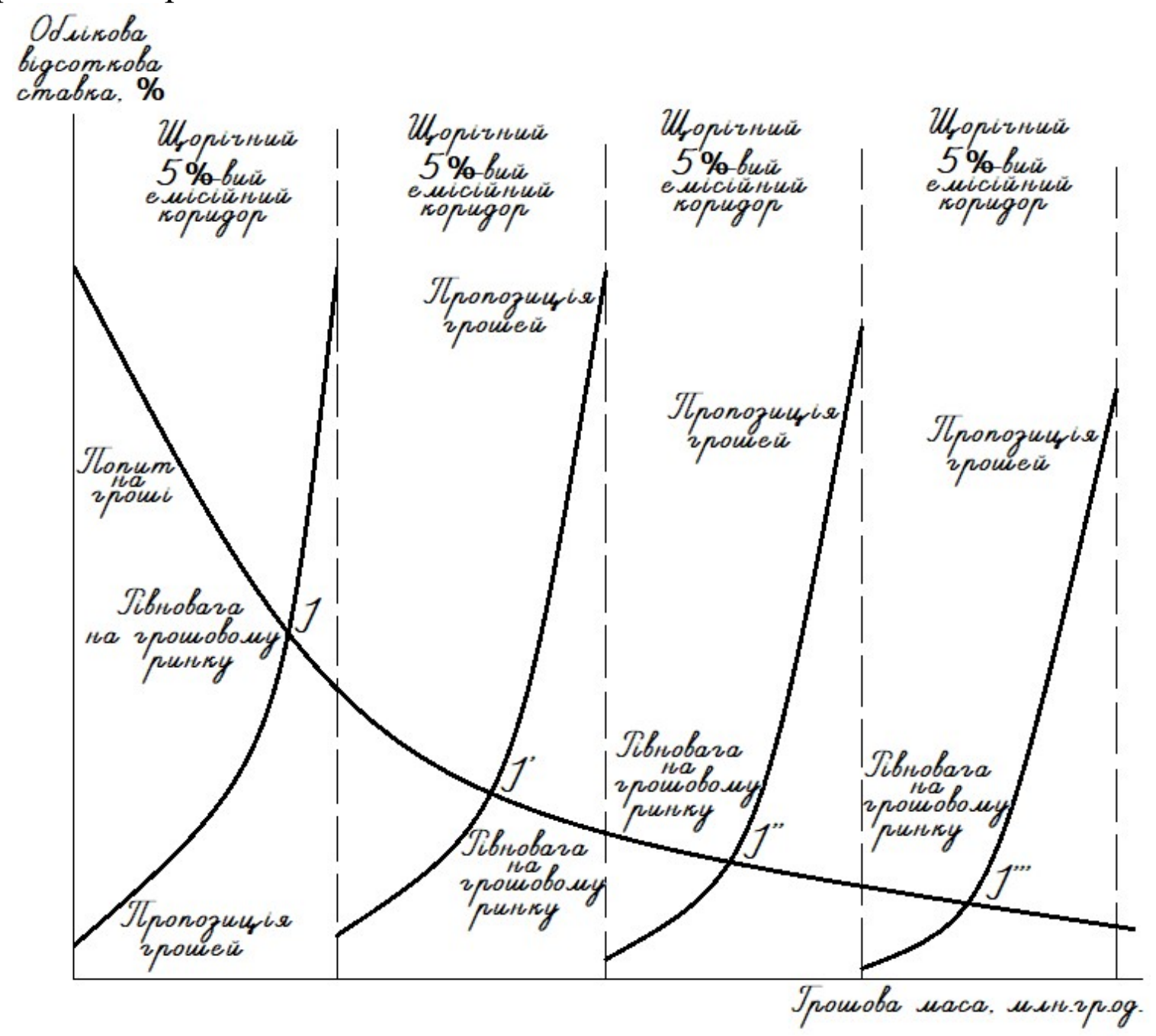

Рис. 2. Рівновага на грошовому ринку країни

Джерело: складено авторами на основі власних теоретичних узагальнень

Даний графік також потребує короткого пояснення. Ринок грошей також має свою специфіку, позаяк повинен у повній мірі обслуговувати безперебійну циркуляцію матеріяльних і нематеріяльних благ вітчизняного й зарубіжного виробництва в межах національної економіки. Відповідно, грошову масу в країні контролює Центральний банк, що володіє унікальною монополією на друк грошей. Річний обсяг емісії перебуває у науково-обгрунтованому діапазоні 5\%. Дана цифра аргументується середньостатистичною величиною зростання ВВП 
розвинених країн за крайні кілька років. Проте може корегуватися, в залежності від особливостей національного економічного зростання із щонайбільше $2 \%$-вим надлишком. Саме тому, щорічно урегульовується рівновага між попитом на гроші та грошовою пропозицією (точки $\left.I, I^{\prime}, I^{\prime \prime}, I^{\prime \prime}\right)$ і проводиться відповідний аналіз. Така регулярність і контроль пов'язані з імовірними інфляційними або дефляційними процесами, які розкручуватимуться негативними макроекономічними спіралями внаслідок виникнення надлишку або дефіциту грошової маси в країні.

Третій індикатор - це збалансований Державний і Зведений бюджет, що можна наочно подати за допомогою рис. 3.

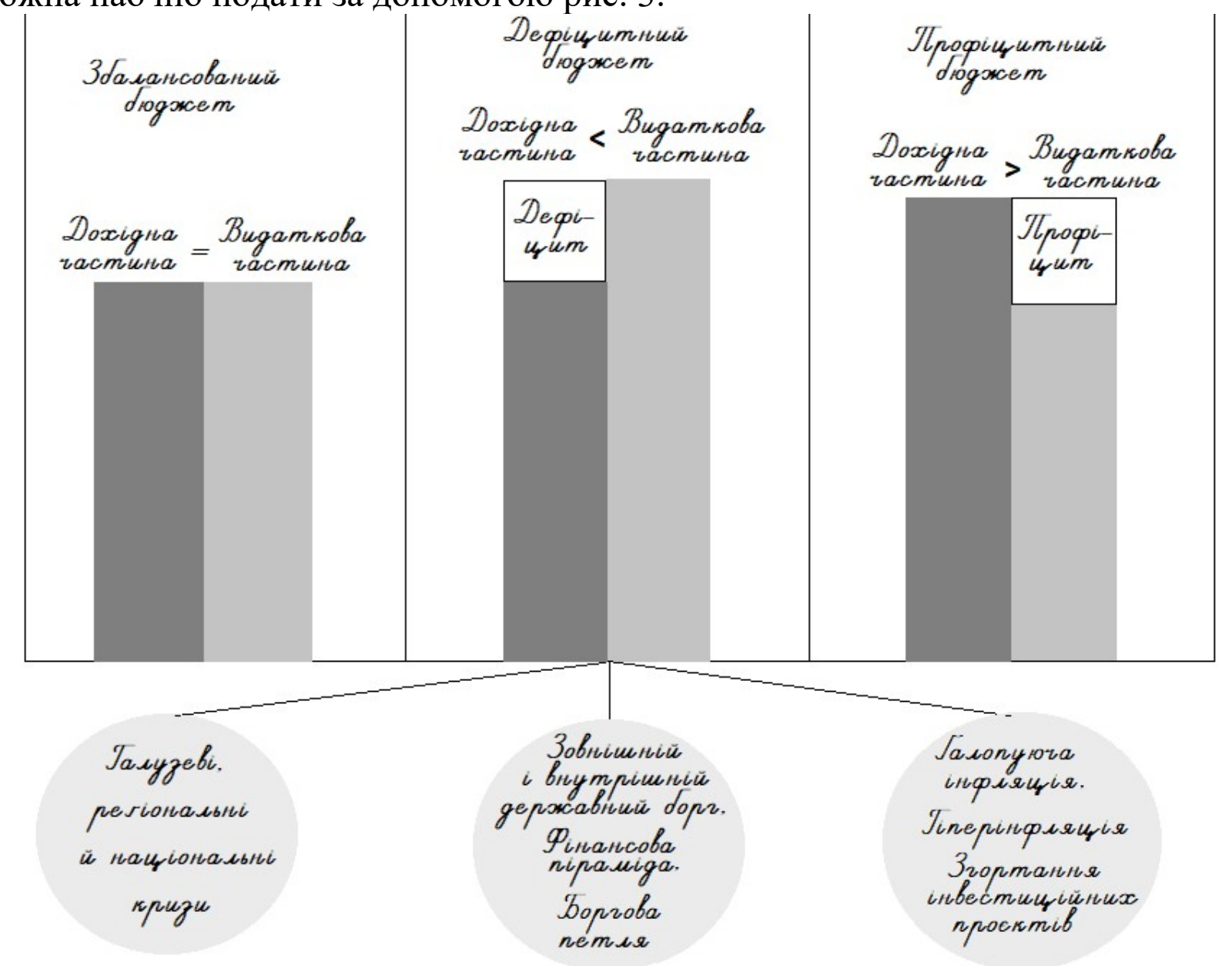

Рис. 3. Варіянти співвідношення дохідної та видаткової частини Державного і Зведеного бюджету

Дюкерело: складено авторами на основі власних теоретичних узагальнень

Державний і Зведений бюджети - це основні макрофінансові плани країни, в яких враховані капітальні й поточні витрати, а також стратегічні, тактичні i нагальні цілі державного й муніципального рівнів у галузево-функціональному розрізі. Економіку, з практичної точки зору, слід розглядати як живий організм iз тісними взаємозалежностями та взаємозв'язками. Відповідно, бюджетне фінансування повинно базуватися на цій основі. Непродумане наповнення коштами одних сфер та регіонів 3 одночасним неналежним фінансуванням инших - може викликати істотні диспропорції в розвитку та розгортання кризових явищ навіть за умов збалансованого бюджету. Найпоширеніший 
дефіцитний бюджет має три шляхи до збалансування - секвестр видаткової частини, боргове та емісійне фінансування. Перший шлях позбавить фінансування низку запланованих статей і позицій, в тому числі й капітальних, що 3 часом може вилитися у звужений характер виробництва та ланцюгове гальмування регіонального, галузевого та національного розвитку. Другий шлях передбачає зовнішні та внутрішні запозичення для покриття бюджетного дефіциту, що спричиняє нарощування зовнішнього і внутрішнього державного боргу, формування фінансової піраміди й затягування боргової петлі. Третій шлях $\epsilon$ найлегшим, однак неконтрольована емісія грошей швидко перетворює повзучу інфляцію у галопуючу, а галопуючу у гіперінфляцію зі стрімкою девальвацією національної грошової одиниці, виникненням ефекту «гарячих» грошей, цілковитим згортанням великих, тривалих та середньострокових інвестиційних проєктів і тотальною бартеризацією відносин. Профіцитний бюджет $є$ рідкісним і випадковим явищем, грошовий надлишок якого повністю спрямовують на обслуговування державного боргу.

Четвертий індикатор - досягнення в країні повної зайнятости шляхом подолання проблеми безробіття, що графічно зображено на рис. 4.

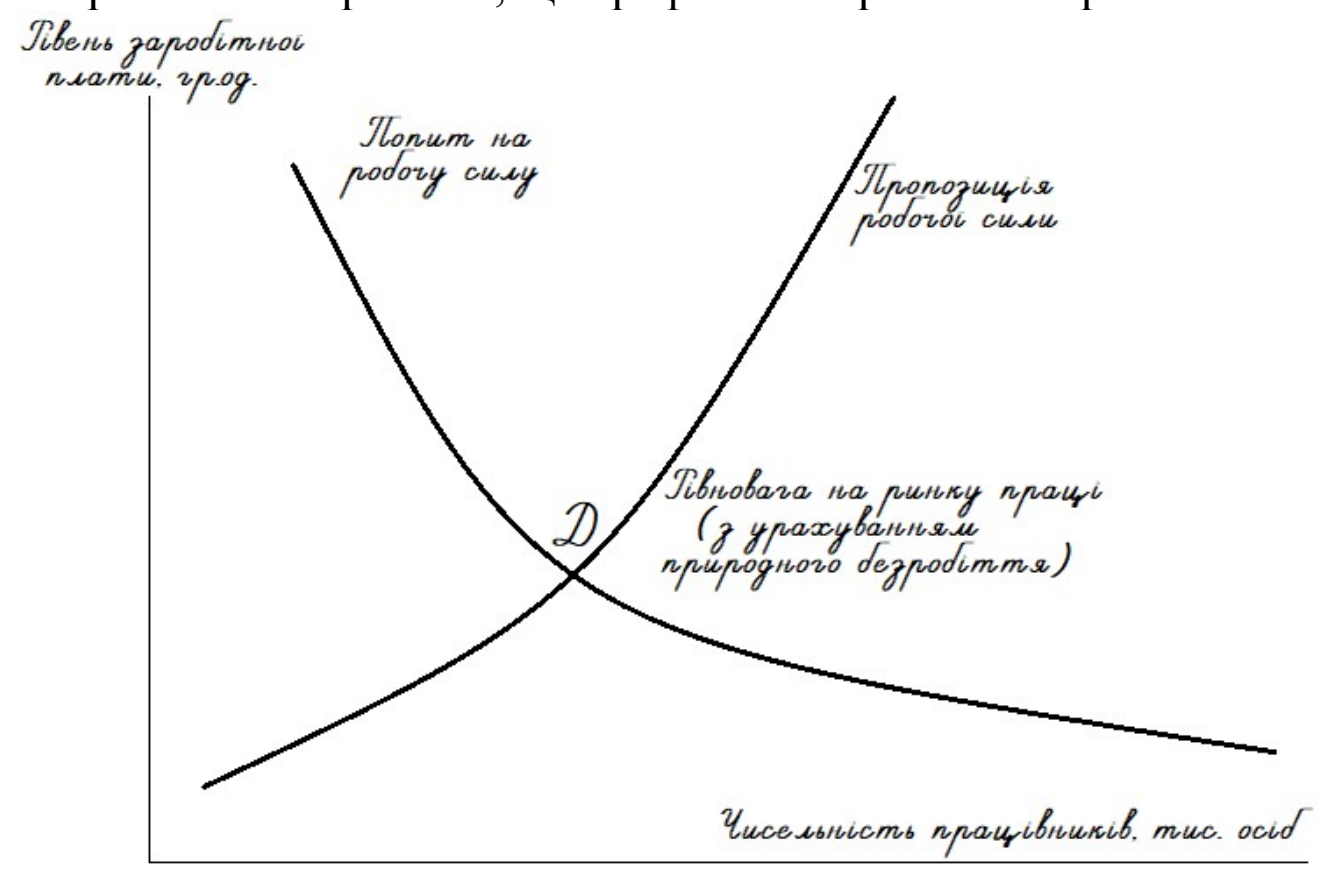

Рис. 4. Рівновага на ринку праці

Джерело: складено авторами на основі власних теоретичних узагальнень

Рівновага на ринку праці (точка Д) передбачає наявність природного безробіття, за якого чисельність безробітних дорівнює кількості вільних робочих місць. Такий вид безробіття практично не піддається регулюванню.

П'ятий індикатор - це мінімізація обсягів тіньової економіки та «чорного» ринку. Дані явища ланцюговою реакцією скорочуватимуть податкові надходження, збільшуватимуть обсяги бюджетного дефіциту, державного боргу та інфляції. Крім того, тіньова економіка і «чорний» ринок мають здатність самонарощуватися, зменшуючи при цьому величину офіційного ВВП.

Шостий індикатор - це платіжний баланс із нульовим сальдо, що ілюстративно випливає з рис. 5. 


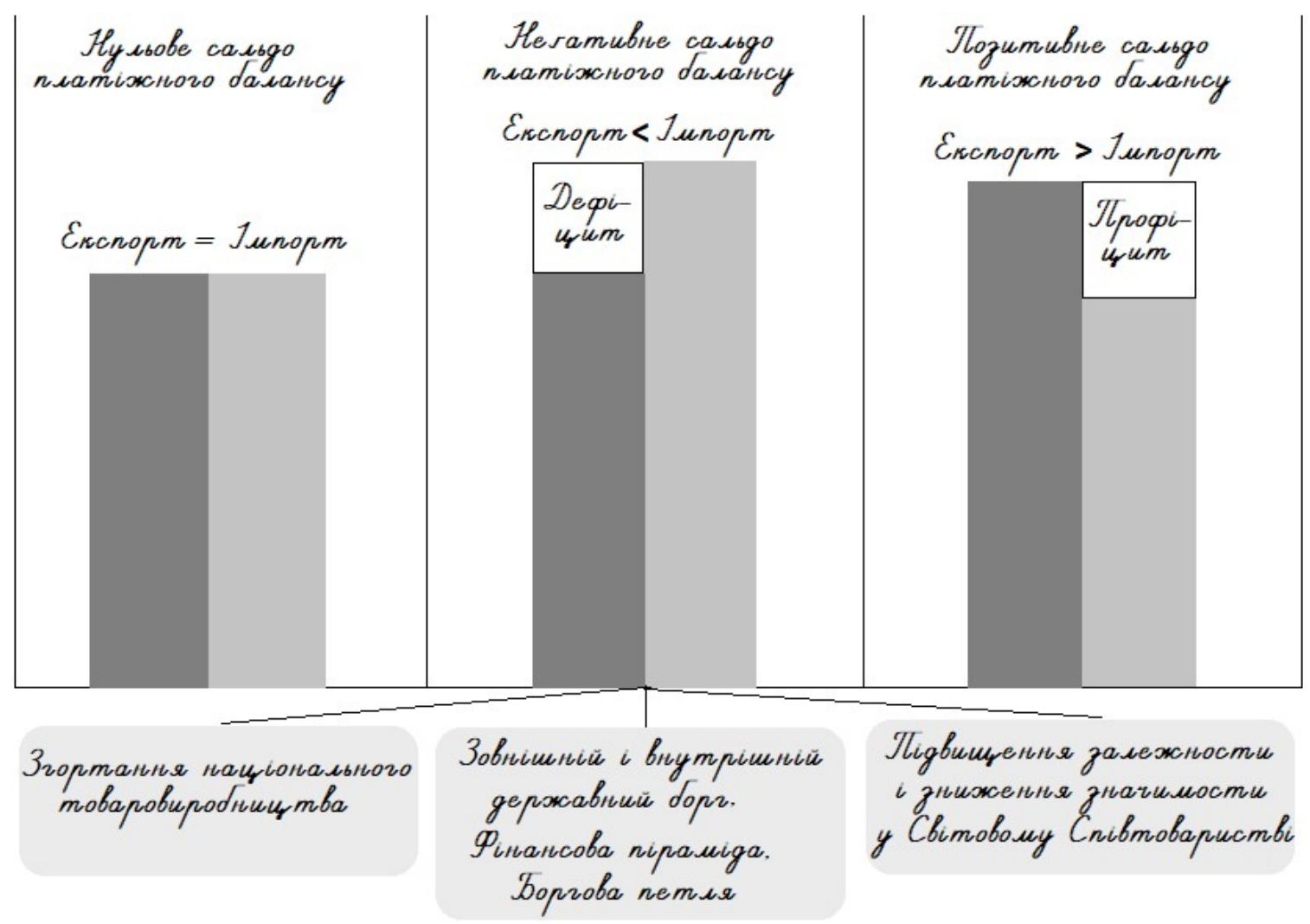

Рис. 5. Види платіжного балансу

Джерело: складено авторами на основі власних теоретичних узагальнень

Нульове сальдо платіжного балансу так само як і збалансований бюджет $\epsilon$ рідкісним явищем, адже зведення експортної та імпортної статей до нульової різниці, за конкурентних ринкових умов, є практично неможливим. Незначні відхилення у бік від'ємного та додатного значення не складуть для економіки значних проблем чи переваг. Проте хронічний дефіцит платіжного балансу підвищуватиме загрозу боргового тягаря й фінансово-товарної залежности від зовнішнього світу, а також поступове внутрішньо-національне згортання виробництва. Девальвація національної грошової одиниці, внаслідок перманентного відтоку валюти й ослаблення економіки, частково активізуватиме експортні операції. Тривалий профіцит платіжного балансу $\epsilon$ бажаною ситуацією, що сприяє притоку капіталу і нарощуванню стимулів для інноваційно-інвестиційної діяльности на мікроекономічному, галузевому, регіональному й національному рівні. Недоліком може бути стійка ревальвація національної грошової одиниці, яка сприяє подорожчанню експортних операцій і робить фінансово привабливішим імпорт.

Вищеподані індикатори макроекономічної рівноваги черговий раз доводять постійну актуальність її досягнення та підтримання. Реалізація цієї мети вимагає залучення значних ресурсів і зусиль, що є можливим тільки за безпосереднього формування державою дієвого фінансового механізму.

Б.Райзберг, Л.Лозовский та Е.Стародубцева підходять до сутности даного явища таким чином: «Фінансовий механізм - це складова частина господарського механізму, сукупність фінансових стимулів, важелів, інструментів, форм і способів регулювання економічних процесів і відносин. Він включає передусім ціни, податки, мита, пільги, штрафи, санкції, дотації, 
субсидії, банківський кредитний i депозитний проценти, облікову ставку, тарифи» [1, с.27].

В.Федосов, С.Огородник та В.Сутормина пропонують на широкий загал власне трактування, згідно якого: «Фінансовий механізм - це сукупність економікоорганізаційних та правових форм і методів управління фінансовою діяльністю держави, які функціонують у процесі формування, розподілу й використання цільових централізованих і децентралізованих фондів грошових ресурсів для задоволення потреб суспільства» [1, с.28].

Н.Метеленко та О.Шульга під фінансовим механізмом вбачають «складову частину господарського механізму, єдиний для всієї фінансової системи країни інструментарій» [2, с.179].

Виходячи з усього вищесказаного, вважаємо за необхідне запропонувати власне тлумачення цієї категорії. Таким чином, фінансовий механізм досягнення макроекономічної рівноваги - це органічна єдність нормативно-правових актів у фінансовій сфері, інституційних, людських та грошових ресурсів, що спільними зусиллями виявляють причини порушення рівноваги між сукупним попитом та сукупною пропозицією, між попитом на гроші та грошовою пропозицією, між попитом на робочу силу і пропозицією робочої сили, між доходами й витратами Державного та Зведеного бюджетів, між експортом та імпортом, виникнення тіньової економіки і «чорного» ринку, а також прорахунок масштабів негативних наслідків, траєкторії їхньго розповсюдження, а відтак розробка і практичне впровадження ефективних шляхів, методів, інструментів, важелів та заходів вирішення існуючих проблем і повернення ситуації у русло стабільности.

Фінансовий механізм досягнення макроекономічної рівноваги не $\epsilon$ сталим упродовж тривалого періоду. Кожна дестабілізуюча ситуація має свої особливості виникнення і прояву. Саме тому, окремі елементи фінансового механізму чи сам підхід до його побудови й застосування в тій чи иншій мірі потребує ситуативного перегляду й корегування. Не менш важливими $є$ прогнозні та запобіжні заходи фінансового механізму.

\section{Література:}

1. Бречко О.В. Фінансовий механізм державного регулювання економіки регіону (на прикладі Тернопільської области). Дисертація на здобуття наукового ступеня кандидата економічних наук. К., 2004. 236 с.

2. Метеленко Н.Г., Шульга О.П. Концептуалізація поняття «Фінансовий механізм». Причорноморські економічні студії. 2016. Вип. 10. С. 171-179. 


\section{ГЕНДЕРНА ПОЛІТИКА: ДОСВІД РОЗВИНЕНИХ КРАÏH CBITY}

Череп Олександр Григорович

д.е.н., професор

Запорізький національний університет

Дрозд Анастасія Сергіївна

Запорізький національний університет

Україна

Анотація. Досліджено теоретичні підходи до визначення сутності поняття «гендер». Запропоновано гендерні характеристики, що використовують маркетологи для створення, збуту і просування товарів і послуг. Визначено чотири етапи втілення політичної гендерної пріоритетизації на рівні країн СС. Виокремлено шість показників, що прийняті для покращення стану гендерних відносин у країнах $\mathrm{CC}$.

Ключові слова. Гендер, гендерна рівність, Свропейські комісії, гендерна пріоритетизація, Індекс гендерної рівності, політичні процеси.

Жіночність - це соматичні, психічні та поведінкові характеристики, які характерні як для жінок так і для чоловіків [1]. Гендер - одне з центральних та основних понять сучасного суспільства. Предмет гендерного дослідження: соціальні уявлення про соціокультурні, психологічні, поведінкові відмінності, або уявлення про особливості між чоловіками та між жінкам [2]. Гендерні дослідження змусили визнати що терміни «стать» та «гендер» не однакові. Стать - це біологічна різниця між чоловіками та жінками, а гендер - соціальна стать, яка часто оцінюється з точки зору ролей, стереотипів та характеристик [3]. Як видно 3 таблиці 1, маркетологи використовують гендерні характеристики, щоб створювати та просувати товари та послуги.

Таблиця 1. Гендерні характеристики, використовувані маркетологами для створення, збуту і просування товарів і послуг

\begin{tabular}{|c|c|c|c|}
\hline \multirow{4}{*}{$\begin{array}{l}\quad \text { Гендерні } \\
\text { аспекти } \\
\text { поведінки } \\
\text { споживачів }\end{array}$} & \multirow[b]{2}{*}{ Ролі } & $\begin{array}{c}\text { Для } \\
\text { чоловіка }\end{array}$ & Батько, син, друг, годувальник \\
\hline & & $\begin{array}{c}\text { Для } \\
\text { жінки }\end{array}$ & $\begin{array}{l}\text { Мати, подруга, дочка, } \\
\text { студентка }\end{array}$ \\
\hline & \multirow{2}{*}{ Стереотипи } & $\begin{array}{c}\text { Для } \\
\text { чоловіка }\end{array}$ & $\begin{array}{l}\text { Захисник сім’ї та її опора, } \\
\text { вдалий бізнесмен, годувальник, } \\
\text { супермен в усьому }\end{array}$ \\
\hline & & $\begin{array}{l}\text { Для } \\
\text { жінки }\end{array}$ & $\begin{array}{l}\text { Домогосподарка і мати, жінка- } \\
\text { кішка, дружина/кохана, } \\
\text { бізнесвумен }\end{array}$ \\
\hline
\end{tabular}




\begin{tabular}{|l|l|l|}
\hline \multirow{2}{*}{ Риси } & Чоловічі & $\begin{array}{c}\text { Активний, раціональний, } \\
\text { логічний, сильний, агресивний, } \\
\text { суворий }\end{array}$ \\
\cline { 2 - 4 } & Жіночі & $\begin{array}{c}\text { Добра, турботлива, емоційна, } \\
\text { слабка, нелогічна, залежна }\end{array}$ \\
\hline
\end{tabular}

Т.Б. Ряб наголошує, що "основні характеристики гендерних стереотипів збігаються з характеристиками соціальних стереотипів".

У політичному забезпеченні гендерна рівність Європейської комісії застосовується подвійний підхід: втілюється політика «гендерна пріоритетизація» та ініціюється спеціальні заходи. Гендерна пріоритетизація передбачає організації, формування, вдосконалення та оцінки політичного процесу в такий спосіб, щоб учасниці та учасники змогли використовувати під час прийняття політичних рішень гендерний підхід в усіх галузей політики та на всіх iï етапах [4]. Виділяють чотири етапи втілення політичної гендерної пріоритетизації, які показані в таблиці 2.

ЄК пропонує цільову ініціативу, щоб ситуація покращилась, пропагує більшу участь жінки на виборах до ЄП тощо. Щороку ЄП звітує, про виконані цілі забезпечених рівностей між жінками та чоловіками в $Є С$, які відповідають низькі індикаторів, серед яких - рівень залучення жінки до прийнятого рішення [5].

Робота над розробкою Індексу гендерної рівності розпочалась у 2010 р., а завершилась презентацією результатів на конференції в Брюсселі в червні 2013 p.

Таблиця 2. Етапи втілення політики гендерної пріоритетизації на рівні ЄС

\begin{tabular}{|c|c|c|}
\hline № & Назва & Характеристика \\
\hline 1 & Підготовчий & $\begin{array}{l}\text { Організація та виконання структурної та } \\
\text { культурної бази для реалізації принципів рівних } \\
\text { можливостей; визначається цільова група, } \\
\text { розробляються цілі, завдання та механізми } \\
\text { досягнення з урахуванням специфіки конкретної } \\
\text { групи }\end{array}$ \\
\hline 2 & $\begin{array}{l}\quad \text { Експертиза } \\
\text { специфіки (вивчення } \\
\text { гендерних } \\
\text { відмінностей) }\end{array}$ & $\begin{array}{l}\text { Дослідження існуючої ситуації гендерної } \\
\text { нерівності та виокремлення пріоритетних сфер; } \\
\text { проведення моніторингових спостережень із } \\
\text { метою виявлення тенденцій чи попередження } \\
\text { проявів гендерної нерівності у таких чотирьох } \\
\text { сферах: } \\
\text { 1. Участь (гендерний паритет у владних } \\
\text { структурах, сфері економіки стосовно } \\
\text { цільової групи населення); } \\
\text { 2. Ресурси (доступ та розподіл таких } \\
\text { ресурсів, як час, гроші, влада тощо); } \\
\text { 3. Норми та цінності (пов’язані з } \\
\text { чоловічими та жіночими } \\
\text { характеристиками); }\end{array}$ \\
\hline
\end{tabular}




\begin{tabular}{|c|c|c|}
\hline & & $\begin{array}{l}\text { 4. Права (розкриття прямої та латентної } \\
\text { дискримінації, реалізація людських прав та } \\
\text { доступ до правосуддя). }\end{array}$ \\
\hline 3 & \begin{tabular}{l}
\multicolumn{1}{l}{ Оцінювання } \\
ефективності гендерної \\
політики
\end{tabular} & $\begin{array}{l}\text { Аналіз їі потенційного впливу на } \\
\text { забезпечення участі (оцінка як кількісних, так і } \\
\text { якісних показників), розподіл ресурсів, норм, } \\
\text { цінностей (у тому числі - орієнтація на } \\
\text { залучення чоловіків до домашньої неоплачуваної } \\
\text { праці) та прав }\end{array}$ \\
\hline 4 & $\begin{array}{c}\text { Політика } \\
\text { переконструювання }\end{array}$ & $\begin{array}{l}\text { Визначення проблемних зон та їх ліквідація } \\
\text { чи заміна згідно з комплексним підходом }\end{array}$ \\
\hline
\end{tabular}

Наступні шість показників були прийняті для покращення стану гендерних відносин у країнах $\mathrm{CC}$ у порівнянні: робота (становище чоловіків та жінок на ринку праці, тривалість життя, якість роботи та захист), гроші (різниця в оплаті праці та ризик бідності), знання (кількість чоловіків та жінок, які навчаються на різних рівнях), час (кількість часу, витраченого на неоплачувану діяльність, в т.ч. догляд за дітьми та догляд на дому, участь у культурних заходах тощо), влада жінок (представництво чоловіків та жінок) у політичній та економічній сферах), охорона здоров'я (доступ до структур охорони здоров'я), інше насильство (насильство проти жінок, стереотипи та упередженості, які перешкоджають покращенню ситуації у напрямку більшої гендерної рівності) (табл. 3).

Таблиця 3 Значення індексу гендерної рівності в СC

\begin{tabular}{|c|c|c|}
\hline № & $\begin{array}{c}\text { Показники } \\
\text { індексу }\end{array}$ & $\begin{array}{c}\text { Значення (1 - повна нерівність, } 100- \\
\text { повна рівність) }\end{array}$ \\
\hline 1 & Робота & 69,0 \\
\hline 2 & Гроші & 68,9 \\
\hline 3 & Знання & 48,9 \\
\hline 4 & Час & 38,8 \\
\hline 5 & Влада & 38,0 \\
\hline 6 & Здоров’я & 90,1 \\
\hline & Загалом & 54,0 \\
\hline
\end{tabular}

Значення індексу становить від 1 (повна нерівність) до 100 (повна нерівність). Загалом індекс гендерної рівності ЄС становить 54, що означає, що гендерна рівність лише вдвічі менша. Стан здоров'я жінок та чоловіків - найкраща позиція в $€ С$, а розподіл відповідальності - найгірший варіант.

Слід зазначити, що подібні висновки містяться в інших міжнародних звітах (таких як Світова доповідь про гендерну розбіжність), які вимірюють стан гендерних відносин у різних сферах суспільного життя.

Щодо влади, Інтернет-платформа "Індекс гендерної рівності" містить низку інформації про політичні ініціативи СС щодо сприяння гендерній рівності. У цій базі даних ви можете шукати певне походження за словом у назві, а також країну, 
рік прийняття, сферу (зокрема - шість елементів покажчика), національний або регіональний рівень. Наприклад, у сфері влади було зібрано 114 національних та 68 регіональних ініціатив. Більшість політичних ініціатив стосуються подолання насильства: 392 на національному рівні та 86 на регіональному рівні.

\section{Список використаних джерел:}

1. Бергман С. Участь та повноваження жінок Північних країн у політиці // Жінки в політиці: міжнародний досвід для України / За заг. ред. Я. Сверлюк та С. Оксамитної // За матеріалами міжнародного наукового семінару «Жінки в політиці: міжнародний досвід для України», Київ - НаУКМА - 7 жовтня 2005 року. - К.: Атіка, 2006. - C. 47-49 // URL: http://dfc.ukma.edu.ua/books/women_politics_ukr_text.pdf

2. Гендерна експертиза українського законодавства. Сутність, необхідність та методологічні основи. (Відп. ред. Т.М. Мельник.) - Київ, 2001.

3. Декларація про загальні засади державної політики України стосовно сім’ї та жінок. - Київ, 1999. - с. 11-12

4. Кисельова О., Коломієць I. Гендерна політика Європейського Союзу: виклики для України. - К., 2007. - 152 с.

5. Конвенція щодо дискримінації в галузі праці і занять. Права людини. Міжнародні договори України. - Київ,1992. - с. 173 


\title{
ОСОБЛИВОСТІ ОРГАНІЗАЦІї ДИСТАНЦЙНОГО ВИВЧЕННЯ ПРИРОДНИЧО-ГЕОГРАФІЧНИХ ДИСЦИПЛІн
}

\author{
Картавий Андрій \\ ст. викладач кафедри екології та агрономії \\ Луцького національного технічного університету \\ Федонюк Віталіна \\ к. геогр. н., доцент кафедри екології та агрономії \\ Луцького національного технічного університету \\ Федонюк Микола \\ к. геогр. н., доцент кафедри екології та агрономії \\ Луцького національного технічного університету
}

В умовах соціальних та організаційних викликів, які постали перед системою вищої освіти в умовах пандемії коронавірусу на протязі 2020 - 2021 рр., питання вибору форм та методів дистанційного навчання набули великої актуальності. Особливо складним $є$ процес розробки та впровадження методів дистанційного вивчення дисциплін природничо-географічного циклу, оскільки в природничих науках практичні, прикладні аспекти підготовки майбутніх фахівців $\epsilon$ надзвичайно важливими $[1,2]$. Вивчення інструментальних методів контролю параметрів навколишнього природного середовища, оволодіння навичками роботи з відповідними приладами і апаратурою, опрацювання картографічних, статистичних, архівних матеріалів, даних спостережень за елементами природних систем, аналіз та інтерпретація таких матеріалів - усе вищеназване потребує тісної взаємодії у системі «викладач, ментор - здобувач освіти», постійного контакту, широкого використання аналогових методів у навчальному процесі, що нелегко реалізувати дистанційно.

В процесі викладання здобувачам першого (бакалаврського) рівня вищої освіти за освітньою програмою «Екологія» та освітньою програмою «Агрономія» циклу дисциплін природничо-географічного спрямування, серед яких «Грунтознавство», «Грунтознавство 3 основами геології», «Геологія», «Метеорологія і кліматологія», «Топографія з основами картографії», авторами було напрацьовано ряд методичних рекомендацій щодо оптимізації дистанційних форм навчання в межах програми названих курсів.

Отже, на першому етапі були виділені наступні проблемні елементи організації процесу вивчення даного циклу дисциплін: 
- Складність організації проведення лабораторних робіт без доступу до спеціалізованих лабораторій, приладів, обладнання;

- Проблемний характер опанування здобувачами розрахунковоматематичних методик, методик розв'язування задач (як типових, так i спеціальних), початкових навичок роботи в програмі «MS Excel»;

- Необхідність додаткового тлумачення та роз'яснення спеціальної термінології, понятійного апарату, тематичної номенклатури у зв'язку 3 широким діапазоном і характером такого тлумачення в інтернет-джерелах, які в умовах дистанційного навчання використовуються здобувачами як основні, що не завжди є коректним та правильним;

- Відсутність можливості тематичних екскурсій на виробничі і дослідницькі об'єкти, у музеї, в науково-дослідні спеціалізовані установи, відсутність умов для організації польових практичних занять.

Слід зазначити, що, на нашу думку, повної адаптації навчального процесу до умов карантину і дистанційного навчання, які частково продовжуються і у 2021 p., не відбулося, i якість підготовки здобувачів вищої освіти зазнала негативного впливу. Проте продовжується активний пошук і напрацювання відповідних форм та методів організації такого навчання, i далі ми зупинимося на аналізові власних напрацювань у даній сфері.

Серед апробованих авторами методик та таких, що зарекомендували себе як ефективні, з хорошим зворотнім зв'язком у системі «здобувач - викладач», розглянемо наступні методи i форми організації дистанційного вивчення дисциплін природничо-географічного циклу:

1. Широке використання прикладних онлайн-сервісів в галузі аналізу природних процесів і явищ; в останні роки такі сервіси активно з'являються i розвиваються на теренах Інтернету, початково вони не були навчальними і мали утилітарний характер. Проте 3 допомогою пояснень і підказок викладача, ментора і при відповідному виборі навчальних вправ на практичних заняттях можна використовувати, зокрема, такі онлайн-сервіси, як Google Earth, Blitzortung.org, Windy.com, Climate-data.org, DataWrapper, Геоінформ та ін.

Детальніше про методи, принципи та засади використання даних інформаційних ресурсів ми писали у [2,3], розглядаючи також практичні завдання і задачі, які можуть виконуватися з конкретних предметів та за певними темами.

2. Використання перерахованих онлайн-сервісів дозволяє формулювати та пропонувати для самостійного виконання здобувачами цікавих і нестандартних завдань, серед яких: територіальний аналіз та планування, робота 3 електронними архівами інформації, онлайн-картографування природних явищ i процесів та багато іншого.

3. Розробка, розгляд і аналіз на заняттях зі здобувачами тематичних наукових словників основних термінів і понять 3 даної дисципліни. Постановка завдань 3 перекладу відповідних текстів та мультимедійних матеріалів. Ефективність такої діяльності може бути значно підвищена, якщо студентам задавати мотивацію відповідальністю (наприклад, «з фрагментів ваших перекладів буде укладено 
повноцінний методичний матеріал для наступників, який буде доступний у репозиторії»).

4. Розподілені завдання з пошуку та створення підбірок (списків відтворення) тематичних відео на YouTube (напр., по властивостях окремих мінералів, по стихійних явищах тощо), із самостійними анотаціями та наступним колективним обговоренням.

Активна робота у режимі відео-конференцій та у месенджерах, групове та індивідуальне особисте спілкування зі здобувачами у телефонному режимі та режимі електронного листування, з одного боку, дозволяє налагодити потрібну комунікацію, але, з іншого боку, суттєво пролонгує час і зусилля, які необхідні для виконання поставлених навчальних завдань. Проте ця проблема не може бути повністю вирішеною до часу повернення студентства і викладачів у навчальні аудиторії та відновлення звичного режиму освітнього процесу, у який ми ввійдемо, озброєні новітніми технологіями та вміннями у сфері онлайнресурсів і засобів навчання.

\section{Список літератури:}

1. Грищенко С. Формування мотивації в процесі вивчення природничих дисциплін на основі інтерактивних інформаційних технологій / С.Грищенко // Вісник Інституту розвитку дитини. - К. : 2012. - № 25. - С.16 - 22.

2. Федонюк В. В., Федонюк М.А., Панькевич С.Г., Досвід використання програми Google Earth при викладанні географічних дисциплін / В.В. Федонюк, М.А. Федонюк, С.Г. Панькевич // Інформаційні технології і засоби навчання, № 6 (38), 2013. - С. 138-148.

3. Федонюк В.В. Приклади використання інтернет-ресурсів у практичному курсі дисципліни «Заповідна справа»/Федонюк В.В., Іванців В.В., Федонюк М.А., Панькевич С.Г. // Інформаційні технології і засоби навчання. - 2015, № 2 (46). - C.109-123. 


\title{
РОЛЬ МІЖНАРОДНОГО КОНКУРСУ 3 УКРАЇНСЬКОЇ МОВИ ІМЕНІ ПЕТРА ЯЦИКА У ВИХОВАННІ МОЛОДОЇ ГЕНЕРАЦЇ̈ УКРАЇНЦІВ У ПАРАДИГМІ УКРАЇНОЦЕНТРИЧНОСТІ
}

\author{
Загребельна Ніна, \\ кандидат історичних наук, доцент, \\ історичний факультет, \\ Національний педагогічний університет імені М. П. Драгоманова \\ Яретик Микола, \\ студент III курсу, \\ історичний факультет, \\ Національний педагогічний університет імені М. П. Драгоманова
}

У 1994 році було створено Міжнародний благодійний фонд «Ліга українських меценатів», фундатором якої став канадський громадський діяч та бізнесмен Петро Яцик. Він уперше запропонував провести в Україні мовний конкурс серед молоді, зробив вагомий внесок у його фінансування. Перший Міжнародний конкурс знавців української мови стартував 9 листопада 1999 року.

Явище меценатства в історії України не має аналогів. Меценатство $є$ важливим чинником підтримки культури, мистецтва, науки і освіти, розвитку творчого, духовного, інтелектуального потенціалу суспільства.

Одним із яскравих представників когорти меценатів $є$ Петро Яцик український достойник, громадський діяч, визначний бізнесмен, простий юнак і3 України, який виріс у Канаді до рівня видатного громадського діяча. Хто б міг передбачити, що з-під солом'яної стріхи бойківської хати у широкий світ вийде людина з такою величчю душі? [6, с. 4]

Петро народився 7 липня 1921 року в селі Верхнє Синьовидне, що на Львівщині, у селянській родині Дмитра та Марії Яциків. Тут пішов до місцевої школи, а згодом - на сільськогосподарські курси. Ще з юного віку виявляв тягу до знань. Усвідомлюючи, що в сільський побут входить техніка, відчуваючи, що за нею майбутнє, хлопець активно шукав свій інтерес у механіці, успішно закінчив у 1939 році шестимісячні залізничні курси та почав працювати помічником машиніста. У роки Другої світової війни пережив і відчув на собі трагедію українського народу в усіх іiі проявах - окупацію, повстанський рух, водночас мусив дбати про родину, якій після смерті батька став опорою. Улітку 1944 року, коли багато українців тікали на захід, як зазначав М. Слабошпицький, 
від «більшовицького раю», вирушив із ними й молодий Петро. У 1945 році він опинився в Баварії (Німеччина), де закінчив середню школу і вступив до Українського технічно-господарського інституту. Водночас почав вивчати англійську, німецьку та іспанську мови. Як зазначав Петро Яцик у своєму листі до українських школярів, «Так можна досягти успіху в житті», під час навчання він засвоїв декілька правил , одне з яких - «коли бачиш, що щось не є добре, зроби так, щоб було добре». «Не нарікай, роби добру роботу, а винагорода прийде» [7, c. 18]

Гідна уваги й наслідування історія успіху: приїхавши до Канади по Другій світовій війні, маючи «всього лише сім долярів у кишені», почавши роботу посудомийником, помічником м'ясника, згодом Петро Яцик із двома партнерами засновує українську книгарню, потім дозріває до відкриття меблевого магазину, а через певний час очолює групу з 18 будівельних компаній, знаних у діловому світі Північної Америки, і стає власником інвестиційного банку, а головне чесно заробивши свій капітал, цей чоловік стає не лише найбагатшою людиною Канади, найбагатшим українцем світу на той час, а й для багатьох - прикладом життєвого успіху, патріотизму і доброчинства. [2, с. 255-256]

Більшість коштів Петро Яцик віддавав на благодійність. Він добре знав, як в Україні нищилося все українське, тому активно підтримував масштабні українські проекти. Одним із них став Міжнародний конкурс з української мови, який тепер носить його ім'я. Він став масовим і залучив до вивчення української мови українців усього світу.

Петро Яцик не був мовознавцем та не мав філологічної освіти. Його робочою мовою за останні п’ятдесят років була англійська, країною проживання - Канада, а коло спілкування - англомовним. Однак його ім'я асоціюється з відродженням та піднесенням престижу державної мови як в Україні, так і поза їі межами.

Ідея проведення конкурсу виникла в Михайла Слабошпицького, письменника i виконавчого директора Ліги українських меценатів. Ця пропозиція зацікавила Яцика, була ним переосмислена і внесена на обговорення в Лізі українських меценатів, президентом якої він тоді був, і згодом спільними зусиллями втілена в життя.

Це мав бути конкурс насамперед для учнів, бо, на особисте переконання канадського бізнесмена, починати треба 3 юних - їм жити в новій Україні та будувати iі майбутнє. Заключний етап Першого Міжнародного конкурсу відбувся в 2000 році та налічував понад 200000 учасників. Петро Яцик вручав премії переможцям на сцені Національної філармонії. [3]

П. Яцик зазначав: «Доки не настав той день, мусимо братися виховувати в юних ту україноцентричність, яка й стане основою для піднесення України в майбутньому. Починаємо з мови, а водночас маємо на увазі й українську історію, й українську ідею, щоб усе це в сумі дало українську волю, українське диво. [6, с. 244] Ці слова повною мірою відображають неоціненне значення мовного марафону. Вже перший конкурс засвідчив, що цей національно спрямований проект на часі, який має на меті утвердження державного статусу української мови, піднесення іiі престижу серед молоді, виховання поваги до культури й традицій українського народу. 
1 листопада 2001 року українці світу втратили найдалекогляднішого та найжертовнішого мецената української науки, завдяки послідовним і відданим зусиллям якого світ поступово, але постійно сприймав та інтегрував у свій живий організм поняття України і українського народу [4, с. 1]. За рішеннями Ліги українських меценатів, конкурсу було присвоєно ім'я Петра Яцика.

Уже другий конкурс міг не відбутися за відсутності головного мецената та ініціатора. Однак понад 200 українців $з$ діаспори передали пожертви на мовний конкурс через Фундацію Петра Яцика. До речі, одним із найщедріших і найзагадковіших жертводавців конкурсу аж до смерті був меценат з Канади Стенлі Пітерсон (Богдан Патик). Він перераховував щорічно по 50 - 55 тисяч канадських доларів. Фундація називала їх «княжим даром у фонд конкурсу». Він переказував кошти і не хотів, щоб про нього писали, але на сотнях дипломів переможців конкурсу залишилося його ім'я, адже в конкурсі всі без винятку дипломи іменні. [3] Конкурс і донині тримається на коштах благодійників 3 України, Канади, США, Австралії...

Конкурс щороку стартує 9 листопада, в День української писемності та мови. Він проходить у чотири етапи за олімпійською системою: шкільний, районний, обласний та всеукраїнський. Переможці конкурсу отримують грошову винагороду (залежно від віку учасників). У конкурсі беруть участь як українці, так і представники інших національностей, які володіють українською мовою та послуговуються нею.

Основні локомотиви конкурсу - виконавчий директор Ліги меценатів, письменник Михайло Слабошпицький, який $є$ незаперечним авторитетом для українських учителів та представників української діаспори; генеральний директор АТ Фармацевтичної фірми «Дарниця», президент Ліги українських меценатів Володимир Загорій, який від сьомого конкурсу і дотепер - головний меценат цього проекту; директор Інституту української мови Національної академії наук України, науковець, мовознавець, голова журі конкурсу Павло Гриценко.

Конкурс залучив до участі не тільки учнів, а й студентів, військових, учнів профтехосвітніх навчальних закладів, дав натхнення і учасникам, і вчителям, адже перемога в ньому - це визнання таланту і знань, підкріплене грошовими преміями, які є гідною нагородою за відмінні успіхи на ниві рідної мови, показником престижності та важливості здобутого рівня. Сам Петро Яцик говорив свого часу, що «справжні знання коштують дорого». [3]

У конкурсі беруть участь практично всі вищі навчальні військові заклади, зокрема - Академія Сухопутних військ імені гетьмана Петра Сагайдачного, Військова академія (Одеса), Академія військово-морських сил імені П.С. Нахімова, Харківський університет Повітряних сил імені Івана Кожедуба, Військовий інститут телекомунікації та інформатизації Державного університету телекомунікацій, Військовий інститут Київського національного університету імені Тараса Шевченка, Житомирський військовий інститут імені С. П. Корольова... Чи не одними з найперших до конкурсу приєдналися учні Київського ліцею імені Івана Богуна. Кожного року на сцені столичного театру імені Івана Франка стояли переможці у військовій формі з різних навчальних 
військових закладів України. Як зазначав один з переможців конкурсу Кирило Гринько, «Ми - майбутні захисники нашої держави, маємо захищати Україну не тільки зі зброєю в руках, а й щоденно стояти на захисті нашої мови...» [3]

Конкурс знавців української мови має статус міжнародного. Тому, крім нашої держави, він вібувається всюди, де проживають українці, які бажають брати участь у цьому мовному змаганні. На сьогодні це українці з понад 30 держав світу - Литви, Латвії, Польщі, Білорусі, Росії, Казахстану, Франції, Німеччини, США, Австралії, Канади, Китаю... Завдання для учасників поширює через інтернет Міністерство освіти і науки України, а дипломи й цінні подарунки передає Міністерство закордонних справ до українських громад, недільних шкіл, церков. Традиційно дипломи й пам'ятні подарунки переможцям вручають на День незалежності України за присутності посла України в тій країні, де відбуваються урочистості нагородження юних переможців. На закритті конкурсу в столичному театрі ім. Івана Франка на сцені майорять стяги тих країн, учасники котрих брали участь у конкурсі Петра Яцика.

XXI Міжнародний конкурс з української мови стартував у Києві 9 листопада 2020 року. Вже 21 рік поспіль, незважаючи на політичні тренди, конкурс відбувається не тільки в Україні, а й у світовій українській діаспорі. За час існування Міжнародного конкурсу з української мови імені П. Яцика виросло не тільки покоління учнів, а й покоління нових учителів, які хочуть знати докладно, хто такий Петро Яцик, чиє ім'я носить конкурс. [1, с. 225] Патріотична ініціатива Петра Яцика удвадцяте знайшла відлуння в тисячах молодих українських сердець, які через участь у цьому міжнародному турнірі долучилися до світової спільноти українців. Перший меценат цього конкурсу Петро Яцик із певністю наголошував: «Ніщо і ніколи так не об'єднає українців, як рідне слово». [5]

Отже, Міжнародний конкурс знавців української мови спрямований на піднесення престижу української мови в Україні та за іiі межами, підвищення рівня знань з української мови, формування культури спілкування, формування в молоді почуття патріотизму, потреби особистої причетності до процесів утвердження і розвитку української мови, виховання молодої генерації українців в україноцентричній системі цінностей, привернення уваги громадськості та органів виконавчої влади, органів місцевого самоврядування до вирішення проблеми функціонування державної мови в Україні.

\section{Список літератури:}

1. Загребельна Н. Яретик М. Роль націокультурної діяльності мецената Петра Яцика в утвердженні духовності молодої генерації українців як основи державотворення в сучасній Україні. Тоталітаризм як система знищення національної пам'яті [текст] : збірник наукових праць за матеріалами всеукраїнської науково-практичної конференції з міжнародною участю 11-12 червня 2020 року / науковий редактор Тетяна Єщенко. - Львів: Друкарня Львівського національного медичного університету імені Данила Галицького, 2020. - C. $222-225$

2. Загребельна Н., Яретик М. Петро Яцик: канадієць-українець, що жив Україною. Драгоманівські історичні студії: зб. наук. праць молодих істориків / відп. ред. і упор. О. В. Потильчак: кафедра джерелознавства та спеціальних 
історичних дисциплін; історичний ф-т; Нац. пед. ун-т імені М. П. Драгоманова. Київ-Ніжин: Видавець Лисенко М. М., 2020. Вип. 5(9). - 400 с.

3. Короненко С. 15 років, 30 країн, тисячі учасників...Газета «День», № 89 (2015). - К: 26 травня, 2015.

4. Марко Р. Стех. Петро Яцик - 1921-2001. Будівничий українознавчих студій. - PressRelease. - Канадський Інститут Українських Студій, 14 лютого 2002 p. - C. 1

5. Режим доступу:

https://www.facebook.com/604487636603344/posts/767602116958561/

6. Слабошпицький М. Українець, який відмовився бути бідним / Михайло Слабошпипцький. - К.: Ярославів Вал, 2011. - 255 с.

7. Слабошпицький М., Сорока М. Меценат, який не відмовився бути українцем. Петро Яцик у спогадах сучасників - К.: Ярославів Вал, 2002. - 195 с. 


\title{
LEGAL E-EDUCATION USING THE ACHIEVEMENTS OF LEGAL SCIENCE
}

\author{
Oksana M. Vinnyk \\ Department of International Private and Comparative Law \\ Academician F.H. Burchak Scientific Research Institute of Private Law and \\ Entrepreneurship of the National Academy of Legal Sciences of Ukraine \\ 01042, 23-a Rayevsky Str., Kyiv, Ukraine \\ ORCID ID: https://orcid.org/0000-0002-9397-5127
}

\begin{abstract}
Olga V. Shapovalova
Doctor of Laws, Professor, Department of Business Law Volodymyr Dahl East Ukrainian National University 93400, 59-a Tsentralnyi Ave., Severodonetsk, Ukraine ORSID https://orcid.org/0000-0002-8813-3849
\end{abstract}

The digitalization of all spheres of public life, including higher education, has become especially widespread in the past year in connection with the coronavirus pandemic and quarantine measures. Accordingly, distance education has become popular (and under conditions of quarantine - mandatory), which, however, requires the provision of the necessary electronic means, including electronic study guides and educational-methodical literature, electronic regulations, access to electronic libraries and websites of scientific institutions, which publish the results of scientific research in the form of monographs, collections of scientific papers, commentaries on legislation, scientific articles, materials of scientific and scientific-practical conferences.

Cooperation between higher educational institutions (in our case- legal) and scientific institutions engaged in scientific research in the field of jurisprudence is acquiring particular importance.

In these conditions, digital resources (in particular, the Internet) came in handy, thanks to which a number of problems can be solved: conducting scientific and educational events online, visiting electronic libraries (the site of a conventional analogue library), searching of regulatory legal acts on the website of the Parliament (Verkhovna Rada of Ukraine), and the results of scientific research - on the websites of scientific institutions. Collaboration between scientific and educational institutions 
is of particular importance, allowing them to combine their resources to ensure quality education.

An example of such cooperation is the creative ties of the Law Faculty of the Volodymyr Dahl East Ukrainian National University (hereinafter referred to as the University) and the Scientific Research Institute of Private Law and Entrepreneurship named after academician F.G. Burchak of the National Academy of Legal Sciences of Ukraine (hereinafter referred to as the Scientific Research Institute). In the creative cooperation of these institutions, an electronic textbook "Commercial law in the context of the digitalization of the economy" was prepared and posted on the website of this university [1]. Subsequently, a paper version of this work was printed [2] for the needs of those students who prefer traditional (paper) books.

In addition, the electronic publications of the Research Institute (monographs, collections of scientific papers, articles, collections of conference materials, etc.), posted on its website (ndippp.gov.ua), became the subject of discussion at scientific events with the participation of University teachers and his students, as well as invited scientific and scientific-pedagogical workers of other institutions [3, 4].

For the training of qualified lawyers, such cooperation is very important, since it allows not only to provide key knowledge about the legal regulation of public relations (in historical and modern aspects), but also the theoretical basis of such regulation, problems that caused the emergence of certain normative legal acts and / or the implementation of various reforms in the field of legal regulation, the emergence of new needs and, accordingly, the search for innovative approaches to such regulation, caused by changes in the life of society, in economic and other spheres. This is especially relevant in the modern conditions of digitalization of public relations and the need to overcome new threats to public well-being, like the current coronavirus pandemic and environmental problems associated with global warming.

The participation of University professors in such studies (for example, on digitalization [5]) together with colleagues from the Research Institute allows students to be connected to the current legal problems of the present and prepare them for practical activities not only in terms of applying the current legal regulation, but and the opportunity to indirectly participate in its improvement by expressing one's position in scientific and popular articles, engaging in research work in the process of preparing dissertation research.

The implementation of an effective educational policy will be facilitated by the balance of traditional education in the field of jurisprudence using legal e-learning. Due to the fact that e-learning mainly functions using digital technologies, there is a need to clarify digital rights not only to participants in the educational process, but also to applicants for electronic transactions that are implemented using the Internet.

One of the main directions for the implementation of digital rights of participants in the educational process is to provide access to electronic platforms of educational institutions. Compared to providing access to the Ukrainian media, access to electronic 
platforms of educational institutions is excessively limited. So, the applicant cannot get acquainted with the educational and methodological support of the disciplines, because the MOODLE platform is available only for students. It would be advisable to place descriptions of disciplines, work programs for studying disciplines and other documentation on an autonomous information platform designed specifically for applicants, with which the applicant can compare his expectations from the educational process in each specific educational institution. This is important for the career guidance of future specialists at the earliest stage of choosing a profession. Therefore, it is advisable to make appropriate additions, clarifications and other changes to special laws on education and by-laws.

\section{Literature:}

1. Vinnyk O. M., Shapovalova O. V. Commercial law in the context of digitalization of the economy: textbook. Under total. ed. Vinnyk O.M. 2020.297p. Electronic, 1CD.

http://dspace.snu.edu.ua:8080/jspui/bitstream/123456789/3845/1/Vinnyk_OM_Shapova lova_OV_Hospodarske_pravo_v_umovakh_tsyfrovizatsii_ekonomiky_Navch_pos_202 $\underline{0 . p d f}$.

2. Vinnyk O. M., Shapovalova O. V. Commercial law in the context of digitalization of the economy: textbook. Under total. ed. Vinnyk O.M.: Research Institute of Private Law and Entrepreneurship named after Academician F.G. Burchak NAPS of Ukraine 2020.314 p.

3. PROGRAM of educational and scientific events dedicated to the 100th anniversary of Volodymyr Dahl East Ukrainian National University ROUND TABLE "DIGITALIZATION OF MODERN BUSINESS PROCESSES AS A VECTOR OF NEW ECONOMIC POLICY". URL https://fileview.fwdedn.com/?url=https $\% 3 \mathrm{~A} \% 2 \mathrm{~F} \% 2 \mathrm{Fmail} . u k r . n e t \% 2 \mathrm{Fapi} \% 2 \mathrm{Fpublic}$ \%2Ffile_view\%2Flist\%3Ftoken\%3DcRTZsKsTcWaNOvcN9Yriw3yPQ1C6oEtFU3 xwEFESaKTf8H_aJJkKogOx1Uak3n9tiBpq2SGzYU2qfytkkQRDJIBtQB6x52kj4lE $\% 253$ A5DIzr-

HqZyMDIdQ_\%26r\%3D1611769192506\&default_mode=view\&lang=uk\#start=0/

4. Digitalization of modern business processes as a vector of the new economic policy. Collection of scientific papers. Under total. ed. O.V. Shapovalova. Severodonetsk: VNU im. V. Dahl, 2019, 70 p. URL : http://pravo-snu.com.uа/науковівидання/

5. Oksana M. Vinnyk, Olga V. Shapovalova, Nino B. Patsuriia, Olena M. Honcharenko, Kateryna V. Yefremova. The problem of ensuring the social direction of the legislation of Ukraine on the digital economy // Asia Life Sciences. Issue 1, July 2020, Pages 133-151

URL

https://drive.google.com/file/d/1_p5MXdlhEkkyKodqVRKWfj4MM33z7njr/view?usp= sharing (date of the application: 27.01.2021). 


\title{
ВІДПОВІДАЛЬНІСТЬ РІЕЛТОРА ЗА ДОГОВОРОМ ПРО НАДАННЯ РІЕЛТОРСЬКИХ ПОСЛУГ
}

\author{
Грущинська Наталія Ігорівна \\ Кандидат юридичних наук, доцент кафедри \\ Цивільного права та процесу \\ Юридичного факултету \\ Львівського національного Університету \\ ім. І. Франка
}

Ріелторські послуги надаються за договором про надання ріелторських послуг, які є різновидом договору про надання послуг. На сьогоднішній день не має спеціального законодавства яке б регулювало ріелторські послуги, тому до них застосовуємо загальні норми цивільного права, зокрема главу 63 Цивільного Кодексу України, послуги, загальні положення.

Згідно до статі 902 Цивільного Кодексу України ( далі ЦК) виконавець повинен надати послугу особисто[1, 52]. Це означає, що виконавець повинен самостійно вчинити всі дії, які становлять зміст його обов'язку за договором про надання послуг. За ріелторським договором, одна сторона - ріелтор - виконавець зобов'язується за завданням другої сторони замовника - фізичної або юридичної особи, споживача ріелторських послуг надати послугу під час здійснення операцій з нерухомістю та \або реалізації ними прав на нерухоме майно, а замовник - споживач ріелторских послуг зобов'язується оплатити виконавцеві ріелтору зазначену суму винагороди, якщо інше не встановлено договором.

Ріелтор має право здійснювати ріелторську діяльність самостійно або в складі агенства нерухомості. За договором про надання ріелторських послуг ріелтор - виконавець може бути фізична особа підприємець або юридична особа - агенство нерухомості.

Особистий характер ріелторської послуги полягає в тому, що відповідальність за невиконання або неналежне виконання умов договору про надання ріелторських послуг несе чітко визначений виконавець в договорі.

За загальним правилом, покладання виконання обов'язку 3 надання ріелторських послуг повністю або в певній частині на іншого виконавця ріелтора не допускається. В такому випадку, замовник - споживач ріелторських послуг, має право відмовитись від прийняття виконання, запропонованого за виконавця - ріелтора іншою особою. Це ще раз підтверджує загальну позицію законодавця, що дії чи діяльність, які становлять зміст послуги, що надається, тісно пов'язані з конкретним виконавцем[2, 701].

Покладання виконання ріелторських послуг на іншу особу - виконавця допускається, якщо це прямо обумовлено в договорі. Саме ця особливість зумовлена свободою договору. Якщо за договором про надання ріелторських послуг надавати послугу буде інший виконавець це не звільняє виконавця - 
ріелтора за договором, як сторону зобов'язання від відповідальності перед замовником. В цьому випадку виконавець - ріелтор залишається відповідальним перед замовником - споживачем ріелторських послуг у повному обсязі за порушення умов договору про надання ріелторських послуг особою, на яку покладено виконання обов'язку з надання послуг.

Згідно до законопроекту "Про ріелторську діяльність " суб'єкти ріелторської діяльності при здійсненні ріелторської діяльності повинні неухильно дотримуватись вимог даного закону, вимог чинного законодавства України, стандартів та правил, затверджених Ріелторською палатою України. За недотримання даних вимог наступає відповідальність передбачена діючим законодавством[3].

Суб'єкт ріелторської діяльності - виконавець ріелторських послуг зобов'язаний не використовувати своїх повноважень на шкоду споживачу даних послуг, в інтересах якого і надаються останні. Це передбачено проектом закону " Про ріелторську діяльність " та Закону України " Про захист персональних даних" згідно до статті 4 якого володілець персональних даних може доручити обробку персональних даних розпоряднику персональних даних відповідно до договору, укладеного в письмовій формі. Натомість, розпорядник персональних даних може обробляти персональні дані лише з метою і в обсязі, визначених у договорі [4].

Ріелтор - виконавець зобов'язаний не розголошувати інформацію щодо особи - замовника та його майнового стану, а також інформацію щодо майна особи, яка є конфіденційною і стала відомою останньому в процесі здійснення ним своєї діяльності. В разі не виконання таких умов договору ріелтор - виконавець зобов'язаний відшкодувати завдані збитки в повному розмірі та моральну шкоду особі - замовнику, споживачу ріелторських послуг.

Виконавець на вимогу споживача ріелторських послуг зобов'язаний надати йому для ознайомлення документи, що підтверджують право на здійснення ріелторської діяльності. Такий обов'язок виконавця послуг передбачено в законопроекті "Про ріелторську діяльність" та в Стандартах і правилах ріелторської діяльності[5]. Ця інформація необхідна для захисту прав споживача за даним договором, оскільки замовник - споживач даних послуг має право на інформацію і конкретна послуга надається виконавцем - ріелтором на платній основі, кваліфікованим суб'єктом ріелторської діяльності, про що i підтверджується у відповідних документах.

Ріелтор, як вже було зазначено вище, зобов'язаний забезпечувати конфіденційність інформації, отриманої під час надання ріелторських послуг, не використовувати таку інформацію в своїх інтересах чи в інтересах третіх осіб. Також ріелтор зобов'язаний забезпечувати збереження документів, отриманих від споживача ріелторських послуг. Для реалізації ріелторської послуги виконавець - ріелтор зобов'язаний надати замовнику - споживачу ріелторської послуги інформацію про об'єкт нерухомості, який відчужується. 
Замовник ріелторської послуги - продавець одночасно з наданням інформації про об'єкт продажу, конкретне нерухоме майно, передає виконавцеві правовстановлюючі документи, на практиці, це, як правило, копії документів для ознайомлення та надання повної та достовірної інформації про відчужуваний об'єкт нерухомості іншому споживачеві ріелторських послуг - покупцю.

Збереження документів - це комплекс заходів, спрямований на забезпечення схоронності останніх, недопущення їх знищення або втрати, а також не розголошення інформації, яка в них міститься[3]. В правовстановлюючих документах міститься інформація, яка відноситься до виду конфіденційної, розголошення останньої допустиме лише за згодою власника. У випадку не виконання даного пункту в договорі, виконавець - ріелтор зобов'язаний відшкодувати збитки споживачу ріелторських послуг в повному розмірі.

Ріелтор - виконавець зобов'язаний повідомити замовника про неможливість надання таких послуг у разі виникнення обставин, які позбавляють суб'єкта ріелторської діяльності можливості надати такі послуги. До суб'єктів ріелторської діяльності застосовують загальні положення про відповідальність, оскільки на даний час не має спеціального нормативно - правового акту який би регламентував питання відповідальності ріелторів. Законопроект Про ріелторську діяльність виділяє відповідальність суб'єктів ріелторської діяльності за порушення даного закону та наводить перелік санкцій, які застосовуються за рішенням Ріелторської палати України. До останніх відносять : попередження, штраф, анулювання сертифікату суб'єкта ріелторської діяльності та внесення відповідної відмітки до реєстру ріелторів України, а також анулювання кваліфікаційного свідоцтва ріелтора та виключення ріелтора з реєстру ріелторів України. В свою чергу рішення ріелторської палати України може бути оскаржене в судовому порядку ріелтором[3].

В кожному конкретному випадку суб'єкт ріелторської діяльності укладає договір про надання ріелторських послуг 3 споживачем даних послуг. В законопроекті наводиться перелік послуг, які може надавати ріелтор, а саме : посередницька діяльність, управління нерухомим майном, ріелторська експертиза, організація та проведення прилюдних торгів, аукціонів та конкурсів щодо нерухомого майна, інформаційно - консультаційна діяльність суб'єктів ріелторської діяльності. За невиконання або неналежне виконання даних послуг виконавець - ріелтор зобов'язаний відшкодувати замовнику збитки.

Згідно до статті 906 ЦК України збитки, завдані замовнику невиконанням або неналежним виконанням договору про надання послуг за плату, підлягають відшкодуванню виконавцем, у разі наявності його вини в повному обсязі, якщо інше не встановлено договором[1, 53]. Застосувавши загальні положення про послуги до договору про надання ріелторських послуг, можна провести аналогію і щодо цивільно - правової відповідальності за договором про надання ріелторських послуг. Частина 1 статті 906 ЦК України регламентує відповідальність виконавця за платні послуги в повному обсязі. 
Проаналізувавши договори про надання ріелторських послуг на практиці можна зробити висновок, що виконавці - ріелтори, суб'єкти підприємницької діяльності, здійснюють таку діяльність на платній основі і у випадку заподіяння збитків замовнику - споживачу послуг, зобов'язані відшкодувати збитки в повному розмірі, якщо інше не встановлено договором.

Законодавець призюмує наявність вини виконавця - ріелтора. Згідно до статті 614 ЦК України особа, яка порушила зобов'язання, несе відповідальність за наявності ії вини ( умислу або необережності), якщо інше не встановлено договором або законом. Сам ріелтор - виконавець, як особа яка порушила зобов'язання за договором про надання ріелторських послуг, зобов'язаний довести відсутність своєї вини. Збитки за даним договором підлягають відшкодуванню у повному розмірі, тобто відшкодовується реальна шкода та упущена вигода.

\section{Список використаних джерел:}

1. Цивільний кодекс України від 16.01.2003р. // ВВР. 2003. №40 - 44. ст. 356.

2. Науково - практичний коментар Цивільного кодексу України / За ред. В. М. Коссака. - К. : Істина, 2008.

3. Проект Закону України " Про ріелторську діяльність" w.1 c.1 rada. gov. ua.

4. Закон України " Про захист персональних даних" // ВВР. 2010. № 34. ст. 481.

5. Принципи та стандарти практики фахівців з нерухомості України, які створені учасниками асоціації фахівців з ринку нерухомості України

/ www. google. com. ua 


\title{
ОСОБЛИВОСТІ СИСТЕМИ КАДАСТРОВОГО ОБЛІКУ ПІД ЧАС ПРОВЕДЕННЯ ЗЕМЕЛЬНОЇ РЕФОРМИ
}

\author{
Жмур Наталія Володимирівна \\ Кандидат юридичних наук, доцент кафедри \\ Національний авіаційний університет, м. Київ \\ Лавренчук Марина Миколаївна \\ Студентка \\ Національний авіаційний університет, м. Київ
}

В умовах вдосконалення господарського механізму в державі особливе значення мають питання управління земельними ресурсами, впровадження нових технологій ведення земельного кадастру, оцінки земель і використання земельно-кадастрової інформації.

Поняття земельного кадастру регламентується статтею 1 Закону України «Про державний земельний кадастр» - це єдина система відомостей про землі, які розташовані в межах державного кордону України, а також дані про якісну характеристику земель, їх оцінку, цільове призначення, їх оцінку, про розподіл земель між власниками і користувачами [2].

Як зазначає Л.П. Фоміна, земельний кадастр це юридично значима інформаційна система, яка необхідна для розвитку земельного обороту, а також планування і контроль раціонального використання земельних ресурсів в інтересах суспільства відповідно до його потреб [ 5, С. 116].

3 часів незалежності України, і початку земельної реформи, розпочався процес приватизації, купівлі-продажу, оренди земельних ділянок громадянами держави. Після десятиліть мораторію на продаж землі, в українському законодавстві розпочинається новий етап земельної реформи - впровадження ринку землі, що регламентуватиметься Законом України «Про внесення змін до деяких законодавчих актів України щодо умов обігу земель сільськогосподарського призначення», який було ухвалено Верховною Радою України 31 березня 2021 року, а набирає чинності з 1 липня 2021 року [1].

Вважаємо, що для успішного сучасного функціонування землі в цивільному обороті, ведення і діджиталізація системи держгеокадастру є одним з основних аспектів захисту прав суб'єктів земельних правовідносин.

Процес покращення кадастрового обліку вже стартував одночасно 3 прийняттям 13 квітня 2020 року Закону України «Про національну інфраструктуру геопросторових даних», який набув чинності 1 січня 2021 року [3]. Перше і найголовніше, чому цей Закон вважають революційним, то завдяки цьому нормативно-правовому акту проводяться роботи по створенню єдиного Геопорталу кадастрів та геопросторових даних, користування яким буде безкоштовним, а інформація стане повністю відкритою і оновлюватиметься в режимі реального часу. 
Це дасть можливість об'єднати інформацію про різні об’єкти інфраструктури, мережі комунікацій та бази даних в одному місці, що забезпечить систематизацію інформації про геопросторові дані й метадані та отримання якісної аналітики. Вже зараз проводяться масштабні ортофотозйомки усіх земельних ділянок на території України, що дозволить повністю оновити кадастрову карту земель; також детально описуються і документуються усі адміністративно-територіальні межі; проводиться реєстрація земельних ділянок.

Наприклад, за офіційними даними Державної служби України з питань геодезії, картографії та кадастру, які опубліковані в Урядовому порталі, станом на кінець грудня 2020 року до Державного земельного кадастру внесено відомості про 22,5 млн земельних ділянок, зокрема 15,1 млн - ділянки землі сільськогосподарського призначення.

Також внесено відомості про межі 8935 адміністративно-територіальних одиниць (за заявами місцевих органів влади). До кадастрових реєстрів надійшло 45,6 тис. заяв про реєстрацію земельних ділянок, зареєстрованими залишилися 39,0 тис земельних ділянок [4] .

Звернувши увагу на опубліковані статистичні дані за січень 2021 року, то на сьогоднішній день до земельного кадастру додано відомості про 500 тис. земельних ділянок, відображено дані про межі 95 адміністративнотериторіальних одиниць, а до реєстрів земельних ділянок надійшло близько 7,5 тис заяв про реєстрацію ділянок землі [4].

Порівнюючи дані Держгеокадастру по вказаних критеріях, можна зробити висновок, що до прийняття вказаного вище Закону усі показники були нижчі на $1,3 \%$. Це означає, що відповідними державними органами проводиться повна підготовка до відкриття ринку землі, адже перед його запровадженням повинна бути повністю актуалізована інформаційна система кадастрового обліку, а також державна система реєстрації прав на нерухомість, особливо для земельних ділянок сільськогосподарського призначення.

Щодо основних нововведень, які чекають кадастрову систему після набрання чинності закону про ринок землі, це: завдяки Державному земельному кадастру буде проводитися перевірка покупця ділянки на предмет можливості іiі придбання в певному розмірі (вводиться обмеження щодо загальної площі земельних ділянок сільськогосподарського призначення, які вправі набувати у власність одна особа). Завдяки оціночним даним, які складатимуться з аналізу грунтів за різними параметрами, Держгеокадастром будуть встановлюватися ціна земельної ділянки [1].

Вважаємо, що доцільним для кращого функціонування кадастрових перевірок необхідно впровадити систему моніторингу земельних ресурсів і систематизувати $\dddot{11}$ для пошуку інформації щодо угод купівлі-продажу землі. Ця система повинна поєднуватися з базою речових прав Міністерства Юстиції України для покращення відслідковування кількості гектарів земельних ділянок, які зареєстровані на одну особу, а також для ефективного управління землями органами територіальної громади.

Отже, сьогодні перед аграрною економікою стоїть ряд невирішених проблем перед запровадженням ринку землі, проте варто пам'ятати, що саме в 
руках Держгеокадастру знаходиться розпорядження всіма землями на території України. Тому актуалізація та систематизація геопросторових даних, а також створення нових систем для покращення ефективності роботи кадастрового обліку є один із першочергових завдань. А для цього слід впровадити технічні інструменти для контролю за обмеженнями щодо концентрації земель у власності громадян та юридичних осіб, створити систему моніторингу земельних відносин, ввести в експлуатацію національний Геопортал, ухвалити методику грошової оцінки земель.

\section{Список літератури:}

1. Про внесення змін до деяких законодавчих актів України щодо умов обігу земель сільськогосподарського призначення. Закон України 31 березня 2020 року № 552-IX. Статус: не набрав чинності. - [Електронний ресурс]. Режим доступу: https://ips.ligazakon.net/ document/view/T200552?an=73

2. Про Державний земельний кадастр. Закон України від 7 листопада 2011 року № 3613-VI. - [Електронний ресурс]. - Режим доступу: https://zakon.rada.gov.ua/laws/show/3613-17\#Text

3. Про національну інфраструктуру геопросторових даних. Закон України від 13.03.2020 року № 37, ст.277. - [Електронний ресурс]. - Режим доступу: https://zakon.rada.gov.ua/laws/show/554-20\#Text

4. Урядовий портал. Ведення Державного земельного кадастру: актуальні показники. - [Електронний ресурс]. - Режим доступу: https://www.kmu.gov.ua/news/vedennya-derzhavnogo-zemelnogo-kadastru-aktualnipokazniki-22-12-20 - Назва 3 екрана. - Дата публікації: 22 грудня 2020 - Дата перегляду: 26.01.2021.

5. Фомина Л.П. Государственное регулирование и право собственности на землю в сельском хозяйстве/ Л.П. Фомина. - М: Изд-во ИГиП РАН.- 1996 .C. $115-128$ 


\title{
COMMUNICATION AS THE BASIS OF BUSINESS AND MARKETING ACTIVITIES
}

\author{
Mandych Oleksandra \\ Doctor of Sciences (Economics), Professor \\ Kharkiv Petro Vasylenko National Technical University of Agriculture \\ Mykytas Arkadii \\ Doctor of Sciences (Economics), Associate Professor \\ Kharkiv Petro Vasylenko National Technical University of Agriculture \\ Babko Natalia \\ $\mathrm{PhD}$ (Economics), Associate Professor \\ Kharkiv Petro Vasylenko National Technical University of Agriculture,
}

The formation of marketing communications is based on marketing theory. But the modern conditions for the development of managerial relations require a deeper understanding of the theory of communications. At the same time, communications for the company's management system should be at different levels with a different essence.

If we accept the theory of communications only in interpersonal communication, then we should understand the peculiarities of the formation of the structure of the personality. Personality structure in the formation of a given life. But the structure of the personality does not have an effective role in the formation of professional activity in any field. Thus, one cannot perceive interpersonal communication only in the direction of social activity. At the same time, communications in the formation of the professional need for their classification according to different criteria. The classification signs should be grouped from several directions. First, the first basics of implementing communications. In this case, their different (horizontal) hierarchies of the management structure are necessary.

The peculiarities of the formation of vertical structures take into account the peculiarities of the formation of interpersonal communications on the one hand. On the other hand, this type of communication is formed in the "manager - subordinate" system and thus removes not the acceptance of only friendly communications in the team, but strengthens the professional component.

The most important communication system is formed in the company when conducting commercial activities. In this format, marketing activities are gaining special relevance. At the same time, the concepts and essence of marketing communications should be separated from communications in marketing activities. 
Thus, the current conditions of market activity require the company's specialists to simultaneously acquire skills in communication in various platforms - offline or online.

If we study the possibility of using competencies in online communication by marketers, then the necessary conditions for distance education in connection with the situation of the pandemic around the world have a number of positive aspects. Thus, marketing education provides a more practical application of communication skills in a team. At the same time, you can also gain practical experience in vertical and horizontal communication (according to the management system).

Thus, the creation of business communications, especially when marketing a company's activities, is one of the most important components of the development of a specialist. In the conditions of a positive moment of the market activity of companies is the training of specialists in the field of marketing through online education, gives them the first communication skills for the real activities of companies.

\section{References}

1. Romaniuk, I. A. (2014). Derzhavna sotsial'na polityka v zabezpechenni produktyvnoyi zaynyatosti sil's'koho naselennya [State social policy in ensuring productive employment of rural population]. Ekonomika APK-APK Economy, 10, pp. 105-109.

2. Kotler F., Keller K. (2006). Marketing menedzhment. 12-e izd. SPb. Piter. S. 52.T. 272 p.

3. Kvyatko, T. M. (2014). Spivvidnoshennya katehoriy efektyvnist' ta konkurentospromozhnist': teoretychni zasady doslidzhen', zahal'ni rysy ta osoblyvosti. Visnyk Kharkivs'koho natsional'noho ahrarnoho universytetu im. VV Dokuchayeva. Ser.: Ekonomichni nauky, 3, pp. 157-162.

4. Kvyatko, T. M. (2013). Benchmarkinh-osnova efektyvnoho rozvytku pidpryyemstva. Vestnyk Sumskoho natsyonal'noho ahrarnoho unyversyteta, (5), pp. 126-129.

5. Romaniuk, I. (2020). Section 2 financial and economic issues of society development in the turbulence conditions. Topical issues of society development in the turbulence conditions, pp. 138.

6. Krasnorutskiy, A. A., Azizov, O. R. (2015). Formirovaniye i funktsionirovaniye organizatsionno-ekonomicheskogo mekhanizma sbytovoy deyatel'nosti agrarnykh predpriyatiy. Vísnik SNAU: Yekonomíka í menedzhment, (5), pp. 3-7.

7. Romaniuk, I. (2020). Directions of introduction of innovation-investment and marketing strategies for effective development of rural green tourism enterprises. University Economic Bulletin, (47), pp. 35-40. 


\section{FEATURES OF DEVELOPING A DIGITAL MARKETING STRATEGY FOR A COMPANY}

Romaniuk Iryna, Ph.D., Associate Professor Kharkiv Petro Vasylenko National Technical University of Agriculture

Kviatko Tetiana, Ph.D., associate professor, Kharkiv Petro Vasylenko National Technical University of Agriculture

\section{Azizov Otabeg,}

Ph.D.,

Kharkiv Petro Vasylenko National Technical University of Agriculture

Marketing is the science and art of creating a meeting place for a seller and a buyer. The emergence of the term digital marketing indicates that today it is the Internet that gives many opportunities for every small and medium business to meet with their consumers online. And it's much easier to do than 5-10 years ago. Today, the success of a business depends primarily on its ability to assert itself with the help of digital tools.

One of the main theories of marketing is the marketing mix (4P). According to this theory, every entrepreneur must first describe: product, price, place, promotion. Indeed, today, by implementing a competent business strategy, companies of different sizes can reduce the price of their product due to the low cost of advertising each unit of production.

It is important to understand that these product features will not be interesting to all people. In order for advertising and posts on social networks to be as effective as possible, it is very important to try to create a product not for everyone. The secret of thrift and efficiency of marketing activities is to segment your target audience. You can segment by age, gender, income, behavioral characteristics and interests. Alex Osterwald's value creation template is a tool that helps to compare the characteristics of the representatives of the segments with the product. The value creation template consists of a customer profile, on the one hand, and a product value map, on the other. The client's profile prescribes the tasks, problems and benefits that he would like to receive. The product value map states: what services it includes, how the product solves the customer's problems and how it benefits him.

Digital marketing strategy is a description of approaches to achieving the company's marketing goals using digital tools, i.e. creating a plan to promote companies through the Internet. The digital strategy should outline the principles of using the company's websites, publishing content on blogs and social networks, working through messengers and email marketing, as well as advertising and digital environment. 
Of course, digital strategy is part of the overall marketing strategy of the company, because digital itself cannot be isolated from the general marketing base, such as customer travel in an offline environment, options for communicating product value, pricing policy and unit-economy and more. The basis for developing a digital marketing strategy is a deep understanding of the structure and goals of the customer's business, as well as the characteristics of consumers of his product or service.

The digital marketing strategy allows you to take into account all aspects of the market and product, explore all possible external and internal data and solve the problem as effectively as possible with the help of digital marketing tools.

\section{References:}

1. Naumenko, I.V. (2019). Formation of product distribution policy in integrated structures. Actual problems of innovative economy, 4, 83-87.

2. Kviatko, T.N. (2013). Benchmarking is the basis of effective enterprise development. Bulletin of Sumy National Agrarian University, (5), 126-129.

3. Babko, N.N., Mykytas, A.V., Naumenko, I.V. (2019). The mechanism of idea formation for strategic marketing of agribusiness entities. Bulletin of KhNTUSG: Economic Sciences, 206, 298-305.

4. Ihnatenko, N.N. (2017). Formation of information security of enterprises and organizations in terms of automation of accounting and financial reporting. Bulletin of Berdyansk University of Management and Business, 4 (40), 84-88.

5. Naumenko, I. V. (2019). The mechanism of formation of the idea of strategic marketing of agribusiness entities. Bulletin of the Kharkiv Petro Vasylenko National Technical University of Agriculture: Economic sciences, no. 206. pp. 298-305.

6. Babko, N. M. (2019). Marketynhove upravlinnya: osoblyvosti implementatsiyi v systemu menedzhmentu ahrarnykh pidpryyemstv. KHNTUS $\cdot H$ : ekonomichni nauky. Bulletin of the Kharkiv Petro Vasylenko National Technical University of Agriculture: Economic sciences, no. 202. pp. 299-307.

7. Mandych, O., Kalinichenko, S., Duyunova, T., Sekovoy, O., \& Mykytas, A. (2018). Competitive development of subjects of the agri-business: theory and practice. Fundamental and applied researches in practice of leading scientific schools, Vol. 28(4), pp. 86-91.

8. Ivashchenko, O. V. (2012). Educational trends in the development of domestic language-entrepreneurship-grain harvesters. Zbirnyk naukovykh prats' Tavriyc'koho derzhavnoho ahrotekhnolohichnoho univercytetu, Vol. 2 (18), pp. 156-153 


\section{АНАЛИЗ ВЛИЯНИЯ ПАНДЕМИИ COVID-19 НА ЭКОНОМИЧЕСКУЮ СИТУАЦИЮ В РОССИИ}

Блинова Екатерина Анатольевна,

К.э.н., доцент

Самарский национальный исследовательский университет имени ак. С.П.

Королева

Разные страны по-разному испытали на себе пандемию короновируса Covid19. Так и экономические последствия в разных частях света различаются. Какието регионы пострадали меньше, какие-то больше. Рассмотрим влияние пандемии на экономическое состояние в России. Для анализа возьмем официальные данные статистики за период с января по октябрь 2020 года и сравним их с аналогичным периодом предыдущих двух лет.

Во-первых, приведем динамику численности рабочей силы в возрасте от 15 лет (рис. 1).

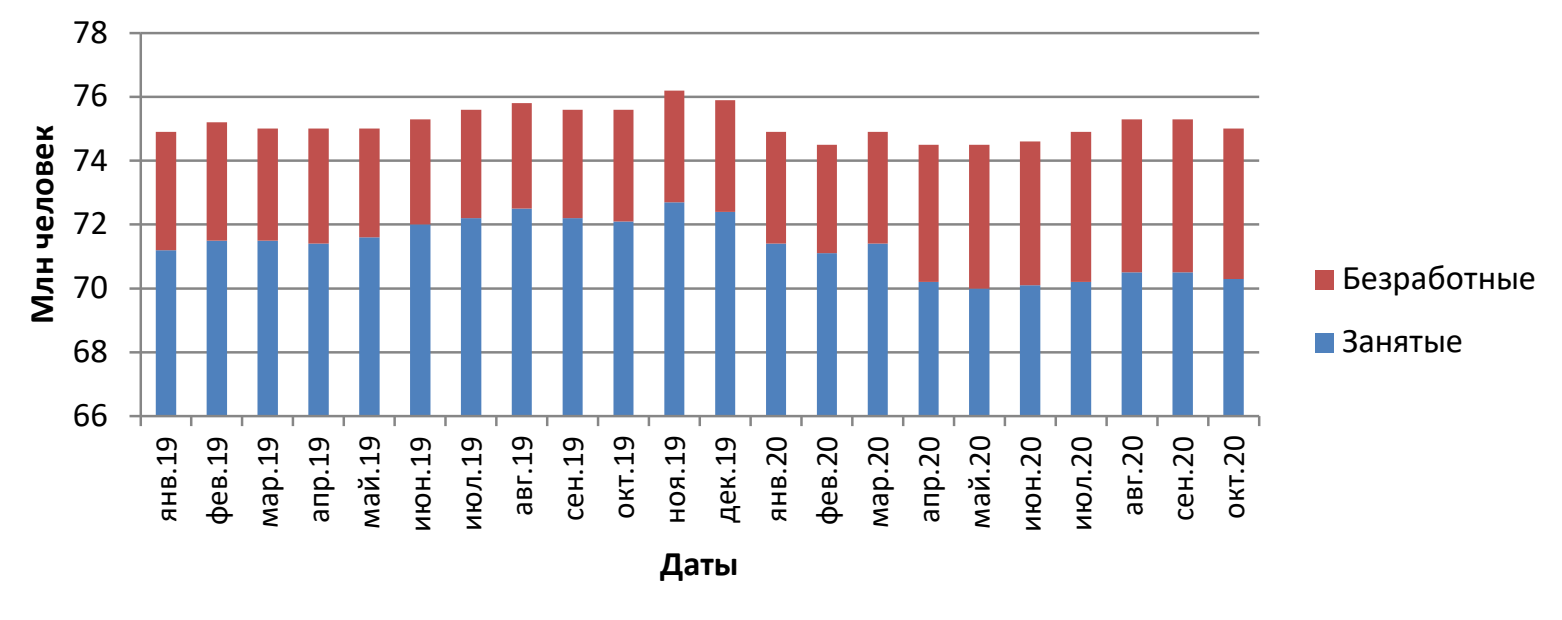

Рисунок 1. Динамика численноси рабочей силы в России.

Диаграмма наглядно показывает, что число безработных (представлено верхней частью столбцов) начало существенно расти с начала повсеместной эпидемии Covid-19 (апрель 2020 года) и, в итоге, превысило число занятого населения России. Тенденция сохраняется и до сих пор.

Во-вторых, экономическую ситуацию наглядно может проиллюстрировать индекс промышленного производства (рис. 2) [1]. 


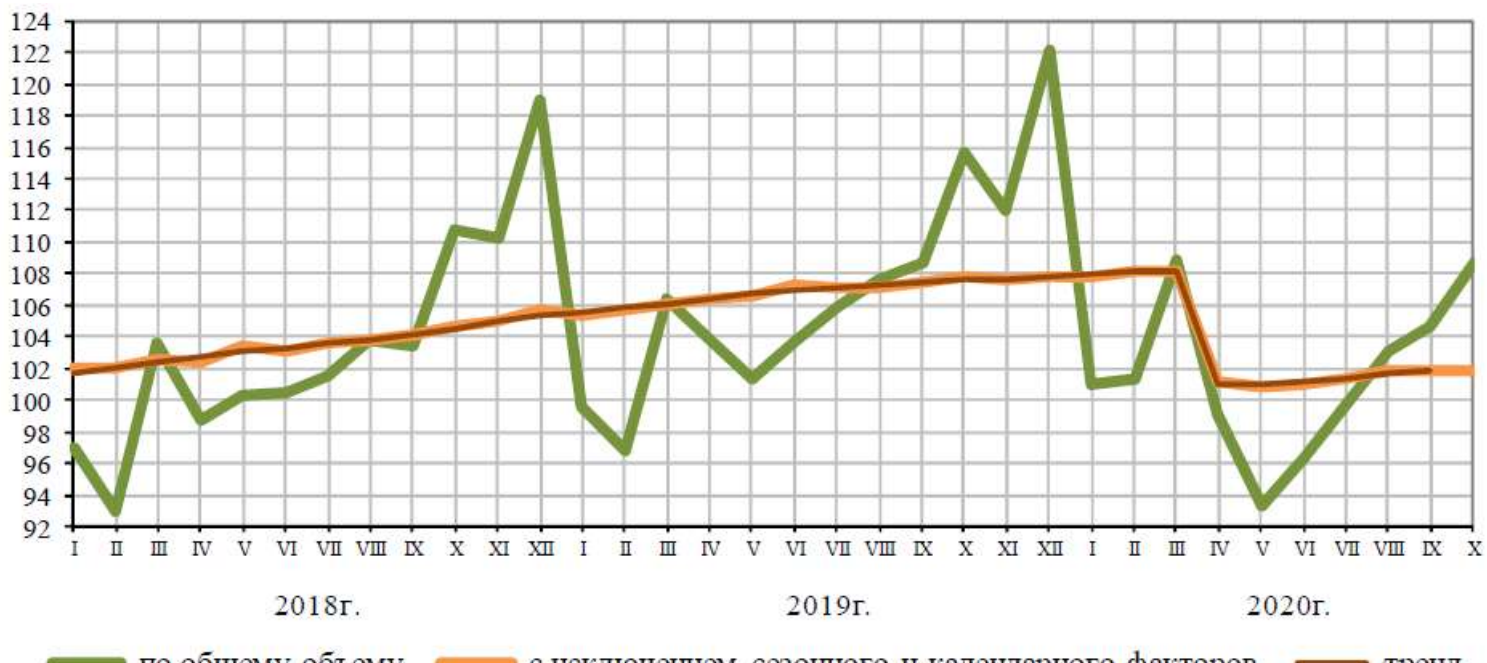

Рисунок 2. Индекс промышленного производства России.

Вопреки общей положительной динамике данного индекса в последние 3 года, с марта по май 2020 года наблюдается его резкий существенный спад. В летние месяцы и далее прослеживается постепенное восстановление значений показателя, но о достижении допандемийного уровня пока речи не идет.

В третьих, аналогичная ситуация наблюдается и с показателями рынка платных услуг населению и оборота розничной торговли.

В частности, хочется отметить туристический рынок и сферу развлечений. Это те отрасли которые пострадали мгновенно и сильнее всего [2]. Для наглядности, приведем график числа заграничных туристических поездок граждан России за последние 3 года (рис. 3).

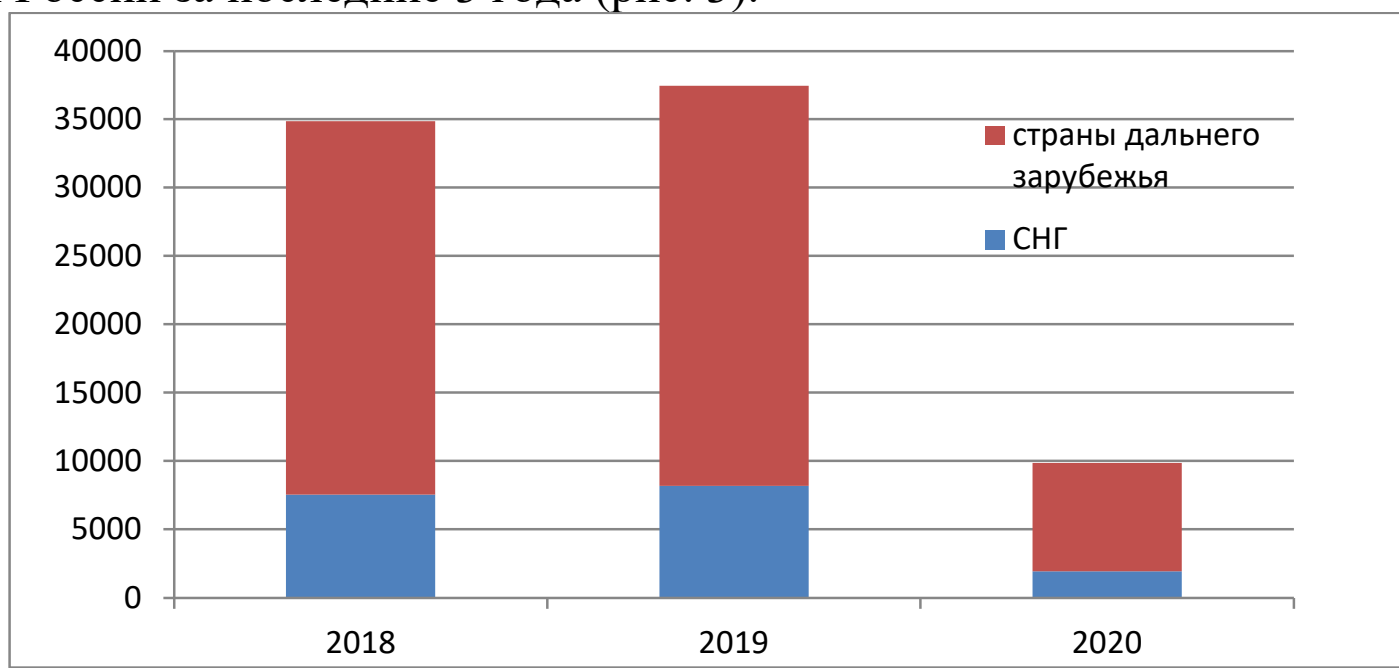

Рисунок 3. Число зарубежных поездок граждан России

В целом, можно сказать, что в России нет такой отрасли, которая бы не пострадала экономически от пандемии [3]. Экономическая ситуация России сильно пошатнулась после марта 2020 года.

Тем не менее, бизнес ищет и находит пути диверсификации своих доходов, промышленность постепенно восстанавливается. Все мы ждем скорейшего угасания распространения короновируса в своей стране и мире и стабилизации экономического положения. 
Список литературы:

1. Информация о социально-экономическом положении России. https://rosstat.gov.ru/compendium/document/50800

2. Новые ценности: во что нужно инвестировать после пандемии // Forbes Contributor. Вадим Логинов. https://www.forbes.ru/finansy-i-investicii/403003novye-cennosti-vo-chto-nuzhno-investirovat-posle-pandemii

3. Инвестиции во время пандемии: анализ поведения рынка, советы стартапам и инвесторам // Финансы. Сергей Москаленко. https://vc.ru/finance/129991investicii-vo-vremya-pandemii-analiz-povedeniya-rynka-sovety-startapam-iinvestoram 


\section{СТИЛЬ УПРАВЛЕНИЯ И ФУНКЦИИ МЕНЕДЖЕРА ОРГАНИЗАЦИЙ}

\section{Ерошкина Татьяна Васильевна}

Доктор мед. наук, профессор, кафедра общей медицины Днепровский национальный университет им. О. Гончара

Борисенко Светлана Сергеевна Доктор философии, $\mathrm{PhD}$ наук о политике и администрации ,ст. преподаватель Днепровский национальный университет им. О. Гончара

\section{Кролевецкая Ирина Эдуардовна}

Студентка

Днепровский национальный университет им. О. Гончара

Актуальность исследования: Решение теоретических и практических задач управления организацией приобретает все большее значение в связи с гуманизацией и демократизацией, возрастанием роли и значимости защиты прав и свобод человека, развитием рыночных отношений, формированием новых социальных структур и форм управления. Поэтому современному руководителю для эффективного влияния на деятельность подчиненных необходимо глубокое понимание основ управления. Хотя эти механизмы все еще недостаточно изучены, но уже имеющиеся результаты научных исследований могут существенно расширить возможности руководителя создавать условия, способствующие формированию заинтересованности членов коллектива в продуктивной работе организации[1].

Внедрение достижений менеджмента в практику управленческой деятельности организации должно рассматриваться как важнейший резерв повышения эффективности решения множества практических проблем, возникающих перед обществом [2].

Людям, которым предстоит выступать в роли субъектов управления организацией или фирмой необходимо понять и применить на практике основы управления и, опираясь на них, повысить эффективность деятельности организации [3]. Указанное определяет актуальность настоящего исследования.

Цель работы: Раскрыть личностные качества руководителей, стиль и эффективность управления организацией на основе современного менеджмента.

Методы исследования: анализ литературных источников и директивных документов, статистический, социологический.

Результаты исследования: Установлено, что список, представляющий исчерпывающую характеристику качеств менеджера, в современной литературе еще окончательно не сформирован. Исследователи сходится лишь на том, что их можно разбить на три группы: профессиональные, личные и деловые качества . 
К профессиональным качествам чаще всего относят те, которые характеризуют любого грамотного специалиста, и обладание которыми является лишь предпосылкой, общим фоновым дополнением обязанностей руководителя. Прежде всего, речь идет о компетентности в соответствующей профессии, формирующейся на основе образования, производственного и иного опыта; далее, руководитель должен обладать определенной широтой взглядов, базирующихся как на общей эрудиции, так и на хорошем знании не только собственной сферы деятельности, но и смежных с ней.

Руководителю как профессионалу должно быть свойственно стремление к приобретению знаний, постоянному самосовершенствованию, а также обучению других всему тому чем он сам владеет. Руководитель должен уметь планировать свою работу и свое время, с тем, чтобы располагая его ограниченным, как у всех, запасом, удалось сделать как можно больше. Наконец, руководитель должен быть творческой личностью, критически воспринимать и перерабатывать имеющиеся у него и других знания, опыт и навыки, осмысливать окружающую действительность, постоянно искать пути к совершенствованию работы, улучшению ее результатов, овладевать самому новыми методами деятельности и помогать в этом другим [4].

Личные качества руководителя мало чем должны отличаться от личных качеств других работников, желающих, чтобы их уважали и с ними считались; обладание ими также является лишь предпосылкой успешного руководства. К личным качествам, необходимым руководителю, можно отнести: благожелательное отношение к работе и к людям; высокие моральные стандарты; психологическое и физическое здоровье; самообладание; трезвость мышления; отзывчивость; заботливость; оптимизм; уверенность в себе; высокий уровень внутренней культуры и многое другое [5].

Однако руководителем делают человека не профессиональные и личные, а именно деловые качества. Прежде всего, это - организаторские способности, предполагающие умение создать организацию или коллектив, обеспечить их деятельность всем необходимым, поставить четкие задачи, распределить их среди исполнителей, координировать, контролировать, стимулировать их решение. Другим важнейшим деловым качеством руководителя должна быть доминантность, имеющая в своей основе властность, честолюбие стремление к личной независимости, к лидерству в любых обстоятельствах бескомпромиссность в отстаивании своих прав, высокий уровень притязаний, целеустремленность, смелость, решительность, воля, напористость, требовательность [6].

Еще одно важнейшее качество руководителя - контактность; оно подразумевает коммуникабельность, умение работать с подчиненными, расположить к себе людей, понять их проблемы, убедить в правильности своей точки зрения, повести за собой, при необходимости оказать помощь, уладить возникшие конфликты[7]. Не последнее место среди качеств, свойственных руководителю, занимает мобильность; она проявляется в инициативности, гибкости, оперативности в деле решения больших и малых проблем, умении 
быстро сконцентрироваться на главном или перестроиться в случае необходимости.

Ни один руководитель не сможет по-настоящему управлять другими, если не научится управлять собой, своим поведением, своими отношениями с окружающими, своим рабочим временем. Способность осуществлять подобное самоуправление= также является одним из деловых качеств, которыми должен обладать современный менеджер. И, наконец, качеством, без которого его просто невозможно представить, является стремление к самосовершенствованию работы, нововведениям, преобразованиям, готовность идти на определенный риск, связанный с их осуществлением, умение вовлекать в этот процесс подчиненных, преодолевая их боязнь и сопротивление [8].

Требования к этим качествам руководителя неодинаковы на различных уровнях управления. На низших, например, у менеджеров в большой степени ценится решительность, независимость, самостоятельность и острота суждений и даже некоторая агрессивность; на высших же требуется в большей мере иное: умение анализировать, ставить перспективные цели, создавать сплоченные коллективы и организовывать процесс совместного творчества в них. Все личностные качества руководителя проявляются в его стиле управления. Стиль управления - это определенная система предпочитаемых руководителем способов, методов и форм управленческой деятельности.

Выбор того или иного стиля руководства обусловлен множеством взаимодействующих объективных и субъективных факторов.

К объективным факторам можно отнести такие как содержание выполняемой деятельности, мера трудности решаемых задач, сложность условий, в которых осуществляется их решение, иерархическая структура руководства и подчинения, социально-политическая ситуация, социально-психологический климат в коллективе и другие.

К субъективным факторам следует отнести типологические свойства нервной системы (темперамент), свойства характера, направленность, способности человека, привычные способы деятельности, общения, принятия решений, знаний, опыт, убеждения.

Большинство ученых различают 3 основных стиля руководства: авторитарный (директивный), демократический (коллегиальный), либеральный (попустительский) [9].

Авторитарный стиль руководства основываются на отдаче распоряжений подчинённым при отсутствии всяких объяснений их связи с общими целями и задачами деятельности организации и стремления узнать их мнение или получить одобрение. Авторитарный стиль руководства также основываются на том, что руководитель определяет не только содержание заданий, но и конкретные способы их выполнения. При этом приоритет отдается приказам, а среди стимулов преобладает угроза наказания. Применение этого стиля наиболее успешно, когда подчиненные полностью находятся во власти руководителя (например на военной службе) или безгранично ему доверяют, а руководитель не уверен в том, что они смогут без его команд действовать правильно, надлежащим образом. 
В противоположность авторитарному, демократический стиль руководства предполагает, что подчиненные самостоятельно принимают решения и ищут пути их реализации, а руководитель заранее создает для этого процесса необходимые условия, предопределяющие конечный результат, и задает лишь основные параметры работы. Подчиненные получают возможность ставить конкретные цели и в рамках предоставляемых полномочий определять способы их достижений, а также избавлены от назойливого текущего контроля, который заменяется проверкой результатов и поощрением имеющихся успехов, чему отдается предпочтение по сравнению с наказаниями. Все это приносит работникам удовлетворение. Обычно этот стиль применяются в случае, когда подчиненные хорошо знают свою работу и могут внести в ее исполнение определенный элемент творчества.

Авторитарный и демократический стиль руководства основываются на активной роли руководителя в управлении деятельностью подчиненных. В противоположность им либеральный стиль руководства предполагает в основном его пассивное поведение. Руководитель ставит общую задачу, разрабатывает правила игры и контролирует их соблюдение. При этом поощрения и наказания отступают на второй план по сравнению с внутренним удовлетворением, получаемым подчиненными от возможности реализовать свои потенциалы и творческие способности. Эффективность данного стиля обусловлена реальным стремлением подчиненных к этому, правильной формулировкой руководителем задач и условий их деятельности и его справедливостью в отношении оценки и вознаграждения результатов.

Многочисленные исследования стилей руководства по выделенным характеристикам показали, что в целом руководство, ориентированное на интересы подчиненных, вызывает более высокий уровень их удовлетворенности. Однако далеко не всегда эта ориентация руководителя приводит к большей продуктивности руководимого и коллектива. Каждому конкретному руководителю не может быть присущ только какой-либо один стиль. Опытный руководитель способен использовать тот или иной стиль в зависимости от обстоятельств: содержания решаемых задач, конкретного состава руководимой группы и других. Стиль руководства оказывает большое влияние на деятельность подчиненных, и эффективность работы организации. В соответствии с современными представлениями руководитель является лицом, персонифицирующим функции управления. Чаще всего речь идет о пяти функциях: стратегической; административной; экспертно-инновационной; воспитательной; лидирующей.

Стратегическая функция руководителя заключается в постановке им на основе анализа ситуации и прогнозов целей организации, координации процесса разработки стратегии и составления планов. Она считается главной функцией в мирное время. Все большее значение приобретает экспертно-инновационная функция руководителя, тесно связанная с предыдущей. Она требует от него постоянного целенаправленного знакомства с новинками, их квалификационной оценки, создания условий для безотлагательного внедрения в практику, а при необходимости - для перестройки фирмы, а также соответствующего 
консультирования подчиненных. В связи с этим несколько уменьшилось значение традиционной для руководителя прежних времен административной функции. Она в большей степени сохраняет свое значение на нижних этажах управленческой иерархии, за исключением, той ее части, которая относится к контролю, оценке результатов, осуществлению коррекции деятельности, поощрениям и наказаниям - все это по-прежнему централизуется, прежде всего, в руках высшего руководства. В то же время организационная работа (распределение ресурсов, задач, инструктаж, координация исполнителей), также обеспечение коммуникаций (проведение собраний, совещаний, прием посетителей, ответы на телефонные звонки, распространение информации т. п.) по возможности передается “вниз”.

Важность той роли, которую играют в жизни организации ее работники, возлагает на руководителей, осуществляющих воспитательную функцию: создавать в коллективе благоприятный морально-психологический климат, поддерживать традиции, разрешать возникающие конфликты, а еще лучше - их предотвращать; формировать стандарты поведения; помогать подчиненным в трудную минуту.

И, наконец, успеха во всех этих делах руководителю будет трудно добиться, если он не овладеет в полной мере функциями лидера, как умение[10]:

1. Планировать - принять порядок действий:

- установить, куда ведет выработанный курс (спрогнозировать);

- определить желаемые конечные результаты;

- решить, как и когда достичь цели (развить стратегии);

- выстроить приоритеты последовательности и времени конкретных шагов (составить программу);

- выделить ресурсы;

- стандартизировать методы;

-принять постоянно действующие решения по важным вопросам.

2. Организовать - построить работу для эффективного выполнения цели:

- разработать устав (составить организационную структуру);

- определить линии связи для облегчения координации (описать взаимоотношения);

- определить взаимоотношения, ответственность и полномочия (создать описание должностей);

3. Работать с кадрами:

- набрать компетентных людей на должность в организации (подобрать);

- познакомить новых людей с ситуацией (сориентировать);

- выработать навыки инструктированием и практикой (обучить);

- помочь улучшению знаний, подходов и навыков (развить);

4. Направлять - координировать действия для получения желаемых результатов:

- установить ответственность и точную отчетность по результатам (делегировать);

- убеждать и вдохновлять людей на принятие желательных действий (мотивировать); 
- прилагать усилия в наиболее эффективных комбинациях (координировать);

- стимулировать творчество и инновации для достижения целей (управлять изменениями);

5. Контролировать - обеспечить продвижение к цели согласно плана:

- определить, какие данные абсолютно необходимы, как и когда (установить систему сообщений);

- выявлять условия для надежного исполнения ключевых обязанностей (образовать стандарты исполнения);

- определить степень отклонения от целей и стандартов (изменить результаты);

- откорректировать планы, дать консультации по соблюдению стандартов, запланировать заново и повторить цикл (предпринять корректирующие действия);

- вознаградить или наказать.

В различных ситуациях и на разных уровнях управления те или иные функции руководителя имеют неодинаковые значение, в связи с чем в теории управления сформировались концепции архетипов, то есть, основополагающих типов менеджеров. В соответствии с ними для периода создания или перестройки организации наиболее важны руководители предпринимательского типа, имеющие новые направления и формы деятельности, использующие нетрадиционные, рискованные подходы для решения стоящих проблем, а также руководители-лидеры, реализующие замыслы предпринимателей, увлекая людей новыми перспективами, раскрывая их способности и направляя их энергию на решение конкретных задач. Для периода стабильного развития более подходят руководители-плановики, оптимизирующие будущее в свете сегодняшней деятельности, на основе ее анализа создающие планы и программы с дозированным риском, и руководители-администраторы, осуществляющие в соответствии с плановыми заданиями организаторскую, координационную, контролирующую деятельность, управляющие людьми с помощью приказов, поощрений и наказаний.

Если рассматривать функции менеджера с точки зрения уровней управления, то особо выделяется топ-менеджмент, или высшее руководство фирмы. Основная его задача состоит в выработке миссии, стандартов и ценностей, формировании организационной структуры, поддержании контактов с главными контрагентами (в том числе и государством), управлении в кризисной ситуации.

Функции высших руководителей чрезвычайно сложны, характеризуются новизной и разноплановостью, требуют глубоких аналитических и мыслительных способностей, задатков политика, дипломата, публициста, оратора, поэтому больше никто в организации их выполнять не может. Но и само высшее руководство их реализует в команде, поскольку один человек не в состоянии объединить в себе все требуемые качества.

Основной функцией топ-менеджмента является общее руководство. Последнее состоит в том, что управляющим приходится принимать слабо структурированные решения в духе конвергенции всех остальных функций с учетом перспектив их развития, ибо ориентация только на одну функцию и 
только на сиюминутные интересы не приносит успеха. Это организационная функция, отвечающая за эффективность деятельности организации в целом, направленная на оптимизацию соотношения ее целей в настоящем и будущем[11].

Роль руководителей среднего уровня рассматривается в основном негативно, поскольку этот слой работников с неопределенными функциями создает эффект одеяла, тормозя любые решения высшего руководства и увеличивая число уровней управления.

Менеджер низшего уровня осуществляет непосредственное руководство людьми, координирует их деятельность. Несет ответственность за их дела и поступки; именно на него ложится вся тяжесть повседневного управления.

Выводы: Таким образом, каждый руководитель, стремящийся к максимальной эффективности своей работы и желающий получить от подчиненных наибольшую отдачу, должен научится пользоваться всеми стилями руководства и функциями, используя те, которые отвечают конкретной ситуации. Вышеизложенное составляет тот минимум теоретических знаний, которым любой менеджер должен владеть и уметь применять на практике, чтобы управленческая деятельность была эффективной.

\section{Список литературы:}

1. Магура М. Эффективное управление компанией / М. Магура// Управление персоналом.-2006.-№4(134).-54c

2. Вачугов Д. Д. Основы менеджмента / Д. Д. Вачугов, Т. Е. БерезкинМ.:”Высшая школа", 2001 - 503 с

3. Веснин В. Р. Основы менеджмента / В. Р. Веснин- М.: “ИМПЭК”, 1999$468 \mathrm{c}$

4. Виханский О. С. Менеджмент/ О. С. Виханский, А. И. Наумов- М.: "Гардарики", 1998- 527c

5. Велков И. Г. Личность руководителя и стиль управления/ И. Г. Велков М. 1993 - 75c.

6. Липсиц И.В. Секреты умелого руководителя / И.В. Липсиц- М.: “Экономика", $1991-112 \mathrm{c}$

7. Розанова В.А. Психология управления/ В.А. Розанова-М., 2000-412c.

8. Сергеева О. Б. Лидерство и управление как компитенции руководителей среднего звена/ О. Б. Сергеева//Управление персоналом.-2005.-№19(125).

9. Мескон М. Х. Основы менеджмента / М. Х. Мескон, М. Альберт, Ф. Хедоури -М.: “Дело”,1995-701с.

10. Вершигора Е. Е. Менеджмент / Е.Е. Вершигора - М.: "ИНФРА-М”, 1999280c.

11. РайченкоА.В. Общий менеджмент/ А.В. Райченко-М.:"ИНФРА-М",2005$382 \mathrm{c}$. 


\title{
AMINO ACIDS IMBALANCE AS A POSSIBLE PATHOGENETIC LINK OF DISTURBANCE OF GAS TRANSMITTERS SYNTHESIS IN STABLE ANGINA
}

Bohdan Tetyana, MD, Associate Professor, Professor of the Department of Internal Medicine № 4, Bogomolets National Medical University

\author{
Slobodianyk Olga, \\ Assistant of the Department of Internal Medicine №4, \\ Bogomolets National Medical University \\ Bohdan Viktor, \\ Senior Laboratory Assistant, \\ Department of Obstetrics and Gynecology №1, \\ Bogomolets National Medical University
}

Despite significant advances in the diagnosis, treatment and prevention of cardiovascular disease over the past decade, disability and mortality from this pathology continues to remain high in the world, and in Ukraine in particular. An important place belongs to coronary heart disease (CHD), which is leading in the structure of cardiovascular pathology in terms of morbidity and mortality [1]. Scientists are constantly working to study possible pathogenetic links in the development of coronary heart disease.

Of particular importance is the study of the exchange of gas transmitters (gas mediators), "endogenous gases", "signaling molecules of gaseous substances", "gas modulators", which include oxide (monoxide) of nitrogen (NO), carbon monoxide (carbon monoxide, $\mathrm{CO}$ ) and hydrogen sulfide (hydrogen sulfide, H2S). Gas transmitters are light inorganic compounds - gases that freely cross cell biomembranes. They do not bind to receptors on the cell surface, but interact directly with intracellular proteins. Gas mediators have the following features: 1) are small molecules of gases; 2) freely penetrate through biomembranes and do not act through a special receptor; 3 ) are synthesized endogenously enzymatically and their generation is regulated; 4) in physiological concentrations have clearly defined specific functions; 5) their cellular functions may or may not be mediated by other messengers; 6) they are quickly removed or enzymatically degraded after release (their biological half-life is measured in seconds); 7) have potential systemic toxicity in supraphysiological concentrations therefore previously considered as air pollutants (pollutants); 8) in addition to neurotransmitter have a paracrine or even systemic function [2]. 
Material and research methods. We examined 59 patients with coronary heart disease (stable angina (SA)) aged 59-76 years (mean age - 62.3 years \pm 6.4 years). The control group (CG) included 15 healthy individuals aged 48-56 years (mean age - 51.3 years \pm 4.5 years $)$.

Determination of plasma arginine, cysteine and glutamic acid levels was performed by ion-exchange liquid column chromatography on an automatic amino acid analyzer T-339 produced by Microtechna (Czech Republic, Prague) at the Palladin Institute of Biochemistry of the National Academy of Medical Sciences of Ukraine. Statistical processing of the study results was performed in "MSExelXP" and SPSS-17 for Window. Student's parametric criterion was used to assess intergroup differences.

Results of research and discussion. The metabolism of gas transmitters is related to the metabolism of amino acids (AA). Nitric oxide (NO) is formed from Larginine, which is an isodimer of arginine under the control of the enzyme NO-synthase (NOS). We note that the exogenous introduction of L-arginine can inhibit the processes of free radical oxidation through the NO-regulatory system due to the oxidativeantioxidant dualism of NO. NO regulates many processes in the body, affecting the tone of the hollow organs of the abdominal cavity, the condition of the bronchi and alveoli of the lungs, the rheological properties of blood, immune processes, neuromuscular transmission. It is now established that NO is involved in the regulation of vascular tone as an antagonist of the adrenergic nervous system, inhibits platelet aggregation and their adhesion on the walls of blood vessels [3].

In patients with a stable course of coronary heart disease found a significant decrease in arginine levels by $2.67 \mu \mathrm{mol} / 100 \mathrm{ml}$, which indicates an increase in intracellular metabolism of this AK, and therefore, possibly increased synthesis of NO. Such changes in arginine balance are likely to be a compensatory response to myocardial ischemia.

The second gas mediator is hydrogen sulfide (H2S). In the synthesis of H2S involved replacement AK - cysteine. In a previous publication, the properties of $\mathrm{H} 2 \mathrm{~S}$ and its importance in the regulation of the functioning of the cardiovascular system [4]. In patients with SS compared with CG, a significant increase in cysteine levels by 1.63 $\mu / \mathrm{mol} / 100 \mathrm{ml}$ was found, which indicates a violation of intracellular metabolism of this $\mathrm{AK}$, ie a probable decrease in the formation of $\mathrm{H} 2 \mathrm{~S}$.

The third gas mediator is carbon monoxide (carbon monoxide, $\mathrm{CO}$ ). Endogenous $\mathrm{CO}$ is produced in humans and animals during heme degradation, resulting in the formation of biliverdin, iron and $\mathrm{CO}$. This reaction is catalyzed by the enzyme hemoxygenase (HO), which has two main isoforms - HO-1 (inducible) and HO-2 (constitutive), and are the products of two different genes located on different chromosomes. However, the catalytic domain, consisting of 24 amino acids, is evolutionarily conservative and identical in both isoforms. The main heme-containing (tetrapyrrole) compound in humans and animals is erythrocyte hemoglobin. A smaller amount of $\mathrm{CO}$ can be formed during the degradation of other tetrapyrrole (hemecontaining) compounds - myoglobin, cytochrome oxidase and cytochrome P-450, catalase. The main physiological effect of carbon monoxide is the modulation of blood vessels. Like NO, it relaxes vascular smooth muscle and has a vasoprotective effect, in 
particular by inhibiting oxidation and apoptosis. It has been shown that the endothelial layer is rich in NO-2, and NO inhibitors reduce vascular relaxation.

$\mathrm{CO}$ plays an important role in regulating cerebral circulation. Its production in brain tissue increases in response to glutamate, as well as pro-inflammatory cytokine a tumor necrosis factor- $\alpha$. Glutamate is a product of deamination of glutamine - a substitute for AA. Like NO, CO also inhibits platelet activity and inhibits the process of thrombosis [2].

A number of studies have been conducted with CO donors (they are called CORM Carbon mon Oxide Releasing Molecules). In particular, in an experiment on mice fed a high-fat diet, it was shown that long-term administration of CORM-A1 inhibits the development of obesity, as well as stimulates the metabolism and remodeling of adipocytes. In wild-type or knockout mice of NO-synthase genes, CORM-2 treatment has been shown to inhibit chronic inflammatory pain, and this effect occurs in interaction with the NO-synthase system - NO [5].

In patients with SA there was a significant decrease in the level of glutamic acid compared with CG by $10.36 \mu \mathrm{mol} / 100 \mathrm{ml}$, which indicates an increase in intracellular metabolism of this AA, and therefore, possibly increased CO synthesis. Such changes are likely to be a compensatory response to myocardial ischemia.

\section{References}

1. Gandziuk VA Analysis of the incidence of coronary heart disease in Ukraine. // Ukr. cardiol. magazine. - 2014. - № 3. - P. 45-52.

2. Sukmansky OI, Sukmansky IO Geotransmitters are a new type of boregulators. // Journal of the National Academy of Medical Sciences of Ukraine ”, 2014, vol. 20, № 2. - P. 153-159.

3. Gurevich KG, Shimanovsky NL Nitric oxide: biosynthesis, mechanisms of action, functions // Vopr. biol. honey. farm. chemistry. - 2000. - № 4. - P. 16-22.

4. Bogdan TV, Zhornichenko DM, Matviychuk AR Imbalance of sulfur-containing amino acids in patients with stable angina combined with hypertension. Proceedings of the II International Scientific Conference on Scientific and Practical Technologies, January $26-28,2021$, p. 232-235.

5. Beschasny SP, Gasyuk OM Carbon monoxide donor (CORM-2) affects the level of serum immunoglobulins and the state of the bone marrow in the immune response in mice. // Current issues of pharmaceutical and medical science and practice. 2020. -T. 13, - № 3 (34) .- P. 415-420 


\title{
THYROID TRANSCRIPTION FACTOR 1 IN THYROID NEOPLASMS
}

\author{
Zalyubovska Olga Illivna \\ Doctor of Medical Sciences, professor, \\ Kharkiv National Medical University
}

\section{Hladkykh Nadiia Oleksandrivna}

$\mathrm{PhD}$ researcher

Kharkiv National Medical University

Thyroid carcinoma is the most common endocrine malignancy. It usually presents as a thyroid nodule, but occasionally patients manifest with unusual features. The presence of metastatic disease at the time of diagnosis is a bad prognostic feature, and patients who present with symptomatic metastases do very poorly [1-4].

The use of immunocytochemical studies, thanks to its specificity, allows you to localize and identify antigens, the mechanism of their binding to antibodies. Our study examined the role of thyroid-1 transcription.

The aim of this study is analysis of transcription factor-1 expression of thyroid gland in thyroid delese neoplasms.

Material and methods. During the the research work the results of diagnostics of 60 patients with thyroid neoplasms aged 21 to 83 years (mean age $54.6 \pm 1.9$ years) who underwent fine-needle aspiration puncture biopsy. Patients were divided into three groups according to the Bethesda System (BSRTC) classification category. The 1st group included 18 patients of category II BSRTC (Benign, benign lesions), of which $88.9 \%$ were women and $11.1 \%$ were men and the mean age was $46.6 \pm 3.7$ years. Group 2 included 20 patients with category V BSRTC (Suspicious for Malignancy SFM, suspected malignancy), female (100\%) and mean age $58.7 \pm 3.1$ years. And other 22 patients with category VI BSRTC (malignant tumor) formed the 3rd group, of which $90.9 \%$ were women and $9.1 \%$ were men, the mean age was $57.4 \pm 2.4$ years. Patients underwent ultrasound examination with fine-needle aspiration, cytological and immunocytochemical studies. Immunocytochemical researches were conducted at points fixed with methanol and stained according to Romanovsky method by restoring the activity of antigenic determinants. An indirect immunoperoxidase method using mouse monoclonal antibodies was used (Dako Cytomation, Denmark). Antibodies against mouse g-globulins labeled with horseradish peroxidase (Dako Cytomation, Denmark) were used as secondary.

Statistical processing of the results was performed using the methods of parametric and nonparametric statistics, implemented in the application packages MDCalc statistical software and Microsoft Excel 2019 (Microsoft).

Results. The research of the proliferative activity of thyroid tissue based on the expression of TTF-1 protein showed it's high differential prognostic significance for 
assessing the risk of malignant process in the thyroid gland $-\chi^{2}=109.6 ; \mathrm{r}=0.96 ; \mathrm{p}$ $<0.001$.

Thus, in the benign process in all cases (100\%) the negative status of TTF-1 expression was established, in the case of suspected tumor malignancy - a weak reaction $(+)$ in $100 \%$ of patients $(\mathrm{p}<0.001)$, in metastatic lesions - in $18.2 \%$ cases of strong expression $(+++)$, in $72.7 \%$ - moderate $(++)$, in $9.1 \%$ - weak $(\mathrm{p}<0.001$ compared to previous groups).

Conclusion. Analysis of the study of the expression of TTF -1 suggests that its use plays a key role in assessing the malignant potential of the tumor in the preoperative stage. Benign thyroid disease (category II BSRTC) is likely to be associated with a negative reaction to TTF-1 (100\%).

Differential prognostic markers of thyroid cancer with risk of malignancy (category V BSRTC) include an increased positive response to TTF-1 (100.0\%)

Statistically significant markers of thyroid malignancy (category VI BSRTC) are: moderate or severe expression of TTF-1 (90.9\%).

Thus, the use of this marker is appropriate and practically important for preoperative diagnosis of thyroid tumors.

\section{References:}

1. Strate SM, Lee EL, Childers JH. Occult papillary carcinoma of the thyroid with distant metastases. Cancer1984; 54:1093-100.

2. Laskin WB, James LP. Occult papillary carcinoma of the thyroid with pulmonary metastases. Hum Pathol1983;14:83-5.

3. Koller BA, Tourtelot JB, Pak HS, et al. Papillary and follicular thyroid carcinoma metastatic to the skin: a case report and review of the literature. Thyroid 1998;8:1045-50.

4. Dahl PR, Brodland DG, Goellner JR, et al. Thyroid carcinoma metastatic to the skin: a cutaneous manifestation of a widely disseminated malignancy. J Am Acad Dermatol 1997;36:531-7. 


\title{
СЕМІНАРСЬКІ ЗАНЯТТЯ В МЕДИЧНІЙ ПІСЛЯДИПЛОМНІЙ ОСВІТІ ТА МЕТОДОЛОГІЧНІ ПІДХОДИ ДО ЇХ ПРОВЕДЕННЯ
}

\author{
Дерпак Юрій Юрійович
}

д.мед.н., доцент кафедри гематології і трансфузіології

Кучер Олена Володимирівна

д.мед.н., професор кафедри гематології і трансфузіології

Видиборець Станіслав Володимирович

д.мед.н., професор, завідувач кафедри гематології і трансфузіології Національна медична академія післядипломної освіти імені П. Л. Шупика MO3

України

Наразі післядипломне навчання лікарів зазнає суттєвих змін у всьому світі $[5,8,11]$. Це обумовлено впровадженням новітніх технологій в педагогічний процес, зокрема, елементів дистанційного навчання, поширенням індивідуалізованих форм навчання із застосуванням комп'ютерів та використанням мережі Інтернет, електронних комп'ютерних підручників, віртуальних тренажерів, безупинним ростом інформації, підвищенням вимог до підготовки фахівця в світлі вимог викладених у концепції безперервного професійного розвитку лікаря $[3,7,10]$. Однак медична освіта за інтенсивністю використання інформаційного інструментарію помітно відстає від інших освітянських напрямків, що, очевидно, обумовлено складнощами як формалізації компонентів викладання, так і консервативністю медичної освіти та недостатнім рівнем володіння інформаційними технологіями викладачами [3]. Кінцевою метою навчання лікаря $є$ формування фахівця такого рівня, який зможе самостійно і кваліфіковано виконувати свої професійні обов'язки $[4,9,11]$. Для успішного вирішення означеної мети повинна бути потужна, добре обладнана та оснащена сучасною діагностичною та лікувальною апаратурою навчальна та лікувальна бази, наявність висококваліфікованого професорсько-викладацького складу.

Слово і поняття «seminarium» (у перекладі «semen» 3 латинської значить «сім'я ») - означає розсада, розсадник, саджанець. Вперше в історії навчання, прообраз сучасного семінару був у вигляді діалогу, що зафіксовано в історичних давньогрецьких джерелах. У ті часи дійство називалося і мало форму симпозіуму. «Simposium» (із слів «sim» та «positio») у перекладі із грецької значить бенкет. Спільними у обох поняттях симпозіуму і семінару є установка, посадка, розсадник, причина. Але означені форми спілкування мають ще глибше спільне смислове значення - турбота про саджанець знань, розвиток пізнання [1].

У навчальні плани додипломного і післядипломного навчання лікаря входить певна кількість семінарських занять. Організації та якості їх проведення 
слід приділяти значну увагу, оскільки саме семінарські заняття значно підвищують мотивацію до навчання. Впровадження в педагогічний процес нових інноваційних технологій диктує необхідність зміни дидактичних та методологічних підходів при підготовці до їх проведення [1, 4, 6, 10]. Наразі певна кількість педагогів, незважаючи на трансформації в навколишньому світі i впровадження новітніх технологій, переконані в тому, що навчати лікаря за допомогою дистанційних або електронних технологій взагалі неможливо. На їх думку, всупереч реальним змінам обличчя освітніх систем у всьому світі, підготовлювати лікаря можна лише біля ліжка хворої людини. Не можна не погодитись, що підготовлений таким чином лікар $є$ результатом діяльності системи освіти відповідно до існуючих стандартів, що забезпечує формування відповідних професійних навичок та вмінь i професійно-соціальної компетентності [2]. Слід зауважити, що майже всі викладачі системи післядипломної підготовки лікарів не мають грунтовної базової педагогічної освіти, тому вони прагнуть шляхом самоосвіти опанувати щонайповнішу інформацію щодо сучасного розуміння суто педагогічних понять - моделі, методів і стратегії навчання, методики i засобів викладання, критеріїв оцінювання знань, впровадження освітніх стандартів та контролюючих тестових програм. Новітні інформаційні технології служать інструментом у викладацькій діяльності педагога для передачі і засвоєння знань слухачами, зокрема і при проведенні семінарів. Необхідно завчасно інформувати слухачів про мету семінарського заняття, план та умови його проведення, перелік рекомендованої літератури для самостійного вивчення, що без сумніву має сприяти формуванню на базі отриманих знань певних професійних навиків та вмінь. Застосування новітніх технологій при проведенні семінарів сприяє більш ефективному передаванню знань тому, кого навчають. Щоб бути компетентним фахівцем, необхідно безперервно підвищувати рівень теоретичної підготовки та вдосконалювати практичні навики та вміння [1, 3-5, 10].

Семінари за змістом розподіляють на інформаційні, дослідницькі та контрольні. На семінарах лікарі можуть здійснювати поглиблене вивчення певного курсу, розділу, теми, причому, семінар за тематикою інформаційно може бути не пов'язаним 3 лекцією. За формою проведення семінари можуть бути: семінар-конференція, семінар-дискусія, семінар-колоквіум, семінар з клінічного розбору історії хвороби хворого, семінар-екскурсія, семінар з обговорення попередньо підготованих слухачами рефератів, семінар 3 обговорення контрольних робіт, семінар-конференція, семінар з обміну досвідом роботи, семінар-тренінг, семінар ділова гра, семінар-підсумок. Окремої уваги заслуговують телесемінари. Всі перераховані види семінарів повинні мати свою мету, форму організації, і методику проведення [1, 3].

Для проведення семінарів у системі післядипломного навчання ставлять такі вимоги. Семінар має мати чітко визначену мету і завдання, поєднувати інформаційне навантаження 3 дослідженням проблеми та елементи контролю, стимулювати слухачів до засвоєння матеріалу і підвищення своєї професійної майстерності, активізувати слухачів до здобуття грунтовних і міцних знань, умінь та навичок, поєднувати індивідуальну та колективну роботу слухачів, 
забезпечувати тісну співпрацю викладача і слухачів, сприяти демократизації $\mathrm{i}$ об’єктивізації навчального процесу, підвищувати вимогливість до професійної та педагогічної діяльності викладача, поєднувати усталені стратегії і методи із новітніми технологіями [2].

До проведення семінарів ставлять певні вимоги щодо якості проведення, тематики, методичного плану. При складанні плану кожного семінарського заняття визначають його основну мету, структуру, зміст, методи, форми та прийоми заохочення слухачів до активної дискусії. Логічним завершенням семінару повинно бути підведення підсумків, оцінювання участі кожного слухача при його проведенні та формулювання загальних висновків із кола питань, що обговорювались.

Внаслідок специфіки організації, постановки мети і завдань, семінар $є$ одним із тих надійних видів занять, що підвищують мотивацію до навчання у лікарів і сприяють активному опануванню слухачами конкретної теми, розділу та курсу навчальної програми. Особливого значення означене набуває в умовах впровадження в педагогічний процес нових інформаційних технологій та зміні педагогічних і психологічних аспектів медичної освіти.

Семінарські заняття мають особливе значення і для формування клінічного мислення у лікарів. Під клінічним мисленням розуміють творчий процес діяльності лікаря із накопичення, обробки та тлумачення інформації про пацієнта, що за кульмінаційний момент має прийняття відповідального рішення щодо обстеження, проведення діагностики та диференційної діагностики, складання плану лікування, реабілітації, первинної та вторинної профілактики хвороби. Формування клінічного мислення $\epsilon$ найскладнішим i найвідповідальнішим завданням професійної підготовки лікарів. Серед усіх різновидів семінарів при цьому важливе місце посідають семінари 3 клінічного розбору хворих $[1,5,6]$. Насамперед, саме семінарські заняття дозволяють максимально контролювати ступінь засвоєння прийомів та методів обстеження хворих, опанування діагностичних та диференційно-діагностичних технологій, схем та стандартів лікування тощо $[7,8]$.

Контроль $є$ вкрай важливою складовою частиною навчального процесу. За правильного його застосування при проведенні семінарських занять, він може суттєво сприяти досягненню їх остаточних результатів - формування клінічного мислення та становлення особистості лікаря. Клінічне мислення в процесі діагностично-лікувальної роботи лікаря поділяють на п'ять основних етапів. Насамперед, це збирання інформації щодо стану органів і їх систем у пацієнта. Його повнота залежить від досвіду та набутих знань при попередньому навчанні лікаря. Наступним етапом $є$ оцінка стану органів і їх систем у пацієнта, що залежить від обсягу і повноти зібраної інформації, здатності лікаря абстрактно мислити, виділяти основні синдроми тощо. Третім етапом $є$ складання уяви про етіологію, патогенез окремих змін у органах та системах, здатність правильно оцінювати їхній взаємозв'язок та взаємозалежність, що дозволяє правильно оцінити фазу патологічного процесу, його перебіг. Четвертий етап полягає у діагностиці нозологічної форми, визначенні варіанту перебігу та призначенні лікування. П'ятий етап - перевірка правильності встановлення діагнозу, що 
досягається за допомогою ретельного самоаналізу проведеної диференційної діагностики та консультацій із колегами або лікарями-консультантами $[3,4,9]$.

Важливою передумовою успішного формування клінічного мислення $\epsilon$ глибокі базові знання лікарів. Їх контролюють на семінарських заняттях 3 допомогою визначення базового рівня знань, що дозволяє формувати групи слухачів відповідно до ступеня початкових знань і вносити корективи до мети та постановки завдань при плануванні проведення семінарів $[8,9]$.

Узагальнюючи значний досвід післядипломного навчання лікарів, пропонують наступну схему семінару. Вступна частина повинна становити 15$20 \%$ часу. Саме у вступній частині вмотивовуються основні теоретичні засади проблеми, якій семінар присвячено, встановлюється мета семінару i уточнюються шляхи вирішення поставлених завдань. У основній частині 50-60\% слухачі працюють самостійно. Викладач стимулює активність учасників семінару шляхом вирішення ситуаційних задач, прийняття рішень, встановлення діагнозу, визначення нормативно-технічної документації, наказів, настанов, розпоряджень, призначення протоколів обстеження та/або лікування, які необхідні для вирішення конкретного завдання, У заключній частині (20-30\%) обговорюються приклади вирішення поставлених завдань, шляхом обговорення і творчої конструктивної дискусії визначають оптимальні варіанти.

При проведенні семінарських занять можливі наступні різновиди контролю $[1,10,11]$. Класично виділяють усний та письмовий контроль. Головною перевагою усного опитування є безпосередній контакт між тим, хто навчається і викладачем, що забезпечує можливість визначення індивідуальних особливостей рівня знань слухачів, їх коректування, навчання логічно грамотній побудові відповідей, правильному застосуванню медичної термінології. Недоліками усного опитування $є$ коректність поставлених питань, нестача часу для опитування всіх присутніх на семінарі. Можлива втрата уваги частини слухачів під час відповіді певного слухача.

Перевагами письмового різновиду контролю є можливість за короткий час перевірити знання всіх присутніх на семінарі, об'єктивізувати рівень знань слухачів. Недоліками даного методу контролю $є$ витрати часу на перевірку письмових робіт, відсутність контакту між слухачем і викладачем, іноді неможливість простежити логіку відповіді слухача.

За повнотою охопленням слухачів, що навчаються, розрізняють індивідуальну перевірку, групову (перевіряються знання частини групи) та фронтальну (контролюються всі учасники).

За побудовою навчальної програми рекомендують наступні види контролюючих занять-семінарів. Початковий (вхідний) контроль - контроль знань та вмінь слухачів перед початком навчання. Даний вид контролюючого семінару іноді застосовують для допуску до навчання чи за його результатами формування навчальних груп. Поточний контроль - безперервне моні торування рівня засвоєння знань і умінь слухачами на заняттях. Тематичний (рубіжний) контроль - оцінювання умінь і знань слухачів після закінчення вивчення певної теми чи розділу навчального плану. Даний вид контролю дозволяє оцінювати результативність навчального процесу. Підсумковий контроль - контроль знань 
і вмінь за результатами навчального плану. Віддалений контроль - контроль залишкових знань і умінь через певний час після навчання. Даний вид контролю дозволяє перевірити виживання знань [11]. Контроль знань може здійснюватися і у дистанційному режимі, зокрема, це стосується віддаленого контролю.

Таким чином, семінарські заняття $\epsilon$ складовою частиною багатокомпонентного динамічного навчального процесу. Семінар $є$ ефективним методом інтерактивної передачі нової інформації, який дозволяє систематизувати власний накопичений досвід із новими знаннями, вміло їх аналізувати. Під час семінарів можливо відстежувати досвід інших слухачів, отримувати додаткову інформацію, аналізувати, моделювати ситуації, спільно шукати шляхи вирішення різних питань.

\section{Список літератури}

1. Aronson L. Twelve tips for teaching reflection at all levels of medical education. Medical Teacher 2011; 33(3): 200-205.

2. Cook D.A., Beckman T.J., Bordage G. Quality of reporting of experimental studies in medical education: A systematic review Med. Educ. 2007; 41: 737-745.

3. Cook D.A., Bordage G., Schmidt H.G. Description, justification, and clarification: A framework for classifying the purposes of research in medical education. Med. Educ. 2008; 42: 128-133.

4. Gibbs T., Durning S., Artino A.R. Theories in medical education: Towards creating a union between educational practice and research traditions Medical Teacher 2011; 33(3): 183-187.

5. Gruppen L.D. Is medical education research "hard" or "soft" reseach? Adv. Health Sci. Educ. Theory Pract. 2008; 13(1): 1-2.

6. Lewkonia R. Patient rights and medical education: Clinical principles Medical Teacher 2011; 33(5): 392-396.

7. Lindgren S., Gordon D. The doctor we are educating for a future global role in health care Medical Teacher 2011; 33(7): 551-554.

8. Lindgren S., Brannstrom T., Hanse E. et al. Medical Education in Sweden Medical Teacher 2011.-Vol.33, №7.-P.798-803.

9. Pericleous $S$. Undergraduate medical education in Cyprus: The introduction of two medical schools Medical Teacher 2011; 33(7): 530-534.

10. Solomon $P$. Student perspectives on patient educators as facilitators of interprofessional education Medical Teacher 2011; 33(10): 851-853.

11. Tavakol M., Dennick R. Post-examination analysis of objective test Medical Teacher 2011; 33(6): 455-458. 


\section{ГОСТРА ТОКСИЧНІСТЬ НАФАЗОЛІН НІТРАТУ}

Зазуляк Тетяна

кандидат біологічних наук, старший науковий співробітник, завідувачка Центрольної науково-дослідної лабораторії та лабораторії промислової токсикології Львівський національний медичний університет ім. Данила Галицького

Призиглей Ганна науковий співробітник Центрольної науково-дослідної лабораторії та лабораторії промислової токсикології Львівський національний медичний університет ім. Данила Галицького

\section{Швец Ірина}

молодший науковий співробітник Центрольної науково-дослідної лабораторії та лабораторії промислової токсикології Львівський національний медичний університет ім. Данила Галицького

Нафазолін нітрат (Naphazoline) - активний фармацевтичний інгредієнт протинабрякових лікарських препаратів, призначених для місцевого застосування при захворюваннях порожнини носа. За хімічною структурою похідне імідазоліну, агрегатний стан - кристалічний порошок білого чи майже білого кольору. Механізм терапевтичної дії нафазолін нітрату полягає у стимуляції $\alpha 2$-адренорецепторів, що призводить до звуження периферичних кровеносних судин [1-3]. До проявів побічної дії згаданих препаратів відносяться: відчуття печіння або сухості; набряк Квінке; при тривалому використанні ефективність препаратів знижується внаслідок розвитку тахіфілаксії (звикання) та можливий розвиток медикаментозного риніту, при якому відміна лікв викликає закладення носа.

В умовах виробництва лікарських засобів нафазолін нітрат може поступати у повітря робочої зони у вигляді аерозолю дезінтеграції та негативно впливати на здоров'я працівників [4]. 3 метою профілактики захворювань в результаті впливу шкідливих чинників хімічної етіології здійснюється регламентація допустимого вмісту хімічних сполук у повітрі робочої зони розобка Гранично допустимих концентрацій, чи Орієнтовно безпечних рівнів впливу (в країнах $\mathrm{CC}$ - Occupational exposure limits). Визначальним етапом розробки гігієнічних регламентів допустимого вмісту хімічних забруднювачів повітря робочої зони є вивчення параметрів гострої токсичності речовин, що і визначило мету дослідження.

Мета дослідження: встановлення параметрів токсичості нафазолін нітрату в умовах гострого експерименту на лабораторних тваринах.

Матеріали та методи.

Оцінку гострої токсичності нафазолін нітрату здійснювали згідно з МУ 2163 та MB 544 [5, 6]. При цьому встановлювали наступні показники: 
середньосмертельна доза $\left(\mathrm{DL}_{50}\right)$ при введенні в шлунок, коефіцієнт видової чутливості тварин (КВЧ), середньоефективний час загибелі тварин $\left(\mathrm{ET}_{50}\right)$ [7]. Інтерпретацію клінічних проявів проводили за Hayes A. W. [8]. Розрахунок $\left(\mathrm{DL}_{50}\right)$ здійснювали методами пробіт-аналізу за В. Б. Прозоровським і за методом Litchfielda \& Wilcoxon [9]. Речовину вводили однократно перорально білим мишам-самцям в дозі 200 мг/кг та білим щурам-самкам в дозах від мг/кг до 1000 мг/кг. Середній час загибелі тварин при однократному впливові речовини $\left(\mathrm{ET}_{50}\right)$ встановлювали за Г. Н. Красовським [10].

При проведенні експериментів дотримувались вимог «Європейськаої конвенції щодо захисту хребетних тварин, яких використовують для експериментів або в інших наукових цілях» та Закону України «Про захист тварин від жорстокого поводження» $[11,12]$.

\section{Результати та їх обговорення.}

У клінічній картині гострої пероральної інтоксикації в результаті дії речовини у тварин спостерігалась хитка хода, завалювання на бік, розпластане положення, тремтіння голови, судоми. Через 5-10 хвилин після введення у тварин порушувався ритм і частота дихання (у щурів 66/хв.), в подальшому тварини приймали бокове положення, відмічалась відсутність реакції на зовнішні подразники. Загибель мишей відбувалася упродовж доби, а загибель щурів - упродовж трьох діб. При розтині загиблих тварин спостерігалось кровонаповнення легень, у мозку - гіперемія кіркових судин. Нормалізація стану тварин, які вижили, наставала на 5-7 добу.

Динаміка загибелі щурів-самок наведена в табл. 1.

Таблиця 1

Динаміка загибелі білих щурів-самок при одноразовому пероральному введенні нафазолін нітрату

\begin{tabular}{|c|c|c|c|c|c|c|c|c|c|c|}
\hline \multirow{2}{*}{$\begin{array}{l}\text { № } \\
\Pi / \Pi\end{array}$} & \multirow{2}{*}{$\begin{array}{l}\text { Дози, } \\
\text { мг/кг }\end{array}$} & \multirow{2}{*}{$\begin{array}{c}\text { Кіль- } \\
\text { кість } \\
\text { тварин } \\
\end{array}$} & \multicolumn{6}{|c|}{ Терміни спостереження, доби } & \multirow{2}{*}{$\begin{array}{c}\text { Кількість } \\
\text { тварин,що } \\
\text { загинули } \\
\end{array}$} & \multirow{2}{*}{$\begin{array}{c}\text { \% заги- } \\
\text { белі }\end{array}$} \\
\hline & & & 1 & 2 & 3 & 4 & 5 & 14 & & \\
\hline 1. & 100,0 & 6 & 0 & 0 & 0 & 0 & 0 & 0 & 0 & 0,0 \\
\hline 2. & 300,0 & 6 & 1 & 1 & 0 & 0 & 0 & 0 & 2 & 30,0 \\
\hline 3. & 500,0 & 6 & 2 & 1 & 1 & 0 & 0 & 0 & 4 & 60,0 \\
\hline 4. & 600,0 & 6 & 2 & 1 & 1 & 0 & 0 & 0 & 4 & 60,0 \\
\hline 5. & 1000,0 & 6 & 6 & 0 & 0 & 0 & 0 & 0 & 6 & 100,0 \\
\hline
\end{tabular}

Середньосмертельна доза нафазолін нітрату $\left(\mathrm{DL}_{50}\right)$ при пероральному введенні для білих мишей-самок становила 162 мг/кг, для білих мишей-самців 300 мг/кг, для білих щурів-самок - 380 мг/кг, білих щурів-самців - 1210 мг/кг (табл. 2). 
Таблиця 2

Середньосмертельні дози нафазолін нітрату для лабораторних тварин при пероральному введенні

\begin{tabular}{|c|c|c|}
\hline \multirow{2}{*}{ Вид тварин } & \multicolumn{2}{|c|}{ DL $_{50, \text { мг/кг }}$} \\
\cline { 2 - 3 } & за Лічфільдом і Уілкоксоном & $\begin{array}{c}\text { 3a Van der } \\
\text { Waerden }\end{array}$ \\
\hline Білі щурі-самки & $380(230,3-627,0)$ & - \\
\hline Білі щурі-самці & - & 1210 \\
\hline Білі миші-самки & - & 162 \\
\hline Білі миші-самці & - & 300 \\
\hline
\end{tabular}

Коефіцієнт видової чутливості (КВЧ) для самців щурів та мишей $-4,0$ (виражена видова чутливість), для самок щурів та мишей - 2,3 (слабовиражена видова чутливість). Коефіцієнт статевої чутливості становить 3,18 .

Для оцінювання ступеня потенційної і реальної небезпеки виникнення гострого смертельного отруєння під дією нафазолін нітрату було розраховано наступні кількісні параметри: величина, зворотна середньолетальній концентрації (абсолютна токсичність) - $1 /$ ЛД $_{50}$, діапазон смертельних концентрацій (зона гострої токсичної дії) - ЛД $84 / Л_{16}$, функція кута нахилу ефективної прямої (варіабельність смертельних доз) - S, сумарний показник небезпечності (токсичності) -1/(ЛД 50 S) (табл. 3), відповідно до яких сполуку можна вважати малонебезпечною речовиною.

Таблиця 3

Показники небезпеки гострого несмертельного отруєння нафазолін нітратом

\begin{tabular}{|c|c|c|c|c|}
\hline \multirow{2}{*}{ Вид тварин } & \multicolumn{4}{|c|}{ Показники } \\
\cline { 2 - 5 } & $\begin{array}{c}\text { абсолютна } \\
\text { токсичність, } \\
1 / Л_{50}\end{array}$ & $\begin{array}{c}\text { зона гострої } \\
\text { токсичної дії, } \\
\text { ЛД }_{84} / Л_{16}\end{array}$ & $\begin{array}{c}\text { варіабельність } \\
\text { смертельних } \\
\text { до3, } \mathrm{S}\end{array}$ & $\begin{array}{c}\text { сумарний } \\
\text { показник } \\
\text { токсичності, } \\
1 / \text { ЛД }_{50} \cdot \mathrm{S}\end{array}$ \\
\hline Білі щурі & $2,6 \times 10^{-3}$ & 5,27 & 2,15 & $5,6 \times 10^{-3}$ \\
\hline
\end{tabular}

Висновки. В результаті проведених досліджень встановлено, що середньосмертельна доза нафазолін нітрату $\left(\mathrm{DL}_{50}\right)$ при пероральному введенні для білих мишей-самок становила 162 мг/кг, для білих мишей-самців 300 мг/кг, для білих щурів-самок - 380 мг/кг, білих щурів-самців - 1210 мг/кг. Коефіцієнт статевої чутливості - 3,18. За показниками небезпеки розвитку гострого перорального несмертельного отруєння нафазолін нітрат відноситься до малонебезпечних сполук. 


\section{Список літератури}

1. Mortuaire G., de Gabory L., François M., Massé G., Bloch F., Brion N., et. al. Rebound congestion and rhinitis medicamentosa: nasal decongestants in clinical practice. Critical review of the literature by a medical panel. Eur Ann Otorhinolaryngol Head Neck Dis. 2013. 130(3). P. 137-144.

2. Kuzminov B.,Turkina V., Kuzminov Y. Rationale for naphazoline effects indepth study. Current Issuesin Pharmacy and Medical Sciences. 2018. 31(1). P. 29-33.

3. Котляр С. И. Медицинское применение нафтизина. Фармацевтический бюллетень. 2000. 3-4. С. 40-43.

4. Кузьмінов Б. П., Зазуляк Т. С. Контроль вмісту активних фармацевтичних інгредієнтів у повітрі робочої зони на ділянці з виробництва лікарського засобу нафтизин®. Актуальні проблеми профілактичної медицини. 2018. Вип. 1-2 (16). C. 45-52.

5. Методические указания к постановке исследований для обоснования санитарных стандартов вредных веществ в воздухе раб очей зоны: утв. МЗ СССР от 04.04.1980 № 2163-80. М. 1980. 20 c.

6. Обгрунтування гранично допустимих концентрацій лікарських засобів у повітрі робочої зони і в атмосферному повітрі населених місць: методичні вказівки, затв. МОЗ України від 21.10.2005 № 544. К. 19 с.

7. Токсикометрия химических веществ, загрязняющих окружающую среду / Под общей редакцией доктора медицинских наук, профессора А.А. Каспарова и доктора медицинских наук, профессора И. В. Саноцкого. Москва: Центр Международных проектов ГКНТ, 1986. 426с.

8. Hayes A. W. Principles and Methods of Toxicology. York: Raven Press, 1989. 899 p.

9. Беленький М.Л. Элементы количественной оценки фармакологического эффекта / Беленький М. Л. - Ленинград: Медгиз, 1963. - 146 с.

10. Красовский Г. Н., Егорова Н. А., Жолдакова З. И. и др. Среднее время гибели животных как параметр для прогнозирования хронической токсичности веществ. Гигиена и санитария. 1982. № 7. С. 12-14.

11. Про захист тварин від жорстокого поводження: Закон України від 21.02.2006 № 3447-IV. URL: https://zakon.rada.gov.ua/laws/show/3447-15) (дата звернення: 25.01.2021).

12. Порядок проведення науковими установами дослідів, експериментів на тваринах: наказ МОН України від 01.03.2012 № 249. Офіційний вісник України. № 24, стор. 82, стаття 924, код акта 60909/2012. 


\title{
ОСОБЛИВОСТІ ТОТАЛЬНОЇ АРТРОПЛАСТИКИ ПРИ ПРОГРЕСУЮЧІЙ ДИСПЛАЗІЇ КУЛЬШОВОГО СУГЛОБА
}

\author{
Канзюба Анатолій Іванович \\ Доктор медичних наук, доцент, \\ професор кафедри загальної хірургії \\ ДВНЗ Ужгородський національний університет
}

Прогресуюча дисплазія кульшового суглоба $\epsilon$ провідною причиною раннього початку коксартрозу у віці до 60 років і належить до найбільш тяжких уражень опорно-рухової системи. Середній вік пацієнтів 3 проявами дисплазії різної важкості, що потребують ендопротезування, коливається від 31,2 до 44,6 років $[1,2]$. Серед досліджених пацієнтів у віці до 50 років, що перенесли тотальну артропластику кульшового суглоба, у 48,4 \% головним етіологічним чинником виникнення дегенеративного процесу визначена прогресуюча дисплазія $[3,4]$. При прогресуючій дисплазії тотальна артроластика кульшового суглоба визнається безальтернативним хірургічним утручанням, що дозволяє відновити, або покращити опорно-рухову функцію $[2,5]$. Численні і складні анатомічні й фізіологічні порушення, що спостерігаються в пацієнтів, зумовлюють складнощі планування операції та необхідність оптимізації хірургічної тактики 3 урахуванням особливостей ортопедичного й загально соматичного стану пацієнтів $[6,7]$.

Мета роботи - аналіз факторів, що визначають вибір хірургічної тактики й особливості первинної тотальної артропластики при диспластичному коксартрозі.

До ретроспективного аналізу включено 157 пацієнтів, серед яких було 148 жінок і 9 чоловіків віком від 19 до 56 років (середній вік 37,4 $\pm 3,2$ року). За даними рентгенографії 93 (59,2 \%) пацієнти мали ураження обох кульшових суглобів. Загальна кількість операцій первинної артропластики - 193 (100\%), у тому числі $36(18,7$ \%) - на обох кульшових суглобах.

Планування лікувальної тактики проводили на підставі даних рентгенографічного дослідження й спіральної комп'ютерної томографії (СКТ). Прояви дегенеративно-дистрофічного процесу відповідали 3-й стадії артрозу. Отримані результати були систематизовані за ступенем проксимальної дислокації стегна (Crowe et al., 1979) [8] .

Статико-динамічну функцію пацієнтів перед артропластикою й у різні терміни після операції оцінювали за шкалою Harris Hip Score.

Аналіз результатів передопераційного обстеження пацієнтів дозволив виділити складові патології опорно-рухового апарату, які впливають на вибір хірургічної тактики, визначають особливості хірургічних утручань і результати ендопротезування. 
1. Прояви деструктивно-дистрофічного ураження суглоба. Характеризуються поширеним асептичним некрозом головки й шийки при їх малих розмірах, що обмежує можливості використання видалених фрагментів як пластичного матеріалу.

2. Власне прояви дисплазії вертлюжної западини. Недорозвиненість i навіть відсутність склепіння, недорозвиненість задньої i, особливо, передньої стінки, зменшення глибини западини 3 потоншенням медіальної стінки зумовлюють загальний дефіцит кісткової тканини в цій ділянці.

3. Порушене співвідношення диспластичної вертлюжної западини й головки стегнової кістки (II-IV типи за Crowe) визначає різні, інколи контраверсійні підходи до зведення стегна й розташування штучної западини: атипове, більш проксимальне розміщення чашки, різних варіантів укорочуючої остеотомії [9], закрите зведення стегна із застосуванням дистракційних апаратів перед виконанням артропластики $[9,10,11]$.

4. Деформація проксимального відділу стегна: варусна чи вальгусна деформація шийки; вкорочення шийки й надмірна антеверсія; вузький i деформований кістково-мозковий канал; багатоплощинні деформації нижче від малого вертлюга після попередніх реконструктивних утручань, інколи невидалені конструкції.

5. Наявність двобічного ураження кульшових суглобів, деформація тазового кільця, сколіотична деформація хребта — це фактори, що визначають відновлення довжини обох нижніх кінцівок і загалом адаптацію пацієнта до нових біомеханічних умов.

6. Дисбаланс і слабкість м'язів тазового поясу, а також супутні деформації кінцівки диспластичного генезу, післяопераційні деформації діафіза стегнової кістки й вторинні деформації колінних суглобів необхідно враховувати при плануванні післяопераційної реабілітації, насамперед як фактори ризику вивихів у штучному суглобі.

7. Локальний (або системний) остеопороз - фактор, що визначає інтраопераційні ризики додаткових пошкоджень, вибір технології ендопротезування й строки виживання імплантатів.

Найчастіше труднощі імплантації ацетабулярного компонента пов'язані із дефектом кісткової маси в ділянці вертлюжної западини. Головні моменти мала глибина западини, недостатність, а часто відсутність верхньої стінки або склепіння. Розташування чашки ендопротеза відповідно до фізіологічних параметрів має забезпечити відновлення природного центру обертання кульшового суглоба, офсету й балансу м'язів. Орієнтиром для визначення місця формування кісткового ложа обирали нижній край істинної вертлюжної западини.

Головним правилом при цьому вважаємо максимальне збереження кісткової маси. У випадках занадто малої і тонкої передньої стінки необхідно зберегти іï субхондральну кортикальну пластинку. Кісткове ложе для чашки рекомендуємо формувати римерами, переважно за рахунок більш міцної й масивної задньої колони. 
Відповідальний етап - поглиблення вертлюжної западини. В окремих випадках при видаленні кортикальної пластинки утворюється кістковий дефект дна сформованої западини. У таких випадках перед імплантацією чашки виконуємо аутопластику дефекту кістковими чипсами, які через невеликий отвір розміщуємо під медіальною стінкою (дном) вертлюжної западини.

При дефекті покриття ацетабулярного компонента більше ніж $30 \%$ застосовували кісткову пластику склепіння кортикально-губчастим трансплантатом, сформованим із видаленої головки та шийки стегнової кістки. В окремих випадках, коли через деструкцію, наявність кіст, значний остеосклероз об'єм такого трансплантату видавався недостатнім, додатково використовували трансплантати із гребеня клубової кістки. Мінімальне можливе видалення кісткової тканини при підготовці западини й застосування кісткової пластики забезпечують надійну фіксацію й необхідну просторову орієнтацію імплантату. У більшості пацієнтів діаметр ацетабулярних імплантатів коливався від 42 до 48 мм.

Складнощі імплантації стегнового компонента — ніжки ендопротеза пов'язані 3 малим поперечним розміром і деформацією кістково-мозкового каналу проксимального відділу стегнової кістки, особливо після перенесених реконструктивних операцій. У наших спостереженнях відзначено деформацію на рівні малого вертлюга та дистальніше від нього. У 6 пацієнтів вальгусна деформація дорівнювала 25-30. Через занадто вузький канал, навіть у пацієнтів із надмірною масою тіла, в окремих випадках вимушено імплантували ніжку мінімального розміру.

Дизайн (конфігурацію) ніжки обирали при плануванні оперативного втручання на підставі багатоплощинного дослідження, використовуючи дані СКТ. Через деформацію інколи не досягається щільний контакт кістки з усією поверхнею ніжки протеза, необхідний для забезпечення пресової посадки імплантату (фіксація PressFit). Це зумовило застосування цементної фіксації при протезуванні 11 суглобів. Однак необхідно зазначити, що через деформацію каналу, цементна мантія навколо імпланту, у окремих ділянках, нерівномірна і має недостатню товщину.

У переважної більшості пацієнтів застосоване безцементне ендопротезування. При значній деформації проксимального відділу після попередніх реконструктивних утручань у 5 пацієнтів для імплантації стегнового компонента виконано корегуючу остеотомію на рівні деформації (нижче від малого вертлюга) із накістковою фіксацією фрагментів пластинкою.

У 2 пацієнтів із значною вальгусною деформацією й антекурвацією в підвертлюговій ділянці після операції Шанца - Ілізарова ніжка ендопротезу імплантована в канал стегнової кістки після остеотомії на рівні деформації.

Оптимальні біомеханічні умови для подальшого функціонування опорнорухової системи забезпечує розташування ацетабулярного компонента ендопротеза відповідно до фізіологічних параметрів щодо тазової кістки.

При значній проксимальній дислокації стегна переміщення його до рівня імплантованої чашки ендопротеза пов'язане з подоланням ригідності м'яких тканин і ретракції м’язів. 
У наших спостереженнях для мобілізації стегна ми застосовували декілька прийомів: реліз сідничних м'язів, висічення суглобової капсули, міотомію аддукторів, відтинання від малого вертлюга сухожилка m. iliopsoas. Найбільш часто застосовували остеотомію великого вертлюга 3 м'язами, що до нього прикріплюються, із подальшим його зведенням і фіксацією, а також flapping trochanter osteotomy. У 3 випадках, коли було необхідне зведення стегна до 6 см, застосовано укорочуючу остеотомію дистальніше малого вертлюга із видаленням сегмента кістки заввишки 3,5-4 см.

Віддалені результати за шкалою Harris Hip Score були досліджені у 124 (78,98 \%) оперованих пацієнтів у терміни від 2 до 12 років після артропластики. Тридцять два пацієнти перенесли артропластику обох кульшових суглобів. Середній термін спостереження $-7,8 \pm 1,1$ року. Узагальнені результати визнано відмінними (середній бал 93,67 $\pm 0,35)$ у 47 (37,9\%), добрі (середній бал $85,69 \pm 0,52)$ - у $48(38,7 \%)$, задовільні (середній бал 75,56 $\pm 0,58)$ - у $22(17,7$ $\%)$ осіб. Погані результати (середній бал $46,96 \pm 3,05)$ у 7 (5,7 \%) пацієнтів були зумовлені розвитком нестабільності компонентів. Асептична нестабільність у 5 пацієнтів виникла через 3-5, 7 i 11 років після артропластики. Септична нестабільність у 2 пацієнтів виникла через 6 і 7 років. У 5 пацієнтів у подальшому виконано ревізійне ендопротезування.

\section{Висновки}

1. При значних деструктивно-дистрофічних змінах у кульшовому суглобі, зумовлених дисплазією, тотальна артропластика визнається безальтернативним хірургічним утручанням, що дозволяє відновити опорно-рухову функцію.

2. При ендопротезуванні кульшового суглоба 3 приводу диспластичного коксартрозу у складних ситуаціях необхідно передбачати різні прояви анатомічних і біомеханічних порушень опорно-рухової системи, різні варіанти фіксації вертлюжного та стегнового компонентів, можливості застосування кісткової пластики й реконструкцій, а також не відкидати інтраопераційне рішення про зміни ходу оперативного втручання.

3. Під час первинної артропластики необхідно зберігати i навіть створювати анатомічні резерви кісткової тканини для можливого виконання в майбутньому ревізійних утручань.

\section{Список літератури}

1. Vasileios I. S., Michael C., Gregory S., George C.B. Reconstruction of the Acetabulum in Developmental Dysplasia of the Hip in total hip replacement. Arch Bone Jt Surg. 2014. 2(3). P. 130-136. PMCID: PMC4225014

2. Goran Bicanic, Katarina Barbaric, Ivan Bohacek, Ana Aljinovic, Domagoj Delimar Current concept in dysplastic hip arthroplasty: Techniques for acetabular and femoral reconstruction. World J Orthop. 2014. September 18. 5(4). P. 412-424. DOI: 10.5312/wjo.v5.i4.412 
3. Karachalios T, Hartofilakidis G. Congenital hip disease in adults: terminology, classification, preoperative planning and management. J Bone Joint Surg Br. 2010. 92 (7). P. 914-21. DOI: 10.1302/0301-620X.92B7.24114

4. Clohisy J.C., Dobson M.A., Robison J.F. Radiographic structural abnormalities associated with premature, natural hip-joint failure. J Bone Joint Surg Am. 2011. Vol. 93. Suppl. 2. P. 3-9. DOI: 10.2106/JBJS.J.01734

5. Xinyu Q., Ke J., Jinlun C. (et al.). Post-THA gait training to improve pelvic obliquity and decrease leg length discrepancy in DDH patients: a retrospective study. Journal of International Medical Research. 2020 . 48(3). P. 1-8. DOI: 10.1177/0300060519898034

6. Olukemi L., Michael O., Imoniche A.-S., Charles A. Acetabular and femoral reconstruction in total hip replacement for adult hip dysplasia: A technical guide for surgeons in our environment. Nigerian Journal of Orthopaedics and Trauma. 2019. Vol.18. Iss. 1. P. 1 - 3. DOI: 10.4103/njot.njot_1_19

7. Xiao-tong S., Chao-feng L., Cheng-ming C., Chun-yang F., Shu-xuan L., Jian-guo L. Preoperative Planning for Total Hip Arthroplasty for Neglected Developmental Dysplasia of the Hip. Orthopaedic Surgery. 2019. Vol. 11. P. 348-355. DOI: 10.1111/os.12472

8. Crowe J.F., Mani V.J., Ranawat C.S. Total hip replacement in congenital dislocation and dysplasia of the hip. J Bone Joint Surg Am. 1979. № 61. P. 15-23. PMID: 365863 9. Greber E.M., Pelt C.E., Gililland J.M., Anderson M.B., Erickson J.A., Peters C.L. Challenges in total hip arthroplasty in the setting of developmental dysplasia of the hip. J Arthroplast. 2017. 32 (9S). P. 38-44. DOI: 10.1016/j.arth.2017.02.024

10. Sakellariou V.I., Christodoulou M., Sasalos G., Babis G.C. Reconstruction of the acetabulum in developmental dysplasia of the hip in total hip replacement. Arch Bone Jt Surg. 2014. 2 (3). P 130-136. PMID: 25386570

11. Heng Z., Jiansheng Z., Jianzhong G., Hai D., Zhiyan W., Qirong D. How to restore rotation center in total hip arthroplasty for developmental dysplasia of the hip by recognizing the pathomorphology of acetabulum and Harris fossa? Journal of Orthopaedic Surgery and Research. 2019. 14. P. 339-347. DOI: 10.1186/s13018-0191373-9 


\section{ЕКОНОМІЧНА ДОЦІЛЬНІСТ ПРОВЕДЕННЯ БІОХІЧНОГО ДОСЛІДЖЕННЯ ФУНКЦІЙ ПЕЧІНКИ У ВАГІТНИХ 3 БЕЗСИМПТОМНИМ НОСІЙСТВОМ HBSAG}

Курташ Наталія Ярославівна,

К.мед.н., доцент кафедри акушерства та гінекології ім.І.Д. Ланового Івано-Франківського національного медичного університету

Кравчук Інна Валеріївна

К.мед.н., доцент кафедри акушерства та гінекології ім.І.Д. Ланового Івано-Франківського національного медичного університету

Ласитчук Оксана Миколаївна

К.мед.н., доцент кафедри акушерства та гінекології ім.І.Д. Ланового Івано-Франківського національного медичного університету

Хронічний гепатит В при вагітності - це одна з найактуальніших проблем сучасного акушерства [1,2]. Виявлення носійства HBsAg в Україні станом на 2020 рік офіційно складає більше 1 млн.680 тис. випадків. Окрім, безумовного негативного впливу на перебіг вагітності та пологів у вигляді передчасних пологів та пренатальних втрат, вірус гепатиту В призводить до органічних та функціональних змін печінки, що в свою чергу може призвести до розвитку цирозу печінки, гепатоцелюлярної карциноми, що призведе до інвалідизації таких жінок в майбугньому та негативних економічних та соціальних наслідків [2].

Метою нашого дослідження було виявлення змін функціонального стану печінки у вагітних з безсимптомним клінічним перебігом HBV-інфекції, на підставі оцінки результатів біохімічних досліджень крові, якіє простими ідоступними на всіх рівнях організації медичної допомоги і економічно обгрунтованими новим рівнем організациї медичної допомоги на сучасних етапах надання медичного обслуговування в Украӥні.

Матеріали та методи. Нами було обстежено 98 вагітних жінок в терміні гестації 31-38 тижнів, які розподілені на дві групи: I група-52 жінок 3 позитивним HBsAg, який був виявлений при обстеженні вагітних на рівні жіночої консультації згідно із наказами МО3, та II група-46 фізіологічно вагітних жінок. Проведено визначення в сироватці крові аспартатамінотрансферази (АсАТ), аланін амінотрансферази (АлАТ), тимолової проби, гамаглутанілтранспептидази (ГГТП), альбуміно-глобулінового індексу, ефективної концентрації альбумінів (ЕКА) та рівня загального білка. Ступінь 
фіброзу печінки оцінювали за еластометрією на апараті Fibroscan (Франція) 3 інтерпретацією результатів за шкалою (METAVIR).

Результати дослідження. Показники білковосинтетичної функції печінки в жінок з вірусним гепатитом В був достовірно більшим: в I групі тимолова проба була вищою в 3,21 раз, порівняно з показниками II групи $(\mathrm{p}<0,001)$. У вагітних I групи було відмічено падіння рівня зального білка на $17,1 \%, \mathrm{~A} / \Gamma$ коефіцієнт був знижений на $13,9 \%$ та ЕКА на $39,8 \%(\mathrm{p}<0,05)$, порівняно із жінками II групи, що є свідченням диспротеїнемії.

Встановлено значне підвищення активності трансаміназ у 41 вагітної жінки з HBV-інфекцією, так АлАТ в 1,71 раз вище від показників II групи, рівень АсАТ був вищим в 2,07 раз, при достовірності $\mathrm{p}<0,05$. Зростання активності ферментів можна інтерпретувати як віддзеркалення порушення гістогематичних бар'єрів або наявність активації цитолізу.

Рівень екскреторного ферменту ГГТП був достовірно вищим у жінок 3 позитивним маркером вірусного гепатиту В в порівнянні зі здоровими вагітними i у I групі був в 4,32 раза вище, ніж у II групі $(p<0,05)$. Гамаглутамілтранспептидаза була підвищеною у 47 жінок з HBV-інфекцією $(\mathrm{p}<0,001)$, і свідчить про вищу діагностичну цінність та чутливість даного показника, порівняно із рівнем трансаміназ.

Висновки. Дані, отримані під час дослідження, підтверджують наявність у вагітних з HBV- інфекцією порушення функціонального стану печінки та розвитку фіброзу без наявних клінічних скарг вагітних, що вимагає медикаментозної корекції та моніторингу загального стану вагітних, а також ретельного ведення ускладнених вірусом гепатиту В вагітностей. Окрім отриманих клінічних результатів, запропонований пакет обстежень $\epsilon$ доступним для лабораторної служби на всіх рівнях надання акушерської допомоги в Україні і економічно обгрунтованим.

\section{Список літератури:}

1. Management of hepatitis B infected pregnant women: a cross-sectional study of obstetricians / Stephanie D. Chao, Chrissy M. Cheung, Ellen T. Chang, Allison Pei \& Samuel K. S. So // BMC Pregnancy and Childbirth volume 19, Article number: 275 (2019)

2. EASL Clinical Practice Guidelines: management of chronic hepatitis B // J. Hepatol. - 2009. - 50. - 227-242. 


\title{
ДЕЯКІ СКЛАДОВІ НАВЧАЛЬНОГО ПРОЦЕСУ ТА ЇХ ЗНАЧЕННЯ У ФОРМУВАННІ ОСОБИСТОСТІ ЛІКАРЯ
}

Кучер Олена Володимирівна

д.мед.н., професор кафедри гематології і трансфузіології

Дерпак Юрій Юрійович

д.мед.н., доцент кафедри гематології і трансфузіології

\begin{abstract}
Видиборець Станіслав Володимирович
д.мед.н., професор, завідувач кафедри гематології і трансфузіології Національна медична академія післядипломної освіти імені П. Л. Шупика

МO3 України
\end{abstract}

За сучасних умов соціально-економічної трансформації суспільства, важливим напрямком реформування медичної галузі $\epsilon$ трансформування додипломної і післядипломної медичної освіти. Тенденції останнього часу, що простежуються у вищій медичній освіті, призвели до деякого зниження іiі престижу з наслідками, що з нього випливають, а саме - з скороченням годинного обсягу вивчення переважної більшості дисциплін навчального плану, ускладненням із забезпечення лікарів-слухачів навчально-методичною літературою та посібниками, особливо державною мовою, скрутністю 3 фінансуванням закладів вищої освіти тощо, що безпосередньо впливає на організацію всього навчального процесу у закладах вищої освіти.

Якщо до означених обставин додати рівень базових знань (що постійно знижується) випускників середніх шкіл, і рівень знань абітурієнтів, які потрапляють на перший курс за контрактом (платні послуги), то гострота проблеми стане ще очевиднішою.

Щодо впровадження ступеневої освіти «бакалавр - спеціаліст - магістр», то це потребує доопрацювання не тільки навчально-методичної літератури, а й майже всіх нормативних матеріалів, зокрема, навчальних планів, освітньопрофесійних програм, освітньо-кваліфікаційних характеристик тощо, а також пошуку нових критеріїв оцінювання знань студентів i лікарів, які б поглиблювали та розширювали знання, сприяли подальшому підвищенню активізації пізнавальної діяльності. Все означене вимагає від працівників вищої школи пошуку нових ефективніших форм і методів організації навчального процесу.

Поява нових наукових технологій позначилась на різноманітних сферах людської діяльності, зокрема, на сфері навчання лікарів [1-4]. Сучасний стан розвитку медичної освіти характеризується все ширшим використанням нових складних технічних засобів навчання i устаткування, інформаційних i телекомунікаційних технологій. Оскільки останнім часом спостерігається 
ускладнення понятійного апарату, з появою багатьох нових понять, важливо розрізняти такі поняття, як засоби навчання, навчальна техніка, навчальні матеріали, засоби нових інформаційних технологій.

Із терміном «навчальна техніка» (educational technology) пов'язують цілий напрямок досліджень. Сформувалась нова галузь професійної спеціалізації технолог освіти, фахівці якої займаються дослідженням проблем постачання навчальних матеріалів і організацією технічного аспекту роботи закладів освіти. Термін “навчальна техніка" - в англомовній літературі виникас як міждисциплінарне поняття, що практично пов'язане з усіма галузями освіти i стосується таких широких дисциплін як педагогіка, психологія, телекомунікаційні системи, інформаційні системи, менеджмент, інженерні науки. В цілому, галузь навчальної техніки має відношення до всього, що включається в процес викладання - від матеріалів для викладання (через усі пов'язані з даним закладом освіти проблеми організації людей і ресурсів) і до розвитку суспільних організацій та міського планування. Більш конкретно, можна навести часткові випадки цього поняття: навчальна техніка як аппаратура для викладання; освітній технолог як творець підручників. Аналітичний огляд літератури доводить, що термін "навчальна техніка" не використовується як аналітично точне поняття, оскільки в англійській мові слово “техніка" (technology) $є$ полісемічним, немає визначеності щодо значення терміну “техніка” взагалі. Можна відокремити такі поняття “техніка”: обладнання; галузь діяльності; технічні прийоми; процес (в системному аналізі); технологія; галузь науки про поведінку людини. Під навчальною технікою слід розуміти сферу досліджень і практики (у межах освіти), що пов'язана з усіма аспектами організації навчальних систем і процедур, де використовуються ресурси, щоб досягти специфічних $\mathrm{i}$ потенційно повторюваних навчальних цілей. $\mathrm{y}$ вітчизняній літературі даному значенню терміну “навчальна техніка" традиційно відповідає термін “технічні засоби навчання". 3 огляду на означене, слід відокремлювати таке поняття, як "інструменти викладання" (instrumentation of education). При цьому під технікою розуміють використання механічних, електротехнічних, електронних та підсобних автоматичних засобів. Інше важливе поняття, поширене поряд 3 “навчальною технікою”, $€$ “аудіовідеозасоби" (audiovisual aids). До них належать аудіовізуальні машини (слайдпроектори, телевізори, комп'ютери, магнітофони тощо) та матеріали слайди, постери, транспаранти, діаграми, діафільми, відеофільми, кінофільми, аудіозаписи, тексти і звукові коментарі. Під терміном "засоби навчання" (educational media), слід розуміти будь-які засоби, агенти чи інструменти, що використовуються для передачі навчальної інформації. Це друковані тексти, графічні об'єкти, усні (лекції, аудіоплівки), малюнки (телевізійні, друковані). У даному контексті, комп'ютер, що друкує слова на екрані, розуміється як такий же засіб комунікації, як і підручник. Відтак передаючі пристрої самі по собі виступають не як засоби, а скоріше - як інстументи, що розповсюджують або передають повідомлення, застосовуючи засоби комунікації. Під терміном "навчальне середовище" (educational enviornment) слід розуміти простір навчання (аудиторії, лабораторії, бібліотеки, інтернет-класи тощо) і простір 
середовища навчання (будівлі навчального закладу, клінічної бази, навчальні плани та програми, організаційні форми навчання, центри постачання навчальних ресурсів тощо). Використання означених засобів дозволяє підготувати висококваліфікованого лікаря на всіх етапах його навчання.

Для розвитку творчого потенціалу викладача закладу вищої медичної освіти потрібно створити умови ще під час його навчання в аспірантурі. Формування творчого, ініціативного, самокритичного педагога може бути здійснено лише тоді, коли майбутній асистент кафедри уже в роки навчання в аспірантурі буде поставлений в умови, наближені до його практичної діяльності за допомогою активних методів навчання, що готують його до спілкування з студентами, лікарями-інтернами чи лікарями-слухачами циклів підвищення кваліфікації. Процес спілкування викладача вищого медичного закладу і студента чи лікаря становить суттєвий компонент змісту науково-педагогічної діяльності. Однією із найважливіших якостей педагога $\epsilon$ його вміння організовувати взаємодію 3 слухачами, тобто спілкуватись із ними, керувати їх діяльністю.

У сучасній науково-педагогічній літературі термін "професійно-педагогічне спілкування" розглядається як система засобів і навичок органічної взаємодії педагога і слухачів, до змісту якої входить обмін інформацією, пізнання особистості, прояв виховного впливу, організація стосунків з допомогою різних комунікативних засобів тощо. Ступінь готовності до спілкування з слухачами у аспірантів, як у майбутніх науково-педагогічних кадрів, визначається наступними критеріями: знанням суті, структури спілкування i можливих моделей педагогічних ситуацій; здатністю до аналізу педагогічних явищ та фактів; вмінням до проектування (конструювання) змісту та способів майбутнього педагогічного впливу; практичним застосуванням моделювання педагогічних ситуацій у навчальному процесі. Моделювання будь-якої педагогічної ситуації містить: аналітичний етап (аналіз і оцінювання ситуації, формування завдання, яке потрібно вирішити), проекційний етап (плануються засоби та форми для моделювання ситуації, розроблюється проект ії вирішення), виконавчий етап (реалізація задуму та практичне відтворення розробленого проекту). Управління діяльністю слухачів містить два основних функціональні аспекти: інформаційний, що пов'язаний з розробленням предметного змісту діяльності студента чи лікаря, і організаційний, спрямований на розроблення форм діяльності слухачів при реалізації педагогічного задуму.

Демонстраційні досліди є складовою частиною забезпечення навчального процесу при вивченні багатьох медичних дисциплін. Формування експериментальних умінь, передбачає засвоєння слухачами (студентами, лікарями) наступної послідовності дій під час проведення будь-яких дослідів: 1) висунення та усвідомлення мети експерименту (визначення явища, властивості чи процесу, що слід вивчити; розуміння завдання експерименту, уміння дати загальний опис явища, графічно відобразити процес, установити зв'язок між величинами, що вивчаються, знайти їх числові значення тощо); 2) планування експерименту (визначити предмет спостережень, методику проведення дослідження, скласти принципову схему дослідної установки, приладу; встановити необхідні для демонстраційного досліду матеріали, намітити план і 
послідовність виконання дій); 3) безпосереднє проведення демонстраційного досліду (вміння визначати параметри вимірювальних приладів, проводити спостереження і виміри, зафіксувати отримані дані); 4) аналіз результатів експерименту (обробка отриманих результатів відповідно до мети демонстраційного досліду, формулювання висновків, складання звітів). Наведений загальний план можна вважати алгоритмічним прописом, який конкретизується при проведенні демонстраційних дослідів. Під час проведення дослідів слід обов'язково дотримуватись такої послідовності дій: визначити мету досліду, вказати, які прилади та матеріали чи реактиви будуть застосовуватися, визначити явище, за яким мають спостерігати слухачі, виконати дослід, проаналізувати результати спостережень і вимірювань, зробити висновки. Під час проведення демонстраційних дослідів слухачі залучаються до формулювання завдань досліду, конструювання дослідної установки, проведення досліду, аналізу явищ, визначення показань шкали вимірювального приладу тощо. Засвоєння плану діяльності при проведенні демонстраційного досліду визначає відповідні вміння, а саме - уміння знімати показники приладу, аналізувати результати спостереження тощо.

Використання групової форми навчання (ГФН) дозволяє повніше реалізувати людський потенціал i, власне, закон розвитку особистості. Підвищується активність слухачів, змінюється мотивація навчання. За фронтальної (ФФН) та індивідуальної (ІФН) форм навчання весь процес спілкування здійснюється через викладача (а вийти на нього не кожному слухачеві під силу з різних причин), а відтак звернення до колег-лікарів за своєю ініціативою, отримання та надання їм допомоги, обмін інформацією значною мірою можуть здійснюватись лише при ГФН. Якщо проаналізувати різні форми навчальної роботи, то стає зрозумілим, що найширші можливості формування вмінь, яких потребує спілкування, надає ГФН. До того ж ГФН має переваги і при вирішенні дидактичних проблем. На практичних заняттях дидактичний смисл іiї полягає головним чином у забезпеченні оперативного зворотного зв'язку. При вивченні нового матеріалу ГФН створює передумови для аналізу особистого досвіду кожного члена групи i, таким чином, дозволяє уникнути неправильних узагальнень, оскільки навіть погано організована дискусія в групі дає більше розуміння слухачами змісту предмета. При вивченні нового матеріалу можливо використовувати як ФФН, так і ГФН. Остання виявляється ефективнішою тоді, коли сам зміст навчального матеріалу має проблемний характер, потребує обмірковування, осмислення. ГФН дозволяє досягти вищої ефективності усіх слухачів і при повторенні матеріалу, оскільки при цьому виникає можливість використовувати знання кожного, що їх набуто із різних джерел. До того ж ГФН сприяє успішному формуванню у студентів-медиків та лікарів комплексу таких позитивних якостей, як: здатність швидко адаптуватися, вміння вирішувати спільні для всіх завдання, уміння швидко встановлювати контакти, обмінюватися інформацією та формувати відповідні погляди, готовність взяти на себе відповідальність за прийняте рішення, здатність встановлювати контакти, правильно розподіляти і організовувати роботу, долати опір, попереджувати суперечки, готовність розглядати проблему 3 точки зору 
опонента, оцінювати рівень своєї компетенції, здатність чітко і переконливо доводити свою думку тощо.

\section{Список літератури}

1. Видиборець С.В. Підтвердження звання лікар-спеціаліст на курсах стажування та правові засади правильного зарахування на посаду лікаря (провізора)-стажиста / С. В. Видиборець // Goal and role of world science in modernity: Abstract of VII Scientific and practical conference (Helsinki, Finland, March 09-10, 2020). - SH SCW "NEW ROUTE": Helsinki, Finland,, 2020. - P. 5255. URL: http://isg-konf.com.

2. Видиборець С.В. Актуальні питання викладання теоретичної, клінічної і виробничої трансфузіології у післядипломному навчанні лікарів / С. В. Видиборець // Modern Scientific and Technical Metthods of Management Information flow and their influenceon the Development of Society: Abstracts of V International Scientific and Practical Conference (Frankfurt am Main, Germany, February 24-25, 2020). - SH SCW "NEW ROUTE": Frankfurt am Main, 2020. - P. 135-137.URL: http://isg-konf.com

3. Видиборець С.В. Лекційне забезпечення навчального процесу на курсах підвищення кваліфікаціїі лікарів / С. В. Видиборець // Modern information technologies and their implementation in the process of social and technical project management: Abstracts of IV International Scientific and Practical Conference (Boston, USA, February 17-18, 2020). - SH SCW "NEW ROUTE": Boston, 2020. P. 71-76. URL: http://isg-konf.com

4. Видиборець С.В. Клінічний розбір пацієнта як різновид практичної підготовки лікарів у системі післядипломної освіти / С. В. Видиборець // Man and Environment, Trend and Prospects: abstract of III International Scientific and Practical Conference (Tokio, Japan, 10-11 February 2020). - SH SCW "NEW ROUTE": Tokio, 2020. - P. 264-267. URL: http://isg-konf.com 


\title{
ОСОБЛИВОСТІ РЕАЛІЗАЦІЇ ОСВІТНЬОЇ СКЛАДОВОЇ ОСВІТНЬО-НАУКОВОЇ ПРОГРАМИ ЗДОБУВАЧІВ ТРЕТЬОГО (ОСВІТНЬО-НАУКОВОГО РІВНЯ) ВИЩОЇ ОСВІТИ 3 ВИКОРИСТАННЯМ ТЕХНОЛОГІЙ ЕЛЕКТРОННОГО НАВЧАННЯ В УМОВАХ ВПРОВАДЖЕННЯ КАРАНТИННИХ ЗАХОДІВ, СПРИЧИНЕНИХ ПАНДЕМІЕЮ КОРОНАВІРУСНОЇ ІНФЕКЦІЇ COVID-19, В ТЕРНОПІЛЬСЬКОМУ НАЦІОНАЛЬНОМУ МЕДИЧНОМУ УНІВЕРСИТЕТІ IМЕНІ І.Я. ГОРБАЧЕВСЬКОГО МІНІСТЕРСТВА ОХОРОНИ ЗДОРОВЯ УКРАЇНИ
}

\author{
Потіха Наталія Ярославівна, \\ кандидат медичних наук, доцент, \\ завідувач відділу аспірантури та докторантури \\ Тернопільський національний медичний університет \\ імені І.Я. Горбачевського \\ Міністерства охорони здоров’я України
}

Ковалик Ольга Степанівна, магістр філології, провідний фахівець відділу аспірантури та докторантури Тернопільський національний медичний університет імені І.Я. Горбачевського Міністерства охорони здоровя України

В умовах карантинних обмежень, спричинених пандемією коронавірусної інфекції COVID-19, актуальним $€$ питання організації безперервного освітнього процесу у вищих навчальних закладах та наукових установах 3 метою повноцінного i своєчасного здобуття програмних компетентностей та програмних результатів навчання, формування висококваліфікованого фахівця, науковця і педагога. У цьому контексті актуальним $є$ підготовка спеціалістів 3 використанням технологій дистанційного навчання.

Під дистанційним навчанням розуміється індивідуалізований процес набуття знань, умінь, навичок і способів пізнавальної діяльності людини, який відбувається в основному за опосередкованої взаємодії віддалених один від одного учасників навчального процесу у спеціалізованому середовищі, яке функціонуе на базі сучасних психолого-педагогічних та інформаційнокомунікаційних технологій. Метою дистанційного навчання є надання освітніх послуг шляхом застосування у навчанні сучасних інформаційно-комунікаційних 
технологій за певними освітніми або освітньо-кваліфікаційними рівнями відповідно до державних стандартів освіти [1].

Поняття „дистанційне навчання” і „електронне навчання” (Electronic Learning або E-Learning) синонімічні. За визначенням фахівців ЮНЕСКО: «ЕLearning - навчання за допомогою Інтернет і мультимедіа» [2].

Елементами електронного навчання $є$ : самостійна робота 3 електронними матеріалами, з використанням персонального комп'ютера, мобільного телефону, DVD-програвача, телевізора; отримання консультацій, порад, оцінок у віддаленого (територіально) викладача, можливість дистанційної взаємодії; цілодобовий доступ до електронних навчальних матеріалів; стандарти i специфікації на електронні навчальні матеріали та технології, дистанційні засоби навчання; формування та підвищення інформаційної культури в усіх здобувачів освіти і оволодіння ними сучасними інформаційними технологіями, підвищення ефективності своєї звичайної діяльності; освоєння і популяризація інноваційних педагогічних технологій.

Перевагами електронного навчання $€$ : можливість розвивати власні навчальні веб-ресурси; можливість у будь-який час і будь-якому місці отримати сучасні знання, доступність вищої освіти особам 3 особливостями психофізичного розвитку.

У Тернопільському національному медичному університеті імені І.Я. Горбачевського Міністерства охорони здоров’я України запроваджено навчання здобувачів третього (освітньо-наукового) рівня вищої освіти в аспірантурі за спеціальностями: 222 Медицина, 221 Стоматологія, 226 Фармація, 228 Педіатрія, 223 Медсестринство галузі знань 22 Охорона здоровя 3 використанням технологій електронного навчання 3 часу введення суворого і адаптивного карантину. Засвоєння освітніх компонентів аспірантами відбувається дистанційно. Лекції, практичні (семінарські) заняття для аспірантів та здобувачів наукового ступеню доктор філософії проводяться в онлайн-режимі за допомогою програмного забезпечення Microsoft Teams.

Науково-педагогічні працівники університету інформовані про особливості проведення освітнього процесу для аспірантів та здобувачів наукового ступеню доктор філософії в умовах запровадження карантинних заходів. Викладач-лектор напередодні проведення лекції створює та налаштовує онлайн-лекцію в системі Microsoft Teams („Відеоподія”) та надсилає посилання для підключення тим групам аспірантів, які мають іiі прослухати, вказавши назву лекції, дату та час іiі проведення. Аналогічно напередодні проведення практичного (семінарського) заняття викладач зобов'язаний особисто створити (запланувати) та налаштувати онлайн практичне заняття в системі Microsoft Teams („Нарада”). Викладач вказує назву практичного заняття, дату та час його проведення, додає прізвища аспірантів та здобувачів. Технічну підтримку Microsoft Teams здійснює відділ інформаційних технологій університету.

Слід відмітити, що усі необхідні навчально-методичні комплекси для опанування дисциплін, передбачених навчальними планами аспірантури, розташовані у відкритому доступі на платформі Moodle. Вони включають в себе: робочі програми та силабуси 3 дисциплін, презентації лекцій, матеріали для 
підготовки до лекцій і практичних занять, методичні вказівки для здобувачів вищої освіти для підготовки до практичних та семінарських занять, розклади занять та відпрацювань пропущених занять і лекцій. Крім того, аспіранти мають можливість переглядати записані викладачами лекції або презентації з відеосупроводом у популярному відеохостингу „You Tube” за умови, що вони мають посилання на дану лекцію.

Щоденний контроль знань аспірантів здійснюється також на платформі Moodle шляхом тестування. Здобувачам вищої освіти пропонується пройти компютерну тестуючу програму у вигляді 24 тестових завдань множинного вибору з однією правильною відповіддю. Семестровий контроль з відповідних дисциплін відбувається з використанням системи Microsoft Teams (в режимі „Нарада”, усна частина іспиту) та платформи Moodle (тестування, письмова частина іспиту).

Як свідчать результати опитувань аспірантів щодо задоволеності ними рівнем викладання окремих дисциплін, якості навчально-методичних комплексів, то слід відмітити, що 88 \% здобувачів позитивно оцінюють досвід електронного навчання. 3 врахуванням того, що 65 \% аспірантів працюють на посадах науково-педагогічних працівників та лікарів, використання технологій дистанційного навчання у освітньому процесі дозволяє ефективніше і швидше засвоїти потрібні освітні компоненти. Стрімкість сучасного світу вимагає застосування найбільш швидких і дешевих способів процесів генерації і передачі знань. E-Learning є одним з можливих інструментів, які дозволяють вирішувати цю гостру проблему сучасності. Широкий спектр методів дистанційного навчання дозволяє вибирати метод з урахуванням індивідуальних вимог та уподобань слухача.

Серед перспектив успішного застосування E-Learning в академічній спільноті найбільше значення належить таким напрямкам: розширення $\mathrm{i}$ удосконалення E-Learning контенту; розвиток корпоративної стратегії ЕLearning; впровадження і використання нових технологій та інструментів ЕLearning, управління й оцінка ефективності ініціатив E-Learning, врахування потреб i побажань здобувачів вищої освіти, збільшення технологічних потужностей для підтримки E-Learning.

\section{Список літератури}

1. Положення про дистанційне навчання, затверджено наказом Міністерства освіти і науки України, 25.04.2013 № 466.

2. Bates T. National strategies for e-learning in post-secondary education and training / Bates Tony - UNESCO, 2001. - 132 p. 


\title{
НОКТУРІЯ - НЕДООЦІНЕНА ПРОБЛЕМА
}

\author{
Стусь Віктор Петрович \\ д.мед.н., профессор \\ кафедра «Урології» ДЗ «ДМА МОЗ України» \\ Поліон Микита Юрійович \\ к.мед.н., доцент \\ кафедра «Урології» ДЗ «ДМА МОЗ України»
}

\section{Сніцар Герман Миколайович \\ Лікар-уролог \\ КНП КМР «МЛ №7»}

Ноктурія - це стан, який характеризується необхідністю прокидатися $\geq 1$ разів за ніч, для випорожнення сечового міхура (для сечовипускання). Ноктурія $\epsilon$ многофакторним станом, який може співіснувати з іншими симптомами нижніх сечових шляхів, найбільш розповсюдженим фактором $\epsilon$ підвищене сечоутворення у нічний час.

Розповсюдженність: $69 \%$ чоловіків та $76 \%$ жінок (у віці $\geq 40$ років) у США, Великобританії та Швеції, мають $\geq 1$ нічних епізодів сечовипускання. Від $4 \%$ до $18 \%$ жінок у віці від 20 до 30 років страждали $\geq 2$ нічних епізодів сечовипускання, збільшилось до $28-62 \%$ у жінок у віці 70-80 років. Подібні діапазони були зареєстровані у чоловіків. Доля чоловіків у віці від 20 до 30 років, які повідомили про $\geq 2$ нічних епізодів сечовипускання, склала від $2 \%$ до $17 \%$, збільшилась до 29-59\% у чоловіків у віці від 70 до 80 років.

Класифікація. Необхідно розрізняти наступні терміни, при яких зустрічається ноктурія. Глобальна поліурія, при якій підвищений добовий діурез, а співвідношення нічний/денний діурез збережено (діурез > 40 мл/кг/добу) . Ноктурічна поліурія - переважання нічного діурезу над денним. Розраховується через ноктурічий індекс, який не повинен перевищувати $20 \%$ у категорії до 60 років, $33 \%$ у категории 60 років та старше.

Причинами ноктурії можуть бути урологічна патологія (доброякісна гіперплазія передміхурової залози, рак сечового міхура, нейрогенний сечовой міхур), ендокринопатії (цукровий діабет, нецукровий діабет, полідіпсія), так і спосіб життя (споживання алкоголю, кофеїн містящих напоїв, рідини ввечері), споживання діуретіків у другій половині дня, зсув секреції сечі у бік нічного (ідиопатична ноктурічна поліурія). 
Була показана кореляція між ноктурією та переломом шийки стегна у пацієнтів у віці від 40 до 80 років. Травматизм збільшився у 2.67 разів у пацієнтів із ноктурією $\geq 2$ (ICS Philadelphia 2018 Population-based analysis of the relationships between falls, fractures and nocturia). Серед біля 3000 опитаних пацієнтів «Що ймовірно порушає ваш сон?», серед інших причин ноктурію відмітили $60 \%$ пацієнтів (Middelkoop et al. J Ger Sci Med Sci 1996. Bliwise et al. Sleep Med 2009)

Лікування пацієнтів із нейрогенним сечовим міхурем соліфенацином 10 та 5 мг не показало результатів у відношенні ноктурії (Brubaker et al. Int Urogynecol J. 2007). Лікування ДГПЗ методом ТУР простати у 359 пацієнтів показало ефективність тільки у 20\% випадках (Yoshimura et al. Urology 2003).

Методи діагностики. Окрім збору скарг, анамнезу захворювання та анамнезу життя, одним із найважливіших методів діагностики - щоденник сечовипускання протягом 3 діб, із зазначенням часу та об'єму сечовипускання, випитої рідини, прийому препаратів, часу засинання та пробудження (не включається останнє сечовипускання перед сном, але включається перше сечовипускання після сна), розрахування ноктурічного індексу.

В останній час вважається найважливішою причиною нокутрічної поліурії недостатність продукції вазопрессину гіпоталамусом, або мутація гену рецепторів вазопресину у нирках, мутація гену аквапоринів 2 типу. Недостатність вазопресину визиває зсув діурезу у бік нічного.

Лікування. В усьому світі ноктурічну поліурію лікують із задопомогою десмопресину (синтетичний аналог вазопресину) «Ноктіва», який був затверджений агенством FDA. Це назальний спрей, який використовується у дозі 1.66 мкг и 0.83 мкг на добу. Основним побічним эфектом являеться гіпонатріємія (виникала у пацієнтів більше 65 років та при дозі 1.66 мкг). Свропейська асоціація урологів рекомендує споживання десмопресину пацієнтам із ноктурією. Визначати рівень натрія сироватки крові рекомендуеться перед початком прийому препарату, на 3-й, 7-й добі лікування, через місяць та далі індивідуально. Необхідно обговорювати із пацієнтом всі плюси та мінуси лікування десмопресином, особливо із пацієнтами у віці 65 років та більше через ризик виникнення гіпонатріємії. У нашій державі на даний момент немає відповідних препаратів.

\section{Список літератури:}

1. Analysis of nocturia with 24-h urine volume [ Y. Udo et al, 2010]

2. Nocturia: consequences, classification and management [ Noam D. Fine et al, 2017]

3. Nocturi: etiology, diagnosis, and treatment [Rodney A Apell, Peter Sand, 2008] 


\title{
ОСОБЛИВОСТІ ДИСТАНЦЙНОГО НАВЧАННЯ ГІГІЕНІ ПОРОЖНИНІ РОТА ДІТЕЙ ШКІЛЬНОГО ВIКУ
}

\author{
Удод Олександр Анатолійович \\ д. мед. н., професор, професор кафедри стоматології №1 \\ Донецький національний медичний університет \\ Яковлева Наталія Миколаївна \\ в. о. декана стоматологічного факультету \\ Донецький національний медичний університет \\ Вороніна Ганна Сергївна \\ асистент кафедри стоматології №1 \\ Донецький національний медичний університет
}

Проблема раціональної гігієни порожнини рота, за умови доведеної провідної ролі мікробного біофільму в етіології та патогенезі найрозповсюдженіших стоматологічних хвороб, у теперішній час $\epsilon$, безперечно, актуальною [1]. Особливо гострою вона виглядає у дітей шкільного віку, тверді тканини постійних зубів яких, перш за все, емаль, протягом деякого часу після прорізування мінералізуються [2]. На процес мінералізації твердих тканин впливає низка загальних та місцевих чинників, у тому числі функціональна активність пульпи цих зубів, біохімічний склад та біофізичні властивості ротової рідини, однак інші зовнішні місцеві фактори, зокрема, широкий мікробний спектр, який присутній на органах та тканинах порожнини рота, зубні відкладення, склад яких містить, крім мікроорганізмів, часточки їжі, клітини епітелію тощо, здійснюють безпосередній негативний вплив та відіграють вирішальну роль у формуванні критичної ситуації щодо розвитку карієсу зубів та захворювань пародонта [3]. Карієсогенна та пародонтогенна мікрофлора, яка у кожної особи відрізняється певними індивідуальними особливостями, впливає або навіть формує її схильність до виникнення у порожнині рота того чи іншого захворювання [4]. Таким чином, аксіоматично необхідною для збереження стоматологічного здоров'я дитини $\epsilon$ раціональна та максимально індивідуалізована гігієна порожнини рота.

Стійкі навички з гігієни порожнини рота у дітей формуються, перш за все, за умови поінформованості кожної дитини щодо обов'язковості дотримання гігієнічних вимог. Важливою складовою $є$ також їх психологічна мотивація, яку повинні постійно підтримувати батьки та педагоги, а також шкільний медичний персонал. На жаль, далеко не у всіх школах та ліцеях функціонують стоматологічні кабінети, як відомо, їх існування у закладах шкільної освіти за нормативними документами більше 10 років назад було припинено. 
Ефективною формою санітарно-просвітницької роботи відносно популяризації раціональної гігієни порожнини рота дітей шкільного віку цілком обгрунтовано вважають так звані заняття з стоматологічного здоров'я, однак у нових умовах, що вимушено створилися внаслідок жорстких протиепідемічних заходів, вони мають бути трансформовані з набуттям інших інформаційних та індивідуалізованих ознак.

У даній роботі вивчені можливості дистанційного навчання школярів міста Краматорська Донецької області знанням з гігієнічного догляду за порожниною рота та його ефективність.

В інформаційно-освітніх заходах 3 дистанційного навчання дітей, які отримують середню освіту у школах міста Краматорська, основам раціональної гігієни порожнини рота за згоди батьків та педагогів брали участь 65 дітей віком 12 років, серед яких було 36 хлопчиків (55\% від загальної кількості дітей) та 29 дівчаток (45\%). Перед початком навчання на електронні адреси школярів було розіслано спеціально розроблену анкету для первинного опитування 3 метою встановлення рівня їх базових знань відносно індивідуальної гігієни порожнини рота. Кожний з опитаних школярів мав можливість також скласти та надіслати список запитань, на які він хотів би отримати обгрунтовану відповідь щодо засобів та методів гігієни. Після проведення навчання гігієні у дистанційному режимі провели повторне опитування для визначення рівня засвоєння наданої інформації.

Первинне опитування показало низький рівень знань більшості дітей 3 індивідуальних гігієнічних заходів щодо порожнини рота, школярі, як правило, знають лише назви, а не склад та вміст активних компонентів широко розрекламованих зубних паст відомих брендів, тим більш, що дітям не відомі критерії вибору зубних паст та певні застереження, наприклад, щодо вмісту деяких компонентів, зокрема, сполук фтору, які прийнято вважати ефективним лікарським засобом у комплексній профілактиці карієсу, однак, з іншого боку, ці сполуки вимагають диференційованого підходу до щоденного використання у гігієні порожнини рота дітей. Переважна більшість дітей не знають підходів до вибору зубних щіток, а також, 3 чого вони виготовлені, як потрібно їх утилізувати, щоб забезпечити природне розкладання штучної щетини зубної щітки. У той же час, діти добре поінформовані щодо наслідків глобального потепління та інших проблем екології, зокрема, розкладання мікропластику.

Проведене опитування дозволило спрямовано сформувати матеріали відеолекції про засоби та методи проведення індивідуальної гігієни порожнини рота з більш детальною інформацією відносно вибору зубних паст та щіток. Для усіх учасників відеоконференції були продемонстровані методи та правила раціонального чищення зубів, що було показано на збільшених моделяхфантомах верхньої та нижньої щелеп. Демонстрація була проведена в ігровій формі з наочними прикладами та застереженнями щодо можливих помилок. Кожна дитина за бажанням могла описати покроково віртуальний процес чищення зубів. Усі учасники відеоконференції отримали яскраві презентації 3 інформацією щодо гігієни порожнини рота. 
За результатами повторного опитування встановлено значне покращення знань школярів щодо індивідуальної гігієни порожнини рота. Таким чином, проведені у дистанційному режимі інформаційно-освітні заходи показали, перш за все, зацікавленість дітей та їх батьків відносно навчання індивідуальній гігієні порожнини рота та достатню ефективність таких підходів до популяризації гігієнічних знань і мотивації дітей до збереження стоматологічного здоров'я.

Список літератури

1. Профілактика стоматологічних захворювань: підруч. для студ. Вищих мед. навч. закл. / Л. Ф. Каськова, Л. І. Амосова, О. О. Карпенко [та ін.]; за ред. проф. Л. Ф. Каськової. - Х.: Факт, 2011. - 392 с.

2. Хоменко Л. О. Контроль над карієсом зуба: еволюція концепції / Л. О. Хоменко, Н. В. Біденко, О. І. Остапко, І. М. Голубєва, Г. В. Сороченко, Ю. М. Трачук // Стоматология: от науки к практике. - 2013. - № 1. - С. 53-65.

3. Окушко В. Р. Основы физиологии зуба / В. Р. Окушко. - Тирасполь: Издво Приднестр. ун-та, 2005. - 240 с.

4. Борисенко А.В. Кариес зубов / А.В. Борисенко. - К. : Книга-плюс, 2005. $416 \mathrm{c}$. 


\title{
ENSURING CONTROL OF STUDENTS' KNOWLEDGE IN DISTANCE LEARNING
}

\author{
Abaturov Aleksandr, \\ Honored Worker of Science and Technology of Ukraine, MD, \\ Professor, Head of Department of Pediatrics 1 and Medical Genetics \\ SI "Dnepropetrovsk Medical Academy of the Ministry of Health of Ukraine" \\ Nikulina Anna, \\ $\mathrm{PhD}$, Assistant of Department of Pediatrics 1 and Medical Genetics, \\ Assistant professor SI "Dnepropetrovsk Medical Academy \\ of the Ministry of Health of Ukraine"
}

\begin{abstract}
Ensuring adequate forms and methods of control of students' knowledge during distance learning is an urgent problem in the context of the Covid-19 pandemic, which is due to the need to involve innovative information technologies in the management of the educational process. The article on the basis of literature data presents the main functions and didactic principles of knowledge control in terms of distance learning, lists the important components of successful organization of the pedagogical process and components of the Learning Management System. At the same time, the authors of the article focus on ensuring the quality of distance learning emphasizes the effectiveness of information technology used and pedagogical skills.
\end{abstract}

Keywords: distance learning, knowledge control functions, didactic principles of knowledge control, Learning Management System, components of the learning management system

\section{Introduction}

Control of students' knowledge during the distance form of education is the organization of feedback as a means of managing the educational process. The urgency of this problem is due to the fact that the entire system of higher education in Ukraine is subject to complete organizational restructuring and implementation of this method of education in connection with the Covid-19 pandemic.

Prior research showed that student performance in online courses is associated with socio - demographic characteristics, motivation, self-efficacy, and interaction with instructors. Foreign researchers analyzed the effectiveness of distance learning at technical universities in comparison with traditional off line classes. The effectiveness of distance learning was assessed according to three parameters: the level of mastering the discipline, current academic performance and the level of satisfaction with the training course. It was found that the level of mastering the discipline did not differ in 
the groups. However, students who took the course online were slightly less satisfied with the learning process. Researchers believe this is primarily due to a lack of experience and time management skills. With almost equal educational results, the cost of teaching one student in a mixed format turned out to be $15-19 \%$ less, and in the distance form - by $79-81 \%$, depending on the course. And this is even taking into account the costs of creating and maintaining online resources. According to the data obtained by the authors of the study, if universities completely switch to the distance format, then with the same tuition costs they will be able to increase the number of students by $15-18 \%$. [1]. At the same time, social and ethical aspects of distance learning, including using the Artificial Intelligence system, telemedicine data and the possibility of developing clinical thinking and practical skills when examining real patients in medical higher educational institutions remain open $[2 ; 3]$.

\section{The importance of organizing the control of students' knowledge in terms of distance learning}

Knowledge control performs the following functions and has didactic principles, tabl. 1.

Table 1

Functions and didactic principles of knowledge control

\begin{tabular}{|l|l|l|l|}
\hline $\begin{array}{c}\text { Knowledge } \\
\text { control } \\
\text { functions }\end{array}$ & $\begin{array}{c}\text { The essence of the } \\
\text { process }\end{array}$ & $\begin{array}{c}\text { Didactic } \\
\text { principles of } \\
\text { knowledge } \\
\text { control }\end{array}$ & \multicolumn{1}{|c|}{$\begin{array}{c}\text { The essence of the } \\
\text { process }\end{array}$} \\
\hline Control & $\begin{array}{l}\text { A form of state } \\
\text { control of knowledge, } \\
\text { the indicators of } \\
\text { which are the only } \\
\text { basis for judging } \\
\text { learning outcomes } \\
\text { and th level of } \\
\text { success rectiveness }\end{array}$ & $\begin{array}{l}\text { Testing and assessment } \\
\text { of students' knowledge } \\
\text { should not only reflect } \\
\text { the level of knowledge } \\
\text { acquisition, but also } \\
\text { always encourage } \\
\text { students and teachers to } \\
\text { achieve new successes } \\
\text { in academic work }\end{array}$ \\
\hline Training & $\begin{array}{l}\text { Ensuring learning } \\
\text { objectives associated } \\
\text { with the pedagogical } \\
\text { skills of the teacher }\end{array}$ & $\begin{array}{l}\text { The pystematic } \\
\text { examination planned } \\
\text { assessment and } \\
\text { knowledge is carried } \\
\text { out on the basis of } \\
\text { interdisciplinary } \\
\text { integration; continuous } \\
\text { control throughout the } \\
\text { educational process in a } \\
\text { consistent manner with } \\
\text { the gradual }\end{array}$ \\
\hline
\end{tabular}




\begin{tabular}{|c|c|c|c|}
\hline & & & $\begin{array}{l}\text { complication of tasks, } \\
\text { content and methods of } \\
\text { teaching }\end{array}$ \\
\hline Educating & $\begin{array}{l}\text { A means of forming } \\
\text { socially valuable } \\
\text { personal qualities and } \\
\text { academic integrity }\end{array}$ & Individuality & $\begin{array}{l}\text { The desire to deeply } \\
\text { and fairly assess the } \\
\text { progress of each } \\
\text { student, not the group as } \\
\text { a whole }\end{array}$ \\
\hline Organizational & $\begin{array}{l}\text { A means of } \\
\text { organizing the } \\
\text { systematic daily work } \\
\text { of students to acquire } \\
\text { knowledge }\end{array}$ & Differentiation & $\begin{array}{l}\text { Is to identify } \\
\text { quantitative and } \\
\text { qualitative differences } \\
\text { in knowledge, skills and } \\
\text { abilities of students and } \\
\text { their evaluation }\end{array}$ \\
\hline Developing & $\begin{array}{l}\text { Promoting the } \\
\text { development of the } \\
\text { student's personality, } \\
\text { the formation of } \\
\text { cognitive abilities and } \\
\text { mastering the } \\
\text { techniques of mental } \\
\text { activity }\end{array}$ & Objectivity & $\begin{array}{l}\text { Correspondence to the } \\
\text { true quality and } \\
\text { quantity of acquired } \\
\text { knowledge, skills and } \\
\text { practical abilities }\end{array}$ \\
\hline Methodical & $\begin{array}{l}\text { A means of } \\
\text { simultaneous } \\
\text { evaluation of methods } \\
\text { of teaching lectures, } \\
\text { seminars and practical } \\
\text { classes }\end{array}$ & $\begin{array}{l}\text { Unity of } \\
\text { requirements }\end{array}$ & $\begin{array}{l}\text { The same system for } \\
\text { assessing the level of } \\
\text { knowledge, skills and } \\
\text { practical skills of all } \\
\text { teachers according to } \\
\text { the developed criteria }\end{array}$ \\
\hline
\end{tabular}

Ensuring the organization of the educational process in distance educational technologies in a higher educational institution includes:

1). An educational portal that contains educational, methodological and organizational and administrative information for students;

2). Equipment that has access to a telecommunications network (Internet, satellite $\mathrm{TV}$, the use of a virtual branch of Artificial Intelligence [2];

3). Computer labs and access to international databases of electronic libraries (for example, Open Access Medicine, provided by McGrawHill Professional);

4). Educational content (with extensive use of telemedicine data, digital files with images and audio data of patient examination (The Web-based Simulation of Patients (Web-SP) project) [4], project method [5], teaching in interdepartmental cooperation and other interactive methods);

5). Multimedia laboratories for creating your own content (local and network);

6). Knowledge control materials that meet international standards (for example, The United States Medical Licensing Examination, USML or IFOM NBME); 
7) Learning Management System (LMS), for example, Moodle or national online education platforms that were recently established in many countries, including China (XuetangX, WEMOOC, and CNMOOC), India (Swayam), and Russia (National Platform of Open Education (OpenEdu);

8). Learning Content Management System (LCMS) [6; 7].

Comprehensive use of communication is one of the main valuable features of the system. The core of the distance learning system is LMS or educational process management system. LMS is usually designed to control and manage the educational process with a large number of students, Fig. 1.

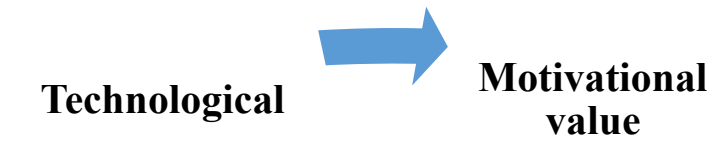

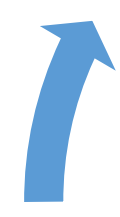

Communication

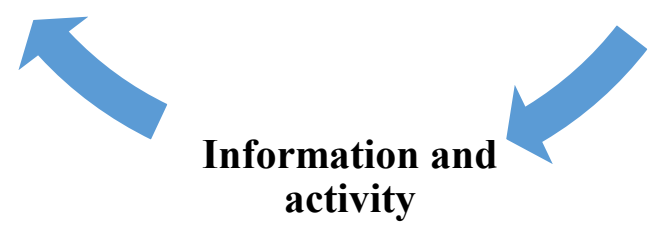

Figure 1. Components of the learning management system [8].

\section{Ensuring Academic Integrity in Distance Learning}

Monitoring activities to ensure the principles of academic integrity in preschool conditions [9]:

1). Implementation of a system of access to educational resources by individual passwords and identifiers;

2). Use of various ciphers and encodings to protect the tests themselves from unauthorized access, by running testing programs strictly using passwords;

2). Organization and implementation of control works on the basis of certified regional training centers with access to the Internet;

3). Use of additional peripheral devices, such as video cameras, individual PIN input devices;

4). Time limit for response;

5). Random mixing of answer options and tasks from an extensive bank;

5). Statistical protection during testing;

6). Evaluation of these protocols using special algorithms for multivariate data analysis, allowing to detect fraud, especially in the case of systematic and massive fraud $[10 ; 11]$. 


\section{Conclusion}

The quality of distance learning depends on the effectiveness of the information technologies used and pedagogical skills. Therefore, the pedagogical, meaningful organization of distance learning (professional staff and associations, innovative and interactive pedagogical technologies) is an integral part of the learning process. It is on these important conceptual pedagogical provisions that the modern formation of distance learning is based.

\section{Conflict of interest}

The authors declare that they have no conflict of interest.

\section{References}

1. Chirikov I, Semenova T, Maloshonok N, et al. Online education platforms scale college STEM instruction with equivalent learning outcomes at lower cost. Science Advances. 2020; 6(15): eaay5324. doi: 10.1126/sciadv.aay5324.

2. Hamet P, Tremblay J. Artificial intelligence in medicine. Metabolism. 2017 Apr;69:36-40. doi: 10.1016/j.metabol.2017.01.011.

3. Sinclair P, Kable A, Levett-Jones T. The effectiveness of internet-based elearning on clinician behavior and patient outcomes: a systematic review protocol. JBI Database System Rev Implement Rep. 2015 Jan;13(1):52-64. doi: 10.11124/jbisrir2015-1919.

4. Zary N, Johnson G, Boberg J, Fors UG. Development, implementation and pilot evaluation of a Web-based Virtual Patient Case Simulation environment-WebSP. BMC Med Educ. 2006 Feb 21;6:10. doi: 10.1186/1472-6920-6-10].

5. Abaturov AE, Nikulina AA. The business game is a process of odeling real practical activities and a means of developing students'creative abilities. Scientific achievements of modern society. Abstracts of the 4th International scientific and practical conference. Cognum Publishing House. Liverpool, United Kingdom. 2019. Pp. 613-625.

6. Ziegenfuss JT Jr. Quality management as a learning system. Am J Med Qual. 2001 May-Jun; 16 (3): 79-80. doi: 10.1177/106286060101600301.

7. Niyazova GZh, Duisenova GA, Imanbekov BA. Features of using LMS Moodle for distance learning. Young Scientist. 2014. 3 (62):991-994. [Article in Russian].

8. Hsiao YT, Liu HY, Hsiao CC. Development of a Novel Interactive Multimedia E-Learning Model to Enhance Clinical Competency Training and Quality of Care among Medical Students. Healthcare (Basel). 2020 Nov 20;8(4):500. doi: 10.3390/healthcare8040500.

9. Абатуров О.С., Нікуліна А.О. Академічна доброчесність - основна інституційна цінність. Академічна доброчесність: виклики сучасності / Збірник наукових есе учасників дистанційного етапу наукового стажування для освітян (Республіка Польща, Варшава, 28.01 - 08.02.2019). Варшава, 2019. 171 с., с 117 123. 
10. MacKinnon K, Marcellus L, Rivers J, Gordon C, Ryan M, Butcher D. Student and educator experiences of maternal-child simulation-based learning: a systematic review of qualitative evidence protocol. JBI Database System Rev Implement Rep. 2015 Jan;13(1):14-26. doi: 10.11124/jbisrir-2015-1694.

11. Razzakov ShI, Narziev UZ, Rakhimov RB. Knowledge control in the distance learning system Young scientist. 2014;7 (66):70-73. [Article in Russian]. 


\title{
ПРИНЦИПИ МУЗИЧНОГО НАВЧАННЯ І ВИХОВАННЯ
}

\author{
Arystova Lyudmila, \\ Ph.D., Associate professor \\ Mykolaiv V.O.Sukhomlynskyi national \\ university of the Department of Music
}

Сучасна методика викладання музичного мистецтва в закладах загальної середньої освіти носить розвиваючий характер музичної діяльності, що забезпечує таке спілкування, при якому провідну роль грає саме мистецтво, а учитель стимулює спільний пошук нестандартних рішень, розкриваючи сенс існування музики в житті кожної людини і суспільства в цілому. Великого значення у цьому процесі набувають принципи (підходи), що пронизують систему уроків музичного мистецтва.

Принцип (від лат. principium - початок основа) - 1) першооснова, те, що $\epsilon$ основою певної сукупності фактів, теорій, науки; 2) внутрішні переконання людини, ті практичні, моральні й теоретичні засади, якими вона керується в житті, в різноманітних сферах діяльності [1, с. 410].

Принцип виховання - це ідеї методологічного рівня, які задають напрями наукових досліджень і розробки виховних методик [2, с. 712]; вихідні положення, які відображають загальні закономірності процесу виховання i визначають вимоги до змісту, організації та методів виховного впливу.

До основних принципів виховання науковці відносять: принцип національної спрямованості; принцип культуровідповідності; принцип гуманізації виховного процесу; принцип цілісності; акмеологічний принцип; принцип суб'єктсуб'єктної взаємодії; принцип особистісної орієнтації; принцип превентивності; принцип технологізації.

Розглянемо їх більш детально.

- Принцип національної спрямованості - принцип, що передбачає виховання любові до рідної землі, свого народу, шанобливе ставлення до його культури; повагу, толерантність тощо [2, с. 712].

- Принцип культуровідповідності - принцип, що передбачає органічний зв'язок з історією та культурою народу, народним мистецтвом (зокрема музичним), забезпечення духовної єдності, наступності та спадкоємності поколінь. Принцип культуровідповідності передбачає таке змістовне наповнення навчального процесу, в результаті якого мистецтво сприймається учнями як культурна цінність.

- Принцип гуманізації виховного процесу - принцип, що передбачає створення умов для формування кращих якостей і здібностей учнів - гуманності, щирості, людяності, доброзичливості, милосердя тощо.

- Принцип цілісності - принцип, що орієнтує на забезпечення цілісності навчально-виховного процесу, передбачає спрямованість змісту, всіх форм i 
методів навчальної роботи на єдину мету - гармонійний, різнобічний i особистісно-художній розвиток учня;

- Акмеологічний принцип - принцип, що орієнтує виховний процес на сприяння вихованцеві у досягненні ним глобальної зрілості на перехідних вікових етапах його розвитку з метою підготовки до тривалого у майбутньому акме-періоду життя;

- Принцип суб'єкт-суб’єктної взаємодії - учасники навчально-виховного процесу виступають рівноправними партнерами у спілкуванні, беруть до уваги точку зору один одного, визнають право на ії відмінність від власної, узгоджують свої позиції [3, с.12];

- Принцип особистісної орієнтації - означає, що загальні закони психічного розвитку проявляються у кожного індивіда своєрідно і неповторно. Педагог культивує у зростаючої особистості почуття самовартісності, впевненості у собі, визнає ії право на вільний розвиток та реалізацію своїх здібностей; надає їй право почуватися індивідуальністю; спрямовує зусилля на розвиток світогляду, самосвідомості, культури потреб, емоційної сприйнятливості, довільної поведінки, базових якостей особистості [2, с. 713].

- Принцип превентивності - полягає в тому, що виховні впливи держави, всіх виховних інститутів, враховуючи інтереси особистості та суспільства, спрямовуються на профілактику негативних проявів поведінки дітей та учнівської молоді, на допомогу їм, на вироблення імунітету до негативних впливів соціального оточення [2, с. 713].

- Принцип технологізації - виховний процес передбачає послідовні науковообгрунтовані дії педагога та відповідно організовані ним дії вихованців, підпорядковані досягненню спеціально спроектованої системи виховних цілей, що узгоджуються з психологічними механізмами розвитку особистості та ведуть до кінцевої мети виховання. Побудований таким чином виховний процес має ознаки проективності, певною мірою гарантує позитивний кінцевий результат [2, c. 713].

Методика музичного виховання як педагогічна наука підпорядковується закономірностям загальної педагогіки i, подібно до будь-якої методики, спирається на дидактичні принципи.

Принципи навчання (дидактичні принципи) - це основоположні ідеї, що пронизують собою всю систему науково-дидактичного знання і субординують його.

У енциклопедії освіти відзначено, що принципи навчання - це основні вихідні вимоги до організації навчального процесу [2, с. 713]. Принципи навчання (дидактичні принципи) визначають зміст, організаційні форми і методи навчальної роботи.

Отже, принципи навчання - це вихідні положення, що визначають діяльність вчителя і характер пізнавальної діяльності учня.

Викладання уроку музичного мистецтва як і будь-якого уроку будується на основі загальнодидактичних принципів, які були виведені з міркувань та концептуального досвіду, сформульовані ще в XVII столітті Я. А. Коменським, чеським педагогом-гуманістом, основоположником педагогіки нової доби, 
засновником класно-урочної системи навчання: принцип науковості, принцип доступності, принцип свідомості та активності, принцип наочності, принцип міцності знань, принцип послідовності та систематичності, принцип зв'язку теорії 3 практикою (зв'язку навчання 3 життям), принцип природовідповідності [2, с. 714].

Я. А. Коменський не зараховував музику до якоїсь особливої, окремої царини виховання, вважав іiі одним із виховних засобів. Він уважав, що музика повинна органічно входити до життя людини. На його думку, музичне виховання не існує само по собі, а має смисл і цінність лише в рамках загального виховання. Найважливішою умовою виховання, у тому числі музичного, Коменський вважав підтримку «радісного настрою душі людини» [4, с. 67].

Беручи до уваги, що мистецтво на відміну від науки спрямовано не на раціональне мислення, а на переживання, яке має на меті не лише пізнання, але й прояв емоційно-ціннісного ставлення, осягнення гармонії, краси, стратегія діяльності вчителя музичного мистецтва змістовною і процесуальними сторонами повинна спиратися також на принципи музичної (мистецької) педагогіки. Ми будемо розглядати ці принципи у якості того початкового положення, що розкривають сутність мети та задач музичного навчання i виховання, характер його змісту та процесу.

Значний внесок у розвиток теорії і методики музичного навчання і виховання та обгрунтування основних принципів музичного навчання і виховання зробили видатні вчені, педагоги-музиканти: Е. Абдуллін, Ю. Алієв, Б. Астаф'єв, О. Апраксина, В. Бєлобородова, Н. Ветлугіна, О. Гембицька, Н. Гродзенська, Л. Горюнова, Д. Кабалевський, Л. Масол, О. Ніколаєва О. Олексюк, Г. Падалка, Г. Рігіна, М. Румер, О. Ростовський, С. Танєєв, Л. Хлєбникова, В. Шацька, Л. Школяр, В. Черкасов, Б. Яворський, А. Яфальян та ін.

Розглянемо основні з них:

- принцип цілісності (Л. Горюнова, Л. Школяр, Л. Масол, Г. Падалка). Цілісність сприйняття це і виразне переінтонування, і сприйняття характеру музики, національної приналежності, стилю композитора. Цілісність сприйняття може виражатися і в настрої, що виникає у дитини, і в характері розкриття життєвого змісту музики: поетичного опису іiі емоційно-образної суті; сценічного, об'ємного бачення розвитку музичного образу. Цей принцип є дуже важливим для уроків музичного мистецтва і проявляється на різних рівнях: у співвідношенні частини і цілого в музиці і педагогічному процесі; від образу до образу; від імпровізаційності до імпровізації; від подиву до міркувань; від насичення художніми враженнями до розширення поля значень і особистісних смислів, далі до навичок і логічного усвідомлення, від усного до письмового, від багатоголосся до унісонного співу; у співвідношенні свідомого і підсвідомого; емоційного і раціонального; в процесі формування духовної культури дитини тощо;

- принцип образності (Д. Кабалевський, Л. Школяр, Л. Масол) пов'язаний $з$ проблемою впізнавання. Дитина народжується і бачить світ у конкретних образах, і тільки пізніше у неї формується здатність абстрактно-логічного мислення. Цілісне, конкретно чуттєве, образне освоєння світу набагато ближче 
дитині, вона намагається узагальнити отриманий досвід саме через образне, чуттєве бачення світу.

- принцип асоціативності (Л. Школяр), асоціативного порівняння (Л. Алєксєєва). Усе пізнається в порівнянні, зіставленні і протиставленні, пошуку ідентичних станів у різних творах полегшує сприйняття мистецтва.

- принцип естетичної та етичної спрямованості навчального матеріалу (Г. Падалка, Е. Абдуллін, С. Ніколаєв) дає можливість дітям, з одного боку, пізнати красу музики, з іншого, усвідомити через її зміст такі поняття як добро, любов, повага, самовідданість, мужність, героїзм тощо.

- принцип єдності емоційного і свідомого в навчанні (Б. Асафьєв, Ю. Алієв, О. Ростовський, Л. Масол, Л. Безбородова, В. Черкасов). Опора на даний принцип дає можливість учителю розвивати в учнів здатність оцінювати музику, а через неї - виховувати їх інтереси та смаки.

- принцип єдності художнього і технічного (Ю. Алієв, Л. Масол, В. Черкасов). Цей принцип грунтується на тому, що художнє, виразне виконання твору вимагає відповідних навичок і умінь. Він спрямований на те, щоб відібраний музичний матеріал був цікавий дітям, носив виховний, навчальний $і$ розвиваючий характер. Цей принцип вважається одним з головних в оволодінні цінностями музичного мистецтва і полягає у відтворенні інтонаційно-образного змісту музичного твору. Сутність його полягає в поєднанні двох компонентів процесу відтворення і виконання музичних творів, передбачених шкільною програмою.

Так, під «художнім» мається на увазі точне відтворення художньо-образного змісту музичного твору за допомогою основних засобів музичної виразності, а саме: мелодії, ритму, темпу, динаміки, тембру, гармонії, штрихів, регістру.

«Технічне» передбачає своєчасне відтворення мелодичної лінії та ритмічного малюнку в означеному темпі відповідно до динаміки й штрихів [5, с. 199-200.];

- принцип зв'язку музичного навчання з життям (Д. Кабалевський, Ю. Алієв, Е. Абдуллін, М. Олексюк). Цей принцип здійснюється передусім у розкритті змісту навчальних тем, у відборі музичного матеріалу та методах їх розкриття.

- принцип вивчення музики як живого мистецтва, опора на закономірності самої музики (Д. Кабалевський). Цей принцип реалізується через побудову програми навчання на трьох китах - пісні, танцю та маршу. Це найбільш поширені сфери музики;

- принцип тематизму (тематична побудова програми) (Д. Кабалевський). Цей принцип передбачає цілеспрямоване та послідовне розкриття жанрових, інтонаційних, стильових особливостей музики, іiі зв'язку з іншими видами мистецтва;

- принцип уведення учнів у світ великого музичного мистецтва (Д. Кабалевський) - класичного, народного, сучасного, що охоплює різноманіття його форм, жанрів і стилів;

- принцип виявлення схожості і різниці (принцип контрасту) на всіх рівнях організації музичного матеріалу і у всіх видах музичної діяльності (Д. Кабалевський, І. Дьяченко); 
- принцип емоційної духовно-енергетичної насиченості уроків музичного мистецтва, спрямованих на досягнення учнями катарсису в процесі сприйняття світових художніх шедеврів і власної художньо-творчої діяльності (Л. Масол);

- принцип особистісної значущості кожної зустрічі з мистецтвом, що підносить іiі до рівня події в житті особистості, явище, що залишає свій відбиток у душі учня.

- принцип громадянської та патріотичної спрямованості регулює відбір музичного матеріалу, який виховує в дітях любов до своєї Батьківщини і народу;

- принцип діалогічності - створення умов для вільного спілкування, включення учня у діалог, що посилює процес пізнання та проживання естетичних цінностей як важливих потреб особистості як суб'єктивно значимих, стійких життєвих орієнтирів. Суттєвим у реалізації принципу є: активізація особистісних естетичних суджень, занурення у дослідницький пошук через гру, творчість, діяльність, що розкривають особистий (власний) естетичний досвід, пробуджують їх естетичні почуття і особистісне ставлення до мистецтва.

Цей перелік принципів музичного навчання та виховання можна продовжити.

\section{Список літератури}

1. Шинкарук В., Бистрицький Є., Булотов М., Ішмуратов А. та ін. Філософський академічний словник. К.: Абрис, 2002. 743 с.

2. Енциклопедія освіти / Акад. пед. наук України; головний ред. В. Г. Кремень. К. : Юрінком Інтер, 2008. 1040 с.

3. Масол Л. Виховний потенціал мистецтва - джерело освітніх інновацій // Мистецтво та освіта. 2001. №1. С.2 - 5.

4. Ростовський О. Я. Теорія і методика музичної освіти: Навч.-метод. посібник. Тернопіль: Навчальна книга - Богдан, 2011. 640 с.

5. Черкасов В. Ф. Теорія і методика музичної освіти: Навч. посібник. Тернопіль: Навчальна книга - Богдан, 2014. 472 с. 


\title{
ASPECTOS METODOLÓGICOS Y EDUCATIVOS DE LA FORMACIÓN DEL FUTURO CIRUJANO ESPECIALIZADO CUALIFICADO
}

\begin{abstract}
Barannyk Serhiy doctor en ciencias médicas, profesor del departamento de cirugía general Academia Médica de Dnipropetrovsk del Ministerio de Salud de Ucrania

Dnipro, Ucrania

Barannyk Constantine candidato de ciencias médicas, asistente del departamento de cirugía №1 Academia Médica de Dnipropetrovsk del Ministerio de Salud de Ucrania Dnipro, Ucrania

\section{Shevtsov Vadim} cirujano Asociación de Ambulancias Clínicas Dnipro Dnipro, Ucrania
\end{abstract}

Una de las tareas más importantes de la educación en la actualidad es crear condiciones favorables para el desarrollo intelectual de los sujetos del proceso educativo, enfocado en el dominio de los medios de adquisición autónoma de conocimientos, la formación de habilidades y habilidades del trabajo educativo. En este sentido, se presta mucha atención a la formación de la cultura general del estudiante moderno, cuyo núcleo es la cultura del trabajo mental. Es por eso que la tarea principal de la educación superior no es solo la organización del proceso de adquisición de conocimientos en diversas disciplinas, sino también la formación de la capacidad de los estudiantes para adquirir nuevos conocimientos de forma independiente. Todo esto requiere buscar formas nuevas y más efectivas de organizar el proceso de aprendizaje, a saber: la creación de tecnología para la formación de una cultura de trabajo intelectual de los estudiantes, teniendo en cuenta el enfoque de recursos, que brinde apoyo al potencial individual y su consideración. para la organización de las acciones mentales (productividad en poco tiempo, manteniendo suficiente vitalidad del cuerpo humano, etc.).

La práctica pedagógica de los institutos antepone diariamente a los profesores la necesidad de la decisión de una serie de las cuestiones metódicas vinculadas a la preparación y la realización de las clases magistrales, el empleo, la redacción de sus desarrollos metódicos. En realidad, estos problemas en las universidades médicas se resuelven con mayor frecuencia sobre la base de las tradiciones metodológicas departamentales, y deben ser resueltos por especialistas de departamentos especializados que no tienen la capacitación suficiente en el campo de la pedagogía, la psicología y los métodos de enseñanza. 
La preparación y realización de clases magistrales, prácticas, seminarios, recopilación de sus desarrollos metódicos en la escuela superior de medicina requiere del docente un cierto sistema de conocimientos, destrezas y habilidades profesionales psicológicos y pedagógicos, metódicos y que cumplan con los requisitos modernos de la actividad pedagógica.

La formación profesional de un trabajador médico tiene como objetivo formar no solo un sistema de conocimientos, habilidades, habilidades, sino también el desarrollo de rasgos específicos de personalidad que respondan a los requisitos de la futura actividad profesional. Es decir, estamos hablando de la formación de una personalidad holística, cuyo desarrollo está orientado profesionalmente. Además, la universidad médica se enfrenta a un grave problema de desarrollo integral del individuo, que no solo tiene una orientación profesional, sino que también implica su participación en el sistema de valores universales y humanistas.

Los procesos de aprendizaje y educación no pueden separarse, están indisolublemente ligados precisamente porque el primero, planteando tareas cada vez más complejas al alumno y sumergiéndolo en el espacio real de la actividad profesional, provoca un impulso activo al desarrollo de los procesos mentales y ciertos rasgos de personalidad. Por tanto, dependiendo del contenido, las formas, los métodos, la complejidad, la intensidad, la dirección, la naturaleza, el proceso de aprendizaje, obtenemos uno u otro resultado en términos de desarrollo personal de acuerdo con sus exigencias modernas de la profesión y la sociedad.

Así, el proceso de aprendizaje en una institución médica superior en términos de la efectividad de su organización, provoca el desarrollo orientado profesionalmente de los procesos mentales del futuro trabajador médico, específicos puramente médicos: percepción y memoria (visual, auditiva, táctil, sensoriomotora, etc.), pensamiento clínico e imaginación, atención profesional, etc. Además, un proceso de aprendizaje construido con éxito estimula objetivamente el desarrollo de un sistema de rasgos de personalidad profesionalmente significativos, tales como: responsabilidad, sociabilidad, moderación, tolerancia, resistencia y movilidad en situaciones profesionales extremas.

El desarrollo del individuo como un todo y su subestructura profesional en la adolescencia es un proceso complejo, porque implica la penetración en sus valores, actitudes, estructuras morales y éticas, motivacionales, que son núcleos, rasgos profundos, bastante estables, enmascarados, protegidos y los que a menudo se manifiestan directamente. Por eso pertenecen a la categoría de difíciles de diagnosticar y de difícil acceso en cuanto a influencia pedagógica.

La máxima saturación del presente con nueva información científica, cuyo dominio es un factor importante en la formación del estudiante de hoy como futuro especialista calificado, requiere la mejora de los métodos tradicionales de enseñanza. El estudio de la cirugía como una de las ramas más importantes de la medicina comienza con los primeros pasos de la educación superior en el estudio de ciencias básicas como anatomía, fisiología normal y patológica, anatomía patológica, histología, bioquímica y más. Ignorar a algunos estudiantes de este período de sus estudios puede conducir a una visión mecanicista de la patogenia y los principios del tratamiento de la patología quirúrgica en los departamentos de cirugía. El dominio de las disciplinas médicas por 
parte de los estudiantes se lleva a cabo en la dirección de la formación profesional de un médico general. Sin embargo, estudiar en un solo plan de estudios no excluye la posibilidad de que cada estudiante elija una futura especialidad médica. Es decir, el trabajo de un maestro de medicina consiste no solo en el trabajo educativo sino también en el educativo, que debe mostrar ciertas personalidades de cada especialidad médica, ayudar al futuro especialista no solo a elegir una especialidad, sino también a determinar su propia idoneidad para la maestría. eso.

La enseñanza de la cirugía también tiene una responsabilidad educativa para los estudiantes que eligen una carrera futura. Este no es solo el primer conocimiento de la disciplina clínica, sino también la colocación de los primeros ladrillos en el proceso de formación de un futuro especialista. El trabajo individual con cada alumno, especialmente con aquellos que quieran conectar su futura especialidad médica con la cirugía, está orientado a la formación profesional del futuro especialista. Cada uno de ellos debe darse cuenta de que el éxito de la actividad profesional del cirujano depende principalmente de su experiencia y conocimiento de su especialidad, los fundamentos de la ciencia médica moderna en general, pero no menos importantes son sus datos naturales, características, idoneidad para las actividades médicas. La sincera simpatía por el paciente, que debe dominar en el período pre y posoperatorio del tratamiento del paciente, pasa a un segundo plano, dando paso a una cuidadosa concentración durante la cirugía. Pero esto es solo externo, porque incluso durante esta etapa, la actividad profesional del cirujano tiene como objetivo restaurar la salud y salvar la vida del paciente.

La deontología es el elemento más importante de la ética médica y cubre una amplia gama de relaciones que proporcionan tanto el régimen de tratamiento como los intereses del paciente. Se está desarrollando en relación con el progreso de la ciencia médica y las condiciones sociales, asociado con las tradiciones e ideas de los mejores representantes de la medicina nacional y mundial. A lo largo de la historia de la medicina, la conducta del médico estuvo regulada por códigos creados por destacados representantes de esta profesión. Las primeras reglas de conducta del médico se establecieron en el juramento hipocrático. Más tarde, el código de ética médica se incorporó en la "Promesa de la facultad", que fue impartida por graduados de facultades de medicina de universidades de la Rusia prerrevolucionaria. Muchas disposiciones de esta solemne promesa médica han conservado su importancia hasta el día de hoy y se han plasmado en el solemne juramento prestado por los actuales graduados de las universidades médicas del país.

Los tiempos cambian, y con ellos las personas, pero el principio moral de la medicina permanece inalterado: el médico no trata la enfermedad, sino el paciente, una persona específica, es decir, se ocupa de la persona humana. Cualquiera que sea la gran importancia de los últimos medios técnicos proporcionados por la ciencia y la tecnología médicas modernas, el médico con su conocimiento, experiencia social, individualidad es crucial. La actividad de un médico no es solo un trabajo duro, duro y noble al mismo tiempo, sino también una prueba moral diaria. La práctica médica de vez en cuando pone al médico en tales situaciones y conflictos, donde muchos sopesan sus cualidades morales, donde hay que pensar en las consecuencias morales de sus propias actividades. 
La actividad profesional de un cirujano por su personalidad va más allá de lo habitual en el sentido cotidiano de la actividad profesional de un médico. La vida requiere no solo la capacidad de trabajar duro para dominar la futura especialidad, sino también tener una movilidad lo suficientemente alta, la capacidad de tolerar diversas tensiones y evitarlas, la capacidad de establecer contactos comerciales y desarrollarlos productivamente. Las razones de esto no son solo la gran cantidad de trabajo realizado (cirugía, tratamiento de heridas postoperatorias, postoperatorio), sino también las especiales condiciones en las que se encuentra el cirujano.

El trabajo de un cirujano, especialmente en el caso de la atención de emergencia, implica la solución constante del problema principal: testificar rápidamente, determinar con precisión el tiempo y el alcance de la cirugía, lo que afecta directamente la salud y la vida del paciente. Es decir, es en estos momentos cuando "la vida del paciente está en manos del cirujano". El sentido de responsabilidad del cirujano crea una carga psicológica extremadamente fuerte. Aumenta significativamente si el cirujano actúa en situaciones imprevistas, toma decisiones atípicas, lo que también requiere la máxima movilización de esfuerzo mental y físico. Realizar el trabajo en condiciones de máxima carga, suprimiendo el calor emocional, que no tiene salida, intentando conseguir el objetivo con el mínimo riesgo para el paciente es la actividad profesional de un cirujano en un puesto especial.

Por tanto, la profesión de cirujano requiere ciertas condiciones para su personalidad, carácter, esfera emocional, así como cualidades morales y éticas.

El trabajo individual con estudiantes que han decidido vincular sus actividades profesionales con la cirugía se realiza mejor involucrándolos en turnos nocturnos en la clínica quirúrgica. Bajo la supervisión de un médico experimentado de guardia o un asistente regular del departamento, los estudiantes tienen la oportunidad no solo de mejorar las habilidades prácticas para examinar a un paciente quirúrgico y familiarizarse con diversas enfermedades quirúrgicas, sino también de participar prácticamente en la resolución de problemas de diagnóstico. elección de tácticas y tratamiento. La participación personal en el proceso tecnológico de brindar atención de emergencia en situaciones de emergencia le permite presentar claramente la responsabilidad profesional del cirujano por los resultados de sus propias acciones, para la salud y la vida del paciente. La formación adicional de los futuros médicos en grupos de investigación de estudiantes estimula el interés activo en los datos científicos, desarrolla el pensamiento clínico e inculca habilidades para hablar en público, que no todos los profesionales jóvenes poseen. Cultivar el respeto por la futura profesión debería desarrollar en el futuro especialista un deseo constante de superación personal, porque la profesión médica implica una formación constante durante toda la edad activa de trabajar. Sin embargo, cabe señalar que la relación entre el cirujano y el paciente es tan compleja y diversa que es imposible recomendar al médico reglas de conducta para cada caso. Los estudiantes deben ser conscientes de que, en una situación particular, el cirujano debe elegir un enfoque del paciente, que está dictado por las características individuales de este último. Lo principal es inculcar en los alumnos sentido de responsabilidad, humanidad, sinceridad, atención en relación con cada paciente y, por supuesto, la capacidad de reconocer correctamente la enfermedad y determinar correctamente el estado psicoemocional del paciente. Por tanto, es 
recomendable realizar clases especiales sobre psicología del paciente. Desafortunadamente, las horas de práctica no incluyen estos temas en el programa de enseñanza de cirugía. Sin embargo, la formación adicional de los futuros médicos en los círculos de investigación de estudiantes estimula no solo el interés activo por los datos científicos, sino que también desarrolla el pensamiento clínico e inculca habilidades deontológicas de relación con los pacientes, que se consolidan durante los turnos nocturnos en la clínica y las prácticas de verano.

\section{Lista de referencias}

1. Бакшаева Н.А. Психология мотивации 1. студентов [Текст]: Учебное пособие / Н.А. Бакшаева, А.А.Вербицкий. М.:Логос, 2007. 184c.

2. Баранник С.І., Стусь В.П., Трофімов М.В., Схалов В.В., Бараннік К.С. Деонтологічні та індивідуально-психологічні аспекти підготовки майбутніх лікарів хірургічних спеціальностей. Медичний форум. 2017. №11(11). С. 5-8.

3. Barannik S. I., Yechalov V.V., Barannik K.S., Lyachenko P.V. Evolutionary aspects of "click hole" in medicine students and their integration in higher education. "MODERN VIEW OF SCIENCE AND PRACTICE » II International Scientific-Practical Conference (08.06.2019 London, Great Britain). Centre of Scientific and Practical Studies. London, 2019. 62 pages. P. 38-45.

4. Ехалов В.В., Самойленко А.В., Романюта И.А., Баранник С.И., Мизякина Е.В. Проблема культуры речи в современном высшем медицинском образовании. Український журнал медищини, біології та спорту. 2020. T.5. №3(25). C. 392-397.

5. Стусь В.П., Єхалов В.В., Моісеєнко М.М., Романюта І.А., Баранник С.І. Певні якості мислення у лікарів-інтернів різних фахів. Урологія. 2020. Том 24. №2 (93). C. 180-185.

6. Трофімов М.В., Кришень В.П., Задорожний В.В., Баранник С.І., Мунтян С.О., Гузенко Б.В., Панікова Т.М., Лященко П.В., Нор Н.М., Слєсаренко К.С. Сучасні питання викладання загальної хірургії. Медичні перспективи. 2018. T. XXIII, №4, ч. 1. C. 104-106.

7. Barannyk S., Molchanov R., Barannyk C. Fondements methodologiques de motivation pour le choix d'une specialite medicale et education deontologique d'un future specialist. The II International Science Conference on Science and practical Technologies, January 26 - 29, 2021, Luxembourg, Luxembourg. 557 p. P. 337342. 


\section{СПЕЦИФІКА ПРОВЕДЕННЯ ІНДИВІДУАЛЬНИХ МУЗИЧНИХ ЗАНЯТЬ У ЗВО В ДИСТАНЦЙНОМУ РЕЖИМІ}

\section{Dorosh Tetiana}

Ph.D. of Sciences in Public Administration,

Professor of Piano Municipal establishment «Kharkiv Humanitarian-Pedagogical Academy»

Lebedeva Vlada

Student of Municipal establishment «Kharkiv Humanitarian-Pedagogical Academy»

У зв'язку з інтенсивним розвитком нових Інтернет технологій актуальними постають питання щодо модернізації освітнього процесу, пошуку нових форм i методів організації та проведення індивідуальних музичних занять за допомогою електронних мереж або інших засобів телекомунікації. Ці заняття мають бути такої ж високої якості, як й аудиторні (off-line), сприяти вдосконаленню набутих раніше знань, умінь та навичок у творчій діяльності, спиратися на той самий музичний та літературний матеріали, що допоможуть розв'язати проблемні питання. Тому актуальним $є$ дослідження специфіки проведення індивідуальних музичних занять у закладах вищої освіти (ЗВО) у дистанційному режимі.

Методологічна основа дистанційного навчання висвітлена в працях 3. Дубового, В. Бикова, В. Кухаренка та інших, які розглядають цей процес як сукупність сучасних технологій, де інформація подається в інтерактивному режимі за допомогою застосування інформаційно-комунікаційних технологій (IКТ). Водночас, ми можемо констатувати про відсутність наукових досліджень, присвячених специфіки проведення саме індивідуальних музичних занять у ЗВО в дистанційному режимі (у нашій праці - заняття зі спеціального музичного інструмента, фортепіано).

Особливості проведення дистанційних занять у ЗВО чітко визначені нормативно-правовими актами України, зокрема в наказі «Про затвердження Положення про дистанційне навчання»: наказ МОН від 25.04.2015 p. № z0703466 (зі змінами, внесеними згідно з наказом МОН України від 21.08.2015 р. № z0923-15) [6]. Цей документ розкриває основні засади, особливості організації навчального (навчально-виховного) процесу 3 використанням технологій дистанційного навчання (ДН). Варто зазначити, що дистанційна освіта трактується як індивідуалізований процес набуття знань, умінь, навичок i способів пізнавальної діяльності людини, який відбувається у взаємодії віддалених один від одного учасників освітнього процесу в спеціалізованому середовищі [4]. Це середовище характеризується тим, що суб'єкти освітнього процесу знаходяться на відстані між собою в просторі й (або) у часі, але в той же 
час здобувачі мають нагоду підтримувати діалог за допомогою засобів телекомунікації [5, с. 173].

Автори посібника «Технологія створення дистанційного курсу» виділяють зворотний зв' язок між викладачем і здобувачем освіти як важливий компонент дистанційного освітнього процесу, що дозволяє враховувати результати аналізу навчальної діяльності, отримані на підставі даних моніторингу процесу навчання, впливати на їхнє покращення й відповідно з цим оперативно керувати діяльністю здобувачів освіти та вдосконалювати іiі [2, с. 221].

3. Дубовий розглядає дистанційне навчання як оптимальний спосіб втілення в життя гасла «освіта впродовж життя». Ми погоджуємось із його думкою про те, що взаємодія суб'єктів у дистанційному форматі забезпечує безперервність та інтерактивність освітнього процесу $[3$, с. 68, 76].

Безперервність відбувається зі здобувачами ВО під час проведення індивідуальних музичних занять як в off-line, так i в on-line режимах. Нині широко застосовуються різноманітні платформи, програми для дистанційного процесу, що підвищують мотивацію навчальної діяльності здобувачів освіти та рівень засвоєння знань, створюють умови для взаємного спілкування суб'єктів. Слід указати, що на індивідуальних музичних заняттях взаємодія здійснюється синхронним засобом комунікації, де обмін інформацією проходить у реальному часі й передбачає одночасну участь викладача та здобувача освітнього процесу. Це й спільна робота над музичними творами, активний обмін думками, сумісне обговорення проблемних питань тощо в режимі реального часу. Обговорення мотивує майбутнього фахівця на пошук нової інформації для відповіді на нові запитання, що виникають.

Тривалість індивідуальних музичних занять зі спеціального фортепіано - 40 хвилин. Оскільки вони проводяться у форматі реального часу, то альтернативним варіантом зв'язку віч-на-віч є програма Google Duo, яка швидко приймає відеодзвінок, передає зображення та звук (без затримки та відлуння). Для цього має бути якісний Internet-зв'язок по радіоканалу або мобільний чи супутниковий Internet.

Формат індивідуальних музичних занять зі спеціального фортепіано в дистанційному режимі дозволяє учасникам освітнього процесу:

- обирати зручний час для творчої співпраці, ураховуючи інтереси всіх учасників;

- навчатися й отримувати послуги вдома, не відвідуючи 3ВО;

- підтримувати комунікативну взаємодію зі всіма здобувачами освіти;

- швидко отримувати зворотний зв’язок із викладачем;

- приділяти більше часу самостійній роботі над музичними творами, відпрацьовувати технічні труднощі у виконанні інструментальних п'єс, розширювати музичний світогляд (знайомитись із творчістю професійних виконавців на YouTube-каналі, аналізувати, порівнювати їх інструментальну гру зі своєю);

- залучатися до розмаїтих дистанційних заходів.

Розглянемо як проходить індивідуальне музичне заняття зі спеціального фортепіано в дистанційному режимі, де акцентується увага на виразному 
відтворенні художнього образу в творах дитячого репертуару. Зв'язок відбувається через програму Google Duo, що дає можливість не тільки здійснювати голосове спілкування, а й бачити один одного в реальному часі. Застосування цієї програми в дистанційному режимі пожвавлює освітній процес, робить його зручним під час комунікації. Мобільний телефон розташовується таким чином, щоб видно було руки на фортепіанній клавіатурі виконавця, його обличчя (обирається зручний куточок екрану), правильна посадка за музичним інструментом. Репертуар складається із маршів (І. Кишка, О. Тілічеєвої), гопака (Ю. Щуровського), українських народних пісень «Галя по садочку ходила» та «Женчичок-бренчичок». Обов'язковим музичним матеріалом також є «Пісня Лисички» 3 опери «Коза-Дереза» (М. Лисенка). У маршах відпрацьовується чіткий пунктирний ритм, динамічні нюанси, бадьорий, піднесений настрій. Щоб уникнути прискорення або уповільнення темпу, виконавець грає партію мелодії, дивлячись в екран на викладача, який диригує в такт музичного тексту, посилюючи жестом сильну долю (уявляти крокування).

В українському народному танці «Гопак» за допомогою характерних штрихів (staccato та non legato) імітуються карколомні стрибки, підскоки, присядки, швидкі обертання тощо. Хлопками в долоні демонструються енергійні танцювальні рухи, а далі переноситься ця спритність на клавіатуру, у звуках відтворюється темперамент козацького танцю.

Ураховуючи жанр творів - українських народних пісень, слід дотримуватись темпу виконання, виконавської культури, якості звуковідтворення. У процесі дистанційних занять обговорюється художній образ, здійснюються пошуки відповідної динаміки, артикуляції, звертається увага на ритмічну будову музичних фраз (музичний матеріал супроводжується словесним текстом). Власне такого роду опрацювання українських народних пісень $\epsilon$ найбільш цінним і потрібним у подальшій професійній діяльності майбутніх фахівців музичного мистецтва, що допомагає найбільш реальному способу виконання, виходячи передусім із композиційних особливостей твору. Окремої уваги заслуговує питання дихання в піснях. У цьому контексті слід дотримуватись практичних рекомендацій викладача:

- знати в нотному тексті місця дихання співака;

- зазначити в музичному матеріалі моменти дихання спеціальною позначкою над нотним станом - V;

- уявити дитячу аудиторію, кивком голови показувати моменти дихання;

- зберігати цільність слова в сольному виконанні на відміну від ланцюгового дихання в хорі (не допускати словорозрив);

- дотримуватись пауз відповідної тривалості (iї величину не дозволяється скорочувати чи подовжувати);

- відчувати чистоту інтонування (не відхилятися від початкового звуковисотного рівня);

- знати гармонічний аналіз пісень, щоб бути спроможним здійснити транспонування в зручній для дітей тональності.

Такий підхід, на нашу думку, допоможе виконавцеві бути послідовним у своїй роботі, дотримуватись правил відтворення пісенних творів, вчасно уникати 
помилки й неточності, нарешті - відпрацювати власний стиль виконання народних пісень, що $є$ певним показником зрілої майстерності. Такий же принцип варто застосовувати у виконанні «Пісня Лисички» 3 опери «КозаДереза» (М. Лисенка), де зберігаються самобутня краса й мелодійна виразність народних пісень. Весела грайлива пісенька Лисички, яка виступає в опері як позитивний персонаж, відтворюється плавною, гнучкою мелодичною лінією. За допомогою засобів музичної виразності вимальовується чепурна, кокетлива, симпатична хазяйка, яка «не сидить без діла». Опера розрахована на дітей дошкільного та молодшого шкільного віку, усі популярні народні мелодії оброблені в зручному діапазоні, що відповідають вокальним можливостям виконавців [1, с. 21]. Саме на вмінні яскраво образно й художньо виправдано інтерпретувати музичні твори акцентується увага під час проведення індивідуальних музичних занять, що відбуваються в дистанційному режимі.

Підсумовуючи вищевикладене, ми можемо констатувати, що дистанційний процес посилює роль тих, хто навчається, і відповідає сучасним освітнім стандартам як за змістом, так і за організаційними формами та методами навчання. Застосування нових програм і платформ у дистанційній освіті під час проведення індивідуальних музичних занять $\epsilon$ перспективним напрямом i потребує подальшого, грунтовного дослідження.

\section{Список використаних джерел:}

1. Андрієвська Н. Дитячі опери М. В. Лисенка. Київ, 1962. 82 с.

2. Биков В. Ю., Кухаренко В. М., Сиротенко Н. Г., Рибалко О. В., Богачков Ю. М. Технологія створення дистанційного курсу : навч. посіб. ; за заг. ред. В. Ю. Бикова та В. М. Кухаренка. Київ : Міленіум, 2008. 324 с.

3. Дубовий 3. С. Формування самостійності майбутніх учителів музики у процесі дистанційного навчання : дис. канд. пед. наук: 13.00.02. Кривий Ріг, 2019. $260 \mathrm{c}$.

4. Концепція розвитку дистанційної освіти в Україні (затверджено $\begin{array}{lllllll}\text { Постановою } & \mathrm{MOH} & \text { України } & \text { В.Г. Кременем } 20 & \text { грудня } 2000 & \text { р.) }\end{array}$ http://www.osvita.org.ua/distance/pravo/00.html

5. Кудрявцева С. П., Колос В. В. Міжнародна інформація : навч. посібник. Київ : Видавничий Дім «Слово», 2005. 400 с.

6. Наказ Міністерства освіти і науки України «Про затвердження положення про дистанційне навчання». URL : https://zakon.rada.gov.ua/laws/show/z0703-13\#n18. № 466 від 25.04.2013 (дата звернення : 04.01.2021). 


\section{USAGE OF EDUCATIONAL ONLINE PLATFORMS FOR FORMING PROFESSIONAL LEXICAL SKILLS AT ECONOMIC UNIVERSITY}

\section{Gataullina Zarina}

Student of Faculty of Economics, Management and Entrepreneurship Karaganda Economic University of Kazpotrebsoyuz

Makhayeva Assel

Master of Pedagogics

Karaganda Economic University of Kazpotrebsoyuz

The globalization of the economy and science leads to the fact that the speed and ease of transmitting the flow of information occupies a key place in the acquisition of competitiveness, so the knowledge of a foreign language is one of the main advantages of a highly qualified specialist in the labor market. In this context, the development of a foreign language as a means of professional communication takes a priority position in the training of specialists in the economical and business spheres.

To achieve success in professional communication, a qualified specialist in the economical field must possess the necessary amount of specialized terminology.

In this context, the most important task for university teachers is to form a lexical stock of students consisting of economic terms and special vocabulary [1]. However, when performing this task, there is a problem of mastering vocabulary by students, since unlike learning grammar, which is based on rules, learning vocabulary means memorizing as many lexical units as possible, which is directly related to the memory and cognitive abilities of the student. In order to understand how a person remembers information, you should refer to the following classification of types of memory: shortterm, working, and long-term memory.

Short-term memory allows you to remember a limited number of words for a few seconds, for example, after repeating a word after the teacher. Working memory allows you to memorize lexical units for a sufficient time to perform various kinds of manipulations on them, as well as to control the information obtained from short-term memory and extract information from long-term memory. Thus, working memory allows you to process information from short-term to long-term memory. Working memory performance is also limited to 20 seconds [4]. Long-term memory works as storage, its performance is not limited, and the content is stored for a large amount of time. From all of the above, it can be concluded that to increase the effectiveness of learning terminology, it is necessary to ensure that students transfer the information received from short-term and working memory used in the classroom to long-term memory. 
One of the key factors affecting the transfer of information to long-term memory is repetition. That is, in order to remember a certain lexical unit, you must either constantly meet it in various written and oral texts, or periodically return to it. In modern textbooks, special attention is paid to this, there is a constant recycling of the already studied material, but all this concerns the basic and general vocabulary. Several exercises after the text are given to the development of highly specialized terminology, so that students use only two types of memory: short-term and working. This allows them to actively work in the classroom and perform exercises, but due to the lack of repetition, the material presented in the training manuals is not sufficient for the information received to pass into long-term memory. As a result, students are overloaded with new vocabulary that they do not have time to learn. As a result, with a large amount of work, the effectiveness of such training is low.

One of the tools for solving the problem that has arisen can serve as online educational platforms. In our practice, to implement a lexical approach to learning, we tested the Quizlet platform, which is an Internet site or mobile application. After each lesson, as a homework assignment, students enter new lexical units in special training modules, then they work on these modules, which leads to an increase in the efficiency of mastering terminology.

Next, we propose to trace how certain tasks of the above-mentioned educational platform use the principles of information transition from short-term to long-term memory, described by Scott Thornbury [4]:

1. The first stage is entering lexical units into the module. Thus, students create their own electronic dictionary. At this stage, depending on the level of language proficiency, students can choose a translation of the term, its explanation in the language being studied, or a synonym word. It is also possible to listen to any word, phrase or sentence.

2. The second stage, memorization, is directly related to the principles of repetition, tempo and interval. According to the principle of repetition, the more often a certain term occurs, the more likely it is to pass into long-term memory. An important role is played by the interval principle, which assumes that you need to work on vocabulary at certain intervals in time. It is also necessary to take into account the individual rate of information acquisition of each student, since a certain category of students can achieve better results if they are given more time. Taking into account these principles, educational platforms, including Quizlet, help to build an individual trajectory of work on expanding vocabulary. After the new terms have been added to the modules, students begin to actively work on these lexical units. At the stage of memorization, it is suggested to choose or write a limited number of words that are repeated with a certain frequency. The number of repetitions depends on the correctness of the task, if the user makes mistakes, the number of tasks for the specified lexical units increases. The stage of memorization is completed only when the student stops making mistakes. Therefore, this task is correlated with all the principles described above, since it forces you to repeat the term several times at a certain interval. Also, depending on the 
individual pace of mastering the material, students are invited to perform additional tasks. It should be noted that it is necessary to periodically return to this stage to repeat the topics already covered. As the practice of working with this platform shows, this stage is the main one and helps to significantly expand the passive vocabulary.

3. The third stage, working with cards, is related to the extraction principle. In order to ensure better memorization of a word, it is necessary to provide the learner with the opportunity to extract its meaning from the context in a sentence or phrase. At this stage, an entire sentence is entered in the field for the introduction of the "term", that is, an example of the use of the lexical unit that should be worked out. In the "definition" field, enter the translation of the sentence, the translation of the term or the definition of the term in the language being studied. Thus, when viewing the cards, the user is forced to remember the word independently in a certain context, and then check himself by turning the card over. You can increase the effectiveness of this task by exchanging modules between students of the same group. As a result of such activities, students create their own database of virtual cards with examples of the use of terms in various contexts.

4. The fourth stage, writing, expands and develops the techniques laid down in the third stage. It involves further work with suggestions made for working with cards, and is directly related to the principle of use. In order to remember a word for a long time, you need to enter it into oral or written speech. This is not difficult to do if we are talking about basic vocabulary. However, the introduction of even written terms causes difficulties for students of non-linguistic universities. In this regard, students are invited to write previously compiled sentences using the necessary term. It is possible to build several variations of this task: complete translation of sentences from Russian to English, filling in the gap with the necessary term in the sentence in the language being studied, selection of synonyms and selection of the term for definition. We believe that translation is the most effective variation for memorizing terminology, as it requires the greatest cognitive activity from the learner. As in the previous sections, tasks are offered until they are completed correctly. To complicate the task, we recommend organizing an exchange of modules between students to increase the number of repetitions of specific terms.

5. The fifth and final stage, testing, is related to the principle of cognitive depth. According to this principle, lexical units should not only be repeated and used, but they also need to be carried out cognitive work. To improve memorization, you should make decisions about the use of terms, the more complex these decisions are, the more likely it is that the word will pass into long-term memory. Simple studying does not produce effective results. During testing, the program offers various options for checking the studied terms and sentences compiled with them. The test is not limited to just choosing an answer, the user is also required to write a word or a whole sentence. Thus, the student has to think about the use of the word and its correct spelling, which leads to increased concentration and, as a result, to better memorization. 
In this approach, the responsibility for expanding the professional vocabulary is shared between the student and the teacher. The first is required to enter new terms in the database, create modules and perform the above tasks, which allows the student to control the process and adjust it to their needs and abilities. Also, visualization of the process of mastering new lexical units, which is represented by diagrams and the percentage of mastered lexical units to undeveloped ones, helps to see your progress, which increases motivation, both for further use of the platform and for learning the language in general. This visualization allows you to identify problems and make a plan to solve them. Thus, there is a departure from mindless memorization for the purpose of writing dictation, in which, according to the Forgetting Curve of Hermann Ebbinghaus, no more than 20 percent of the learned terms remain in long-term memory [3]. Students move on to meaningful self-education. At the same time, the teacher faces an equally important task - to organize the process of working with this educational platform, since in order to achieve high results, it is necessary to constantly monitor the implementation of all exercises, the creation of modules and the exchange of modules between students

This educational platform was tested with first-year students of the Karaganda Economic University of Kazpotrebsoyuz in the specialities of "Information Systems", "Economics", "Law", "Ecology", "Accounting and Audit" with three hours of academic classes per week. In the circumstances, the work as homework have significantly increased the performance of students and helped to implement a lexical approach to teaching in which the emphasis on maximum expansion of vocabulary that is needed to work with specialized texts. In addition to improving quality indicators, the introduction of modern educational information technologies can increase the motivation of students and form their skills of independent building of the learning process [2].

\section{References}

1. Dzhandalieva, E. K. Teaching special vocabulary in English classes at university / E. K. Dzhandalieva / / Almanac of Modern Science and Education. - 2013. - №. 6. p. 51-53.

2. Panyushkin, O. A. Practice the use of new technologies for enrichment of vocabulary in learning foreign languages / O. A. Panyushkin // Historical and socioeducational thought. - 2014. - №. 3. - p. 199-235.

3. Rubinstein, S. L. Fundamentals of general psychology / S. L. Rubinstein. - St. Petersburg: Piter, 2002. -720 p.

4. Thornbury, S. How to teach vocabulary / S. Thornberry. - Harlow: Longman, 2002 - - $185 \mathrm{p}$. 


\title{
CONVERGENCE ONLINE 15 TECHNIQUES FOR BRINGING TOGETHER STUDENTS IN ONLINE LEARNING
}

\author{
Heronovych Marta \\ Master of Philology \\ Foreign Language Teacer \\ Lviv Secondary School№30
}

\section{Introduction}

Online learning has invaded our lives and we must realize that it will remain with us even after the end of quarantine. So, the best option is to acknowledge all his challenges and make the most of all opportunities.

Here are some practical tips if you decide to bring the student team together through online learning.

\section{Technique 1}

"Tik-Tok Group"

Objective: Rapprochement of the student body in the conditions of online learning, assistance formation of friendly relations in the team, the importance of performing a common task, understanding the uniqueness of each student.

Audience: students of grades 4-11

Preparation time: 30 minutes.

Timing of: 20 minutes

Process: Stage I. Find interesting and fun videos to play.

Stage II. Discuss in a group or pair about the possibility of creating a video with your own audio track.

Stage III. Explaining tasks to students.

Stage IV. Execution of tasks.

Stage V. Summing up. Reflection. Watch videos.

\section{Technique 2}

"Everybody Dance"

Objective: Rapprochement of the student team, the formation of friendly relations in the team, obtaining a common result (video of the dance), rehabilitation of students: morning meeting (charging), a minute of physical education during the lessons.

Audience: students of grades 4-11

Preparation time: 10 minutes (pick up music)

Timing of: 20 minutes

Process: There is a moving song (presenter: teacher or student independently selects a fun song, music). The presenter introduces the conditions of the game: demonstrates the movements and says when and what movements to do (movements reflect the meaning of the song, for example: large - hands describe the large radius 
dimensions, Sun - described by hands circle, the word "Good" - hand strokes his head and so on). So everyone is dancing, looking at the presenter (online). This technique will help to bring students together in online learning.

\section{Technique 3}

"Jamboard - magic or practical online facilitation tools"

Objective: Development of creativity and visual thinking, establishing friendly relations between students; promoting team creativity and expression of each,

supporting each other in co-creation, creating an emotionally comfortable space of interaction.

Audience: students of grades 1-11

Preparation time: 15 minutes, if you need to create your own template

Timing of: up to 30 minutes (if necessary, depending on age).

Process: The technique is based on working with known tools for the development of visual thinking and imagination - druds.

You can take any doodle. I took clouds in the exercise. The participants are divided into several groups of 4-5 people.

Task: to agree and finish painting together the image of which this cloud is a part. The image can be rotated, but the whole must be clear and recognizable.

It is fun, with enthusiasm. We discuss and support the work of teams. We find additional images.

\section{Technique 4}

"Secret Wizard"

Objective: To establish warm informal relations between team members, rapprochement of even familiar team members, expression of empathy, trust and

mutual support.

Audience: students of grades 7-11.

Preparation time:

Timing of: 1 week.

Process: By secret draw, the children in the class are divided into pairs so that each student has a ward for whom he or she will become a "secret wizard".

Next in the class chat we agree on the rules of "POSSIBLE" and "NOT POSSIBLE".

For the next seven days, the children secretly try to work miracles for each other, and a joint online meeting at the end of the week summarizes the game.

It is interesting to ask about the impressions of those who felt and who did not feel their "secret magician", to establish whether this student really played his role, to find out whether the couples matched, to mark online reactions of real "secret magicians" who showed imagination and gave unexpected joy and support to classmates. It is important to give children understand how you can give joy and happiness to others even without being around,realize your feelings when you help others, or understand what other people need for their own emotional comfort. 


\section{Technique 5}

\section{"History for the mood"}

Objective: To establish a positive atmosphere in the student body; setting up students to work in a team, establishing friendly relations; promoting understanding

the character of each and each of the children through a warm story in a storytelling format.

Audience: students of grades 5-11

Preparation time: 20 minutes

Timing of: 10-12 minutes

Process: Before conducting the lesson in the format of an online conference, the teacher asks the students to prepare one flash card (image) that relates to a specific topic.

The map can consist of two parts: on the title page - the image, on the reverse side the teacher can offer to make a sentence at home, choose a quote, aphorism,

choose keywords on the topic of the lesson. During the online conference, the teacher begins the story with a sentence, demonstrating his pre-prepared first image, and

gives the floor to any of the students to make the next sentence of the story,

showing your image. Thus, for 6-7 minutes children make a storytelling using prepared images. You can pre-select a future story scenario, for example, by combining time, place and participants.

Note: to perform this technique online on the Zoom platform, the teacher offers to send the image to the chat conference and, using the raised hand function, join the story. As soon as the student joins the story, the teacher exhibits the image sent by him.

Student actions: 1 . Choose an image, perform a certain task on it.

2. Send the image to the chat conference.

Offer your sentence and image to the plot of the story.

Teacher's actions: 1. Prepare the first image of the story.

2. Demonstrate a scheme for constructing a story.

3. Choose with students the future plot of the story.

4. Demonstrate the first image and compose the first sentence of the story.

5. Choosing the following image, together with students to make a story. You can compose a future story script by combining individual elements from five columns. For example, a funny story about a literary hero, a dentist who is looking for treasures in a zoo.

Preliminarily, children need to be introduced to the structure of the storytelling itself. Schematics are attached in a text document.

\section{Technique 6}

"The Adventures of Moles"

Objective: To establish teamwork; formation of responsibility for the team, the participation of each is important; rapprochement of all participants; logical thinking; ability to negotiate; repeat the rules learned during distance learning. 
Audience: students of grades 4-6

Preparation time: 20 minutes

Timing of: 30 minutes

Process: Before starting the game on the field, the leader places the obstacles and closes them.

Players are divided into teams. The task of the game is to get the carrot first. The team can make a move if it correctly answers the questions on spelling and morphology.

One correct answer from the team is enough. You can only move 1 cell to the right, left, up, or down. It is not allowed to move diagonally. The mole game chip can go in both forward and reverse order.

\section{Technique 7}

\section{Shared drawing "Our mood"}

Objective: To create a favorable atmosphere for learning; emotional rapprochement of students in the class; development of empathy to each other.

Audience: students of grades 5-9 .

Preparation time: 30 minutes.

Timing of: 15 minutes.

Process: During the lesson in the format of an online conference (using ZOOM), the teacher offers to create a joint drawing of the class on the topic "My mood today". Students take turns drawing a certain element of the picture on the board. At the same time everyone the next "artist" should focus on what has already been painted by his predecessor. The participation of all students in the class is mandatory. After the drawing, a joint discussion (2-3 minutes): what is the mood among the children today, do everyone like the created drawing, what would you like to add or change? Each time you can determine which elements are allowed to be added to the common image whether it is only geometric figures, or only lines, or free imagination, and so on.

\section{Technique 8}

"The Art of Memorizing Poetry"

Objective: To use the method of eidetics, which awakens the active mental activity of the child interested in the learning process, as well as provide the student with a "tool" for processing information, memorizing it and instantly remembering at the right time by visualization in pictures.

Audience: Students of grades 5-11.

Preparation time: 30 minutes.

Timing of: 15 minutes (Time is adjusted depending on the complexity of poetry)

Process: The technique of associative perception and reproduction in pictures allows students to easily learn program poems. I used this technique successfully during

distance learning in Zoom and Viber video chat (a group of up to 20 participants).

\section{Technique 9}

"Cooking" 
Objective: Cooking together can be an unforgettable pastime for all participants, which will promote the development of creative potential and imagination of students. As children learn about different foods and ingredients, they will develop an interest in trying them all, a receptivity to new tastes, cooking skills and healthy eating habits.

Audience: 5-9 grades

Preparation time: 1 hour

Timing of: $1-1.5$ hours

Process: It is best to choose a relatively easy and quick recipe so that children do not lose interest halfway. By explaining what each member of your cooking team will do, you will avoid confusion and trouble in the web kitchen, especially if children are involved in the process. If they are too small, advise them to start with something simple, such as entrusting them with more complex tasks as they grow older. By turning work in the web kitchen into a pleasant experience for children, you will help them develop healthy eating habits and lay the foundation for lifelong cooking skills. And each student learns the preferences and tastes of their classmates. This, of course, will help bring them closer to remote conditions.

\section{Technique 10}

"Hat of wishes"

Objective: To establish friendly relations in the team.

Audience: students of 5-9 grades.

Preparation time: 1 hour

Timing: 1-1.5 hours

Process: the course of the exercise: the teacher in an online meeting shows the children a hat with papers on which the names of all children in the class are written. After that, he names the children's names and takes a pair from their hats at random. This is how pairs are formed. If children odd number, the child can unite with the teacher. After that, the children are given a task: to make a greeting card for their partner (for example, before Christmas). At the next meeting, students demonstrate their work and read their wishes.

\section{Technique 11}

"Steps forward"

Objective: To establish friendly relations in a class family. To teach to see the best in yourself and others, to teach students to make surprises, understanding personal space, managing emotions, understanding the mood of others. Ability to make decisions and take responsibility for their actions.

Audience:students of ages $6+99$

Preparation time: 10 minutes

Timing of: From 1 week to the school quarter or school year

Process: You can tell the children the story described in Kevin Alan Milne's book - "Steps forward" treasure is always where your heart is ... We both want to be winners -probably that's why we quarrel so often. But I want to fight you not verbally, but in a different way. All these years we have been mentally counting each other's mistakes. I 
want us to start another account. I want us to monitor the manifestations of a good attitude towards each other -how we love and respect each other. We agreed to give each other points for good deeds and kind words towards the other person. At the end of each week, after summing up, as a reward the winner chooses.... (what movie will we watch, what song will we sing next week).

\section{Technique 12}

"We study not for school, but for life"

Objective: Setting students to work in a team; establishing friendly relations, mutual understanding, mutual support during the distance learning; testing of knowledge and skills during online training.

Audience: students of 6 th grade.

Preparation time: 30 minutes

Timing of: 45 minutes

Process: Before the lesson in the online conference, the teacher offers to fill in the slides of the joint Google presentation. On each slide, the children had to show how their learning process takes place at home and how they relax. Also, make a brief conclusion and express your impressions of this form of learning. At the end of the lesson, the teacher summarizes results based on children's responses. None of the types of distance learning will replace live communication. This exercise allows children to appreciate their communication at school with classmates, peers, and feel the lack of live communication with the teacher.

\section{Technique 13}

"Our common Padlet board"

Objective: Rapprochement of the student body in the conditions of online learning, assistance formation of friendly relations in the team, the importance of performing a common task, understanding the uniqueness of each student.

Audience: students aged $6-18$

Preparation time: 10 minutes - creating a board, 30 minutes - explaining to students

Timing of: 1 week

Process: Padlet is a virtual wall to which you can attach photos, files, links to pages. They work together on this board. Therefore, the one who created it sends it notifications to other project participants enter their email addresses, and gives them the right to write on the board or moderate it. We offer topics for meetings on the Padlet board:

- my morning;

- what color is my mood;

- wishes for a certain letter;

- My healthy breakfast

- physical minutes;

- weekend book.

\section{Technique 14}

"Circle of Trust" 
Objective: To help students resolve conflicts peacefully through renewable practices such as mediation, decision-making, and work on

formation of a safe atmosphere in the team.

Audience: students of grades 5-11

Preparation time: 1 hour

Timing of: 25 minutes

Process: During the online conference, each participant will have the opportunity to describe their vision of the conflict situation; comment on how the conflict can be resolved; all solutions will be discussed in detail and the participants will choose only the option of resolving the conflict that will suit both of them; based on the results of the meeting will be an agreement on the agreement of the participants was signed. Feature of the mediation procedure determined by its principles - voluntariness, division of responsibilities, neutrality and impartiality, confidentiality. At the beginning of the meeting, it should be emphasized that the task of the facilitator is to help the parties to negotiate, not to decide which of them is right, but who is to blame. The mediator follows the procedure of the meeting, promotes the creation and maintenance of a safe, predictable, and productive course of negotiations. Instead, the participants themselves identify the key issue, jointly propose and discuss solutions to the situation, and are responsible for resolving their conflict.

\section{Technique 15}

"Olympic Relay"

Objective: To promote sports and promote a healthy lifestyle, to remind students that health is everyone's responsibility, to cultivate respect for athletes, to form a sense of pride for their country.

Audience: students of grades 6-11.

Preparation time: 5 days.

Timing of: within two days.

Process: 1. To take part in the relay, the participant must: - shoot a video (duration 30-40 seconds) with the performance of an exercise from his favorite sport or sports movements in the frame and symbolically convey an object that reflects your activity, and at the same time pass the baton to the next participant who needs it mark under/in the video; or - take a photo of an exercise in your favorite sport or sport movement, showing the image of Olympic rings or the inscription OlympicDay in the frame and pass the baton to the next participant who needs to mark in the post.

2. In the video and/or in the text of the post to the photo, the participant must address the audience with

the following messages: "I am joining the relay race of the 2021 Olympic Day in your country! I share Olympic values! I pass the baton...».

3. Post a post with this video or photo (not a story) with a hashtag on your Facebook or Instagram page.

Of course, online training requires special approach. After all, it is impossible to simply translate the usual approach into electronic format. 
We hope that these tips will help you not just become a "talking head", but get the maximum effect and pleasure from work.

\section{References}

Golovanova E.V., Psychological games to unite the teaching staff. Team cohesion training (workshop for teachers), Kyiv, 2012

Abrosimova M.A., Formation of the school staff. Psychological support. LLC "TC Sphere", 2005.

Monina G.B. Communicative training: teachers, psychologists, parents / G.B. Monina, EK February-Roberts. - SPb.: Promova, 2007.

Teleshman V.I., Training program "Development of school cohesion", Chernivtsi, 2012 


\title{
DISTANCE LEARNING VIABILITY IN TEACHING ENGLISH FOR SPECIFIC PURPOSES
}

Husak L.Ye.

professor at the Foreign Languages for Humanities Department of Lesya Ukrainka Volyn National University, Lutsk, Ukraine

\author{
Vorobiova T.V. \\ associate professor at the Foreign Languages for Humanities Department \\ of Lesya Ukrainka Volyn National University, Lutsk, Ukraine
}

Internet space, social networks, the latest computer technologies, ability to learn regardless of distance, state borders, and time differences allow significantly translate the learning process into the plane of a practical application of knowledge and skills. The idea appears to be especially attractive in terms of the current pandemic in the world.

Today, colleges and universities all across the world are temporarily canceling their face-to-face classes to cope with the impact of the COVID-19 situation. As we look through the materials suggested by various teaching and learning centers and instructional technology groups, we can notice that the resources have focused almost exclusively on the technology facilities: tools to record lectures, create discussion platforms, and conduct exams. The technological know-how to connect virtually with our students is quite necessary, but it is not sufficient to continue teaching and learning endeavors. It is not only a technological issue that matters. There are a lot of more important problems to be solved when we shift to on-line learning.

Online education is in the focus of a higher education system all over the world. Many institutions recognize that online courses have great potential to improve the state of things in higher education if they are designed and facilitated effectively. In connection with the above, the concept of distance education, blended learning as a significant moderator of modern science is being actively developed in higher educational institutions. The use of information technology in teaching promotes the development of individual resources of both students and teachers, develops skills of independent thinking, initiative, and responsibility for the work performed. It reduces the psychological burden on students and teachers in the process of knowledge exchange. The main goal of blended learning is to combine the benefits of traditional face-to-face and distance learning.

The study has revealed that a system of distance learning in Ukraine is in its infancy stage. However, its importance and viability is evidenced by the development of a comprehensive regulatory framework [1] and the growing number of scientific papers on the implementation of distance learning, in general, including works on the problems of distance learning of English for specific purposes in a non-language institution of higher education [3].

Distance education is characterized by [2]: flexibility, which is manifested in the absence of the need to attend regular classes and the opportunity to study at a 
convenient time and place; modularity, which manifests itself in the modular principle of individual courses design and organization, and hence in the creation of a holistic view of a particular subject area; parallelism, that means getting university training simultaneously with the professional activities or combining studies in the other subject area; a large audience that involves many students, simultaneously turning to a large number of sources, and enables students to communicate with each other and with teachers via telecommunication.

We cannot but mention some shortcomings of distance learning implementation. We can divide them provisionally into those that relate primarily to students and those that apply to the teachers and institutions that are going to introduce this new form of education [4]. The first category includes: lack of social interaction, which is a direct consequence of the virtual learning format; the technological problems, which most often consist in fear of introducing new technologies or their absence; portability of materials due to the electronic form is usually convenient, but not always one hundred percent better than traditional textbooks. The second category includes such disadvantages as high initial investment without which it is impossible to develop and implement this form of training; technological issues of training; improper materials that are not suitable for use in distance learning; lack of the appropriate cultural acceptance of e-learning (not everyone in our country is ready for a new form of teaching-learning process and take it seriously, and, therefore, it is obviously necessary to conduct some preparatory work with both students and teachers).

However, the advantages outweigh the disadvantages, and therefore the need for a distance learning system is urgent and applies to all disciplines without exception, including English.

The purpose of the discipline "Foreign language for professional/specific purposes" is to develop the ability and skills of intercultural communication, which, in the case of future lawyers, engineers, or historians, has a professional orientation and is realized via the formation of intercultural communicative competence. The latter, in turn, is defined as a level of proficiency in speech, writing, socio-cultural and vocational knowledge, skills and abilities to communicate in native and foreign languages, which all together allow carrying out intercultural communication in a proper way. Based on the analysis of the content of the future specialist's professional activity, researchers point to the priority of mastering the skills in all aspects of foreign language communication. Nevertheless, speaking competency in English is becoming increasingly important in view of the strengthening of Ukraine's integration processes into the European and world structures. In the long term, future professionals will have a chance to apply for internships in other countries, where they will have to communicate orally.

Distance learning effectively solves this problem by providing the possibility of constant and sufficiently dynamic telecommunication between teacher and student at a distance, allowing students communicate among themselves and with native speakers during the educational process. And this communication can be initiated by any of the listed above subjects of the educational process.

One of the resources of distance learning and teaching of English for future professionals is an 'electronic textbook'. It is advisable to compile the materials of such 
textbooks or guides, taking into account the principle of a programmed control of the learning process. In distance learning, we can use tests to check foreign language acquisition level or do it via control translation and oral communication with a teacher. Moreover, in the case of the test, the verification and evaluation of answers are carried out automatically, using the distance learning testing system.

One of the first attempts to introduce elements of distance learning may be providing consultations for students via e-mail or via Skype instead of (or in addition to) the traditional face-to-face live consultation within the walls of the higher education institution. According to the results of an oral survey, the students consider such an organization of consultations rather attractive and a particularly good idea. In their opinion, the most convenient is consultation by e-mail because they can write to their teacher at any time convenient for them and get a fairly quick response without having to wait almost a week for a face-to-face consultation at the faculty.

An important and effective way of introducing distance education elements in full-time and part-time university training courses is the use of the Moodle system, which allows teachers to create their own online courses and manage the content of the site. This system offers a variety of ways to provide learning material holistically, test students' knowledge acquisition objectively, and monitor their academic progress timely. This program will be useful for learning new vocabulary and developing reading, listening, and writing skills. In particular, it is advisable to place a set of exercises for better acquisition of grammar and lexical tests, as well as the tests for listening and reading comprehension and writing assignments. Computer tests are perceived positively by students because the verification of the results is automatic, thus excluding the influence of a human factor. In addition, such tests contribute to better mastering of the material because, in the long term, the students can easily reproduce examples from them in the live communication.

The development of distance learning courses is a complex and time consuming process that requires hard work and the development of a comprehensive and reliable theoretical framework, which is the goal of further research.

\section{REFERENCES}

1. Datsiuk, V.B. Perspektyvy dystantsijnoi osvity ta virtual'nykh universytetiv v Ukraini [Prospects of distance education and virtual universities in Ukraine], available at: http://mediacenter.uz.ua/data/daciuk.pdf.

2. Kontseptsiia rozvytku dystantsijnoi osvity v Ukraini [The concept of distance education development in Ukraine], available at: http://www.osvita.org.ua/distance/pravo/00.html

3. Olijnyk, O.V. (2014), Innovatsijni tekhnolohii dystantsijnoho navchannia inozemnoi movy dlia studentiv nemovnykh VNZ [Innovative technologies in distance learning of foreign language for students of non-linguistic higher schools]. Linhvistychni doslidzhennia: zbirnyk nauk. prats' KhNPU imeni H.S. Skovorody [Linguistic studies: Collection of Sciences. papers of KNPU named after G.S. Skovoroda], issue 38, pp. 238-246.

4. Kruse, K. The Benefits and Drawbacks of e-Learning, available at: http://www.corebiztechnology.com/software article elearning d.htm 


\title{
ИНФОРМАЦИОННЫЕ ТЕХНОЛОГИИ В ОБРАЗОВАНИИ (НА ПРИМЕРЕ КАЗАХСТАНА И ТУРЦИИ)
}

\author{
Kamiyeva Gulmira, \\ кандидат педагогических наук, ассоциированный профессор \\ Республика Казахстан, Astana IT University
}

Moldakhmetova Zulkiya, кандидат педагогических наук, доцент Республика Казахстан, Казахский национальный университет искусств

\begin{abstract}
АННОТАЦИЯ
Целью данного исследования является анализ вопросов, связанных с внедрением информационных технологий в образовательную систему на примере Турции и Казахстана. Информационные технологии все чаще используются в образовательных учреждениях для повышения качества обслуживания и достижения эффективных организационных результатов в контексте конкурентной международной среды. Интеграция компьютерных технологий в образовательную систему зависит от их успешной разработки и применения, что является дорогостоящим и сложным процессом. Это исследование также раскрывает сотрудничество между Казахстаном и Турцией в сфере информационных технологий и науки. Результаты и рекомендации могут быть применены в стратегиях развития образовательной, научной системы и представляют значительный интерес для казахстанской и турецкой научной и образовательной мысли.
\end{abstract}

Ключевые слова: образовательные технологии, информационные и коммуникационные технологии, интеграция, высшее.

1. ВВЕДЕНИЕ

В настоящее время во многих странах политики и практики образования пытаются интегрировать информационные и коммуникационные технологии в свои образовательные системы. В данном статье рассматривается проблема внедрения информационных технологий в систему высшего образования Турции и Республики Казахстан. Эти страны были выбраны для анализа, поскольку они тесно и эффективно сотрудничают в этой области и могут создать последовательную основу для дальнейших исследований в этой области.

Данное исследование дает комплексный анализ процессов международного сотрудничества по внедрению информационных инноваций в систему высшего образования Республики Казахстан и Турции. Эта проблема особенно актуальна, поскольку современное развитие человеческой цивилизации характеризуется следующим этапом технологической революции - внедрением информационных и коммуникационных технологий, меняющих жизнь людей и являются фундаментом и материальной базой для перехода к информационному обществу, 
обществу с высоким социально-экономическим, политическим и культурным развитием.

В 1984 году Министерство национального образования Турции впервые внедрило компьютеры в средние школы. Затем в 1991 году компьютерная инструкция была включена в национальную политику.

Первый Президент Казахстана Нурсултан Назарбаев инициировал начало информационного образования в Казахстане 22 сентября 1997 года, утвердив Государственную программу информатизации системы среднего образования, которая получила название «Программа Президента». В нем решались многие проблемы, в том числе подготовка и переподготовка педагогических кадров, развитие материально-технической базы, создание специализированных научнометодических центров, издание специализированной литературы и учебников для общеобразовательных школ и так далее.

Ключ к реформированию заочного образования заключается в широком внедрении в образовательный процесс информационно-коммуникационных технологий, в том числе технологий дистанционного обучения. Также следует отметить, что дистанционное обучение органично вписывается в образовательную систему. В 2003/2004 учебном году впервые прошел набор студентов по специальности «Электронные вычислительные машины, системы и сети», получивших по окончании учебу квалификация «Организатор сети дистанционного обучения». Первые эксперименты показали, что практический опыт внедрения сетевых удаленных технологий оказался успешным.

Официальный визит главы Государственного комитета по культуре Казахстана в Турцию 31 января 1991 года и соглашение о сотрудничестве, подписанное министром здравоохранения 14 февраля того же года, укрепили культурные связи между двумя странами.

На основании постановления Верховного Совета Республики Казахстан от 15 января 1992 года принят Закон «О науке и научно-технической политике Республики Казахстан». В рамках закона казахстанские студенты имели возможность учиться примерно в 30 университетах Турции, в том числе в высших учебных заведениях Стамбула «Босфор», в Анкаре «Ближневосточный технический университет» (METU), «Билкент» [1].

\section{2. ОБЗОР ЛИТЕРАТУРЫ}

Информационные технологии выступают в качестве технического помощника в разработке новых моделей и инструментов обучения и преподавания в образовательных учреждениях. Зандвлит и Стрейкер [2] подчеркнули, что применение информационных технологий растет почти во всех областях и во многих школах по всему миру.

Успешная реализация технологий сложна, поскольку зависит от многих взаимосвязанных переменных. Brummelhuis и Plomp [3] описывают интеграцию компьютерных технологий в образовательный процесс как сложную и многогранную инновацию, имеющую множество проблем, которые необходимо успешно решить, прежде чем можно будет говорить об эффективных инновациях. Они могут привести к медленной адаптации, будучи 
дорогостоящим и отнимающим много времени инструментом для пользователей и учащихся, что может расстроить и запутать их [4].

Более того, у практикующих специалистов в области образования есть дополнительные потребности, потому что их рекомендуют немедленно и компетентно применять новые знания в образовательных приложениях в своих классах. Следовательно, успешная интеграция информации и коммуникационные технологии зависят от преодоления проблем с развитием персонала [5,6], инвестиций в программное обеспечение и оборудование [7], лидерства [8], учебной программы [9], отношения учителей [10] и приверженности учителей [11].

Согласно MacNeil и Delafield (1998), основным сдерживающим фактором для интеграции технологий в процесс обучения является нехватка времени для профессионального развития и подготовки, а также денег на программное обеспечение, оборудование и инфраструктуру. В защиту этих результатов Пелгрум [12] обратился к преподавателям из Журнала теоретических и прикладных информационных технологий 30 июня 2016 г. Том 88. № 3.

В настоящее время многие исследования предполагают, что дальнейшие исследования должны выходить за рамки инструментов, основанных на технологиях, и включать большее количество социальных факторов $[13,14]$. Следовательно, необходима четкая структура для прогнозирования и понимания использования и принятия технологий практикующими педагогами.

\section{3. МЕТОДОЛОГИЯ}

В исследовании использовались как качественные, так и количественные методы. Источники данных включали наблюдения в классе и изучение соответствующих документов. В этом исследовании использовалась качественная структура в анализе информации для сбора большего количества отзывов о фактическом успехе информационных программ через голоса участников. В тематическом исследовании также использованы официальные статистические данные о применении информационных технологий, образовательные акты и указы Президента Республики Казахстан, реализующие политику в области международного научно-технического развития Казахстана.

4. РЕЗУЛЬТАТЫ И ОБСУЖДЕНИЕ

Результаты показывают, что учителя обеих стран в основном используют информацию и коммуникационные технологии для следующих целей: обучение применению технологий, управленческие цели, учебные цели и не образовательные задачи. Система образования в Турции западного образца. Система обучения в форме западной Турции.

В 2005 году на основании Указа Президента Республики Казахстан «О совершенствовании деятельности органов государственного управления в сфере экономики» была образована Организация науки и технологий Республики Казахстан. Задачи Министерства заключались в следующем:

- проводить политику в области международного научно-технического развития страны;

- координировать подготовку научно-педагогических кадров нашей страны; 
- организация международного сотрудничества в научно-технической сфере нашей страны. Турция ближе по культурной, религиозной, языковой ситуации. Отношения эмигрантов, проживающих в Европе и Турции, по-прежнему крепки. Действительно, европейские эмигранты - это те, кто переехал с территории Турции. В этом контексте видны межличностные отношения, поскольку представители казахстанских эмигрантов называют своим детям турецкие имена, традиции и обычаи, праздники напоминают турецкие. Это естественно, ведь тюркские народы всегда были близки с древних времен, и проживание в Турции внесло огромный вклад в культуру казахов.

Связи европейских казахов с Турцией сильнее, чем связи Казахстана. Многие из них живут в Турции, Китае, на Алтае. В Стамбуле активно действует Фонд турецких казахов. Муниципалитет Стамбула выделил Фонду помещения. Руководители фонда открывают путь к изучению казахского языка, организуют встречи с представителями казахстанской культуры и искусства. В помещениях офисов Фонда есть казахская юрта, благоустройство казахских вещей, сборная литература, которую демонстрируют на различных торжествах, собраниях, концертах.

Казахстанская делегация посетила Турецкую структуру научно-технических исследований и совет высшего образования и рассмотрела пути развития сотрудничества с ними. На переговорах между министрами образования двух стран обсуждалась текущая оценка отношений в сфере высшего образования и некоторые решения ряда вопросов. В частности, по итогам переговоров подписан Меморандум о сотрудничестве в области профессиональнотехнического образования. Согласно меморандуму, турецкая сторона согласилась поделиться знаниями и опытом в области науки с казахстанской стороной.

\section{5. ЗАКЛЮЧЕНИЕ}

Анализ указанных выше стратегий показывает, что ведущая роль в формировании национальной стратегии информационного развития и консолидации всех слоев общества для достижения целей информационного и инновационного развития в область образования передана правительству. С 1992 года более 4 тысяч казахстанцев окончили вузы Турции. В качестве образца дружбы между двумя странами при поддержке глав государств был открыт Яссауский международный казахстанско-турецкий университет, который стал одним из престижных университетов. Здесь также есть частный университет им. С. Демиреля и университет иностранных языков и бизнеса, а также 30 казахскотурецких лицеев и 9 средних школ [15].

В целях укрепления научных, образовательных и культурных связей между Турцией и Казахстаном две страны имеют одну и ту же среднюю школу в городе Туркестан - Международный казахско-турецкий университет имени Яссауи. За последние 10 лет около 25 тысяч человек из Казахстана прошли стажировку в Турецкой Республике [16].

Интеграция информационных и коммуникационных технологий в образование - это реформа образовательной системы Турции и Казахстана, направленная на построение общества знаний. Однако этот процесс по- 
прежнему будет проблематичным, если не будет хорошо спланированных программ повышения квалификации для учителей, школьных администраторов, компьютерных координаторов и специалистов в области образования. Несмотря на то, что имеется достаточно информации о межкультурном опыте интеграции информационных и коммуникационных технологий, дальнейшие исследования, направленные на поиск решений этих проблем, определенно будут способствовать нашему пониманию передового опыта в интеграции технологий. Кроме того, каждую проблему следует изучать с кросс-культурной точки зрения, чтобы в дальнейшем предложить схематическую основу для практиков в области образования и политиков.

Подводя итоги, следует отметить, что сегодня правительство принимает все меры для того, чтобы подрастающее поколение получило конкурентоспособное образование на мировом рынке. С каждым годом увеличивается объем финансирования образования. Разрабатываются и внедряются новые интересные идеи в области информационных и коммуникационных технологий. В итоге все это создает новые условия для формирования личности, способной работать в открытом информационном журнале теоретических и прикладных информационных технологий общества, где присутствует значительная доля интеллектуальной сферы, современных технологий и международного сотрудничества.

\section{Список литературы:}

1. Ergöbek, Q., Elbası batasımen. Egemen Qazaqstan, 2007..

2. Zandvliet, D. B., \& Straker, L. M., Physical and psychosocial aspects of the learning environment in information technology rich classrooms. Ergonomics, 44 (9), 2001, pp. 838-857.

3. Brummelhuis, A., \& Plomp, T. (1991). The relation between problem areas and stages of computer implementations. Paper presented at the Annual meeting of the American Educational Research Association, April 3-7, 1991, Chicago, USA.

4. King, K. P., Educational technology professional development as transformative learning opportunities. Computers and Education, 39, 2002, pp.283-297., 39, 2002, pp.283-297.

5. Holland, P. E., Professional development in technology: Catalyst for school reform. JournaI of Technology and Teacher Education, 9 (2), 2001, pp. 245-267.

6. Cooley, V. E., Implementing technology using the teachers as trainers staff development model. Journal of Technology and Teacher Education, 9 (2), 2001, pp. 269-284.

7. Casey, P. J., Presenting teachers with a model for technological innovation. Technology and Teacher Education Annual, 1995, pp. 855-858.

8. Akbaba-Altun, S., Information technology classrooms and elementary school principals' roles: Turkish experience. Education and Information Technologies, 9 (3), 2004, pp. 255-270.

9. Hakkarainen, K., Students' skills and practices of using ICT: Results of a national assessment in Finland. Computers and Education, 34, 2000, pp. 103-117. 
10. Swan, K., Holmes, A., Vargas, J. D., Jenning, S., Meier, E., \& Rubenfeld, L., Situated professional development and technology integration: The capital area technology and inquiry in education (CATIE) mentoring program. Journal of Technology and Teacher Education, 10 (2), 2002, pp.169-190.

11. Schuttloffel, M. J., A handbook for technology implementation. Technology and Teacher Education Annual, 1995, pp. 859-862

12. Pelgrum, W. J., Obstacles to the integration of ICT in education: results from a worldwide educational assessment. Computers \&Education, 37, 2001, pp. 163-178.

13. Bielaczyc, Katerine, "Designing social infrastructure: Critical issues in creating learning environments with technology", Journal of the Learning Sciences, 15, 3, 2006, pp.301-329.

14. Selwyn, N., "The use of computer technology in university teaching and learning: A critical perspective", Journal of Computer Assisted Learning, 23, 2, 2007, pp.83-94. 15. Qaliev, N.Q., Jahandanw: qaterler men qundilıqtar. Qazaq rwxanïyat1, 1, 2010. 16. Sawdabaev, Q., Kazaxstan-Twrcïya: vozrojdennıe otnoşenïya. In: Kazaxstan-Twrcïya: 5 let drwjbı ï sotrwdnïçestva.Ankara: Bïlïg, 1996. 


\title{
THE ROLE OF THE CASE-METHOD IN IMPROVING THE EFFECTIVENESS OF TRAINING MEDICAL STUDENTS IN DISTANCE EDUCATION
}

\author{
Kashchenko Olga \\ $\mathrm{Ph} . \mathrm{D}$, Associate professor \\ Odessa National Medical University \\ Narbutova Tamara \\ Ph.D, Associate professor \\ Odessa National Medical University \\ Volokhova Galina \\ Ph.D, Associate professor \\ Odessa National Medical University
}

One of the main peculiarities of the European Declaration on the implementation of the Credit Transfer System (CTS) is its intensification, a large amount of independent work, strengthening creativity and knowledge and practical skills of future professionals. In this regard, the issue of improving the pedagogical system for medical training in higher education becomes especially relevant. Today we need highly qualified specialists who are able to implement conceptual changes in the organization of the system of training doctors in conditions of distance education.

In order to increase the effectiveness of training future specialists in the field of medicine at the departments of Odessa National Medical University is constantly improving the purpose and content of the educational process through various tools, forms, new teaching methods, curriculum development, criteria for assessing students' knowledge and skills and bringing them in line with European standards. Thus, during the educational process much attention is paid to the principles of sequence of teaching material, systematic and systematic in the learning process, as well as strengthening the interdisciplinary integration of medical and biological disciplines with practical, general and psychological and pedagogical disciplines. systems and mechanisms of their regulation under the influence of various adaptive factors.

In this direction, as our experience shows, one of the effective approaches to intensify the learning process is the use of case-method with a step-by-step solution, which have great didactic potential and allow in a short time to significantly intensify practical training of students for work both in normal and urgent conditions. The conditions of the practical situational task are reproduced with the maximum approximation to the model of a specific professional situation. At the same time, we use a differentiated application of the complexity of the conditions that are reproduced in situational tasks, taking into account the specialization and course of future professionals - from simple to the most complex. When solving complex situational problems, in addition to the standard conditions of physiological processes and their 
modifications, students are offered complex situational cases that require quick complex decisions, due to the introduction of additional conditions. The proposed situational tasks are accompanied by specially selected results of functional studies of human health, such as electrocardiogram, electroencephalogram, polycardiogram, spirogram, hemogram, analysis of the composition of gastric juice and other laboratory tests on the topic of classes, which are deciphered by students. This approach provides effective assimilation of study material by students of both theoretical and practical skills.

As a result of assimilation of practical skills, students improve to a professional level knowledge of the functioning of organs and systems in normal conditions and in terms of adaptive changes in the body, which will increase the level of professional assistance in future professional activities. All this allows students to form elements of practical thinking and the necessary skills to solve standard and non-standard professional situations before the start of direct professional activity, increases the efficiency of perception of the next material and reduces the percentage of erroneous actions in subsequent activities.

Thus, as our experience shows, increasing the efficiency of training future medical specialists in the distance educational study is especially effective in the introduction of active forms of learning with extensive use of problem-solving methods, in particular with the inclusion of situational tasks. The solution of such problems, along with the theoretical assimilation of lecture material and practical classes is an individual and visual form of active learning within the CTS, which encourages the activation of cognitive and creative activities of students, conscious study of medical and biological disciplines. 


\title{
DEVELOPMENT OF TRANSFORMATION LITERACY
}

\author{
Khalina Veronika, \\ Ph.D., Associate Professor
}

Kharkiv National University of Civil Engineering and Architecture

Butskyi Vyacheslav,

Ph.D., Associate Professor

Kharkiv National University of Civil Engineering and Architecture

Transformational literacy is the ability of a system to respond to the challenges of destruction in ways that go beyond simply optimizing the status quo. This is the ability of the system to be aware of and agree on future opportunities as they arise. This ability is based on deep listening, a sense of social field and the activation of confidence in action to stimulate collective action arising from a common understanding and awareness of everything [1]. We've learned that you can create transformative innovation and learning environments at scale by combining digital platforms and awareness-driven social leadership technologies. But it requires very intentional storage space, well-developed techniques and tools, and ecosystem-level orchestration. The blind spot in our current educational institutions is transformational literacy. This is true for both universities and schools. However, when you talk to companies, you will learn that transformational literacy is an underdeveloped skill that many organizations are trying to develop in their employees [1].

The world is currently undergoing the largest transformations in the last few decades. Their concentration is so great that it certainly causes anxiety, fear and, of course, resistance in most people. Hence the need to develop transformational literacy, which is designed to eliminate the negative in relation to change and stimulate the search for opportunities in any crisis situation.

Entrepreneurship is the activity that most painfully responds to the changes that are taking place today. Businesses of all sizes face challenges that are generated and transformed on a daily basis and need to be prepared to adapt.

According to statistics, every second inhabitant of Europe, at least once organized his startup or participated in it. And many business failures are due to lack of entrepreneurial skills, which should be developed as early as possible, preferably in school [2].

This year, the skills of the future were traditionally voiced at the World Economic Forum. The Executive Chairman of the Forum, Professor Klaus Schwab, emphasized that we now have the tools at our disposal, and that the generosity of technological innovation that defines our modern age can be used to unleash human potential. By $2025,50 \%$ of all employees will need retraining as technology deployment grows, according to a World Economic Forum report on the future of jobs. Critical thinking and problem solving are the number one skills that employers say will grow in popularity over the next five years. Recently, self-management skills such as active learning, resilience, stress tolerance and flexibility have emerged [3]. The ongoing 
global pandemic encourages us, and society as a whole, to apply new technologies more actively in life and at work, and reaffirms the importance of media and information literacy. And in the world of post-truth and harsh realities of the Ukrainian information space, media literacy for everyone is a really necessary tool to protect against misinformation and fakes.

In the future (until 2040) the required competencies will be those that will not be able to generate machines and jobs, namely: the ability to make decisions, analyze the possible losses and benefits of future actions; generating ideas, and what matters is not their quality, but, oddly enough, the number of which artificial intelligence will calculate the possible options; the ability to personally teach others; ability to understand long-term learning outcomes and the impact of new information on them; originality; creative thinking; adaptability; ingenuity; cross-functionality and interdisciplinarity.

Therefore, it should be emphasized that ingenuity will be the most popular skill in the future, and educators who care about their students must create curricula to provide just such skills.

The tools for the development of entrepreneurial skills that are most effective are: internships for students in existing business, entrepreneurial experience, which in contrast to internships, entrepreneurial experience offers students who have a viable idea and desire to develop their business, the opportunity to be an entrepreneur, work with cases (an increasingly popular form of group work on practical tasks are hackathons), mentoring schemes, incubator services.

Yanning Duan, a representative of the University of Bradford, calls the following rules of a successful curriculum: the introduction of entrepreneurship education as a positive development activity; encouraging self-assessment for students to understand how well they have developed their skills; linking learning with examples of entrepreneurs and the benefits they bring to business [4].

In general, most of the activities, professional and not so much that will appear in the future, will be designed to preserve the integrity of the ecosystem, human and animal life and health, resources for future generations and ensure the safety of everyone. Thus, ensuring the achievement of the established global goals of sustainable development.

\section{References}

1.URL:https://medium.com/presencing-institute-blog/the-darkest-hour-is-justbefore-the-dawn-cc4df0749108.

2.URL:https://happymonday.ua/navychky-majbutnogo-dlja-roboty.

3.URL:https://www.weforum.org.

4.URL:http://gohigher.org/yak_rozvyvaty_pidpryyemnytski_navychky_studenti v_u_kreatyvnykh_industriyakh. 


\title{
TEACHER-STUDENTS INTERACTION IN DISTANCE TEACHING OF PROGRAMMING
}

\author{
Pavlo Kindrat, \\ $\mathrm{PhD}$, Associate Professor \\ Rivne state university of humanities
}

The development of education and technological solutions used in the educational process is carried out not only in the direction of improving traditional methods of presenting information and control of acquired knowledge, but also by increasing the involvement of the audience and individualization of learning. The development of information and communication technologies has become a significant basis for the development of pedagogical methods in recent years. Increasing the integration of technological solutions has allowed not only to increase motivation to learn, but also to ensure the development of student self-organization.

The widespread introduction of modern technological solutions in the educational process has long been slowed by the inertia of education, outdated guidelines, unwillingness to radically change and improve what already works. From this point of view, the emergence of a pandemic and the introduction of quarantine restrictions allowed for the abrupt transition to new realities. New requirements for the organization of the educational process have forced many teachers to adopt the latest technologies and allowed to overcome the inertia.

At the same time, the mentioned transition exposed the problems of education and revealed not only the unwillingness of some teachers to use modern educational services, but also the imperfection of the services themselves.

One of the areas that suffer significantly due to the lack or not high enough quality of publicly available specialized educational services is the study of programming, especially for undergraduate students. The organization, conduct and discussion of the theoretical part of the course is not much different from that for other subjects. Therefore, it does not require any special attention. At the same time, conducting practical and laboratory classes causes a number of problems.

Distance learning - an individualized process of acquiring knowledge, skills, abilities and ways of human cognitive activity, which occurs through the indirect interaction of distant participants in the learning process in a specialized environment that operates on the basis of modern psychological, pedagogical and information and communication technologies. Within the distance learning, asynchronous and synchronous mode are distinguished. The synchronous mode is carried out in accordance with the approved schedule of the educational process at the time determined according to the study schedule with the use of information and communication technologies without the presence of students in the classrooms. Thus, in general, it differs from classroom teaching only by the method of interaction of students with teachers.

The main problem faced by students and teachers in the organization of distance learning during the quarantine was the nonavailability of higher education institutions 
to organize it in a unified synchronous mode. That all led to the dominance of the asynchronous mode, which is based on the independence of students' practical and laboratory work and sending the results for verification through appropriate services or e-mail. As a result the teacher's mentoring work was leveled.

The inability to receive a prompt response (hints or clarification of the algorithm of the task) not only reduces the effectiveness of training, but can also lead to improper learning of educational material and deflated self-esteem. This problem is especially relevant for junior students, who are just beginning to be actively involved in programming. For them, the developing of a well-understood idea of the practical application of principles which are the essence of writing quality software products is especially important. As practice shows, it is extremely difficult for students who have improperly mastered the material in the initial courses to catch up with their classmates.

Popular software training services such as Moodle, Google Classroom, Microsoft Teams for Education, etc. among the functionality for conducting online lessons include only the means of exchanging file documents between students and teachers, as well as video conferencing tools with different levels of functionality. However, even the multi-user screen demonstration that is available in Google Classroom does not adequately ensure the teacher's participation in the student's practical and laboratory work. The teacher can only act as an observer and provide verbal tips. For a group of even 12 students, this approach makes it impossible to organize a discussion of completed tasks.

Thus, to ensure the quality of the educational process, it is necessary to choose specialized platforms that will provide not only the ability to check the software code in real time, but also its discussion and error correction.

One way to solve this problem is to use the free online platform JDoodle (jdoodle.com). Despite the fact that this platform is in English, its interface is intuitive and requires a minimum level of English, which is especially useful for junior students.

This platform has a standard set of online compiler tools: it allows you to choose one of more than 50 programming languages, the ability to write console software applications without the need to install the compiler of the selected language, storage and exchange of software projects, and more. Its feature is the ability to organize "Collaborate / Peer Programming", which allows you to organize simultaneous work (with synchronization of changes in real time) with the same program code of several users. This supports the possibility of voice discussion, chatting, and visualization of actions of one of the participants on the screen of another one.

At the beginning of the lesson, students can connect to the online conference organized with the help of an educational service used by the educational institution. After receiving the assignments and starting work on them, students send the teacher links to their Collaborate Programming sessions. As a result, the teacher has the opportunity to objectively monitor the progress of the task of each student in real time and, if necessary, give advice and comments. The capabilities of the platform allow you to organize individual meeting rooms to discuss problems that have arisen in the process of working on the task. This ensures a proper working atmosphere and the general voice chat does not turn into a fuss. 
The use of this platform enables peer-to-peer learning. According to education expert Professor Phil Race "difficult topics can be easier to understand when they are explained by someone who only recently learned the material themselves. Peer-to-peer learning develops students with the confidence to search for solutions by themselves, often in quite creative and ingenious ways. This is particularly important in computer programming, where individuals are notorious for lacking certain human skills". [1] It also provides opportunities to organize and conduct group brainstorming and competitions designed to teach students to work on projects in a team. The experience of involving senior students as moderators of competitions turned out to be especially interesting.

The main disadvantage of using this platform is its focus on writing console applications, which makes it impossible to use it as a universal distance tool for teaching programming. In particular, the platform does not support the ability to create full-fledged web applications and software products based on visual programming technology.

In summary, we can conclude that the use of the Jdoodle platform can significantly expand the methodological and organizational capabilities of a teacher in the organization of distance and, in part, classroom learning programming for junior courses. Providing timely feedback, as well as peer learning can increase student motivation and improve the quality of learning material in practice.

\section{References:}

1. Pickles, M. (2016, 25 October) University opens without any teachers. Retrieved from https://www.bbc.com/news/business-37694248 


\section{FEATURES OF DISTANCE EDUCATION STUDENTS OF SPECIALTY "PHYSICAL THERAPY, ERGOTHERAPY"}

Kireyev Igor,

M.D., Professor

Kharkiv National University of Pharmacy

\section{Zhabotynska Nataliia}

Ph.D., Associate Professor

Kharkiv National University of Pharmacy

Under the quarantine caused by the COVID-19 pandemic, the National University of Pharmacy organized distance learning for students of all educational programs in pursuance of the Regulation on Distance Learning approved by the Cabinet of Ministers of Ukraine [1]. Distance learning is an open learning system that provides interactive interaction of teachers and students at different stages of learning and independent work of students with the materials of the information network using modern information and communication technologies [2].

Distance learning requires the creation and use of a single information and educational environment that contains various electronic sources of information. Such a single information and educational environment was chosen as a learning platform Moodle (Modular Object-Oriented Dynamic Learning Environment) [3, 4]. This platform contains a large number of different learning elements (so-called "modules"), which provide dialogue and cooperation between teacher and students. To provide students with material for theoretical training in each discipline, a full-fledged course was created, which included lecture material, lesson plans, electronic resources, materials for independent work, test tasks. The use of multimedia video and audio materials, drawings significantly increases the effectiveness of teaching and students' interest in learning new material.

At the National University of Pharmacy for students majoring in "Physical Therapy, Ergotherapy" teaches a number of medical disciplines in the professional field, namely "Fundamentals of Cardiology and Pulmonology", "Internal and Surgical Diseases", "Traumatology", "First pre-medical aid in Emergencies", etc. The study of such disciplines requires close contact of students with the teacher, which can be achieved through ZOOM-conferences. ZOOM service allows teacher to more closely monitor the attendance and work of the student during the practical lesson. Teaching medical disciplines requires the development of skills and abilities of practical activity. During the broadcast of the ZOOM-conference, the teacher has the opportunity to explain and demonstrate the practical skills that students must perform. In turn, students can also use the "screen demonstration" function to perform the tasks of the teacher.

The organization of distance learning through a combination of theoretical material presented on the distance learning platform Moodle, interesting interactive tasks and video communication with the ZOOM service during lectures and practical 
classes should be a good basis for even in quarantine students majoring in "Physical Therapy, Ergotherapy" received high-quality theoretical and practical training and acquired the competencies inherent in the curriculum in medical disciplines in the professional field.

\section{References:}

1. Про затвердження Положення про дистанційне навчання [Електронний ресурс] : Постанова Кабінету Міністрів України № 466 від 25.04.2013 р. - Режим доступу:http://zakon4.rada.gov.ua/laws/show/z0703-13. —Назва 3 екрану.

2. Блощинський І.Г, Сутність та зміст поняття «дистанційне навчання» в зарубіжній та вітчизняній науковій літературі // Вісник Національної академії Державної прикордонної служби України, 2015 Випуск 3 file://C:/Users/\%D0\%9E $\% \mathrm{D} 0 \% \mathrm{BF} \% \mathrm{D} 0 \% \mathrm{~B} 5 \% \mathrm{D} 1 \% 80 \% \mathrm{D} 0 \% \mathrm{~B} 0 \% \mathrm{D} 1 \% 82 \% \mathrm{D} 0 \% \mathrm{BE}$ $\%$ D1\%80/Downloads/Vnadps_2015_3_4.pdf

3. https://osvita.ua/vnz/high_school/72285/

4. Moodle[Електронний pecypc]. - Режим доступу:https://moodle.org/. Назва з екрану. 


\section{MODERN PARADIGM OF LEARNING WITH DISTANCE TECHNOLOGIES}

Yevhenii Koroviaka

Ph.D., Associate Professor

Dnipro University of Technology, Dnipro, Ukraine

Oleksandr Pashchenko

Ph.D., Associate Professor

Dnipro University of Technology, Dnipro, Ukraine

Volodymyr Khomenko

Ph.D., Associate Professor

Dnipro University of Technology, Dnipro, Ukraine

The modern world is undergoing a process of active transformations - the transition from an industrial society to an information society. With the change in the nature of modern society, there is also a change in the requirements for the education system as a whole. Today's educational paradigm provides for equality and accessibility of education with different starting opportunities. The requirements for the results of mastering basic educational programs, the conditions for the implementation and structure of the basic general educational program, which are impossible without the availability of an information educational environment, the widespread use of information technologies and electronic educational resources, are changing. A characteristic feature of the modern world is the rapid development of information technologies.

The problem of improving the system of higher education in order to improve the quality of training of specialists and bring the level of their professional training to international requirements is one of the most urgent. It is impossible to ensure the proper quality of student training using exclusively traditional teaching methods. For example, the correspondence form of education has a number of essential features (a small classroom cycle, a large amount of independent work), which causes the need to improve the educational process [1].

The specificity of distance learning leaves its mark on the technologies used. First of all, this is due to the role of the teacher in the educational process. If earlier in the traditional education system the teacher occupied a central place as an interpreter of knowledge, now, in the context of informatization, this place increasingly belongs to the student who independently acquires knowledge from various sources. In these conditions, the teacher acts as a coordinator, helping the student to acquire knowledge and apply it in practice. The subject of the teacher's work is the choice of methods and technologies for the implementation of their activities. And the main role here is played by methods of active and developmental learning [2].

The next feature of distance learning is the ability to implement student-centered learning, i.e. training, taking into account the personal qualities of the student, his 
capabilities and educational goals. Technologies for the implementation of independent work on the basis of interactive multimedia teaching tools allow you to build an individualized differentiated teaching [3].

The main role assigned to telecommunication technologies in distance learning is to provide educational dialogue. Learning without feedback, without a constant dialogue between the teacher and the student is impossible. Learning (as opposed to self-education) is a dialogical process by definition. In full-time education, the possibility of dialogue is determined by the very form of organization of the educational process, the presence of the teacher and the student in one place at the same time. With distance learning, educational dialogue must be organized using telecommunication technologies [4].

Communication technologies can be divided into two types: on-line and off-line. The former provides the exchange of information in real time, that is, a message sent by the sender, reaching the addressee's computer, is immediately sent to the appropriate output device. When using off-line technologies, received messages are saved on the recipient's computer. The user can view them using special programs at a convenient time. In contrast to face-to-face training, where the dialogue is conducted in real time, where it can also go in a delayed response mode $[3,4]$.

The development of information technology and telecommunications creates the basis for the implementation of educational programs at a qualitatively new level. The creation of high-speed telecommunications and the development of real-time technologies makes it possible to implement models of a distributed educational environment based on technologies of remote access to information resources and computer communication means [2].

The introduction of distance learning technologies into the educational process is due to the fact that in the conditions of modern society, a person has to engage in selfeducation throughout his adult life, which implies the continuity of education. In turn, lifelong education, for a number of reasons, is much more convenient and economical to carry out using distance learning technologies. Therefore, students need to be proficient in distance learning technologies. The teacher's readiness to use distance learning technologies in the educational process is part of the teacher's professional competence. It is also a prerequisite for further professional development [3].

In pedagogical work with students who have a poorly formed ability for independent cognitive activity, distance courses with the support of traditional teaching are suitable. The effectiveness of any kind of distance learning depends on the interaction of the teacher and the student, on the feedback between the teacher and the student, on the pedagogical technologies used and the developed teaching materials. The success of distance learning to a large extent depends on the organization and methodological quality of the materials used, as well as on the leadership, skill of the teachers involved in this process [4].

A distance learning model with the support of traditional learning should provide for a flexible combination of independent cognitive activities of students with various sources of information, teaching materials specially developed for this course (reference, additional materials), and operational systematic interaction with the teacher, as well as group work with participants in this course , using all the variety of 
problem, research, search methods in the course of work on the corresponding modules of the course. In addition, this model should provide for joint telecommunication projects with other educational institutions in the form of teleconferences, exchange of views, information with course participants $[2,3]$.

The benefits of real-time technology are clear. They allow combining the material and computing resources of educational and research centers to solve complex problems, attract leading specialists and create distributed research laboratories, organize online access to shared resources and joint computing and laboratory experiments, carry out joint research projects and educational programs.

The intensive development of distance learning will allow to preserve and develop the intellectual potential of the nation, lays the foundations for a democratic education system that guarantees the necessary conditions for full, high-quality education at all levels, expands opportunities for quality education, creates favorable conditions for the formation of the educational services market and the integration of the Russian education system to the world educational community [3].

Learning using distance technologies performs additional didactic functions and, accordingly, expands the learning opportunities; allows you to improve the quality of education by increasing the proportion of independent mastering of the material, which ensures the development of such qualities as independence, responsibility, organization and the ability to realistically assess their strengths and make informed decisions. The novelty of using distance technologies also lies in the specifics of the region, where students for a sufficiently long period are not able to attend an educational institution due to objective reasons (illness, quarantine, activated day, etc.). Each student can study according to a personal schedule, varying the pace and time of learning to master the subject being studied.

Modern education is based on the use of an activity approach and an electronic information educational environment of an educational institution, in which remote interaction of participants in the educational process should be organized, both among themselves and with other organizations in the social sphere. The practice of organizing e-learning shows that materials originally prepared for conducting distance learning are then used in full-time education and vice versa, thus, there is a mutual integration of full-time and based on the use of distance learning technologies.

\section{References}

1. Mayorov A.N. Monitoring in education. - M.: Intellect-Center, 2013

2. Ponomareva E.A. Universal learning activities or learning skills. - Municipal formation: innovation and experiment. 2, 2010.

3. Troyan G.M. Universal information and telecommunication technologies in distance education. Textbook for the system of advanced training and professional retraining of specialists. - M.: RITS "Alpha" MGOPU them. M.A. Sholokhova, 2002. - $153 \mathrm{p}$.

4. Tereshchenko N.N. Research of the market of educational services of higher education: monograph. - KSU, Krasnoyarsk, 2005. - 267 p.

5. O.A. Pashchenko, A. V. Ilyina Problems of computerized science // Adequate systems and monitoring of the safety of the food industry of Ukraine: a study of 
advanced science. - practical conference, April 2013, Dnipropetrovsk / Ministry of Education and Science, Youth and Sports of Ukraine, State University of Applied Sciences. "Nats.girn.un-t". - D.: DVNZ "NGU", 2013. - 369 p.

6. O.A. Pashchenko, T. V. Ratsina Victory of the computerized system and control and assessment // Adequate system and monitoring of the quality of health education in Ukraine: the study of advanced science. - Practical conference, April 2013, Dnipropetrovsk / Ministry of Education and Science, Youth and Sports of Ukraine, State University of Applied Sciences. "Nats.girn.un-t". - D.: DVNZ "NGU", 2013. - 369 p. 


\title{
ДИСТАНЦЙНЕ НАВЧАННЯ 3 ХОРЕОГРАФЇ̈ ІЗ УЧНЯМИ МОЛОДШОГО ШКІЛЬНОГО ВІКУ
}

\author{
Mashynets Lina \\ teacher of the highest category, \\ artistic director of the ensemble \\ folk dance «Syayvo» \\ Municipal establishment \\ «Center for children and youth creativity № 3» \\ Kharkiv city council
}

У період карантину, що значно обмежив роботу багатьох закладів, у тому числі й позашкільної освіти, хореографічні заняття 3 учнями молодшого шкільного віку продовжилися в дистанційному режимі. Виявилось достатньо складним їх проведення, оскільки здобувачі освіти вимагали постійного контролю з боку керівника, який своєчасно вказував на помилки, виправляв недоліки, допомагав засвоїти новий матеріал теоретично, технічно та практично.

Дистанційне навчання хореографічного мистецтва - один із видів освітньої системи, де перевага надається дистанційним технологіям навчання та організації освітнього процесу. Завдяки такому глобальному явищу як Інтернет, дистанційна освіта охоплює широкі шари суспільства, стає найважливішим фактором його розвитку [2]. Серед широкого спектру педагогічних технологій, що застосовуються в дистанційному навчанні, вагоме місце посідають технології, де реалізуються групові методи навчання, в основі яких є взаємодія, взаємодопомога, співробітництво, спільна мета й досягнення цілей.

Керівнику хореографічного колективу необхідно визначити місце, розробити сценарій організації та проведення заняття, застосувати зручні програми (наприклад, Zoom), продовжити підтримувати взаємозв'язок 3 учнями та батьками (через мобільний додаток Viber), сприяти творчому розвитку здобувачів освіти.

В. Моляко розглядає творчу людину як такою, що виражає вищий ступінь розвитку, підготовленості до конкретних видів діяльності й до життя в цілому, до зміни стилів поведінки, до пошуку виходів із кризових ситуацій тощо [3, с. 20]. Отже, творчість ми пов'язуємо з активною діяльністю особистості, у результаті якої розвиваються стійкі творчі інтереси, здійснюється цілеспрямований пошук у розв'язанні проблемних завдань тощо.

Оскільки хореографічні заняття покликані сприяти творчому, фізичному, естетичному розвитку вихованців, ми виділили деякі їх особливості, що, на наш погляд, $\epsilon$ результативними в дистанційному процесі з учнями молодшого шкільного віку, серед них:

- заняття мають проходити в позитивній атмосфері;

- звертати увагу на вміння учнів емоційно відгукуватися на виразні засоби музичних творів, слухати музику та в такт відтворювати відповідні рухи;

- ретельно відпрацьовувати елементи танцю, комбінації рухів; 
- надавати звукову (аудіо) інформацію, оскільки аудіо в поєднанні зі словесним текстом і зображенням, покращує запам'ятовування;

- підтримувати ефективного й правильного зворотного зв'язку;

- налаштовувати виступ колективу на участь у концертних виступах, фестивалях, конкурсних перегонах, змаганнях із настановою на успіх.

Ураховуючи вікові особливості дітей 1-4 класів, можемо говорити про їх підвищену емоційність, активність, енергійність, бажання постійно розширювати коло своїх інтересів. Автор українського педагогічному словника С. Гончаренко розглядає інтерес, як форму прояву пізнавальної потреби, яка забезпечує спрямованість особистості на усвідомлення мети діяльності [1]. При наявності інтересу знання засвоюються міцно, грунтовно. Завдяки інтересу учні можуть швидко включитись в активну творчу діяльність, добрати цікаві, різноманітні, нові за формою чи змістом завдання, які спонукають до самостійних, активних роздумів. Однак не слід забувати, що діти цього віку швидко втомлюються, тому танцювальні вправи доцільно чергувати, відводити кожній 10-15 хвилин.

Окрім цього, варто вказати, що в дистанційному навчанні керівник хореографічних занять має застосовувати ті форми, методи, прийоми, за допомогою яких у вихованців виникає здатність співчувати, співпереживати, а отже, і спільно діяти зі своїми однолітками, реагувати на зауваження дорослих.

Розглянемо дистанційне навчання 3 хореографії 3 учнями молодшого шкільного віку (основного рівня) комунального закладу «Центр дитячої та юнацької творчості № 3» Харківської міської ради, що відбувається через програму Zoom. Мобільний телефон розташовується таким чином, щоб цілком було видно керівника (його поставу, обличчя, руки, ноги). Група складається 3 12 осіб. Мета заняття - розвиток художньо-естетичних поглядів в учнів, дійового інтересу до хореографічного мистецтва та потреби в ньому.

Заняття розпочинається із ввічливого привітання, уклін супроводжується інструментальною грою акомпаніатора, звучить українська народна мелодія танок «Запрошення». Далі педагог-хореограф пропонує учням промарширувати, зробити невеликий розігрів м'язів рук і ніг. При цьому звертається увага на правильну осанку, положення тулуба, активну роботу ніг (відпрацьовуються по черзі із зігнутими ногами біля колін). У цей час руки розташовані на поясі, голова не озирається навкруги, а зосереджена прямо в екран на керівника. Після цього учням надаються елементи класичного танцю, що є необхідними для подальшої танцювальної роботи. У стрибках від них вимагається чітке й швидке виконання рухів, узгодженість із музикою (чітко в такт під жваву музику Ф. Надененка). Корисними $є$ гімнастичні вправи на підлозі «павуки» (розтяжка, поперек шпагат), «жабеня», «годинник», «гойдалка» тощо, де відбувається єдність фізичного й психічного розвитку вихованця, дотримуються відповідні правила. Після виконання вправ учні обмінюються думками, звертають увагу на свої помилки, якщо такі мали місце, роблять певні висновки. Під час обговорювання вони також уточнюють певні поняття, обмірковують що і як краще виконати, виявляють ініціативу. Не менш цікавим для вихованців $\epsilon$ й уміння імпровізувати під музичний супровід. Наприклад, у музиці «Гарний настрій», «Лісові друзі» їм 
належить яскраво передати той чи інший образ, продемонструвати характер задуманого персонажу, чітко відтворити його в рухах. Слід указати, що навіть на відстані підтримується й не втрачається зв'язок керівника та учнів, який заснований на довір'ї, доброзичливості, щирості.

На завершенні заняття педагог-хореограф виказує слова вдячності своїм вихованцям, бажає їм берегти своє здоров'я, але й не забувати відпрацьовувати ті танцювальні елементи, що вивчались упродовж цих хвилин. Учні та керівник вклоняються й оплесками дякують один одного за цікаве заняття та отримані позитивні емоції.

Таким чином, правильно організоване дистанційне навчання 3 хореографічних занять сприяє всебічному та гармонічному розвитку учнів молодшого шкільного віку, пробуджує інтерес до танцювальної музики, виховує наполегливість і любов до мистецтва, відкриває перед ними можливості застосування отриманих знань у життєвій практиці.

\section{Список літератури}

1. Гончаренко С. У. Український педагогічний словник. Київ, 1994. C. $147-148$.

2. Дистанційна освіта / Освітній портал. URL : http://www.osvita.org.ua/distance/ (дата звернення : 10.01.2021).

3. Здібності, творчість, обдарованість: теорія, методика, результати досліджень : колективна монографія ; за ред. В. О. Моляко, О. Л. Музики. Житомир : Вид-во Рута, 2006. 320 с. 


\section{MEDICAL ETHICS AND DEONTOLOGY}

Mytchenok Mariia Petrovna, Phd, Associate Professor

Bukovinian State Medical University

Department of Pediatric Dentistry

Mytchenok Alexander Viktorovich,

Phd, Associate Professor

Bukovinian State Medical University

Department of Therapeutic Dentistry

History of medicine has elaborated such kind of phenomenon between a doctor and a patient when relations are filled with humane content - this is medical ethics and deontology. Medical ethics assumes a wide range of issues: relations of medical workers with patients, students, and themselves in their associations. In this respect medical ethics is closely connected with medical deontology assuming the norms of relations between a doctor and a patient mainly. In its historical formation and development deontology is completely obliged to the moral factors [1].

Medical worker ethics has found its practical implementation in particular moral principles stipulating doctor's attitude to sick persons during communication with them and their relatives. The whole moral-ethical complex is considered to be termed "deontology". Therefore, deontology is practical implementation of moral-ethical principles in the work of doctors and junior medical staff. It is the study of the nature of duty and obligation. Deontology is directed to the creation of maximum favorable atmosphere for effective treatment of patients.

Under present-day conditions a good doctor is not only a person who received a proper professional training, but is able to apply knowledge for the benefits of patients and keeps to the norms of medical deontology. It is a matter not only of a proper behavior of medical staff but also elimination of harmful consequences after inadequate activity of a medical worker.

Universal moral standards must be the highest for a modern doctor. Therefore, he/she cannot but follow the conceptions of moral and value character in the process of making a decision. The doctor moderates as an expert who on the basis of clinical data and examination findings makes the final diagnosis, explains to the patient everything concerning disease paying attention to patient's everyday problems.

During the first visit a doctor of any specialty has to come down the patient, remove emotional stress, target $\mathrm{him} / \mathrm{her}$ to successful treatment, and inspire the hope in recovery. To solve this difficult task a complete contact and mutual understanding, patience, ability to listen to the patient, empathy with his sufferings are essential [2].

In addition to medial-biological and general training in the process of learning a future doctor should master the foundations of many medical subjects, be able to examine and treat patients on a high professional level. In their turn, patients require special attention, sympathy and ability to understand their worries. Professional 
training of a medical specialist requires from a person who decides to devote his life to medicine self-sacrifice and self-improvement, maximum efficiency of moral and physical energy, devotion to work, since human life and health, the most valuable things, are in the hands of doctors. In this respect, educational-professional work should be carried out with students both during classes and after them for the whole period of studies at a medical university.

Seeing a patient the student must keep to essential elements of communicative skills, that is, nice smile during first meeting and communication, greeting, introducing, formation of confidence, colleting anamnesis, substantiation of reasonability to conduct appropriate physical methods of examination, explaining the results of examination and planning the following actions, and completion of talk.

A future doctor should master the art to listen to the patient. Certain tactfulness and patience are essential in order not to interrupt and listen to the end. Careful listening enables to understand patient's inner world with all his worries and anxiety, promotes to establish a good contact and mutual understanding.

Relations of a doctor with co-workers and whole medical staff are one of the most important parts of medical ethics requiring a lot of knowledge and training, proper behavior and self-control, good breeding and self-education. Rude manners, tactlessness, unfriendly relations between medical staff members are not acceptable inside the medical institution. Only the atmosphere of friendship, kindness, sympathy, concern and mutual support should be dominating. In other case you will fail to achieve effective psychotherapeutic effect on patients' minds [3].

Confidence is one of the cornerstones in medicine. The patient will choose only the specialist he entrusted. Doctor's contact with the patient is already the beginning of the therapeutic process. A doctor who is not entrusted with patient's confidence and who does not care about relieving patient's mental sufferings cannot treat. To gain the patient's confidence and prestige one should be good doctor. To be a good doctor one should not only increase professional knowledge but improve moral qualities as well (kindness and love for people). It must become a habit.

One of the main ethical and moral principles is keeping medical secrecy: the doctor does not have the right to disclose confidential information about his patient and express a doubt concerning the results of recovery. Medical secrecy is the information the doctor gets while performing his duties.

Ethical commitment of a dentist is to respect the patient's right to make a decision himself. At the same time, dentist's work is inevitably affected by such human factors as subjective opinion, fatigue, lack of time, errors of other people, technical failure etc. Today specific activity of a dentist includes a comprehensive implementation of bioethical principles: personal autonomy, privacy, written consent, dignity, voluntariness, vulnerability, justice. Patients want to believe that their doctor always makes a correct diagnosis and never makes an error in treatment, but sometimes it is not so. The combination of human relations and technological things increases probability of medical errors. Ethics requires from the doctor to inform his patient about his possible errors made in case they influence upon the patient's health. Open recognition and analysis of errors will benefit both the patient and dentist in practical work [1]. 
Medical workers must know and always keep to the legal and moral standards ensuring professional perfection of work and its ethical-deontological direction. It is precisely this fact that will be the earnest of success of a modern doctor.

\section{References:}

1. Rybalov O.V., Lytovchenko I.Iu., Kolomiiets S.V., Prochankina V.L. Deontolohiia i profesiina etyka $\mathrm{v}$ diialnosti likaria-stomatoloha. [Deontology and professional ethics in the activities of a dentist. Ukrainian Dental Almanac]. Ukrainskyi stomatolohichnyi almanakh. 2018. № 2. S. 37-40. [in Ukr.]

2. Kornaha S.I., Denefil O.V., Mandzii Z.P. Etyka i deontolohiia v navchalnomu protsesi studenta-medyka. [Ethics and deontology in the educational process of a medical student]. Medychna osvita. 2014. № 4. S. 48-50. [in Ukr.]

3. Semenoh O., Kravchenko O. Formuvannia profesiinoi etyky maibutnoi medychnoi sestry u vymirakh pedahohichnoi dii: monohrafiia. [Formation of professional ethics of the future nurse in the dimensions of pedagogical action]. Cherkasy: Chabanenko Yu. A., 2014. 304 s. [in Ukr.] 


\title{
SCAFFOLDING IN THE FOREIGN LANGUAGE LEARNING PROCESS OF TERTIARY EDUCATION
}

\author{
Nykyporets Svitlana \\ lecturer at the Department of Foreign Languages \\ Vinnytsia National Technical University
}

The term "scaffolding" was first used in 1976 by David Wood and Jerome Bruner. After analysing the process of problem solving in pairs, consisting of an expert and a novice, the authors described scaffolding as a process by which an expert motivates a novice to solve more complex problems. In this sense, an analogy can be drawn between scaffolding and such pedagogical support that allows the child to function at a higher level, the level of his zone of proximal development (ZPD). "Scaffolding is a process that enables a learner to solve a problem, complete a task, or achieve goals that are beyond their individual endeavours of capabilities." [1]

"Scaffolding" is a metaphor describing a special type of instruction process that takes place in situations of interaction between the teacher and students in solving educational problems. "Fading help" from the teacher at the beginning of the training can be frequent and meaningful, and by the end of the course it is significantly reduced or absent altogether.

Basic principles of scaffolding are as follows:

$\checkmark$ the problem does not change, but the level of support for the student's actions to solve it varies;

$\checkmark$ the support level changes from maximum to minimum until it ends completely;

$\checkmark$ the invariable nature of the task is especially important for those tasks in which their simplification, in essence, changes the very nature of the knowledge that the learner should master.

As the learner acquires new actions or new information, responsibility for completing the task shifts from the adult to a distributed form and then to the child himself. All types of support are temporary and gradually decrease as the student becomes more independent.

Scaffolding is also referred to as a method of instructing learner who encounters difficulties in work or learning - this is a learning strategy or, as R. Zhao and M. Orey [2] believe, this is a special type of instructing process that takes place in situations of interaction between a teacher and learner to solve problems.

The specific strategies used in the scaffolding process, the educator can vary depending on the nature of the task and the characteristics of the learner, for example, in one case, simulate the correct action, and in the other, indicate a missing step in its implementation.

There are three stages of scaffolding:

1) contingency or dependence;

2) "fading aid";

3) transfer of responsibility [2]. 
At the first stage of scaffolding, the teacher selects the educational material of the lesson in accordance with its tasks and capabilities, determined by the level of training of students (level of competence), assists students in completing assignments, serves as a source of information, organizes students' independent work using clear instructions and recommendations, and controls results.

Gradually, the help from the teacher becomes "fading", the teacher transfers part of his functions to the student, simultaneously increasing the responsibility of the student. The teacher observes and if necessary helps with advice, reminds, consults, together with the students discusses and corrects the results of their activities. Power of "fading" depends on the level of training of students and the level of their competence.

Fading is related to the third characteristic of scaffolding - the transfer of responsibility. Through "fading away," responsibility for the task is gradually transferred to the student. The third stage of scaffolding assumes that the teacher does not give advice, but only structures and inspires the search for an independent solution. The stage of transferring responsibility assumes a high level of mutual understanding [2].

The authors deduce two basic rules: to help a beginner in performing tasks that he cannot yet cope with; and also allow the learner to perform such a volume or such a number of tasks that he can already cope with independently. It is believed that the main indicator of scaffolding is "fading aid" from the side of the teacher, i.e. a decrease in the degree of intensity of assistance until the moment when the student becomes completely independent and autonomous, and by the end of the training it is significantly reduced or absent altogether.

Typically, scaffolding techniques are such as activating existing knowledge, prompting students about the best strategy for completing an assignment, using the "thinking out loud" tactic, speaking or vocalizing the process of thinking about an assignment after completing it, questions, collaboration, modelling, stress reduction techniques, practical assistance, etc.

At the same time, our practice with the groups of bachelors and masters of power engineering at the Faculty of Power Engineering and Electromechanics in Vinnytsia National Technical University shows that the scaffolding strategy is more appropriate in the system of higher education, especially for undergraduates and graduate students, and it is difficult to apply it in the adaptation system due to the insufficient competence of both young specialists and sometimes the teachers themselves.

With all the diverse learners in our classrooms, there is a strong need for teachers to learn and experiment with new scaffolding strategies. Scaffolding a lesson may, in fact, mean that it takes longer to teach, but the end product is of far greater quality and the experience much more rewarding for all involved.

So as we see, within the framework of modern changes and the introduction of a new educational standard, when the lesson becomes focused on the student's personality, the use of scaffolding technology helps students to achieve the goals and objectives set for them in the lesson. 


\section{References}

1. Pol J. van de, Volman M., Beishuizen J. Scaffolding in Teacher-Student Interaction: A Decade of Research. (2010) Available at: http://link.springer.com/article/10.1007/s10648-010-9127-6/fulltext.html

2. Zhao, R., and Orey, M. (1999). The Scaffolding Process: Concepts, features, and Empirical Studies. University of Georgia Press.

3. Scaffolding. Available at: http://epltt.coe.uga.edu/index.php?title=Scaffolding

4. Wood D., Brooner J.S., and Ross G. (1976) The Role of Tutoring in Problem Solving. Journal of Psychology and Psychiatry (17).

5. Lange, V. L. (2002). "Instructional Scaffolding". Available at: http://condor.admin-ccny.cuny.edu/ group 4/cano.doc.

6. 6 Scaffolding Strategies to Use With Your Students. Available at: https://www.edutopia.org/blog/scaffolding-lessons-six-strategies-rebecca-alber 


\title{
CONTEMPORARY PEDAGOGY CHALENGE INSUING FROM THE COVID SITUATION AND FORCED DISTANT EDUCATION
}

\author{
Oleynik Olga \\ Senior lecturer \\ Dnepripetrovsk state university of internal affairs
}

No matter how hard scientist are working to reveal the most important issues that are in direct relation to the shaping of our future and even today's reality no efforts can be considered as sufficient. And as just we start thinking, that we got accustomed to one way of things to happen, even learnt to cope with some more or less stable range of fluctuation in variables, which life brought to the process of education.

We can never underestimate the real need in increasing the literacy of population all over the globe, but to our opinion the most vicious thing that is about to happen is the dramatic downturn in the level of education if the approaches for distant education (that not deliberately turned out to be the today's reality for many teachers and students) will remain just the same.

The approaches that work for offline education (at least not all of them) are suitable and efficient for a distant form of education, to say nothing of those obsolete methods still used in the study rooms as those that are considered to belong to classical or old school methods. And the most ridiculous thing about what is happening in one of the most important spheres of human beings' activity is when advances technologies are being tried to be drown onto those methods to represent the ensuing transformation as a new and effective way of education. But the matter of fact is that the result of described above actions is a some kind of disability.

We cannot escape mentioning some sort of discrimination that occurs against those participants of educational process, who simply do not possess corresponding equipment that would meet the requirement and be able to eliminate lags and going downs of the system.

Considering all this, we can summarize, that educational process under such conditions will give and already giving poor results in terms of residual students' knowledge.

All above said gives as the real picture of the state of affairs in the sphere of distant education as it is currently.

Among all the disadvantages of distant education the most vicious and notorious is the tearing apart of the connection between the master (teacher) and the student. The authority, aspiration to knowledge and inspiration for achievement has been deprived 
from both sides through the depriving of that sacral connection. Which is a sly plan of making a whole generation of people of one button.

Fortunately, those who realize what is going on find the way to restore the connection and adjust to the given conditions by changing the approach using the technologies for good and new methods of teaching are being developed, they take into account the experiences of the best result giving approaches and invent new.

And those are NOT tests! Tests cannot be used for teaching. Tests are one of the worst type of students` check and cannot be represented as main form of revision. It deprived from students creativity skills and ability to express thought. Which can in not such a distant prospective give rise to ignorance and ignorance can give rise to destructions in all possible ways of its manifestation.

References:

1. Collen Peters Halupa RISKS: THE IMPACT OF ONLINE LEARNING AND TECHNOLOGY ON STUDENT PHYSICAL, MENTAL, EMOTIONAL, AND SOCIAL HEALTH, available at electronic resource: https://www.researchgate.net/publication/311362980_RISKS_THE_IMPACT_OF_O NLINE_LEARNING_AND_TECHNOLOGY_ON_STUDENT_PHYSICAL_MENT AL_EMOTIONAL_AND_SOCIAL_HEALTH

2. THE IMPAC $\overline{\mathrm{C}}$ OF ONLINE TEACHING ON HIGHER EDUCATION FACULTY'S PROFESSIONAL IDENTITY AND THE ROLE OF TECHNOLOGY: THE COMING OF AGE OF THE VIRTUAL TEACHER: By EDWIGE SIMON, available at electronic resource: https://www.colorado.edu/atlas/sites/default/files/attachedfiles/the_impact_of_online_teaching_on_higher_education_faculty.pdf 


\title{
CLOUD TECHNOLOGIES FOR DISTANCE LEARNING OF ENGLISH
}

\author{
Olha Shalaieva, \\ Teacher of English \\ Professional Pedagogical College \\ Ivan Franko National University of Lviv
}

The article is devoted to the analysis of distance learning through Internet resources that can be used in the study of a foreign language. The most popular and accessible resources are named in the article. It also analyses positive and negative aspects of using cloud services in learning and teaching process.

In today's world the term "Distance Learning" appeared due to the society needs and in a short period of time combined all the benefits of using modern technologies in the educational process, namely the use of cloud technologies, social networks and multimedia with traditional methods. There are many approaches and interpretations of the term "distance learning". If you consult the English Dictionary of Pedagogical Terms, an explanation of this term is: «Distance learning - taking classes in locations other than the classroom or places where teachers present the lessons. Distance learning uses various forms of technology, especially television and computers, to provide educational materials and experiences to students" [1]. The author of the monograph "Theory and methods of informatization in education", I.V. Robert defines the term "distance learning" as a process of educational interaction between student, teacher and interactive source of information. Usage of Information Computer Technology (ICT) is the main requirement in knowledge transfer, forming of skills and abilities [2].

Thus, having analyzed the author's definitions and definitions from dictionaries, we can conclude that the main components of the concept of "distance learning" are: the subjects of the process; components of the educational process (teaching aids, organizational and control methods); ICT tools.

It should be noted that distance learning of foreign languages focuses on the effectiveness of learning communication skills, technological aspects of language learning and autonomous learning. Based on the results of the study, a number of advantages of distance learning in higher education are obvious: access to knowledge, regardless of the location of the student or teacher; reduction of university costs (rent, utilities, etc.); the possibility of conducting classes for a large audience of students; increasing the amount of independent work; raising the level of knowledge through the use of modern ICT tools.

Distance learning technologies represent new opportunities for teaching foreign languages, which allow to expand the range of teaching methods. It is important to review these distance learning options to distinguish their ability levels, as these systems have different limitations on the learning process. For example, one-way systems that use only presentations have been criticized for not providing anything other than a video distribution system that could be reproduced by sending videos to students. The lack of bilateral interaction, which characterizes many distance education 
programs, is contrary to the goals of foreign language teaching. However, using this interaction, distance technologies can maintain the integrity of foreign language teaching. Learning strategies that encourage student-teacher dialogue and student autonomy in distance learning situations should be included in learning.

As far back as 1988, the governments of Britain and Canada were already trying to teach languages through distance learning. Students worked using a workbook and audiocassettes. According to the defined program in each block the teacher gave the student feedback by phone. The telephone conversation also provided the student with oral practice. The teacher recorded a telephone conversation and sent the student a tape to watch. The evaluation of the 1988 program showed that both teachers and students were satisfied with the program.

Today, there are electronic devices, many social networks and learning platforms that allow teachers to conduct distance learning in the same but improved ways. The use of e-devices such as the Internet and multimedia is the main means of providing elearning, and content, technology and services are the three key sectors of e-learning.

Digital learning management systems in Education are:

Blackboard - is an application for interactive learning, creating initial groups and sharing knowledge.

CenturyTech is a platform with tools for distance learning.

ClassDojo is a communication platform for the school that teachers, students and parents use for distance learning at school.

Edmodo - tools and resources for classroom management and distance learning for students.

Edraak - creation and publication of interactive educational content.

Google Classroom is a free web service created by Google for educational institutions to facilitate the creation, distribution and classification of tasks without paper.

Moodle - a learning platform designed to unite teachers, administrators and students in one reliable, secure and integrated system to create a personalized learning environment

Schoology is a virtual learning environment for schools and universities that allows users to create, manage and share learning content

Seesaw is a platform for creating digital learning portfolios and learning resources.

Skooler - tools for turning Microsoft Office software into an educational platform.

To learn a foreign language using multimedia technology, students must be independent and use new strategies. Because language learning in the traditional way usually takes place in live communication, and distance learning through Internet communication is a slightly different system without the participation of live contact. Through the use of the Internet, students can strengthen their communication skills, learn about different cultures and improve their skills such as listening, speaking, reading and writing. As you study online, anxiety decreases and responses are quickly transmitted and students become more confident. Teachers try to integrate the Internet with their learning materials and learning styles to create a meaningful learning environment. Students gain autonomous use of the Internet, with some favorable factors influencing this process: 1) using the Internet, students have the opportunity to 
choose their own methods, teaching materials and depth of study; 2) self-control; 3) cooperation; 4) websites that provide a large number of texts for listening, speaking, reading and writing; 5) online journals for learning English; 6) chat.

The expansion of international relations encourages educational institutions to reach a level of student training at which students will be able to participate in intercultural communication in a foreign language. Global informatization of society contributes to the wider use of information and communication technologies (ICT) in the educational process. Among them, the most promising for use in educational institutions are cloud technologies.

Cloud technology services can be classified by functionality [3]:

1. SaaS (Software as a Service) - software as a service. This type of cloud technology makes it possible to use Internet software in education. In English language teaching, this type of service can provide students with access to e-mail, various educational sites, blogs, video, audio, materials on the Internet. For example, Google Apps for Education provides Internet technologies and tools to create an educational environment, and Microsoft Live@edu is used in the learning process to provide students with all the necessary online tools without additional costs for software, hardware and support.

2. PaaS (Platform as a Service) - platform as a service. The service provides a set of programs, services and libraries that can be used to develop your own electronic educational resources (EER). An integrated platform can be provided to develop, test, and support web applications based on cloud computing. This type of service can be used to develop integrated applications that use "in the cloud" for joint research.

3. HaaS (Hardware as a Service) - providing hardware capabilities as a service, such as a certain amount of memory, CPU time, bandwidth, etc.

4. IaaS (Infrastructure as a Service) - can be considered as the development of HaaS technology, which involves the provision of certain systems that underlie the construction of other systems, such as virtualization, load balancing, and so on. IaaS may include hardware (servers, storage systems, client systems and equipment); operating systems and system software (virtualization tools, resource management); interconnection software (e.g. network integration, hardware management). The application of this technology makes it possible to eliminate the need to support complex data processing infrastructures, client and network infrastructures.

5. CaaS (Communication as a Service) - a new type of service that is a development of SaaS technology. Communication services, such as IP telephony, mail, chat, are provided as a service. For example, e-mail is used as a service for an educational institution.

6. DaaS (Desktop as a Service) - users receive as a service a fully operational virtualized workplace. This service is a development of SaaS technology, which has become widespread in recent years.

Significant cost reduction is a solution to the problem of ensuring equal access to information technology due to the fact that quite powerful resources can be obtained via the Internet, determine the popularity of cloud technologies in the educational process. However, it is worth noting some shortcomings of cloud technologies, mainly technical and technological. These include limited functionality of the software 
compared to local counterparts, insufficient number of cloud service providers (Amazon, Google, Salesforce and others concentrated in the US), limited international standards, as well as the lack of a legal framework for the use of cloud technologies.

The main goal of learning a foreign language is the formation of communicative competence, the ability to obtain fairly complete information when reading foreign texts, the ability to understand the interlocutor, as well as to express their views, points of view orally and in writing. Thus, the purpose of learning is not so much knowledge of the language itself, as the development of certain skills and abilities of different types of speech activity based on knowledge of the method of activity [4]. Cloud technologies make it possible to integrate various active learning methods into the information environment. To achieve this goal, the most popular and affordable Internet services are as follows:

1. Google Docs - is an online office where you can create various documents, as well as provide the ability to collaborate with documents;

2. OneDrive - similar to the previous service of Microsoft;

3. Scribd - an online cloud storage service that allows you to publish documents prepared in most popular formats: Microsoft Office, Open Office, Adobe Acrobat, etc.;

4. SlideShare - online storage of presentations;

5. Google Scholar - search engine for educational and scientific publications;

6. YouTube - a service that allows you to download and watch videos in the browser;

7. Wikipedia - an online encyclopedia based on Wiki technology;

8. Blogger is an Internet service in the form of an online diary (or blog);

9. Byju's is a learning app with large repositories of educational content designed for different classes and levels of learning.

10. Discovery Education - free educational resources and lessons about viruses and diseases for different classes.

11. Khan Academy - free online courses and lessons.

12.Dingtalk is a communication platform for video conferencing, task and calendar management, attendance tracking, and instant messaging.

13. Lark is a set of collaboration tools, including chat, calendar, content creation, and cloud storage.

14.Hangouts Meet is Google's instant messaging and video conferencing software.

15. Teams - a platform for chat, online meetings and collaboration, integrated with Microsoft Office software.

16. Skype - a program for video and voice communication.

17. Zoom - a cloud platform for video and audio conferences and webinars.

Thus, the use of cloud technologies in the study of a foreign language has become a necessity. While traditional teaching methods almost always focus on the role of the teacher, who is the central figure in the learning process, cloud technologies, which use diverse Internet resources, increase the role of students in the learning process and focus on their self-preparation, and the teacher acts only as a coordinator. 


\section{References:}

1. Pedagogical Vocabulary "The language of Instruction" / C. W. Branco - Kean University: College of Education, Teaching Performance Center. - 65p. [Electronic resource] - Mode of access: https://www.kean.edu/ tpc/

2. Robert I.V. Theory and methods of informatization of education (psychological, pedagogical and technological aspects). - 2014. - 398 p. [Electronic resource] - Access mode: https://docplayer.ru/30279183-Teoriya-imetodikainformatizacii-obrazovaniya.html

3. Kravtsov G.M, Gnedkova O.O Methods of using cloud services in foreign language teaching [Electronic resource]. Access mode:

http://elibrary.kdpu.edu.ua/jspui/bitstream/0564/2456/1/paper8.pdf

4. Methods of teaching foreign languages: a textbook / Col. authors under the guidance of S.Y. Nikolaeva. Kyiv: Lenvit, 2019. 320 p. 


\section{THE PRACTICAL EXPERIENCE OF ORGANIZING CLASSES IN THE FORMAT OF DYNAMIC TRAINING USING THE TECHNOLOGY OF THE WORKSHOP}

Shulska Nataliia, $\mathrm{PhD}$ in Philology, Associate Professor in The Department of Social Communications Lesya Ukrainka Eastern European National University, Lutsk, Ukraine

Rymar Nataliia, $\mathrm{PhD}$ in Philology, Associate Professor in The Department of Slavic philology, pedagogy and teaching methods Bila Tserkva National Agrarian University, Bila Tserkva, Ukraine

The modern educational system of Ukraine is developing dynamically due to geopolitical, social, economical, information factors. The movement of our country towards the European intellectual space actualizes the increase in university education quality. In this regard, a national educational process is aimed at the search of new ideas, concepts and technologies which will not just formally meet international standards but will also modernize Ukrainian education toward improving its quality, and promoting equal access to it throughout life. One of the priorities of national policy is the development of the information society through the educational system, in particular by introducing the latest information and communication technologies (ICTs) into the educational process. N. Grytsyshyna states in her research that a «contemporary graduate must have a number of competencies, not just a set of knowledge and skills that are not always possible to form by means of traditional ways of learning» [1, p. 49].

New approaches and requirements to students' professional development lead to substantial changes of the methods in the educational process, content and tools of training practice. Indeed, modern teacher, in addition to a thorough knowledge of the subject, should be able to deliver educational material to students on advanced scientific level but at the same time skillfully and creatively applying innovative information technology methods and ICT. The vector of university lecturer's activity increasingly shifts towards the application of information and communication technologies (ICT) and innovative forms of work with students both in class and in extracurricular time. On this account I. Konovalchuk observes: «A significant role in the innovative educational processes is assigned to information and communication technologies (ICT) that serve as effective means of gathering, processing, storing, transmitting the information necessary to provide scientific, methodological, informational, managemental and general advisory support for developing innovations in secondary schools» [2, p. 124]. Unconventional, interesting, active methods of education with using ICT help students to develop communicative competence, train 
them to successfully solve problems and overcome challenges, to prove and substantiate their own opinion, to show organizational skills, to make strategic decisions and so on.

Focusing on European practices, Ukrainian universities are actively implementing innovative educational technologies, such as distance learning, e-learning, mobile learning (m-learning), blended learning, applying interactive learning techniques, etc. According to O. Korotun, «this is due to the availability of high-speed Internet, high level of trainees' computer literacy and advanced technical (computer) equipment at higher educational institutions» [3, p. 117]. In order to improve the efficiency of specialists training and learning activities in universities and to direct them into active interaction, teachers at the lectures and practical classes are increasingly using interactive techniques and ICTs: business games, online master classes, video collections, training workshops, training forums. Such technologies are extremely popular, as «they provide large-scale exchange of experience between practice and theory, give students an opportunity to study real examples, to demonstrate gained knowledge and prove themselves as good specialists in the future» [4, p. 338].

We fully support the opinion of the scientists that the use of ICT indicates the benefits of traditional teaching methods in the context of the implementation of a person-oriented approach, since they contribute more to the implementation of the principles of individualization and differentiation of educational process, expanding its content, enhancing the intensification and effectiveness of learning in general $[5, \mathrm{p}$. 7]. Little tested, but very promising in terms of university education process is such innovative technology as workshop. Under workshop we understand innovative technology, characterized by intensive activity of both training activities subjects (trainers and trainees) aimed at practical implementation of the acquired knowledge and skills. In the article we take as the key definition of the workshop the definition, introduced by its founder in education K. Fopel: «The form of intensive training event where participants learn first of all, thanks to their own active work in groups» [6, p. 13]. We unanimously support the idea that the workshop is a form of dynamic learning.

We found only a few publications devoted to studying the use of workshop technology in teaching. Thus, O. Kudyrko focused on the methodological aspect of adapting workshop technology to practical classes at universities [4]. It her turn N. Grytsyshyna defined workshop as one of new forms and methods of teaching foreign languages [1]. S. Litvinenko described the peculiarities of using workshop technology while preparing future psychologists to professional activity [17]; $\mathrm{N}$. Borynets focused on workshop technology application in design and technology training at schools [18]. All researchers who to a certain extent examined workshop as educational phenomenon agree that it is a special form and technology of adult groupwork which is filled predominantly with interactive forms of work. The leading role in acquiring knowledge and decision-making belongs to the participants of educational groups themselves $[17$, p. 10-12]. The technology of the workshop in education was partially researched by foreign scholars such as N. Manouselis, 
H. Drachsler, K. Verbert and O. Santos [19]; J. Yost, D. Ciliska and M. Dobbins [20]; L. Uden, J. Sinclair, Y. Tao and D. Liberona [21] and others. However, there are not many of such researches and they all relate to the workshop as a traditional «educational practical class». Despite the introduction of innovative communication technologies, new creative forms of work with students, distance and blended learning which resulted in growing number of research on the innovative techniques adoption by teachers in recent years still there are no comprehensive studies devoted to the analysis of workshop technology in university education. In this connection, attention is paid to the analysis of the peculiarities of the ICTsupported workshop technology in the educational process in higher school. At the present stage up-to-date studies aimed at summarizing experience of ICTsupported workshops are high up on the agenda. Certainly it is appropriate to do the step-bystep study of the workshop-class organization, especially in terms of specific professions or disciplines; determine the positive and negative aspects of the specified educational method implementation. It is also important to describe the teacher's role and duties as a leader, manager or moderator while organizing an event in the form of workshop. Due to the fact that the educational process in universities involves information technologies and multimedia, it would be appropriate to explore the possibility of providing workshops for university students with information support which will not only provide additional technical capabilities, but can generally be conducted online. All these abovementioned points have been the object of our study.

The special advantages of conducting lessons in the format of the workshop using ICT are also shown in the application of a variety of methods for working with students: these are brainstorming, lecture-dialogue (interactive lecture), work in pairs, small group work, discussions (debates, dialogues), presentations, demonstrations, simulations, action learning (skills training), games (business, role), video training, case method, focus group, aquarium, show, tour [16, p. 4]. This educational technology also has great potential in terms of physiological and psychological characteristics of those who take part in it, because, as it is known, physiologically a person assimilates only $10 \%$ of the read information, $20 \%$ of information is perceived aurally, 30-40\% from the data portrayed in the visual form, $60 \%$ - during the oral discussion, $80 \%-$ in the process of independent search and problem formulation, $90 \%$ - in the process of independent problem formulation and solution. The workshop technology most completely realizes the last two practices while the work within study group studio with clearly defined thematic focus provides independent formulation and joint solution of problem tasks. We see the uniqueness of the workshop technology in the fact that on the one hand it provides independent learning of each participant and on the other - team learning, since workshop provides a certain dynamic work of microgroups. This technology leads to the creation of imaginary educational studio in which students who are learning a discipline become active members of the group with imaginary roles. Workshop allows translating theoretical knowledge into practice during the active communicative interaction, it helps to build a model of learning in 
which action prevails and that distinguishes this technology from others. Receiving actual experience in terms of group work is a major component of successful educational workshop. Successful organization of workshop requires great effort from teacher, because: «... well-organized workshop provides a set of different methods, activating participants and incorporating them into group discussions and reflections, as well as independent knowledge acquisition» [17, p. 11]. In order to truly become a high-performance educational studio workshop on the one hand should imply great work intensity within the whole group and on the other it should provide maximized independence and activity of each participant. Major role is also assigned to the supervisor (moderator) - the expert of workshop, because he/she directs the activities of participants into educational track, selects the methods and techniques to obtain good results, effectively controls the whole learning process. Teacher (invited expert) must observe the following key components to effectively conduct workshop: the moderator should choose those educational techniques that fit the situation and the specific group of students; during the class it is necessary to maintain the climate of acceptance; the feeling of trust should dominate in a study group. He must also have high qualification skills of the trainer and consultant, highest level of information and communication competence, be a good actor, since repeatedly you need to quickly switch from one role to another one. A teacher must have a firm grasp of the proposed technology, know all the peculiarities of the participants group; be sure of tools used and consistently carry out all tasks. Because in the end the workshop class should achieve its main goal: every student - participant of the workshop should discover more than they knew of the topic and be able to do more than they could before.

In addition, the workshop should be organized so that each stage of training is interesting and semantic, giving the chance to manage the educational process. The group of participants should keep positive atmosphere of support, respect and recognition providing everyone with the opportunity of open communication. We believe that for workshop to become a productive educational activity it is necessary to organize educational process in such a way that skills evolve gradually. Given the physiological and psychological characteristics of each group member, the teacher should involve visual, emotional, tactile, auditory, verbal and nonverbal abilities of each student in a three-hour mini-workshop.

The short-term intensive integrated workshop entitled «Editorial and publishing guidance for freshers handbooks» consisted of the following educational steps: 1) teacher (workshop moderator) organizes an active group of third-year students and announces workshop; 2) students formulate the goals, objectives and identify the methods of operation within the imaginary training studio; 3) students watch online master class on the manual method of brochures preparation and manufacturing; 4) students watch a video presentation in the form of interviews with first-year students; 5) students formulate and present the concept and content of the future publishing product; 6) students discuss and choose the actual concept for further work with the freshers guide in the form of brochure; 7) students manually work on a guide-advisor 
for first-year students using improvised means; 8) Students summarize results - get ready the final publishing product.

A mini-workshop (1,2 hours) on the topic «Rules for the design of a bibliography» was organized during the class «Professional Workshop». In order to achieve a dynamic effect and maximum practical nature, in addition to a moderator-in-charge, specialists of the university library were involved - the staff of the bibliographic department. Having previously obtained brief theoretical information about the reference and bibliographic apparatus of the publication directly from the specialists, students in practice implemented their bibliographic skills, working with the virtual help, electronic library catalogue. As a result of the workshop, students deepened their knowledge of bibliographic description of documents, as well as learned to incorporate lists of literature into scientific works, bibliographic indexes, etc. During the organization of such an occupation, the workshop involved technical (multimedia) support, as the workshop participants could virtually travel online through the electronic library site, use the electronic catalogue, receive the necessary information from the virtual reference. Moderators also used multimedia presentations, additional electronic materials, etc. during workshop.

The analysis of the researches on the possibilities of using the workshop technologies in education, allow us to draw the following conclusions. Workshop activities using ICT have significant advantages over traditional teaching. Among them, the most important are the following: the predominance of practical exercises over the theoretical; personality-oriented approach taking into account psychophysiological peculiarities of learning participants; the educational process has both independent and collective character, dynamic learning; the dominant role of students and a less active role of teacher; comfortable, easy learning through the changed role of the teacher (teacher is now only a moderator); the presence of multimedia support, innovative role-play techniques.

\section{References:}

1. N. Hrytsyshyna, "Workshop technology as one of the new forms and methods of teaching a foreign language by students", Almanakh sovremennoi nauky y obrazovanyia. no. 3 (58). p. 49-51, 2012. (in Russian).

2. I. Konovalchuk, "Information and communication technologies in modern models of innovative educational processes" Informatsiini tekhnolohii i zasoby navchannia. т. 46, no. 2. p. 124-131, 2015. (in Ukrainian).

3. O. V. Korotun, "Methodological masters of mixed education in higher educaton", Informatsiini tekhnolohii v osviti. no. 3(28). p. 117-129, 2016. (in Ukrainian).

4. O. Kudyrko, "Workshop: nature and methodical feature of application workshops on classes by students of higher school", From teaching subjects to the mastering of sciences: the transformation of content, technology education and the development of educational skills, Kyiv, 2013. p. 338. (in Ukrainian). 
5. L. Ye. Pethukhova, O. V. Spivakovskyi, "Actual questions of formation of informative competences of future teachers of elementary school", Kompiuter u shkoli ta simji. no. 1. p. 7-11, 2011. (in Ukrainian).

6. K. Fopel, The effective workshop. The dynamic learning. Moskva, Rossyiskaia Federatsyia: Henezys, 2003. (In Ukrainian).

7. O. S. Voronkin, "Information and communication technologies as a key factor of innovative development of hicher educatoin: global dimension", Informatsiini tekhnolohii i zasoby navchannia. т. 55, no. 5. p. 12- 30, 2016. (in Ukrainian).

8. O. S. Voronkin The basics of using ICT in modern higher school: textbook Luhans'k, Ukraina : LDIKM, 2011. (in Ukrainian).

9. O. O. Hovorovska, Informatization of the higher education of Ukraine at the end of XX-beginning of XXI centuries: global, social and cultural dimensions, author report of dis. for getting of scientific degree of the Dr. of History Science, speciality 07.00.01 «History of Ukraine», PereiaslavKhmelnytskyi, Ukraina, 2015. (in Ukrainian).

10. O. O. Hrytsenchuk, "Theory and methodology of ICT application into a social study in abroad and Ukraine: general approaches", Informatsiini tekhnolohii i zasoby navchannia. т. 19, no. 5. p., 2010. Available at: http://www.ime.edu-ua.net/em.html (in Ukrainian).

11. G. O. Kozlakova, T. V. Kovaliuk, "Implementation of ICT in the educational process", Visnyk NTUU «KPI». Filosofiia. Psykhologiia. Pedahohika, no 3(27), ch. 2, 2009. Available at: http://ela.kpi.ua/handle/123456789/9810 (in Ukrainian).

12. M. Yu. Kademiya, I. Yu. Shaikh, ICT in the educational process, navchalnyi posibnyk, Vinnycya, Ukraina: Planer, 2011 (in Ukrainian).

13. S. Petrov, Is workshop a new technology training or a vacation for a coach? Available at:https://newsland.com/user/sergeypetrov/content/vorkshop-novaia-tekhnologiiaobucheniia-ili-otdykhdlia-trenera/5404996. Accessed: May. 31, 2016. (in Russian).

14. O. B. Chikurov, What is a Workshop? Pskov, Bilorus, 2001. (in Russian).

15. O. Abasaliieva (2015), "Workshop training as a form of ethnic consciousness" III Mizhnarodna dystantsiina nauk.-prakt. konf.Scientific quest XXI century: the youth dimension, Kyiv, 2015. p. 10-14. (in Ukrainian).

16. O. Zaporozhets, "Library workshop as a method of implementation of interactive technologies", Shkilnyi bibliotekar. no. 7. p. 3-6, 2015. (in Ukrainian).

17. S. Lytvynenko, "Using workshops in preparation of future psychologists to professional activity", Onovlennia zmistu, form ta metodiv navchannia i vykhovannia v zakladakh osvity. no. 9 (52). p. 10-12, 2014. (in Ukrainian).

18. N. Borynets, "Technology of workshop in a labor training". Available at: https://www.slideshare.net/ippo-kubg/ss-55431698. Accessed: May 31, 2016. (in Ukrainian).

19. N. Manouselis, H. Drachsler, K. Verbertand O. C. Santos, Recommender Systems for Technology Enhanced Learning: Research Trendsand Applications, Hardcover, 2014. (in English).

20. J. Yost, D. Ciliska and M. Dobbins, "Evaluating the impact of an intensive education workshop on evidence-informed decision making knowledge, skills, and behaviours: a mixed methods study", BMC Medical Education, vol. 14:13. Available: https://www.ncbi.nlm.nih.gov/pmc/articles/PMC3929552/. (in English). 
III International Science Conference on E-Learning and Education

21. L. Uden, J. Sinclair, Y. Tao and D. Liberona, "earning Technology for Education in Cloud. MOOC and Big Data" on Third International Workshop, LTEC 2014, Santiago, Chile, 2014. (in English). 


\title{
ФОРМУВАННЯ ГОТОВНОСТІ МАЙБУТНІХ УЧИТЕЛІВ МУЗИКИ ДО КОНЦЕРТНИХ ВИСТУПІВ
}

\author{
Turukina Olena \\ Senior teacher of the Piano Department \\ Municipal establishment \\ «Kharkiv Humanitarian-Pedagogical Academy» \\ of Kharkiv regional council
}

Специфіка підготовки майбутнього вчителя музики до професійної діяльності вимагає володіння відповідними знаннями, уміннями, навичками. Одним із ключових таких умінь є здатність до концертних виступів, де виконавець зобов'язаний відтворити реальний образ на сцені, який органічно вплітається в музичну тканину твору, розкрити задум композитора, осмислити й зрозуміти музичну дійсність, виявити достатню принциповість, власний погляд на мистецтво.

Варто також зазначити, що в процесі підготовки до концертного виступу майбутній учитель музики включається в активне соціальне життя, своїми зусиллями приносить користь людям, змушує їх рухатися в напряму духовного збагачення, розвивати свої власні здібності. Розглядаючи поняття «здібності» 3 педагогічної точки зору, С. Гончаренко трактує їх як стійкі індивідуальні психічні властивості людини, що $є$ необхідною внутрішньою умовою пї успішної діяльності [1].

Для того, щоб виконання було переконливим, успішним необхідно мати артистичну силу волі, сценічну витримку, упевненість, наполегливість. В. Петрушин пропонує на заключному етапі роботи, коли музичний твір уже готовий для концертного виконання, грати його цілком до самого кінця, не зупинятися, уявляти слухацьку аудиторію [5, с. 295]. Такий прийом допомагає виявити слабкі сторони: можливість сценічного хвилювання, невпевненість у нотному тексті через технічні труднощі, посилену нервовість. Застосування цього прийому декілька разів розвиває у виконавця здатність контролювати власну поведінку, свої емоції, протистояти негативним почуттям та небажаним думкам, дозволяє зробити правильний вибір в інтерпретації музичного твору.

Інтерпретацію ми розглядаємо як необхідну професійну якість майбутнього вчителя музики, яка полягає в створенні інтерпретатором особистісної концепції твору. Інтерпретатор завжди тлумачить твір у межах свого розуміння. I, будучи обов'язковою складовою музичного сприймання, інтерпретація відбувається незалежно від способу сприймання (на слух, 3 нотного тексту тощо), мети (слухання музики, підготовки до виконання), рівня підготовленості [4, с. 21]. Тобто, можемо констатувати, що інтерпретація не створюється спеціально, вона $\epsilon$ природним результатом осягнення музичного твору. Головне - зберігати авторські закономірності.

Розглянемо як відбувається підготовка майбутнього вчителя музики до концертних виступів на індивідуальних заняттях зі спеціального музичного 
інструмента (фортепіано). При доборі репертуару враховуються такі чинники як природні музичні здібності здобувача освіти, його загальна музична підготовка, рівень опанування інструментальною (фортепіанною) технікою, інтелектуальний розвиток, музичні уподобання, психологічна врівноваженість тощо. Емоційно-образний зміст і музична форма інструментальної п'єси мають бути доступними й зрозумілими для майбутнього фахівця. У підготовчому процесі доцільно звертати увагу на формування у виконавця правильного розуміння музичного твору, здійснення слухового контролю, розвиток аналітичного мислення та усвідомлення справжніх цінностей музичного мистецтва, де цінністю $є$ його духовний світ [3, с. 86].

Духовний потенціал майбутнього вчителя музики стає найбільш дієвим під час його концертного виступу. Так, у мистецькому заході «Усе минає, а музика вічна» виконавець зобразив «як хвилі в просторі шумлять, як в струнах чарівні пісні звучать» Е. Гріга «Серце поета» (із циклу «Мелодії серця») [2]. Хвилеподібні пасажі шістнадцятих із нижнього регістру стрімко несуться ввись i завдяки динаміці творять вражаючий колористичний ефект. Безперервність руху створює відчуття нескінченого музичного розвитку твору. Паузи не зупиняють цього потоку, октавна фактура та акцентовані акорди розширюються за рахунок збільшення діапазону звучання. У процесі індивідуальних музичних занять ведеться досить копітка й наполеглива робота над програмними творами. Відповідно до цього постають такі завдання:

- дослідити структуру музичного твору, зробити гармонічний аналіз;

- добрати зручну аплікатуру, щоб не відволікатися на зайві рухи в технічних пасажах;

- оволодіти динамічними та артикуляційними прийомами в музичному творі для збереження емоційної виразності;

- відпрацювати технічні пасажі для більш впевненого виконання;

- дотримуватись правильного відтворення штрихів, педалізації, яка має бути художньо виправданою (пам'ятати, що безпедальне звучання - це теж цікава фортепіанна барва);

- окремо відпрацювати ті елементи, що можуть завадити цільному виконанню (уміти виявити проблемні питання);

- усвідомлювати єдину драматургію музичного твору;

- уміти спрогнозувати свій сценічний виступ (перспективне бачення), оцінити свою інструментальну гру;

- бути мобільним і сконцентрованим під час свого публічного виступу.

Ці завдання зберігаються й у наступній підготовці майбутнього вчителя музики до концертного виступу, присвяченого студентській весні. У цьому плані показовою $€$ інструментальна п’єса сучасної української композиторки Л. Фучаджі «Цирк». Фортепіанний дует відтворює різнокольорові барви циркового мистецтва, де присутні яскраві образи, утілює в реальність загальну інтерпретацію музичного твору. Головним аргументом цієї співпраці $\epsilon$ узгодженість і злагодженість обох виконавців. Варто вказати на те, що заздалегідь визначається спільна концепція виконання твору, рівноправна взаємодія двох партнерів, при цьому зберігається авторський задум, з'ясовується 
форма фортепіанної п’єси, елементи фактури кожної партії, кульмінаційні вершини, темпова єдність, динаміка, штрихи, продумуються відповідні технічні прийоми. Для ознайомлення із твором застосовуються різні способи й прийоми, a саме:

- прочитання нотного тексту за інструментом (фортепіано) по нотах;

- прочитання внутрішнім слухом (подумки проспівується мелодія 3 одночасним диригуванням);

- прослуховування запису своєї власної гри (начебто зі сторони);

- пошук цієї п’єси на каналі YouTube у виконанні найкращих музикантів, що сприяє розвитку в слухачів здатності до аналітичного мислення, емоційноціннісного сприйняття, розуміння цілісної інтерпретації музичного твору тощо.

Складність цього процесу полягає в тому, щоб привчити майбутніх учителів музики об'єднувати отримані знання 3 музично-теоретичних дисциплін із заняттями спеціального музичного інструмента (фортепіано), ефективно застосовувати їх на практиці.

Узагальнивши вищесказане, можемо зробити висновки, що формування готовності майбутніх учителів музики до концертних виступів $\epsilon$ результатом наполегливої праці, що реалізується на індивідуальних музичних заняттях i виступає якісним показником засвоєння здобувачем освіти фахових знань, умінь, сприяє розвитку креативного мислення.

\section{Список використаних джерел:}

1. Гончаренко С. У. Український педагогічний словник. Київ, 1994. С. 127.

2. Гріг Е. Серце поета. Текст. URL : http://www.megalyrics.ru/lyric/edvardgrigh/sierdtsie-poeta.htm (дата звернення : 23.01.2020).

3. Дорош Т. Л. Методика підготовки майбутнього фахівця в галузі музичного мистецтва : електронний навч.-метод. посіб. Комунальний заклад «Харківська гуманітарно-педагогічна академія» Харківської обласної ради. Харків, 2019. 131 с.

4. Крицький В.М. Музично-виконавська інтерпретація: педагогічні проблеми музично-виконавської підготовки : монографія. Ніжин : Видавництво НДУ імені М. Гоголя, 2009. $158 \mathrm{c.}$

5. Петрушин В. И. Музыкальная психология : учебное пособие для вузов. 3-е изд. Москва : Академический проект; Гаудеамус, 2009. 400 с. 


\title{
ОСОБЛИВОСТІ ЧИТАННЯ ЛЕКЦІЙ ІНОЗЕМНИМ СТУДЕНТАМ НА КАФЕДРАХ МОРФОЛОГІЧНОГО ПРОФІЛЮ МЕДИЧНИХ ВУЗІВ
}

\author{
Білаш Валентина Павлівна \\ к.б.н., доцент кафедри анатомії людини \\ Лисаченко Ольга Дмитрівна \\ к.б.н., доцент, доцент кафедри гістології, цитології та ембріології \\ Срошенко Галина Анатоліївна \\ д.мед.н., професор, завідувачка кафедри медичної біології \\ Українська медична стоматологічна академія
}

\begin{abstract}
Морфологічні кафедри медичних вузів вивчають фундаментальні дисципліни, які закладають базис знань майбутнього лікаря, формують теоретичну основу його практичної діяльності та нерозривно пов'язані з усіма напрямками медицини. Завдяки вивченню цих дисциплін студент-медик пізнає загальні закономірності життєдіяльності здорового організму та приступає до вивчення клінічних дисциплін. Без глибоких знань законів життєдіяльності клітин, тканин, органів, взаємовідношення організму людини 3 навколишнім середовищем, неможливі розкриття закономірностей порушення функцій організму та пошук механізмів їх відновлення, попередження виникнення хвороб, їх діагностики і лікування. Теоретичні знання набуті студентами на кафедрах морфологічного профілю являються базисом та підгрунтям для вивчення клінічних дисциплін на старших курсах навчання в медичних вузах [1]. У зв’язку з цим, організація навчального процесу на даних кафедрах направлена на орієнтацію студентів до їх майбутньої практичної діяльності, пов’язаної 3 професією лікаря, особлива увага приділяється при цьому постійному удосконаленню методів викладання дисциплін та контролю знань студентів під час занять.

Викладання морфологічних дисциплін (гістології, цитології, ембріології та анатомії людини) проводиться згідно розроблених робочих програм для студентів, що навчаються по спеціальності «медицина» і «стоматологія». Курс дисциплін складається 3 лекційних годин, практичних занять і самостійної роботи студентів. Для читання лекцій на кожній з кафедр підготовлені текстові варіанти лекцій, мультимедійні презентації та методичні розробки мовою викладання, які адаптовані до сприйняття іноземними студентами (не містять складних мовних зворотів, наукова інформація подається у стислій і лаконічній формі). Лекції мають велике значення для якісного засвоєння знань та виконують важливу роль в освітньому процесі. Досвідчені викладачі подають матеріал, що містить не завжди легко доступну для аудиторії інформацію, яку студенту важко знайти самостійно. Лекції характеризуються такими критеріями продуктивності,
\end{abstract}


як доказовість і аргументованість змісту, науковість та інформативність. Зазвичай лекційний матеріал яскраво оформлений, а тому привертає увагу студента, містить достатню кількість переконливих прикладів і фактів, має чітку структуру змісту та логіку його розкриття. Під час лекцій використовуються проблемні форми пред'явлення матеріалу та виносяться на розгляд аудиторії дискусійні питання. Мультимедійні презентації лекцій з гістології, цитології та ембріології мають велику кількість схем, зображень гістологічних препаратів та електронограм. Лекції 3 анатомії людини включають велику кількість демонстраційного матеріалу в вигляді макропрепаратів і схем. При подачі лекційного матеріалу викладачами морфологічних кафедр широко висвітлюються новини наукових досліджень в даній галузі, розкривається історія вивчення даної проблематики. Важливе значення для успішного проведення лекції має методична грамотність лектора, його емоційна взаємодія з аудиторією. Лектор повинен створити умови для активізації мислення студента, зацікавити використанням нетипових прийомів та неординарних фактів 3 практики. На лекції повинна панувати атмосфера інтриги, елементів дискусії, ефекту новизни, залучення студентів до наукового і клінічного мислення.

Для підвищення ефективності освітнього процесу в іноземних студентів та покращення якості отриманих ними знань, потрібно поряд 3 класичними методами навчання застосовувати сучасні інформаційні технології та досягнення науки i техніки. Особливу увагу слід приділити методиці проведення та оснащенню демонстраційним матеріалом лекцій у іноземних студентів. Найбільш вдалою формою подання лекційного матеріалу $є$ мультимедійні презентації [2]. Поєднання текстової інформації з ілюстративним матеріалом (електронограмами, макро- та мікрофотографіями гістологічних препаратів, таблицями, схемами) дозволяє акцентувати увагу аудиторії на основних аспектах представленого матеріалу, робить лекцію більш доступною за рахунок візуального сприйняття, що сприяє кращому розумінню та засвоєнню інформації 3 дисципліни.

Студенти, що приїзжають на навчання в Україну, мають можливість отримувати медичну освіту російською та англійською мовами. В першому випадку велику роль при читанні лекцій таким студентам відіграє рівень опанування ними російської мови, адже багато проблем виникає саме через погане розуміння іноземними студентами матеріалу, що подається лектором. Часто втрачається увага студентів, їм становиться не цікаво, адже вони не розуміють про що іде мова. В другому випадку, коли навчання відбувається англійською мовою, теж існує ряд особливостей в організації навчального процесу, а саме при читанні лекцій. Певні труднощі виникають у плані спілкування викладача зі студентами. 3 одного боку, деяким викладачам необхідно поглибити знання іноземної мови та опанувати правильну вимову спеціальних термінів. 3 іншого боку, деякі студенти й самі недостатньо добре володіють англійською мовою. Вони надзвичайно повільно читають текст, не достатньо чітко його розуміють та не встигають записувати лекційний матеріал.

Часто на прохання студентів деякі розділи пояснюються лектором більш детально, з повторами. На лекціях пропонується ілюстративний матеріал у 
вигляді мультимедійних презентацій, анімацій, фрагментів фільмів, ситуаційних задач. Деякі лекції супроводжуються показом відеофільмів 3 синхронним перекладом і подальшим їх обговоренням. За бажанням студентів матеріал відеофільмів копіюється для подальшого перегляду вдома. Активний зворотній зв язок лектора 3 аудиторією, дозволяє викладачу з'ясувати рівень базової підготовки студентів і зосередитися на найскладніших і найважливіших розділах теми лекції [3].

Для виходу вищої освіти України на світовий рівень, необхідно постійно реформувати та удосконалювати навчальний процес за рахунок використання досвіду інших країн. Стратегією розвитку медичної освітньої системи має бути iii глибока модернізація, інтеграція освіти і науки, розширення інноваційних технологій та методів навчання, розвиток креативних здібностей студентів. Викладачі кафедр морфологічного профілю особливу увагу приділяють пошуку нових форм i методів викладання, які сприятимуть покращенню процесу навчання іноземних студентів [4]. Оптимізація викладання дисциплін передбачає створення підручників російською та англійською мовами, навчальних посібників, відео- і кінофільмів, демонстраційного матеріалу, навчальних та навчально-контролюючих програм. Особливе місце займає удосконалення лекцій шляхом урізноманітнення наочності, використання сучасних інформаційних технологій та розширення методів подачі нового матеріалу.

\section{Список літератури}

1. Ригонен В.И. Современные аспекты преподавания морфологических дисциплин в медицинских вузах / В. И. Ригонен // Журнал анатомии и гистопатологии. - 2015. - Т. 4, № 3 С. 104.

2. Весніна Л.Е. Значення мультимедійних лекцій у викладанні фізіології іноземним студентам / Л.Е. Весніна // Світ медицини і біології. - 2013. - Вип. 2 (37). - С. 3538 .

3. Шепітько B.І. Шляхи удосконалення методики викладання гістології, цитології та ембріології іноземним студентам англійською мовою/ В.І. Шепітько, О.С. Якушко, Г.А. Єрошенко, О.Д. Лисаченко // Світ медицини та біології, Вип. 4. - 2012. - C.132-133.

4. Старченко И.И. Пути оптимизации преподавания морфологических дисциплин иностранным студентам / И.И. Старченко // Світ медицини і біології. - 2013. - Вип. 2 (37). - С. 173-175. 


\title{
ФОРМУВАННЯ МОТИВАЦІЇ У МАЙБУТНІХ ПЕДАГОГІВ ДОШКІЛЬНОЇ ОСВІТИ ДО ЗДОРОВ'ЯЗБЕРЕЖУВАЛЬНОЇ ДІЯЛЬНОСТІ
}

\author{
Гаращенко Лариса Василівна \\ к.пед.н., доцент кафедри дошкільної освіти \\ Київський університет імені Бориса Грінченка (Україна, м. Київ)
}

Постановка проблеми у загальному вигляді. У сучасних умовах розвитку вищої педагогічної освіти гостро постала проблема підвищення якості освіти. Удосконалюються зміст і педагогічний інструментарій фахової підготовки, технологізація освітнього процесу, а також засоби психолого-педагогічного супроводу студентів. Закономірно, що це впливає на формування у студентів мотивації до здобуття професійної підготовки.

Аналіз останніх досліджень і публікацій з даної проблеми. Різні аспекти проблеми удосконалення професійної підготовки майбутніх педагогів дошкільної освіти стали предметом вивчення сучасних дослідників (Г. Бєлєнька, О. Богініч, Н. Гавриш, І. Дичківська, Н. Левінець, М. Машовець, О. Половіна, Т. Поніманська та ін) $[1 ; 3 ; 5 ; 6 ; 8]$. Ми поділяємо думку О. Богініч, що фундаментальна роль у процесі фахової підготовки належить готовності майбутніх педагогів дошкільної освіти до вирішення завдань фізкультурнооздоровчого напряму [2].

Мета статті - визначення основних механізмів формування у студентів мотивації до здійснення здоров’язбережувальної діяльності в умовах закладів дошкільної освіти.

Виклад основного матеріалу дослідження. Ураховуючи нові вимоги до підготовки майбутніх педагогів дошкільної освіти, можемо ствердно зазначити, що основним механізмом формування у студентів мотивації до здобуття професійної підготовки у галузі здоров'язбереження дітей дошкільного віку $є$ активізація навчально-пізнавальної діяльності (репродуктивна - пошукова дослідницька - навчально-пізнавальна). Найбільш доцільними є використання різних лекцій (академічних, нетрадиційних, відео-лекцій); проведення різних видів семінарських та практичних занять у формі ігор та змагань (ділові, рольові ігри, круглі столи, батли, конкурси, вікторини, турніри, дуелі, естафети, аукціони, педагогічна рада, конференція та ін.); проведення практичних занять на базі закладу дошкільної освіти; професійно-практичне спрямування навчально-пізнавальних завдань, завдання різних рівнів складності та ін.

Усвідомлене та ціннісне ставлення майбутніх фахівців до проблеми формування здоров'я дітей, готовність до вивчення дитини, ситуації ії розвитку, до відбору значимого для цього процесу змісту освіти, готовність забезпечувати умови для збереження і зміцнення здоров'я дітей, готовність до варіативного та доцільного застосування інноваційних оздоровчих технологій - ті пріоритети здоров'язбережувальної діяльності, що відповідають запитам батьків вихованців та сучасним тенденціям розвитку дошкільної освіти. Майбутній 
вихователь повинен уміти забезпечувати можливість вибору дитиною самоцінних для неї видів дитячої діяльності та допомогти дитині набути суб'єктивний здоров'язбережувальний досвід (досвід прийняття оздоровчих рішень, оволодіння оздоровчо-поведінковими навичками). Закономірно, що це обумовлює зміну педагогічного інструментарію фахової підготовки. Саме тому важливою умовою організації навчально-пізнавальної діяльності студентів $\epsilon$ забезпечення викладачем практично-професійної спрямованості змісту навчальних занять, навчально-пізнавальних завдань, самостійної роботи студентів, творчих проєктів, завдань оздоровчого спрямування тощо. Професійно-практичне спрямування змісту навчально-пізнавальних завдань слугує основою для реалізації особистісного методичного доробку студента під час педагогічної практики. Імперативом дистанційного навчання є розроблення та активне використання в освітньому процесі електронних навчальних курсів навчальних дисциплін, що обумовлює удосконалення змісту робочої програми навчальної дисципліни, змісту підготовки, прозорості оцінювання викладачем результатів навчальної діяльності студентів. На посилення мотивації студентів до здійснення здоров'язбережувальної діяльності в умовах закладів дошкільної освіти впливає усвідомлення об'єктивних і суб'єктивних причин необхідності формування здоров'я.

Висновки. Реалізація діяльнісного компонента фахової підготовки передбачає особистісну зацікавленість студента у власному професійному становленні. Лише особистісний базис педагога (мотивація якісного оволодіння професійним досвідом, прийняття дитини як активного учасника та творчого суб'єкта виховного впливу, рефлексія, творче ставлення до життя) сприятиме професійному становленню і зростанню у безперервній педагогічній освіті, формуватиме готовність до педагогічної діяльності у нових соціальних умовах.

\section{Література}

1. Бєлєнька Г. В. Формування професійної компетентності сучасного вихователя дошкільного навчального закладу : монографія. Київ: Київ. ун-т ім. Б. Грінченка. 2011. 320 с.

2. Богініч О.Л. Основні механізми удосконалення системи підготовки фахівців дошкільної освіти. Вісник Глухівського державного педагогічного університету. Вип. 9. Серія: Педагогічні науки. Глухів : ГДПУ, 2007. С. 10-16.

3. Гаращенко Л. В. Шляхи вдосконалення фахової підготовки майбутніх вихователів до здоров'язбережувальної діяльності. Вісник Луганського національного університету імені Тараса Шевченка. Випуск №1 (324) березень. Ч. II. C. 195-202.

4. Гаращенко Л. Технології формування професійних умінь у майбутніх педагогів дошкільної освіти (обмін досвідом) : abstracts of the $\mathrm{I}^{\text {st }}$ International Science Conference on Multidisciplinary Research (Berlin, January 19-21, 2021), Germany, Berlin. 2021. 1115 p. Pp. 632-634.

5. Левінець Н. В. Історико-педагогічні аспекти підготовки національних педагогічних кадрів у галузі фізичного виховання дітей // Теорія і практика дошкільної освіти в Україні : монографія / 3. Борисова, Г. Бєлєнька, О. Богініч, Н. Голота та ін. - Київ : Київськ. ун-т ім. Бориса Грінченка, 2011. - С. 205-216. 
6. Машовець М. А. Професійна підготовка майбутнього вихователя дітей дошкільного віку: науково-аналітичний огляд. Теорія $і$ практика дошкільної освіти в Україні : монографія / З. Борисова, Г. Бєлєнька, О. Богініч, Н. Голота та ін. Київ : Київськ. ун-т ім. Бориса Грінченка, 2011. С. 173-180.

7. Петько Л. В. Виклики XXI століття для освітнього простору України Наукові праиі [Чорноморського державного університету імені Петра Могили комплексу "Києво-Могилянська академія"]. Серія : Педагогіка : наук. журн. / Чорном. держ. ун-т імені Петра Могили; ред. кол. : О. П. Мещанінов (голова) [та ін.]. - Миколаїв : Вид-во ЧНУ імені Петра Могили, 2017. Т. 303. Вип. 291. С. $10-14$.

8. Петько Л. В. Гурток «Мандрівники» та формування соціальної активності молодших школярів. Педагогічний альманах : зб. наук. праць / Редкол. В. В. Кузьменко та ін. Херсон : КВНЗ «Херсонська академія неперервної освіти», 2018. Вип. 37. С. 34-39. 


\title{
ДИСТАНЦЙНЕ НАВЧАННЯ МОЛОДШИХ ШКОЛЯРІВ: ОСОБЛИВОСТІ ЗАСТОСУВАННЯ
}

\author{
Годлевська Валентина \\ доктор історичних наук, професор \\ Вінницький державний педагогічний університет \\ ім. М. Коцюбинського
}

11 березня 2020 року Всесвітня організація охорони здоров'я оголосила COVID-19 глобальною пандемією. Швидкісне поширення коронавірусу у всьому світу змусило більшість урядів застосувати безпрецедентні заходи соціального стримування, щоб зупинити хвилю. Ці заходи, серед іншого, вимагали соціальної дистанції та тимчасового фізичного закриття навчальних закладів.

Незапланована, швидка та невизначена тривалість підходу викликала проблеми на всіх академічних рівнях.

Завдання дистанційного навчання для всіх школярів виявилось складним завданням. Найкращі інструменти можуть бути на місці, але без рівного доступу всіх школярів до інструментів, адекватного часу на підготовку та навчання для вчителів, а також адаптації існуючих навчальних планів або розробки нових програм навчальних курсів було важко відтворити, а також досвід особистого навчання в Інтернеті. Отже, деякі запитання, що виникли при дистанційному навчанні, полягали у тому, чи запропонує воно таке саме значення, як навчання в класі, і чи допоможе учням засвоїти знання, як це було б, якби вони були в класі? Хоча ці питання є актуальними, $є$ й додаткові суттєві проблеми, які навчальні заклади повинні були розглядати, наприклад, як допомогти учням без надійного доступу до Інтернету та / або технології брати участь у цифровому навчанні. Нерівність у доступі до технологій та доступу до Інтернету особливо виявилась очевидною серед населення.

Дистанційне навчання, також відоме під різними назвами, такими як електронне навчання, мобільне навчання або навчання в Інтернеті, $\epsilon$ формою навчання, коли відсутній безпосередній контакт викладачів та учнів. Це також навчальна практика, яка ефективно використовує широкий спектр інструментів та технологій для збагачення досвіду навчання школярів та сприяння спілкуванню школярів та викладачів. Мінімальні технологічні вимоги для успішного дистанційного навчання включають наявність спеціального обладнання, такого як комп'ютер, мобільний пристрій (стільниковий телефон) або веб-камера, пристрій для прослуховування певної форми, програми для відеоконференцій, такі як WebEx або Zoom, операційні системи Microsoft Windows або Apple, і стабільне з'єднання з Інтернетом.

При організації дистанційного навчання необхідно враховувати фізіологічні та психологічні особливості молодших школярів. Використання комп'ютера не означає, що дитина повинна сидіти перед екраном весь день. Навчання повинно залишатися настільки необхідним, наскільки дозволяє ситуація, що склалася [2]. 
Отже, щоб розібратися, як правильно організувати віддалене навчання молодших школярів, можна розглянути нескладну модель.

Першим блоком, як, правило, є пояснення нового матеріалу. Ця інформація подається вперше і має бути засвоєна на занятті. Якщо дорослі люди можуть більш-менш спокійно вивчати якісь матеріали самостійно, то дитині молодшого шкільного віку необхідна для цього допомогу дорослого.

Тут йде мова про роботу в зоні найближчого розвитку. Як ми знаємо, завдання із зони найближчого розвитку дитина не може вирішити сама, але здатна впоратися з ними разом $з$ дорослим.

Другий блок - це закріплення. Дитина засвоїла нову тему, але щоб знання i навички закріпилися міцно, їй необхідно виконати ряд самостійних завдань. Тема вже перейшла із зони найближчого в зону актуального розвитку і повинна там вкоренитися. Знання і вміння необхідно перетворити у навик. 3 такого роду завданнями дитина може впоратися сама.

Третім блоком $є$ контроль і зворотний зв'язок. Без цього важливого блоку цикл працювати не буде. Контроль необхідний, по-перше, 3 точки зору коригування курсу. Діти допускають неточності, роблять помилки з тих чи інших причин, і нам важливо вчасно відкоригувати дитину, не дати навику закріпитися в спотвореній формі. Всі ми знаємо, що переучувати набагато складніше, ніж навчити. По-друге, контроль важливий для мотивації - в його відсутності навіть дорослі працівники починають працювати гірше, не кажучи вже про дітей.

Описані три блоки утворюють певний цикл. Він може бути коротким або довгим. У випадку з молодшими школярами важливо, щоб він був якомога коротшим, тому що вольові якості у них ще недостатньо розвинені для довгого виконання завдань без зовнішнього контролю. Чим коротший цикл зворотного зв'язку, тим ефективніше навчання [3].

Дистанційна освіта накладає обмеження на безпосередній контакт 3 педагогом. Навіть в режимі інтерактивної відеоконференції і дитині, і вчителю чогось не вистачає - електронний посередник унеможливлює важливі канали взаємодії: не можна вчасно підійти до дитини, поправити його посадку та рух, відкоригувати індивідуальним правильним питанням або зауваженням ще не допущену помилку, вчасно і правильно відстежити емоції дітей, коли вони засмучуються або відволікаються, разом попрацювати 3 роздатковим матеріалом. Цифрове посередництво обмежує маневреність і чуйність педагога, робить контакт 3 дітьми неповноцінним, скороченим.

Тому при дистанційному навчанні необхідна допомога батьків. Батькам не варто перебирати не себе роль вчителів, а навпаки - організувати і забезпечити дитині умови для навчання. Дистанційна форма не передбачає відповідальність батьків за весь процес, їх завдання - організувати. Учитель відповідає за інформацію, учень - за її засвоювання, батьки - за організацію.

Важливо визначити умови підвищення ефективності дистанційного навчання. Воно буде продуктивним тільки в разі його розумного використання відповідно до визначених норм і вимог [4, с.151]. Такі вимоги можна задати через опис наступних умов, необхідних для подальшої ефективної реалізації дистанційного навчання: 
- дистанційне навчання має бути представлено в системі;

- повинна бути організоване єдине електронне освітнє середовище, яке буде

забезпечувати: взаємодію всіх користувачів; зберігання, регулярне оновлення i систематизацію навчально-методичних ресурсів; підтримку учасників навчальної діяльності за допомогою дистанційних технологій;

- навчання повинно поєднувати аудиторні та дистанційні заняття, самостійну роботу учнів, а також включати традиційні навчально-методичні матеріали;

- необхідно враховувати індивідуальні особливості кожного учня.

Дистанційне навчання молодших школярів в умовах глобальної пандемії здатне частково досягти запланованих освітніх результатів освоєння основної освітньої програми початкової загальної освіти. Але створити основу для самостійного успішного засвоєння учнями нових знань, умінь, компетенцій, видів і способів діяльності не в змозі.

\section{«Список літератури»}

1. The Dos and Don'ts of Distance Learning in a Pandemic https://www.educationnext.org/dos-and-donts-distance-learning-pandemiccoronavirus-covid-19/

2. Котова Светлана Аркадьевна. Организация дистанционного обучения в начальной школе // Общество: социология, психология, педагогика. 2015. № 1. - C. 37-39.

3. Как проводить дистанционное обучение младших школьников на карантине? https://russianclassicalschool.ru/vopros-otvet/item/1278-kak-provoditdistantsionnoe-obuchenie-mladshikh-shkolnikov-na-karantine-chast-1.html

4. А.Ю. Федосов. Дистанционное обучение младших школьников: проблемы, тенденции, подготовка кадров // Сборник научных статей XVIII Объединенной конференции «Интернет и современное общество» IMS-2015, Санкт-Петербург, 23-25 июня 2015 г. С. 146-152. 


\title{
МЕЖДУНАРОДНЫЕ ИНТЕГРАЦИОННЫЕ ПРОЦЕССЫ В СФЕРЕ ФИЗИЧЕСКОЙ КУЛЬТУРЫ И CПОРТА
}

\author{
Дарпинян Рафаэль Самвелович, \\ Магистрант ИЕСТ \\ Московский городской педагогический университет
}

\section{Лубышев Евгений Александрович,} к.П.н., доцент

Российский экономический университет им. Г.В. Плеханова

Аннотация. На современном этапе развития экономических отношений особую актуальность представляют вопросы развития индустрии физической культуры и спорта. Процесс глобализации является важнейшим элементом экономики любой развитой страны. В статье рассматриваются явления глобализации индустрии физической культуры и спорта. При этом особое внимание уделяется взаимосвязи спорта с современными социальнокультурными процессами. В особом порядке рассмотрен процесс трансформации спорта в современный товар, в социальную услугу.

Ключевые слова: экономика,глобализация, социально-культурные процессы, спорт, международный спорт.

На данном этапе развития спортивной науки существуют несколько весьма различных подходов в отношении проблемы определения и значения глобализационных процессов.

Считается, что глобализация подразумевает под собой некую динамику производства темпа роста международного обмена товарами, услугами, капиталом, а качественный показатель состоит в усилении взаимосвязи и взаимозависимости между национальными хозяйствами.

Многие исследователи отмечают, что глобализация это развитие экономической и политической взаимозависимости стран и регионов до такого уровня, на котором становится возможной и необходимой постановка вопроса о создании единого мирового правового поля и мировых органов экономического и политического управления.

Другая группа исследователей утверждает, что под глобализацией трактуется процесс сочленения различных компонентов человечества в ходе его эволюции в противоположность процессу дифференциации человечеств.

Глобализация - процесс культурной, политической, научной, технической унификации и установления взаимосвязей между отдельными, уникальными, самостоятельными социальными объектами и явлениями. 
Термин «глобализация» появляется в Гарвардской школе бизнеса и связывается с глобальной деятельностью транснациональных корпораций. Формирование глобального сообщества действительно начинается с динамичных изменений в экономической сфере. Феномен глобализации выходит за чисто экономические рамки и оказывает влияние на все сферы общественной жизни, но все же, количественным показателем глобализации являются опережающие динамику производства темпы роста международного обмена товарами, услугами, капиталом, а качественный показатель состоит в усилении взаимосвязи и взаимозависимости между национальными хозяйствами. В то же время глобализация включает в себя множество аспектов, среди которых:

- международная торговля

- телекоммуникации

- международные финансы

- деятельность транснациональных корпораций

- техническое и научное сотрудничество

- культурный обмен новых типов и масштабов

- миграция и потоки беженцев

- отношения между бедными и богатыми странами мира.

Через средства массовой информации, в процессе глобализации, общества стали сближаться друг с другом, увеличилась скорость обмена между разными культурами. Технологические разработки также привели к появлению новой глобальной медиа индустрии, где производство стало международным. Общая среда обитания, возникшая в результате развития коммуникационных технологий и явления глобализации, изменяя местные привычки и выходя за пределы национальных границ, направляет людей во многих аспектах жизни в общий образ жизни.

Чемпионат мира по футболу - это одно из самых прибыльных спортивных событий во всем мире. Что определяется и размером охвата через средства массовой информации. Суммарное количество человек, которые смотрели футбольные матчи на чемпионате мира 2014, составило примерно 2,7 млрд человек, а на чемпионате мира 2018 около 3,5 млрд человек, что в процентном соотношении на 22,8 \% больше по сравнению с предыдущим чемпионатом мира. Доход «ФИФА» от реализации прав трансляции футбольных матчей через средства массовой информации на чемпионате мира 2014 составил примерно 3,1 млрд долларов, а на чемпионате мира 2018 около 4,2 млрд долларов, что в процентном соотношении на 26,1 \% больше по сравнению с предыдущим чемпионатом мира.

Спорт имеет право обращаться ко всем обществам на земле, независимо от социальных, культурных структур. Мы стали свидетелями быстрой глобализации всемирного спорта. Конечным результатом процесса глобализации на спортивной арене являются общие правила, принципы и цели, которые определены для всех стран в рамках единой структуризации. В 
настоящее время матчи чемпионатов по футболу транслируются в прямом эфире по телевидению, за которыми с огромным удовольствием следят массы людей во всем мире.

Самым важным фактором, ускоряющим глобализацию спорта, является быстро развивающиеся технологии. Культурное взаимодействие стало проще, чем раньше, в то время как средства массовой информации почти сняли понятие расстояния. Социальные структуры, преобразовавшись, создали массовую культуру, что привело к однородной культуре. Электронные средства массовой информации явились драйвером глобализации спорта.

Летние Олимпийские игры - это одно из самых затратных спортивных событий во всем мире. Что определяется масштабом и размером охвата проведения этого мероприятия. Суммарные затраты на проведение летних Олимпийских игр 2012 в Лондоне составили около 9,3 млрд долларов, а на проведение летних Олимпийских игр 2016 в Рио-де-Жанейро суммарные затраты составили примерно 12,1 млрд долларов, что в процентном соотношении на 23,1 \% больше по сравнению с предыдущим летними Олимпийскими играми.

Сегодня спортсмены могут соревноваться с помощью более современного оборудования наряду с технологическими разработками. С помощью этого теперь можно побить рекорды, которые казались невозможными в прошлом. Это способствует развитию спорта, с одной стороны, и с другой стороны, формированию таких деструктивных факторов в мировом масштабе, как, например, допинг. Как следствие, глобализация во многом определяет актуальность вопросов этики международного спорта.

Подводя итог, стоит сказать, что влияние глобализации на международный спорт носит комплексный, многоплановый характер и в настоящий момент времени не поддается однозначной оценке. Сегодня многие многонациональные компании стремятся увеличить продвижение своей продукции, привлекая к рекламным кампаниям выдающихся спортсменов. Акции и презентации, использующие спортивный контент, продолжают подтверждать свою высокую степень аттрактивности, что находит свое отражение в положительном экономическом эффекте. С этой точки зрения можно сказать, что и сам спорт ускорил темпы глобализации, сменив роль «проводника» на статус акселератора процессов трансформации на мировом уровне.

\section{Литература:}

1. Красильников А.А. Новые технологии обучения в образовательном процессе по физической культуре // B сборнике: ADVANCING IN RESEARCH AND EDUCATION. Abstracts of XII International Scientific and Practical Conference. 2020. C. 348-353.

2. Пушкина В.Н., Гернет И.Н., Федорова Е.Ю., Оляшев Н.В. Трансформация подходов к занятиям физической культурой в современной образовательной среде // В сборнике: Трансформация подходов к физическому воспитанию в образовательных организациях. сборник статей по материалам 
Межрегиональной научно-практической конференции института естествознания и спортивных технологий. 2019. С. 102-107.

3. Лубышев Е.А., Красильников А.А., Закиров Ф.Х. Ценностные ориентации в области физической культуры и проблемы их формирования в молодежной среде // В сборнике: Инновационные технологии в спорте и физическом воспитании подрастающего поколения сборник статей по материалам $\mathrm{X}$ научно-практической конференции с международным участием. 2020. C. 288-294.

4. Николаева Н.И., Лубышев Е.А., Красильников А.А. Соответствие должностей и видов деятельности в профессиональном стандарте «Тренер» квалификационным требованиям отрасли «Физическая культура и спорт» // Физическая культура: воспитание, образование, тренировка. 2020. № 6. С. 70-73.

5. Красильников А.А., Лубышев Е.А., Валиев Р.Р. Программные продукты и сервисы в работе учителя физической культуры // В сборнике: Инновационные технологии в спорте и физическом воспитании подрастающего поколения сборник статей по материалам $\mathrm{X}$ научно-практической конференции $\mathrm{c}$ международным участием. 2020. С. 259-267.

6. Пушкина В.Н., Оляшев Н.В., Гернет И.Н., Федорова Е.Ю. Функциональные способности кардиореспираторной системы у лиц с разным типом кровообращения // В сборнике: Физическая культура, спорт, туризм: инновационные проекты и передовые практики. Материалы Международной научно-практической конференции, посвященной 90-летию основания кафедры физического воспитания. Под редакцией Л.Б. Андрющенко, С.И. Филимоновой. 2019. С. 711-718.

7. Лубышев Е.А. Спорт и социализация: социокультурный аспект // В сборНИК: НАУЧНО-ПЕДАГОГИЧЕСКИЕ ШКОЛЫ В СФЕРЕ ФИЗИЧЕСКОЙ КУЛЬТУРЫ И СПОРТА. Материалы Международного научно-практического конгресса, посвященного 100-летию ГЦОЛИФК. 2018. С. 452-456.

8. Красильников А.А., Лубышев Е.А. Ключевые преобразования образовательной среды в контексте внедрения информационно-компьютерных технологий // В сборнике: СУЧАСНІ ВИКЛИКИ І АКТУАЛЬНІ ПРОБЛЕМИ НАУКИ, ОСВІТИ ТА ВИРОБНИЦТВА: МІЖГАЛУЗЕВІ ДИСПУТИ. МатеріалИ IX Міжнародної науково-практичної інтернет-конференції. 2020. С. 382-389.

9. Красильников А.А., Лубышев Е.А., Измененная образовательная среда в контексте внедрения цифровых технологий в образовании // В сборнике: Study of modern problems of civilization. Abstracts of V International Scientific and Practical Conference. 2020. C. 307-312.

10. Zakirov F. H., Krasilnikov A. A., Pushkina V. N., Gernet I. N., Andruschenko L. B., Yamaletdinova G. A. The role of damages and epigenetic modifications of dna in alzheimer's disease // Indo American Journal of Pharmaceutical Sciences. 2019. - T. 6. - №5 - C. 9700-9703.

11. Лубышев Е.А., Красильников А.А., Лубышева Г.С. Спортивные сооружения как движущий фактор развития массовой физической культуры в обществе // В сборнике: СУЧАСНІ ВИКЛИКИ І АКТУАЛЬНІ ПРОБЛЕМИ 
НАУКИ, ОСВІТИ ТА ВИРОБНИЦТВА: МІЖГАЛУЗЕВІ ДИСПУТИ. Матеріали IX Міжнародної науково-практичної інтернет-конференції. 2020. С. 425-432.

12. Красильников А.А. Применение информационных технологий в преподавании физической культуры // В книге: Trends in the development of modern scientific thought. Abstracts of X International Scientific and Practical Conference. 2020. C. 470-475.

13. Лубышев Е.А., Красильников А.А. Занятия карате киокушинкай в системе дополнительного образования студентов экономического ВУЗа // В сборнике: Шаг в науку. сборник статей по материалам III научно-практической конференции института естествознания и спортивных технологий. 2019. С. 7981 .

14. Федорова Е.Ю., Пушкина В.Н., Гернет И.Н., Сизов А.Е. Типовой портрет физической активности обучающихся общеобразовательных организаций Москвы // Ученые записки университета им. П.Ф. Лесгафта. 2019. № 9 (175). С. 304-309.

15. Закиров Ф.Х., Красильников А.А. Использование технологии подкастинга как инновационного метода обучения в физической культуре // В сборНИКе: ИННОВАЦИОННЫЕ ТЕХНОЛОГИИ В СПОРТЕ И ФИЗИЧЕСКОМ ВОСПИТАНИИ ПОДРАСТАЮЩЕГО ПОКОЛЕНИЯ МатериалЫ IX Всероссийской научно-практической конференции. Институт естествознания и спортивных технологий Московского городского педагогического университета Коллектив авторов. 2019. С. 112-116.

16. Закиров Ф.Х., Красильников А.А., Лубышев Е.А., Чубанова Г.Р. Перспективы использования биомаркеров остеопороза в диагностике и лечении // Хирургическая практика. 2019. № 1 (37). С. 45-47.

17. Лубышев Е.А., Красильников А.А. Индивидуализация современных образовательных технологий в преподавании теории физической культуры // В сборнике: Трансформация подходов к физическому воспитанию в образовательных организациях Материалы Межрегиональной научнопрактической конференции института естествознания и спортивных технологий. 2019. C. 77-82.

18. Zakirov F.Kh., Krasilnikov A.A. Age-related differences in decision-making process in the context of healthy aging // B сборнике: BIO Web of Conferences. 2020. C. 01022 .

19. Красильников А. А., Лубышев Е. А., Закиров Ф. Х. Информационные технологии в методологии преподавания физической культуры // Материалы III научно-практической конференции (І всероссийской) института естествознания и спортивных технологий. 2019: сборник научных статей - Москва, 2019. Москва: МГПУ - С. 66-70

20. Федорова Е.Ю., Красильников А.А. Медико-социальные особенности пациентов со стенокардией и сахарным диабетом 2 типа // В сборнике: СУЧАСНI ВИКЛИКИ І АКТУАЛЬНІ ПРОБЛЕМИ НАУКИ, ОСВІТИ ТА ВИРОБНИЦТВА: МІЖГАЛУЗЕВІ ДИСПУТИ. Матеріали IX Міжнародної науково-практичної інтернет-конференції. 2020. С. 255-264. 
21. Красильников А.А. Возможности применения цифровых ресурсов в образовательном процессе системы высшего образования // В сборнике: Академические исследования в области междисциплинарных инноваций. 2020. C. 278-283.

22. Битейкин М.М., Красильников А.А. Дистанционное обучение по предмету «физическая культура» как способ мотивации обучающихся к самостоятельной двигательной активности // В сборнике: Шаг в науку. сборник статей по материалам IV научно-практической конференции молодых ученых. 2020. С. 103-110.

23. Кокоулина О.П., Иванов В.А., Лубышев Е.А., Буянова Т.В., Маврина С.Б. Социально-психологическая адаптация спортсменов после завершения профессиональной карьеры // Теория и практика физической культуры. 2019. № 7. C. 49-51.

24. Алмазова Ю.Б., Лубышев Е.А., Столяр К.Э., Кондраков Г.Б. Актуализация личностного смысла участия студентов в подготовке и сдаче нормативов ВФСК ГТО // Теория и практика физической культуры. 2019. № 9. C. 21-23.

25. Пушкина В.Н., Закиров Ф.Х., Красильников А.А., Гернет И.Н. Возможности применения новых технологий в преподавании физической культурЫ // В сборнике: ИННОВАЦИОННЫЕ ТЕХНОЛОГИИ В СПОРТЕ И ФИЗИЧЕСКОМ ВОСПИТАНИИ ПОДРАСТАЮЩЕГО ПОКОЛЕНИЯ. Материалы IX Всероссийской научно-практической конференции. Институт естествознания и спортивных технологий Московского городского педагогического университета Коллектив авторов. 2019. С. 160-162.

26. Закиров Ф. Х., Красильников А. А., Лубышев Е.А. Фитнес-трекеры на уроках физической культуры: примеры и перспективы // Московский экономический журнал. - 2020. - №4 - С. 63.

27. Пушкина В.Н., Гернет И.Н., Оляшев Н.В., Лубышев Е.А. Состояние системы внешнего дыхания у юношей, проживающих в разных регионах России // Теория и практика физической культуры. 2020. № 4. С. 17-19.

28. Красильников А. А., Закиров Ф. Х. Подкастинг как инновационная методика обучения студентов на примере медицинского образования // Педагогический журнал. - 2018. - Т. 8. - №5А. - С. 553-558. 


\title{
ЕКОЛОГІЧНЕ ВИХОВАННЯ ТА ЕКОЛОГІЧНА КУЛЬТУРА ДЛЯ РОЗВИТКУ ТВОРЧОЇ ОСОБИСТОСТІ.
}

\author{
Докаль Ольга Ярославівна \\ Викладач методист ,викладач вищої категорії \\ Фаховий коледж ЧНУ імені Юрія Федьковича
}

Решетнікова Людмила Юріївна Вчитель методист, вчитель вищої категорії Чернівецький ліцей № 3

\section{Зрибнсва Ірина Василівна}

Вчитель методист, вчитель вищої категорії Чернівецька ЗОШ I -III ступенів № 4

Вступ.

На порозі екологічної катастрофи суспільство прагне якнайшвидше відновити віковий досвід взаємовідносин людини і навколишнього світу. Ця проблема набула статусу глобальної, оскільки успішність ії вирішення обумовлює життєві інтереси всього людства. Врятувати природу, а отже і людство можуть лише докорінні зміни у системі цінностей, що існують у суспільстві.

Сьогодні виникла гостра необхідність у штучному підтриманні природних умов оскільки посилення спустошення природи очевидне для всіх. Коренем цієї проблеми є глибока моральна, ціннісна криза особистості, одним із сумних аспектів якої $\epsilon$ знищення природного середовища. Важливою умовою $\epsilon$ екологічна освіта і виховання молодого покоління, оскільки саме з дитячих років людина повинна сприймати себе, як невід*ємну частину природи, бо в цей період життя формується світогляд, закладаються моральні цінності, моделюється культура поведінки особистості. У найважливіших документах міжнародного і державного значення, зазначено, що екологічна освіта сьогодні $є$ необхідною складовою гармонійного і екологічно безпечного розвитку.

Екологія (гр. oikos - дім, родина) - наука, що вивчає закономірності існування, формування і функціонування біологічних систем усіх рівнів - від організму до біосфери та їхньої взаємодії із зовнішніми умовами.

Екологічна культура людини - це засвоєна система наукових знань про взаємозалежність життя природи і людини, нормативні основи ії господарської діяльності та поведінки в природі, а також сформована готовність до захисту природного середовища свого існування.

Екологічне виховання - педагогічна діяльність, спрямована на розвиток в учнів екологічної культури."Природа - найкраща із книг, написана особливою мовою, - говорив російський письменник Гарін Михайлівський, - і цю мову потрібно вивчати". Учні вивчають іiі на предметах природничого циклу, під час щоденного спілкування з нею. Таке спілкування, як стверджував М.К.Реріх, 
завжди освячує людину, навіть якщо воно відбувається у такій "грубій формі", як полювання. Однак найчастіше поняття "природа" ототожнюють 3 картинами первісних диких краєвидів у всій їхній чистоті. На жаль, побачити їх з кожним роком стає все важче і важче.

"Я дотепер відчуваю, - писав знаменитий норвезький мандрівник Тур Хейердал, - що первозданну природу можна побачити лише в одному місць У своїй власній душі..."Коли процес екологічного виховання становить систему, твірним чинником якої є мета, спрямована на збереження природних основ існування людини, то системною властивістю за цих умов стає мисленнсвий образ збережених або очищених від згубних результатів діяльності людини куточків природи, великих іiі регіонів або й усього глобального природного комплексу. Такий образ найчастіше формується на уроках дисциплін природничого циклу, у різних формах позакласної та позашкільної роботи. У поєднанні із засобами образотворчого мистецтва, відповідної музики сформовані образи можуть справляти імпресуючий вплив на учня."Ми знаємо країну 1000 озер - Фінляндію, - говорить, наприклад, на уроці географії України вчитель. Знаємо країну 13677 островів - Індонезію. Але рідко задумуємося над тим, що живемо в країні 72000 рік. Ті ріки - то кровоносні судини землі. Немов жили в людському тілі, покрили вони голубим плетивом Україну. I там, де густа їхня сітка, все буяє зеленню і цвіте, а там, де їх немає, все сохне під палючим промінням сонця...

"Екологічне виховання - це виховання, насамперед, почуття приналежності до великого світу природи" який віруючі називають Творінням Божим. Це почуття виховувалося в людей упродовж тисячоліть усіма релігіями світу. I, мабуть, не завжди християнин, накладаючи під час молитви на себе хрест, усвідомлював, що він цим самим з'єднував себе по горизонталі та вертикалі 3 усім світом, ставав його невід'ємною частиною. Екологічне виховання не $є$ чимось чітко відособленим у загальному навчально-виховному процесі освітнього закладу. Воно поєднується з національно-патріотичним, моральним, трудовим. В учнів формується готовність не лише самим дотримуватись правил співжиття із світом природи, а й готовність до виправлення помилок у господарюванні, допущених попередніми поколіннями. Однак під це підводяться відповідні знання, формується чітка картина втраченого. Наприклад, відомо, що за всю історію людства у світі втрачено два мільярди гектарів грунтів. 3 них більшу частину - протягом останніх десятиліть. I значний "вклад" у цю справу нищення зроблено в Україні. Після війни в ній було 40 мільйонів гектарів орних земель, нині лишилося близько 32. Не стало 8 мільйонів гектарів першокласних чорноземів. Уражено ерозією і потребують рекультивації ще 600 тисяч (А.Травлєсв).Подібні факти висвітлюються, аналізуються не лише на уроках, а й на різних формах класної та позакласної виховної роботи. Там вони отримують свою оцінку та відповідне емоційне закріплення.

Таким чином, екологічне виховання базується на поєднанні таких основних принципів: міждисциплінарного підходу, систематичності й безперервності вивчення екологічно значущого навчального матеріалу, єдності інтелектуального та емоційно-вольового компонентів, взаємозв'язку 
глобального, національного і регіонального. Важливим його психологічним новоутворенням $є$ сформоване почуття причетності до долі світу і людини у цьому світі.Трудове виховання - процес залучення учнів до різноманітних видів продуктивної праці з метою усвідомлення та пізнання ними життєорганізуючої сили іiї у житті людини. Цей процес супроводжується формуванням у вихованців звичок та навичок активної трудової діяльності, тобто засвоєнням певного виробничого досвіду, розвитком творчого практичного мислення, десугестуванням негативних сугестивних комплексів, сформованих на уявленнях про труд як утруднення життя, своєрідну кару, яка затьмарює його радощі. Зміст трудового виховання визначається навчальною програмою для кожного класу. Він передбачає такі напрями підготовки: загально трудовий, загальновиробничий, загально технічний, спеціальний. Загально трудовий пов'язаний з оволодінням знаннями, уміннями і навичками 3 планування та організації своєї праці. Загальновиробничий передбачає освоєння знань про науково-технічний потенціал основних галузей виробництва, основ економіки та організації праці. Загально технічний націлює на оволодіння знаннями, які стосуються специфіки галузі, в яку входить обраний профіль трудової підготовки. Спеціальний передбачає формування початкових умінь і навичок праці з обраної спеціальності.

Важливою складовою трудового виховання $\epsilon$ трудове навчання, яке розподілене на три основні етапи:

Перший етап (початкові класи) передбачає формування в учнів елементарних навичок роботи з папером і картоном, пластиліном, різноманітними природними матеріалами. Діти залучаються до вирощування сільськогосподарських рослин на пришкільній ділянці, до ремонту наочних посібників, виготовлення подарунків, іграшок для підшефного дитячого садка та для мам на свято 8-го Березня. Це покликане сприяти розвитку захоплень та інтересів молодших школярів

Другий етап (5-9 класи) пов'язаний із набуттям учнями знань, умінь та навичок з обробки металу, дерева, основ електротехніки, графічної грамоти. У міських школах має місце технічна й обслуговуюча праця, у сільських сільськогосподарська, обслуговуюча і технічна.

Третій етап надає трудовому навчанню професійно орієнтованого характеру. Старшокласники отримують можливість початкового оволодіння тими професіями, які визначаються на місці з урахуванням народногосподарських потреб і наявної навчально-матеріальної бази

Для того, щоб праця виховувала, вона повинна відповідати низці вимог: бути цілеспрямованою, доступною, колективною, пов'язаною з навчальною роботою, організованою на наукових засадах, спрямованою на формування творчого ставлення до неї. Профорієнтаційна робота у середньо освітньому навчальному закладі ні в якому разі не повинна бути нав'язливою. Професійні уподобання старшокласників повинні випливати 3 їхньої внутрішньої спрямованості. Професійна орієнтація як системне утворення має такі складові: професійне інформування, професійна діагностика, професійна консультація, професійний відбір, професійна адаптація. Професійне інформування - забезпечення учнів 
вихідною інформацією для професійного самовизначення. Професійна діагностика - вивчення учня психологами, педагогами, медиками 3 метою встановлення професійно значущих якостей вищої нервової діяльності, фізичного стану здоров'я, ціннісних орієнтацій, психологічних установок на вибір певної професії. Професійна консультація - надання старшокласникам здебільшого на основі професійної діагностики порад стосовно найоптимальніших шляхів їхнього професійного самовизначення. Професійний відбір-допомога учням-випускникам у виборі конкретної професії 3 перспективою подальшого працевлаштування. Професійна адаптація - процес пристосування молодих людей до умов професійної діяльності. Трудове виховання покликане донести до учнів загальносуспільну та власно особистісну значущість чесної, сумлінної і творчої праці, в якій би формі вона не виступала.

Висновок:

Отже, формування екологічної культури є динамічним і комплексним процесам, ефективність якого впливає екологоціннісна та освітньосередовищна складова. Для оптимізації процесу екологічної освіти потрібно впроваджувати інноваційні педагогічні технології, колективну творчу діяльність, інтерактивні технології, проектну діяльність, тобто евристичну діяльність.

Напрямом подальших моїх досліджень може стати розробка критеріїв інструментаріїв експерементів визначеності екологічної культури в учнів, рейтинг екологічної культури особистості та суспільства в цілому

Використання комплексного підходу до екологічної освіти і виховання учнів дозволить реалізувати його завдання й отримати екологічно компетентне покоління, яке сформоване екологічним світоглядом активною екологічною позицією.

Екологічна освіта необхідна для формування людського ставлення до природного визначення допустимої межі її перетворення. Школа майбутньогоце школа всебічного розвитку особистості, якій притаманні екологічний світогляд, екологічне мислення, екологічна культура, мораль, етика.

\section{Література:}

1. Алексеев B. 300 вопросов и ответов по экологии / В. Алексеев ; худож. В. Янаев, В. Куров. - Ярославль : Академия развития, 1998. - 239 с. ил. (Расширяем кругозор детей).

2. Буринська Н. Досвід формування екологічної свідомості в учнів / Н. Буринська / Біологія і хімія в шк.-2008- С. 43-45.

3. Василенко Г. Екологічна освіта та виховання / В. Василенко // Початк. шк.

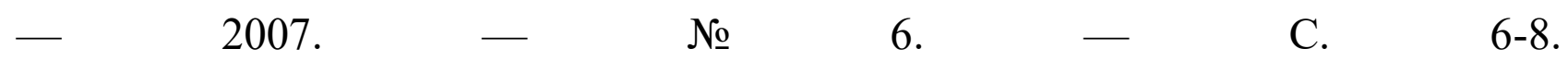
Поліпшення екологічної освіти підростаючого покоління, методичні рекомендації щодо проведення заходів з екологічного виховання.

4. Вербицький В. Еколого-натуралістична освіта в Україні:історія, проблеми, перспективи. / В. Вербицький. - К :Аверс. - 2003. - 304 с. Місце і роль еколого-натуралістичних позашкільних закладів в загальній системі освіти. 
5. Вербицький В. Проектна форма навчання і виховання у загальноосвітніх навчальних закладах та позашкільних закладах освіти еколого-натуралістичного напряму : проблеми та шляхи їх вирішення / В. Вербицький // Рідна шк. - № 3. - C. 35-47.

6. Вороніна Л. Взаємодія школи й сім’ї в екологічному вихованні / Л. Вороніна // Шк. світ. — 2005. — № 18-19. — С. 3-25.

7. Даценко Г. Екологічна освіта як аспект гуманізації шкільного навчання та виховання / Г. Даценко // Біологія. — 2007. — № 10. - С. 5-

8. Екологічне виховання на уроках хімії та в позакласний час // Хімія. 2007. — № 11. - С. 1-43.

9. Екологічна стежка - одна із форм природоохоронної роботи / $Г$. Гончаренко [та ін.] // Хімія. Біологія. - 2005. — № 62. - С. 1-16.

10. Екологічні стежки України. Живи, Земле!: метод. матеріали / під ред. В. Вербицького. — К. : АВЕРС, $2003 .-196$ с. У посібнику зібрано матеріали семінарів „Екологічні стежки України”, що розкривають перспективний педагогічний досвід роботи з екологічної освіти в природі, а також рекомендації щодо створення екологічних стежок.

11. Крисаченко В. Екологічна культура : теорія і практика : навч. посіб. / В. Крисаченко. - К. : Заповіт, 1996. - 352 с.

12. Лях В. Прикладна творчість у туристсько-екологічній діяльності школярів (З досвіду роботи екоцентру «Мурашка») : навч.-метод. посіб. Ч. 1. / В. Лях, М. Лях. - Суми : СумДПУ ім. А.С. Макаренка, 2003. - 2003. - 60 с.

13. Плохій 3.Сучасний зміст екологічного виховання / 3. Плохій // Дошк. виховання. -2008 . - № 3. - С. 3-6

14. Подорож Гідринки : кн. з еколог. виховання дітей дошк. та мол. шкіл. віку / авт.-уклад. Т. Васильєва, В. Шелегеда. - Запоріжжя : Поліграф, 2003. 32 с. : ілюстр. Книжка у цікавій формі розповідає про кругообіг води у природі, властивості води, будову та екологічний стан малих річок. 


\section{ПИТАННЯ ЯКОСТІ ДИСТАНЦЙНОГО ТЕСТУВАННЯ У ВH3}

\section{Кодак Ольга Антонівна,}

к.Т.н., доцент

Національний університет «Полтавська політехніка імені Юрія Кондратюка»

У національній системі освіти останнім часом відбуваються кардинальні зміни, які зумовлені необхідністю підвищення якості освітніх послуг, подолання корупції в оцінюванні знань, тощо. Новаціями, зокрема, є перехід на незалежне зовнішне тестування випускників шкіл, впровадження у вищій школі дистанційної системи навчання, яке також передбачає тестування за змістовими модулями дисциплін.

Процес реформування вітчизняної вищої освіти під європейські стандарти потребує особливої уваги до питання якості освітніх послуг. Якість освіти розуміють як зумовлений соціальним замовленням рівень сформованості передбачених навчальною програмою знань та вмінь, професійних якостей людини, що навчається.

Якість освітніх послуг багато в чому визначається й системою зворотного зв’язку на етапах вхідного, поточного, проміжного, підсумкового і відстроченого контролю, який називають ще контролем залишкових знань. Внутрішня діагностика успішності студентів за кожною навчальною дисципліною здійснюється викладачами.

Тому контроль знань - це ще й можливість удосконалювати форми, методи й засоби педагогічної майстерності 3 метою ефективного формування знань у студентів, розвитку їх творчих здібностей. За таких умов методи тестового контролю знань студентів набувають особливого значення.

Останній рік, проведений людством в умовах пандемії, особливо загострив питання якісної дистанційної освіти для молоді.

Разом із впровадженням комп'ютерних тестових програм, поширенням дистанційної форми освіти тестування стає неодмінним елементом будь-якого навчального процесу.

Безсумнівно, маємо переваги цього процесу: можливість перевірки рівня знань i навичок у студентів протягом обмеженого часу, зменшення трудомісткості процесу, можливість охопити одночасним тестуванням великий контингент екзаменованих, забезпечення студентів самоконтролем у перевірці засвоєного матеріалу [1].

Проте, постає питання об'єктивності оцінювання знань за рахунок ліквідації прямого контакту "викладач-студент". Адже поверхневий, некваліфікований підхід до складання тестів, самої процедури тестування і аналізу результатів наносить більше шкоди, ніж користі. Дистанціювання викладача в процесі тестування від студентів, не дає можливості одержати останнім підказку, роз'яснення. Тому зростають вимоги до коректного, чіткого й недвозначного 
формулювання запитань, до підбору адекватних дистракторів (варіантів неправильних відповідей). Тестові завдання не повинні перетворюватися лише на перевірку можливостей пам'яті студентів. Тестом мають перевірятися й логічне мислення студента, його здатність до встановлення зв'язків, інтерпретації фактів, застосування відомих принципів у нових ситуаціях. I складання тестів такого рівня потребує певних дидактичних навиків i педагогічного досвіду [2].

Щоб досягти найбільшої об'єктивності тестового оцінювання знань необхідно виключити всі можливі способи шахрайства зі сторони студентів. А саме:

$\checkmark$ передачу свого пароля/логіна більш освідченій людині для проходження тесту;

$\checkmark$ користування допоміжними засобами інформації (довідниковою літературою, гаджетами);

$\checkmark$ найбільш примітивний спосіб проходження тестів - відповіді навмання;

$\checkmark$ проходження тестів одним студентом 3 наступною передачею правильних відповідей усій групі.

Можна запропонувати тестуючому викладачу наступні дії, що зменшують ризики необ' єктивного оцінювання:

○ особиста присутність студентів в аудиторії при тестуванні (як відбувається здача ЗНО);

○ проходження дистанційних тестів одночасно всією групою 3 ввімкненим відеозвязком з викладачем та обмеженням у часі;

○ розробка великої кількості запитань та уникнення альтернативного типу тестових питань (так/ні), в яких вірогідність правильної відповіді становить $50 \%$;

о використання широкої бази питань, з якої випадково вибираються питання для автоматичного формування індивідуальних тестів кожному студенту.

Що стосується графічних дисциплін, то їх специфіка змушує ширше застосовувати відкриті тести, в яких студенти мають змогу показати свої практичні навички виконання креслень 3 додержанням вимог державних стандартів за допомогою таких графічних редакторів, як Автокад, Компас та ін.

Відсутність в системі вищої освіти чітко визначеної технології оцінювання якості знань, застосування нестандартизованих засобів контролю якості освіти у ВНЗ часто призводить до дискредитації тестування, негативного його сприйняття як викладачами, так і студентами, непотрібного соціального напруження в суспільстві.

Тому в нинішніх умовах викладачам вищих навчальних закладів потрібне термінове навчання новітнім технологіям складання критеріально-орієнтованих тестових завдань для оцінки якості знань у відповідності з критеріями валідності, надійності, складності тощо [3], які до них висуваються. 
Список літератури

1. Методичні рекомендації 3 організації тестового контролю освітньопрофесійної підготовки вчителя. - Тернопіль: видавництво ТНПУ ім.В.Гнатюка, 2004. - 100c.

2. Малихін А. Тести у навчальному процесі сучасної школи // Рідна школа 2001 - №8.

3. Педагогическая диагностика. Под ред. К.Ингенкампа. Перевод с нем. - М., 1991. - 525 c. 


\section{ПСИХОЛОГІЧНІ ПРОБЛЕМИ ІНФОРМАТИЗАЦЇ̈ ГУМАНІТАРНОÏ ОСВІТИ}

\section{Коробко Тетяна Олександрівна}

старший викладач

Одеський національний морський університет

Педагогічна мета інформатизації гуманітарної освіти полягає, в тому, щоб забезпечити на цій основі загальний і спеціальний розвиток особистості. Впровадження в навчальний процес новітньої технології навчання, тобто науково-методичного забезпечення, метою якого стає для педагога - покращення навчального процесу, а в наслідок цього успішного засвоєння навчального матеріалу студентами.

Об'єкт дидактики охоплює всю сукупність важливих відношень в процесі діяльності і спілкування педагога і студентів. При визначенні ефективності навчального процесу, при впровадженні посібника, методичних вказівок, або інших технологій навчання - ставимо мету конкретного дослідження одного із співвідношень, яке $\epsilon$ в центрі уваги, але враховувати необхідно і всі інші. Таким чином, об'єктом дослідження є навчальний процес [6].

Психологічний аспект спілкування - $\epsilon$ засобом розвитку свідомості i діалогічне за засобом здійснення. Працюючи з комп'ютером, людина має справу не 3 предметом, а з різними формами їх модельного відображення. Це веде до безпредметності, викривлення змісту предмета. Результатом $\epsilon$ руйнування свідомості та особистості людини. Для того, щоб попередити можливості небажаної трансформації діяльності і спілкування, треба знайти шляхи збереження предметності, які здійснюються за допомогою комп'ютеризації, i вірно визначити місце предметно-практичної діяльності і живого людського спілкування.

Не зважаючи на те, що існує безліч методів викладання, все ж таки немає одного методу, який нарешті задовольнив би усіх. Але інформатизація навчання у різних іiі виглядах в останні часи грає не останню роль, у тому ж самому навчанні і вихованні.

Наприклад, метод Холта [3]. Цей метод було перенесено в американські університети, і у трохи зміненому вигляді, він став відомий як «аудіовізуальний» й цілком витіснив традиційний метод читання й перекладу. Замість перекладів широко увійшло в практику вживання різного наочного приладдя, малюнків, пояснення рухами. «Аудіовізуальна» система панувала впродовж шістдесятих років минулого століття, аж поки не почулися голоси, що дорослим студентами хочеться бачити більш дорослий підхід, де вони мали б можливість проявляти більше ініціативи й користуватися своїми аналітичними здібностями, а не повторювати механічно. Почалися пошуки нового методу.

Сьогодні ситуація дещо змінилась. Існує нова теорія у психології інформатизації навчання під назвою «моніторна модель», яка твердить, що це зовсім відмінні процеси: перший - смислово-спостерігальний, другий - 
аналітичний, систематизований. Перший назвали «надбання», другий «вивчення» [4].

Стосовно останнього, можна навести дослідження I.I. Мархеля. У своїх роботах $[7,8]$ він аналізує місце дидактичних засобів в умовах комп'ютеризації навчання, їх проблеми й перспективи розвитку, а також в його роботах подається класифікація комп'ютерних дидактичних засобів.

На сьогоднішній день, найбільш перспективним напрямком у використанні можливостей інформаційних технологій, для підвищення якості підготовки студентів $\epsilon$ дистанційне навчання. Тому актуальним зараз $є$ розуміння ідеї психолого-педагогічних складових інформатизації у процесі підготовки студентів гуманітарних напрямків освіти, як найважливішого засобу організації інтерактивного навчання (мови).

Визначення терміну «Інформатизація» дає «Словник педагогічних термінів»:

1) Інформатизація - соціальний процес підвищення престижу інформаційних наук, розповсюдження інформаційних методів практичної діяльності;

2) Організаційний, соціально-економічний та науково-технічний процес створення оптимальних умов для задоволення інформаційних потреб та реалізації прав громадян, органів державної влади, органів місцевого самоврядування, організацій, громадських об'єднань на підставі формування і використання інформаційних ресурсів [10].

У поняття «інформація» також входить отримання різними засобами (органами чуття) інформації з навколишнього світу. Це і зір (візуально) і слух (аудіо), дотик. Тобто засобів поповнити інформацією свою уяву безліч. I всі їх треба використовувати у навчальному процесі, щоб покращити результат цього процесу. I дуже було б добре розробити метод, який би об'єднував усі ці засоби.

Кожний метод викладання грунтується на певних психологічних постулатах. Постулатах, які випливають з філософії педагогіки і включають питання мети освіти взагалі та людських можливостей цю мету осягнути. Різні методи можуть віддавати перевагу різним аспектам мововжитку: в одних переважає вміння розмовляти, в інших акцент робиться на читанні, у третіх - перекладі. Деяких лінгвістів взагалі не цікавить практичний чи комунікативний аспект мови, і вони пропонують студентам вивчати саму структуру - парадигми, закони сполучень, лишаючи ознайомлення з живою мовою на пізніше [4].

Певний час (50-ті роки минулого століття) в Америці був популярний метод Холта. Холт розробив цей метод під час Другої Світової Війни в американських військових школах. Холт будував свою систему на припущенні, що найприроднішим для усіх $\epsilon$ той шлях, яким засвоюють мову діти: спочатку вони чують слова й речення, придивляються й прислухаються до того, як дорослі їх вживають, і згодом самі починають їх вживати. Холт вирішив якомога ближче наслідувати цей метод: треба повторювати готові моделі доти, доки вони не вріжуться в пам'ять.

Виявляється, що в старшому віці наш психично-навчальний апарат працює зовсім інакше. Отже, методи міняються, але питання про те, чи існує відмінність між засвоєнням мови дітьми та дорослими, залишається розв'язаним. 
Прихильники теорії «моніторної моделі» переконливо доводять, що коли дитина підростає, в неї розвиваються аналітичні здібності, які уможливлюють спостереження окремих явищ.

Таким чином, можна стверджувати, що «інформатизація» втручається в процес навчання на різних стадіях і в різний спосіб, часом витягаючи мовні навички періоду «надбання», причому тут грає неабияку роль психічний стан мовця i соціальні обставини, в яких він перебуває. Тому до процесу інформатизації треба дещо додати, а саме психічні та соціальні чинники, які вливають на процес навчання.

У науці існують різні точки зору на можливості застосування комп'ютерів у гуманітарній області. Одні вченні вважають, що це може призвести до дегуманізації освіти, й пропонують обмежити область застосування комп'ютерів сферою предметів природно-математичного циклу. При цьому викладається точка зору, що саме гуманітарні предмети повинні виступати свого роду захистом людини від ЕОМ. Інші стверджують, що розумне використання комп'ютерів у гуманітарній освіті може дати позитивні результати, іноді навіть більш ефективні, ніж при традиційній методиці навчання [11].

Інформатизація гуманітарної освіти передбачає рішення багатьох соціальних, методичних, психологічних, лінгвістичних, логічних проблем, що пов'язані передусім з посиленням ролі людського фактору, 3 впливом комп'ютера на здоров'я та психіку людини [12].

Виникає також питання про методологічну специфіку рішення інформаційних проблем у гуманітарному пізнанні. Чи допоможе комп'ютер гуманітарію у аналізі та оцінці матеріалу, у пошуку необхідних документів, різноманітних фактів, тобто у посиленні його інтелектуальної діяльності, у наближенні гуманітарного пізнання до можливості отримання найбільш точних та об' єктивних результатів?

Місце комп'ютера у даному випадку залежить, з одного боку, від специфіки навчального предмету (історії, літератури, рідної та іноземної мови) та закономірностей процесу навчання, 3 іншого - від технічних можливостей комп'ютера і дидактичних функцій, якими він володіє. Питання треба ставити так: у чому методичні переваги комп’ютера порівнюючи 3 традиційними засобами навчання.

Нові інформаційні технології навчання стали вимагати принципово нових форм організації навчального процесу, що в цілому збагатило теорію навчання дидактику. Основні дидактичні принципи реалізуються у комп'ютерній технології навчання на більш вищому рівні на підставі кібернетичного підходу до управління навчальним процесом, що передбачає у перспективі комплексне застосування всіх видів дидактичних засобів. Комплексне використання таких засобів комп'ютерної технології навчання передбачає розробку та застосування різних видів навчаючих і контролюючих програм, їх поєднання із звичайними способами та засобами навчання, при якому проявляється ефект інтеграції [8].

При застосуванні у навчальному процесі дидактичних засобів спостерігається тенденція до підвищення успішності студентів. Запровадження цих засобів, дозволяє найбільш повно використовувати педагогічні можливості 
нових інформаційних технологій навчання та забезпечують оптимізацію навчального процесу, удосконалюють засоби надання студентам навчальної інформації, активізують пізнавальну діяльність студентів, розвивають їх самостійність у рішенні конкретних навчальних задач.

Але, тільки при збережені провідної ролі викладача у навчанні можливий перспективний розвиток комп'ютерних дидактичних засобів та оптимальне використання їх у навчально-виховному процесі. Але як завершення даного процесу, постає питання у вирішенні проблем дослідження наслідків комп'ютеризації освіти.

Інформатизація суспільства протікає занадто стрімко, що висуває перед вищими навчальними закладами задачу підготовки випускників, здатних гнучко адаптуватися у життєвих ситуаціях, самостійно творчо та критично мислити, генерувати нові ідеї, вміти працювати з інформацією, бути комунікабельним, самостійно працювати над розвитком свого інтелекту, культурного рівня.

Новою освітньою науковою установкою $\epsilon$ дистанційне навчання, яке дозволяє не тільки сформувати індивідуальне навчання, використовуючи можливості сучасних інформаційних технологій, але і повністю задовольнити потреби студентів у освітніх послугах. Тому велике значення у процесі дистанційного навчання має педагогічний супровід.

При дистанційному навчанні викладач повинен організувати самостійну діяльність студентів таким чином, щоб навчити їх самостійно здобувати знання та застосовувати отриманні знання на практиці. Тому розвиток педагогічних технологій пов'язаний, перед усім, 3 використанням нових інформаційних технологій.

Дистанційне навчання, засноване на комп'ютерних технологіях, має переваги перед традиційними формами навчання. Воно вирішує психологічні проблеми студентів, знімає часові та просторові обмеження, які пов'язані з віддаленістю студентів від викладачів та навчальних закладів, допомагає навчатися людям 3 обмеженими фізичними можливостями, виключає конфліктні ситуації при очному навчанні, розширює комунікаційну сферу студентів.

Для педагогічного супроводу в процесі дистанційного навчання важливими $\epsilon$ наступні параметри: мотивація студентів, психологічні аспекти вивчення дисципліни, принцип інтерактивності; психологічні особливості сприйняття студентами інформації і т.п.

Основу освітнього процесу в дистанційному навчанні складають цілеспрямована й контрольована інтенсивна самостійна робота студентів.

В гуманітарній освіті ефективність процесу дистанційного навчання досягається наступними умовами: наявність у студентів комп'ютерної грамотності, з урахуванням психологічної особливості сприйняття, пам'яті, мислення, уваги, вікових, індивідуальних та особистісних рис студентів, вміння викладачів вести діалог засобами інформаційних технологій, знаходити індивідуальних підхід до студентів, здійсненням особливим чином організованого самоконтролю студентів і систематичного контролю викладача за засвоєнням знань, володіння студентами навичками самостійної роботи, 
забезпеченням ефективної взаємодії усіх компонентів системи дистанційного навчання.

На сьогоднішній день зрозуміло, що навчальний комп'ютер без «дидактичного» наповнення не забезпечить позитивного результату при використанні в навчальному процесі комп'ютерних технологій навчання.

В свою чергу комп'ютерні технології на пряму пов'язані з інформатизацією освіти. Створення ефективної системи інформатизації навчання потребує дослідження іï елементів як об’єктів інформатизації. Необхідно розробити методику досліджень, застосування яких забезпечувало б отримання параметрів об'єктів інформатизації, необхідних для визначення оптимальних параметрів системи інформатизації в гуманітарній освіті.

Основною сутністю інформатизації гуманітарної освіти $є$ використання інформаційних технологій у різних видах діяльності, які здійснюються в системі освіти, в тому числі і дистанційне навчання.

Галузь застосування дистанційного навчання дуже велика - від вивчення окремих навчальних дисциплін до організації системи дистанційного навчання. Дистанційне навчання необхідне студентам, які мають ускладнення при традиційному, очному навчанні: «замкнуті» студенти, студенти особливого психотипу, комп'ютерно-орієнтовані студенти.

Дистанційне навчання пропонує декілька різних технологій, які можуть бути використані при проведені занять. Базовою технологією дистанційного навчання $\epsilon$ технологія, що побудована на використанні Інтернет-технологій. У межах дистанційного навчання знайшли застосування всі засоби, які пропонує користувачам Інтернет.

Як підсумок необхідно зазначити, що в гуманітарній освіті використання технології дистанційного навчання, що побудована на використанні Інтернеттехнологій, витісняє усі інші технології дистанційного навчання. У тому числі 3 причин того, що Інтернет-технологій поступово включають у себе інші інформаційні технології. Наприклад, телефонія все більше стає частиною Інтернету.

\section{Список літератури}

1. Аксьонова О.В. Методика викладання економіки: Навч. посібник. - К.: KHEУ, 1998. $-280 \mathrm{c}$.

2. Алексюк А.М. Педагогіка вищої освіти України. Історія. Теорія: Підручник. - К.: Либідь. 1998. - 560 с.

3. Бахтина О.И. Технические возможности компьютера в процессе обучения.//Воросы обучения и воспитания. - 1996. - №11. - С.306.

4. Бєляєва О.М. Концепція інтенсивного навчання.// Українська мова i література в школі. - 1991. - №6. - С.151.

5. Загвязинський В.Н. Методология и методика дидактического исследования. - М.: Педагогика, 1982. - 160 с.

6. Кизима Р.А. Методика визначення ефективності нових технологій навчання // Нові інформаційні технології навчання в навчальних закладах України: Сб. - Одесса, 2001. - С. 123-125. 
7. Мархель И.И. Дидактические средства в условиях компьютеризации обучения // Нові інформаційні технології навчання в навчальних закладах України: Сб. - Одесса, 1996. - С. 75-82.

8. Мархель И.И. Компьтерные технологии обучения: проблемы и перспективы развития // Нові інформаційні технології навчання в навчальних закладах України: Сб. - Одесса, 2001. - С. 3-7.

9. Нагаєв В.М. Методика викладання у вищій школі: Навч. посібник. - К.: Центр учбової літератури, 2007. - 232 с.

10. Словник педагогічних термінів. - Київ, 1993. - 183 с.

11. Теклюк В.Я. Психолінгвістичні основи методу зосередження над мовою. //Українська мова і література в школі. - 1991. - №12. - С.61.

12. Шишук А.Ф. Використання динамічних таблиць для активізації розумової діяльності учнів. //Українська мова і література в школі. - 1997. - №4. - C.51. 


\title{
РОЛЬ ШТУЧНОГО ІНТЕЛЕКТУ ЯК ІНТЕЛЕКТУАЛЬНОГО АГЕНТА В ІНТЕРАКТИВНОМУ НАВЧАННІ СТУДЕНТІВ
}

\author{
Кравцова Наталія Василівна \\ к.фарм.н, асистент кафедри фармакології \\ Національний медичний університет імені О.О. Богомольця \\ Ходаківська Ольга Віталіївна \\ к.фарм.н, доцент кафедри фармакології \\ Національний медичний університет імені О.О. Богомольця \\ Кравцов Григорій Олексійович \\ к.т.н, старший науковий співробітник \\ Інститут проблем моделювання в энергетиці імені Г.Е. Пухова НАН \\ України
}

Технології інтерактивного навчання досить широко використовуються в сфері освіти для вдосконалення навчального досвіду та покращення засвоєння знань студентами [1]. Зрештою, було доведено, що інтерактивне навчання в шість разів більше допомагає учням навчатися [2]. Хоча цей підхід до навчання протягом багатьох років набув форми рольових ігор, розповіді історій (storytelling), а також зворотного зв'язку, він сильно видозмінився та розвинувся в епоху цифрових трансформацій.

Технології штучного інтелекту (ШІ) вже не є футуристичними ідеями, а інтенсивно впроваджуються в усі сфери людського життя. Так, аналітики прогнозують зростання ринку штучного інтелекту в освітньому секторі США на рівні CAGR 47,77\% протягом періоду 2018-2022 років [3]. Крім того, пандемія COVID-19 змусила педагогів та студентів у більш ніж 186 країнах світу перейти в онлайн формат та активно використовувати сучасні інформаційно-комп'ютерні технології (ІКТ) в інтерактивному онлайн навчанні [4].

Така тенденція призводить до ряду змін у модель взаємодії «студентвикладач», оскільки невід ємною третьою частиною цієї взаємодії стає інтелектуальний агент (IA). Метою впровадження IA $\epsilon$ побудова процесу навчання таким чином, щоб при мінімальних затратах часу досягти максимального ефекту навчання.

Модель мультиагентної системи, що представлена на Рис.1, може забезпечити одну з основних вимог інтелектуального інтерактивного навчання: реалізація та підтримка персоналізованого навчання, яке сприяє наданню освітніх послуг, що будуть максимально відповідати рівню підготовки та потребам користувачів (учнів та студентів). 


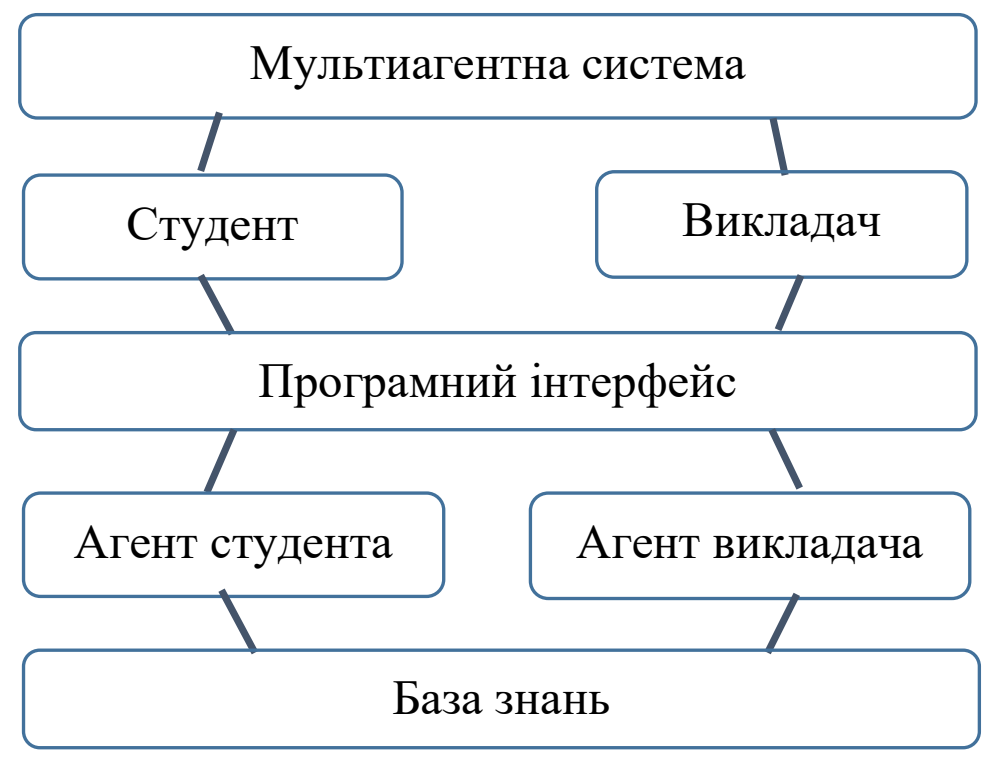

Рис.1. Модель мультиагентної навчальної системи

Основне призначення агента студента - проаналізувати персональний профіль кожного студента, відобразити його можливості та здібності до навчання, особливості сприйняття інформації, потреби та інтереси. Далі, інформувати про них систему, формувати адаптовану програму та сценарій навчання, підбирати контент відповідного формату (текст, картинки, анімації, відео і т.д), таким чином мотивуючи та залучаючи студентів до навчання. Агент викладача бере на себе частину рутинних задач викладача по базовому підбору відповідних навчальних матеріалів, інформуванню студентів, проведенню тестувань та оцінці.

Так як штучний інтелект здатний аналізувати одночасно великі об'єми інформації і враховувати фактори, які іноді людина може упустити, агент викладача може формувати для викладача чіткий персональний профіль кожного студента, який включатиме психологічні особливості студента, вихідний рівень знань, здібності до навчання, рівень мотивації до навчання, глибину занурення в навчальний матеріал, особливості сприйняття інформації (аудіал, візуал, кінестетик), інтерес до певного матеріалу та пріоритети в навчанні.

Важливим $є$ факт, що даний аналіз профілю буде виконаний штучним інтелектом без урахування вікових, гендерних, етичних, расових та релігійних особливостей студента, мінімізуючи таким чином стереотипність мислення та рівень суб `ктивізму, що в певній мірі характерні для людей [5].

Отже, підсумовуючи вищесказане, можна виділити наступні основні функції інтелектуального агента в мультиагентному середовищі:

- Аналіз

- Адаптація

- Автоматизація

- Персоналізація

- Оцінка

- Мотивація 


\section{- Прогноз}

Інтелектуальні мультиагентні системи $є$ найбільш перспективним напрямком штучного інтелекту в сфері навчання [6]. Велика кількість науковців усього світу, спеціалісти в області нейробіології, нейрофізіології та комп'ютерних наук прагнуть зрозуміти, як працює мозок людини, як розвивається інтелект, як людина навчається та як зароджуються нові знання. Адже, глибоке й чітке розуміння цих процесів у мозку людини здатне наблизити науковців до створення сильного штучного інтелекту, максимально наближеного до людського, тобто такого, що буде володіти самосвідомістю, рефлексією та здатністю імітувати поведінку людини [7].

Станом на сьогодні чітких уявлень про те, як працює мозок людини немає. Як результат, використовуються технології слабкого штучного інтелекту, який виконує роль допоміжного інструменту в виконанні рутинних задач, автоматизації певних процесів, перевірці тестів і оцінці знань, елементарному підборі необхідного навчального матеріалу, розпізнаванні голосу і обличь. Однак, потенціал штучного інтелекту до кінця не розкритий.

Сильний штучний інтелект повинен вміти взаємодіяти 3 користувачем за допомогою натуральної мови (natural language), правильно інтерпретувати слова 3 урахуванням контексту. За таких властивостей штучний інтелект матиме здібність виконувати роль репетитора, інтелектуального тьютора, який здатен адаптувати програму навчання під індивідуальні особливості студента, відповідати на запитання, правильно розуміти студента та прогнозувати можливий результат навчання (predictive analytics).

Цілком зрозуміло, що ідея розробки та впровадження штучногоу інтелект має на меті полегшення людського життя та сприяння прогресу. Однак, потрібно враховувати i виклики, які стоять сьогодні перед людством. Необхідно формувати критичну позицію, перш ніж повністю інтегрувати штучний інтелект в освітні процеси. Як частина цієї критичної позиції, по-перше, необхідна розробка комплексної державної політики в області штучного інтелекту для стійкого розвитку, забезпечення інклюзивності та рівності в освіті. По-друге, необхідне створення якісних систем даних та навчання викладачів на базі технологій штучного інтелекту. По-третє, існує потреба у розробці етичної політики та чіткому визначенні етичних меж того, як штучний інтелект збиратиме, використовуватиме та розповсюджуватиме дані. Врахування цих аспектів допоможе розвивати та якісно впроваджувати технології штучного інтелекту в освітній простір.

\section{Список літератури:}

1. Ibrahim M., \& Al-Shara O. (2007). Impact of interactive learning on knowledge retention. In M.J. Smith \& G. Salvendy (Eds.), Human Interface and the Management of Information. Interacting in Information Environments. Human Interface 2007. Lecture Notes in Computer Science, vol 4558. Berlin, Heidelberg: Springer (pp. 347355). URL: https://doi.org/10.1007/978-3-540-73354-6_38 
2. Koedinger, K. R., Kim, J., Jia, J. Z., McLaughlin, E.A., \& Bier, N.L. (2015). Learning is not a spectator sport: doing is better than watching for learning from a MOOC. In Proceedings of the Second (2015) ACM Conference on Learning @ Scale (L@S' 15). Association for Computing Machinery, New York, NY, USA, 111-120. URL: https://doi.org/10.1145/2724660.2724681

3. Artificial Intelligence Market in the US Education Sector 2018-2022. URL: https://www.researchandmarkets.com/reports/4613290/artificial-intelligence-marketin-the-us

4. Online Education Market Study 2019. URL: https://www.globenewswire.com/news-release/2019/12/17/1961785/0/en/OnlineEducation-Market-Study-2019-World-Market-Projected-to-Reach-350-Billion-by2025-Dominated-by-the-United-States-and-China.html

5. Ten Facts About Artificial Intelligence in Teaching and Learning. URL: https://teachonline.ca/sites/default/files/tools-

trends/downloads/ten_facts_about_artificial_intelligence_0.pdf

6. Зайцева И.Н., Фортунова Н.А. (2017). Реализация мультиагентного подхода при создании обучающих систем. Вестник ВГУ, серия: Системный анализ и информационные технологии, (4), 134-138.

7. Кравцов Г.А., Кравцова Н.В. (2021). Искусственный интеллект в образовательном процессе. Материалы I международной конференции по мультидисциплинарным исследованиям. Берлин, Германия, 19-21 января, 670674. 


\title{
ИГРОВЫЕ И СОРЕВНОВАТЕЛЬНЫЕ МЕТОДЫ В ФИЗИЧЕСКОМ ВОСПИТАНИИ КАК ФАКТОР ФОРМИРОВАНИЯ МОТИВАЦИИ ШКОЛЬНИКОВ К ЗАНЯТИЯМ ДВИГАТЕЛЬНОЙ АКТИВНОСТЬЮ
}

\author{
Красильников Арсентий Александрович \\ к.п.н., доцент кафедры физического воспитания и безопасности \\ жизнедеятельности \\ ГАОУ ВО Московский городской педагогический университет
}

\begin{abstract}
Аннотация. В данной статье рассматриваются вопросы применения игровых и соревновательных методов не только в рамках школьной программы на уроках физической культуры, но и во время внеклассной физкультурнооздоровительной работе, организации и проведении массовых спортивных мероприятий.
\end{abstract}

Последнее время общество и государство уделяют большое внимание развитию спорта и проявляют заботу о здоровье нового поколения. Но, не смотря на все усилия, показатели здоровья нового поколения и физическая подготовка детей оставляет желать лучшего. Чтобы выработать у учащихся потребность к систематическим занятиям спортом и физической культурой, необходимо как минимум пять уроков физической культуры, а не три как предполагает учебная программа в настоящее время.

Особую важность имеют внеклассные спортивные мероприятия, которые помогают решать следующие задачи:

- разностороннее развитие школьников;

- развивают патриотизм, чувство коллектива, вырабатывают силу воли, которая может развить хорошую дисциплину;

- привлекают обучающихся к занятиям физической активностью на систематической основе, способствуют популяризации спорта;

- позволяют подвести итоги проведенной работы, подготовиться к сдаче нормативов.

Качество развитости внеурочной работы, имеет большое влияние на то, насколько здоровыми обучающиеся закончат школы и начнут взрослую жизнь. Спорт способствует формированию активной жизненной позиции, воспитанию в человеке упорства, дисциплинированности, физической выносливости, терпения, мужества и силы.

У подростков в 11-15 лет, обучающихся как правило в 5-7-х классах, наблюдается выраженный подъем жизненных сил, сопровождаемый перестройкой организма. В этот период происходит физическое созревание 
человека, формирование личности, повышение моральной и интеллектуальной развитости. Подростковый возраст называют таким, потому-что он характеризуется переходом от детского состояния к взрослому, от незрелости к зрелости [1].

Спорт отличается ранним включением регуляции в освоение. Спортивная деятельность втягивает ребенка в профессиональную сферу практически на взрослом уровне, но школьники не готовы по взрослому относиться к себе и эффективно регулировать свои психические состояния, что отражается как на их деятельности, так и на их отношениях с окружающими [2].

Школьники, активно занимающиеся спортом с раннего детства, привыкают к необходимости сочетать несколько важных видов дел: учебу в общеобразовательной школе, спортивные тренировки, соревнования. Совмещение такого количества дел развивает организованность, дисциплину и учит составлять график занятий. В конечном итоге спорт дает подросткам осознание того, что усилия, прикладываемые как и к учебе, так и к спорту дают возможность лучше реализоваться и там и там.

Самая важная цель на уроках по физической культуре, является всевозможное развитие личности обучающихся. Физическое воспитание обязано быть нацелено на формирование у обучающихся следующих качеств: ответственное отношение к своему здоровью, физическому развитию, гигиене; интерес к физической культуре и спорту; потребность в постоянных физических упражнениях [3]. Практически все физические качества (кроме гибкости) развиваются во время применения игровых и соревновательных методах. Кроме того, применение этих методов развивает владение техникой двигательных действий, решительности, упорству и прочим волевым качествам.

Соревновательный метод используется в качестве одного из содержательных элементов физкультурного занятия, направленного на повышение и поддержание интереса, a также стимулирование выполнения других упражнений. В более обширном представлении соревновательный метод применяется в виде официальных, контрольно-зачетных спортивных соревнований.

Важной составной частью соревновательного метода является возможность сравнения противоборствующих сил в условиях соревновательной деятельности, борьбы за победу или даже высокое достижение. Это и предопределяет характерные особенности соревновательного метода.

Во время состязательной деятельности, особенно когда она является значимой, как для личностного, так и общественного отношения, по сравнению с игрой, наиболее ярко проявляется психологическая напряженность. В данном случае действует фактор столкновения противоположно направленных интересов, противоборства, противодействия. Более того, в командных состязаниях детьми применяются отношения взаимопомощи и ответственности перед командой за достижение победы. Сравнительно с другими методами 
физического воспитания соревновательный позволяет предъявить наиболее высокие требования к функциональным возможностям организма и тем самым способствовать их наибольшему развитию [4].

Проанализировав литературные источники, можно сделать следующий вывод о том, что игровой и соревновательный методы являются незаменимыми в среднем школьном возрасте в системе физического воспитания общеобразовательной школы, поскольку они влияют на эмоциональную сферу учащихся и позволяют повышать активность подростков в физкультурномассовых мероприятиях.

Кроме того, рациональная организация игр и праздников по физической культуре во всех возрастах, способствует привлечению большого количества учащихся. Следовательно, прививается желание заниматься физической культурой и спортом. Обучающиеся с практически любым уровнем физической подготовленности могут проявить себя, а также повысится уровень заинтересованности школьников при участии в физкультурно-массовых мероприятиях и занятиях спортом в целом.

\section{Литература:}

1. Красильников А.А. Новые технологии обучения в образовательном процессе по физической культуре // В сборнике: ADVANCING IN RESEARCH AND EDUCATION. Abstracts of XII International Scientific and Practical Conference. 2020. C. 348-353.

2. Пушкина В.Н., Гернет И.Н., Федорова Е.Ю., Оляшев Н.В. Трансформация подходов к занятиям физической культурой в современной образовательной среде // В сборнике: Трансформация подходов к физическому воспитанию в образовательных организациях. сборник статей по материалам Межрегиональной научно-практической конференции института естествознания и спортивных технологий. 2019. С. 102-107.

3. Лубышев Е.А., Красильников А.А., Закиров Ф.Х. Ценностные ориентации в области физической культуры и проблемы их формирования в молодежной среде // В сборнике: Инновационные технологии в спорте и физическом воспитании подрастающего поколения сборник статей по материалам $\mathrm{X}$ научно-практической конференции с международным участием. 2020. C. 288-294.

4. Николаева Н.И., Лубышев Е.А., Красильников А.А. Соответствие должностей и видов деятельности в профессиональном стандарте «Тренер» квалификационным требованиям отрасли «Физическая культура и спорт» // Физическая культура: воспитание, образование, тренировка. 2020. № 6. С. 70-73.

5. Красильников А.А., Лубышев Е.А., Валиев Р.Р. Программные продукты и сервисы в работе учителя физической культуры // В сборнике: Инновационные технологии в спорте и физическом воспитании подрастающего поколения 
сборник статей по материалам $\mathrm{X}$ научно-практической конференции $\mathrm{c}$ международным участием. 2020. С. 259-267.

6. Пушкина В.Н., Оляшев Н.В., Гернет И.Н., Федорова Е.Ю. Функциональные способности кардиореспираторной системы у лиц с разным типом кровообращения // В сборнике: Физическая культура, спорт, туризм: инновационные проекты и передовые практики. Материалы Международной научно-практической конференции, посвященной 90-летию основания кафедры физического воспитания. Под редакцией Л.Б. Андрющенко, С.И. Филимоновой. 2019. C. 711-718.

7. Лубышев Е.А. Спорт и социализация: социокультурный аспект // В сборНИКе: НАУЧНО-ПЕДАГОГИЧЕСКИЕ ШКОЛЫ В СФЕРЕ ФИЗИЧЕСКОЙ КУЛЬТУРЫ И СПОРТА. Материалы Международного научно-практического конгресса, посвященного 100-летию ГЦОЛИФК. 2018. С. 452-456.

8. Красильников А.А., Лубышев Е.А. Ключевые преобразования образовательной среды в контексте внедрения информационно-компьютерных технологий // В сборнике: СУЧАСНІ ВИКЛИКИ І АКТУАЛЬНІ ПРОБЛЕМИ НАУКИ, ОСВІТИ ТА ВИРОБНИЦТВА: МІЖГАЛУЗЕВІ ДИСПУТИ. Матеріали IX Міжнародної науково-практичної інтернет-конференції. 2020. С. 382-389.

9. Красильников А.А., Лубышев Е.А., Измененная образовательная среда в контексте внедрения цифровых технологий в образовании // В сборнике: Study of modern problems of civilization. Abstracts of V International Scientific and Practical Conference. 2020. C. 307-312.

10. Zakirov F. H., Krasilnikov A. A., Pushkina V. N., Gernet I. N., Andruschenko L. B., Yamaletdinova G. A. The role of damages and epigenetic modifications of dna in alzheimer's disease // Indo American Journal of Pharmaceutical Sciences. 2019. - T. 6. - №5 - C. 9700-9703.

11. Лубышев Е.А., Красильников А.А., Лубышева Г.С. Спортивные сооружения как движущий фактор развития массовой физической культуры в обществе // В сборнике: СУЧАСНІ ВИКЛИКИ І АКТУАЛЬНІ ПРОБЛЕМИ НАУКИ, ОСВІТИ ТА ВИРОБНИЦТВА: МІЖГАЛУЗЕВІ ДИСПУТИ. Матеріали IX Міжнародної науково-практичної інтернет-конференції. 2020. С. 425-432.

12. Красильников А.А. Применение информационных технологий в преподавании физической культуры // В книге: Trends in the development of modern scientific thought. Abstracts of X International Scientific and Practical Conference. 2020. C. 470-475.

13. Лубышев Е.А., Красильников А.А. Занятия карате киокушинкай в системе дополнительного образования студентов экономического ВУЗа // В сборнике: Шаг в науку. сборник статей по материалам III научно-практической конференции института естествознания и спортивных технологий. 2019. С. 7981 .

14. Федорова Е.Ю., Пушкина В.Н., Гернет И.Н., Сизов А.Е. Типовой портрет физической активности обучающихся общеобразовательных организаций Москвы // Ученые записки университета им. П.Ф. Лесгафта. 2019. № 9 (175). С. 304-309. 
15. Закиров Ф.Х., Красильников А.А. Использование технологии подкастинга как инновационного метода обучения в физической культуре // В сборНИКе: ИННОВАЦИОННЫЕ ТЕХНОЛОГИИ В СПОРТЕ И ФИЗИЧЕСКОМ ВОСПИТАНИИ ПОДРАСТАЮЩЕГО ПОКОЛЕНИЯ МатерИаЛЫ IX Всероссийской научно-практической конференции. Институт естествознания и спортивных технологий Московского городского педагогического университета Коллектив авторов. 2019. С. 112-116.

16. Закиров Ф.Х., Красильников А.А., Лубышев Е.А., Чубанова Г.Р. Перспективы использования биомаркеров остеопороза в диагностике и лечении // Хирургическая практика. 2019. № 1 (37). С. 45-47.

17. Лубышев Е.А., Красильников А.А. Индивидуализация современных образовательных технологий в преподавании теории физической культуры // В сборнике: Трансформация подходов к физическому воспитанию в образовательных организациях Материалы Межрегиональной научнопрактической конференции института естествознания и спортивных технологий. 2019. C. 77-82.

18. Zakirov F.Kh., Krasilnikov A.A. Age-related differences in decision-making process in the context of healthy aging // В сборнике: BIO Web of Conferences. 2020. C. 01022 .

19. Красильников А. А., Лубышев Е. А., Закиров Ф. Х. Информационные технологии в методологии преподавания физической культуры // Материалы III научно-практической конференции (I всероссийской) института естествознания и спортивных технологий. 2019: сборник научных статей - Москва, 2019. Москва: МГПУ - С. 66-70

20. Федорова Е.Ю., Красильников А.А. Медико-социальные особенности пациентов со стенокардией и сахарным диабетом 2 типа // В сборнике: СУЧАСНІ ВИКЛИКИ І АКТУАЛЬНІ ПРОБЛЕМИ НАУКИ, ОСВІТИ ТА ВИРОБНИЦТВА: МІЖГАЛУЗЕВІ ДИСПУТИ. Матеріали IX Міжнародної науково-практичної інтернет-конференції. 2020. С. 255-264.

21. Красильников А.А. Возможности применения цифровых ресурсов в образовательном процессе системы высшего образования // В сборнике: Академические исследования в области междисциплинарных инноваций. 2020. C. 278-283.

22. Битейкин М.М., Красильников А.А. Дистанционное обучение по предмету «физическая культура» как способ мотивации обучающихся к самостоятельной двигательной активности // В сборнике: Шаг в науку. сборник статей по материалам IV научно-практической конференции молодых ученых. 2020. С. 103-110.

23. Кокоулина О.П., Иванов В.А., Лубышев Е.А., Буянова Т.В., Маврина С.Б. Социально-психологическая адаптация спортсменов после завершения профессиональной карьеры // Теория и практика физической культуры. 2019. № 7. C. $49-51$.

24. Алмазова Ю.Б., Лубышев Е.А., Столяр К.Э., Кондраков Г.Б. Актуализация личностного смысла участия студентов в подготовке и сдаче 
нормативов ВФСК ГТО // Теория и практика физической культуры. 2019. № 9. C. 21-23.

25. Пушкина В.Н., Закиров Ф.Х., Красильников А.А., Гернет И.Н. Возможности применения новых технологий в преподавании физической культурЫ // В сборнике: ИННОВАЦИОННЫЕ ТЕХНОЛОГИИ В СПОРТЕ И ФИЗИЧЕСКОМ ВОСПИТАНИИ ПОДРАСТАЮЩЕГО ПОКОЛЕНИЯ. Материалы IX Всероссийской научно-практической конференции. Институт естествознания и спортивных технологий Московского городского педагогического университета Коллектив авторов. 2019. С. 160-162.

26. Закиров Ф. Х., Красильников А. А., Лубышев Е.А. Фитнес-трекеры на уроках физической культуры: примеры и перспективы // Московский экономический журнал. - 2020. - №4 - С. 63.

27. Пушкина В.Н., Гернет И.Н., Оляшев Н.В., Лубышев Е.А. Состояние системы внешнего дыхания у юношей, проживающих в разных регионах России // Теория и практика физической культуры. 2020. № 4. С. 17-19.

28. Красильников А. А., Закиров Ф. Х. Подкастинг как инновационная методика обучения студентов на примере медицинского образования // Педагогический журнал. - 2018. - Т. 8. - №5А. - С. 553-558.

29. Красильников А.А., Закиров Ф.Х. Возможности применения информационно образовательных технологий и цифровых образовательных ресурсов в преподавании физической культуры // В сборнике: Современные проблемы физического воспитания и спорта, безопасности жизнедеятельности в системе образования. Сборник научных трудов III Всероссийской научнопрактической конференции с международным участием, посвященной юбилею доктора педагогических наук, профессора Л.Д. Назаренко. Под редакцией Л.И. Костюниной. 2019. С. 492-496.

30. Красильников А.А. Модель инновационной педагогической системы образовательного учреждения // В сборнике: Инноватика в образовании. Сборник статей по материалам II научно-практической конференции. Институт инновационной деятельности в образовании, РОССИЙСКАЯ АКАДЕМИЯ ОБРАЗОВАНИЯ. 2014. С. 27-38. 


\title{
САМООСВІТА-ПДВИЩЕННЯ КОМПЕТЕНТНОСТІ ПЕДАГОГІВ
}

\author{
Ластовецька Ірина Юріївна \\ Викладач вищої категорії,методист \\ Новобузький коледж Миколаївського \\ національного аграрного університету
}

1. Нажливішим завданням сьогодення в освітній галузі є підвищення якості підготовки і рівня кваліфікації педагогічних кадрів.Здатність до самоосвіти набагато важливіша, ніж сама освіта у навчальному закладі.Це має сприяти професійному розвитку педагога, відновленню і збагаченню цілісності особистості, актуалізації здібностей та прояву його самобутності.

Тому виникає потреба в оволодінні найновітнішими технологіями в самоосвіті та самовдосконаленні педагога. Проблеми самоосвіти педагогів досліджували В. Бондаревський, М. Бондаренко, С. Гергуль, О. Горленко, А. Громцев, Г. Закіров,О. Кочетов, П. Підкасистий, О. Прокопова, Б. Райський, М. Рогозіна, Н. Терещенко та ін.

2. Педагогіка поняття «самоосвіта» визначає як освіту, яка набувається у процесі самостійної роботи без проходження систематичного курсу навчання в стаціонарному навчальному закладі.Важливу роль у формуванні навичок самоосвіти відіграє школа [12, с.296].

На думку В. Сухомлинського, самоосвіта - це самостійне оволодіння теоретичним матеріалом і практичними вміннями [12, с.31], особисті зусилля кожного окремого вчителя,котрі спрямовані на підвищення власної професійної майстерності та педагогічної культури.Педагог особливого значення надавав обізнаності вчителя в основах психології, тому що першочерговими завданнями педагога $\epsilon$ вивчення особистості учня, його психологічних особливостей, темпераменту, характеру тощо [7, с.229].

Як усвідомлену потребу в постійному вдосконаленні власної професійної діяльності викладача, спрямовану на розширення та поглиблення знань і вмінь, трактує самоосвіту О. Горленко [9, с.38]. М. Рогозіна, у свою чергу, самоосвіту майбутніх педагогів розглядає як творчий процес оволодіння професійними знаннями. На думку вченої, мотивація до самоосвіти залежить від: уміння педагога створювати ситуації емоційного переживання щодо конкретної наукової, навчальної чи методичної інформації, значущої для його професійного становлення; наявності у вищих навчальних закладах організованої системи педагогічного забезпечення самоосвітньої діяльності [11, с.175]. Це включає в себе:

- принцип особистісно зорієнтованого підходу до організації самоосвіти;

- сприйняття набутих знань як особистих цінностей;

- організація самоосвіти як творчого процесу, в ході якого відбувається перетворення набутих знань на основі власних думок і почуттів; 
- одночасне збагачення фаховими та загальними знаннями, їх гармонійне співвідношення;

- створення ситуацій емоційного переживання своїх дій у самоосвітній роботі;

- стимулювання готовності до здійснення професійно-педагогічної діяльності.

3. Самоосвіта - це вища форма самовираження особистості, в якій адекватно беруть участь всі фізичні і духовні сили людини. Сучасні вимоги до педагога на перше місце ставлять систематичну самостійну роботу з розвитку професійної компетентності, поглиблення його теоретичних знань та практичних умінь.Однією 3 необхідних умов успішного професійного зростання $\epsilon$ цілеспрямована й систематична самоосвіта.

Основними принципами самоосвіти є:

- безперервність;

- цілеспрямованість;

- інтегративність;

- єдність загальної та професійної культури;

- взаємозв'язок і наступність;

- доступність;

- випереджаючий характер;

- перманентність переходу від нижчої ступені до вищої;

- варіативність та ін.

Для цього використовуються найрізноманітніші форми:

1) спеціальна освітня підготовка (отримання вищої освіти або другої спеціальності);

2) підвищення кваліфікації;

3) індивідуальна самоосвітня робота за напрямками:

- розробка електронних уроків, посібників тощо;

- розробка пакета тестового матеріалу в електронному вигляді;

- розробка пакета стандартного планування з теми чи групи тем;

- комплект дидактичного матеріалу 3 предмета: самоосвітні, практичні, контрольні роботи;

- розробка комплекту роздавального матеріалу з предмета;

- створення термінологічного словника з предметної теми, розділу;

- кабінет інформаційних технологій;

- розробка навчальних проектів;

- проект особистої методичної веб-сторінки;

- база даних запитань і задач із предмета;

- зв'язок самоосвіти з практичною діяльністю педагога (результатом самоосвіти має стати підвищення якості навчально-виховного процесу). 
4. Самоосвіта вимагає від суб'єкта чіткого бачення життєвої необхідності уміння, здатності до самоорганізації і контролю, самостійного мислення i вольових якостей особистості: організованості, наполегливості, витримки та ін. У зв'язку із цим, людина може здійснювати самоосвіту, починаючи з юнацького віку, коли ці якості досягають необхідного рівня розвитку [10, с.313].

Основні етапи діяльності по самоосвіті:

1. Розробка особистого плану самоосвітньої діяльності, вибір методів, форм і засобів його реалізації.

2. Формування загальної мети самоосвіти як засобу професійного становлення.

3. Визначення завдань самоосвіти, оволодіння теорією та технологією самоосвітньої діяльності.

4. Самоконтроль якості виконання особистого плану самоосвіти.

5. Самооцінка рівня сформованості набутих знань відповідно до запланованого рівня.

5. У сучасному світі існує багато різноманітних можливостей отримати знання:

- книжки (наукова, науково-методична, методична, публіцистична, художня та інші літератури);

- фахова періодика (газети, журнали);

- Інтернет-ресурси;

6.Одна 3 актуальних форм організації самоосвіти - дистанційна освіта форма навчання, яка реалізується, в основному, з використанням технологій дистанційного навчання.

Інтернет(найбільші відомі онлайн ресурси для самоосвіти) http://www.slideshare.net/nadjablust/online-51949375

http://prometheus.org.ua/courses/

http://vkurse.ua/educations/dlya-sozdaniya-sobstvennykh-kursov.html http://si-sv.com/dir/6 https://www.coursera.org/courses?cats=teacherpd\&categories=teacherpd http://www.parta.com.ua/courses/

У рамках самоосвіти кожен учитель може взяти участь у вебінарах. Вебінар - онлайн-семінар, який дозволяє ведучому передавати інформацію (досвід, знання, вміння, завдання).

Мережеві педагогічні спільноти або об'єднання вчителів - це нова форма організації професійної діяльності в мережі. Участь у професійних мережевих об'єднаннях дозволяє вчителям, які живуть у різних куточках, спілкуватися один 3 одним, вирішувати професійні питання, реалізувати себе і підвищувати свій професійний рівень (мережа вчителів-новаторів, мережа «Партнерство в навчанні»).

7. Результат самоосвіти може подаватися у формі:

- доповіді, виступи на семінарі, педагогічні раді, методичному об єднанні;

- програми;

- методичного посібника;

- статті до фахового видання; та інше

Висновки 
Самоосвіта вчителя повинна стати безперервним процесом, який передбачає щоденну роботу над здобуттям нових знань, постійне підвищення власної кваліфікації, пошук і розв'язання найефективніших навчально - виховних проблем.

Формування соціально-економічних та культурологічних засад постіндустріального суспільства створює умови переходу від епохи традиційної самоосвіти до нової епохи smart-самоосвіти - самоосвіти майбутнього; самоменеджменту; креативної, всеохоплюючої самоосвіти упродовж життя, безстрокової, не обмеженої рамками соціальних інституцій, природно вписаної в життєвий устрій людини; самоосвіти, що реалізується шляхом надання клієнтоорієнтованих освітніх послуг, побудова персональних освітніх траєкторій.

\section{Список літератури}

1. Айзенберг А. Я. Самообразование: история, теория и современные проблемы [текст] : учеб. пособие для вузов / А. Я. Айзенберг. - М. : Высш. шк., 1986. $-128 \mathrm{c}$.

2. Антипов С. В. Современные технологии разработки web-сайтов / С. В. Антипов // Информатика и образование. - 2004. - № 3. - С. 57-60.

3. Биков В. Ю. Моделі організаційних систем відкритої освіти : монографія / В. Ю. Биков. - К. : Атіка, 2008. - 684 с.

4. Бондар В. I. Підвищення ефективності дидактичної підготовки педагогічних кадрів / В. І. Бондар // Радянська школа. - 1986. - № 7. - С. 88-89.

5. Болюбаш Я. Я. Організація навчального процесу у вищих закладах освіти: навчальний посібник [для слухачів закладів підвищення кваліфікації системи вищої освіти] / Я. Я.Болюбаш. - К.: Компас, 1997. - 64 с.

6. Бондаренко М. І. Самоосвіта як умова підвищення якості підготовки майбутнього вчителя / М. І.Бондаренко // Вісник. - К., 2005. - Вип. 6. - С.12-19.

7. Гергуль С. М. Самоосвіта вчителя як джерело формування свободи та відповідальності школярів у творчій спадщині В. О.Сухомлинського: Зб. наук. Пр. / С. М.Гергуль. - Полтава, 2005. - Вип. 6 (45). - С. 229-233. - (Серія «Педагогічні науки»).

8. Гончаренко С. Український педагогічний словник / [С. Гончаренко]. - Київ: Либідь, 1997. - 376 с.

9. Горленко О. Керівництво самоосвітньою діяльністю вчителя / О. Горленко. - Школа, 2006. - № 8. - С. 38-45.

10. Психологічна енциклопедія / [автор-упорядник О. М.Степанов]. - К: Академвидав, 2006. - 424 с.

11. Рогозіна М. Ю. Самоосвіта як фактор особистісно-професійного становлення майбутнього вчителя / М. Ю.Рогозіна // Особистісні та ситуативні Детермінанти поведінки і діяльності людини. - Донецьк, 2007. - С. 175-184.

12. Сухомлинський В. О. Павлиська середня школа. // Вибрані твори: в 5 т. К: Рад. шк., 1977. - Т. 4. - С. 31-393. 


\title{
АКТУАЛЬНІ ПИТАННЯ ТА ВИМОГИ ЩОДО ВОЛОДІННЯ УКРӒ̈НСЬКОЮ МОВОЮ ЯК ІНОЗЕМНОЮ ДЛЯ ІНОЗЕМНИХ СТУДЕНТІВ СПЕЦАЛЬНОСТІ "СТОМАТОЛОГІЯ"
}

\author{
Личук Світлана Василівна \\ к.філол.н., доцент \\ Івано-Франківський національний медичний університет
}

\begin{abstract}
Навчальна дисципліна «Українська мова як іноземна» вивчається чужоземними студентами-медиками спеціальності 221 «Стоматологія» упродовж чотирьох курсів і завершується складанням іспиту.

Основними принципами навчальної програми є:

- комунікативний напрям;

- індивідуальна спрямованість;

- автономія студента;

- інтегроване викладання різних мовних навичок (аудіювання, розмова, читання та письмо).
\end{abstract}

Дисципліна формує комунікативну компетентність 3 виразним фахово орієнтованим i загальнонауковим компонентами i забезпечує комунікативні потреби не тільки у побутовій, соціально-культурній і навчально-професійній сферах, а й розвиває відповідні професійно орієнтовані знання, уміння й навички на другому середньому рівні В2 (незалежний користувач) володіння сучасною українською літературною мовою (брати участь у дискусії, наводячи релевантні пояснення, аргументи i коментарі; пояснювати основні положення теми, вказуючи на переваги та недоліки різних суджень; розмірковувати про причини, наслідки, гіпотетичні наслідки тощо).

Навчання іноземних мов передбачає практичне оволодіння студентом мовленнєвими навичками на рівні, достатньому для іншомовного спілкування 3 чотирма видами мовленнєвої діяльності (аудіювання, розмова, читання та письмо) у стандартних ситуаціях.

Дисципліна «Українська мова як іноземна» для стоматологів спрямована на засвоєння інокомунікантами основних видів мовленнєвої діяльності (читання, письма, говоріння (монологічного й діалогічного мовлення), слухання, аудіовізуальної рецепції) 3 урахуванням вимог до володіння мовною компетенцією на другому середньому рівні В2.

Предметом вивчення навчальної дисципліни «Українська мова як іноземна» є сучасна українська літературна мова, а саме: іï адаптаційний, соціокультурний, комунікативний, загальнонауковий i фаховий компоненти, представлені основними видами мовленнєвої діяльності; норми сучасної української літературної мови, мовленнєвий етикет i культура спілкування; актуальні 
комунікативні ситуації, репрезентовані відповідними мовленнєвими актами й інтенційними програмами.

Упродовж навчання української мови як іноземної в інокомунікантів формуються навички вимови, письма, слухання й читання автентичних чи мінімально адаптованих текстів описового й розповідного характеру 3 елементами роздуму на тематику, актуальну для соціально-культурної, навчальної, науково-популярної та професійно орієнтованої сфер спілкування; структурного й граматичного оформлення мовлення в його усній / письмовій формах на ситуативно зумовлену та професійну тематику.

Через те, що навчальна дисципліна «Українська мова як іноземна» у ЗВО MO3 України перебуває в когерентному зв'язку не тільки з дисциплінами гуманітарного, природничого й суспільного, а й стоматологічного (медичного) профілю, процес іiі вивчення передбачає засвоєння лексико-граматичного матеріалу з виразним професійно орієнтованим спрямуванням, що мотивується необхідністю удосконалення активного соціально-культурного дискурсу й закріплення фахово забарвленого «мовленнєвого усвідомлення», що виникло i сформувалося на попередніх етапах; розширення необхідного словникового запасу шляхом професійної орієнтації української мови як іноземної відповідно до базових навчальних дисциплін стоматологічного (медичного) профілю ${ }^{1}$; проходження студентами-чужоземцями фахової практики у відповідних лікувально-профілактичних закладах України (виробнича лікарська практика).

Студенти повинні оволодіти програмним матеріалом як засобом проектування та розуміння виразів у процесі спілкування на рівні, визначеному стандартом. Для цього студенти повинні розуміти та опановувати комунікативні функції засобів комунікації для їх правильного застосування в певних мовленнєвих ситуаціях. Вони повинні самостійно вибрати мовні та мовні засоби, які $є$ найбільш оптимальними для реалізації комунікативного наміру та адекватні сфері спілкування в соціально-функціональному аспекті.

\section{Список літератури}

1. Личук С.В. Збірник текстів з української мови для іноземних студентів різних спеціальностей (з дисципліни "Українська мова як іноземна"). ІваноФранківськ: Івано-Франківський національний медичний університет, 2020. 384 c.

2. Личук. С. В. Українська мова для іноземних студентів : навч. посібн. для іноземних студентів, які навчаються у вищ. мед. і фармац. закл. України I-IV p. акред. Ч.1 : Фонетика. Орфоепія. Орфографія. Лексикологія. Фразеологія. ІваноФранківськ : ДВНЗ «ІФНМУ», 2018. 100 с.

3. Українська мова як іноземна для англомовних студентів-медиків : підручник з електронним аудіодод. : у 2 кн. Кн. 1. Соціокультурна комунікація / С. М. Луцак, А. В. Ільків, Н. П. Литвиненко та ін. / за ред. С. М. Луцак. Київ : ВСВ «Медицина», 2019. 504 с.

\footnotetext{
${ }^{1}$ Анатомія людини, фізіологія, імунологія, гігієна й екологія, пропедевтика внутрішньої медицини, загальна хірургія, радіологія, медична психологія, терапевтична стоматологія, ортопедична стоматологія, хірургічна стоматологія в т. ч. щелепно-лицева онкологія, ортодонтія, дитяча ортопедична стоматологія, дитяча хірургічна стоматологія тощо.
} 
III International Science Conference on E-Learning and Education

4. Українська мова як іноземна для англомовних студентів-медиків : підручник $з$ електронним аудіодод. : у 2 кн. Кн. 2. Основи професійного мовлення / С. М. Луцак, А. В. Ільків, Н. П. Литвиненко та ін. / за ред. С. М. Луцак. К. : ВСВ «Медицина», 2019. 580 с. 


\title{
ВИКОРИСТАННЯ ВІДКРИТОГО ОСВІТНЬОГО РЕСУРСУ НАВЧАННЯ ЗДОРОВ'Ю В УНІВЕРСИТЕТІ
}

\author{
Літвінова Анастасія Миколаївна \\ кандидат педагогічних наук, доцент кафедри валеології \\ Харківський національний університет імені В. Н. Каразіна
}

\begin{abstract}
Пснов Вадим Васильович кандидат педагогічних наук, доцент кафедри здоров'я людини та цивільного захисту Одеський національний університет імені I. I. Мечникова
\end{abstract}

Тимченко Ганна Миколаївна кандидат біологічних наук, доцент, доцент кафедри валеології Харківський національний університет імені В. Н. Каразіна

На сьогодні відбувається реформування умов сучасності не лише завдяки науково-технічному розвитку сучасності, але й постає питання про реформування різних галузей людської діяльності задля адаптації до умов сучасності. Не оминала це коло реформ і система освіти. Нова українська школа - це ключова інновація Міністерства освіти і науки. Головна мета - створити заклад, у якому буде приємно здобувати знання і яка даватиме учням не тільки навички та вміння, як це відбувається зараз, а й спосіб застосовувати їх у житті.

Відповідно до ключових компентенцій Нової української школи саме питання про здоров'я займають ланку екологічної грамотності та здоров'я, підкреслюючи «здатність і бажання дотримуватися здорового способу життя». Але актуальним постає питання навчання основам здорового способу життя задля реалізації базової компетентності Нової української школи.

Одним із можливих шляхів вирішення цього питання на нашу думку постає у реалізації навчання здоров'ю крізь інформаційну-цифрову компетентність, яка передбачає векторне, а водночас критичне застосування інформаційнокомунікаційних технологій (ІКТ) для втілення, пошуку, обробки інформації, в публічному оточенні та приватному спілкуванні. Інформаційна й медійна грамотність, основи програмування та відтворення інформаційних технологій, алгоритмічне мислення, роботи з базами даних, навички безпеки в Інтернеті та кібербезпеці. Розуміння етичних принципів роботи з інформацією (авторське право, інтелектуальна власність тощо). А також крізь призму компетентності «Уміння навчатися впродовж життя», яка відокремлена як здатність до пошуку та засвоєння нових знань, набуття нових вмінь і навичок, організації навчального процесу (власного i колективного), зокрема через ефективне керування ресурсами та інформаційними потоками, вміння визначати освітні цілі та засоби їх реалізації, вибудовувати свій навчальний вектор, оцінювати власні результати навчання та успіхи, навчатися впродовж життя [1]. 
Кожному сучасному фахівцю необхідно володіти засобами, які сприяють формуванню здорового способу життя та відкривають у нашому організмі приховані резерви, що дозволяють почуватися здоровим, парцездатним, стресостійким та повним сил. Поряд із цим завдяки науково-технічному прогресу та розвитку інноваційних технологій ми спостерігаємо підйом i розвиток неформального навчання, що пов'язано, в першу чергу з бурхливим розвитком E-Learning - джерелом неформального навчання, із зростанням величезної кількості інновацій, які користуються попитом в бізнес-індустрії 3 метою підвищення іiї продуктивності. Неформальне навчання забезпечує не лише рентабельність передачі знань та формування компетенцій, але й сприяє підвищенню організаційної ефективності [2].

Дослідження показують, що 70\% навчання є неформальним, а $30 \%$ формальним. Таким чином при правильній організації неформального навчання можна скоротити і витрати на навчання. Поява соціальних сервісів та розвиток теорій навчання показує, що поєднання формального й неформального видів навчання дозволяє зробити процес навчання успішним за наступних умов: не все навчання організоване в курсі; існує безліч підходів для доставки курсів; при необхідності використовуються змішані рішення; навчання вбудовано у процес роботи; тренери виконують функції «керівництво на стороні», а не «мудреці на сцені».

Одними з найпопулярніших технологій сьогодення стали змішані підходи до навчання, бо саме вони дозволяють скористатися гнучкістю i зручністю дистанційного курсу з перевагами традиційного класу. Існує велика ймовірність, що $з$ певним перебігом часу змішане навчання може перевершити традиційні методи навчання. До основних рекомендацій з використання МООС - массових відкритих он-лайн курсів для університетів належать: досвід якісного навчання в форматі он-лайн, інвестиції та підтримка розвитку цифрових компетенцій, використання та створення відкритих освітніх ресурсів. Нажаль, на сьогодні кількість українських ресурсів, присвячених вивченню основ здоров'я відсутня. Саме тому виникає потреба у створенні відкритих сервісів та ресурсів навчання основам здоров'я в університетах, особливо в осередках формування знань про здоров'я та здоровий спосіб життя.

Прикладом є відкритий освітній ресурс навчання здоров'ю, розміщений в базі LMS Moodle Центру електронного навчання Харківського національного університету імені В.Н. Каразіна для студентів. Це перший відкритий дистанційний курс «Моє здоров'я» (викладач Тимченко Г. М.). Цей курс створений 3 метою діагностики та профілактики здоров'я студентів 3 використанням сучасних електронних засобів діагностики та навчання, а також 3 метою пропаганди знань про здоров'я та здоровий спосіб життя серед молоді.

Курс складається з наступних розділів:

1). Рухова активність.

2). Добові ритми.

3). Сезонні ритми.

4). Добові енерговитрати та харчування.

5). Діагностика та моніторинг здоров'я. 
6). Стратегії розвитку особистості в професії.

В кожному розділі $\epsilon$ інтерактивна складова, яка допомагає здійснити в дистанційному режимі діагностику шляхом відповідей на запитання анкетитесту та визначити певний показник діяльності.

Слід зазначити, що завдяки розташуванню електронного паспорту здоров'я та відеопідказчика щодо проведення діагностики здоров'я в домашніх умовах (кількість переглядів відеороликів за результатами аналітики YouTube становила 230) питання електронної валеологічної діагностики стає можливим для широкого кола користувачів.

Аналіз даних, отриманих в результаті педагогічного експерименту, проведеного у відкритому дистанційному курсі «Моє здоров'я» показав, що серед 183 учасників, які зареєстровані на курс 150 виконали всі розділи та навчальні завдання, тобто успішність навчання склала $82 \%$.

Слід зауважити, що у зв'язку із відсутністю стандартів до відкритих курсів та освітніх ресурсів в системі відкритого навчання особливої уваги набуває факт розміщення відкритих освітніх ресурсів саме у кращих брендових вишах країни. Харківський національний університет імені В. Н. Каразіна виробив наступний алгоритм створення доступної дистанційної освіти:

- розміщення каталогу відкритих інформаційних джерел за фахом та спеціалізаціями;

- створення каталогу відеолекцій провідних фахівців Каразінського університету Karazin Universarium на каналі YouTube;

- створення власного каналу Інституту післядипломної освіти та заочного (дистанційного) навчання Харківського національного університету імені В. Н. Каразіна із розміщенням відеозаписів семінарів, тренінгів, науково-популярних роликів та навчальних відеофільмів;

- створення системи відкритого навчання Каразінського університету.

\section{«Список літератури»}

1. Літвінова А. М., Пєнов В. В., Тимченко Г. М. Використання відкритого освітнього ресурсу навчання здоров'ю в системі класичної освіти. Забезпечення якості професійної підготовки майбутніх фахівців в умовах упровадження ідей нової української школи: Матеріали Міжнародної науково-практичної онлайнконференції (6-7 травня 2020 р., м. Прилуки) / Прилуцький гуманітарнопедагогічний коледж імені І. Я. Франка, 2020. С. 105-108.

2. Тимченко Г. М., Літвінова А. М., Закревський А. М., Левчук В. Г. Технології створення відкритих освітніх ресурсів та відеосервісів навчання основ здоров'я. Вісник національного університету «Чернігівський колегіум» імені Т. Г. Шевченко. Серія: «Педагогічні науки», 2020. - Вип. 7 (163). - С. 153161.

3. Літвінова А. М., Пєнов В. В., Тимченко Г. М. Використання інформаційних технологій у фізичному вихованні студентів. Науково-методичні основи використання інформаційних технологій в галузі фізичної культури і спорту: 
III International Science Conference on E-Learning and Education

збірник наукових праць [Електронний ресурс]. - Харків : ХДАФК, 2020. Випуск 4. - C. 47-51. 


\section{АДАПТАЦІЯ РЕСУРСІВ ДИСТАНЦІЙНОЇ ОСВІТИ ДЛЯ ФОРМУВАННЯ КРЕАТИВНОСТІ МАЙБУТНІХ ПЕДАГОГІВ ПРОФЕСІЙНОГО НАВЧАННЯ}

Мартинюк Ольга Петрівна, Здобувачка вищої освіти ОПП «Професійна освіта (Сфера обслуговування)», 2 курс ДВНЗ «Переяслав-Хмельницький державний педагогічний університет імені Григорія Сковороди»

\section{Ненюк Ірина Олексіївна}

Здобувачка вищої освіти

ОПП «Професійна освіта (Сфера обслуговування)», 4 курс ДВНЗ «Переяслав-Хмельницький державний педагогічний університет імені Григорія Сковороди»

\section{Любов Вікторівна Басюк}

к.пед.н., доцент кафедри професійної освіти, ДВНЗ «Переяслав-Хмельницький державний педагогічний університет імені Григорія Сковороди»

Інформаційно-комунікаційні технології (ІКТ) $є$ головним фактором розвитку та формування нової глобальної економіки та швидких змін у суспільстві.

Освітні системи у всьому світі зазнають все більшого тиску інформаційних та комунікаційних технологій (IКТ) для навчання студентів. Це передбачає трансформацію освітнього процесу та нові масштаби отримання викладачами та студентами доступу до знань.

3'являються нові можливості, які вже мають потужний вплив на задоволення основних потреб у навчанні, і очевидно, що освітній потенціал технологій дистанційного навчання лише починає розкриватися. Синергетичний ефект виникає, коли технології використовуються для розвитку людського потенціалу.

Для ефективного використання потужності нових технологічних здобутків для вдосконалення навчання, мають бути створені наступні основні умови:

- Студенти та викладачі повинні мати достатній доступ до цифрових ресурсів.

- Цифровий зміст повинен бути високої якості, змістовний та культурно адаптивний, бути доступним для вчителів та учнів.

- Викладачі повинні мати знання та вміння користуватися новими цифровими інструментами та ресурсами для допомоги всім студентам у досягненні високих академічних стандартів.

Але варто пам'ятати про загальні поняття цифрової педагогіки: 
• вплив технологій на глобальне суспільство та наслідки для освіти

- створення більш ефективних моделей для залучення студентів в освітні середовища

- критичне значення контексту, культури, лідерства та навчання протягом усього життя.

Важливим $\epsilon$ здатність ресурсів дистанційної освіти та IКT зокрема до формування креативності як однієї 3 найвищої творчої якості фахівця. Креативність полягає у нестандартному баченні підходів та визначенні інноваційних стратегій для досягнення поставлених цілей.

Ускладнення завдань і способів вирішення проблеми педагогічних кадрів зумовлюють гостру потребу в теоретичному обгрунтуванні креативності як важливої характеристики професіоналізму сучасного педагога, створення необхідних умов для реалізації особистісно орієнтованого навчання в практиці вищоїшколи та експериментальній перевірціметодики навчального процесу, що дозволяє подолати суперечності між вимогами, які ускладнюються, до педагогічної професії й здатністю випускників педуніверситету творчо працювати в обраній професійній сфері, використовувати багатогранність своєї особистості у вирішенні професійних завдань [1].

Протягом останнього десятиліття ресурси дистанційної освіти принципово змінили освітній процес та способи взаємодії у ньому.

Перевагами використання гаджетів у навчанні $є$ поліпшений доступ до освіти людям з обмеженими можливостями, оптимізація поширення навчальних матеріалів, можливість розроблення гнучкого графіка навчання та підвищення рівня мобільності студентів. До негативних pис m-learning можна віднести постійну необхідність наявності доступу до Інтернету та високу вартість сучасних гаджетів із достатньо потужними для повноцінної роботи характеристиками [2].

Креативність починається зі змісту та технологій, що використовуються в освітньому процесі. Основними акцентами при формуванні креативності 3 використанням ресурсів дистанційної освіти $є$ те, що складні курси та теми повинні бути переосмислені і презентовані в ігровому форматі із залученням мотивації та цікавості. Крім того, відкрита система дистанційного навчання повинна бути структурізована, в тому сенсі, що люди повинні мати можливість вчитися в будь-якому місці, де вони знаходяться. Національні ідеали, фольклор, національна символіка, програми соціальної орієнтації, громадянська культура, політична соціалізація та інші мінливі фактори, які можуть стимулювати, покращувати становлення фахівця повинні бути задіяні у змісті при формуванні креативності як частини світогляду.

Для того, щоб ресурси дистанційної освіти були спрямовані на формування креативності важливим фактором $\epsilon$ підготовка викладачів, а саме: забезпечення належного рівня сформованості IКТ навичок, моделювання нової цифрової педагогіки та інструментів для навчання, лідерство у визначенні того, як найкраще використовувати нові технології, контекст культури, потреб та економічних умов в країні. 
Важливим аспектом при формуванні креативності $€$ розуміння сутності навчання як процесу передачі та прийому інформації. Значна частина сучасного суспільства залишається «орієнтованим на інформацію», коли студенти відтворюють знання, а не виробляють власні. В таких умовах, коли студент відлучений від творчого процесу та мотивації до нього процес формування креативності є неефективним.

Отже, дистанційні технології володіють ресурсним потенціалом для формування мотивації до винайдення інноваційних шляхів розв'язання проблем у нестандартних умовах, що характеризуються невизначеністю та хаотичністю. Також ресурс ІКТ технологій $є$ унікальним для створення та функціонування онлайн взаємодії, що розширює можливості міжнародної академічної співпраці та студентського спілкування.

\section{Список використаних джерел:}

1. Петришин, Л. Й. (2013). Креативне середовище як педагогічна умова формування креативності майбутніх соціальних педагогів. Соціальна педагогіка: теорія та практика, (2), 61-71. http://www.irbis-nbuv.gov.ua/cgibin/irbis_nbuv/cgiirbis_64.exe?I21DBN=LINK\&P21DBN=UJRN\&Z21ID=\&S21RE $\mathrm{F}=10 \& \mathrm{~S} 21 \mathrm{CNR}=20 \& \mathrm{~S} 21 \mathrm{STN}=1 \& \mathrm{~S} 21 \mathrm{FMT}=\mathrm{ASP} \_$meta\&C21COM=S\&2_S21P03 $=$ $\mathrm{FILA}=\& 2 \_\mathrm{S} 21 \mathrm{STR}=\mathrm{spttp} \_2013 \_2 \_10$

2. Мельник, Т. А. Доцільність реалізації концепції BYOD у системі підготовки майбутніх педагогів професійного навчання [Текст] / Т. А. Мельник // Фізико-математична освіта : науковий журнал / Міністерство освіти і науки України, Сумський державний педагогічний університет імені А. С. Макаренка, Фізико-математичний факультет ; [редкол.: М. П. Вовк, М. Гр. Воскоглу, Т. Г. Дерека та ін.]. - Суми : [СумДПУ імені А. С. Макаренка], 2020. - Вип. 1 (23), ч. 2. - C. 53-59. - DOI: 10.31110/2413-1571-2020-023-1-2-008. 


\title{
МЕТОДИЧНІ ПІДХОДИ ДО ОРГАНІЗАЦЇ̈ ПОШУКОВО-ДОСЛІДНИЦЬКОЇ РОБОТИ 3 ПРИРОДНИЧОЇ ОСВІТНЬОЇ ГАЛУЗІ В НОВІЙ УКРАЇНСЬКІЙ ШКОЛІ
}

\author{
Мелаш Валентина Дмитрівна \\ к.п.н., доцент кафедри початкової освіти Мелітопольського державного \\ педагогічного університету імені Богдана Хмельницького
}

\section{Руденко Юлія Андріївна} здобувач вищої освіти Мелітопольського державного педагогічного університету імені Богдана Хмельницького

Дієвим засобом та оптимальним методичним інструментом формування природничої компетентності учнів початкової шкільної ланки є організація їх пошуково-дослідницької роботи, враховуючи що: 1) зміст навчального матеріалу націлює на гуманну й конструктивну взаємодію з навколишнім середовищем; 2) молодшим школярам властива підвищена сенситивність, безпосередність, емоційна чутливість, ініціативність, висока потреба відкривати для себе навколишній світ; 3) процес дослідження передбачає активне чуттєве сприйняття нового природничого матеріалу, тому мотивує активність та самостійність його пізнання, що власне i забезпечує розв'язання поставленого вчителем дослідницького завдання [1].

За допомогою грамотного педагогічного управління з боку вчителя в процесі пошуково-дослідницької роботи молодші школярі по-перше, щоб отримати нові знання і способи вирішення завдань, підбирають серед засвоєних раніше необхідні знання і способи дій або відшукують і пропонують власні; по-друге опановують пізнавально-дослідницькі та супутні дослідженню уміння.

В початкових класах практичні та інтелектуальні дослідження учнів вчитель спеціально організовує, використовуючи різноманітні дидактичні засоби опосередкованого й перспективного керівництва, різні форми і дидактичні прийоми, що забезпечують їхній високий пізнавальний, виховний, розвивальний ефект. Щоб внутрішньо мотивувати учнів до дослідницької діяльності, вчитель має створювати умови для ситуації відкриття, коли дитина завдання усвідомлює, але, для його виконання бракує знань, разом з тим, їх цілком достатньо для пошуку способів здобуття потрібних знань. При цьому відбувається становлення компетентності, оскільки працюють і розвиваються види розумової діяльності, потрібні для вирішування будь-якої проблеми: усвідомлення неможливості застосувати відомий спосіб, формулювання проблеми, висунення припущень щодо iї розв'язання, випробування вірності гіпотези в ході дослідження, формулювання висновку [2; 3].

Доречно акцентувати увагу молодших школярів на особистісній цінності дослідницької діяльності, показати, що знання та висновки з багатьох питань, 
можна отримати в результаті певних пізнавальних зусиль, консультацій (3 вчителем, друзями, батьками, фахівцями відповідних галузей), опрацювання різних джерел інформації, навчальних сайтів.

Нами розроблено методичні рекомендації по створенню власних навчальних сайтів, де учні можуть презентувати результати свого дослідження. На основі критичного мислення треба проаналізувати:

1. Назва Web_caUTa

2. Ким може бути використаний сайт (обведіть всі відповідні варіанти)

а) учнями б) учителем в) іншими;

3. Основне призначення сайту (цілі створення)?

4. Ким розроблений сайт (ім’я розробника або назва організації)?

5. На які ресурси, що відповідають тематиці сайту, є посилання?

6. На які ресурси схожої тематики є посилання в матеріалах сайту?

7. Сайти яких організацій посилаються на даний сайт (використовуйте пошукові системи для пошуку посилань)?

8. Хто автор публікацій на сайті?

9. Чи передбачений на сайті механізм зворотного зв'язку з авторами публікацій?

10. Наскільки матеріал, представлений на сайті, сучасний? Чи не застарів він?

11. Опишіть, як ви можете використовувати цей сайт в дослідницької діяльності молодших школярів?

Створення електронного супроводу 3 пошуково-дослідницької роботи 3 природничої освітньої галузі в новій українській школі дозволяє заповнити недолік 3 методики формування природничої компетентності молодших школярів [4, с. 45].

Наше дослідження підтверджують високий пізнавальний результат, якщо оптимально поєднувати виконання молодшими школярами репродуктивних (виконуваних за взірцем, з використанням усних чи письмових інструкцій учителя) та творчих дослідницьких завдань, які передбачають самостійне вирішення запропонованої вчителем чи самостійно обраної природничої проблеми, використовуючи ресурси Е-освіти.

Використання означених методичних підходів в природничій пізнавальнодослідницькій діяльності забезпечує розвиток і саморозвиток молодших школярів, становлення їх природничої компетентності, що дозволяє гуманно й конструктивно взаємодіяти $з$ природним і соціальним довкіллям.

Таким чином, пізнавальні можливості та набутий досвід учнів 3,4 класів дають можливість вчителю практикувати другий і третій етап організації учнівського дослідницької діяльності. В зв'язку з цим, методичні підходи до організації пошуково-дослідницької діяльності молодших школярів спрямовані на покрокове нарощування рівня складності дослідницьких завдань, ініціативи, самостійності та креативності їх виконання шляхом систематичного, послідовного засвоєння алгоритму дослідження, прийомів пізнання, порядку, безпеки та техніки виконання дій та реалізуються за допомогою ефективних дидактичних засобів, форм, прийомів та принципів. Грамотне пряме i опосередковане керівництво дослідницькою діяльністю учнів забезпечує ефективне формування пізнавально-дослідницьких та супутніх дослідженню умінь молодших школярів. 


\section{Список літератури}

1. Державний стандарт початкової освіти: затв. постановою Кабінету Міністрів України від 21.02.2018 № 87. URL: https:/www.kmu.gov.ua/ua/npas/ pro-zatverdzhennya-derzhavnogo-standartu-pochatkovoyi-osviti.

2. Мелаш В.Д. Навчальні практики з методик викладання природознавства, біології, екології / В.Д. Мелаш, В.В. Молодиченко, Т.Д. Олексенко. Мелітополь, Видавничий будинок МДПУ, 2012. 332 с. (Серія «Екологічна освіта для сталого розвитку»).

3. Мелаш В.Д., Кондратович О. Особливості організації дослідницької діяльності молодших школярів Науковий вісник Мелітопольського державного педагогічного університету: Збірник наукових праџь. Вип. 23 (2). Мелітополь: Вид-во «Мелітополь», 2019. С.118-123.

4. Нова українська школа: порадник для вчителя / за заг. ред.Н. М. Бібік. К.: Літера ЛТД, 2018. 160 с. 


\title{
УКРАЇНСЬКА ОСВІТА ЯК ПРОВІДНИК ІНТЕГРАЦІЙНИХ ЗМІН НА ОСНОВІ "ІСТОРІЯ ПОНЯТТЯ
}

\begin{abstract}
Мельник Лариса Миколаївна
магістр психології, старший викладач кафедри

Хмельницького обласного інституту післядипломної педагогічної освіти
\end{abstract}

У статті розглядаються необхідність та конструктивна можливість включення українських освітніх інституцій в інтеграційні наукові процеси. Актуалізується важливість в конкретно-історичні наукові комунікації, що сприятимуть інтеграції освітніх інституцій в Україні на всіх рівняв та співпрацею 3 науковціями на міжнародному рівні Зосереджується увага на методології «історії понять»,на інтеграції основних положень німецької та англосаксонської школи "історії понять", базуючися на принципах і методах дослідження, що сприятимуть модернізації української освіти.

Ключові поняття: історія понять, поняття, знання,сенси,методологія історії поняття,інформація,архітектоніка громадянскої думки.

Важливою складовою процесу модернізації $є$ зміни в суспільній свідомості, які визначають спрямованість розвитку соціуму i водночас відображають еволюцію в уявленнях, комунікаціях і поведінці людей, що обумовлені стереотипами 3 минулого, водночас - спрямовані в майбутнє. Різноманітні відносини,що вибудовуються завдяки й освіті, пов'язані 3 продуктивною діяльністю людини, людства, які через економічні відноносини стають характером взаємодій між соціальними стратами, проявляють особливості політичного розвитку і культурного ландшафту - всі ці складові процесу модернізації безпосередньо впливають на суспільну свідомість,що вербалізуються в текстах підручників,історичних джерелах(4), медіа для різного видового застосунку.

Саме тому актуальними постають дослідження масштабних громадськосуспільних змін, які неможливі без розуміння того, яким чином відбувалося їх осмислення на рівні різних форм мовної практики взаємодії. Якщо для історика принципово важливі патерни- знання, що зауважують автора джерела, вживаючи те чи інше поняття, вказуючи додаткові конотації, що отримували при 
використанні в різних контекстах(5), яким чином відбувалося коригування конструкту змісту, як відомих раніше, так і запозичених понять и 3 «іншого»джерела (зазначаємо, більше користувалися - "чужого") культурного середовища.

В сьогоденні засобами освіти та активними інструментами ми має окреслювати еволюцію поняття з позиції " в майбутнє". Це дозволить, з одного боку, враховуючи «осучаснення» мови минулого, чітко окреслювати спосіб застосування понять, що розкривають сенси відношень та дій, використовуючи в комунікації їх базову сенсову цінність,а відтак відходити від некоректного застосунку понять, явищ, що виникали в більш пізній хронологічний період, а 3 іншого боку - тлумачити знаннєвість, а не лише інтерпретувати - чому одні і ті ж поняття могли використовуватися для вираження різних,часто діаметрально протилежних один одному застосунків, позицій i обгрунтуваннь в їх різноспрямованих практичних діях. Все це обумовлює необхідність звернення до методологічних установок сучасної «історії понять», яка дозволяє синхронізувати сенсові еволюційні зміни чи критично осмислювати підміни, критично осмислювати розмивання, відхилення від їх сакральности та символізму. Ось саме в цьому і постає питання в розумінні змістовности та сенсовости знань чи їх підміни знаннєвости, освічености лиш у володінні інформацією, завдяки, якій швидке орієнтування у ставленнях, відношеннях і діях, лиш виступає ситуативною "цінністю", що не здатна породжувати конструюючі, передбачуючи і відповідальні локальні- глобальні взаємини, моделювати сталости, в основі яких культура дискусій і науковий підхід приводить до культури вбереження. В сучасній історіографії «історії понять» послуговувуються двома основними напрямки, які варто осмислювати українському науково- освітньому співтовариству:

- німецька школа Begriffsgeschichte - Райнгарт Козеллек є одним із провідних науковців світу, німецьких історіків - теоретиків напрямку німецької історіографії, що отримало назву "історії понять". Райнгарт Козеллек своєю роботою "Минуле майбутнє" окреслив фундаментальний напрямок, який функціонально пов,язав досвід історичного часу та поняття, їх "часовість" - часове поняття(3). I Як би зазначили математики, окреслив необхідну та достатню умову модальности проявлення історичного явища, яке пов.язане 3 причинністю та майбутньою обумовленістю історичности та часовости поняття - явища, що історично окреслює горизонти майбутньої еволюційности .

- англосаксонська - History of Concepts (History of Concepts: Comparative 
Perspectives - IAIN HAMI'SIIER-MONK, KAIUN TILMANS, FRANK VAN VREE - 1998,Published by: Amsterdam University Press. Pages: 303). ідейні основи цього напрямку в червні 1998 року два видатних політологи Мелвін Ріхтер з Міського університету Нью-Йорка та Карі Палонен з Університету Ювяскюля організували та обговорили під час конференції на тему: "Концептуальні зміни в європейських політичних культурах" в Лондоні тендіції щодо застосунку "історії понять" для XXI ст.. Ця зустріч зібрала вчених з чотирнадцяти країн для обговорення поточних спільних проєктів щодо соціальних та політичних концепцій у таких місцях, як Нідерланди, Фінляндія, Франція, Данія та представників кріїн колишнього Радянського Союзу, а також для обговорень та дискусії різноманітних емпіричних та методологічних виступів 3 суміжних напрямків, що осмислювали еволюцію в творенні нової реальности та застосунку понять, що за сенсами розкривали нові виклики. Інформуванням багатьох звітів та обмінів послужили відносно завершеному тому Geschichtliche Grundbegriffe - або, коротше, GG - під редакцією Отто Бруннера, Вернера Конце та Рейнхарта Козеллека (1).

В основі конференції лежали аргументи Ріхтера та Палонена щодо можливої конвергенції німецького "Begriffsgeschichte" та так званого підходу (кембриджських шкіл) до історичного вивчення політичної думки і культурному формуванні суспільної громадянської думки. I Рейнхарт Козеллек, і Квентін Скіннер, відвідаши 3 конференцію, сприяли іiі широкому емпіричному та методологічному обміну. На завершення конференції присутні домовились сформувати міжнародну мережу, яка регулярно збиратиметься, публікуватиме бюлетень та розроблятиме архів проектів та пропозицій, а також інтерв'ю та критичні роздуми тих, хто бере активну участь в еволюційному процесі для осмислення процесів XXI сторіччя.

Виклики над- обумовлює потребу актуалізувати під час підготовки освітян, науковців в нових парадигм в методичному відношенні, коли поняття та явища в сферному ( не лінійному)просторі: знання - сенси - інформація комунікації набувають потреби актуалізованих осмислень та дискусій, коли явище "перманентне оновлення освіти" стає важливим. В методичному відношенні представники цієї школи послуговуються даними соціальних змін, історій віддалених та історій сьогодення, в яких перш за все аналізуються кодові мовні маркери з метою критичного осмислення досвіду історичного часу та коректного, конструктивного застосунку синхронізованого потенціалу часових понять. Ми б позбавилися дискусії щодо проблем у створенні конструктивного, динамічного та перманетно доповнюючого шкільного чи студенстського 
підручника, якщо б автори проходили тривале навчання, завдяки якому вони отримували семантично-історично обумовлену культуру творення змістів, які формували та розвивали потребу в знаннях, а не лише орієнтували в інформації, що спряє відреагуванню на тест з використаням додаткових інформацій. "Саме семантика"(4), як методологія, виступає ефективним індикатором у відкритті зрушень, архітектурних підходів історії, що спричиняють еволюцію історичного часу та створюють креативних візій, а відтак - креативної спільноти.

3 моменту свого першого зібрання в Лондоні Група збиралася щорічно дев'ятнадцять разів і на чотирьох континентах, на конференціях, які мали різний масштаб - від невеликого робочого семінару (Копенгаген, 2000 р.) До середніх засідань (Ріо-де-Джанеро, 2004 ; Орхус, 2016), до досить великих академічних конгресів (Більбао, 2003 та 2013; Москва, 2010; Буенос-Айрес, 2011; Білефельд 2014; Тімішора, 2015). Серед їх тем «Вживання та зловживання словами» (Париж, 1999), «Риторика та концептуальні зміни» (Тампере, 2001), «Переклад та історія концепцій» (Нью-Йорк, 2005), «Транснаціональні концепції та Трансфери »(Стамбул, 2007) та« Розповсюдження західних концепцій в Азії »(Сеул, 2008). На засіданні в Гельсінкі у 2012 році членство погодилося змінити назву на "Група історії концепцій", визнаючи зростаючий інтерес до концепцій 3 таких сфер, як релігія, природничі науки та філософія. Тим не менше, дослідження соціального та політичного характеру - хоч би які вони були широко чи вузько визначені - все ще мають тенденцію домінувати. Темами останніх конференцій були "Концепції у світі: політика, знання і час" (Осло, 2017) та "Міждисциплінарність: концептуальні дослідження" (Малага, 2018). Членство в групі «Історія концепцій» відкрите для нових та відомих науковців; особливо заохочується участь аспірантів. Членство включає можливість брати участь у щорічних конференціях та включає підписку на рецензований журнал HCG Contribution to the History of Concepts. Ось вже у вересні 2021 року відбудеться 23 міжнародна Конференція з історії концепцій: "Глобальна сучасність. Емоції. Тимчасовості та концепції". Долучення української наукової, освітянської спільноти до цієх наукової спільноти стане тим динамічним індикатором в осмислені процесів трансформаційности у світі та цифрової цивілізаціїі, що $\epsilon$ важливою та знаковою місією та завданням, адже "історія понять" - це не лише дисципліна, а наша реальність, що досліджує характерні для тієї чи іншої доби(5), географії, держави, спільноти, моделі ( починаючи з давніх часів) сенсів політичних, економічних, соціальних та культурних, що в своєму вираженні застосовують поняття (наприклад, "конституція", "біль про права", "народовладдя", "держава", "країна", "стратифікація", "клас", "секулярність", "еволюція"тощо). Це дає ту силу істинности знань, змісті, в яких ці поняття 
текстуально зафіксовані і завдяки "конвергенції поняття та історії" включені в процеси глобальних історичних архітектонічних змін.

Кожне поняття пов,язане з словом. що відображує історичне явище, яке в собі несе тотожности, що розкривають сенси промовляючого. Соціальнокультурні та політичні є такими в застосунку, що в собі концентрують інтивідуальний, колективний досвід людства, які розкодовуються не лише мовними засобами на рівні тлумачення слів, а й застосовувають методологічні підходи, які розархівовуються минулим причинним досвідом, який сприяє набуттю досвіду тут і тепер в майбутнє. Загалом, у творенні сьогодення, через поняття історичні, політичні, економічні. соціальні, культурні та цивілізаційні ( "штучний інтелект", "нанотехнології", "електронні комунікації", "кібербезпека" і т.п.) визначені орієнтири реальности в напрямках 3 груп(3):

1) поняття, що виникали, формувалися в античні часи і $є$ в конструктивному застосунку сучасниками;

2) поняття, що з моменту їх історичного виникнення актуальні в сьогоденні, тому що історично вплинули на антропологію, онтологію еволюції людства пізнаючи цей світ;

3) поняття, що ще лише проявляються, виявляються та вивчаються в мовній фіксації, що пов,язані з інноваційною природою явища, політичними та культурними інціаціями - подіями та відносинами, а ілюструють нові горизонти пізнання.

Отже історія поняття - то є проєкція активного пізнання світу та безмежних горизонтів в осмисленнях Всесвіту людиною, науковцем, освітянином, громадянином, взаємодія яких не підмінялася процесом інформування і процесу трансляцій еволюційної природи людини(5), а потребує синхронности взаємодій 3 декодуванням термінологічного та змістовного, сенсового в джерелах і водночас має багато спільного 3 методом критичного осмислення джерел, щоб вартість знань вберігали цінність Людини, сприяли твореннб громадянського суспільства.

Джерела :

1.The History of Concept Group https://www.historyofconcepts.net/, https://www.historyofconcepts.net/23rd-international-conference-2021/

2. Енциклопедія історії України: Т. 3: Е - Й / Редкол.: В. А. Смолій (голова) та ін. НАН України. Інститут історії України.- К.: В-во "Наукова думка", 2005. - 672 с.: 
3. Козеллек Р. Історія понять і соціальна історія. В кн.: Козеллек Р. Минуле майбутнє. Про семантику історичного часу. К., 2005

4. Райнгарт Козеллек Минуле майбутнє. Про семантику історичного процесу. Пер. $з$ нім. - К.: Дух і літера, 2005. - 380 с.

5. Стельмах С.П. ІСТОРІЯ ПОНЯТЬ [Електронний ресурс] // Енциклопедія історії України: Т. 3: Е-Й / Редкол.: В. А. Смолій (голова) та ін. НАН України. Інститут історії України. - К.: В-во "Наукова думка", 2005. - 672 с.: іл.. 


\title{
ЗДАТНІСТЬ ДО САМООСВІТНЬОЇ ДІЯЛЬНОСТІ ЯК СКЛАДОВА ПРОФЕСІЙНОЇ КОМПЕТЕНТНОСТІ МАЙБУТНЬОГО ВЧИТЕЛЯ
}

\author{
Носовець Наталія Михайлівна, \\ к. пед. н, доцент, завідувачка кафедри педагогіки, \\ психології і методики технологічної освіти, \\ Національний університет «Чернігівський колегіум» імені Т. Г. Шевченка,
}

Пискун Оксана Миколаївна,

к. пед. н., доцент кафедри педагогіки, психології і методики технологічної освіти, Національний університет «Чернігівський колегіум» імені Т. Г. Шевченка,

Джевага Григорій Васильович

к. пед. н., доцент кафедри педагогіки, психології і методики технологічної освіти, Національний університет «Чернігівський колегіум» імені Т. Г. Шевченка,

У сучасному світі суспільство та науки розвиваються з великою швидкістю, більша частина нових знань і технологій втрачає свою актуальність, інформація швидко застаріває. Це стосується і формування професіоналізму майбутніх педагогів. Сьогодні, як правило, успішними та професійно компетентними педагогами стають люди, здатні до саморозвитку, самоосвіти, які вміють адаптуватися до нових реалій і приймати самостійні рішення. Гарний спеціаліст сьогодні вже завтра може стати не затребуваним. Для того, щоб залишатися професіоналом, необхідний постійний, безперервний процес самоосвіти.

Актуальність питання самоосвіти педагогів постає більш гостро в умовах інформаційного суспільства, в якому на місце пасивного сприймання інформації ставиться самостійний пошук нових даних, уміння аналізувати i використовувати інформаційний потенціал для орієнтації в провідних концепціях і теоріях, щоб на їхній основі формувати власне мислення. Саме тому сучасний педагог повинен постійно удосконалювати свої знання та вміння.

Самоосвіта - основа зростання вчителя як спеціаліста. У сучасній педагогічній літературі немає єдиного погляду на тлумачення категорії «самоосвіта». Різні дослідники по-своєму трактують самоосвіту, виділяючи ту чи іншу її сторону.

Різноманітні підходи до розуміння суті самоосвіти дозволяють розглядати цю дефініцію як: форму отримання й поглиблення знань (Г. Бичкова, С. Лебедєв); процес розвитку інтелектуальних якостей і розумових здібностей (О. Кочетов); вид пізнавальної діяльності (І. Гончаров, Н. Косенко); засіб саморозвитку творчої особистості, керування іï розумовою діяльністю (Л. Рувінський). 
Теоретичний аналіз проблеми дозволив нам визначити самоосвіту майбутнього вчителя як саморегульовану пізнавальну діяльність, що орієнтована на формування професійної компетентності та особистісний розвиток. Саморегульований характер проявляється в тому, що управління діяльністю здійснюється самим суб'єктом, тобто людина, яка здійснює самоосвітню діяльність, по відношенню до себе виступає одночасно об'єктом і суб'єктом управління. Самоосвітня діяльність $є$ вищою формою задоволення потреб та інтересів особистості, що характеризується самостійністю, високою інтелектуальною активністю й усвідомленістю, потребує прояву значних вольових зусиль та самоорганізованості.

Основним завданнями самоосвіти $є$ удосконалення теоретичних знань i практичних вмінь, розвиток здібностей та професійно важливих особистісних якостей педагога; оволодівання новими формами, методами, прийомами навчання і виховання; вивчення та впровадження у власну практику передового педагогічного досвіду, новітніх досягнень педагогічної, психологічної наук, нових педагогічних технологій; удосконалення професійної майстерності.

У Законі України «Про освіту» (2017р.), Концепції «Нової української школи» (2016 р.) проголошено курс на впровадження компетентнісного підходу до освіти. Компетентнісно орієнтований підхід $є$ концептуальним орієнтиром у процесі професійної підготовки висококваліфікованих педагогів, а проблема формування самоосвітньої компетентності майбутніх учителів у процесі професійної підготовки є надзвичайно актуальною.

У 2020 році в Україні затверджений Професійний стандарт за професіями «Вчитель початкових класів закладу загальної середньої освіти», «Вчитель закладу загальної середньої освіти», «Вчитель 3 початкової освіти (з дипломом молодшого спеціаліста)», який втілює сучасний підхід до визначення переліку та опису загальних i професійних компетентностей вчителя. Так, до групи професійних компетентностей увійшла здатність до навчання продовж життя, що передбачає здатність визначати умови та ресурси професійного розвитку впродовж життя, здатність взаємодіяти 3 іншими вчителями на засадах партнерства та підтримки (у рамках наставництва, супервізії тощо) [1].

На основі проаналізованих досліджень українських науковців 3 проблем самоосвітньої компетентності (Н. Бухлова, Н. Воропай, Л. Вьюшкова, А. Громцева, Ю. Демченко, Н. Коваленко, Б. Коломієць, I. Наумченко, Г. Федоренко та ін.) нами було зроблено висновок, що самоосвітня компетентність майбутнього вчителя - це інтегрована багатокомпонентна професійно значуща якість особистості, що відображає здатність і готовність майбутнього педагога до здійснення ефективної творчої самоосвітньої діяльності у межах професійної педагогічної сфери. Самоосвітня компетентність $\epsilon$ важливою характеристикою становлення та розвитку особистості, сприяє самостійному підвищенню іiї педагогічного потенціалу.

Отже, до сучасного вчителя висуваються такі вимоги як професіоналізм, мобільність, здатність до творчої переробки великого обсягу інформації та його компетентного використання в практиці. Мета закладів вищої освіти: 
підготувати студента не тільки до практичної діяльності, але й до подальшого систематичного підвищення своєї професійної кваліфікації.

3 метою визначення стану самоосвітньої діяльності майбутніх учителів трудового навчання та технологій нами було проведене опитування, в якому взяли участь 67 студентів старших курсів денної форми навчання технологічного факультету Національного університету «Чернігівський колегіум» імені Т.Г. Шевченка. Ми намагалися 3'ясувати, чи сформована у них потреба в самоосвітній діяльності, чи вміють вони самостійно, без сторонньої допомоги організувати власну самоосвітню діяльність, які $є$ особливості й пріоритети їхньої самоосвітньої діяльності, які труднощі виникають у них при цьому і яким чином вони намагаються справлятися з цими труднощами.

Результати опитування показали високий ступінь розуміння студентами важливості самоосвіти для сучасної людини, яка хоче стати успішною в будьякій сфері діяльності (78\%). Проте, на даний момент більш, ніж у чверті опитаних потреби в самоосвіті не виникало, або вони ії не відчувають. У решти - потреба в самонавчанні виникає часто (36\%) або ситуативно (38\%). За словами студентів, основними чинниками, що спонукають їх до самостійного пошуку інформації і навчання є: неповнота чи нестача знань, що дають викладачі на заняттях; необхідність виконання завдань творчого і дослідницького характеру (написання рефератів, курсових і дипломних робіт, виконання проєктів); необхідність оволодіння новими знаннями і вміннями для своїх хобі, роботи, творчих видів діяльності; необхідність знань і вмінь для вирішення конкретної проблемної ситуації; цікавість до невідомого, бажання розібратися в незрозумілому, глибше вивчити й дослідити предмет, щоб бути (чи принаймні виглядати) компетентним у спілкуванні з професіоналами; бажання постійно розвиватися, вдосконалюватися і пізнавати нове.

Щодо здатності до організації самоосвітньої діяльності, приємно, що більш, ніж $30 \%$ студентів, за їх словами, здатні організувати себе, цілеспрямовано і систематично вивчаючи певний курс, i прагнуть самостійно в усьому розібратися, а решта - принаймні намагаються самоконтролювати i саморегулювати власну самоосвітню діяльність, наскільки вистачає сили волі.

Опитування також показало, що більше половини респондентів (54\%) не вміють швидко й легко знаходити, вибирати, оцінювати й аналізувати необхідну навчальну інформацію. І при цьому пошук нової інформації вони здійснюють виключно лише в мережі Інтернет (45\% студентів), ігноруючи усі інші джерела інформації.

Очевидно, що в процесі самоосвітньої діяльності постійно виникають певні труднощі. Так, зокрема студенти назвали технічні проблеми 3 Інтернетз'єднанням, складності в самоорганізації, незрозумілість поставлених навчальних завдань або відсутність чіткої інструкції щодо їх виконання, труднощі у пошуку необхідної інформації або іiі відсутність, і найбільше складності в опануванні нових практичних умінь, коли усне пояснення чи відео просто не можуть дати ясного уявлення про виконання, наприклад, певної трудової операції, оскільки відсутній безпосередній контакт 3 майстром. 
Вирішують ці труднощі в основному зверненням по допомогу до одногрупників, викладачів, компетентних людей.

Завдяки самоосвітній діяльності деякі студенти, як вони зазначили в анкеті, оволоділи, зокрема за минуле півріччя, різноманітними новими видами діяльності відповідно до своїх інтересів і потреб (від професійного складання віршів і вивчення іспанської мови до ремонту автомобілів, будівництва, програмування, дизайну інтер'єрів і організації дитячих свят), що не входили до обов'язкового навчального плану, або вдосконалили наявні знання та вміння. Проте, нажаль, переважна частина опитаних займалися в цей час лише обов'язковими навчальними дисциплінами, зовсім не приділяючи часу неформальній чи інформальній освіті.

Отже, результати нашого дослідження яскраво продемонстрували протиріччя між нагальною потребою сучасних студентів в самонавчанні i самоосвіті і несформованістю у них чіткого механізму самоосвітньої діяльності, а також часто відсутністю таких особистісних якостей, як організованість, дисциплінованість, уважність, сила волі, соціальна й професійна мобільність. I при цьому однією з найголовніших проблем у процесі самонавчання постає невміння студента працювати 3 джерелами інформації.

3 метою вирішення цього протиріччя необхідно здійснювати в закладі освіти цілеспрямовану й систематичну навчально-виховну роботу 3 формування у студентів самоосвітньої компетентності, яка має проходити червоною ниткою через усі навчальні дисципліни і практики.

По-перше, вже починаючи з першого курсу необхідно впроваджувати в усі навчальні предмети елементи самонавчання з поступовим ускладненням завдань i підвищенням ступеня самостійності. Для того, щоб студент зміг самоорганізуватись, необхідно розробити спеціальні дидактичні матеріали 3 чіткими інструкціями щодо пошуку, оцінки, якісного аналізу нового навчального матеріалу, відбору головного, відокремлення суттєвого від другорядного, критичного осмислення й продуктивного опрацювання.

По-друге, в програмах усіх навчальних дисциплін передбачити окремі теми або питання (бажано, на вступному занятті 3 предмету) щодо організації самостійної навчальної роботи, особливостей дистанційного i змішаного навчання з даного предмету.

По-третє, упроваджувати в навчальний процес елементи «перевернутого» навчання. Наприклад, на технологічному факультеті при вивченні курсу «Психологія» студенти заздалегідь отримують електронні тексти лекцій i матеріали для самостійної роботи, які вони опрацьовують вдома. Це дозволяє на занятті розглядати цей матеріал вже з певним рівнем розуміння, осмислення, що дає можливість не просто слухати лекцію, а й обговорювати тему, звертати увагу на незрозумілі питання, проводити дискусії, розв'язувати проблемні ситуації, розглядати більше прикладів і додаткових матеріалів.

По-четверте, впровадити (по можливості в кожну навчальну дисципліну) обов'язкові залікові завдання, що передбачають самостійне опанування студентами певним новим видом діяльності, новою технологією тощо, які не 
входять до навчальної програми даного курсу, але відповідають індивідуальним інтересам і запитам студента.

Так, наприклад, у професійній підготовці майбутніх учителів трудового навчання і технологій ми практикуємо наступне: під час вивчення навчальної дисципліни «Теорія і методика технологічної освіти» впродовж семестру кожен студент має самостійно опанувати певний, новий для нього вид декоративноужиткового чи образотворчого мистецтва, чи нову техніку, чи технологію, розробити й виготовити проєкт, а також провести в студентській групі майстерклас $з$ цього виду діяльності і навчити своїх одногрупників.

Програма «Педагогіки вищої школи» для другого (магістерського) рівня освіти передбачає вільний вибір студентами теми для вивчення в рамках даної дисципліни. Магістранти повинні запропонувати тему, розробити питання $\mathrm{i}$ підготувати матеріал для проведення заняття. Цьому передує аналіз сучасних проблем педагогічної практики і теорії, самоаналіз власної готовності до професійної діяльності. Наприклад, студентами була запропонована тема для вивчення «Теорія поколінь: чи існує проблема?», матеріал якої вони самостійно розробили для вивчення і підготували вправи і завдання для мінітренінгів.

У змісті курсу «Растрова і векторна графіка» студентам пропонується обрати тему індивідуального самостійного проєкту 3 певного напрямку мистецтва художньої обробки зображень, для виконання якого не достатньо знань і умінь, отриманих під час лекцій і лабораторно-практичних занять. Тільки самостійне опрацювання визначених питань 3 курсів «Растрова і векторна графіка», «Теорія дизайну» $\mathrm{i}$ «Вебтехнології» дозволяє на якісному рівні виконати індивідуальний творчий проєкт. Ці питання спрямовані на підвищення ефективності роботи 3 інструментами графічних редакторів, вдосконалення технології редагування цифрових зображень, вивчення сучасних напрямків і стилів мистецтва і дизайну.

По-п'яте, запропонувати студентам вивчати окремі питання, теми чи розділи навчальної дисципліни за допомогою онлайн курсів, що дасть можливість розширити обсяг знань й уникнути однобічності подання інформації викладачем. Отримавши сертифікат, студент зможе отримати відповідну кількість балів 3 курсу автоматично. Так, 3 навчальної дисципліни «Основи роботи 3 мультимедіа» студентам магістратури пропонується пройти безкоштовні онлайн курси «Дизайн информации в презентациях», «Візуалізація даних (проєкт «Ти можеш усе! Можливості безмежні!»)», вебінар «Основи дизайну для педагогів. Практикум».

По-шосте, передбачити в усіх видах практик обов'язкові залікові завдання 3 самоосвітньої діяльності, які б спрямовувались не лише на відпрацювання й удосконалення вже наявних у студентів знань та вмінь, а й на пізнання нових аспектів обраної професійної діяльності. Це можуть бути онлайн курси, опрацювання педагогічних першоджерел та сучасних педагогічних видань, вивчення передового педагогічного досвіду. Так, під час проходження педагогічних практик наші студенти отримують обов'язкове завдання: впродовж періоду практики підвищити свій професійно-педагогічний рівень шляхом проходження безкоштовних онлайн курсів підвищення кваліфікації вчителів, участі у вебінарах, онлайн конференціях, форумах, семінарах, тренінгах, 
марафонах тощо психолого-педагогічного змісту (на вибір студента) і на захисті практики пред’явити відповідні сертифікати. Оцінка за цей вид роботи залежатиме від якісного вибору тематики і кількості годин, витрачених на онлайн освіту.

Слід зауважити також, що у процесі індивідуальної роботи викладача зі студентом щодо розвитку самоосвітньої компетентності останнього необхідно надавати студентові допомогу у виборі самоосвітніх завдань, у плануванні й організації його самоосвітньої діяльності, цілеспрямовано спонукати студента до самовдосконалення i саморозвитку, застосовуючи методи переконування, заохочення і прикладу.

У процесі професійної діяльності вчителя необхідність у самоосвіті з'являється під час проблемних ситуацій, яку без додаткової інформації вирішити неможливо. Наприклад, проблемні ситуації виникають під час роботи 3 учнями 3 особливими освітніми потребами, налагодження порозуміння 3 «поколінням Z», під час впровадження нових мультимедійних або інформаційнокомунікаційних технологій у навчальний процес, забезпеченні дистанційного навчання, оновлення змісту навчального предмету, у разі появи нових наукових відкриттів чи розробок - все це вимагає вивчення нової інформації чи формування нових компетентностей. Подібні умови доцільно створювати й у навчанні студентів для напрацювання відповідної моделі поведінки під час виникнення проблемних ситуацій, що виховуватиме у них звичку до самоосвіти.

Отже, викладачу ЗВО необхідно проєктувати, стимулювати і підтримувати прагнення студентів до оволодіння знаннями, духовного зростання, готовності до професійної діяльності, формувати у майбутніх учителів власну установку на професійну самоосвіту, подальше підвищення кваліфікації.

Список літератури:

1. Професійний стандарт за професіями «Вчитель початкових класів закладу загальної середньої освіти», «Вчитель закладу загальної середньої освіти», «Вчитель 3 початкової освіти (з дипломом молодшого спеціаліста)». НАКАЗ № 2736 від 23 грудня 2020 року URL: https://osvita.ua/doc/files/news/787/78704/ Nakaz_2736_3_.pdf 


\title{
ТЕОРЕТИЧНІ ОСНОВИ ІНДИВІДУАЛІЗАЦІЇ НА УРОКАХ ФІЗИЧНОЇ КУЛЬТУРИ
}

\author{
Півень Олександр Пилипович \\ кандидат пед. наук, доцент \\ кафедра спортивних дисциплін і туризму \\ університет Григорія Сковороди в Переяславі, Україна \\ Горбенко Микола Іванович \\ доцент, заслужений тренер України \\ кафедра спортивних дисциплін і туризму \\ університет Григорія Сковороди в Переяславі, Україна
}

Анотація: Дана стаття на основі систематизації та аналізу літературних джерел розкриває проблеми індивідуалізації у фізичному вдосконалюванні школярів, які є дієвим, єфективним та потужним засобом виховання фізично і гармонійно розвиненої особистості школярів.

Ключові слова: розвиток, проблеми індивідуалізації, фізичне виховання, здоровий спосіб життя, гармонійний розвиток.

Постановка проблеми, актуальність. Проблема підвищення результативності навчально-виховного процесу безпосередньо пов'язана 3 індивідуалізацією.

Увага до виховання людини, турбота про всебічний розвиток їі здібностей, вдосконалення особистих якостей уходить в коло проблем сучасного суспільства. Існування індивідуальних відмінностей між людьми - факт очевидний. Необхідність індивідуального підходу викликана тією обставиною, що будь-яка дія на дитину заломлюється через його індивідуальні особливості, через «внутрішні умови», без урахування яких неможливий по-справжньому дієвий процес виховання. Всебічний розвиток кожної людини - програмна мета нашого суспільства - припускає як важливу умову виявлення творчого потенціалу особи, формування індивідуальності як вищого рівня іiі розвитку. Кожна людина повинна мати можливості виявити себе. У цьому зацікавлені й окрема особистість, і все суспільство. Вікові ролі людського чинника в розвитку нашого суспільства поставило питання про індивідуальну роботу як важливій формі виховання. Індивідуальний підхід ніяк не протистоїть принципу колективності - основному принципу не тільки виховання, але й всього устрою нашого життя.

Індивідуальний підхід це не разовий захід. Він повинен пронизувати всю систему дії на дитину, і саме тому це загальний принцип виховання. Разом $з$ тим в різних сферах виховання й навчання цей підхід виявляється в різній мірі. Індивідуальний підхід націлений у першу чергу на зміцнення позитивних якостей і усунення недоліків. При умінні й своєчасному втручанні можна уникнути небажаного, болісного процесу перевиховання. 
Розробку проблем індивідуального підходу у фізичному вихованні як складової частини здорового способу життя неможливо здійснювати без всебічних знань про особливості розвитку дитини і діалектичного підходу при педагогічному аналізі численних даних, отриманих і накопичених у фізіології, морфології,психології, антропології, генетиці та інших науках про людину. Найважливішим положенням $\epsilon$ висновок про те, що фізичний i психічний розвиток є результатом взаємодії соціального і біологічного, а не однозначного зв'язку спадковості та середовища. Вчені вказують на діалектичну єдність соціального, психологічного і біологічного підходів до розгляду особистості.

На думку 3.I. Кузнецової, Г.Л. Апанасенка [1], для здійснення індивідуального підходу спочатку необхідно створити таку систему виховання $\mathrm{i}$, зокрема,фізичного, котра дозволила б забезпечити кожній дитині повноцінний $\mathrm{i}$ гармонійний розвиток його здібностей, забезпечити засвоєння дітьми оптимального обсягу рухових умінь, навичок і знань 3 фізичної культури. 3 іншого боку, необхідно озброїти педагогів методикою диференційованого педагогічного впливу, заснованою на знаннях про особливості особистості школяра, його фізичного розвитку, та стан здоров'я.

Зниження результатів педагогічного впливу, невдачі у формуванні мотивів часто обумовлені тим, що в школах існує стратегія орієнтації на "середнього учня" [2].

На жаль, проблема індивідуалізації під час занять фізичними вправами у загальноосвітній школі ще й досі не вирішена. На нашу думку, історикотеоретичний аналіз даної проблеми дозволить визначити основні проблеми недостатньо ефективного використання індивідуального підходу у фізичному вихованні школярів, що і визначає актуальність дослідження.

За допомогою індивідуального підходу можна знайти «ключ» до кожної дитини. Індивідуальний підхід - один з головних принципів педагогіки. Сама проблема індивідуального підходу носить творчий характер, але існують основні моменти при здійсненні диференційованого підходу до дітей.

Метою дослідження $\epsilon$ ретроспективний аналіз розробки проблеми індивідуального підходу у фізичному вихованні школярів.

Результати дослідження та їх обговорення. Проблема індивідуалізації вимагає і перегляду критеріїв оцінки успішності. Неправомірно підходити 3 однаковими вимогами до всіх дітей,тому що результати рухових проявів залежить від психологічних, фізіологічних, антропометричних особливостей учнів. Діти,недостатньо руховообдаровані від природи, незабаром втрачають інтерес до занять.

Великий виховний ефект дає оцінка успіхів кожного в освоєнні тих чи інших вправ, індивідуальні "зрушення" у результатах. При розробці методів індивідуального підходу повинні враховуватися здатності кожної дитини, особливості особистісних проявів.

Проблема індивідуалізації вимагає виконання дуже складних завдань, пов'язаних із розробкою типології учнів. Першими вихідними даними, що слугували основою для розробки характеристики типологічних особливостей 
людини, були антропометричні показники і дані досліджень вищої нервової діяльності.

Спроби встановити найбільш істотні характерні особливості людини і на цій основі передбачити його реактивність починалися ще в далекій давнині. Вважалося, що статура визначає особливості темпераменту. А вони - ці особливості, - щось уроджене, як і будова тіла. Дотепер залишається дискусійним питання: "Чи може бути темперамент людини і конституція тіла вродженими?".

Цікаво, що історія антропометрії розпочинається ще в період античності. В той час була розроблена не тільки перша емпірична концепція конституції Гіппократа, але і ряд прийомів виміру фізичного розвитку тіла людини. За особливостями статури людини Гіппократ намагався виявити характерні риси психічного складу людей, розділяючи їх на чотири основних темпераменти.

Ідеї Гіппократа і Галена розвив у своїй прославленій роботі "Тілобудова i характер" німецький психіатр Е. Кречмер. Він розглядає конституційні особливості як обумовлені спадкоємними факторами і виділяє три типи статури: астенічний, атлетичний і пікнічний. Прагнучи пов'язати морфологічні типи статури організму 3 особливостями його реактивності, Е. Кречмер наділяє виділені ним конституційні типи певними, нібито властивими їм,психологічними рисами.

Наступну велику спробу взаємопов'язати статуру, особливості організму і характер людини здійснили в сорокових роках минулого століття американці У. Шелдон і С. Стивенс. Вони виділили чотири типи статури і характеру, вірніше, темпераменту, що визначає характер. Аналогічну теорію висунув у 1958 р. Г. Гримм, який також зважав, що поняття конституції повинно грунтуватися на взаємозв'язку форм тіла і стану його найважливіших функціональних систем,включаючи вищу нервову діяльність. За основу наступних класифікаційних конструкцій взято сукупність ознак статури, які визначались антропометричним методом.

Визнаючи важливе значення тілобудови й особливості фізичного розвитку людини в оцінці його конституції, не можна не відмітити, що конституційна характеристика являє собою недостатньо розроблену проблему. Часто розходячись по цілому ряду питань, усі дослідники згодні з тим, що однією 3 істотних ознак, що характеризують конституційні особливості організму, $є$ статура людини.

У вченні про конституцію людини вже 3 початку 20го століття чітко виділяються два протилежних напрями: одні автори конституцію вважають спадковою, інші - розглядають iї формування як вплив факторів зовнішнього середовища.

Характерно, як відмічає Б.А. Никитюк, що серед багатьох напрямів генетики розвитку людини, які розробляються на молекулярному, клітинному, органному, системному та інших рівнях, найбільш прикладне значення для практики педагогіки, фізичного виховання і спортивної медицини має антропологічне вчення. Дослідженнями Е.А. Силиної, А.Л. Трегубова встановлено, що антропометричні індекси пов'язані багатозначною залежністю 3 показниками 
серцево-судинної системи і психодинаміки. За даними досліджень Т.Ю. Круцевич [3], встановлено виражений взаємозв'язок між властивостями нервової діяльності й окремих систем організму школярів, а також і 3 такою інтегральною характеристикою, якою $є$ фізичний розвиток людини.

Наявність високої криволінійної залежності відмічали й інші автори. Таким чином, не тільки функціональний стан кори головного мозку впливає на процеси росту і розвитку, але існує і зворотний зв'язок. Ймовірно, недостатньо виділяти групи за рівнями розвитку фізичних якостей. Заняття фізичною культурою, як і будь-яка інша діяльність, втягують у роботу індивіда в цілому,не обмежуючи тільки руховою системою.

За твердженням В.К. Бальсевича, важливою умовою підвищення ефективності процесу фізичного виховання школярів $\epsilon$ розробка загальних та окремих критеріїв здоров'я, які можна було б виразити у визначених індексах, ранжированих за шкалами і які слугували б показником ефективності зміни фізичного стану конкретного учня, шкільного колективу. Програмні вимоги та їхні кількісні нормативи повинні орієнтувати не тільки батьків школярів молодших класів кожного конкретного учня середніх і старших класів, але також i вихователя групи продовженого дня, класного керівника i, природно, учителя фізичної культури на конкретну спрямованість роботи 3 фізичного удосконалювання організму дитини давати уявлення про ефективність впливу фізичних вправ на організм дитини.

Дослідження методу стандартних тренувальних завдань $є$ своєрідним інструментом контролю, оскільки дозволяє спостерігати процес фізичного удосконалення учнів при тому самому виді фізичної активності. На думку В.К. Бальсевича, стандартні фізичні навантаження у вигляді визначених програм фізичних вправ і нагромадження статистики їхньої ефективності забезпечує удосконалювання здоров'я i розвитку дітей, методики їхнього фізичного виховання,визначення оптимуму тренувальних i навчальних впливів. У структуру запропонованого методу закладена здатність до саморозвитку i самовдосконалення.

За даними досліджень А. П. Бондарчука, чим одноманітніше і постійніше діє будь-яка система подразнень, тим швидше відбуваються в організмі як короткочасні, так і тривалі адаптаційні перебудови, тобто він швидше пристосовується до них, а отже, входить у стан тренованості, тому що воно $\epsilon$ наслідком згаданих вище перебудов. Чим одноманітніше і постійніше впливають будь-які подразники, тим легше системам організму, особливо центральній нервовій системі, сформувати відповідну реакцію за типом випереджувального відображення.

Досить цікавим $є$ антропологічне вчення в педагогіці і психології, що носило назву педології (нім. — Kinder Fjrschung, англ. — child study), тобто наука про дитину, яке було популярним у СРСР у 20 -х роках XX ст. Досягнення і помилки цього вчення стали надбанням усього світу. Видано багаточисельні праці по загальній і віковій педагогіці. Згодом тільки підсилюється увага світової педагогічної думки до теоретичної і прикладної спадщини "російської школи" педагогічної антропології, що виходить 3 культурно-історичного і практично- 
діяльного розуміння природи людини. Це становить суть теорії "спонтанності", що базується на антропологічному трактуванні здібностей людини до виховання і навчання. Серед подібних робіт виділяються праці англійського антрополога Д. Таннера, який стверджує, що прогресивний розвиток кісткової системи $\epsilon$ загальним чинником,що задає темп як фізичному, такі розумовому розвитку. Причому, він вважає доведеним тільки один зв'язок: розумовий розвиток залежить від фізичного. Свої докази Д. Таннер будує на тому,що діти будь-якого віку від 7 до 17 років більш розвинені у фізичному відношенні, одержують і більш високі бали в психологічних тестах, чим їхні однолітки,які мають нижчий рівень фізичного розвитку.

Справа не в тому, якими є окремі антропологічні показники,а в тім, чи $€$ гармонійним фізичний розвиток дітей, наскільки розвинуті їхні рухові здібності, у якому обсязі вони володіють руховими уміннями і навичками. Сенс полягає в тому, щоб на основі знань про закономірності фізичного розвитку організму дітей об'єктивно відрізняти індивідуальне в особистості дитини й успішно впливати на підвищення розумових і фізичних можливостей кожного школяра.

Необхідно відмітити, що для сучасних вчителів основними критеріями диференційованого індивідуального підходу є успішність і вік дитини. Дані досліджень А.К. Атаева, К.Ф. Бакуненеу співавторстві з Ж.А. Білокопитовою свідчать про те, що діти одного віку мають значні відмінності у здібностях, можливостях,темпах засвоєння знань, у працездатності. Значна диференціація школярів за рівнем працездатності відмічається у всіх вікових періодах школярів.

За даними досліджень Л.І. Абросимової (у співавторстві з О.Д. Дубогай), близько половини школярів молодшого, середнього і старшого віку мають середній (вихідний) рівень працездатності. Однак третина школярів молодшого i середнього вікуй одна четверта частина старшого віку мають високу працездатність. Менше школярів у всіх вікових групах з низьким рівнем працездатності. Звертає на себе увагу, що від молодшого до середнього і потім до старшого шкільного віку збільшується група школярів 3 низьким вихідним рівнем працездатності. На думку ряду авторів, це може бути пов'язано з деякими факторами,які тривало впливають на організм, у тому числі і впливи високого навчального навантаження в шкільні роки.

Наслідком цього багатофакторного негативного впливу навчальних навантажень на організм дітей за період навчання у школі $є$ також погіршення рівня їхнього здоров'я. Сьогодні вже не таємниця, що кількість хворих дітей перевищує кількість здорових, які приходять у перший клас, у третьому класі їхня кількість збільшується до 32 \%,восьмому - до $47 \%$, а серед старшокласників їх уже $53 \%$.

Однією з причин різкого погіршення стану здоров'я дітей за період навчання в школі $є$ їхня функціональна непідготовленість до шкільного навчання, особливо на початковому етапі.

За даними М.В. Антропової, виявлено тісний зв'язок між рівнем функціональної готовності в момент вступу до школи і подальшою успішністю, працездатністю, станом деяких вегетативних функцій. У дітей, функціонально 
не готових до навчання,рівень розумової працездатності нижче, а динаміка іiі гірше, ніжу функціонально підготовлених школярів.

За спостереженнями А.Г. Хрипкової, М.В. Антропової, діти, які під час вступу до школи були визнані "незрілими", протягом трьох років навчання в школі мали більш низьку працездатність,гіршу академічну успішність і погану пристосованість дошкільних навантажень порівняно 3 функціонально підготовленими до навчання однолітками. А.Я. Савченко встановила, що несприятливий вплив навчального навантаження на функціональний стан організму і здоров'я "незрілих" школярів особливо чітко виявляється у другому навчальному році. Недостатня функціональна зрілість дітей виявляється в більш низькій успішності, особливо з предметів, які ставлять підвищені вимоги до координації дрібних м'язів кисті й артикуляції (читання, українська мова).

Висновки: Отже, на думку вчених, одним із питань вирішення проблеми індивідуалізації може бути створення спеціальних умов для фізично ослаблених дітей, які практично становлять основний контингент функціонально не підготовлених до школи учнів. Це такі умови: полегшення програми, обмеження числа уроків у день 335 хвилинною тривалістю, введення обмеженої кількості занять у середині тижня, корекція навчальних планів тощо. Звісно, головна увага повинна приділятись вдосконаленню організаційно-методичних основ занять фізичними вправами з дітьми і підлітками в умовах загальноосвітньої школи.

\section{Список літератури}

1. Алпанова Н. М. Тато, мама, я - українська спортивна сім'я (спортивнопатріотичне свято) / Н. М. Алпанова // Фізичне виховання в школах України. 2017. - № 10. - C. 29-32.

2. Ганчева В. І. Микола Денисюк посів III місце у Всеукраїнському конкурсі "Інноваційний урок фізичної культури та урок фізичної культури з елементами футболу" 2016 року / В. І. Ганчева, В. Г. Гусєв // Фізичне виховання в рідній школі. - 2017. - № 4. - С. 17-18.

3. Крамаренко В. Майстер-клас із фізичної культури / Валерій Крамаренко // Здоров'я та фізична культура. - 2017. - № 3. - С. 27-32.

5. Круцевич Т.Ю. Методы исследования индивидуального здоровья детей и подростков в процессе физического воспитания. / Т.Ю. Круцевич // - К.: Олимпийская литература, 1999. - 232 с.

6. Мороз В. М. Методичні рекомендації з теми "Гра як основа в системі управління фізичним станом підлітків на уроках фізичної культури" / В. М. Мороз // Фізичне виховання в рідній школі. - 2017. - № 5. - С. 18-20. 


\title{
ДИСТАНЦІЙНА ОСВІТА В ШКОЛІ ПІД ЧАС КАРАНТИНУ. БІЛЬШЕ ПЕРЕВАГ ЧИ НЕДОЛІКІВ?
}

\author{
Решта Валентина Миколаївна \\ вчитель російської мови та зарубіжної літератури
}

Овсяник Любов Миколаївна вчитель російської мови та літератури

Кисла Ірина Іванівна вчитель української мови та літератури Полтавська гімназія «ЗЗдоров’я» № 14

На сьогодні одним з актуальних напрямків розбудови сучасної освіти в Україні $є$ впровадження у навчальний процес дистанційного навчання. Така форма організації навчального процесу $\epsilon$ вимушеною мірою в умовах розповсюдження COVID-19, наслідком якого є введення обмежень у спілкуванні людей, в тому числі й учасників освітнього процесу. Введення жорсткого карантину спонукало педагогічні колективи шкіл до пошуку нових підходів постачання інформації суб'єктам навчання, змінюванні та удосконаленні методів навчання, вивченні платформ, на яких проводяться уроки, освоєнні новітніх інформаційних технологій навчання. Дистанційна форма навчання дає можливість розвитку безперервного навчання, загального обміну інформацією, тому ії називають освітньою системою 21 століття.

Дистанційна форма навчання передбачає доступ до Інтернету, наявність технічного забезпечення (комп'ютери, планшети, смартфони, мобільні пристрої) в усіх учасників освітнього процесу та вміння вчителів володіти технологіями дистанційного навчання. Педагоги повинні організувати якісне навчання 3 використанням цифрових технологій та мотивувати учнів до навчання. Для цього вибираються електронні освітні платформи, онлайн-сервіси та інструменти для організації дистанційного навчання. Учителі обирають форми, методи й засоби дистанційного навчання виходячи з доцільності і ефективності їхнього використання.

Дистанційне навчання $є$ перспективною сферою розвитку освіти в умовах іiі цифровізації i дозволяє забезпечити індивідуальну освітню траєкторію здобувача освіти та неперервність освітнього процесу у випадках обставин, які унеможливлюють відвідування закладів освіти [1]. Дистанційне навчання в умовах карантину стало викликом не лише для вчителів та учнів, а й для їхніх батьків. Виникла проблема забезпечення технічними засобами навчання усіх дітей в родині, а це не просто, адже у одній сім'ї буває 2, а іноді 3 або й 4 учні. Не кожна родина може дозволити собі розкіш в придбанні кількох ноутбуків чи планшетів. Також часто виникає проблема контролю дисципліни дітей, адже більшість батьків працює. На плечі батьків лягає відповідальність за виконання дітьми домашніх завдань, допомога в роз'ясненні незрозумілих для них тем, 
адже учень не завжди в таких умовах якісно може опанувати навчальний матеріал. На жаль, це не прерогатива діяльності батьків, і не всі 3 них можуть виконати роль педагога.

В умовах дистанційного навчання виникає багато проблем і у вчителів. Одна із них - необхідність постійного стимулювання учнів до роботи, відсутність можливостей розгортання діалогу для обміну думками між учнями і учителями, пропозиціями та висловлюваннями власних думок та суджень.

Дистанційне навчання створює нові виклики для дотримання норм і правил академічної доброчесності. У школярів з'являється можливість списування, використання інформації з Інтернету, а у педагогів виникає проблема справедливого об'єктивного оцінювання. Розраховувати на високий рівень академічної доброчесності можуть лише ті шкільні спільноти, які культивували iї постійно під час очного навчання, де була вибудувана довіра між учасниками освітнього процесу. Водночас використання певних педагогічних прийомів може спонукати дітей чесно й самостійно виконувати завдання [2].

Дистанційне навчання в системі української освіти продовжує вдосконалюватись, вчителі поступово набувають досвіду роботи в умовах карантину, учні адаптуються до навчання в домашніх умовах і стають більш дисциплінованими. Одночасно 3 розвитком інтернет-технологій i широким вдосконаленням методів дистанційного навчання виникають проблеми зі зв'язком, спостерігаються перебої в роботі Інтернету. Це дає підстави деяким учням шукати вигадані проблеми, щоб виправдати невиконання завдань та неготовність до уроків, аргументувати свою відсутність на он-лайн заняттях.

При дистанційному навчанні учителі повинні подбати про здоров'я дітей, тому працюють 3 дотриманням санітарних норм, які передбачені рекомендаціями МОН. Правилом «не нашкодь» керуються при формуванні розкладу уроків, згідно норм визначають тривалість роботи 3 технічними засобами навчання, дозовано задають домашні завдання. Під час онлайн-уроків учитель нагадує учням про правильну поставу, вправи для очей та фізичного розвантаження.

Навесні, під час першої хвилі карантину, учителі та учні не були готові до навчання в таких умовах, тому нерідко виникали проблеми з наявністю технічних засобів в обох сторін навчального процесу, виборі платформ для навчання, налагодженні контактів і зв'язків з учнями. 3 поступовим набуттям досвіду учителі опанували навиками роботи не лише з Вайбером (як було раніше), а й іншими освітніми платформами. Зокрема, в даний час особливою популярністю користується Zoom. На сьогодні існує можливість проводити заняття в он-лайн режимі, спілкуватися з учнями, надавати їм необхідні дидактичні матеріали, проводити контроль знань, налагоджувати з ними зворотній зв'язок.

Життя постійно вносить корективи в наші плани, що й сталося під час карантину. Незважаючи на численні дискусії щодо переваг та недоліків дистанційної освіти, а також критику багатьох педагогів, дистанційне навчання стало невід'ємною частиною сьогодення. До переваг дистанційного навчання можна віднести: вільний доступ до навчання (за наявності Інтернету); навчання у комфортній домашній обстановці; використання індивідуального підходу до кожного здобувача освіти. Серед основних недоліків виділяють: відсутність 
безпосереднього контакту між сторонами освітнього процесу; необхідність внутрішньої мотивації для навчання; недостатній рівень володіння сучасними платформами дистанційного навчання; відсутність соціальної взаємодії $[3,4]$.

Bсі розуміють, що дистанційна форма навчання, в такому вигляді як вона $\epsilon$, має більше мінусів, ніж плюсів. Адже якісне подання матеріалу учням найкраще відбувається при особистому спілкуванні педагогів і дітей, тобто «наживо». По закінченні карантину i знятті всяких обмежень в спілкуванні учасники освітнього процесу обов'язково повернуться до традиційних форм навчання, використовуючи елементи накопиченого під час дистанційного навчання досвіду.

\section{Список літератури}

1. Положення, затвердженене наказом МОН від 8 вересня 2020 року №1115 і зареєстровано в Міністерстві юстиції 28 вересня 2020 року за №941/35224.

2. Організація дистанційного навчання в школі. Методичні рекомендації. 2020.$71 \mathrm{c}$.

3. Баришнікова В. В. Основні переваги та недоліки дистанційної освіти // В.В. Баришнікова, О.О. Авласенко-Канарович / Матеріали I Всеукраїнської науковопрактичної конференції «Дистанційна освіта Україні: інноваційні, нормативноправові, педагогічні аспекти», 16 червня 2020 року - С.13-15.

4. Переваги та недоліки дистанційного навчання. - [Електроний ресурс]. - Режим доступу: https://kerivnyk.info/perevahy-ta-nedoliky-dystantsijnoho-navchannya 


\section{СПІВВІДНОШЕННЯ КРИТЕРІЇВ ТА ПОКАЗНИКІВ КОМУНІКАТИВНОЇ КОМПЕТЕНТНОСТІ МАЙБУТНІХ ВИКЛАДАЧІВ ІНОЗЕМНИХ МОВ}

\section{Сергій Миколайович Галецький}

к.П.н., старший викладач

Національний університет «Острозька академія»

У процесі формування комунікативної компетентності майбутніх викладачів іноземних мов засобами інформаційно-комунікаційних технологій постає потреба у розробці інструментів вимірювання рівня комунікативної компетентності майбутніх викладачів іноземних мов. В основі виділення критеріїв дослідження лежить положення, що критерій відображає характерологічні властивості стану й рівня функціонування предмету пізнання [1]. У педагогічному словнику С. Гончаренка критерій розкривається як засіб перевірки гіпотези дослідження за допомогою інтеграції експериментальних даних [2].

Критерії виступають ознаками, за якими здійснюється оцінювання сформованості педагогічного явища - відповідно, вони повинні: бути узгодженими 3 компонентами предмету пізнання (В. Беспалько [3], О. Колесников [4], В. Полонський [5]); відображати його суттєві характеристики (I. Блощинський [6], В. Курило [7]); кількісно виражати якісні характеристики предмету дослідження (С. Гончаренко [2], А. Новіков [8], І. Рудинський [9]).

Проведений аналіз наукової літератури 3 проблеми визначення критеріїв експериментальної роботи (І. Білецький та О. Кузь [10], О. Власенко [11], С. Гончаренко [12; 13], О. Клименюк [14], С. Максименко [15], М. Садовий [16], С. Скворцова й Ю. Вторнікова [17], С. Сисоєва і Т. Кристопчук [18] , Н. Чайченко й інші [19]) дозволяє нам сформувати ключові (еталонні) критерії та відповідні їм показники результативності процесу професійної підготовки майбутніх фахівців (табл. 1):

пізнавальний критерій - обсяг і якість фахових знань; розуміння сутності та змісту термінології; здатність до синтезу, аналізу, узагальнення, структурування та продукування професійних знань;

мотиваційний критерій - наявність пізнавальних інтересів та пізнавальнокомунікативних потреб у обраній галузі; наявність внутрішніх мотивів професійного зростання; бажання самовдосконалюватися;

діяльнісний критерій - сформованість професійних умінь; розвиненість усного та писемного мовлення; досвід практичної діяльності за фахом; професійна творчість й активність [20].

Кожен 3 компонентів має співвідноситися 3 критеріями і показниками. Означене співвідношення ми представили в таблиці 1. 
Таблиця 1

Співвідношення критеріїв та показників комунікативної компетентності майбутніх викладачів іноземних мов

\begin{tabular}{|c|c|}
\hline $\begin{array}{c}\text { Критерії } \\
\text { комунікативної } \\
\text { компетентності } \\
\end{array}$ & Показники комунікативної компетентності \\
\hline Мотиваційний & $\begin{array}{l}\text { Спрямованість на отримання якомога глибших знань та вмінь } 3 \\
\text { іноземної мови } \\
\text { Здатність працювати з текстами з будь-яких джерел } \\
\text { Уміння добирати та систематизувати інформацію за допомогою } \\
\text { сучасних ІКТ } \\
\text { Здатність до постійного розширення кола знань і вмінь } \\
\text { Уміння обгрунтовувати власну думку } \\
\text { Толерантне ставлення до інших культур } \\
\text { Вміння аналізувати свою діяльність } \\
\text { Здатність до самооцінки } \\
\text { Вміння бути комунікабельним }\end{array}$ \\
\hline Пізнавальний & $\begin{array}{l}\text { Знання про мовні норми структури тексту } \\
\text { Граматична й лексична коректність } \\
\text { Зв’язне мовлення } \\
\text { Уміння виконувати навчальні завдання усно й письмово } \\
\text { Уміння працювати } 3 \text { сучасними інформаційно-комунікаційними } \\
\text { технологіями } \\
\text { Уміння переказувати своїми словами прочитаний текст, та виділяти } \\
\text { в ньому головну думку } \\
\text { Уміння працювати } 3 \text { науковою літературою, в тому числі } \\
\text { віртуальною } \\
\text { Знання методів наукового пізнання } \\
\text { Здатність розуміти прочитане й почуте } \\
\text { Вміння узагальнювати інформацію, отриману з різних джерел, в } \\
\text { тому числі й віртуальних } \\
\text { Уміння формулювати власну думку } \\
\text { Уміння розпізнавати наміри повідомлення, які відповідають певним } \\
\text { різновидам текстів } \\
\text { Здатність оцінювати масив сучасної інформації, в тому числі } \\
\text { віртуальної } \\
\text { Уміння розуміти та переносити наміри повідомлення на адекватні } \\
\text { ситуації } \\
\text { Знання й уміння з орфографії, морфології, синтаксису, лексики }\end{array}$ \\
\hline Діяльнісний & $\begin{array}{l}\text { Уміння пояснювати та обгрунтовувати сказане } \\
\text { Вміння висловлюватися, передаючи тонкі значеннєві відтінки } \\
\text { Вміння активно використовувати } \\
\text { суспільному,професійному житті та в навчанні } \\
\text { Вміння чітко й вичерпно висловлюватися } \\
\text { Вміння виступати перед аудиторією } \\
\text { Уміння використовувати предметні знання } \\
\text { Уміння складати доповіді про свою навчальну та професійну } \\
\text { діяльність } \\
\text { Уміння розподіляти й організовувати роботу серед інших } \\
\text { Вміння працювати в команді } \\
\text { Вміння попереджувати та вирішувати конфліктні ситуації } \\
\text { Вміння виявляти емпатію }\end{array}$ \\
\hline
\end{tabular}




\begin{tabular}{|l|l|}
\hline Здатність проектувати свою діяльність, в тому числі із \\
застосуванням ІКТ \\
Вміння оформлювати звіти про виконану роботу & \\
& Уміння презентувати свою дослідницьку та професійну діяльність \\
\hline
\end{tabular}

Джерело: розроблено автором

Така структура критеріїв i показників узгоджується із результатами досліджень європейських учених, наприклад, Б. Шпітсберг та У. Куп [21] до основних компонентів комунікативної компетентності відносять мотивацію, знання й навички, що можна співвіднести із представленими вище критеріями.

Одночасно обрана система критеріїв і показників дозволяє дотично вивчати три основні функції спілкування фахівців: комунікативно-мовленнєву, соціально-перцептивну та інтерактивну [22].

Таким чином, нами обгрунтовано критерії та показники сформованості комунікативної компетентності майбутніх викладачів іноземної мови засобами інформаційно-комунікаційних технологій.

\section{Список літератури}

1. Лемак, М. В., Петрище, В. Ю. 2011. Психологу для роботи. Діагностичні методики: збірник. Ужгород: Вид-во О. Гаркуші.

2. Гончаренко, С. У. 1997. Український педагогічний словник. Київ: Либідь., с.181

3. Беспалько, В. П. 1989. Слагаемые педагогической технологии. Москва: Педагогика.

4. Колесников, О. В. 2011. Основи наукових досліджень: навчальний посібник. 2-ге вид., випр. та доп. Київ: Центр учбової літератури.

5. Полонський, В. М., 2015. Критерії оцінки якості й методи визначення новизни результатів науково-педагогічних досліджень. [online] Хелпикс.Орг Интернет поморник. Режим доступу: https://helpiks.org/5-99482.html [Дата звернення 12 листопада 2019].

6. Блощинський, I. Г., 2001. Обгрунтування критеріїв і показників ефективності процесу формування адекватної самооцінки курсантів у навчальному процесі ВВЗО. Наукові записки: Педагогіка і психологія, вип. 4. с. 74-76., c. 75

7. Курило, В. С., 1999. Моделювання системи критеріїв оцінки розвитку освіти в регіоні. Педагогіка і психологія, 2, с. 35-39., с. 35

8. Новиков, А. М. 2003. Как работать над диссертацией: пособие для начинающего педагога-исследователя. Москва: Издательство «Эгвес».

9. Рудинский, И. Д., Клеандрова, И. А., 2003. Как оценить объективность контроля знаний. Педагогическая диагностика, 3, с. 109-116., с.112

10. Білецький, І. П., Кузь, О. М. 2005. Філософія науки: навчальний посібник. Харків: Харківський національний економічний університет.

11. Власенко, О. М. 2014. Специфіка викладання спецкурсу «Методика педагогічного експерименту». В: О. А. Дубасенюк, ред. Професійна педагогічна освіта: становлення і розвиток педагогічного знання: монографія. Житомир: Видавництво ЖДУ ім. І. Франка, с. 380-396. 
12. Гончаренко, С. У. 2003. Педагогические исследования: содержание, организация, обработка результатов. Москва: Издательский центр АПО.

13. Гончаренко, С. У. 2010. Педагогічні дослідження: методологічні поради молодим науковцям. Вінниця: ТОВ фірма «Планер».

14. Клименюк, О. В. 2006. Технологія наукового дослідження: авторський підручник. Київ: ТОВ «Вид-во «Аспект-Поліграф».

15. Максименко, С. Д. 1998. Психологія в соціальній та педагогічній практиці: методологія, методи, програми, процедури. Київ: Наукова думка.

16. Садовий, М., 2012. Особливості педагогічного експерименту у дисертаційних дослідженнях. Наукові записки Кіровоградського державного педагогічного університету імені Володимира Винниченка. Сер.: Педагогічні науки, вип. 106, с. 110-120.

17. Скворцова, С. О., Вторнікова, Ю. С. 2013. Професійно-комунікативна компетентність учителя початкових класів: [монографія]. Одеса: Абрикос Компани.

18. Сисоєва, С. О., Кристопчук, Т. Є. 2009. Педагогічний експеримент у наукових дослідженнях неперервної професійної освіти: навчально-методичний посібник. Луцьк: ВАТ «Волинська обласна друкарня».

19. Чайченко, Н. Н., Семеног, О. М., Артюшкіна, Л. М., Рудь, О. М. 2015. Науково-педагогічне дослідження: навчальний посібник для магістрантів. Суми: СОІППО.

20. Структура ИКТ-компетентности учителей. Рекомендации ЮНЕСКО. [online] Режим доступу: http:// iite.unesco.org/pics/publications/ru/files/3214694.pdf [Дата звернення 16 грудня 2018].

21. Communication Competence Defined! Dr Lane's Perspective. [online] Available at: http:www.uky.edu/drlane/captone/commcomp.htm [Accessed 03 April 2019].

22. Корніяка, О. М., 2009. Сучасні підходи до вивчення комунікативної компетентності особистості. Проблеми сучасної психології: збірник наукових праць Кам'янець-Подільського національного університету ім.І. Огієнка, вип. 3, c. 294-316. 


\section{КВЕСТ-ТЕХНОЛОГІЯ ЯК НОВА ОСВІТНЯ ФОРМА У ВИЩИХ НАВЧАЛЬНИХ ЗАКЛАДАХ}

Сидоренко Лілія, старший викладач КПІ ім. Ігоря Сікорського

На сучасному етапі розвитку освітньої системи з'являються нові технології та форми, в основі яких лежить активізація роботи студентів під час навчання. Найбільш сучасними $\epsilon$ інтерактивні форми, що дозволяють задіяти всіх учасників освітнього процесу, реалізувати їхні творчі здібності, втілювати набуті знання і навички у практичній діяльності. На сьогодні, найбільш популярною технологією є освітній квест або квест-технологія.

На думку Марча Т. [1], квест - це навчальна структура, яка використовує посилання на важливі ресурси в Інтернеті та автентичні завдання для того, щоб мотивувати учнів до дослідження будь-якої проблеми 3 нестандартним рішенням, розвиваючи тим самим їх вміння працювати як індивідуально, так і в групі. У своїх працях Виготський Л.С. стверджував, що цей вид пошукової діяльності потребує певної бази знань, які повинен надати викладач

Вперше квест був запропонований в 1997 році в США в Університеті Санд професорами Bernie Dodge i Tom March, які працювали над моделлю навчання 3 використанням інтернет-ресурсів для викладання різних дисциплін. На думку Bernie Dodge веб-квест - це дослідницьке завдання, під час виконання якого студенти використовують інформацію, отриману переважно 3 інтернетджерел[2].

Веб-квест розвиває комунікативні навички та сприяє дослідницькій діяльності студентів. Робота в рамках веб-квесту полягає в отриманні інформації у всесвітній павутині під керівництвом викладача.

Освітній квест $\epsilon$ абсолютно новою формою навчальних програм, за допомогою яких можна отримати заряд позитивних емоцій та активно включитися до роботи. Ця навчальна структура не тільки дозволяє кожному учаснику проявити свої знання, здібності, але також сприяє розвитку комунікації між студентами, стимулює їх спілкування і спільну роботу.

Таким чином, освітній квест - це педагогічна технологія, що включає в себе набір проблемних завдань 3 елементами рольової гри, для виконання яких потрібні ресурси Інтернету.

Освітній квест, як інтерактивна технологія, дозволяє вирішити такі завдання:

1) освітні - залучення студентів до активного пізнавального процесу;

2) розвиваючі - розвиток інтересу до навчання, розкриття своїх здібностей;

3) виховні - виховання командного духу і особистої відповідальності за кінцевий результат.

Розглянемо класифікацію веб-квестів:

1) репродуктивні веб-квести: інформація надається з різних джерел, при цьому самостійна обробка студентами цих матеріалів не проводиться; 
2) репродуктивно-когнітивні веб-квести: стаття, презентація, повідомлення, віртуальна подорож, виступ перед аудиторією, переконання та ін .;

3) когнітивні веб-квести: пошук, аналіз і систематизація інформації з певної теми;

4) когнітивно-креативні: пошук відповіді на питання, розробка проекту на основі заданих умов за визначеними пунктами;

5) креативні: обгрунтування власної думки з певної проблеми та виконання задуманого сценарію в різних жанрах.

Розробку квесту необхідно почати з визначення мети та завдань, а також пов'язаних з ними навчальних результатів. Викладач повинен знати тих, для кого готує квест та кількість учасників. Квест-технологія за своїм змістом універсальна, тобто може застосовуватись під час вивчення будь яких предметів і не має обмеження за віком.

Структура проведення освітнього квесту складається з п'яти етапів:

1. Перший етап - прописуються правила, описується передбачуваний сюжет розвитку квесту, розподіляються ролі, ставиться мета, даються рекомендації щодо виконання завдань та порядок їх виконання.

2. Другий етап - рольова діяльність: учасники виконують завдання відповідно до їх ролей.

3. Третій етап - результат спільної діяльності та підсумок роботи кожного.

4. Четвертий етап - осмислення та узагальнення отриманого досвіду під час квесту.

5. Загальний підсумок [3].

До переваг використання веб-квесту належать:

1) використання студентами перевірених сайтів;

2) обмежений обсяг інформації;

3) достовірна інформація;

4) навчання у зручному режимі;

5) розвиток інформаційно-комунікативної компетенції.

До недоліків використання веб-квесту у навчальній діяльності належать:

1) не всі учні, одночасно, можуть мати доступ до персонального комп'ютера або Інтернету;

2) завантаження деяких матеріалів або сторінок може бути тривалим процесом або неможливим;

3) відсутність навичок роботи з офісними програмами;

4) необхідність використання в аудиторії мультимедійного проектору [3].

Розробники технології веб-квестів виділяють такі їх види за термінами виконання: короткострокові (розраховані на переробку інформації за 1-3 заняття) та довгострокові (направлені на уточнення та розширення знань, обробку нового матеріалу через інтерактивні розповіді, документи; направлені на погодження чи спростування теорій, які висувають. На виконання цих завдань може піти від одного тижня до півроку.

Отже, квест належить до автентичного навчання - педагогічний педхід якого, дозволяє студентам досліджувати, обговорювати та свідомо будувати нові концепції для створення нових проектів, які можуть мати практичне 
застосування. Квест-технологія застосовується в освіті з метою максимальної інтеграції Інтернету в навчальний процес на різних рівнях підготовки. Квести можуть охопити як окрему тему предмета, так і декілька навчальних курсів. Технологія веб-квестів дозволять збільшити ефективність педагогічного пропроцесу, сформувати комунікативні компетенції та компетенції саморозвитку. Сформовані під час виконання квестів вміння стануть запорукою підготовки кваліфікованого фахівця, здатного організовувати свою пізнавальну діяльність у професійній сфері в умовах формування інформаційного суспільства

\section{Список літератури}

1. March T. Why WebQuests? / T. March. - USA. - 1998. - 100 p.

2. Dodge B. Some Thoughts About WebQuests. - URL: http://webquest.sdsu.edu/about_webquests.html.

3. Ільченко О.В. Використання web-квестів у навчально-виховному процесі [Електронний ресурс] / О.В. Ільченко. - Режим доступу: http://osvita.ua/school/lessons_summary/edu_technology/30113/. 


\title{
СОЦАЛЬНО-ПЕДАГОГІЧНА ПРОФІЛАКТИКА ПОВТОРНОГО КРИМІНАЛЬНОГО ПРАВОПОРУШЕННЯ НЕПОВНОЛІТНІМИ
}

\author{
Суліцький Вадим Володимирович \\ кандидат психологічних наук, доцент \\ Інститут людини Київського університету імені Бориса Грінченка
}

Вік від 14 до 18 років можна охарактеризувати як період стрімких психологічних, фізіологічних і соціальних змін в особистості. В залежності від індивідуальних соціально-психологічних характеристик неповнолітнього дані зміни можуть проявлятися з різною інтенсивністю. Тому, стійкий вплив того чи іншого негативного чинника в даний період може призвести до вчинення підлітками кримінального правопорушення. Незважаючи на те, що у своїй більшості юнаки та дівчата, після вчинення свого першого кримінального правопорушення, не планують повторно вчиняти протиправні дії, проте, подальший вплив на них таких чинників як високий рівень агресивності, недостатнє матеріальне забезпечення та наявність певного негативного шаблону дій («злочин, як однин із варіантів виходу 3 важкої життєвої ситуації»), невизнання своєї провини, можуть завадити їх майбутньому виправленню та формуванню у них правослухняної поведінки. Орієнтуючись на неповнолітніх, важливо застосовувати позитивний профілактичний вплив, який дозволить підліткам, які перебувають на етапі переходу до самостійного життя та прийняття важливих життєвих рішень, не вдаватися до імпульсивних вчинків і піддаватися негативним впливам близького соціального оточення.

Аналіз наукових джерел свідчить, що проблеми делінквентної поведінки неповнолітніх вивчали вітчизняні та зарубіжні науковці. Серед них ми можемо визначити таких, як О. Беца, В. Бурлаков, С. Горенко, В. Горіхів, В. Джемс, А. Долгова, А. Зелінський, О. Колб, Е. Кречмер, А. Лічко, Н. Максимова, О. Неживець, В. Павлов, У. Пірс, В. Пирожков, В. Синьов, А. Степанюк, Х.Шелдон та інші. Вченими були досліджені питання: профілактики кримінальних правопорушень i злочинів, які вчиняють неповнолітні; ресоціалізації засуджених у місцях позбавлення волі [3]; загальні проблеми ресоціалізації неповнолітніх у межах пенітенціарної педагогіки та виховного процесу [4]; соціально-психологічних і соціально-педагогічних напрямів впливу на ресоціалізацію підлітків [5]. Особливої уваги заслуговують наукові праці Т. Журавель, I. Яковець, О. Янчука з проблем адаптації пробаційних програм і оцінки ризиків вчинення повторних кримінальних правопорушень серед неповнолітніх, які знаходяться на обліку в повноважених органах філіях Державної установи «Центр пробації» [6; 7].

У своєю чергу, запобіганню насильницьким злочинам правоохоронними органами присвячені праці А. Алексєєва, В. Баранова, С. Галахова, А. Шевченко, Т. Шевчука, В. Шендрика, Б. Штейнбрика, О. Юхна та ін. [2] 
Щодо профілактики рецидиву кримінального правопорушення, однією 3 найбільш обгрунтованих точок зору є бачення О. Яковлєва, який виділяє три рівня попередження злочинів:

1) загально-соціальну профілактику, тобто попереджувальну діяльність, що здійснюється у суспільстві в цілому;

2) профілактику у соціальних групах і колективах;

3) індивідуальну профілактику (ранню та безпосередню) [9].

Виокремлюють також четвертий рівень - профілактику кримінальних правопорушень на регіональному або галузевому рівні [1].

Незважаючи на те, що проблемі соціальної профілактики протиправної поведінки присвячена значна частина наукових праць як вітчизняних, так i зарубіжних науковців, тема запобігання кримінальним правопорушенням ще мало вивчена та потребує додаткових досліджень, спираючись на основні положення закону України «Про пробацію» [8], аналізу ефективності наявних пробаційних програм і програм для попередження повторної (рецидивної) злочинності, від яких великою мірою залежить соціально-педагогічна й психологічна робота 3 підлітками.

Через аналіз чинників, які спонукають підлітків на вчинення повторного кримінального правопорушення, ми проаналізували пробаційні програми щодо формування у засуджених усвідомленого ставлення до каяття, совісті, толерантності й відповідальності за власні вчинки.

Аналізуючи первинне дослідження проблеми на базі уповноважених органів філій Державної установи «Центр пробації» у Києві та Київській області, нами були виділені такі основні чинники ризику вчинення неповнолітніми повторного кримінального правопорушення як: високий рівень вербальної та невербальної агресивності, матеріальні труднощі та недостатній соціальний досвід у вирішенні побутових конфліктних ситуацій, невизнання власної провини, зневажливе ставлення до жертви. А це, у свій час, заважає майбутньому виправленню та ресоціалізації підлітків, які перебувають у конфлікті з законом. Саме тому, пробаційні програми, що використовуються в Центрах пробації, були розраховані на неповнолітніх, які перебувають на етапі переходу до самостійного життя та прийняття важливих життєвих рішень, схильні до імпульсивних вчинків і часто підпадають під вплив інших людей, які мають кримінальну спрямованість.

Основною засадою запропонованою нами методики, було створення оптимальних позитивних можливостей, завдяки яким неповнолітні сформували уявлення про:

- загально-суспільні цінності та права людини;

- шляхи мирного врегулювання конфліктних ситуацій;

- можливість відстоювати власну думку без використання як прямої, так i непрямої агресії;

- можливості йти на компроміс, використовуючи навички спілкування, діалогу, активного слухання, словесно аргументуючи свою позицію. 


\section{Навчитися:}

- накопичувати власний життєвий досвід, робити аналіз своїм вчинкам для недопущення помилок у майбутньому;

- розширювати своє уявлення про світ;

- вдосконалювати власний «внутрішній світ»;

- с ставити перед собою цілі та шукати шляхи їх покрокового втілення в життя, аналізуючи свої сильні та слабкі сторони;

- груповій роботі, що допомагає розвинути навички співпраці, конструктивного обміну думками та поглядами, приміряти на себе різні соціальні ролі, адекватно реагувати на критику та шукати можливості досягнення злагоди.

Ефективність програми «Профілактики злочинної поведінки та повторної злочинності» перевірялася за допомогою двох анкет:

1. «Актуальність форм і методів впливу пробаційних програм», що спрямована на виявлення обізнаності учасників занять щодо питань $\mathrm{i}$ навичок, які будуть представлені, вивчатися та практично відпрацьовуватися в ході реалізації програми.

2. «Оцінка ефективності впливу», що направлена на оцінку зміни рівня обізнаності щодо інформації структурних блоків пробаційних програм.

На другому етапі було проведене анкетування в уповноваженому органі філії Державної установи «Центр пробації» у м. Києві та Київської області. В ньому взяли участь 210 засуджених, серед яких 140 осіб чоловічої статі й 70 осіб жіночої статі. Вік досліджуваних складав від 14 до 18 років.

Так, проведення методики «Агресивна поведінка» (за С. Ільїним та П. Ковальовим) визначило рівень агресивності серед підлітків. Це показник дозволив встановити наскільки рівень агресивності змінився після проведення занять із пробаційних програм. У ході опитування були отримані такі результати: високий рівень агресії у засуджених виявлений не було; середній рівень агресії мали 20 респондентів (юнаки - 17; дівчата - 3); низький рівень агресії спостерігався в 190 осіб. При чому, високий рівень припадав саме на вербальну агресію, невербальна агресія у досліджуваних була повністю усунена. Таким чином, більша частина опитуваних позбулася високого або ж середнього рівня агресії. Це свідчить про ефективність запропонованих пробаційних програм.

Результати анкети «Ризики повторного (рецидивного) правопорушення у підлітків, які перебувають у конфлікті з законом» були узагальнені відносно до основних категорій, що демонстрували основні напрями ставлення порушника до кримінального правопорушення, потерпілого, їх рівень соціального включення та плани на майбутнє.

Так, показники ставлення до праці неповнолітніми, які мають конфлікт із законом, змінилися у позитивний бік. Якщо до проведення тренінгу $38 \%$ 
респондентів негативно ставилися до праці, то, через місяць після проведення соціально-педагогічної роботи, це показник становив - $6 \%$.

Якщо досліджувати чинники усвідомлення неповнолітнім свого кримінального правопорушення («Як ви ставитесь до вироку суду?»; «Як Ви вважаєте, чи справедливий до Вас вирок суду?»; «Чи визнаєте ви завдану вами шкоду потерпілому?»), після проведення тренінгу: $87 \%$ респондентів дали відповідь - погоджуюся, 10\% - погодилися, але жалілися на великий строк покарання; 3\% - не дали однозначної відповіді; на питання «Як Ви вважаєте, чи справедливий до Вас вирок суду?», відповіли: так - $81 \%$; так, але можна було б дати строк менше - 10\% респондентів; 9\% - не захотіли давати відповідь. На питання «Чи визнаєте ви завдану вами шкоду потерпілому?» отримали такі відповіді: так, визнаю та відшкодую - 140 осіб; ні, але відшкодую - 70 осіб. При цьому, на питання «Як ви ставитеся до свого злочину?» 204 опитаних дали відповідь: «Каюсь».

У ході анкетування також були отримані такі результати:

- у загальному молоді люди обізнані з правами й обов'язками громадянина, проте їх знання не $є$ повними або ж $є$ «перекрученими»;

- опитаним було властиве стереотипне мислення відносно фактичної безкарності особи, яка не досягла 18-ти річного віку;

- підлітки не знають про те, що певні їх дії підпадають під визначення кримінального правопорушення та передбачають певне покарання;

- неповнолітні мають бажання відшкодувати заподіяні збитки потерпілому;

- більшість (85\%) виправдовують свої протиправні вчинки такими поняттями як життєві обставини, захист честі та гідності родини тощо;

- підліткам притаманне агресивне ставлення до навколишнього середовища (агресія в основному має прихований характер, а тому, їх легко можна «вивести 3 себе»);

- неповнолітнім майже не відомі методи заспокоєння, саморегуляції. Це стало відомо під час проведення занять пробаційних програм);

- підлітки не мають достатнього досвіду щодо вирішення складних життєвих, конфліктних ситуацій.

Після проведення занять із пробаційних програм, ми отримали зворотній зв'язок від учасників. В анкеті ми пропонували досліджуваним записати рефлексію та вказати що змінилося в власних відповідях, помітивши це іншим кольором. У результаті аналізу наданих відповідей з боку респондентів, ми встановили, що заняття допомогли неповнолітнім:

- розширити свій кругозір; 
- замислитися стосовно побудови свого життєвого плану;

- зрозуміти потребу працювати та приносити користь країні;

- змінити ставлення до найближчого соціального оточення.

Деякі рекомендації, що були отримані в ході тренінгу неповнолітніми, вони планували використовувати в подальшому своєму житті.

Загалом, Анкета «Оцінка ефективності впливу» показала збільшення знань і вмінь учасників, в передбачених напрямах пробаційної програми на 79\%.

Таким чином, після завершення занять, підлітки: краще пізнали себе; стали більш упевненими у власних силах; сформували негативне ставлення до агресії, насильства та проявів порушення прав інших людей; усвідомили ризики протиправної поведінки; навчилися робити власний, корисний для них, вибір життєвого шляху; навчилися не допускати помилок минулого та проєктувати їх на майбутнє. Проте, не зважаючи на результативність даної програми, проблема соціальної профілактика повторних кримінальних правопорушень серед підлітків залишається актуальною та тому потребує подальшого вивчення.

\section{Список літератури:}

1. Зайченко М.В. Діагностика та корекція делінквентної поведінки учнів. Соціальна педагогіка. Київ, 2010. № 2. С. 41-55.

2. Змановская Е.В. Девиантология и делинквентное поведение. Психология отклоняющегося поведе-ния. Москва : Академия, 2004. 270 с.

3. Кудрявцев В.Н. Генезис злочину: досвід кримінологічного моделювання. Москва, 1998. 125 с.

4. Журавель Т.В. Методики та інструменти роботи з неповнолітніми, які перебувають в конфлікті з законом : навчально-методичний посібник. Київ, 2017. $291 \mathrm{c}$.

5. Електронний ресурс. Пробаційні програми для неповнолітніх. URL: https://www.probation.gov.ua/?page_id=150 (дата звернення: 28.01.2021).

6. Дисертація на здобуття наукового ступеня кандидата юридичних наук за спеціальністю 12.00.08 «Кримінальне право та кримінологія; кримінальновиконавче право». - Приватний вищий навчальний заклад «Львівський університет бізнесу та права», Національний університет «Львівська політехніка», Львів, 2018.

7. Яковлев А.М. Индивидуальная профилактика преступного поведения. Горький, 1977. С.5.

8. Блувштейн Ю.Д., Зырин М.И., Романов В.В. Профилактика преступлений. Минск, 1986. С.27.

9. Електронний ресурс. Пробація України. URL: http://www.probation.gov.ua/ (дата звернення: 29.01.2021). 


\title{
ОСОБЛИВОСТІ ВИКОРИСТАННЯ ХМАРНОГО СЕРЕДОВИЩА GOOGLE CLASSROOM ПРИ ВИКЛАДАННІ ДИСЦИПЛІНИ «БЕЗПЕКА жИТТєДІЯЛЬНОСТІ»
}

\author{
Трофімчук Володимир Миколайович \\ к.п.н., завідувач кафедри загальнотехнічних дисциплін і технологій та цивільної \\ безпеки (ЗТДіТтаЦБ) \\ Рівненський державний гуманітарний університет \\ Трофімчук Людмила Олексіївна \\ вчитель, Обласний науковий ліцей в м.Рівне
}

\section{Дідик Віталій Анатолійович}

здобувач першого (бакалаврського) рівня вищої освіти з напряму підготовки 015 «Професійна освіта (охорона праці)» Рівненський державний гуманітарний університет

В умовах цифрової трансформації суспільства та невтішних реалій сьогодення, пов'язаних 3 пандемією поширення коронавірусної інфекції (COVID-19), державні й приватні освітні установи усіх існуючих сегментів системи освіти змушені перейти на дистанційну форму надання освітніх послуг. Навчальні заклади за таких умов повинні бути орієнтовані на наскрізне застосування в навчальній практиці онлайн-платформ для дистанційного навчання, які миттєво інтегруються в освітній процес. Разом 3 тим, реформування системи вітчизняної освіти неможливе без системного використання цифрових технологій в освітньому процесі, управлінській діяльності та системі професійного розвитку науково-педагогічних працівників. На цьому конкретно наголошено у «Концепції розвитку цифрової економіки та суспільства України» [1], «Стратегії розвитку інформаційного суспільства в Україні» [2] та Указі Президента України «Про національну стратегію розвитку освіти в Україні на період до 2021 року» [3]. Зазначені документи чітко спрямовані на розвиток ІТ-освіти та інтеграцію кращих світових практик у систему підготовки здобувачів освіти, а також акцентують увагу на необхідності розвитку «цифрових навичок» та «цифрової грамотності» громадян країни.

Для безперебійного забезпечення дистанційного навчання, в умовах пандемії доцільним $є$ перехід на різноманітні онлайн-платформи та віртуальні навчальні середовища. Тому, при викладанні дисципліни «Безпека життєдіяльності» ми перейшли на використання пакету хмарних сервісів типу Google classroom, базовий тарифний план якого доступний для освітніх установ безкоштовно. Незаперечною перевагою сервісу Google classroom, у порівнянні з іншими - це простота у використанні. Крім того, середовище Classroom коректно відтворюється як на стаціонарних комп'ютерах чи ноутбуках (через веб-версію), 
так і на смартфонах, за допомогою додатків для Android та iPhone (iOS). Інакше кажучи, за наявності ноутбука або мобільного пристрою з доступом до мережі Інтернет, можна будь-якої миті долучитися до віртуального класу. Це, у свою чергу, сприяє ефективній організації роботи педагога зі студентами, що, як показує досвід, значно заощаджує час на підготовку та перевірку завдань.

У сервісі Classroom можна створити власний віртуальний клас - для організації та проведення навчальної діяльності, так і окремі курси - причому, для кожного створеного класу присвоюються унікальні коди, за якими доступ до них отримують студенти.

В середовище Google Classroom можна увійти з власного аккаунту Google, аккаунту навчального закладу, в якому використовується $G$ Suite for Education (такі аккаунти створюються і керуються адміністратором навчального закладу) [4; 5], або ж перейти на сторінку classroom.google.com та ввести ім'я користувача і пароль. Ще одним з варіантів входу у віртуальне середовище для власників комп'ютерів - натиснути квадрат у правому верхньому куті браузеру Google Chrome та знайти піктограму «Клас». Власники ж мобільних телефонів мають окремо встановити безкоштовний додаток через магазини «Play Market» чи «App Store».

Важливим є те, що середовище Google Classroom не містить жодних рекламних оголошень, а особисті данні користувачів $є$ захищеними.

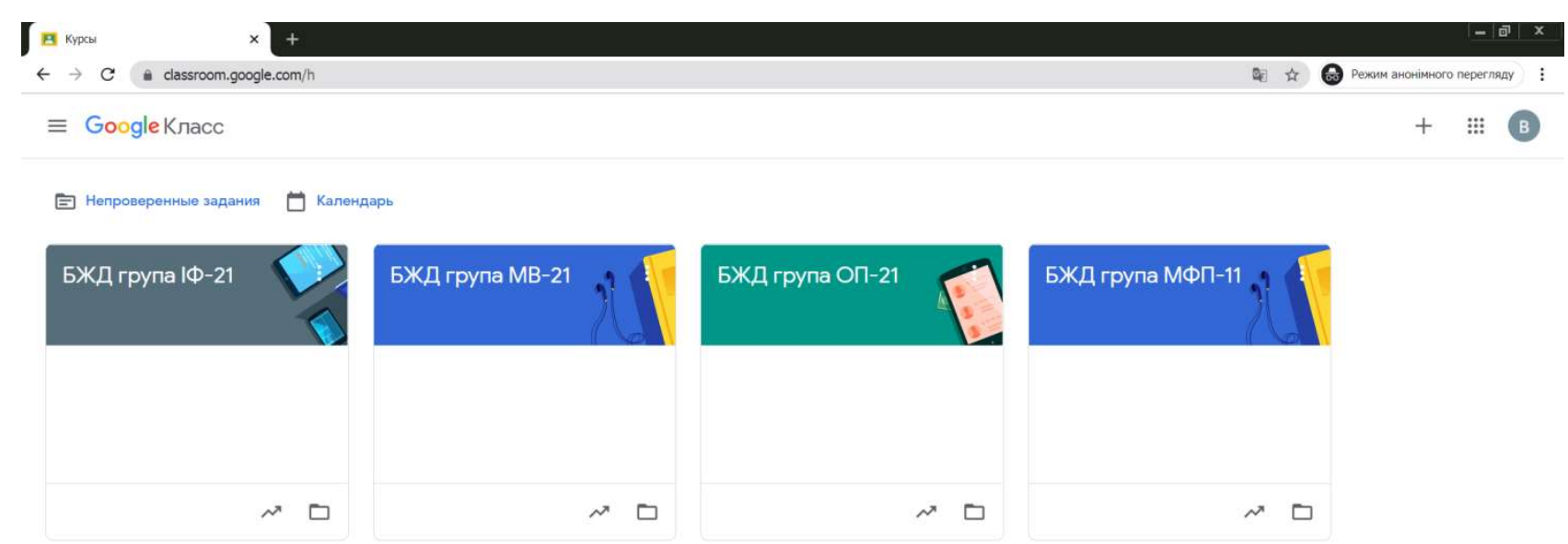

Рис.1 Віртуальні класи середовища Google Classroom в режимі викладача.

Система Google Classroom дозволяє нам працювати в двох режимах викладача та студента, які відрізняються не тільки зовнішнім виглядом, але й функціональними можливостями. На рисунку 1 зображено всі віртуальні курси одного викладача, а на рисунку 2 - середовище відкритого віртуального класу в режимі викладача. Середовище Google classroom в режимі викладача дозволяє:

- створювати різні аудиторії для кожного навчального предмету;

- контролювати поведінку кожного студента (відстежувати рівень успішності);

- контролювати рівень викладання у кожному класі;

- змінювати зміст відповідно до рівня складності. 


\section{International Science Conference on E-Learning and Education}

Ще однією важливою перевагою сервісу Google classroom є те, що оцінки, отримані студентами, записуються на платформі, формуючи таблицю, а також фіксується дата надсилання кожної діяльності, що дозволяє викладачу швидше та персоніфіковано стежити за успішністю кожного студента.
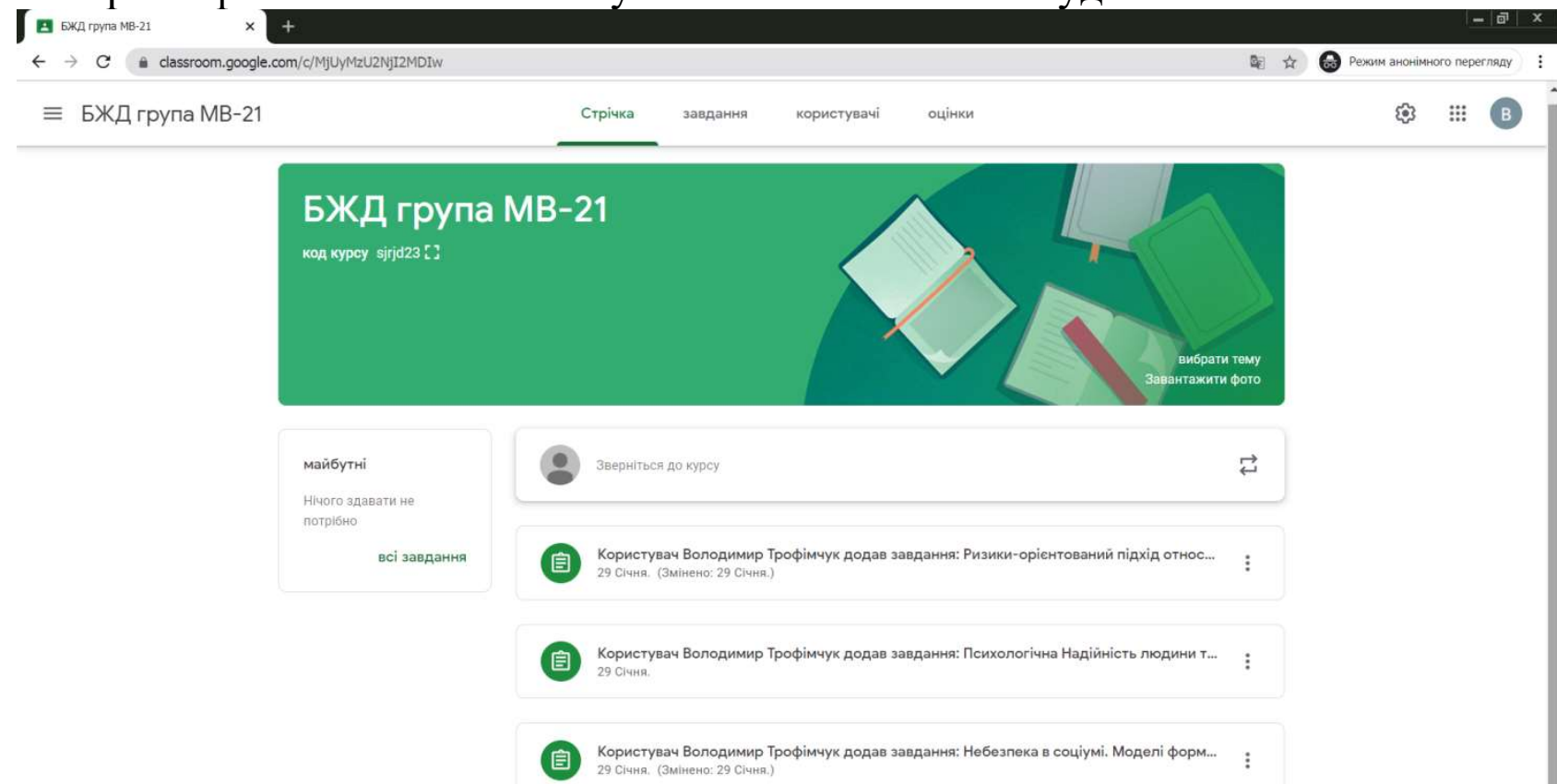

Рис.2 Середовище відкритого віртуального класу в режимі викладача

Віртуальна класна кімната у режимі викладача має 4 вкладки «Потік», «Завдання», «Люди» та «Оцінки». Вкладку «Потік» ми використовуємо для відображення новин, коментарів, запитань. На вкладці «Завдання» створюємо та призначаємо завдання (різні за своїм типом). Наприклад, натиснувши кнопку «Створити», можна додати матеріали різних категорій - завдання, завдання 3 тестом, запитання, навчальний матеріал, а також структурувати їх за темами.

Щоб не забути виконати завдання вчасно, у блоці «Незабаром» система автоматично нагадуватиме про справи у межах курсу, які необхідно виконати, наприклад, найближчого тижня. Крім того, середовище Google Classroom дає унікальну, на наш погляд, можливість прикріплювати до завдання не лише текстові документи, а й відео та аудіоматеріали, зображення, тестові завдання тощо.

На рисунку 3 зображено приклад відкритого завдання, яке формується викладачем, 3 налаштуванням терміну здачі роботи та критеріїв ії оцінювання. Система автоматично фіксує час здачі а, якщо робота здана із запізненням, то поруч із зданим завданням з'явиться відповідне повідомлення. Водночас, ми не обмежені системою оцінювання, так як градація балів для оцінки роботи студента варіює від 0 до 100 балів, або взагалі «Без оцінки». 


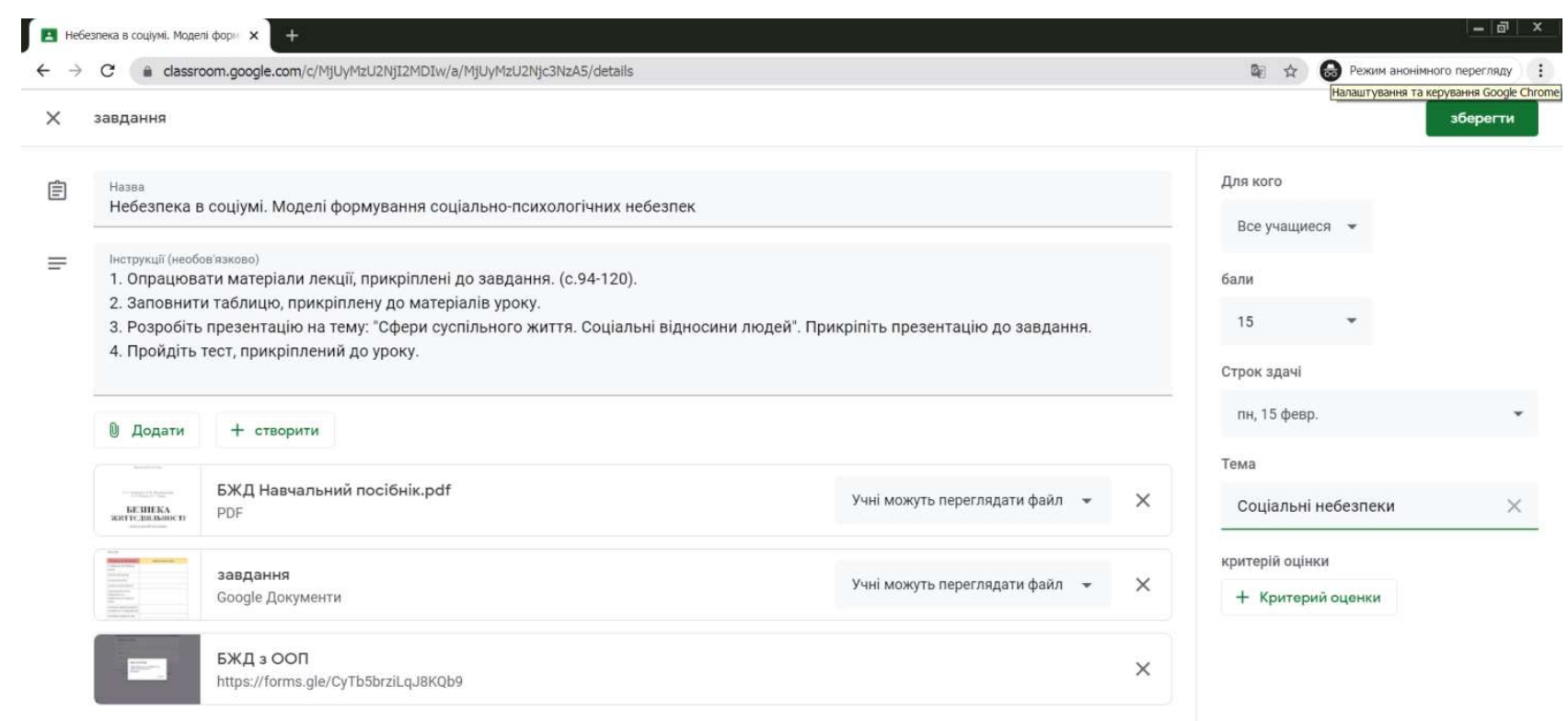

Pис. 3 Відкрите завдання середовища Google Classroom в режимі викладача 3 налаштуваннями термінів здачі та критеріїв оцінки

У віртуальному класі ми публікуємо, збираємо, перевіряємо та оцінюємо завдання, а виконані роботи учнів автоматично структуруються на Google диску. У середовищі Google Classroom ми маємо можливість бачити кількість виконаних, зданих та призначених робіт студентів.

Через вкладку «Люди» можна запрошувати учасників вашого курсу або студентів класу, використовуючи їхні еmail-адреси. На вкладці «Оцінки»у вигляді таблиці будуть відображатися всі створені навчальні модулі та оцінки студентів (вже після того, як буде сформований клас).

Перевірка та оцінювання роботи не є складним процесом. Нам достатньо відкрити виконане завдання, переглянути його та поставити оцінку, яка автоматично генерується 3 журналом виконаних робіт у тому ж віртуальному класі. За потреби ми маємо можливість переглядати оцінки як окремого студента, так і цілої групи, відстежувати прогрес кожного, повертати роботу 3 оцінкою та коментарями приватного або загального характеру. Таким чином, викладач та студенти мають можливість підтримувати постійний зв'язок.

Віртуальна кімната студента відрізняється функціональними можливостями та має вкладки «Люди», «Завдання», «Потік». На вкладці «Люди» студент має можливість бачити своїх одногрупників. Вкладка «Завдання» містить структуровані за темами завдання. Після відкриття умов завдання перед студентом відкривається вікно, в якому він може додати коментар, виконати завдання, прикріпити виконані роботи, а також надати статус роботі (наприклад, відмітити як виконану). Усі створені студентами роботи автоматично відправляються викладачу, при цьому зберігаються на Google Диску. Усі призначені та виконані завдання, кожен студент може відслідковувати у календарі або у вкладці «Завдання» «Переглянути роботу». Вкладка «Потік» відображає новини у класі, загальні коментарі.

Суттєвою перевагою середовища Google Classroom став інтегрований в нього додаток Google Meet, який з легкістю можна використовувати для проведення 
онлайн уроків. Крім того, за потреби викладач може здійснювати відеозапис проведеного уроку, який зберігається на Google диску і в подальшому надавати можливість студентам, які з тих чи інших причин не могли бути присутніми на уроці доступ до перегляду. Зазначимо, що студенти слідкують за заняттями в режимі реального часу, у час, погоджений 3 викладачем через віртуальний календар Google.

Таким чином, завдяки простоті використання, хмарне середовище Google Classroom є зручною платформою для дистанційного навчання, в умовах пандемії поширення коронавірусної інфекції.

\section{Список літератури}

1. Про схвалення Концепції розвитку цифрової економіки та суспільства України на 2018-2020 роки та затвердження плану заходів щодо ії реалізації: Розпорядження Кабінету Міністрів України від 17 січня 2018 р. № 67-p. URL: http://zakon2.rada.gov.ua/laws/show/67-2018-\%D1\%80

2. Про схвалення Стратегії розвитку інформаційного суспільства в Україні : Розпорядження Кабінет Міністрів України № 386-р від 15.05 .2013 р. [Електронний ресурс]. - Режим доступу: http://zakon1.rada.gov.ua//laws/show/386-2013-p

3. Національна стратегія розвитку освіти в Україні на період до 2021 року // схвалена Указом Президента України від 25 червня 2013 р. № 344/2013. - Режим доступу: http://zakon2.rada.gov.ua/laws/show/344/2013.

4. Войтович Н.В. Використання хмарних технологій Google та сервісів web 2.0 в освітньому процесі. Методичні рекомендації. /Войтович Н., Найдьонова А. - Дніпро: ДПТНЗ «Дніпровський центр ПТОТС», 2017 - 113 с.

5. Гриценко В. Використання сервісу GOOGLE CLASSROOM для управління освітніми процесами [Електронний ресурс]/ В. Гриценко, I. Юстик// Використання сервісу GOOGLE CLASSROOM для управління освітніми процесами. - 2015. - Режим доступу: http://www.kspu.kr.ua /ua/ntmd/konferentsiy/2015-10-06-06-17-54/sektsiia4/3930-vykorystannya-servisugoogle-classroom-dlya-upravlinnya-osvitnimyprotsesamy 


\title{
ПЕРСПЕКТИВНІСТЬ ВИКОРИСТАННЯ СМАРТ ТЕХНОЛОГІЙ В СУЧАСНІЙ УНІВЕРСИТЕТСЬКІЙ OCBITI
}

\author{
Шапран Юрій \\ доктор педагогічних наук, професор, \\ завідувач кафедри біології, методології і методики навчання, \\ Університет Григорія Сковороди в Переяславі, м. Переяслав, Україна \\ ORCID iD: orcid.org/0000-0002-4176-7502 \\ Ольга Шапран \\ доктор педагогічних наук, професор, \\ завідувач кафедри загальної педагогіки і педагогіки вищої школи, \\ Університет Григорія Сковороди в Переяславі, м. Переяслав, Україна \\ ORCID iD: orcid.org/0000-0002-7514-6632 \\ Олексій Шапран \\ студент 3-го курсу, Київський національний \\ торговельно-економічний університет, м. Київ, Україна \\ ORCID iD: orcid.org/0000-0003-1329-4047
}

Розвиток сучасного суспільства детермінується глобальними змінами, що спричинені невпинним розвитком інформаційних систем і технологій, комп'ютеризацією і тотальним упровадженням технічних інновацій у сферу професійної діяльності й буття кожного індивідума. Існуючий прорив у розвитку інформаційно-системних технологій спонукає кожного до якісного оволодіння ними. Цілком логічним виявляється переконання, що сучасне інформаційне суспільство зазнає суттєвої трансформації, що визначається якісно новим етапом його розвитку, а саме - становленням Smart-суспільства.

У процесі модернізації освіти з'являється потреба в усвідомленні нових понять, сучасних освітніх технологій, їх грунтовного розуміння, з'ясуванні сутнісних ознак і перспектив використання у практиці роботи університетів.

Серед чисельних праць за проблемою дослідження смарт-технологій найбільш вагомими є дослідження науковців Uk. Dong, D. Foray, Van Ark, J. Goddard, L. Kempton, P. Vallance та ін. Деякі аспекти впровадження Smart-технологій в освітній процес розглядаються у працях Б. Абдрахманової, Г. Бонч-Бруєвича, К. Джонсона, С.Кадзіти, К. Кіма, Г. Косенка, Х. Пена, С. Якубова, Н. Тихомирової, В. Тихомирова, Я. Якініна та ін. Методика практичного використання технології smart Board досліджувалася В. Абрамовим і Т. Косенко. О.Глазунова вивчала проблему Smart підходу до формування електронного навчального курсу на платформі MOODLE, М. Коденська - перспективи розвитку смарт-технологій. 
У smart-суспільстві спостерігається чітка тенденція заміни традиційної моделі навчання на модель «розумного навчання» (Smart-education). Остання проявляється в інтерактивному освітньому середовищі засобами комп'ютерних інформаційних технологій без лімітування часовими й територіальними бар'єрами. Завданням smart-освіти $є$ забезпечення можливості кожному здобувачу освіти не лише самостійно опановувати знаннями, але й вибудовувати власні освітні стратегії.

Отже, Smart-освіта реалізується шляхом використання в освітньому процесі педагогічних smart-технологій. Основу їх розвитку становить світова (глобальна) інформаційна мережа. Smart-технології виявляють ознаки інтерактивного навчального комплексу, котрий уможливлює створення і поширення широкому загалу мультимедійних навчально-методичних матеріалів.

C. Іванов зазначає, що «технології SMART-education $\epsilon$ концепцією, яка передбачає комплексну модернізацію всіх освітніх процесів, а також методів і технологій, що використовуються в цих процесах. Концепція SMART в освітньому розрізі тягне за собою появу таких технологій, як розумна дошка, розумні екрани, доступ в Інтернет з будь-якої точки. Кожна 3 цих технологій дозволяє по-новому побудувати процес розробки контенту, його доставки i актуалізації. Навчання стає можливим не тільки в класі, але і вдома і в будьякому місці: громадських місцях, таких як музеї чи кафе. Основним же елементом, що зв'язує освітній процес, стає активний освітній контент, на базі якого створюються єдині репозиторії, що дозволяють зняти часові та просторові рамки» (Іванов, С., 2018, с. 36).

Отже, smart-технології спонукають до використання двох підходів організації освітнього процесу в університетах, а саме: синхронного й асинхронного. При синхронному навчанні викладач і студент одночасно залучені в систему навчання в умовах аудиторій університету, а при асинхронному - вони дистанційовані один від одного, комунікують між собою засобами smartтехнологій.

Підсумовуючи вище наведе можна дійти висновку, що використання smartтехнологій в освітньому процесі сприяє:

- $\quad$ інтеграції закладів освіти в єдиний освітній простір;

- $\quad$ вільному доступі студентів до освітніх ресурсів із використанням можливостей світової електронної мережі;

- $\quad$ забезпеченню комунікативної мобільності учасників освітнього процесу;

- $\quad$ здешевленню витрат на організацію освітнього процесу;

- $\quad$ поліпшенню якості освітнього процесу шляхом активізації творчого потенціалу здобувачів освіти;

- $\quad$ у умотивованості до пізнавальної діяльності студентів;

- $\quad$ організації самовдосконалення шляхом розробки індивідуальних освітніх стратегій;

- $\quad$ доступності подання й інтерактивності навчального матеріалу; 
- $\quad$ м ожливістю опрацювання необмеженого об’єму інформації;

- $\quad$ формуванню фахових навичок, що необхідні в майбутній професійній діяльності.

Засобами сучасної smart-освіти є: Smart Board; Smart-art; Smart Classroom (стаціонарні і мобільні); віртуальні лабораторії із використанням smartтехнологій і технологій дистанційного навчання (e-learning, m-learning); мобільні пристрої; малогабаритні бездротові презентаційні засоби; електронні системи, що забезпечують індивидуальну траєкторію навчання; «інтелект-тренінги» тощо.

Окрім того, важливе значення в освітньому процесі належить таким технічним засобам, як: смартфони, планшети, ноутбуки, проєктори, smart-телевізори тощо. Використання їх дозволяє здобувачам освіти подавати навчальну інформацію у формі доповідей, електронних презентацій, відеороликів, веб-сторінок, сайтів, блогів тощо. Отже, технічні носії інформації спонукають студентів до швидкого віднаходження необхідних матеріалів щодо визначеної програми дискусій й обговорень.

Однією із новітніх smart-технологій $є$ інтерактивний програмно-технологічний навчальний комплекс на основі smart Board. Biн об'єднує у собі цілий комплекс електронних засобів і програмного забезпечення, а саме: сенсорну панель, персональний комп'ютер, мультимедійний проектор і відповідне комунікаційне обладнання. Інтерактивна дошка є могутнім мультимедійним засобом з усіма можливостями комп'ютера. Вона дозволяє використовувати існуючі ресурси програмного забезпечення, самостійно створювати оригінальні розробки освітніх програм, що можуть бути адаптованими для здобувачів освіти різного рівня підготовки, різних пізнавальних інтересів, різного професійного спрямування тощо. Використання інтерактивної дошки сприяє інтенсифікації освітнього процесу, створює атмосферу інтерактивності й вмотивованості здобувачів освіти до отримання нових знань, розвиває їх творчий потенціал i комунікативні навички тощо. Можливості програми «Smart Notebook» дозволяють в режимі on line демонструвати навчальний матеріал, записувати й виділяти спеціальним маркером, робити письмові коментарі поверх зображення на екрані, закріплювати об'єкти, переміщувати їх, додавати зображення, фото, відео, текстову й різноманітну графічну інформацію. При цьому візуалізовані відомості, що презентуються на інтерактивній дошці Smart, можуть передаватися студентам через Internet-мережу, зберігатися на магнітних носіях, роздруковуватися, надсилатися електронною поштою, розміщуватися на сайтах університету.

У процесі проведення навчальних занять (лекційних, семінарських, практичних, лабораторних) із використанням інтерактивної дошки здобувачі освіти зосереджують свою увагу на: сутнісних ознаках явища, що вивчається; на втановленні взаємозалежностей його окремих складових; на визначенні найсуттєвіших ознак досліджуваного феномена; на з'ясуванні закономірностей і прогнозуванні ймовірних варіантів його подальшого розвитку тощо. Водночас виникає необхідність створення інформаційного контент-забезпечення різних 
навчальних дисциплін, що значно полегшує роботу здобувачам освіти й викладачам, адже дозволяє швидко віднайти, систематизувати й проаналізувати наявну навчальну інформацію, яка стає більш доступною для розуміння $\mathrm{i}$ засвоєння. Варто зазначити, що в цьому контексті відпадає необхідність у занотовуванні, бо використання smart-технології забезпечує можливість отримання електронного варіанту заняття із позначками й коментарями викладача. Комплект файлів Smart Notebook зі змістом лекційних і практичних занять набуває особливого значення при підготовці здобувачів освіти до модульного й підсумкового контролю, а також в умовах дистанційної освіти. Важливим аспектом використання Smart-технологій є ведення викладачем закладу вищої освіти персонального блогу, що призводить до неформальної взаємодії із здобувачами освіти й дозволяє прискорити досягнення визначеної освітньої мети. Правильно організований блог виконує ряд функцій, а саме: інформаційну, наукову, дидактичну, методичну, комунікаційну й рефлексивну. Однією із Smart-технологій є веб-квест технологія, використання якої суттєво оптимізує освітній процес у вищій школі. Веб-квест технологія є сукупністю методів і прийомів організації дослідницької діяльності з елементами рольової гри, у процесі якої здобувачами освіти здійснюється пошук необхідної інформації із використанням інтернет-ресурсів.

Вебквести - це міні-проєкти, що виявляють ознаки проблемності. Із метою їх розв'язання студенти не лише відбирають великий об'єм необхідної Інтернетінформації, але й скеровують свою діяльність на іiі грунтовний аналіз, систематизацію і подальшу презентацію. Веб-квест технологія є дидактичною структурою, у рамках якої викладач формує пошукову діяльність студентів, визначає параметри й часові межі такої діяльності. Вона дозволяє працювати в групах (від трьох до п’яти учасників), розвиває конкурентність, комунікативні вміння і лідерські якості, підвищує внутрішню мотивацію до процесу здобуття знань, формує відповідальність за результати проведеної діяльності, навчає роботі в команді (планування, розподіл функцій, взаємодопомога, взаємоконтроль), сприяє умінню віднаходити раціональні способи розв'язання проблемної ситуації, розвиває навички публічних виступів тощо. Умовою використання вказаної технології є доступ до Інтернет-ресурсів.

Використання веб-квест технології передбачає дотримання певної етапності:

- $\quad$ визначення теми, мети й завдання міні-проєкту;

- $\quad$ підбір Інтернет-ресурсів, пошук необхідної інформації;

- $\quad$ напрацювання учасниками веб-квест технології розв'язку мініпроєкту;

- $\quad$ створення веб-сторінок і веб-сайтів, їх презентація;

- обговорення результатів виконання веб-проєкту, його оцінювання (Шапран, 2019, с.44-45).

На першому етапі міні-проєкту проводиться підготовча робота, відбувається ознайомлення студентів університету 3 темою, остаточним формулюванням основної проблеми (напрацьовується усіма учасниками), визначення завдань, які необхідно розв'язати. 
Наступний етап передбачає визначення веб-сайтів Інтернет-мережі, в яких можна віднайти необхідну інформацію. Здобувачі освіти мають усвідомити принципи відбору матеріалу, навчитися виокремлювати головне від другорядного, ефективно відбирати матеріал, що дотичний до тематики мініпроєкту.

Стадія напращювання варіантів розв'язку міні-проєкту виявляє найбільший розвивальний потенціал. Вона сприяє розвитку критичного мислення, розвиває уміння порівнювати й аналізувати, класифікувати об'єкти і явища, критично мислити, працювати в команді, комунікувати, публічно захищати власну точку зору тощо.

Стадія оформлення результатів передбачає відбір інформації щодо розв'язку міні-проєкту й розміщення іiі на веб-сторінці або веб-сайті. Вона може бути подана у формі текстових повідомлень, бази даних, графічних зображень (графіків, діаграм, схем), слайд-шоу, буклетів, анімації, постеру, фоторепортажу.

Стадію обговорення результатів роботи над веб-квестами доцільно проводити у формі конференції, круглого столу, семінару із можливістю організації діалогу за допомогою електронних ресурсів в он-лайн режимі. На цій стадії у здобувачів освіти розвивається відповідальність за виконану роботу, самокритика, самооцінка, взаємопідтримка, уміння виступати перед аудиторією, захищати власну думку тощо. Оцінювання здійснюється за наперед визначеними критеріями, які враховують автономність учасників проєкту, їх автономність, активність, креативність, критичність, незалежність, комунікативність тощо.

Веб-квест вміщує такі основні елементи:

- $\quad$ вступ (наводиться мета, завдання, проблемна ситуація і терміни виконання міні-проєкту);

- $\quad$ посилання на ресурси електронної мережі, що вміщують необхідний

для веб-квесту матеріал (електронні адреси, інформаційні сайти, освітні електронні ресурси тощо);

- $\quad$ поетапний опис процесу виконання завдання (наводяться принципи обробки інформації);

- підсумок (оприлюднюються результати виконання завдання, презентація отриманих результатів, їх практичне застосування, перспективи подальшої самостійної роботи із означеної теми).

Отже, Smart-освіта може слугувати ефективною складовою освітньої системи, що визначає освіту нового типу, котра передбачає реалізацію освітнього процесу з використанням відповідних інформаційних Smart-технологій. Перспективним вбачається використання в освітньому процесі інтерактивного програмнотехнологічного навчального комплексу Smart Board і веб-квест технологій, а також більш активне ведення викладачами персонального освітнього блогу. Подальшого дослідження потребує удосконалення системи вищої освіти, яка має базуватися на актуалізації технологій навчання у відповідності до наявних тенденцій розвитку смарт-суспільства, а саме - передбачати використання мультимедійної освіти («m-learning») і соціальних мереж («s-learning»). 


\section{Список використаних джерел}

1. Іванов С. М. Аналіз переваг використання смарт-технологій в економіці. Економіка та держава. 2018. № 7. С.35-38.

2. Шапран Ю.П. Веб-квест технологія. Педагогічна інноватика: термінологічний словник /авт. кол. за заг. ред. О.І. Шапран. ПереяславХмельницький: Домбровська Я.М., 2019. С.44-45.

\section{References}

1. Ivanov S. M. Analiz perevah vykorystannia smart-tekhnolohii v ekonomitsi. Ekonomika ta derzhava. 2018. № 7. S. 35-38.

2. Shapran Yu.P. Veb-kvest tekhnolohiia. Pedahohichna innovatyka: terminolohichnyi slovnyk/avt. kol. za zah. red. O.I. Shapran. Pereiaslav-Khmelnytskyi: Dombrovska Ya. M., 2019. S.44-45. 


\title{
ЕЛЕКТРОННИЙ КУРС-РЕСУРС ЯК ЗАСТОСУНОК ДЛЯ ДИСТАНЦЙНОГО НАВЧАННЯ ЗДОБУВАЧІВ ВИЩОї ОСВІТИ
}

\author{
Шевченко Інна Юріївна, \\ доктор економічних наук, доцент \\ Харківський національний автомобільно-дорожній університет
}

Пандемія хвороби COVID-19 змінила освітню систему України суттєвіше, ніж десятиліття реформ. I справа не в доведеній до автоматизму тріаді «маски рукавички - соціальна дистанція» у навчальному процесі, а в глобальній переорієнтації з традиційних форм навчання на дистанційну форму. Будемо відверті: дистанційне навчання раніше видавалося якоюсь диковинкою, що призначена для надання освітніх послуг іноземцям, які не мають змоги виїхати 3 країни перебування, або особам з особливими потребами, або особам, які працюють і не мають змоги полишити виробничий процес. Тобто дистанційна форма навчання видавалася скоріше винятком, ніж правилом.

Минулий рік приніс кардинальні зміни до навчального процесу: раптовий карантин навесні поставив розгублених викладачів перед фактом - навчання буде здійснюватися дистанційно. I почалася метушня довкола співвідношення онлайн і офлайн форматів з огляду на санітарно-гігієнічні норми використання ЕОМ у навчальному процесі, платформ і застосунків для надання освітніх послуг за дистанційною формою навчання. Виникало безліч проблем із доступом до Інтернету, інших проблем технічного забезпечення навчального процесу у дистанційному форматі, а подекуди - й необхідність підвищення кваліфікації (в тому числі рівня цифрової грамотності) викладацького складу.

Більшість зазначених проблем були вирішені до осіннього карантину, адже 3'явилися нормативно-правові акти та документи, що носять рекомендаційний характер, положення яких регламентують порядок і особливості здійснення навчального процесу в дистанційному форматі. Але пандемічне сьогодення дає цілком зрозуміти, що дистанційна форма навчання вже скоро буде вважатися такою ж традиційною, як очна форма та заочна форма. У таких умовах гостро постає питання розроблення якісного програмно-технічного забезпечення провадження навчального процесу за дистанційною формою навчання.

Для закладів вищої освіти раптовий і масовий перехід на дистанційну форму навчання не був настільки стресовим, як для закладів загальної середньої освіти та професійно-технічної освіти, адже вишами вже давно практикувалося створення електронних бібліотек із навчальними матеріалами.

Останнє десятиліття мала місце й практика створення дистанційних курсів педагогічними працівниками закладів вищої освіти. Але важливо відмітити той факт, що дистанційні курси створюються для осіб, які вступають на навчання саме за цією формою. Тоді як тимчасова трансформація навчального процесу в дистанційний формат чи здійснення навчання за змішаною формою не є саме 
тією дистанційною формою навчання, для якої створюються дистанційні курси. У цьому контексті більш «гнучким» застосунком $\epsilon$ електронний курс-ресурс.

Електронний курс-ресурс - це матеріали навчально-методичного комплексу дисципліни (посібник, підручник або конспект лекцій, методичні вказівки до виконання лабораторних і практичних робіт, робоча програма дисципліни, тестові завдання) та інформація про викладача (методичний кабінет викладача), які розміщені у дистанційному курсі (наприклад, Moodle) для ефективного використання студентами [1].

Коли навчальний процес здійснюється за традиційними очною формою та заочною формою, електронний курс-ресурс виконує функцію звичайного репозитарію навчально-методичних матеріалів за дисципліною. У разі ж, коли виникає потреба швидкого переходу на дистанційну форму навчання, «легким рухом руки» в електронному курсі-ресурсі створюються «навчальні тижні», які заповнюються навчально-методичними матеріалами, призначеними саме для певного тижня. Тут же на «навчальному тижні» створюються відеоконференції для проведення занять. Зазначені зміни відображаються в оголошеннях і форумі новин, про що слухачі курсу отримують повідомлення на електронні пошти. Відповідно, система заздалегідь забезпечує інформування слухачів курсу про посилання для онлайн-підключення. Онлайн-заняття підлягають запису та зберігаються на місці посилання на відеоконференцію, що є дуже зручним, адже мінімізує витрати часу на пошук запису здобувачами вищої освіти, які бажають ще раз прослухати заняття, або слухачами курсу, які не змогли доєднатися до онлайн-підключення. Заповнення електронного курсу-ресурсу поступово за «навчальними тижнями» також створює зручності для слухачів, які пізніше доєдналися до курсу, - тим самим здобувачі вищої освіти бачать, який обсяг навчального матеріалу вже було пройдено. Усі дії (активності) учасників електронного курсу-ресурсу фіксуються у системі, що створює можливості для викладача відслідковувати активність здобувачів вищої освіти, зокрема, скільки часу вони проводять у середовищі електронного курсу-ресурсу та якими навчальними матеріалами користуються в цей час.

Попри ряд суттєвих переваг електронного курсу-ресурсу як застосунку для дистанційного навчання здобувачів вищої освіти, справедливим буде відмітити й наявність деяких його слабких сторін і необхідність певного доопрацювання: так, зокрема, під час семінарських занять наразі немає можливості розподілити учасників за групами (сесійними залами) для командної роботи, як, наприклад, це можливо у застосунку ZOOM.

\section{Список літератури:}

1. Положення про електронний курс ресурс. URL: https://www.khadi.kharkov. ua/fileadmin/P_LITO/pologenia_ekr.pdf 


\title{
ОСОБЛИВОСТІ ДИСТАНЦЙНОГО НАВЧАННЯ МЕДИЧНИХ СЕСТЕР НАВЧАЛЬНИХ ЗАКЛАДІВ НА КУРСАХ ПІДВИЩЕННЯ ПЕДАГОГІЧНОӤ КВАЛІФІКАЦІї
}

\author{
Шопіна М. О., \\ кандидат психологічних наук, \\ Інститут післядипломної освіти \\ Київського університету імені Бориса Грінченка, \\ м. Київ, Україна \\ Якунін Я. Ю., \\ кандидат хімічних наук, \\ Інститут післядипломної освіти \\ Київського університету імені Бориса Грінченка,
} м. Київ, Україна

На курсах підвищення кваліфікації в Інституті післядипломної освіти Київського університету імені Бориса Грінченка для медичних сестер навчальних закладів було розроблено і впроваджено модуль для дистанційного навчання: «Як допомогти дитині подолати страх перед медичним кабінетом». Головне завдання представленого модулю полягає у тому, щоб надати слухачам більше корисної інформації за короткий час та показати їм практичне впровадження отриманих на курсах знань. У модулі послідовно викладені психологічні прийоми, що допоможуть налагодити контакт із дитиною у медичному кабінеті. Описано як організувати роботу з дітьми для подолання страху перед медичним кабінетом, наведені приклади вправ із рухливими іграми для подолання напруження, арт-терапевтична методика малювання страху, метод ігрової терапії з дітьми для подолання страху перед щепленням, казкотерапія з прикладами казок для подолання страху уколів та відвідування стоматолога. Надано 8 парад, що можна надати батькам. Модуль містить у собі три теми: 1. Як налагодити контакт із дитиною у медичному кабінеті. 2. Як організувати роботу з дітьми для подолання страху перед медичним кабінетом. 3. Що Ви можете порадити батькам. Для успішного проходження курсу i отримання сертифікату на 10 годин підвищення кваліфікації, слухачі мають виконати практичне завдання: «Стисло опишіть 2-3 випадки з Вашої практики, як вирішувалась проблема "страху медичного кабінету"». Наведемо нижче декілька прикладів відповідей слухачів курсу:

1. «Моя дитина теж боялася лікарів. Коли нам потрібно було зробити щеплення, я за заздалегідь купила дитячий іграшковий набір лікаря. Ми весь час гралися і лікували іграшкових тварин. I коли прийшов час робити щеплення, я ще раз спокійно проговорила їй, що: «лікар зробить укол дуже швидко, ти відчуєш легкий дотик». Вона довірилась мені. Я дуже вдячна лікарю, яка 
виявилась доброзичливою, вона весь час розповідала різні цікаві історії. Все пройшло дуже добре.

Коли нам треба було пройти стоматолога ми вирішили, що першого дня ми не будемо лікувати зубки, а тільки познайомимось з лікарем і його кабінетом. До чого було моє здивування, що лікар мене підтримав в цій ситуації. Він дозволив роздивитися кабінет і що в ньому знаходилось. Відповів на всі запитання дитини. Ми домовились 3 ним що прийдемо наступного дня. Коли ми прийшли в друге, моя дитина сама з задоволенням зайшла в кабінет».

2. «Одного разу у вихованця моєї групи Матвія заболіла ручка. Він зовсім не хотів іти в медичний кабінет. Але я не розгубилася, перев'язала лапку Ведмедикові, і сказала, що в нього теж болить лапка. I запропонувала Матвію разом з Ведмедиком піти полікуватися. Матвій погодився. Медсестра полікувала ручку Матвію та лапку Ведмедикові. Також у нас є розвиваюче заняття-гра у якій ляльці Катрусі потрібно відвідати лікаря, але вона боїться. Завданням дітей $\epsilon$ переконати Катрусю у тому, що лікар не страшний і допоможе ій подолати недугу. Доречи, коли є необхідність відвести дитину до медичного кабінету, я часто "звертаюсь по допомогу" до ляльки Катрусі. Я кажу, що вона занедужала, але боїться іти до медсестри. I прошу дитину, яка потребує медичної допомоги, супроводжувати нас із Катрусею. У кабінеті медсестра "пропонує" Катрусі пройти медичні маніпуляції (наприклад, виміряти температуру). Катруся "боїться", тож я прошу свого вихованця показати Катрусі, що це не лячно. Крім того у групі $є$ іграшковий набір лікаря і ми 3 дітьми часто граємо у лікарів та пацієнтів. Діти мають змогу дослідити іграшковий стетоскоп, шприц, термометр тощо та "приміряти" на себе різні ролі».

3. «Цього року ми працюємо з дітьми молодшого дошкільного віку. На початку вересня ми проводили планове зважування дітей і вимірювання їх зросту. Всі діти, окрім однієї дівчинки та хлопчика, у доброму гуморі пройшли ці прості медичні процедури. Не виникло проблем і з відвіданням ортоптичного кабінету, у всіх, окрім тих же дівчинки та хлопчика. I в медичному, і в ортоптичному кабінетах дівчинка ціпеніла, як тільки заходила до них, iї очі майже не кліпали, а погляд зосереджувався на одній точці, долоньки ставали холодні й вологі. При тому, вона беззвучно плакала i, здавалося, не чула та не бачила нікого і ніщо. Процедури для цієї дитини довелося відтермінувати. У бесіді з батьками вдалося з'ясувати, що дівчинка не відвідувала ясла і до 4річного віку майже весь час перебувала та контактувала лише з мамою, татом i старшою сестричкою. Дитину надмірно опікували батьки, що призвело до того, що вона почала боятися вулиці, чужих дітей і дорослих. Щоб послабити страх дитини перед медичними процедурами та чужими людьми, якими виявилися для неї медична сестра та ортоптист, наступного разу ми взяли з собою їі старшу сестричку, яка відвідує старшу групу нашого садочка. I це спрацювало. Першою піддалась процедурам старша дівчинка, в той час як молодша спостерігала за нею. В результаті, молодша дівчинка теж дозволила медсестрі зважити себе та зміряти іiі ріст, хоча і з деякою осторогою і без посмішки. Та це лише перша сходинка в подоланні страху перед чужими людьми. 
Реакція хлопчика, що був згаданий вище, на спроби піддати його означеним процедурам була кардинально відмінною від поведінки дівчинки. Побачивши медичну сестру, він почервонів і почав голосно плакати та кричати. Коли вона намагалася поставити його на ваги, він не давав їй це зробити, весь час вириваючись та бігаючи по кабінету. Про відвідини хлопчиком ортоптичного кабінету у той день і мови не могло бути. Отож, процедури для нього теж довелося відтермінувати. У бесіді з дитиною та його батьками вдалося з'ясувати причину виникнення страху. Він страшенно боїться людей у білих халатах через біль, якого він зазнав в результаті проведення планових щеплень та великої кількості ін'єкцій та крапельниць, коли перебував у лікарні з запаленням легень, а пізніше з ротавірусною інфекцією. У випадку хлопчика знадобилось більше часу та методів, щоб створити в дитини асоціацію, що медичні процедури не завжди пов'язані з болем. Були застосовані індивідуальні роз'яснювальні бесіди 3 дитиною про те, що лікарі допомагають дітям бути здоровими, і обійтися без них ніяк не можна; відвідини медичного та ортоптичного кабінетів для ознайомлення 3 корекційними апаратами; спостереження за тим, як інші діти піддаються процедурам; залучення до активної участі у сюжетно-рольових іграх «Поліклініка» та «Лікарня». Врешті-решт, дитина зголосилась пройти означені медичні процедури, але за умови, що вихователь буде весь час тримати його за руку. Я також запропонувала дитині зняти на відео те, як він буде поводити себе в медичному кабінеті, щоб пізніше показати його батькам, який він сміливий $\mathrm{i}$ сильний. Дитині ця ідея сподобалась. А ще, маючи чотирьох онуків і часто відвідуючи з ними приватні клініки та лабораторії, я перейняла від них спосіб винагороди грамотами за відвагу, адже позитивні враження перекривають негативні. Таку грамоту отримав і наш хлопчик. 3 кабінету він вийшов 3 посмішкою».

4. «Маленький хлопчик Андрій М. 4 роки дуже нервував перед щепленням, тому що це боляче. Медсестра розповіла хлопчику про те, що потрібно робити щеплення, щоб бути здоровим та сильним, посадила та " зробила щеплення" м'якому кошеняті , яке зовсім не плакало, а потім отримало цукерку. Кошеня " дивилося" на хлопчика і це додало йому мужності. Після щеплення дитину заохотили цукеркою і похвалили.

Коли привели дітей молодшої групи для вимірювання ваги та зросту, то двоє дітей боялися та плакали. Я рекомендувала вихователям не ставити їх на вимірювання першими. Коли ці діти побачили, що це зовсім не страшно, i їх товариші проходять ці процедури залюбки, то вони теж їх пройшли, хоча 3 острахом і недовірою. Похвала вихователя завершила процес формування позитивного ставлення до медичного кабінету та медичних працівників».

5. «Привели дівчинку з середньої групи 3 «розбитою колінкою». Дитина плакала i боялась зеленки. Після промивання ранки я спитала у дитини : «що будемо малювати - листочок чи хмарку?» Дитина заспокоїлась і відповіла ,що листочок. Їй уже стало не страшно, а цікаво: «який же вийде листочок?». так було подолано страх перед медичною процедурою та медичним працівником».

6. «Найпоширенішим і найдієвішим варіантом є розмальовані стіни, проте не просто розмальовані, а ще із коридору. Оскільки я працюю медичною сестрою у 
дошкільному навчальному закладі, і мені доводиться приводити до медичного кабінету малюків ясельної групи щомісяця, то коридор у нас розмальований у вигляді крапельок, жабенят,листя латаття. І ми усі разом : вихованці, вихователі і я стрибаємо як крапельки, як жабенята прямісінько у кабінет. У кабінеті дітки вже веселяться, адже настрій у них хороший. На стетоскоп я пошила чохол у вигляді змії з мультику 33 папуги. Малюки не бачать що саме у мене на плечах, адже коли я маю необхідність послухати їхнє дихання (за фахом я фельдшер), вони бачать милу змійку. По-перше вона тепла, а по-друге м'якенька».

\section{Література}

1. Шопіна М.О., Якунін Я.Ю. Формування нової парадигми освіти в умовах карантинних обмежень // Шляхи розвитку науки в сучасних кризових умовах: тези доп. I міжнародної науково-практичної інтернет-конференції, 28-29 травня 2020 р. - Дніпро, 2020. - Т.2. - С. 591- 592.

2. Шопіна М.О., Якунін Я.Ю. Дослідження потреб освітян щодо покращення навчальних модулів на курсах підвищення педагогічної кваліфікації, Конференция: High scientific goals 2020, декабрь 2020 Высокие научные цели '2020: Сборник тезисов. - Минск: Ёлнать, 2020 (Серия «SWorld-Bel Conference proceedings»). C. 27-30. 


\title{
СУЧАСНІ ПІДХОДИ ДО РОЗРОБКИ ДИСТАНЦІЙНИХ КУРСІВ 3 ФАРМАЦЕВТИЧНОЇ ТЕХНОЛОГІЇ У СИСТЕМІ ПІСЛЯДИПЛОМНОЇ ОСВІТИ
}

\author{
Огарь Світлана Володимирівна, \\ кандидат фармацевтичних наук, доцент, \\ Інститут підвищення кваліфікації спеціалістів фармації \\ Національного фармацевтичного університету \\ Шульга Людмила Іванівна, \\ доктор фармацевтичних наук, професор \\ Інститут підвищення кваліфікації спеціалістів фармації \\ Національного фармацевтичного університету \\ Губченко Тетяна Дмитрівна, \\ кандидат фармацевтичних наук, доцент, \\ Інститут підвищення кваліфікації спеціалістів фармації \\ Національного фармацевтичного університету
}

Сучасний фармацевтичний сектор охорони здоров'я розвивається динамічно та потребує кваліфікованих й конкурентно здатних фахівців, які націлені на безперервний професійний розвиток. Сучасну освіту неможливо представити без використання Інтернет-ресурсів, у тому числі в системі підвищення кваліфікації спеціалістів фармації. Крім того, реалії попереднього року, а саме, ситуація 3 розповсюдженням короновірусної інфекції у світі, довели необхідність використання електронних ресурсів у системі післядипломної освіти.

У межах реалізації інформальної післядипломної освіти фахівців практичної фармації впровадження дистанційних технологій навчання в Інституті підвищення кваліфікації спеціалістів фармації проводиться протягом декількох попередніх років і ми маємо вже певний досвід такого навчання. Використання електронних освітніх ресурсів, створених на основі інформаційнокомунікаційних технологій, представляють собою дистанційні курси. Однак, процес розробки дистанційних курсів для підвищення кваліфікації досить трудомісткий та тривалий, оскільки основними характеристиками його, у порівнянні з іншими електронними ресурсами, $\epsilon$ :

- структурованість навчально-методичних матеріалів;

- чіткий графік виконання слухачами навчально-тематичного плану i програми циклу підвищення кваліфікації; 
- налагоджена система інтерактивної взаємодії викладача зі слухачами за допомогою технологій дистанційного навчання протягом усього часу навчання на циклі;

- наявність якісно розроблених навчальних матеріалів, які дають можливість слухачам удосконалити (чи набути) компетентності, задекларовані у програмі циклу тематичного удосконалення;

- система самоконтролю і контролю викладачем виконання усіх видів завдань у процесі освітньої діяльності.

Безумовними конкурентними перевагами використання дистанційних технологій в освітньому процесі Інституту підвищення кваліфікації спеціалістів фармації $\epsilon$ : освітній процес, що організовано 3 урахуванням вікових i професійних особливостей; набуття тими, хто навчається, фахових знань та умінь у зручний для себе час, у необхідному обсязі, з можливістю вибору тематики; прозорість і об'єктивність освітнього процесу; можливість гнучкої корекції навчальних планів і програм на вимогу ринку праці; проведення викладацьким складом усіх видів занять 3 підвищення кваліфікації 3 урахуванням нових, соціально важливих й перспективних завдань фармацевтичного сектору охорони здоров'я.

В останні роки 3 успіхом апробовано новий освітній контент, що розроблений нами, зокрема навчально-методичний комплекс 3 курсу «Фармацевтична технологія» 3 інноваційними елементами для навчання та діагностики компетентностей як у вигляді тестів різного рівня складності, так і у вигляді мультифункціональних навчальних завдань нового покоління, які орієнтовані на реалізацію усіх рівнів навчальної діяльності за таксономією Блума. Розроблені типові інтерактивні навчальні завдання мають багаторівневу структуру, розв'язання яких вимагає задіяння Інтернет-ресурсів та сприяє удосконаленню загальних та фахових компетентностей. Такі завдання мають на меті реалізацію навчальної діяльності від рівня «знань» до «оцінки».

Європейські аналітики освітнього простору передбачають вихід дистанційної освіти на принципово новий рівень, який дозволить задіяти значну за обсягом професійну аудиторію. Таким чином, наші напрацювання та подальший розвиток дистанційних технологій у системі післядипломної освіти залишаться актуальними й перспективними у інноваційному навчанні фахівців фармацевтичного сектору галузі охорони здоров'я.

\section{Список літератури}

1. Lukienko O., Shulga L., Ogar S., Domar N. Tasks of the new generation as a component of the modern education and methodological complex of the course «Pharmaceutical technology». Contemporary technologies in the educational process. Monograph 40. Katowice, Poland. P. 302-307. 


\title{
АНГЛОМОВНА МЕДИЧНА ТЕРМІНОЛОГІЯ: АНАЛІЗ, ІСТОРІЯ СТАНОВЛЕННЯ ТА ОСОБЛИВОСТІ
}

\begin{abstract}
Davydenko Nataliia Viktorivna,
Lecturer

National Technical University of Ukraine «Igor Sikorsky Kyiv Polytechnic Institute»

Давиденко Наталія Вікторівна,

викладач

Національний технічний університет України «Київський політехнічний інститут імені Ігоря Сікорського»
\end{abstract}

Медична термінологія є однією із найбільших за кількістю термінологічних систем. За різними джерелами у ній нараховується від 200000 до 500000 термінів, що перевищує кількість термінологічної бази будь-якої іншої дисципліни. Виокремлюють до 200 областей медицини, кожна із яких має свою окрему мікросистему термінів.

Протягом останніх десятиліть більше 75\% медичної інформації друкується англійською мовою. Сучасна англійська наукова термінологія пройшла досить довгий i складний шлях розвитку. Від термінологізації англійських загальновживаних слів, прямого запозичення лексичних одиниць з латинської, грецької та західноєвропейських мов до вироблення власних, нових словотворчих моделей. Формування англійських терміносистем, зокрема i термінів медицини, відбувалося протягом багатьох сторіч і відображає процес розвитку означеної галузі знань і професійної діяльності. Виокремлюють наступні етапи формування англійської медичної термінології: грецький період, арабський період, латинський період, національний період та англійський період. 
III International Science Conference on E-Learning and Education

Терміносистема медицини інтернаціоналізована, що зумовлюється використанням багатьма мовами греко-латинського фонду як джерела словотвірних формантів. Кількість інтернаціональних термінів у медицині дорівнює приблизно 89\%. Усе це сприяло поділу медичної лексики на «народну» i «професійну» 3 відповідними ознаками певної стильової приналежності. Терміни, запозичені з грецької мови, зазвичай використовуються у сфері клінічної термінології. Анатомічна та гістологічна номенклатури, що входять до складу медичної термінології, базуються переважно на коренях латинського походження. Сюди відносять запозичені греко-латинські терміни, а також терміни, створені штучно із греко-латинських терміноелементів. За різними джерелами в англійській мові 86-95\% термінів створено на основі класичних мов.

Активне створення термінів 3 класичних терміноелементів призвело до свідомого впливу на термінологію: медичні терміни мають високий ступінь вмотивованості і є семантично прозорими.

Хоча варто зазначити, що формування сучасної англомовної медичної терміносистеми відбувається не лише за рахунок відбору термінів 3 інтернаціонального фонду, значно активніше залучаються одиниці германського походження.

Оскільки греко-латинські терміни лежать в основі медичної термінології практично всіх європейських мов, більшість медичних термінів $€$ інтернаціональними, у професійній мови медика будь-якої країни, деякі сталі вирази вживаються лише латинською мовою (in vivo, in vitro, per os тощо)

Англійська медична термінологія містить численні термінисловосполучення, які завдяки своїй складній, багатокомпонентній структурі надають оптимальну номінацію фахового поняття.

Аналізуючи історію творення та становлення зокрема й медичної термінології слід зауважити, що у медицині є терміни, які можна розглядати як релікти минулих культурних епох: міфологізми (з часів античності), біблеїзми (період середньовіччя), терміни з астрології і хіромантії (епоха Відродження). У 
медичній термінології $є$ слова, що увібрали в себе чимало не лише 3 історії минулих епох, але й з інших сфер культури («гастростомія» і «ахіллотомія», «неврологія» і «венерологія», «омфаліт» і «Голова Медузи», «спинальгія» i «симптом Петрушки», «деперсоналізачія» і «синдром Аліси в країні чудес», «хвороба Дауна» та «Едіпів комплекс», «сінна гарячка» і «гарячка геморагічна», «намисто Венери» $\mathrm{i}$ «рефлекс бульдожсий тощо).

3 кінця позаминулого століття і особливо в минулому столітті виникла мода на епонімічні назви хвороб, тобто назви за іменами лікарів, що вперше здійснили їх опис. Деякі з них втратили епоніміку.

Наприклад, зараз ніхто не називає ревматизм хворобою Сокольського-Буйо, або нефрит хворобою Брайта. Проте за багатьма захворюваннями залишилися епоніми - назви їх «авторів»: «Синдром Хаммана-Річа», «синдром Дауна», «хвороба Вільсона-Коновалова», «синдром Рея» тощо.

Видаються багатосторінкові довідники, що увібрали в себе не одну сотню епонімів, що зустрічаються часто, і тому не викликають діагностичний «острах» у фахівців, а також і рідкісні, назва яких нічого не говорить лікареві про клінічну суть хвороби. Виявлення симптомів цих хвороб не приводить спеціаліста до їх назви логічним шляхом. Розуміючи патогенетичну суть цих симптомів, лікар ставить патогенетичний і локальний діагноз, але, якщо не знає або не пам'ятає епонімну назву хвороби, формально правильний діагноз не поставить [1, С. 280].

Згідно з визначенням «Словника сучасної медицини», епонім - це термін, який виражає поняття синдрому, ураження, хірургічної процедури або симптому, що носить ім'я лікаря, який вперше описав даний феномен, або, у деяких випадках, імена пацієнтів, у яких вперше було зареєстроване дане захворювання [2, с. 197]. Обов'язковим складником терміна-епоніма $є$ власна назва, яка під час перекладу транскрибується (Lyme disease) або транслітерується (Addison anemia).

Використання епонімів у медичній термінології відбувається частіше, ніж в інших сферах. У деяких випадках це призводить до використання двох чи більше синонімів на позначення одного і того ж поняття. Це є однією з причин, чому термінологічна варіативність $є$ особливо поширеною в медицині. 
III International Science Conference on E-Learning and Education

Епонімічні назви складають значний відсоток у деяких медичних терміносистемах. Так, у неврології на терміни-епоніми припадає до 30 \% від загальної кількості термінів, в англійській травматологічній термінології епоніми складають $10 \%$ від загальної кількості терміноодиниць, хоча в медсестринській справі вони майже відсутні. Дослідники вважають, що виникнення таких термінів пов'язане із позамовними факторами: історичними, соціальними, психологічними [3;4].

У досліджуваній термінології власне ім'я, яке спочатку називало конкретну особу, тобто було семантично зумовленим, у результаті внутрішнього семантичного перетворення піддалося переосмисленню й у сучасній англійській мові фактично не є назвою особи, а сприймається як позначення диференціальної ознаки терміна.

Серед термінів-епонімів, що найчастіше сполучуються із власними назвами виділяють: терміни-епоніми, які містять анатомічні назви. (Henderson-Paterson bodies (тільия Гендерсона-Патерсона); терміни-епоніми, які описують закони медицини (Behring's law (закон Берінга - кров і сироватка імунізованої особи при переливанні передає імунітет іншій особі); функціональні порушення (назви хвороб, симптомів і синдромів захворювань: Ebstein's disease (хвороба Ебштейна, вроджена вада серця)); назви методів і технік лікування, операцій, тестів, процедур (Schilling blood count (підрахунок лейкоцитів за Шіллінгом)); назви хірургічних приладів та апаратів (Cammann's stethoscope (cmemocкon Камманна)) тощо.

Отже, специфічною особливістю англомовної медичної термінології є переважна однозначність лексичного складу. Разом з тим, незначна кількість загальнонаукових термінів, що функціонують у всіх галузях медичної термінології, іноді призводить і до міжгалузевої омонімії. Професійна медична лексика є досить динамічною, оскільки нові явищаі відкриття в медицині потребують утворення нових термінів для їх номінації - неологізмів (voicelift косметична операція на голосових зв'язка, щоб голос звучав молодшим, flexitarian - вегетаріанець, який час від часу їсть м'ясо) тощо [5, С. 235]. 
Динамізм та варіативність медичної термінології зреалізовуються також у синонімії, коли разом із науковими термінами вживаються їх загальновживані еквіваленти: cephalalgia - headache, heamorrhage - bleeding [6; С. 80]. Проблема аналізу та дослідження англомовних медичних термінів, зокрема для подальшого укладання галузевих термінологічних словників продовжує залишатися однією із актуальних проблем сучасного мовознавства. Адже сучасна медична термінологія - одна 3 найбільш широких і складних у понятійному відношенні систем. Щороку до наукового обігу вводиться більше тисячі нових медичних термінів. Тому вивчення медичної термінології завжди привертатиме особливу увагу лінгвістів та перекладачів.

\section{References}

1. Комиссаров В. Н. Теория перевода (лингвистические аспекты): Учеб. для ин-тов и фак. иностр. яз. - М.: Высшая школа, 1990. - 253 с.

2. Segen J. C. The Dictionary of Modern Medicine / J. C. Segen. - New Jersey: Carnforth, 1992. $-800 \mathrm{p}$.

3. Воробьева М.Б. Особенности реализации эпонимов-терминов в научном тексте // Научная литература / Язык, стиль, жанры. - М.: Наука, 2005. - 33-47 с.

4. Даниленко В.П. Русская эпонимотерминология: Опыт лингвистическогоописания. - М.: Наука, 2007. - 246 с.

5. Бархударов Л.С., Рецкер Я. И. Курс лекций по теории перевода. - М., 2001. -263 c.

6. Борисова Л.И. Перевод неологизмов с английского языка на русский в научно-технических текстах. - М.: ВЦП, 2007. - 114 с. 


\section{JAIL SLANG IN LINGUISTICS}

\section{Derik Ilona,}

Ph.D., Associate Professor State Institution «South Ukrainian National Pedagogical University named after K.D. Ushynskyi»

Jail slang is an interesting social and communicational phenomenon which encompasses as it is the subject of a separate discipline - communal translation in the penitentiary system. There also are distinguished jail slang dictionaries and glossaries. Among the sources of the authentic jail slang there is the US site 'Prison Diaries' and British BBC series 'Porridge'.

The objective of these theses was to give a short outline of jail slang peculiarities and highlight distinctive features of this lexis stratum.

First and foremost, jail slang is an argot used primarily by criminals and detainees in penitentiary institutions. It's a form of anti-language, widely used among prisoners and ex-prisoners to encrypt their messages from the other citizens. Words of jail slang are employed to denote criminal behavior, jail life, legal cases, street life, and different types of inmates. Jail slang varies depending on institution, region, and country. The out-of-date name for jail slang was 'thieves' cant', as it used to be called in Dickens's and Thackeray's times.

Among the jail slang words which penetrated into literary English bulk there are 'snitch' for an 'informant', 'ducking' for manipulation technique with prison officers.

All jail slang words may be subdivided into such groups as: monosemantic words, polysemantic words, rhyme-based words on the analogy with Cockney dialect. From the point of view of the regional varieties there are also distinguished US slang, UK slang, Australian slang, Israeli slang, Zimbabwe slang.

The most widely used terms for informants are 'squealer', 'nark', 'rat' and 'grass' in UK jail slang. 'Rat' is a case of zoosemy.

The most recurrent term for drug-dealers is 'bagman', while drugs are usually ciphered as 'cookies', 'sweets', 'candy' and drug injection is nominated as 'fix', 'hit', 'shot', 'bang' or 'doze'.

To illustrate difference in terms coinage in British and American jail slang we can adduce two variants for solitary confinement: respectively 'seg' in UK jail slang which originated as shortening from the word-combination 'administrative segregation' and 'block' or 'box' in US jail slang.

'Porridge' can denote not only most popular meal in jail but also imprisonment as such, later on giving name to BBC series 'Porridge' aimed at popularizing many jail slang words.

In Australian an informant is termed as 'dog'. It's another example of zoosemy.

There are also many examples of homonymy among the regional varieties.

'Green' in US jail slang means 'money' and 'greens' in Australian jail slang means 'jail clothing'. 
There are many toponyms and anthroponyms among jail slang words which acquire new meaning.

'Pompey' is in Northern England jail slang term for a correctional institution.

There are also sound-imitating words coined to resemble literary onomaetopoeic words. Thus, 'cockatoo' coined on the basis of 'cockadoodldoo' means an inmate who is on the alert to inform his cellmates of prison officers in advance.

Shortenings and abbreviations are almost the most numerous coinages among jail slang words ('cellie' for 'cellmate', 'crim' for 'criminal', 'C.O.' for 'Correctional Officer').

Sometimes idioms are used. Thus, 'to be in the hole' means 'to be in solitary confinement', 'take flight' means 'to fight with other inmates'.

It's interesting that there are also gender varieties in jail slang. In female jail slang prison robe is called 'blue' because of blue jeans, in male jail slang it's 'greens'. Prison guards are called 'chiefs' by male inmates and 'bosses' by the females. Women call their cellmates not 'cellies', but 'bunkies' from' bunkbed'. Cell is termed 'hole' by male detainees and 'cage' by the female ones.

The analysis of the different varieties has revealed the following tendencies:

1) the most recurrent objects of nomination are represented by inmates and criminals' types;

2) there exist both areal and gender discrepancies between different varieties of jail slang;

3) the core of any jail slang variety is formed by the lexis coined by means of shortening, sound-imitation, transfer of meaning, word-formation on analogy and abbreviation.

There have been attempts to research jail slang, carried out by Bert Little and Alicja Dziedzic-Rawska on American prison slang. The perspective of our research is seen in contrasting existing approaches to this study and also investigating the issue of adequate translation of English jail slang into Ukrainian.

\section{References:}

1. Little, Bert (1982). Prison Lingo: A Style of American English Slang. Anthropological Linguistics. Vol. 24, No. 2 (Summer, 1982). Trustees of Indiana University. PP. 206-244. Retrieved January, 2021, from https://www.jstor.org/stable/30027838.

2. Dziedzic-Rawska, Alicja (2016). Linguistic Creativity in American Prison Settings. Lublin Studies in Modern Languages and Literature Vol.40, Iss.1. Wydawnictwo Naukowe Uniwersytetu Marii Curie-Sklodowskiej. PP.65-80. Retrieved January, 2021, from https://scholar.google.pl/scholar?oi= bibs\&cluster $=17090561669126648099 \&$ btnI $=1 \&$ hl $=$ pl. 


\section{ONLINE LEARNING: ADVANTAGES AND DISADVANTAGES}

Kushmar Lesia,

Ph.D., Associate Professor Kyiv National University of Trade and Economics

Liubov Kolot, Senior Lecturer Kyiv National University of Trade and Economics,

Olha Dubinina,

Senior Lecturer

Kyiv National University of Trade and Economics

The COVID-19 pandemic has triggered new ways of learning. It is important to continue on the path of learning and discovery, especially as career-oriented students who hope to advance both personally and professionally.

Online education has become a popular channel for many students to pursue their degree. The fact shows that most online students are successfully complete their degree program but $40 \%$ of them failed. Most of online students are pursuing their degree online because they are seeing many advantages of online education that can benefits them but the $40 \%$ that failed do not aware of the disadvantages of online education that cause their failure [1].

All around the world, educational institutions are looking toward online learning platforms to continue with the process of educating students. The new normal now is a transformed concept of education with online learning at the core of this transformation. Today, digital learning has emerged as a necessary resource for students all over the world. For many educational institutes, this is an entirely new way of education that they have had to adopt. Online learning is now applicable not just to learn academics but it also extends to learning extracurricular activities for students as well. In recent months, the demand for online learning has risen significantly, and it will continue doing so in the future [2].

Of course, there are advantages and disadvantages of online learning for higher education to take into consideration (Table 1). 
Table 1.

Virtual Learning Environment

Virtual Learning Environment

\begin{tabular}{|l|l|}
\hline \multicolumn{1}{|c|}{ Advantages } & \multicolumn{1}{c|}{ Disadvantages } \\
\hline - Time flexibility & - Lower quality of communication \\
• Location independence & - Demands high self-discipline \\
- Cheaper degree & - Lack of practice \\
- Improved management & - Delayed answers \\
- More learning materials & - Not for all countries \\
- Engaging online activities & - Requires investment \\
\hline
\end{tabular}

The first obvious advantage of online classes helps save time, which it can be invested in online learning and any other task that needs the attention. Learning online offers teachers an efficient way to deliver information to students. It has a number of tools such as videos, PDFs, podcasts, and teachers can use all these tools as part of their lesson plans. Another advantage of online education is that it allows students to attend classes from any location of their choice. It also allows educational establishments to reach out to a more extensive network of students, instead of being restricted by geographical boundaries. Additionally, online lectures can be recorded, archived, and shared for future reference. This allows students to access the learning material at a time of their comfort. Online education is also far more affordable as compared to physical learning. This is because online learning eliminates the cost points of student transportation, student meals, and most importantly, real estate. Additionally, all the course or study materials are available online, thus creating a paperless learning environment which is more affordable, while also being beneficial to the environment. And every student has a different learning journey and a different learning style. Some students are visual learners, while some students prefer to learn through audio. Similarly, some students thrive in the classroom, and other students are solo learners who get distracted by large groups. The online learning system, with its range of options and resources, can be personalized in many ways. It is the best way to create a perfect learning environment suited to the needs of each student [2].

On the other hand, online learning has the negative aspects. To begin with, for many students, one of the biggest challenges of online learning is the struggle with focusing on the screen for long periods of time. With online learning, there is also a greater chance for students to be easily distracted by social media or other sites. Therefore, it is imperative for the teachers to keep their online classes crisp, engaging, and interactive to help students stay focused on the lesson. Another key challenge of online classes is internet connectivity. While internet penetration has grown in leaps and bounds over the past few years, in smaller cities and towns, a consistent connection 
with decent speed is a problem. Without a consistent internet connection for students or teachers, there can be a lack of continuity in learning. Students can learn a lot from being in the company of their peers. However, in an online class, there are minimal physical interactions between students and teachers. This often results in a sense of isolation for the students. In this situation, it is imperative that the educational establishments allow for other forms of communication between the students, peers, and teachers. This can include online messages, emails and video conferencing that will allow for face-to-face interaction and reduce the sense of isolation. The problem with many video conferencing tools is that they are strictly video conferencing tools. They provide the ability to see and hear and the chance to be seen and heard but not much else. In order for learners to get the most out of their live session, their online course or digital learning environment must closely replicate traditional learning in the physical classroom as much as possible. In a physical classroom instructors have a chalkboard or whiteboard at their disposal to illustrate points more clearly. They can split students into smaller groups to be able to collaborate more easily. They can administer quizzes to gauge learner understanding. The digital environment must be more of a virtual classroom rather than your basic video conferencing tool in order for students to get the most out of the lesson. Instructors must successfully translate the feel and practices of a live classroom into a virtual environment [3]. Online learning requires teachers to have a basic understanding of using digital forms of learning. However, this is not the case always. Very often, teachers have a very basic understanding of technology. Sometimes, they don't even have the necessary resources and tools to conducts online classes.

It is clear that the advantages of online learning surpass its disadvantages. A good solution to this would be to have been reached new heights by technological capabilities and many of the major concerns of students taking online classes have been addressed, the advantages of online classes are beginning to eclipse the disadvantages.

\section{List of used resources}

1. Advantages and Disadvantages of Online Education [Electronic resource]. Excess code: https://www.streetdirectory.com/travel_guide/62604/phoenix_university/advantages_ and_disadvantages_of_online_education.html.

2. Advantages and Disadvantages of Online Education [Electronic resource]. Excess code: https://elearningindustry.com/advantages-and-disadvantages-onlinelearning.

3. The Advantages and Disadvantages of Online Classes for Higher Education [Electronic resource]. - Excess code: https://corp.kaltura.com/blog/advantagesdisadvantages-online-classes/. 


\section{ТЕСТ НА ВЖИВАННЯ МОДАЛЬНИХ ДІССЛІВ "SHALL" TA "SHOULD"}

Максименко Ольга Олександрівна, доктор філософії в галузі психології (МАУП-МКА-МВУ), провідний соціолог, Інститут соціології Національної академії наук України

Запропонований тест складається з 10 питань 3 полем для вводу відповіді. Окремо подано правильні варіанти відповідей та пояснення до них.

Fill in the gap in each sentence with shall (shall not, shan't) or should (should not, shouldn't). Write your answer in the space below.

1. It's none of my business but I don't think you ... accept this job offer. I've heard there's too much turnover.

2. ... I throw a party for you and invite your crush?

3. ... I apply for a job right now? - I don't think you ... Complete your Bachelor's degree first.

4. You ... have told your friends that you had changed your mind. You've simply let them down.

5. The Board of Directors ... hold a meeting at least once a year.

6. How often ... I feed my cat?

7. You ... pass! ("The Lord of the Rings")

8. ... we conduct a pilot survey to see how the questionnaire works? - Yes, you definitely ...

9. Applicants ... remain in their seats until all the papers have been collected.

10. We ... overcome all the hindrances in our way.

\section{$\underline{\text { Ключ до тесту }}$}

1. Правильна відповідь: should.

Пояснення:

The verb "should" is mainly used for giving advice or making recommendations.

2. Правильна відповідь: shall.

Пояснення:

The verb "shall" is often used for making offers or suggestions.

"Crush" (informal) is a person who you love and admire but often cannot have a relationship with.

3. Правильна відповідь: Should, should.

Пояснення:

Here the verb "should" is used to ask for advice. 
4. Правильна відповідь: should.

Пояснення:

The verb "should" is also used to criticise someone's actions.

5. Правильна відповідь: shall.

Пояснення:

The verb "shall" frequently appears in legal texts and has the meaning "must".

6. Правильна відповідь: should.

7. Правильна відповідь: shall not, shan't.

Пояснення:

Here the verb "shall" is used to give an order.

8. Правильна відповідь: Should, should.

9. Правильна відповідь: shall.

Пояснення:

Here the verb "shall" is used to give an instruction.

10. Правильна відповідь: shall.

Пояснення:

Here the verb "shall" is used to express determination.

Список літератури:

1. Oxford Advanced Learner's Dictionary. 9th edition. Oxford, England : Oxford University Press, 2015. 1900 p.

2. Modal verbs // GrammarBank.com. Learning English Online [Electronic resource]. - Access mode: https://www.grammarbank.com/modal-verbs.html

3. Modal verbs and their substitutes // Learn English with Demi [Electronic resource]. Access mode: https://learnenglishwithdemi.wordpress.com/2015/05/23/modal-verbs-and-theirsubstitutes 


\title{
ФЕНОМЕН ГАРМОНIÏ У ÏÏ ЗАХІДНОЕВРОПЕЙСЬКИХ ЗРАЗКАХ
}

\author{
Муляр Володимир Ілліч \\ д. філос. н., професор \\ Державний університет \\ «Житомирська політехніка»
}

Гармонія завжди була у центрі смисложиттєвих проблем. Це видно навіть по тому, що сам термін «гармонія» 3'явився ще в часи міфологічної свідомості. Так, відомий античний міф розповідає, що Гармонія була донькою бога війни Арея (Ареса - В. М.) та богині кохання і краси Афродіти. Коли Зевс видавав їі заміж за Кадма, героя і засновника міста Фіви , то на весіллі були присутні усі боги [1, с. 67] В «Одісеї» та «Іліаді» термін «гармонія» неодноразово використовується у різних смислах: як цвяхи і гармонії для будівництва корабля Одісеєм, як угода, договір тощо.

3 грецької міфології термін гармонія органічно «перекочував» у давньогрецьку філософію, де відомими дослідниками цього феномена були Піфагор, Геракліт, Платон та Арістотель. Не дивно, що методологічно західноєвропейська модель гармонії має своїми витоками твори давньогрецьких філософів. Якщо ж підбити короткі підсумки аналізу вказаного періоду західноєвропейської філософської думки, то очевидним стає той факт, що при всій варіативності тлумачень явища гармонії, яку ми спостерігаємо у різних авторів давньої європейської епохи, в цілому їх можна згрупувати в дві основні теоретичні концепції - піфагорійську та гераклітівську. Незважаючи на те, що обидві з них виходили з розуміння внутрішньої суперечливості світу в цілому та його проявів як головної умови існування гармонії, самі поняття гармонії у Піфагора і Геракліта були якісно різними. У концепції першого з них сутнісні риси гармонії проявляються у пошуках злагоди, примирення протилежностей. Піфагор як і Платон, і Арістотель вбачав гармонію у своєрідному мирному співіснуванні суперечливих проявів буття. В концепції ж Геракліта гармонія також органічно пов'язана 3 суперечливістю світу, але сама гармонія тільки і існує як вічна боротьба протилежностей. В процесі такої боротьби світ та окремі його прояви здійснюють процес постійного становлення, розвитку, вдосконалення.

Аналіз характерних ознак європейської моделі гармонії дає право стверджувати, що ii історія має, очевидно, два основних етапи. Перший пов'язаний з домінуванням піфагорійського уявлення про гармонію, другий гераклітівського. О. Шпенглер називає ці періоди аполонівським і фаустівським. «Я буду називати, - пише німецький дослідник, - душу античної культури, що обрала чуттєве наявне окреме тіло за ідеальний тип протяжності, аполонівською. 3 часів Ніцше це позначення стало для всіх зрозумілим. Її протиставляю я фаустівську душу, прасимволом якої є чистий безмежний простір, а «тілом»- 
західна культура, яка розквітла на північних низовинах між Ельбою і Тахо одночасно 3 народженням романського стилю в X столітті. Аполонівські механічна статика, чуттєві культи олімпійських богів, політично розмежовані грецькі міста, рок Едіпа і символ фалоса, фаустівські - динаміка Галілея, католицько-протестантська догматика, великі династії часу бароко 3 їх політикою кабінетів, доля Ліра та ідеал Мадонни, починаючи від Беатріче Данте до заключної сцени другої частини «Фауста». Аполонівська - живопис, що обмежує окремі тіла різкими лініями і контурами; фаустівська - та, яка за допомогою світла і тіні творить простір...Аполонівське - існування грека, який

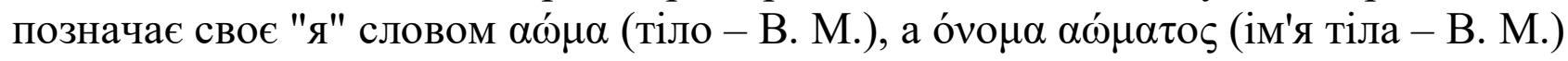
вживає в смислі особистого імені, якому далека ідея внутрішнього розвитку, а значить, і будь-яка внутрішня і зовнішня історія; це евклідівське, точкообразне, далеке рефлексії існування; фаустівським $є$ існування, яке протікає 3 повною самосвідомістю у вигляді внутрішнього життя, яке само себе спостерігає, у вищій мірі особиста культура мемуарів, розмислів, спогадів про минуле i очікувань в майбутньому i, нарешті, совісті. Стереометрія і аналіз, натовпи рабів i динамомашини, атоїчна атараксія і соціальна воля до влади, гекзаметр i рифмоваті вірші - такі символи буття двох в основі протилежних світів» [2, с. 277] Відомий дослідник філософської спадщини цього великого німецького інтелектуала Г. Драч зазначає, що «за думкою О. Шпенглера, антична натурфілософія (в термінології О. Шпенглера - аполонівська (В. М.),яка обирає висхідним пунктом оптично дане і спирається на число як на величину, створює статичну картину природи. Фаустівське ж надбання природи, пов'язане 3 поняттям числа як функції, межі, сприймає природний світ динамічним, спираючись на поняття причинності» [3, с. 16]

Звичайно, вирізнення аполонівського та фаустівського типажів європейської людини та відповідних їм моделей пошуку гармонії досить умовне хоча б тому, що західноєвропейська історія - єдиний процес формування певного ряду соціокультурних і духовно-ментальних рис, які з часом в сукупності дали людству те, що сьогодні називають європейською цивілізацією. Як зазначав німецький філософ минулого століття Карл Ясперс, «незважаючи на серйозні катаклізми, руйнування і як здавалося б повний занепад, неперервність у формуванні культури Заходу не була втрачена . У всякому разі, форми сприйняття і схеми, найменування і формули збереглися на протязі тисячоліть. Навіть там, де був перерваний свідомий зв'язок 3 минулим, залишилась певна фактична неперервність, а за нею настало свідоме відновлення неперервності в розвитку. Китай та Індія завжди продовжували в своєму житті власне минуле. Греція, навпаки, виходила за ці рамки, відштовхуючись від далекого для неї минулого східних народів, а північні народи - від по суті далекої їм культури Середземномор'я. Для Заходу характерна первісність, яка виникає як безперервне продовження минулого далеких йому народів, яке він усвоює, переробляє і перетворює» [4, с. 83] 3 цього приводу Володимир Янів, відомий дослідник явища етнопсихології, у своїй книзі «Нариси до історії української етнопсихології» наводить досить показову думку іспанського мислителя Хосе Ортеги - i - Гасета. «Іспанці, німці, англійці, французи є й остануть так дуже 
різні від себе, як цього тільки можна бажати, проте вони мають ту саму психічну структуру і є скеровані перш за все на ті самі змісти: релігія, наука, право, мистецтво, суспільність і еротичні відчування є спільною їм справою, а те все $\epsilon$ спірітуальні субстанції...Проблема Заходу в традиційному розумінні - це проблема південно-західної й північно-західної Свропи (географічний момент) i відносимо іiі до романської і германської спільноти народів (мовний аспект) індоєвропейської раси (антропологічно-біологічний момент), які розвинулися на основі традицій античного світу й Христової віри (культурно-історичний аспект) та які почуваються до європейської спільноти народів» [5, с. 148]

Отже, ми не можемо говорити про пошуки в історії європейської спільноти якихось чистих зразків гармонії з чіткими часовими рамками. Бо їх просто не існувало. Скоріше, йдеться про домінування характерних ознак тієї чи іншої 3 названих вище моделей гармонії. Домінуванню першої з них (піфагійської) відповідала історія Західної Свропи початкових іiі цивілізованих епох, які в сукупності можна називати традиційними. Це час, що охоплював стародавність та середні віки і культивував пріоритет загального над індивідуальним, своєрідний принцип «індивідуальне невиразне!» 3 епохою Відродження починається інший період західноєвропейської історії, що методологічно та світоглядно грунтується на гераклітівській концепції гармонії, яку я називаю аполонівською моделлю. Це час, що продовжується і до наших днів, культивує пріоритет одиничного над загальним, своєрідний принцип «із себе!», проголошений ще в часи Ренесансу.

\section{Список літератури}

1. Левчук Л. Т. та ін. Естетика: Підручник / Л. Т. Левчук, Д. Ю. Кучерюк, В. І. Панченко; За заг. ред. Л. Т. Левчук. - К. : Вища школа., 1997. - 399 с.

2. Шпенглер О. Закат Европы/Вступ. ст. и комм. д.ф.н., проф. Г. В. Драча при участии Т. В. Весёлой и В. С. Котляровой. - Ростов н/Д. : Феникс, 1998. - 640 с.

3. «Морфология культуры» Освальда Шпенглера // Шпенглер О. Закат Европы / Вступ. ст. и комент. Д.ф.н., проф. Г. В. Драча при участии Т. В. Веселой и В. Е. Котляровой. - Ростов н/Д : Феникс, 1998. - С. 3-35

4. Ясперс К. Смысл и назначение истории: Пер. с нем. - 2-е изд. - М. : Республика, 1994. - 527 с.

5. Янів В. Нариси до історії української етнопсихології / Упоряд. М. Шафовал. - 2-ге вид., перероб. і доп. - К. : Знання, 2006. - 341 с. 


\title{
ИЗУЧЕНИЕ В СОВРЕМЕННОЙ КАРАКАЛПАКСКОЙ ЛИРИКЕ
}

\author{
Юсупов Конысбай Абылович \\ Канд.филолог. наук, доцент \\ Г.Нукус, Республики Узбекстан и Каракалпакстан
}

Аннотация: Ведущим критиком и исследователем каракалпакской поэзии является Қуўанышбай Оразымбетов. Им написано свыше двухсот монографий, исследований, статьей и рецензий. Большая заслуга принадлежит К.Оразымбетову в подготовке учебных программ и учебников для школы и академических лицеях по каракалпакской литературе.

Ключевые слова: критик, произведение, роман, литературовед, образ, творчество, стиль, метод, жанры, язык, литература.

Белгили устазымыз хәм көрнекли алым Қуўанышбай Оразымбетов илим тараўында да, билимлендириў тараўында да көп мийнет еткен дөретиўшилердиң бири. Өйткени, ол бириншилерден болып әдебияттаныў илиминде изертлеўди күтип турған ең әхмийетли теориялық мәселелерди шешип бериўди қолға алып, ғәрезсизлик дәўир әдебият таныў илиминдеги қосық теориясының раўажланыўына тийкар салды. [1].

Профессор Қуўанышбай Оразымбетовтың қарақалпақ әдебияты тарийхы, теориясы хәм әдебий сыны бойынша 150 ден аслам илимий теориялық хәм сын мақалалары, монографиялары, сабақлықлары хәм оқыў методикалық қолланбалары баспадан жарық көрди. [2].Алымның дәслепки монографиясы «Хәзирги дәўирдеги қарақалпақ лирикасында көркемлик излениўшилик» атамасы менен 124 беттен ибарат болып, «Билим» баспасынан 1992-жылы басылып шықты. Бул мийнетинде 1980-жыллардағы қарақалпақ лирикасының раўажланыўындағы өзиншеликлер, лирикада форма саласындағы излениўшиликлер усаған мәселелерди изертлеп, лирика жанры бойынша қәлем тербетип атырған шайырлар дөретиўшилигиндеги жаңа сапалық изленислерди ашып көрсетеди. Бул шайырлардың поэма, баллада, лирикалық қосыкларды дөретиўдеги шеберликлери алым тәрепинен терең изертленген. Усы монографияда И.Юсупов, Т.Мәтмуратов, Ж.Избасқанов, Б.Генжемуратов, Х.Дәўлетназаров, С.Ибрагимов хәм басқа да шайырлардың лирикасынан көркем текстлер мысал етип алынып, оларға филологиялық таллаў жасап, форма жасаўдағы өзиншеликлери дурыс ашып көрсетилген. Илимпаздың бул мийнети бүгинги ғәрезсизлик дәўирдеги жас изертлеўшилердиң қолынан түспес бахалы илимий теориялық мийнетке айналды. [3].

1990-жылларда қарақалпақ әдебияттаныў илиминде арнаўлы изертлеўди талап етип турған мәселелердиң бири-қарақалпақ лирикасында көркем форманы тутас изертлеў машқаласы болды. Бул илимий теориялық машқаланы әдебиятшы Қ.Оразымбетов табыслы изертлеп, өзиниң «Хәзирги қарақалпақ лирикасында көркем формалардың эволюциясы хәм типологиясы» монографиясын «Билим» 
баспасынан 2004-жылы көп нусқада бастырып шығарды. Алымның бул мийнети бойынша әдебиятшылар Ә.Пахратдинов, Қ.Жәримбетов, П.Нуржанов, Қ.Юсупов х.т. басқалар тәрепинен унамлы сын пикирлер билдирилди. Белгили алымның бул изертлеў жумысына шекем XX әсир қарақалпақ поэзиясы, соның ишинде лирика идеялық-тематикалық, жанрдың өсип раўажланыўының тарийхый хронологиялық бағыты, лирикалық қахарман, әдебий портрет, айырым формалық белгилер, әдебий байланыслар бағдарында изертленген. [4]. Тек қосық теориясы бойынша арнаўлы изертлеўшилердиң бири Қ.Муратбаевтиң монографиясында бул мәселе сол дәўир көз қарасы менен айтылған еди. Ал, профессор Қ.Оразымбетовтың монографиясында лирикада көркем формаларды таллаўдың теориялық мазмун бирлиги, жәхән халықлар поэзиясындағы көркем формалардың қарақалпақ лирикасында көриниси, хәзирги қарақалпақ лирикасында әдебий тәсир мәселелери, шығыс көркем формалардың қарақалпақ лирикасында сыяқлы теориялық мәселелери илимий филологиялық бағдарда тереңнен изертленген. Изертлеу барысында қарақалпақ лирикасындағы бул мәселелерди ашып бериў мақсетинде И.Юсупов, Т.Мәтмуратов, К.Каримов, Ж.Избасқанов, Х.Дәўлетназаров, О.Сәтбаев, Б.Генжемуратов, С.Ибрагимов хәм басқа да шайырлардың лирикалық қосықларынан алынған көркем текстлерге илимий филологиялық таллаў жасалған. Теориялық пикирлерин тереңлестирип, рус, өзбек, қазақ, қырғыз, түркмен алымларының көркем форма хаққында билдирген пикирлерине сын көз қарасын билдирген.

Белгили илимпаздың бул мийнетинде хәзирги қарақалпақ лирикасында косық қурылысы хәм оның типологиясы терең изертленип, қосық қурылысының гейпара мәселелери, уйқас хәм оның түрлериниң мазмунға қатнасы, бәнт хәм оның түрлери усаған қосық теориясы бойынша мәселелер анық мысаллар арқалы дәлилленген. Усы мийнетте және бир әхмийетли теориялық проблема яғный лирикалық топлам - бул айрықша көркем форма сыпатында изертленип, бунда лирикалық топламларды дүзиўдиң теориялық тийкарлары, И.Юсуповтың «Дузлы самаллар» топламына әдебий теориялық талқы сыяқлы теориялық мәселелер дәлиллеп көрсетиледи. Қарақалпақ поэзиясында топлам дүзиўдиң үш түри атап өтиледи. Сондай-ақ лирикалық топламның өзиншеликлери хәм оны дүзиўдиң принциплери дурыс дәлилленген.

1990-жыллардан баслап улыўма орта билим бериў мектеплери, кәсип өнер коллеж хәм академиялық лицей оқыўшылары ушын сапалы оқыў бағдарламаларын хәм сабақлықларын ислеп шығыў - бул методист алымлардың алдындағы баслы ўазыйпалардың бири. Сонлықтан методист - алымлар А.Пахратдинов, Қ.Камалов, К.Мәмбетов, Қ.Жәримбетов, К.Алламбергенов, Қ.Оразымбетов, Қ.Юсупов, М.Бекбергенова, К.Палымбетов хәм 3.Бекбергеновалар тәрепинен мәмлекетлик билимлендириў стандартының талабына муўапық жазылған мектеп, кәсип өнер коллежи, академиялық лицей оқыўшылары хәм жоқары оқыў орынлары студентлери ушын әдебият бағдарламалары хәм сабақлықлары баспадан жәрияланды. [5].

Профессор Қуўанышбай Оразымбетовтың орта хәм жоқары оқыў орынларына арналған сабақлықлары 2006, 2010, 2018-жыллары мәмлекетлик баспалардан жан күйерлик пенен сапалы түрде шығарылды. Демек, атақлы алым 
тек әдебияттаныў илимине салмақлы үлес қосып қоймастан, белгили методист сыпатында 2006-жылы «Билим» баспасынан (проф. Қ. Жәримбетов пенен биргеликте) кәсип-өнер колледжлер оқыўшылары ушын сабақлығын баспадан шығарды. Алымлар қарақалпақ әдебияты бойынша бағдарламаға тийисли материалларды қайта ислеп, педагогикалық хәм методикалық жақтан дөретиўшилик пенен қатнас жасап, мәмлекетлик билимлендириў стандартларының талапларына муўапық сабақлықты сапалы ислеп шықты. [5].

Бул сабақлықта қарақалпақ фолклоры, қарақалпақ жазба әдебияты дәреклери, X1V-X1X әсирдиң ақыры XX әсирдиң басындағы қарақалпақ әдебияты, хәзирги қарақалпақ әдебиятына байланыслы дидактикалық материаллар берилген. Авторлар дәўирлерди бөлип, сол дәўирлерге байланыслы материалларды орынлы пайдаланып, сабақлыққа тийисли материалларды дидактикалық жақтан таллап киргизген. Сол сыяқлы Қ.Оразымбетов XX әсир хәм ғәрезсизлик дәўирдеги қарақалпақ әдебиятына байланыслы материалларды саралап, белгили шайыр-жазыўшылардың дөретиўшилигин әдебий портрет сыпатында киргизген. Мәселен, сабақлықта XX әсир қарақалпақ әдебиятының тийкарғы өзиншеликлери, 1920-40-жыллардағы қарақалпақ поэзиясы хәм оның тийкарғы бағдарлары, драматургия, проза, екинши дүнья жүзилик урыс дәўириндеги қарақалпақ әдебияты, 1960-80-жыллардағы қарақалпақ әдебияты бойынша материаллар орын алған. А.Дабылов, Ж.Аймурзаев, К.Султанов, И.Юсупов, Т.Қайыпбергеновлерге әдебий портрет берип, ғәрезсизлик дәўирдеги қарақалпақ әдебияты бойынша материалларға кең дидактикалық таллаў жасаған. Сабақлыққа 60 тест сораўларын берген. Методист-алым сабақлықтағы материалларды бағдарлама тийкарында ықшамластырып бериўи оқыўшылар ушын пайдалы. Өйткени кәсип-өнер колледж оқыўшылары академиялық лицейдиң оқыўшыларындай материалларды тереңлестирип үйренбейди. Олар әдебият бойынша материалларды шолыў лекциялары бойынша тек 1-курсында ғана үйренип шығады. Усы көз қарастан қарағанда сабақлық авторлары материалларды дурыс хәм ықшам берген..

2010-жылы усы авторлардың және де «Билим» баспасынан кәсип өнер колледж оқыўшыларына арналған әдебият сабақлығы шығарылды. Бул сабақлықтың жазылыў тарийхына итибар берсек, оның әхмийетли тәреплери бар. Авторлар фольклордан баслап ғәрезсизлик дәўири қарақалпақ әдебиятына шекемги материалларды дөретиўшилик пенен қайта исленди. Сабақлыққа киргизилген материаллар дидактикалық көз қарастан көп жаңалықларға ийе. Ондағы берилген материаллар бүгинги күн талапларына толық жуўап береди. Автордың бул сабақлығының мазмуны хәм уазыйпалары, бағдарламадағы материалларды изертлениў принциплери 2006-жылы шығарылған «Қарақалпақ әдебияты» сабақлығы менен салыстырғанда түп тийкарынан парқ қылады. Өйткени, соңғы сабақлығы кәсип өнер колледжлеринде билимди басқа тиллерде алып барылатуғын топарлар ушын арналған. Сонлықтан болса керек, сабақлық тарийхый хронологиялық принциплерде дүзилип, материалларды илимий жақтан тереңирек таллаўдан гөре хрестоматиялық бағдар басым болған, жазыўшылардың дөретиўшилигине таллаў жасап, олардың шығармаларынан үзинди келтирип өткен. Әдебият сабақлығы бойынша материаллар қызықлы етип 
берилип, монографиялық хәм хронологиялық принциплерде дүзилген. Екиншиден, сабақлықта берилген материалларды таллаўға дыққатты қаратып, сабақлыққа киргизилген әдебий материаллар түсиникли хәм мазмунлы жазылған.Үшиншиден, сабақлықтағы XX әсирдеги қарақалпақ әдебияты бойынша киргизилген әдебий материаллар дөретиўшилик пенен қайта исленип, бүгинги жаслардың тәрбиясына тәсир ететуғын дәрежеде талланған. [6].

Профессор Қ.Оразымбетов Қарақалпақ филология факультети әдебият теориясы хәм оқытыў методикасы кафедрасының профессоры сыпатында 1-курс студентлерине «Әдебият таныўға кирисиў», 1V курс студентлерине «Қарақалпақ поэзиясында қосық курылысы», 1-курс магистрантларына «Қосық теориясы» пәнлеринен жаңа педагогикалық технологиялық талапларына сай мазмунлы хәм тәсирли лекциялар оқыйды. Оның хәр бир лекциясы жаслар ушын тәрбиялық әхмийети басым, теориялық мағлыўматларға бай хәм студентлер ушын қызықлы лекция болып есапланады. Хәрқандай алым өз шәкиртлери менен мақтаныш етеди хәм абырайы бийик шыңларға көтерилип, жүзи жарқын болады. Усы көз қарастан атақлы алымның тиккелей илимий басшылығында кандидатлық хәм докторлық жумысларын табыслы жақлаған шәкиртлеринен Аманжол Аяпов, филология илимлериниң докторы Огулай Галиева, қарақалпақ әдебияты бойынша философия илимлериниң докторы $(\mathrm{PhD})$ Қабыл Мәмбетов, филология илимлериниң кандидатлары Досымбетова Абадан, Аймырза Алламбергенов, филология илимлери бойынша философия докторлары Әдил Сейтбеков, Қабыл Мәмбетов, Зухра Алламуратоваларды атап өтсек мақсетке муўапық болады.

Хәзирги күнде көрнекли алым қарақалпақ әдебияты кафедрасындағы профессор-оқытыўшылар хәм әдебиятшылар Қ.Жәримбетов, Б.Генжемуратов, П.Нуржанов, Қ.Юсупов, Ж.Низаматдинов, П.Алламбергенова, Қ.Турдыбаев, Ж.Сагидуллаева, Ж.Қаниязова, И.Мәмбетов, И.Алламбергеновалар менен бирге дөретиўшилик бағдарда ислесип, илимге мол табыслар киргизип атыр.

Профессор Қуўанышбай Оразымбетов көп жыллық тәжирийбелерине сүйене отырып жоқары оқыў орны студентлери ушын «Қосық теориясы» атамасындағы оқыў қолланбасын ислеп шықты. Алымның бул методикалық талапларға ылайықлы жазылған оқыў қоланбасы 2010-жылы Ташкент қаласындағы «Әлишер Наўайы атындағы, Өзбекстан Миллий китапханасы» баспасынан басылып шығарылды. [7]. Бул оқыў қолланбада әдебият теориясының бир бөлими болған қосық теориясы үйрениледи. Студентлерге қосық қурылысы тараўында қолланатуғын атамалар хаққында түсиник бериледи. Ырғақ уйқас, өлшем, буўын, бәнт сыяқлы қосық қурылысының элементлери теориялық жақтан сыпатланады. Бул ушын қарақалпақ поэзиясы, үлгилеринен тийисли мысаллар келтирип талқыланады.Теориялық база сыпатында хәзирги әдебияттаныў илими жетискенликлери пайдаланылады. Бул оқыў қолланба көп жаңалықларға ийе. Бириншиден, бул қолланбада материаллар дурыс түсиникли хәм илимий жақтан дәлилленген. Оның мазмуны: кирисиў, ырғақ, уйқас хәм оның түрлери, уйқастың мазмунға қатнасы, өлшем хаққында түсиник, бәнт хәм оның түрлери сыяқлы темадан ибарат. Хәр бир темаға түсиникли етип жоба дүзилген, темалар бойынша сораўлар хәм тапсырмалар берилген. Сондай-ақ, қандай теориялық әдебиятлардан пайдаланыў кереклиги хаққында мағлыўматлар киргизилген. 
Екиншиден, бул оқыў қолланба қосық теориясы бойынша биринши мәрте исленип шығылған. Сонлықтан мийнетте көп теориялық жаңалықлар хәм жетискенликлер бар. Үшиншиден, автор бул қолланбаға ғәрезсизлик дәўирдеги шайырлардың лирикалық қосықларынан мысаллар келтирип, теориялық мағлыўматларды әмелиятта дәлиллеп көрсеткен. Бурын айтылмай жүрген қосық теориясы бойынша терминлер орынлы ислетилген. Бул терминлерди дәлиллеў мақсетинде бир неше көркем текстлерден мысаллар келтирип, оларға филологиялық таллаў ислеген.

Улыўмаластырып айтқанда филология илимлериниң докторы, профессор Қуўанышбай Оразымбетов қарақалпақ әдебияттаныў илимине хәм билимлендириў тараўына салмақлы және де бахалы мийнетлери менен үлес қосып киятыр. Көрнекли алымның илимий тоериялық хәм методикалық изертлеў жумыслары ғәрезсизлик дәўирдеги жасларды илимий теориялық жақтан жетик инсан етип тәрбиялаўда үлкен әхмийетке ийе.

\section{Список литературы:}

1. Юсупов К.А. Методика преподавания каракалпакской литературы. Ташкент: Сано-стандарт, 2018. Стр.336.

2. Юсупов К.А Методика преподавания каракалпакской литературы в академических лицеях. (монография). - Нукус: Каракалпакстан, 2019. -Стр. 112

3. Оразымбетов Қ.К. Творческий поиск в современной Каракалпакской лирике (80-ые годы). Нукус: Билим, 1992, стр.120

4. Оразымбетов Қ.К. Хазирги қарақалпақ лирикасында көркем формалардың эволюциясы хәм типологиясы. Нөкис: Билим, 2004, стр.186

5.Оразымбетов Қ.К., Жаримбетов Қ.Қ. Қарақалпақ әдебияты. Нөкис: Билим, 2006, стр. 207

6.Оразымбетов Қ.К., Жаримбетов Қ.Қ. Қарақалпақ әдебияты. Нөкис: Билим, 2010, стр. 178

7. Оразымбетов Қ.К. Қосық теориясы. - Ташкент: Әлишер Наўайы атындағы, Өзбекстан Миллий китапханасы, 2010. 


\title{
ПСИХОЛОГІЧНІ БАР'СРИ У КАР'СРНОМУ ЗРОСТАННІ СУЧАСНИХ УКРАЇНСЬКИХ ЖІНОК
}

\author{
Бередіна О.В. \\ студентка кафедри психології, \\ Приватне Акціонерне Товариство «ВНЗ \\ «Міжрегіональна Академія Управління Персоналом» \\ Харківський інститут, \\ м. Харків, Україна
}

Ділова жінка в Україні - явище одночасно звичне та нове. Науково-технічний прогрес потягнув за собою професіоналізацію виробництва. Ділові чоловіки та ділові жінки поспішали набути вищий освітній рівень - диплом про закінчення вишу, а згодом й науковий ступінь.

Соціальна група ділових жінок за своїм складом стала ширше. В її структурі значущими стають групи жінок-професіоналів та жінок-державних службовців, кожна з яких має свої особливості, свій особистісний тип.

Дослідники вважають, що «керування - це мистецтво, в основі якого лежать спеціальні вроджені здібності» [1, с. 9]. У жінок $є$ потенціал для керівних позицій, але до цього висновку прийшли порівняно нещодавно. Жінкам Європи та США вдалося подолати психологічний бар'єр, і вони продемонстрували діловий потенціал у повну міру. Жінки-керівники цих урядів наочно демонструють масштаб подолання.

Жінка в Україні, не зважаючи на більш ніж столітній період затвердження гендерної рівності, залишається у полоні традиційних стереотипів про вторинну цінність ділової кар'єри та продовжує перебувати в обмеженнях такої кар'єри.

«Ці стереотипи засновані на фізіологічних і психологічних особливостях жінок, деякі з них багато в чому перебільшені, мають характер упереджень»[2].

Рухатися вперед жінкам заважають внутрішні психологічні бар'єри та закладені в дитинстві цінності, які нерідко визначають вибір не на користь кар'єрних амбіцій. «Насамперед слід зазначити, що у жінок недостатньо виражена ділова спрямованість, їм властива орієнтація на сім'ю» [3, с. 45]. Жінки часто не усвідомлюють можливості однаково успішно поєднувати кар'єру і домашні обов'язки.

У жінок спостерігається важливий феномен - розмови про перешкоди $\mathrm{i}$ бар'єри на шляху жіночої кар'єри нерідко використовуються в якості виправдання. Набагато легше сказати, що “так склалося життя”, ніж визнати, що відмова від підвищення була викликана особистими побоюваннями або просто небажанням рухатися по кар'єрних сходах. Злам окресленого стереотипу потрібен як для суспільства, так і для самої жінки. 
Психологія ділової жінки в минулому була сформована пануванням державної форми власності, що вимагало від працівника сумлінності, працьовитості, необхідного рівня освіти і залишає непотрібними ті здатності людини, які визначають особистий успіх. I сьогодні, в нашій країні, коли соціально-економічна ситуація змінилася, жінка продовжує дотримуватися сформованих установок в системі ціннісних орієнтацій. Жінка не готова піти в управління: їй заважає, в більшій мірі, іiі власна психологія, а ні недолік спеціальних знань.

В Україні соціальна група «жінки-керівники» знаходиться на етапі становлення. Її представниці виконують випробувальну функцію, що природно пов'язана $з$ труднощами й небезпекою невідомого шляху. Але випробувальна функція необхідна для соціального руху суспільства в цілому та його жіночої частини.

Це взаємообумовлені процеси обох сторін: суспільство і держава "отримує” громадян, які беруть активну участь у всіх сферах життя, які прагнуть до рівноправності, а жінка навчається поєднувати в собі лідерські якості та роль берегині домашнього вогнища.

Одним з напрямків цього процесу стає дослідження соціально-психологічних бар'єрів на шляху побудови кар'єри, які заважають жінкам ставати керівниками. Такі бар'єри бувають як зовнішні, так і внутрішні.

До зовнішніх відносять ті фактори, що не залежать від жінки та заважають їй зробити кар'єру. До таких відносяться наступні ключові бар'єри:

• близьке оточення / сім'я, здатні “придушити” прагнення жінки будувати кар'єру;

- існуючі негативні стереотипи щодо «жінки-керівника».

До внутрішніх бар'єрів відносяться ті, що перешкоджають кар'єрі жінок:

- недооцінка свого лідерського потенціалу та відсутність віри в успіх;

- невміння правильно подати себе при просуванні вгору по кар'єрних сходах.

Як показують дослідження, жінки самі не завжди готові боротися зі стереотипами, які нав'язує їм суспільство, внаслідок чого відмовляються від активного прагнення просуватися по службі. В результаті, по-справжньому успішними лідерами стають лише ті жінки, які більшою мірою готові до цих перешкод і труднощів.

Мабуть, нове покоління жінок, соціалізується в інших історичних умовах, долає “стереотипи матерів".

Практичні висновки 3 проведеного дослідження стають основою для розробки психологічних рекомендацій до вирішення проблеми українських жінок у керівництві. 
Список літератури:

1. Козлов В.В. Психология управления: учебник для студ. Высш. Учебн. Заведений / В.В. Козлов, Г.М. Майнулов, Н.П. Фетискин. - 2-е изд., доп. - М.: Издательский центр «Академия», 2013. — 240 с.

2. Удовиченко О.А. Психологические особенности женщины-руководителя в правоохранительной деятельности // Правопорядок: история, теория, практика. 2017. - №3(14). - c. 81-90. URL: https://cyberleninka.ru/article/n/psihologicheskieosobennosti-zhenschiny-rukovoditelya-v-pravoohranitelnoy-deyatelnosti

3. Мельник Л.П. Психологія управління: Курс лекцій. - 2-ге вид., стереотип. — К.: МАУП, 2002. — 176 c. 


\section{ОСОБЛИВОСТІ КОНСТРУКТИВНОГО ВИРІШЕННЯ КОНФЛІКТУ МІЖ ВЧИТЕЛЯМИ ТА ПІДЛІТКАМИ}

Кавиліна Ганна Костянтинівна, к.П.н, викладач Південноукраїнський національний педагогічний університет імені К.Д.Ушинського, Одеса

Kavylina Ganna, $\mathrm{Ph}$

South Ukrainian National Pedagogical University named after K.D.Ushynsky, Odessa

Основне джерело знань про конфлікти є практичний досвід, що являє собою накопичення протягом життя, які передаються із покоління в покоління принципи поведінки. Науковці розглядають конфлікт як складну структуру, де передує певна (конфліктна) ситуація, що має значення для розуміння його сутності [4].

В науці виділяють два основні підходи до вивчення конфліктів: соціологічний і психологічний, кожен 3 яких має своє розуміння виникнення, протікання і вирішення конфліктів.

Так, соціологічний підхід досліджує конфлікт між суспільством і особистістю. Соціологи розглядають конфлікт як природне явище «стан норми», тому виходячи з цих позицій, конфлікти неможливо вирішити, а слід говорити про їх регулюванні. Для цього в демократичних суспільствах $€$

відповідні соціальні інститути.

У психологічному підході центром дослідження є внутрішній світ людини. Велика увага приділяється мотивам і причин їх зіткнення, що призводить до особистісних конфліктів

В основі психологічного підходу лежить принцип конструктивного вирішення конфліктів: дозвіл особистісних конфліктів сприяє розвитку самої особистості, розкриття іiі творчого потенціалу; позитивне вирішення міжособистісних конфліктів $є$ вихід на новий рівень розуміння інших, побудови 3 іншими людьми якісно нових відношень.

Нажаль, сьогодні, заклади середньої освіти зазнають впливу негативних наслідків справжньої суспільної ситуації. У зв'язку з цим виникає проблема не тільки психологічної готовності вчителя конструктивно вирішувати конфліктні ситуації, привнесені в школу ззовні, а й його вміння формувати у підлітків навички вдалого розв'язання конфліктів в майбутньому житті. Навчальна діяльність являє собою складну багатозначну систему, де іï цілі і шляхи їх досягнення сприймаються вчителем і підлітками по різному. 
Підлітки знаходяться на відповідальному етапі входження в самостійне життя. У спілкуванні з вчителями розширюються соціальні межі сприйняття, $\mathrm{i}$ накопичується досвід суспільних відносин. Значному числу учнів старших класів характерна готовність до спілкування 3 вчителем на новому, особистісному рівні. Однак вчитель, часом, не готовий реформувати свої погляди i, отже, не в змозі вийти на вищий рівень спілкування з підлітком. Це впливає на виникнення широкого спектру конфліктних ситуацій у навчальній діяльності [6,7].

Проблема конфліктної поведінки особистості займало філософів 3 найдавніших часів. Період Середньовіччя представляв внутрішній світ людини як поле брання між добром і злом, спокусами плоті і прагненню до чеснот. Філософія Нового часу стала оцінювати можливість душевного світу як обов'язкову структурну характеристику особистості. Так у Дюркгейма основою особистісного конфлікту $є$ подвійність свідомості громадського та особистісного. У Н. Смелсера - це проблема вибору при вирішенні будь-яких життєвих завдань. Близьке розуміння висловлює Парсонс, його «особистісний конфлікт» являє собою вибір різних соціально значущих вчинків. Німецький філософ Георг Зіммель уявляв особистість із заданим способом бачення. I, відповідно до цих форм, людина конструює різні "світи" культури: релігію, філософію, науку, мистецтво і т.д. Кожен з цих світів має свою внутрішню організацію, свою унікальну логіку. А оскільки індивід завжди живе в кількох світах, то ця множинність станів і $€$ джерелом глибинних внутрішніх конфліктів.

Конфлікти вчителя 3 підлітками в процесі навчальної діяльності відбувається на певному тлі соціально-психологічного клімату класу, який значно впливає на характер розвитку конфлікту. У психолого-педагогічній літературі зазначається складність і своєрідність формування психологічного клімату класу.

3 позиції групи конфлікт - це специфічні «організаційні дії»суб'єктів, залежні від стану цієї групи, тобто, від ії організованості. Чим нижче організованість групи, тим більше в ній ймовірності таких організаційних дій, які проявляються як конфлікт в умовах навчальної діяльності. У даних ситуаціях виникає небезпека переходу конфлікту з системи «вчитель - учень» в систему «вчитель - група».

Аналіз педагогічної діяльності вчителя $[1,5]$ показує, що сучасний педагог слабо підготовлений до сприйняття, реагування, використання конфліктів і як вираз в сучасному житті соціальної

динаміки, і як вираз суперечливості педагогічного процесу, У професійній підготовці вчителя, на наш погляд, сьогодні недостатньо приділяється уваги науковому підходу в розумінні конфлікту, що виникає в педагогічному процесі. Домінуючим залишається буденний погляд на конфлікт як на небажане явище.

Наукове розуміння конфлікту дає можливість вчителю бачити його початок - конфліктну ситуацію, прогнозувати ії розвиток в конструктивний або деструктивний конфлікт. Йти i конструювати перші i запобігати другі, переводити їх в конструктивні. 
Провідними факторами розвитку особистості вчителя $є$ його педагогічна діяльність і педагогічне спілкування. Показником зрілості особистості в педагогічній діяльності є сформованість іiі компонентів (педагогічних завдань, засобів і способів їх вирішення, аналіз і оцінка своєї праці), які визначаються рівнем розвитку певних особистісних якостей. 3 професійно значущих якостей (педагогічне цілепокладання, творче мислення, рефлексія, такт, спрямованість), провідним, на думку науковців, [1, 2] є педагогічна спрямованість, яку в визначають як «стійку домінуючу систему мотивів, що визначає поведінка вчителя і його відношення до професії».

Важливу роль у виникненні конфлікту між вчителем і підлітком грає «смисловий бар'єр». Це поняття визначає явище, при якому підліток добре розуміючи і вміючи виконати завдання вчителя, як би не розуміє цю вимогу $\mathrm{i}$ наполегливо його не виконує. Це поняття було виявлено при вивченні дезадаптованих підлітків, проте ми вважаємо, що явище в тій чи іншій мірі характерно для даного віку в цілому.

Для цього віку характерні конфлікти з вчителями окремих предметів. Так М.М. Рибакова [3] виділяє типові конфлікти з викладачами фізкультури, музики, образотворчого мистецтва. У їх основі лежать дві причини: перша - це місце даних предметів в навчально-виховного процесу в школі та друга - вчителя пред'являють вимоги до учнів без урахування його індивідуальних особливостей.

Особливо слід відзначити факт становлення на тлі навчальної нового типу діяльності спілкування, де визначальною $є$ інтимно-особистісна функція. Розвиток взаємин зі старшими відбувається в двох сферах: ділового спілкування і особистісного. Старший підлітковий вік визначається статевої поляризацією в формах міжособистісної поведінки, відбувається становлення систем соціальних установок; важливе місце в цей період займає професійне самовизначення, коли підліток вперше бере на себе відповідальність за зроблений вибір, це і пора першого кохання.

Нерідко конфліктна ситуація характеризується значним ступенем спотворення і невизначеності, що $є$ однією 3 основних причин переходу іï в конфлікт. Як правило, в такій ситуації конфлікт починають люди із заниженою самооцінкою, заздалегідь прирікають себе на поразку. При нейтральній взаємодії конфліктна ситуація сприймається адекватно. І в цьому випадку є спотворення, але вона визначаються особистісним значенням інформації для конфліктуючих сторін.

Кожна 3 перерахованих характеристик даного віку може стати причиною конфлікту підлітка 3 вчителем. Психологічні особливості старшого підлітка $\epsilon$ об'єктивними причинами конфліктних ситуацій і розвиток їх в конфлікт буде залежати як від особистісних якостей і професіоналізму вчителя, так і від особистості самого підлітка.

\section{Список літератури}

1.Антонова О. Є.,Дубасенюк О. А., Семенюк Т. В. Професійна підготовка майбутнього вчителя до педагогічної діяльності. Житомир. держ. пед. ун-т, Житомир.2003. 
2. Галузяк В. М., Добровольська К. В. Розвиток професійної самосвідомості студентів вищих навчальних закладів: Монографія. Вінниця: ТОВ «НіланЛТД», 2015. $256 \mathrm{c}$.

3. Демченко О. П. Формування у майбутніх учителів початкових класів професійної готовності до створення виховних ситуацій : автореф. дис. ... канд. пед. наук : [спец.] 13.00.04 "Теорія і методика проф. освіти" / Демченко Олена Петрівна; Вінницький держ. пед. ун-т ім. Михайла Коцюбинського. Захищена 7.02.2006. Вінниця, 2006. 22 с

4. Тихомирова С. Б., Постоловський С.Р. Конфліктологія та теорія переговорів: Підручник. Рівне: Перспектива, 2007. 389 с.

5. Постова, С. А. (2007) Проблема конфлікту в професійній діяльності педагога. ВІСНИК Житомирського державного університету імені Івана Франка (31). pp. 155-157.

6. Рудзевич І.Л. Теоретичні аспекти проблеми психологічних особливостей юнацького віку в контексті педагогічних конфліктів. Вісник Кам'янецьПодільського національного університету імені Івана Огієнка. Корекційна педагогіка і психологія / за ред. О.М. Вержиховської, В.І. Співака. Вип. 4. Кам'янець-Подільський: ПП Медобори. 2006, 2013. 252 с.)

7. Штефан Л. А. Становлення та розвиток соціальної педагогіки як науки в Україні (20-90-ті pp. XX ст.) : дис. ... доктора пед. Наук : 13.00.01 / Штефан Людмила Андріївна. X., 2002. 492 с. 


\section{ПСИХОЛОГІЧНІ АСПЕКТИ ІНТЕРНЕТ-ЗАЛЕЖНОСТІ МОЛОДІ}

\section{Ольга Артемова,}

кандидат педагогічних наук, доцент, Рівненський державний гуманітарний університет

Зі зростанням впливу засобів масової інформації, зокрема мережі інтернет, який виступає важливим фактором соціалізації дітей та підлітків, йде незворотній процес захоплення ними мережею настільки, що шкодить здоров'ю. Безперечно, інтернет дуже важливий для самовираження людини, для навчальної діяльності учнів та студентів, але без грамотного користування може нести неабияку небезпеку. Певна категорія користувачів може так захопитися інтернетом, що не зможе контролювати себе, оперування його ресурсами забиратиме все більше часу та стане настільки домінуючим, що не вистачить сили волі контролювати власну активність у віртуальному просторі, виникне проблема особистісного та соціального дисбалансу, порушення гармонійних стосунків, відбудеться соціальна дезадаптація, виникнуть труднощі у комунікативній та навчальній сферах. Тобто виникне інтернет-залежність, небезпечний вид психологічної залежності від віртуального інформаційного середовища.

Проблема інтернет-залежності $є$ актуальною, бо вона згубно впливає на особистість, спричиняє руйнування стосунків у сім’ї, соціальних зв'язків, призводить до особистісних деформацій, виникнення адиктивної поведінки.

Дана проблема турбує вітчизняних вчених (О.Ю.Дроздов, О.В.Камінська, Т.В.Карабін, В.А.Лоскутова, Л.М.Юр'єва), звернено увагу та те, що підлітки складають більшість користувачів інтернету і надмірне захоплення інтернетом у цьому віці $\epsilon$ особливо небезпечним. Дослідження особливостей інтернетзалежності, іiі подолання та профілактика $є$ важливим завданням для психологів та педагогів.

Сучасне навчання тісно пов'язане із інтернетом, а молоді притаманні і так важливі різні типи взаємодії 3 інтернет-простором. Саме в молодіжному середовищі надмірна захопленість інтернетом є особливо небезпечною, оскільки особистість ще не до кінця сформована, нерозвинені механізми психологічного захисту. Молоді люди сприймають мережу як джерело самовизначення, реалізації фрустрованих потреб та самоствердження. Але без відповідного вольового контролю над власною активністю у віртуальному просторі, без розуміння того, що потрібно грамотно використовувати інтернет, можна потрапити в інтернет-залежність.

Інтернет-залежність - аномальний потяг до проведення часу в мережі інтернет, який характеризується відчуттям постійної потреби в предметі залежності, або для одержання ефекту, зв’язаного з його застосуванням, або для 
зняття негативних відчуттів, зв'язаних з тривалою відсутністю певних дій [1, 217]. Аномалія в даному випадку проявляється у нав'язливому бажанні проводити час за комп'ютером і неспроможності вчасно зупинитися.

О.В.Камінська зауважує, що небезпечність формування інтернет-залежності зумовлена неадекватним сприйняттям інтернету, використання якого перетворюється на самоціль, відсутністю культури користування інтернетом, недостатнім запровадженням психопрофілактичних заходів, спрямованих на попередження виникнення інтернет-адикції $[2,5]$.

X.I. Турецька звертає увагу на особистісну ідентичність осіб, схильних до інтернет-залежності. Від характеру людини, від його сили, визначеності, вольових якостей залежить стійкість, вміння самостійно керувати процесом взаємодії. А такі риси як тривожність, підвищена образливість, вразливість, низька самооцінка, низька стресостійкість, схильність до депресії, втеча від проблем сприяють формуванню залежності $[3,15]$. Люди, які страждають інтернет- залежністю, не вміють будувати стосунки з протилежною статтю та 3 соціумом в цілому, бояться виступати перед аудиторією, погано контактують 3 людьми. Шукаючи безпечніший, опосередкований спосіб взаємодії із оточенням, відчуваючи складнощі в контактах з близькими та друзями, у вираженні емоцій, індивід намагається уникати виходу із зони комфорту. Інтернет-середовище слугує таким собі засобом самозахисту від поганого настрою, почуття болю і приниження. Залежні від комп'ютера та інтернету часто відчувають нестачу взаєморозуміння 3 боку близьких людей, почуваються самотніми, що і викликає в свою чергу емоційну напруженість $\mathrm{i}$ тривожність.

Отже, психологічні аспекти інтернет-залежності потрібно вивчати, обговорювати з метою iї попередження, профілактики, бо подолати цю проблему можна, але набагато важче. Психологам і педагогам потрібно працювати над визначенням і врахуванням психологічних чинників, самооцінки, суб'єктивного відчуття самотності, комунікативних здібностей, акцентуацій характеру кожного учня. Також активно працювати з батьками в цьому напрямку, оскільки важливі i мікросоціальні чинники виникнення інтернет-залежності, а саме: стиль сімейного виховання, психологічні труднощі та ускладнення спілкування 3 найближчим соціальним оточенням Навчити грамотному i безпечному використанню інтернету - важливе завдання сьогодення.

Список літератури

1. Вінтюк Ю. Узалежнення від комп'ютера: формування і можливості протидії / Ю. Вінтюк // Вісник Львівського університету. Серія філософські науки [Текст] / [М-во освіти і науки України, Львів. нац. ун-т ім. Івана Франка] ; [редкол.: В. Мельник, А. Карась, Л. Рижак та ін.]. - Л. : ЛНУ ім. І. Франка, 2010. Вип. 13. - С. 215-226.

2. Камінська О. В. Психологія інтернет-залежності: Монографія / О. В. Камінська. - Житомир : Вид-во ЖДУ ім. І. Франка, 2015. - 340 с. 
III International Science Conference on E-Learning and Education

3. Турецька X. I. Особистісна ідентичність схильних до інтернетзалежності осіб: автореф. дис. ... канд. психолог. наук: 19.00.05 - соц. психологія; психологія соц. роботи / Х. І. Турецька. - К., 2011. - 20 с. 


\title{
РЕЗУЛЬТАТИ ДОСЛІДЖЕННЯ ОСОБЛИВОСТЕЙ ДЕЦЕНТРАЦІЇ ОСІБ ЮНАЦЬОГО ВІКУ
}

\author{
Шпортун Оксана Миколаївна, \\ доктор психологічних наук, професор кафедри психології \\ КЗВО «Вінницька академія безперервної освіти»
}

\section{Пачевська Антоніна Павлівна, студентка СО Магістр} Донецького національного університету імені Василя Стуса

Проблема вивчення децентрації і є однією з найбільш актуальних в сучасній психології особистості. В останні роки зростає інтерес до вивчення та дослідження даного феномену. Сучасне суспільство вимагає від особистості своє власної позиції та думки, вмінню будувати стосунки з людьми, які нас оточують, але важливим $є$ також вміти сприймати та розуміти думки, ідеї, пропозиції своїх партнерів по спілкуванню.

У процесі дослідження психологічних особливостей децентрації у осіб юнацького віку, ми отримали наступні результати. За методикою «Шкала емоційного відгуку» (А. Меграбяна і Н. Епштейна) було виявлено, що 1,4 \% мають дуже низький рівень емпатійності. Тобто, у таких студентів емпатійність не розвинена, для них особливо важко першими починати розмову, також важкими є контакти 3 дітьми та людьми, які є старшими. Дуже часто відчувають себе незручно і в міжособистісному спілкуванні, не знаходять взаємного розуміння з оточуючими. Дана категорія людей у діяльності занадто зосереджені на собі, тому важко працювати в команді з іншими, з іронією ставляться до сентиментальних проявів; дуже чуттєві до критики, яка спрямована їхню адресу. Низький рівень емпатійності має 3,1 \% студентів. Такі особистості мають певні труднощі у встановленні та налагодженні стосунків з іншими людьми, незручно себе відчувають у великих та шумних компаніях; прояви емоцій у вчинках людей іноді їм не є зрозумілими, а іноді здаються зовсім позбавлені сенсу. Вони надають перевагу індивідуальні роботі, працювати одним, ніж роботі з іншими людьми, $є$ прихильниками точних формулювань і раціональних рішень. Частіше за все, такі люди мають друзів, але й тих що мають, вони цінують більше за схожість інтересів, інтелект, або ж за інші критерії, але не за їх емоційність та чуттєвість. Середній рівень емпатійності (нормальний) мають 13,8 \% досліджуваних. Тобто, люди, які оточують таких досліджуваних не можуть сказати про них, шо вони не відчувають інших, але і дуже чуттєвими також назвати їх не можна. У стосунках з іншими більше оцінюють інших за вчинками, ніж довіряють своїм відчуттям. Власні емоції та їх прояв намагаються тримати під контролем, щоб не показувати їх оточуючим. Надають перевагу не висловлювати власну точку зору, якщо не впевнені в тому, що ії зрозуміють та приймуть. При читанні художніх творів і перегляді кінофільмів частіше стежать за розвитком дій та подіями, ніж за почуттями та емоціями героїв. Високу 
емпатійність мають 78,8 \% досліджуваних. Тобто, більшість студентів співчутливі до проблем людей, які їх оточуюють, сприйнятливі, здібні багато чого прощати іншим; з великими інтересом ставитеся до людей, дуже емоційні, їм подобається заводити нові знайомства та вони себе комфортно відчувають у таких ситуаціях. Оточуючим подобаються такі люди, до них завжди можна звернутись та інші впевнені, що їх емоції та почуття у проблемних та інших ситуаціях будуть зрозумілі. Таким студентам не подобаються конфліктні ситуації, тому намагаються не доводити справу до конфлікту. Якщо ж стався конфлікт, то будуть шукати компроміс. Адекватно сприймають критику на свою адресу. В оцінці подій більше довіряють своїм почуттям. Дуже високу емпатійність мають 3,0 \% студентів. Тобто, у таких студентів на високу рівні розвинене співпереживання. У стосунках та спілкуванні з іншими вони дуже чуттєві, йому реагують на емоційні прояви та почуття людей, навіть якщо інші нічого не кажуть. До таких досліджуваних охоче йдуть за порадами. Дуже часто у таких студентів притаманне переживання за рідних та близьких їм людей. Особистості з дуже високим рівнем емпатійності можуть дуже хвилюватись, якщо їм здається що до них ставляться не справедливо, або від холодного привітання товариша. Така чутливість іноді не дає спокійно відпочивати або засипати досліджуваному, так як в голові завжди прокручують ситуації. В таких випадках досліджувані самі потребують підтримки від інших. За методика «Розуміння приказок» (А. Л. Агєєва та С. В. Заїка), яка спрямована на визначення двох основних властивостей людини бути чи мати, було виявлено, що 6,3 \% досліджуваних мають перший тип «Черепаха». Тобто таким особистостям більше притаманна стратегія ухилення, відступити та не досягти своєї цілі, відмова від участі у командній роботі, один із варіантів цілком незалежної людини. Другий тип «Акула» притаманний 7,9 \% студентам. Тобто, їм хочеться повністю домінувати, так як це стратегія при якій цілі особистості обов'язково повинні бути досягнуті, а конфлікт вирішитися тальки перемогою. Важливим для таких студентів $є$ тільки їхня мета, вони не можуть відступити від власного егоцентризму та у спірній ситуації приймати до уваги точки зору інших людей. Третій тип «Ведмедик» притаманний також 7,9 \% особам юнацького віку. Тобто такі особи намагаються пристосуватись у ситуації, яка склалася, намагаються триматися подалі або не вступати в конфлікт, прагнуть знайти розуміння. У таких досліджуваних присутне бажання бути оціненим і заради цього можуть відмовитися від досягнення власної цілі, успіху. Четвертий тип «Лисиця» мають 27,4 \% досліджуваних. Тобто, їм притаманна схильність до компромісу. Досліджувані з хитрістю та прорахуванням підходять до вирішення ситуації. Вони цінують хороші стосунки з іншими, і намагаються їх такими залишати. При таких відносинах досягають реалізації своєї мети та цілей. П'яти тип «Сова» мають 50,5 \% осіб. Тобто такі студенти більше спрямовані на співпрацю, вони цінують як цілі, так і стосунки з оточуючими, відверто говорять свою точку зору у роботі з іншими по досягненню цілей, прагнуть відшукати таке рішення, з яким би погодилися усі, щоб ніхто не відчував дискомфорту від прийнятого.

За методикою діагностики міжособистісних відносин (Т. Лірі) було виявлено, що за шкалою «Домінування» 62 \% досліджуваних мають позитивне значення. 
Тобто, такі особи мають прагнення мати перевагу в спілкуванні з іншими, домінувати у стосунках, які вони мають. Вони можуть все в потрібний момент 3 легкістю взяти все під свій контроль. Інші 38 \% студентів мають схильність до підпорядкування, тобто вони можуть легко відмовитись від лідерства, так як не прагнуть до нього, а також і від відповідальності.За шкалою «Дружелюбність» позитивне значення мають 51 \% юнаків. Тобто, вони мають намір встановлювати теплі, щирі стосунки як в спілкуванні, так і співпраці з іншими. Такі люди намагаються завжди оцінювати людей 3 позитивом, брати більше до уваги хороші якості людини, не критикувати за якісь вчинки та слова. Вони відкриті до нових знайомств, до нових емоцій та пригод з друзями. Негативне значення за даною шкалою має 49 \%. Тобто, це персони, які можуть проявити агресивноконкурентну позицію. Їм дуже важко успішно взамодіяти з іншими у командній роботі, спільній діяльності. Їм не подобаються встановлювати нові контакти. Шкала «Авторитарний» має 3 рівні прояву. Перший рівень прояву має $1,8 \%$ студентів. Це диктаторська, владна людина, яка має владолюбний характер, тобто нав'язує іiі іншим. Це категорія людей, які $є$ вольовими, стійкими особистостями, які завжди прагнуть бути лідером у командній роботі. Такі особи завжди хочуть показати як правильно зробити, або научати, звикла довіряти своїй думці, але вміє брати до уваги поради та пропозиції інших. Оточуючі схвалюють цю владність, визнають іï . Другий рівень прояву має $45 \%$ досліджуваних. Це люди, які люблять домінувати, енергійні, компетентні, вони $\epsilon$ авторитетними лідерами, завжди намагаються досягати успіху у справах, люблять давати поради, вимагають до себе поваги. Третій тип прояву має 53,2 \% юнаків. Це впевнені у собі особистості, але не прагне бути лідером лідер, завзята і наполеглива. Шкала «Егоїстичний» має 2 рівні прояву. Всі досліджувані мають другий рівень прояву (100\%). Це особи з егоцентричними рисами, які зазвичай орієнтовані на себе та мають потяг до конкуренції. Перший рівень прояву відсутній серед досліджуваних. Це люди, які прагнуть бути вище за усіх, нарцистичні та не вирішують труднощі, а перекладають на інших. Шкала «Агресивний» має 3 рівні прояву. Перший рівень прояву має 3,3\% юнаків. Це можуть бути жорсткі та недоброзичливі по відношенню до оточуючих особистості, а також різкі, жорсткі, мають велику агресивність, яка може бути асоціальною. Другий тип прояву мають 18,3 \% студентів. Це перебірлива особа, яка чітко може висловлювати свої вимоги, прямолінійна, відверта, сувора і в оцінюванні інших, схильна у всьому звинувачувати оточуючих, іронічна. Третій рівень прояву має 78,4 \% опитуваних. Це впертий та затятий юнак, завзятий, наполегливий, енергійний, рішучий, непохитний, непримиренний.Шкала «Підозрілий» має 3 рівні прояву. Перший рівень прояву має $3,2 \%$ досліджуваних. Це людина, яка відсторонюється від злого та ворожого світу відчужений, запозирливий, сумнівний, уразливий, пашквільний, схильний до сумніву в усьому, пам'ятає все погане та зле, дуже часто всіма та всіма невдоволений. Другий рівень прояву має $16,7 \%$ опитуваних. Це особа, яка $\epsilon$ критичною, нетовариською, має труднощі в становленні стосунків та контактів в силу своєї невпевненості у собі, осуду, думки про погану думка інших, замкнена у собі, критично недовірлива, розчарована в людях, свій настрій на 
негативізм висловлює через вербальну агресію. Третій рівень прояву має 80,1\% юнаків. Це особистості, яка має критичний та занепокоєний погляд до всіх соціальних явищ та людей, які оточують їі.

Шкала «Підпорядкований» має 3 рівні прояву. Перший рівень прояву має $1,6 \%$ осіб. Така персона $\epsilon$ покірною, схильною до самоприниження, слабохарактерною, схильна відмовитись від свого заради інших, , завжди винить себе у всьому, тому ставить себе на останні місця, має схильність винити себе у всьому, інертний, потребує підтримки від інших, часто сильніших за себе. Другий рівень прояву має 23,3 \% студентів. Тобто, вони є сором'язливими, лагідними, легко ніяковіють, схильні підкорятися сильнішому без урахування ситуації. Третій рівень прояву мають 75,1 \% досліджуваних. Тобто, їм притаманна скромність, боязкість, поступливість, емоційна стриманість, здатність до підпорядковування, не мають власної думки, завжди добросовісно виконують свої обов'язки. Шкала «Залежний» має 3 рівні прояву. Першого рівню прояву серед тестованих не виявлено. Другий рівень прояву має $15 \%$ досліджуваних. Цьому рівню відповідають такі характеристики, як слухняність, боягузливість, безпорадність, не здатна проявляти спротив, відстоювати власну думку, завжди вважає що перевага на стороні інших. Третій тип має 85 \% юнаків. Тобто, це люди, які піддаються впливу та тиску, м'які, завжди чекають поміч та порад, довірливі, схильні до захоплення оточуючими, ввічливі.Шкала «Дружелюбний» має 2 рівні прояву. Перший рівень прояву має 23,3\% юнаків. Вони $є$ доброзичливми і люб'язними з оточючими, орієнтовані на інших, прагнуть задовольнити вимоги всіх, притаманні такі психологічні механізми захисту як витіснення та придушення. Другий рівень прояву мають 76,7 \% осіб. Це особи, які здатні співпрацювати з іншими, поступливі в проблемних та конфліктних ситуаціях, намагаються знаходити спільні думки 3 навколишніми, свідомо конформні, дотримуються умовностей, намагаються дотримуватись нормам, правилам «хорошого тону» у стосунках 3 оточуючими, завжди проявляють ініціативу у досягненнях мети у командній роботі, завжди хочуть допомагати, намагаються бути помітними серед оточуючих, компанійські, завжди намагаються підтримувати теплоту і дружелюбність у стосунках. Шкала «Альтруїстичний» має 2 рівні прояву. Перший рівень має $30 \%$ студентів. Даному типу притаманні такі властивості, як відповідальність, часто навіть гіпервідповідальність, здатність відмовитися від своїх інтересів, прагнення допомогти усім, хто цього потребує, емпатійність, часто нав'язливість у своїй допомозі, велика активність до навколишніх, приймає на себе відповідальність за інших. Другий рівень має 70 \% юнаків. Такі опитувані є відповідальні по відношенню до людей, люб'язні, м'які, добрі, вміють проявляти емпатію та симпатію, турботливі, вміють підбадьорити і заспокоїти оточуючих, безкорисливі і чуйні.

За методикою «Міжособистісна діагностика стилю взаємодії» (К. Томаса) були отримані наступні результати. За шкалою «Суперництво» було виявлено 20,9 \% студентів. Тобто такі досліджувані є дуже активними і прагнуть йти до вирішення конфлікту своїм курсом, зазвичай здатні до непохитних та рішучих рішень і термінових дій, прагнуть в першу чергу задовольнити особисті інтереси, 
домогтися результату, який здається їм найкращим, ігнорують інтереси і думки інших людей. Такі особистості можуть залучати інших до вирішення конфлікту, але при умові, що вони не чинитимуть опір тим способам, завдяки яким досягається ціль. Особи, які не згодні з обраною стратегією, часто автоматично стають противниками. Даний стиль використовують особи, які впевнені в правильності обраного рішення і своїй здатності втілити це рішення в життя, наполегливі, послідовні. Зазвичай стиль суперництва застосовується коли результат справи дуже важливий; мають належний авторитет і компетентність для прийняття рішення; необхідно швидко прийняти рішення, i досліджуваний має владу, яка дозволяє йому це зробити і взяти за дане рішення відповідальність; немає іншого вибору; людина перебуває в безвихідній ситуації, яка вимагає швидкого реагування, а навколишні не прагнуть взяти відповідальність на себе. За шкалою «Співпраця» було виявлено 9,3 \% юнаків. Тобто, Особистість, яка обирає даний стиль приймає іншу сторону як рівноправний партнера, розуміє, що обидві сторони мають свої інтереси, тому намагаються вирішити конфлікт, аби задовільнити дві сторони. Зазвичай особистість обирає даний стиль у ситуації коли, розв'язання спірного питання $є$ вагомим для обох сторін та жодна сторона не готова відступати; коли між партнерами існують теплі, довготривалі стосунки 3 іншою стороною, інша сторона піклується про стан та комфорт партнера та про подальші стосунки; конфліктуючі сторони добре знають суть питання і бажання обох сторін, поважають один одного і готові до обміну думками стосовно проблеми та пошуку оптимального рішення, яке задовольняє їх. Саме такі юнаки у конфліктній ситуації надають обом сторонам рівних прав i можливостей, хоча даний стиль вимагає додаткових намагань, дій і витрат часу. За шкалою «Компроміс» було виявлено 41,8 \% осіб. Тобто, студенти готові йти на поступки, при умові, що партнер теж буде поступатися. Кожна сторона зменшує вимоги, поступається, щоб задовольнити інтереси. Зазвичай, досліджувані обирають даний стиль, коли партнери мають рівні права; коли рішення необхідно прийняти швидко та дозволяє уникнути додаткових дій, ресурсів; коли одна із сторін визнає, що іiі інтереси були завищені і готова поступитися; інші способи вирішення питання $є$ неефективними; даний стиль дозволяє зберегти стосунки. Вирішення компромісу відбувається шляхом обговорення та переговорів, врахування думки опонента. За шкалою «Уникнення» було виявлено 15,6 \% студентів. За шкалою «Пристосування» було виявлено 12,4 \% особистостей. Тобто, юнак відмовляється від своїх цілей, своїх інтересів на користь іншої сторони, погоджується 3 нею, не наполягаючи на своєму. Проте потрібно зважати. Що пристосування буває добровільним та примусовим, яке особа вибирає від ситуації в якій опинилась. Зазвичай, даний стиль застосовується коли особа не відчуває хвилювань від ситуації, яка відбувається та виграш для вас не є принциповим; намагання зберегти відносини 3 іншими i тому готові поступитися.За методикою «Визначення рівня егоцентризму» були отримані наступні результати. Дуже низький рівень егоцентризму мають $1,4 \%$ опитаних. Тобто, це може означати, що досліджуваний неправильно зрозумів інструкцію, або може бути наслідком несприйняття або приниженням однолітків або старших людей, що 
спровокувало тенденцію до відмови від своїх цілей і дій на користь інших, щоб не звертати увагу на себе. Низький рівень егоцентризму мають 21,6 \% досліджуваних. Тобто, такі особи не спрямовані на себе, розуміють що інші люди можуть мати іншу думку стосовно якогось питання, вона може кардинально відрізнятися від його. Середній рівень егоцентризму було виявлено у 57,1\% студентів. Тобто, такі юнаки мають гармонійний розвиток. Особистість прагне досягати своєї мети, але без заподіяння школи іншому, враховує та проявляє повагу до інших, до їх переконань, інтересів, діяльності, дій. Високий рівень егоцентризму мають 15,4 \% осіб. Тобто, вони мають власну думку, яку вважають, частіше за все, правильною, не розуміють точок зору оточуючих, висувають високі вимоги, дуже важко встановлюють контакти 3 іншими, вважають, що мають переваги над іншими або просто перебільшують свої здібності, щоб здаватися сильнішими та талановитішими, прагнуть завжди бути у центрі уваги. Дуже високий рівень егоцентризму було виявлено у 4,5 \% юнаків. Тобто, це може свідчити про наявність ситуативної чи постійної акцентуації характеру особистості з прагненням до домінування і влади, можуть бути наявні проблеми з самооцінкою.

\section{Список літератури:}

1. Видра О. Г. Вікова та педагогічна психологія. Навч. посіб. [Електронний ресурс] / О. Г. Видра // Центр учбової літератури. - 2011. - Режим доступу до pecypcy:https://pidruchniki.com/1584072022863/psihologiya/vikova_ta_pedagogich na_psihologiya.

2. Інтегративно-особистісний підхід у психологічній науці та практиці: (монограф.) / Г. Балл, О. Губенко, О. Завгородня та ін.; (за наук. ред. Г. Балла). Кіровоград : Імекс-ЛТД, 2012. - 206 с., с.74 


\title{
INFORMATION TECHNOLOGIES IN TEACHING STUDENTS IN MATHEMATICAL DISCIPLINES
}

\author{
Hubal Halyna, \\ Ph.D. (Physical and Mathematical Sciences), \\ Associate Professor, \\ Lutsk National Technical University
}

The learning process is an information process. Naturally, it is subject to a system of objective laws of appearance, storage, transformation, transmission and realization of information that operate in natural processes.

In this sense, the learning process is similar to any information process, has common features and patterns.

The state of the economy and the quality of people's lives depend on the level of information technology development and its pace. Informatization of education is carried out intensively, large funds are invested in the development and implementation of new information technologies [1]. Computers and information technologies not only permeate all disciplines but they change both those disciplines and the methods of their teaching.

Modern didactics, as a science of learning in the information society, will be successful if it is based on objectively known objective laws of origin, storage, transformation, transmission and realization of information occurring in natural processes. Thus, modern pedagogy will receive a fundamental scientific basis. It is the study of the objective laws of information processes in the field of learning, taking into account the personal characteristics of students, can be a new stage in the development of theory and practice of learning.

Computer analytical transformations (symbolic mathematics) automate calculations.

In the system of training future specialists in many fields, special attention should be paid to mathematical training, as mathematical disciplines are widely used in science and practice. An important area in the study of mathematics is the integrated use of information technology to improve the quality of mathematics education. Knowledge of mathematics provides: skills and abilities for applied analysis, analytical and predictive conclusions on any structural model; study of a process or phenomenon.

The use of computer technology allows you to solve problems that are not available due to the complexity of traditional forms of learning. These include research-type tasks. The difficulty of their implementation without information technology is that then it is almost impossible to predict the behavior of an object in a constantly changing environment. Information technology provides such an opportunity. Such tasks are the closest option to real production and scientific situations. To give a clear description is practical within the virtual environment. To increase the efficiency of the process of 
learning the material in this artificial environment, it is necessary to show the relationship of other disciplines with mathematics. Thus, information and computer technologies allow: to use modern technical possibilities; create multimedia complexes necessary for training; create programs modeling the learning environment and create conditions for virtual learning, which increases the efficiency of learning mathematical sciences; to master research skills, which provides increase of independent activity of students due to individualization of learning process by means of computer technologies, and also provides figurative representation of the information that essentially increases efficiency of process of use of information technologies for training of students, provides a deeper understanding of the mathematical sciences, allows you to individualize, differentiate the volume and sequence of their supply.

Learning with the use of computer technology allows to fully implement the principle of independence of knowledge acquisition and the formation of skills and abilities; allows each student to implement an individual learning strategy, choose the time and duration of classes, to monitor the dynamics of their achievements.

This form of learning allows you to more productively implement the didactic principle of unity of individual and collective in the learning process. After all, every student needs his time to master the material: someone more, someone less. In addition, independent work at home is possible only with strong motivation, while working with a computer is interesting in itself, increases the interest in self-knowledge.

The motivation of students can be significantly strengthened if the process of teaching mathematics is systematically carried out on the basis of a well-known concept of professional orientation of teaching mathematics at non-mathematical faculties. Tasks are selected in accordance with the specialization of students. The task, in this case, is built to show the possibilities of applying mathematical knowledge to the specialty of students.

Solving such problems is more enjoyable for the student because they are related to their area of professional interest and, no doubt, are designed for emotional response. Actualization of educational material forms educational motivation, causes the need for new knowledge, makes mathematical knowledge necessary. Assigning students to come up with tasks on their own increases the efficiency of learning the material. The didactic essence of this is as follows: composing and solving a problem are two sides of the same thought process. Both involve awareness of the mathematical model. The student-task compiler automatically becomes a consultant for others, which brings double benefits. First, as you know, the best way to learn the material is to explain it to another student. Thus, the compiler of the problem repeats and consolidates the studied material. Second, students, while communicating, advise weaker students [2].

Solving a large number of similar problems, but with different content or differently formulated, as well as composing problems is, from the point of view of psychology, an effective method of developing abstract thinking, mental abilities and a short way to master the mathematical essence of the problem. This is manifested in the ability to identify types of problems and quickly determine which of them is the proposed problem and what are the ways to solve it.

To train specialists-researchers, it is expedient to build the process of studying mathematics in conditions conducive to the creation of new scientific information by 
students as a result of active work. The educational process must be based on the principles of research, in which the emergence of new information is possible. Teaching should be open, non-linear, problematic, must contain a stochastic component, the effect of chance. At the same time, each student is actively working in the world information field to create their own system of mathematical knowledge.

The use of computer technology in the organization of independent work of students significantly increases their activity and desire to gain knowledge using modern technologies that not only optimize this process, but also make it more attractive and interesting, which significantly increases the level of student training.

The computer has become a powerful tool for the specialist-researcher, it is used to perform complex calculations, search for options, modeling situations and processes, forecasting, processing experimental data.

It is known that the inclusion of elements of interactive technology improves the quality of knowledge; cognitive, motivational and communicative spheres of students. Interactive dialogue that is active exchange of messages between the user and the information system in real time, especially relevant for distance learning. The use of materials from electronic libraries, information resources of the Internet allows students to qualitatively study the theoretical material and prepare for practical classes.

It is important to create electronic textbooks and textbooks in mathematical disciplines.

One of the most important sets of factors that activate learning activities is learning motivation, which includes the need for knowledge, the need for recognition, success, self-actualization. The use of elements of distance learning creates a situation in which the student is interested in an independent, objective assessment of his work, determining the path of his professional movement, the search for new technologies [3]. The use of computer technology in the study of mathematical disciplines allows to identify specific ways of organizing educational activities.

Using a computer in the learning process allows you to:

- effectively develop the role of clarity in the study of mathematical disciplines;

- to increase students' interest in the subject;

- to include new types of tasks in the learning process;

- visually receive the results of his activities;

- to intensify the development of students' spatial thinking;

- increase the objectivity of control of students' knowledge;

- successfully combine collective and individual teaching methods;

- give the student opportunities for self-control.

Visual representation of definitions, formulas, theorems and their proofs, qualitative graphs, moving objects provides effective acquisition of new knowledge and skills.

A wide range of opportunities in improving the efficiency and quality of the educational process is provided by multimedia technologies. The use of animation, modeling and three-dimensional computer graphics is very important in the study of mathematical disciplines. The dynamics of visual images is extremely important. 
Expanding the possibilities of graphical representation of the material allows you to clearly represent geometric shapes, their intersection and geometric transformations over them on the plane and in space.

To control the learning of the material, it is useful to use computer testing of the quality of learning of theoretical and practical material.

The following main components should be included in the composition of electronic educational and methodical complexes in mathematical disciplines:

- theoretical module with hyperlinks, multimedia objects illustrating various geometric images, animated and voiced;

- electronic lecture notes and electronic methodical instructions for practical classes with the necessary explanations and corresponding demonstration developments-presentations;

- interactive modeling environment with the ability to dynamically change the parameters of the model and the drawing editor;

- workshop for consolidation of knowledge, which contains problems with tips and step-by-step consideration of the solution;

- test module with training and control modes, integrated with a database of questions and tasks and a log of results;

- reference book containing a glossary of the course, basic formulas, additional material, information on the history of mathematics, a list of examination questions, a list of recommended bibliographic sources;

- user assistance system, including information on the structure and content of the complex, context-sensitive hints, different types of "navigators", search engine for the keyword, etc.;

- system of methodical support: with the curriculum of the course, with methodical recommendations for different types of classroom and extracurricular work, with methodical instructions for the use of separate modules of the complex, with the editor of presentations, with the subprogram for tests, etc.;

- control module, integrating all other modules of the course.

Electronic educational and methodical complexes should be developed in accordance with fundamental didactic principles. Various text, table, graphic editors (Microsoft Word, Microsoft Excel, Microsoft PowerPoint, etc.), applied mathematical packages (Derive, MathCad, Maple, Mathematica, MATLAB, etc.), Delphi programming environment, $\mathrm{C}++$, Web page wizard, audio and video players can be used for their development.

The creation of such complexes will allow to achieve the following goals:

- development of thinking, creative activity and independence of students, their self-realization;

- acquisition by students of professionally significant skills of work with information, formation of their information culture;

- consolidation and systematization of students' knowledge of mathematical disciplines. 


\section{References:}

1. Bykov V. Educational-scientific system of formation of scientific and pedagogical higher qualification staff in digital transformation of Ukrainian education and science / V. Bykov, A. Iatsyshyn // Information Technologies in Education. - 2019 - Vol. 41, No. 4. - P. 7-20.

2. Ragonis N. Students' awareness and embracement of soft skills by learning and practicing teamwork / N. Ragonis, O. Hazzan, G. Har-Shai // Journal of Information Technology Education. - 2020. - Vol. 19. - P. 185-201.

3. McGuinness C. Digital literacy in higher education: a case study of student engagement with E-tutorials using blended learning / C. McGuinness, C. Fulton // Journal of Information Technology Education. - 2019. - Vol. 18. - P. 001-028. 


\title{
МАТЬЕ, БЕССЕЛЬ ТЕНДЕУЛЕРІН ШЕШУДЕ МАРLЕ ЖУЙЕСІНІН МУМКІНДІКТЕРІН ПАЙДАЛАНЫП ГРАФИКТЕР ТҰРҒЫЗУ
}

\author{
Байсунова Айгуль Нуржановна, \\ Жаратылыстану ғылымдарының магистрі, \\ Баишев жоғары медициналық колледжі \\ Сарсенгалиева Ляйля Муратовна, \\ Информатика пәнінің оқытушы, \\ Баишев жоғары медициналық колледжі
}

Компьютерлік математиканың мүмкіндіктері жыл өткен сайын өсіп келеді, ал компьютердің есептеу жылдамдығы жүз есеге дейін артып отыр. Сонымен бірге компьютердің атқаратын қызмет мазмұны да өзгеріп келеді. Қазіргі кезде компьютерлік математика жүйесінде есептеудің мыңдаған кітапханалық функциялары мен операторлары және визуалды графиктік мүмкіндіктері зор компьютерлік бағдарламалары қолданылуда. Солардың қатарына мынадай компьютерлік бағдарламаларды жатқызуға болады: Excel, Derive, Mupad, Mathcad, Mathematica, Matlab және Maple сияқты математикалық бумалары және т.б.. Әсіресе, бұл жүйелерді қолданудағы математиканың орны ерекше және шешуші маңызға ие болмақшы. Матье функцияларының графиктерін тұрғызу үшін осы бағдарламалардың ішіндегі Maple жүйесінің көмегіне жүгінетін боламыз. Maple жүйесі ғылым мен техниканың әр түрлі салаларында кездесетін математикалық есептерді автоматты түрде шешуге арналған компьютерлік математиканың кең тараған жүйесі [1]. Ол процедуралық бағдарламалаудың типтік жабдықтарымен қамтылған және математика, физика мени механиканың есептерін шығаруда, әсіресе арнайы функциялардың қиын есептелетін мәндерін есептеуде көп жеңілдіктер туғызады. Сонымен қатар, Матье, Бессель функциялары сияқты арнайы функциялардың графиктерін жан - жақты бейнелеуге мүмкіндік беретін компьютерлік математикалық бағдарлама. Оның мүмкіндіктерін Ресейдің оқу орындарында оқу үдерісінің сапасын арттыру үшін тиімді пайдалануда. Атап айтқанда Д.П.Голоскоковтың [2, 3] окулығы математикалық физика теңдеулерінің шешімдерін Maple жүйесінде шығару ерекшеліктеріне арналған.

Ғылыми жұмысымның зерттеу нысаны болып табылатын Матье функциялары екі өлшемді

$$
\frac{\partial^{2} V}{\partial \mathrm{x}^{2}}+\frac{\partial^{2} V}{\partial \mathrm{y}^{2}}+R^{2} V=0
$$

толқындық теңдеуде элиптикалық координаталарға көшу арқылы Матье тапқан

$$
\frac{d^{2} y}{\mathrm{dz}^{2}}+(\mathrm{a}-2 q * \cos 2 z) \mathrm{y}=0,
$$




$$
\frac{d^{2} y}{\mathrm{dz}^{2}}+(\mathrm{a}-2 q * c \mathrm{~h} 2 z) \mathrm{y}=0,
$$

дифференциалдық теңдеулерінің шешімдері болып табылады. дифференциалдық теңдеуі (2) теңдеуінен z орнына \pm iz алу арқылы табылатынын атап өткен жөн. а және q- нақты сандар және q>0 деп ұйғарамыз. Сонда (2) мен (3) теңдеулері сәйкесінше Матье және модифицирленген Матье теңдеулері деп аталады.

Матье функииясының графиктерін тұрвызу. Матье функциясы

$$
y^{\prime \prime}+(a-q \cos (2 z)) y=0
$$

теңдеудің шешімі 1868 жылы табылған.

Матье функциялары:

1. Параметр $+q=k^{2}$ түрінде алу ыңғайлы және ол нақты деп есептеледі.

2. а параметрінің q-ге тәуелділігі теңдеудің периодты шешімдерінің бар болуын қамтамасыз етеді.

3. Айнымалы $z$ нақты деп ұйғарсақ, онда теңдеу нақты айнымалы және параметрлері де нақты болады.

4. Келтірілген ұйғарымдар орындалғанда (4) теңдеудің $C e_{2 n}(x, q)$ және $C e_{2 n+1}(x, q)$ - бірінші текті жұn функииялары деп аталатын периодтары $\pi$ және $2 \pi$ - ге тең шешімдері бар болады.

5. Сонымен қатар Матьенің $\operatorname{Se}_{2 n+1}(x, q)$ және $S e_{2 n}(x, q)$ арқылы белгіленген периодтары $2 \pi$ және $\pi$-ге бірінші текті тақ функциялары да бар болады [4].

1 - Қасиет. $|\mathrm{q}|$ - ның үлкен мәндеріне еш уақытта Матье теңдеуінің екі периодты шешімдерді бір уақытта бар болмайды.

Матье теңдеуінің шешімдерін жуықтап есептеу біршама қиындықтар туғызады. Онда $a$, q-лердің және оларға қатысты параметрлердің жеке жағдайларын ескерту керек. Мысалы:

1. $q=0$ болғанда Матье теңдеуі коэффициенті тұрақты

$$
\frac{d^{2} y}{d x^{2}}+a y=0
$$

теңдеуіне айналады және оның шешімдері $\pm \cos m z, \pm \operatorname{sinm} z$ арқылы өрнектеледі.

1. а) Егер $q \neq 0$ болса, онда (4)-тің периодтары $\pi$ немесе $2 \pi$ болатын шешімдерін табу үшін, $a$ және $q$ параметрлері өзара байланыста болуы керек деген талап қоямыз. Сонда, а параметр $q$ - дың функциясы болады да,

$$
a=m^{2}+\alpha_{1} * q+\alpha_{2} q^{2}+\alpha_{3} * q^{3}+\cdots
$$

деп алсақ $q=0$ болғанда бізге қажетті (5)-формуладағы $a=m^{2}$ тең болады. Ол шешімдері $\pm \operatorname{cosm} z, \pm \operatorname{sinmz}$ болатын коэффициенттері тұрақты екінші ретті дифференциалдық теңдеуге келеді.

Мак-Лахланның [5] моноргафиясында қарапайым мысал ретінде

ә) $\mathrm{q}=0, \mathrm{a}=\mathrm{m}^{2}=1$ - жағдайы қарастырылған. $\mathrm{q} \neq 0$ болғанда (6) - тен

$$
\mathrm{a}=1+\alpha_{1} * q+\alpha_{2} * q^{2}+\alpha_{3} * q^{3}+\cdots
$$

қатары алынатынын көреміз. Бұдан $q=0$ болғанда $\operatorname{cosz}-$ ке тең болатын қатар алу үшін шешімді

$$
y=\cos z+q * c_{1}(z)+q^{2} \cdot c_{2}(z)+q^{3} * c_{3}(z)+\cdots
$$


түрінде іздеу керек. Мұнда, $\mathrm{c}_{1}, \mathrm{c}_{2}, \ldots-\mathrm{z}-$ ке тәуелді және оларды анықтау керек. (8) - ші қатарды (4) - ке қою нәтижесінде бірінші дербес периодты шешімді

$$
\begin{aligned}
c e_{1}(z, q)= & \cos z-\frac{1}{8} q \cos 3 z-\frac{1}{64} q^{2}\left(-\cos 3 z+\frac{1}{3} \cos 5 z\right) \\
& -\frac{1}{512} q^{3}\left(\frac{1}{3} \cos 3 z--\frac{4}{9} \cos 5 z+\frac{1}{18} \cos 7 z\right) \\
& +\frac{1}{4096} q^{4}\left(\frac{11}{9} \cos 3 z+\frac{1}{6} \cos 5 z-\frac{1}{12} \cos 7 z+\frac{1}{180} \cos 9 z\right) \\
& +0\left(q^{5}\right)
\end{aligned}
$$

түрінде табамыз.

Бұл шешімнің дұрыстығын қамтамасыз ететін $a$ - параметрінің мәні (7)-ші қатардағы $\alpha-$ нің мәндерін қойғанда

түрінде келеді.

$$
a=1+q-\frac{1}{8} q^{2}-\frac{1}{64} q^{3}-\frac{1}{1536} q^{4}+\frac{1}{36864} q^{5}+0\left(q^{6}\right)
$$

q-дің берілген мәндерінде (10) формула бойынша табылатын а параметрінің мәні $c e_{1}(z, q)$ Матье функциясының меншікті мәні деп аталады және Матье теңдеуінің шешімдерін табуда маңызды орын алады. Шешімді «се» арқылы белгілеуді элиптикалық цилиндрдің косинусы үшін Уиттекер енгізген.

(4) теңдеудің бірінші текті жұn $\mathrm{Ce}_{2 n}(z, q), C e_{2 n+1}(z, q)$ және тақ функцияларының $S e_{2 n+1}(z, q), \quad S e_{2 n}(z, q)$ қалай алынатындықтары I тарауда келтірілген.

Матье функцияларының графиктерін тұрғызу үшін Maple бағдарламасын тікелей пайдаланған тиімді. Ол үшін Матье теңдеуінің шешімін беретін MathieuC және MathieuS арнайы функциялары енгізілген. Сонымен қатар, Флоке типті шешімді беретін MathieuFloquet функциясы, периодты жағдайлар үшін MathieuCE және MathieuSE функциялары, $(a, q)$ енгізу параметрлеріне байланысты MathieuA, MathieuB, MathieuExponent секілді көмекші функциялар да пайдаланылады [6].

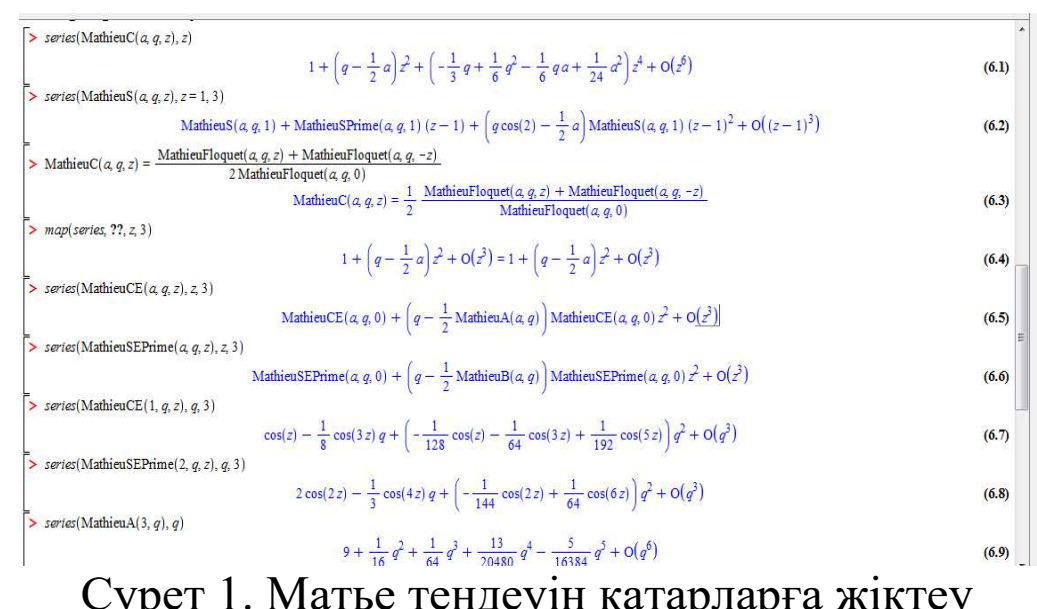

Сурет 1. Матье теңдеуін қатарларға жіктеу

Енді жоғарыда аталған функцияларды пайдаланып, 1-суретте көрсетілген (6.1)-(6.9) қатарлардың графиктерінің қалай тұрғызылатынына тоқталайық. 
2-суретте MathieuA характеристикалық мәнді функциялардың графигі көрсетілген, мұндағы $\mathrm{n}=0 . .5, \mathrm{q}=0 . .15$.

$>$ plotsetup(inline);

$>\operatorname{plot}\left([\right.$ MathieuA $(5-n, q) \$(n=0 . .5)], q=0 . .15$, legend $\left.=\left[{ }^{\prime} a \|(5-n) ' \$(n=0 . .5)\right]\right)$

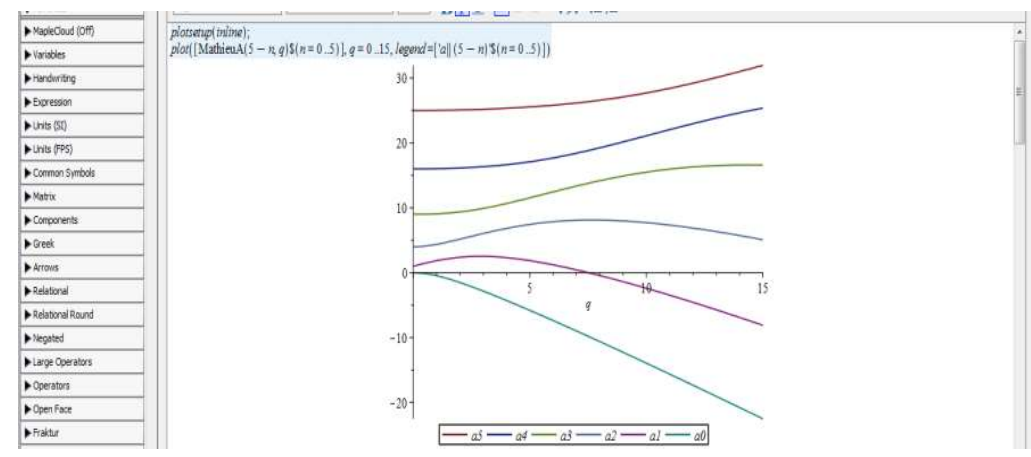

Сурет 2. MathieuA характеристикалық мәнді функциялардың графигі, $\mathrm{a}_{\mathrm{n}}-$ меншікті мәндері, $\mathrm{n}=0 . .5, \mathrm{q}=0 . .15$

3-суретте MathieuB характеристикалық мәнді функциялардың графигі берілген, мұндағы $\mathrm{n}=1 . .5, \mathrm{q}=0 . .15$.

$>$ plotsetup(inline);

$>\operatorname{plot}\left([\right.$ MathieuB $(6-n, q) \$(n=1 . .5)], q=0 . .15$,legend $\left.=\left[' b \|(6-n)^{\prime} \$(n=1 . .5)\right]\right)$

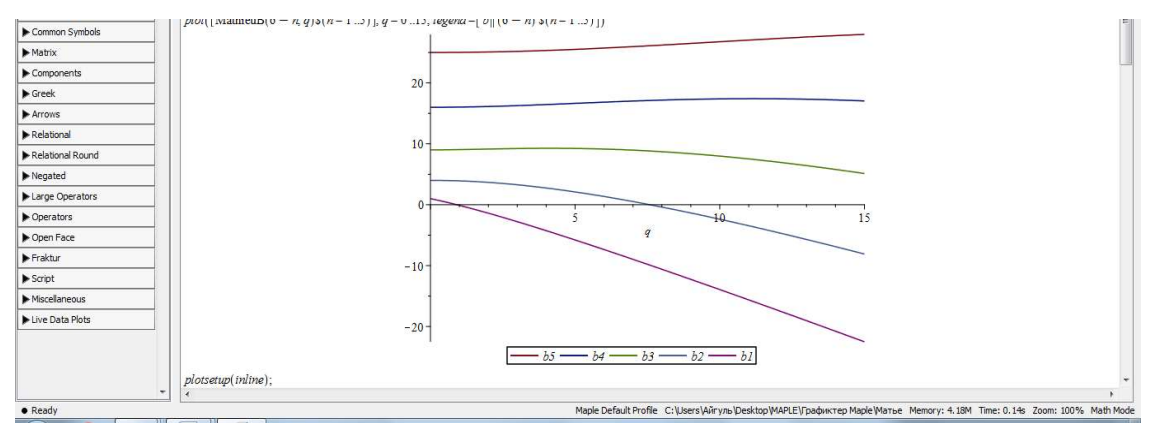

Сурет 3. MathieuB характеристикалық мәнді функциялардың графигі, $\mathrm{b}_{\mathrm{n}}-$ меншікті мәндері, $\mathrm{n}=0 . .5, \mathrm{q}=0 . .15$

4-суретте Жұп периодты Матье функциялардың графигі берілген, мұндағы $\mathrm{n}=0 . .5, \mathrm{q}=1, \mathrm{z}=0 . . \pi / 2$.

$>$ plotsetup(inline);

$>\operatorname{plot}([$ MathieuCE $(n, 1, z) \$(n=0 . .5)], z=0 . . \pi / 2, \quad$ title="Жұп периодты Матье функциясы, q=1",legend=['ce $\| n ' \$(n=0 . .5)])$

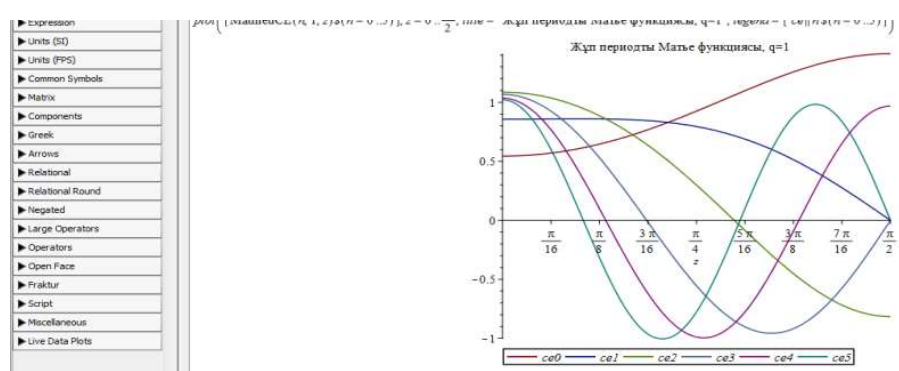

Сурет 4. Жұп периодты Матье функциясы, $\mathrm{n}=0 . .5, \mathrm{q}=1, \mathrm{z}=0 . . \pi / 2$ 
5-суретте тақ периодты Матье функциялардың графигі берілген, мұндағы $\mathrm{n}=1 . .5, \mathrm{q}=1, \mathrm{z}=0 . . \pi / 2$.

$>$ plotsetup(inline);

$>\operatorname{plot}([$ MathieuSE $(n, 1, z) \$(n=1 . .5)], z=0 . . \pi / 2$,title="Тақ п периодты функциясы, q=1",legend=['se $\left.\left.\| n^{\prime} \$(n=1 . .5)\right]\right)$
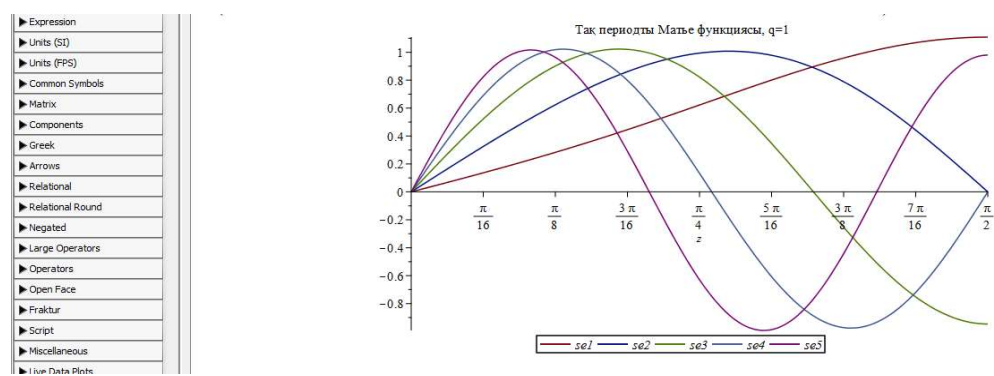

Сурет 5. Тақ периодты Матье функциясы, $\mathrm{n}=1 . .5, \mathrm{q}=1, \mathrm{z}=0 . . \pi / 2$

6-суретте жұп периодты Матье функциялардың графигі берілген, мұндағы $\mathrm{n}=0 . .5, \mathrm{q}=10, \mathrm{z}=0 . . \pi / 2$.

$>$ plotsetup(inline);

$>\operatorname{plot}([$ MathieuCE $(n, 10, z) \$(n=0 . .5)], z=0 . . \pi / 2$, title=" Жұп периодты Матье функциясы, q=10",legend $=\left[\right.$ 'ce $\left.\left.\| n^{\prime} \$(n=0 . .5)\right]\right)$
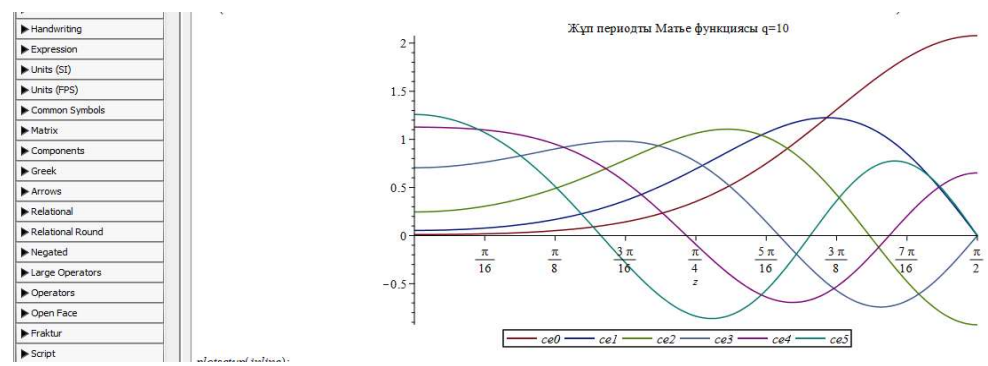

Сурет 6. Жұп периодты Матье функциясы, $\mathrm{n}=0 . .5, \mathrm{q}=10, \mathrm{z}=0 . . \pi / 2$

7-суретте тақ периодты Матье функциялардың графигі берілген, мұндағы $\mathrm{n}=1 . .5, \mathrm{q}=10, \mathrm{z}=0 . . \pi / 2$.

$>$ plotsetup(inline);

$>\operatorname{plot}([\operatorname{MathieuSE}(n, 10, z) \$(n=1 . .5)], z=0 . . \pi 2$, title=" Тақ периодты Матье функциясы, q=10",legend $=[$ 'se $\| n ' \$(n=1 . .5)])$

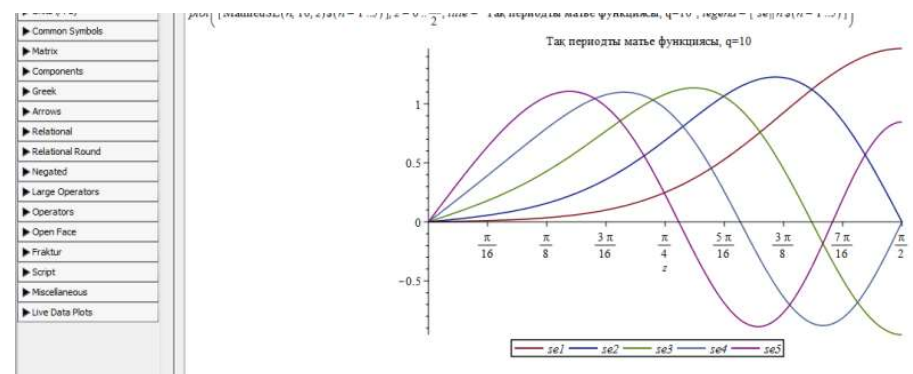

Сурет 7. Тақ периодты Матье функциясы, $\mathrm{n}=1 . .5, \mathrm{q}=10, \mathrm{z}=0 . . \pi / 2$ 
Бессель функциясын [2] есептеуге Maple - дің Bessel (BesselJ- Бірінші текті Бессель функциясы, BesselY - екінші текті Бессель функциясы) функциясын, ал Матье функциясының жуық мәнің есептеп, графигін тұрғызуға Maple-дің MathieuCE, MathieuSE функцияларын пайдаланған дұрыс.

8-суретте бірінші және екінші текті Бессель функцияларының графиктері (анимация түрінде), мұндағы $\mathrm{m}=0 . .5 \mathrm{x}=0 . .20$,

$>\operatorname{display}([\operatorname{seq}(\operatorname{display}(\operatorname{plot}([\operatorname{BesselJ}(\mathrm{m}, \mathrm{x}), \operatorname{BesselY}(\mathrm{m}, \mathrm{x})], \mathrm{x}=0$.. 20, thickness

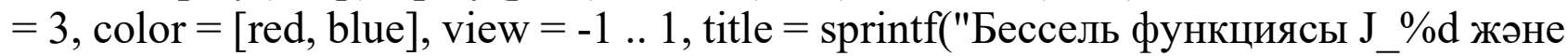
$\left.\left.\left.\mathrm{Y}_{-} \% \mathrm{~d} ", \mathrm{~m}, \mathrm{~m}\right)\right)\right), \mathrm{m}=0 . .5$ )], insequence $=$ true);

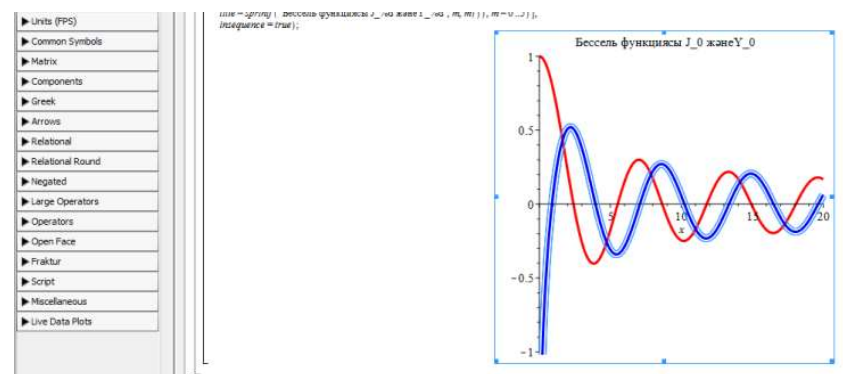

Сурет 8. J_0-5 және Y_0-5 Бірінші және екінші текті Бессель функциясының графигі

Сонымен, мақалада Матье теңдеулерінің шешімдерін жуықтап есептеу туралы мағлұматтар келтіріліп, Матье функцияларының графиктерін Maple ортасында тұрғызу ерекшеліктері қарастырылды.

Maple-де функцияның графиктерін бейнелеу екі түрлі жолмен жүргізілді: тікелей және Бессель функциясы арқылы өрнектеу жолымен. Модифицирленген Матьенің (3) теңдеуінің шешімінің Бессель функциясы арқылы өрнектелу мысалында оның графигінің тұрғызылуы туралы мағлұмат берілді. Maple пакетіндегі Бессель функциялары келтірілді. Maple ортасының мүмкіндіктерін пайдалана отырып Матье теңдеуінің шешімін тікелей графиктер түрінде көрсету тиімді екеніне көзіміз жетті.

Әдебиеттер тізімі:

1. Ватсон Г.Н. Теория Бесселевых функций. Ч.І,ІІ. ИЛ.-М.:1949, 793 с.

2. Голоскоков Д.П. Уравнение математической физики. Решение задач в системе Maple. Учебник для вузов - СПб.: Питерю 2004. - 539 с.:ил

3. Голоскоков Д.П. Курс математической физики с использованием пакета Maple / Д.П. Голоскоков. - СПб.: Изд-во Лань, 2015. - 576 с.

4. Мак-Лахлан Н.В. Теория и приложения функций Матье: Пер. с англ. М:ИЛ, 1953, $474 \mathrm{c.}$

5. McLachlan N.W. Theory and Applications of Mathieu Functions. Oxford, 1951.

6. http://fr.maplesoft.com/support/help/Maple//Mathieu 


\title{
ВИБІР ПРОГРАМНОГО ЗАБЕЗПЕЧЕННЯ ДЛЯ ЦИФРОВОЇ ОБРОБКИ ЗОБРАЖЕНЬ
}

\author{
Кавин Ярослав Михайлович \\ доцент, к.т.н., начальник управління міжнародних зв'язків \\ Українська академія друкарства \\ Кавин Святослав Ярославович \\ аспірант, факультет міжнародних відносин \\ Львівський національний університет імені Івана Франка \\ Кавин Богдан Ярославович \\ студент, факультет міжнародних відносин \\ Львівський національний університет імені Івана Франка
}

Для того, щоб правильно організувати процедуру обробки(фільтрації) зображення, необхідно правильно підібрати програмне забезпечення для операційної системи. Серед відомих програмних пакетів є такі: MatScope, Axio Vision, ZEN, Gwyddion та ін.. Ми обрали для нашого завдання програму Gwyddion, так як вона досить проста та зручна у використанні, а також, можна відразу обробити зображення та безпосередньо вивести зображення з цифрової камери.

Gwyddion це модульна програма аналізу даних C3М. В першу чергу вона призначена для аналізу полів висот, отриманих різними техніками скануючої зондової мікроскопії (АСМ, МСМ, СТМ, СБОМ), але в загальному випадку іiі можна використовувати для аналізу будь-яких полів висот або (монохромних) зображень, наприклад для аналізу даних профілометрії або карт товщини, побудованих спектрофотометрією. Gwyddion $є$ вільним програмним забезпеченням з відкритим вихідним кодом, випущеним під ліцензією GNU General Public License (GNU GPL). Основною ідеєю при розробці Gwyddion було створити модульну програму для аналізу двовимірних даних, яку можна легко розширювати окремими модулями без перепрограмування ядра.

Серед основних необхідних функцій, які нам необхідні для роботи, є: накладення псевдокольору, вікно тривимірного відображення даних за допомогою OpenGL та інструмент відстаней .

\section{Накладення псевдокольору}

Накладення фальшивих кольорів - основний метод візуалізації двовимірних даних. Використовуваний колірний градієнт (також званий палітрою) може бути обраний за допомогою клацання правою кнопкою миші на ту частину вікна даних, де відображається карта фальшивих кольорів. Меню швидкого вибору пропонує список бажаних градієнтів фальшивих кольорів. Крім того, воно 
дозволяє викликати повний список градієнтів за допомогою пункту меню «Додатково», яким надається перевага. Додатковий контроль над тим, як значення відображаються на шкалу кольору можливий за допомогою інструменту «Колірний діапазон».

\section{Вікно тривимірного зображення даних за допомогою пакету OpenGL}

Тривимірне відображення OpenGL для поточного вікна даних можна викликати кнопкою із зображенням куба в ряду кнопок «Вид головного вікна». Ця можливість $\epsilon$ опціональною, тобто вона може бути відключена в процесі побудови. також можливий варіант, коли Gwyddion може відображати тривимірні дані, а ваша система це не підтримує.

Вікно тривимірного виду може існувати в двох варіантах: 3 основними і 3 розширеними елементами управління. Воно буде працювати тільки з основними елементами управління, цей варіант показаний на наступному малюнку. Можна переключити вікно до розширеного виду (і назад) за допомогою кнопки розширення в верхньому правому куті. Натискання на вигляд за допомогою правої кнопки миші викликає вікно швидкого вибору градієнта фальшивих кольорів / матеріалу OpenGL. Основне вікно тривимірного перегляду містить праворуч елементи інтерактивного управління. За замовчуванням перетягування виду мишею обертає його по горизонталі і вертикалі.

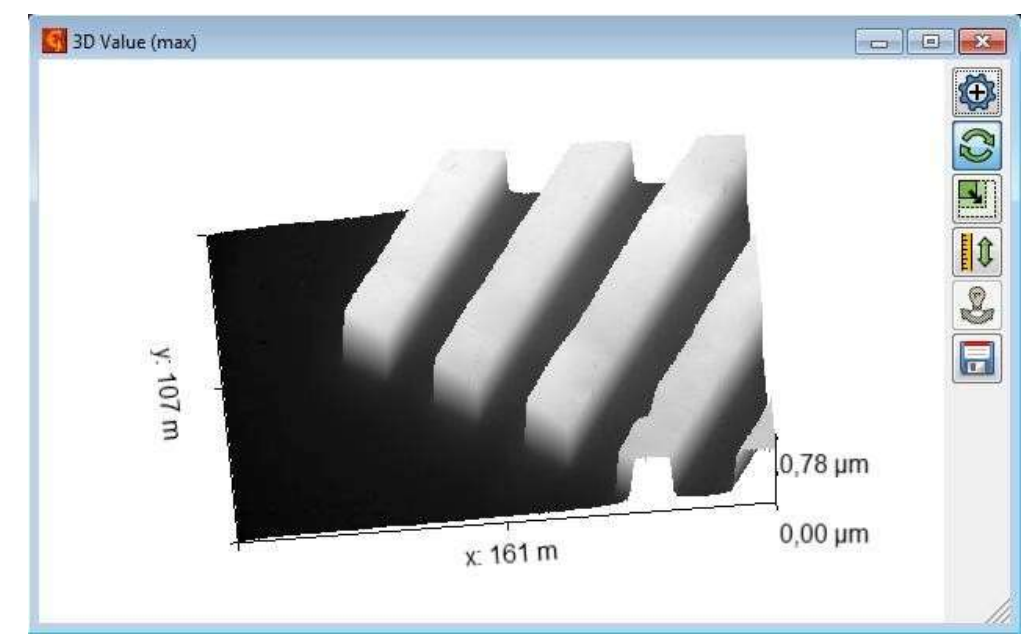

Рис. 1 Вікно тривимірного перегляду даних за допомогою OpenGL 3 основними елементами управління.

Серед представлених елементів управління $\epsilon$ досить важливий пункт «Поворот джерела світла (L)». Цей елемент управління буде доступний якщо в режимі візуалізації є джерело світла, тобто в режимі освітлення і накладення іншого каналу (накладення). Перетягування виду мишею змінює положення джерела світла подібно повороту в нормальному режимі повороту. вертикальне переміщення змінює кут $\theta$ між напрямком світла і горизонтальною площиною. Положення джерела світла показується використовуючи «колесо» навколо поверхні .

Це досить зручно, якщо необхідно дослідити зображення в інтерактивному режимі. Зручність полягає в тому, що не потрібно повертати об'єкт дослідження 
чи змінювати напрям джерела освітлення (тим більш, що інколи це неможливо.

\section{Інструмент відстаней}

Відстані і різниці значень можна вимірювати за допомогою інструменту відстань. Він показує горизонтальне $(\Delta \mathrm{x})$, вертикальне $(\Delta \mathrm{y})$ відстані і загальна відстань по площині (R); азимут $\varphi$ (вимірюється так само, як нахил $\varphi$ ) і різницю значень кінцевих точок $\Delta \mathrm{z}$ для набору ліній обраних для поточних даних. Відстані можна скопіювати в буфер обміну або зберегти в текстовий файл за допомогою кнопок під списком.

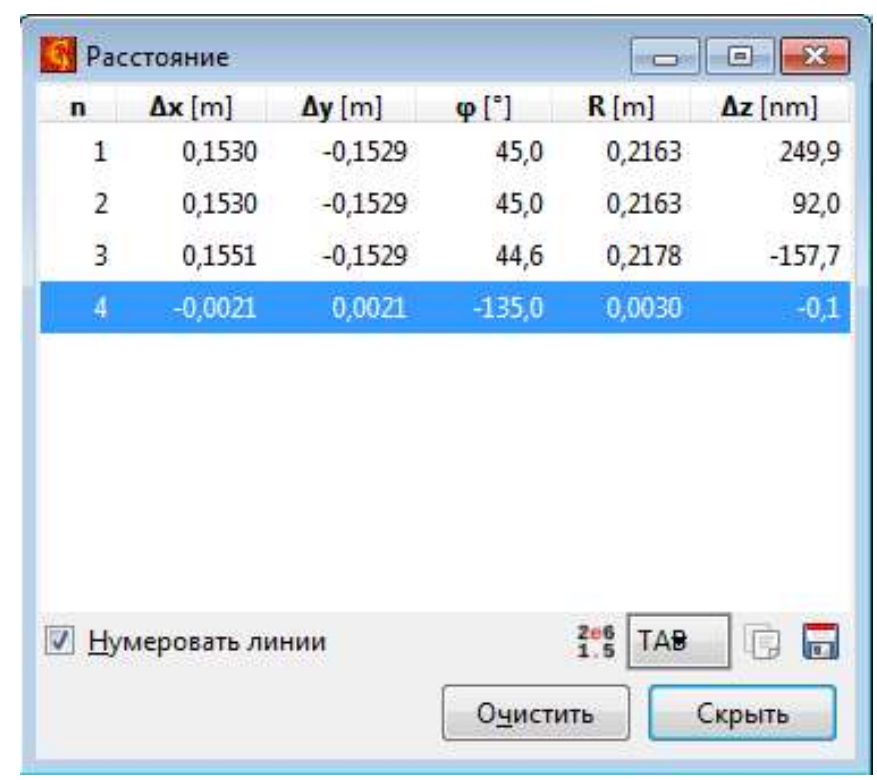

Рис. 2 Інструмент вимірювання відстаней з обраними лініями

\section{Витяг профілю}

Завдяки інструменту по вилучнню профілю можна отримати профілі по поверхнях ліній, намальованих н азопомогою миші (відображення відбувається в інтерактивному режимі). В цілому, профілі буваються різної «товщини», це означає що в напрямку поперек ліній профілю більше сусідніх точок будет використовуватися для розрахунку профілю. Це є досить користим в тих випадках, коли необхідно зменшити кількість шуму під час вимірювання об'єктів. Результатом відображення цієї процедури є графік. Графіків может бути декілька, їх можна як накладати один на одний, так і відобразити в різних вікнах перегляду. 

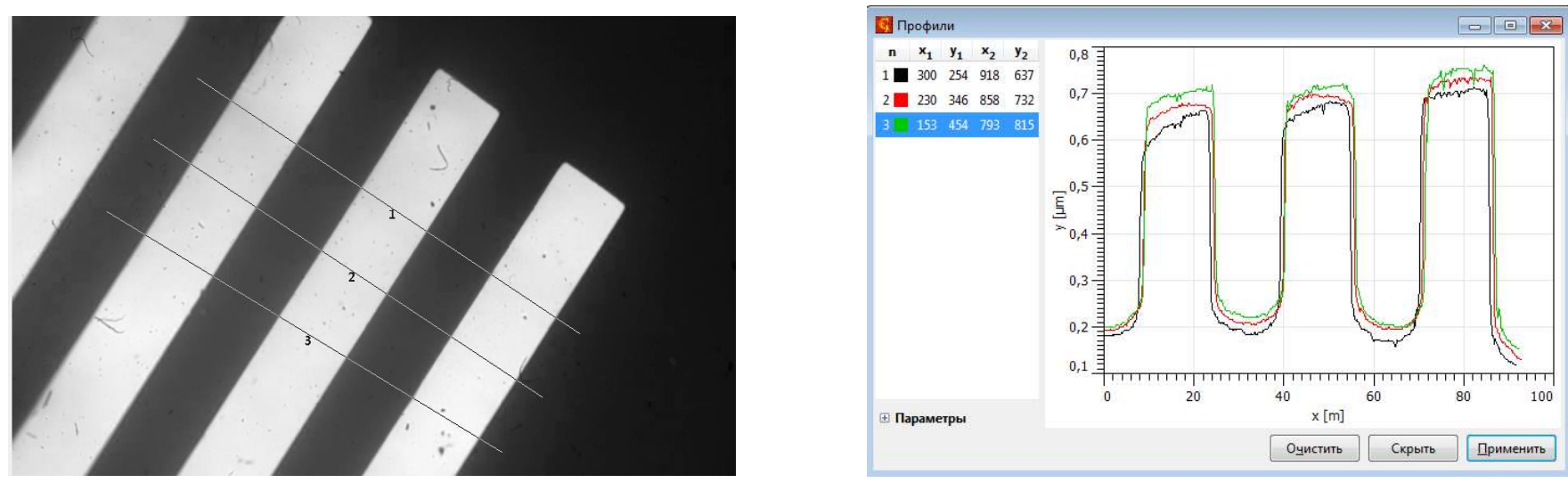

Рис. 3 Інструмент вилучення профілів 3 трьома вказаними відрізками та розкритим налаштуванням

\section{Список використаних джерел}

1. Колобородов В.Г. Застосування методів і алгоритмів цифрової обробки зображень в оптикоелектронних приладах / В.Г. Колобородов, К.В. Харитоненко // Вісник НТУУ “КПІ”. - К. : НТУУ “КПІ”, 2010. - Вип. 40. - С. 23-31.

2. Цифровая обработка изображений / Р. Гонсалес, Р. Вудс. - М.: Техносфера, 2005. - C. 327- 350 .

3. Шапиро Л. Компьютерное зрение / Л. Шапиро, Дж. Стокман. - М. : Бином. Лаборатория знаний, 2006. - 716 с.

4. Форсайт Д. Компьютерное зрение. Современный подход / Д. Форсайт, Ж. Понс. - М. : Вильямс, 2004. - 928 с.

5.Цифровая обработка изображений в информационных системах / И. С. Грузман, В. С. Киричук и др. - Новосибирск : НГТУ, 2002. - 352 с.

6.R.C. Gonzalez, R.E. Woods. Digital Image Processing. - Prentice-Hall, Inc., 2002. P. 793. 


\title{
ВЕБ-ПОСЛУГИ З ЕЛЕКТРОННОГО НАВЧАННЯ
}

\author{
Матейко Олександр Дмитрович \\ Студент 1курсу спеціальності «Комп'ютерні науки» \\ Державний університет економіки та технологій,
}

Соловйова Вікторія Володимирівна,

к.е.н., доцент

Державний університет економіки і технологій,

Електронне навчання (E-learning) - це автоматизоване навчання, що належить до великої науково- практичної галузі.

Своє існування електронна освіта почала 3 досліджень Річарда Майєра, Джона Свеллера та Роксани Морено, що вперше зазначили у науковій літературі принципи ефективного мультимедійного навчання. Більшість 3 них пройшли перевірку на практиці в умовах навчального повсякдення. Подальший експеримент Девіда Робертса, який проводився протягом трьох років з участю студентів університету, довів, що текстова інформація отримана у комбінації 3 мультимедійної має більший ефект. Серія досліджень показали, що цей метод діє i у випадках використання для інших вікових категорій незалежно від змісту навчання [1 - 3].

3 того часу досліди просунулись далеко вперед, розвинув галузь освіти. Так як метод зазначений вище робить акцент саме на мультимедійності, розповсюдження Інтернету сприяло його розвитку, а також появи різноманітних веб сервісів, які на сьогодні і $є$ основною електронного навчання.

Одною 3 них $є$ освітня платформа Prometheus, що пропонує своїм користувачам доступ до великої кількості відкритих онлайн-курсів. Головна мета проекту створеного у 2014-му році - забезпечити доступ зацікавлених осіб до курсів університетського рівня та створити можливість публікації та розповсюдження цих матеріалів провідними викладачами, університетами та компаніями.

Prometheus користується увагою як серед учасників освітнього процесу, так i пересічних громадян. Крім того, платформа $є$ однією з найпопулярніших на території України, хоча і має рівнозначну кількість плюсів та мінусів, які розглянуті у таблиці 1.

Таблиця 1.

Переваги та недоліки сервісу Prometheus

\begin{tabular}{|l|c|}
\hline \multicolumn{1}{|c|}{ Недоліки: } & \multicolumn{1}{|c|}{ Переваги: } \\
\hline $\begin{array}{l}\text { Необхідність постійного підключення } \\
\text { до Інтернету }\end{array}$ & Курси є безкоштовними \\
\hline
\end{tabular}




\begin{tabular}{|l|lrr|}
\hline $\begin{array}{l}\text { Мала кількість матеріалів високого } \\
\text { рівню складності }\end{array}$ & $\begin{array}{l}\text { Можливість інтеграції з навчальною } \\
\text { програмою закладів освіти у форматі } \\
\text { змішаного навчання }\end{array}$ \\
\hline $\begin{array}{l}\text { Сертифікат не гарантує наявності } \\
\text { знань і навичок, що пропонує курс }\end{array}$ & $\begin{array}{l}\text { Використання можливе i на } \\
\text { комп’ютері, i на планшеті чи телефоні. }\end{array}$ \\
\hline
\end{tabular}

Крім сервісів створених для здобуття самоосвіти шляхом використання онлайн-курсів, існують ті, завдяки яким під час пандемії SARS-CoV-2 навчальним закладам різних рівнів вдалося організувати досить інноваційне для України дистанційне навчання. Прикладом таких $\epsilon$ LMS Moodle, популярний у ВНЗ Сполучених штатів Америки, що являє собою вільний веб-додаток завдяки якому можливо створювати сайти для онлайн-освіти.

Ця платформа надає простір для співпраці студентів та викладачів, має різноманітні варіанти відстежування успішності. Також, за умови правильного оформлення, користувачі матимуть доступ до структурованого навчальнометодичного забезпечення дисциплін. Завдання можуть бути обмежені потрібними викладачу термінами, доповнені аудіо, відео та матеріалами 3 Інтернету. Одним з головних плюсів для студентів $\epsilon$ можливість оцінювання незалежного від людського чинника або викладача.

У той же час, Moodle має проблеми с подальшою автоматизацією своєї роботи у більш складних ситуаціях, особливо під час організації екзаменаційної атестації чи автоматичного оцінювання студентів під час проведення занять для великої аудиторії. Ще одним недоліком для користувача може стати неможливість сортування матеріалів, окрім як за алфавітом.

Та все ж таки як і кожна система, що не хоча втрачати своє місце на цьому поприще LMS Moodle має тенденцію до розвитку. До речі, як і більш простий пакет додатків Google for Education, котрий за останній рік зміг зайняти своє місце у закладах середньої освіти через дружелюбність свого інтерфейсу та, головне, безкоштовність для навчальних закладів.

Ось основні функції які пропонує Google для освітян:

- захищене середовище взаємодії;

- налаштування приватного спілкування з студентами / учнями / учасниками;

- ефективна система сповіщень;

- для викладача/організатора ефективна система контролю;

- автоматичне збереження файлів на Google Drive;

- технічні можливості: тиражування матеріалів, опитування, зворотного зв’язку, оцінювання робіт, зведеної інформації про кожного учасника, публікації інформації, організації дискусії тощо.

Кожна з зазначених платформ та багатьох інших, що не увійшли до переліку, отримали неймовірний поштовх до розвитку, за рахунок потреби введення програм дистанційного навчання по всій земній кулі. Усі додатки врешті решт знайшли своїх користувачів, та навіть серед трьох перелічених можна розставити кордони. Наприклад, у той час як Moodle має популярність серед вищих закладів 
освіти через свій перевірений роками потенціал, пакет Google for Education, що с початком пандемії почав сяяти на небосхилі дистанційки, об'єднав учнів та вчителів середнього ступеню своєю інтуїтивністю. Такі ж сервіси онлайн-освіти як Prometheus були і залишаються популярними в першу чергу серед тих, хто готовий самостійно організувати свій процес навчання, або ж отримати додаткові знання ззовні.

Список літератури:

1. Mayer, R., \& Moreno, R. (2002). Aids to computer-based multimedia learning. Learning and Instruction, 12 (1), 107-119.

2. Mayer, R. E. (2005). Cognitive Theory of Multimedia Learning. In R. E. Mayer (Ed.),Cambridge handbook of multimedia learning (pp. 31-48). New York: Cambridge University Press.

3. Sweller, J. (1988), Cognitive Load During Problem Solving: Effects on Learning. Cognitive Science, Vol. 12: 257-285. doi: 10.1207/s15516709cog1202_4

4. https://prometheus.org.ua

5. https://moodle.org

6. https://edu.google.com/products/gsuite-for-education/ 


\title{
ВТРАЧЕНІ ОБ'ЄКТИ ІСТОРИКО-КУЛЬТУРНОЇ СПАДЩИНИ УКРАЇНИ ЯК РЕСУРС ПІЗНАВАЛЬНОГО ТУРИЗМУ
}

\author{
Борисова Оксана Володимирівна \\ Кандидат географічних наук, доцент кафедри туризму \\ Національний педагогічний університет ім. М.П. Драгоманова, м.Київ
}

У зв'язку з активним розвитком туризму на рубежі 20-21 ст. все більшої популярності набувають дослідження з приводу відновлення та збереження втрачених географічних об'єктів, значна частина яких є об'єктами історикокультурної спадщини - як носіїв багатоаспектної інформації про особливості розвитку як регіонів, так і країни в цілому, носіїв їх культурних традицій.

Серед дослідників, що займаються питаннями втраченої природної та історико-культурної спадщини України слід відзначити В.Вечерського, Г.Геврика, К. Горба, Л. Зеленську, К.Поливача, О.Троценко та ін.

Втрачений географічний об'єкт - це цілісне та відносно стабільне утворення землі певного ієрархічного рівня, природного або антропогенного походження, що характеризувалося виконанням природних (у природних системах) та соціально-економічних функцій (в антропогенних чи природноантропогенних системах), просторово-часовим положенням, внутрішньою структурою та енергетично-інформаційним наповненням, зміни яких у наслідок дії процесів та явищ природного й антропогенного характеру призвели до втрати геоінформації [2].

Всі втрачені географічні об'єкти, які досліджуються останнім часом, відповідно до ступеню втраченності, поділяються на не відновлювальні або безповоротно втрачені; потенційно відновлювальні (за ступенем суспільноісторичної значущості); частково втрачені, перейменовані (зниклою $\epsilon$ топонімічна інформація про об'єкт).

Сьогодні, коли майбутнє планети значною мірою залежить від зрілості масової свідомості, рівня людських стосунків, що грунтується на принципах толерантності, взаємовідповідальності, поваги до інших поглядів, цінностей, переконань, аспекти встановлення міжкультурного діалогу набувають особливого значення. Виняткова роль у його забезпеченні належить видам туризму, завдяки яким відбувається безперервний обмін духовно-культурними цінностями. Виявлення, відновлення та збереження втрачених об'єктів історикокультурної спадщини стають основою для розвитку пізнавального туризму в тому чи іншому регіоні, вони не тільки збагачують подієвий календар будь-якої території, а й сприяють формування культурної та історичної складової ії іміджу, тим самим перетворюючи регіон на туристичний центр. Використання бази 
даних про втрачені об'єкти історико-культурної спадщини стає поштовхом не лише для вивчення минулого свого народу, пожвавлення уваги до краєзнавчих досліджень, розвитку туристично-екскурсійної справи, розробці питань адміністративної реформи, а й сприяе духовному відродженню України, збереженню та примноженню історичної пам'яті, виховуючи почуття патріотизму, мужності, гідності, що, в свою чергу, $є$ важливим кроком на шляху до формування повноцінного національно свідомого суспільства. Чимало туристичних агентств в Україні та світі розробляють нові маршрути, включаючи до них інформацію про втрачені об'єкти історико-культурної спадщини, зокрема в якості додатку до портфелю екскурсовода, а також під час проведення самоосвітніх та віртуальних екскурсів.

Серед регіонів України особливе місце займає Полтавська область - лідер за показником розвитку внутрішнього туризму в центральній Україні, яскравий приклад гармонійного поєднання та співіснування природної краси та багатої історико-культурної спадщини. Одне з сьогоднішніх завдань для Полтавщини зібрати та систематизувати вже напрацьований досвід у сфері подорожей, а також розробити сучасний підхід до збільшення кількості внутрішнього туриста, виходу регіону на міжнародний рівень, залучення іноземних туристів. Своєрідною родзинкою території може стати активне залучення в туристичний обіг інформації про виявлені втрачені об'єкти історико-культурної спадщини, які 3 різних причин не дійшли до нашого часу, але без яких не можливо уявити справжню історію регіону.

Один 3 таких об'єктів знаходився на території сучасного Гадяцького району Полтавської області - це Запорозька Свято-Успенська церква (1686 р.) перша кам'яна церковна споруда Гадяцького повіту, яка стала однією 3 найвизначніших пам'яток України козацької доби. За ступенем втраченості, об'єкт належить до категорії потенційно відновлювальних. Побудований на місці дерев'яної церкви, храм належав до етапних творів архітектури українського Відродження. Мурована, хрещата, п'ятибанна, три престольна церква була однією з найбільш досконалих за пропорціями дев'ятидільних споруд свого часу, чудо поєднавши древній візантійський стиль та українське бароко. Чотириярусний іконостас вважався шедевром стародавнього мистецтва i одним 3 найошатніших на Лівобережній Україні. Церкву включено до Програми відтворення видатних пам'яток історії та культури України.

Наступний об'єкт також знаходився у вищезазначеному районі - це садиба Драгоманових. Як і попередній, об'єкт належить до категорії потенційно відновлюваних, маючих велику суспільно-історичну значущість. Слід підкреслити, що Гадяцький край вважається колискою одного з відомих родів в Україні та світі - роду Драгоманових, бо саме звідси починається історія славнозвісної родини, що подарувала світу Олену Пчілку, Михайла Драгоманова, Лесю Українку. Відновлення будинку сприяло б створенню довгоочікуваного унікального на Україні музею-садиби Драгоманових, перетворенню міста на центр літературного туризму, допомогло б замкнути в єдине золоте кільце туризму усі пам'ятні місця, пов'язані з життям та творчістю Лесі Українки. 
Отже, на сучасному етапі сфера збереження та відновлення втрачених об'єктів історико-культурної спадщини характеризується складними та суперечливими процесами. Багато виявлених унікальних об'єктів в різних регіонах України, на жаль, не можуть бути відновленими з різних причин, однак це не заважає використанню цікавої цінної інформації про них, в першу чергу в туристичній діяльності, шляхом створення буклетів, путівників, тематичних екскурсій, розвитку пізнавального та інших видів туризму тощо. Все це буде сприяти формуванню. Національної ідеї, консолідації суспільства навколо охорони культурної спадщини, виділенню символів, які дозволять сформувати туристичний бренд території.

\section{Список літератури}

1. Борисова О.В. Перспективи розвитку літературного та релігійного туризму на Гадяччині // Географія туризму. - К.: Альфа-ПІК, 2015. - Вип. 34. С. 191200.

2. Троценко О.В. Втрачені географічні об'єкти Дніпропетровської області: пошук та історико-географічний аналіз: автореф. дис. канд. геогр. наук - К., 2009. -20 c. 